UNIVERSIDADE DE SÃO PAULO

Faculdade de Arquitetura e Urbanismo

Luzia Helena dos Santos Barros

\title{
REQUALIFICAÇÃO DOS ATERROS DESATIVADOS (BROWNFIELDS) NO MUNICÍPIO DE SÃO PAULO: \\ PARQUES (GREENFIELDS) RAPOSO TAVARES E JARDIM PRIMAVERA
}

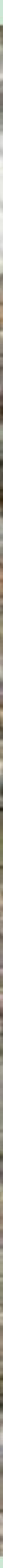

Imagem aérea (14/12/2008) do futuro Parque Jardim Primavera, São Paulo.

Fonte: Google Earth (Jul.2011) 
LUZIA HELENA DOS SANTOS BARROS

\section{Requalificação dos Aterros Desativados (Brownfields) no Município de São Paulo: Parques (Greenfields) Raposo Tavares e Jardim Primavera}




\section{Requalificação dos Aterros Desativados (Brownfields) no Município de São Paulo:} Parques (Greenfields) Raposo Tavares e Jardim Primavera

Paulo Renato Mesquita Pellegrino

Orientador
a Pellegrino

Co-orientadora Marisa Dantas Bitencourt

Área de concentração

Paisagem e Ambiente 
AUTORIZO A REPRODUÇÃO E DIVULGAÇÃO TOTAL OU PARCIAL DESTE TRABALHO, POR QUALQỦER MEIO CONVENCIONAL OU ELETRÔNICO, PARA FINS DE ESTUDO E PESQUISA, DESDE QUE CITADA A FONTE.

E-MAIL: luziahelena@yahoo.com.br

Barros, Luzia Helena dos Santos

B277r Requalificação dos aterros desativados (brownfields) no município de São Paulo: Parques (greenfields) Raposo Tavares e Jardim Primavera / Luzia Helena dos Santos Barros. --São Paulo, 2011. 403 p. : il. + CD ROM.

Tese (Doutorado - Área de Concentração: Paisagem e Ambiente) - FAUUSP.

Orientador: Paulo Renato Mesquita Pellegrino

Co-orientadora: Marisa Dantas Bitencourt

1.Reabilitação de áreas degradadas 2. Áreas contaminadas - São Paulo (SP) 3. Aterros - São Paulo (SP) 4. Parques - São Paulo (SP)

5. Paisagem urbana I.Título 
Aos meus sobrinhos Beatriz, Frederico, Bárbara, Vitória e Natália, pelas horas de descontração

À Sônia (in memorian), pelo incentivo a trilhar o mesmo caminho.

Ao meu pai Walter e à memória de minha mãe Lucia, pelo estímulo sempre. 


\section{AGRADECIMENTOS}

Esta Tese é o resultado do trabalho coletivo realizado por muitas mãos de diferentes, cores, crenças e valores, portanto, quero agradecer a todos os envolvidos nesse processo, me desculpando pelas possíveis omissões.

Com todo o meu carinho a minha família, meus irmãos Walter Lucio e Luiz Antonio, minha cunhada Thaís, minhas tias Elvira e Margarida, meus primos Maria Lucia e Gilson, que compreenderam as minhas ausências e forneceram o apoio e o incentivo necessário para o desenvolvimento da Tese.

De modo especial ao amigo Carlos Alberto da Silva Filho pelo incentivo, revisão e auxílio num dos momentos críticos de redefinição de metas.

Ao amigo Ricardo José F. Garcia pelo incentivo, apoio, revisão e discussões no trabalho de campo e na definição das classes de vegetação.

Aos amigos Carlos Minoru Morinaga e Jane Zilda Ramires pelas discussões ainda no Grupo Técnico Permanente de Áreas Contaminadas (GTAC), durante o desenvolvimento da Tese, pelas revisões efetuadas. pelo incentivo e companheirismo.

À equipe da primeira geração do GTAC Carlos Minoru Morinaga, Jane Zilda Ramires, Joana D'Arc Vítor, Rosimeire Lobato e Milton Motta, que compartilharam comigo as dificuldades para estabelecer procedimentos de organização e análise num tema ainda hoje carente de estrutura.

Aos novos componentes do GTAC João Vicente de Rezende e Amós Luciano Carneiro que durante a pesquisa foram incansáveis no fornecimento de informações.

Ao meu orientador Paulo Renato M. Pellegrino pela oportunidade de realizar esse trabalho, favorecer a criatividade, pelo estímulo e atenção.

A minha co-orientadora Marisa Dantas Bitencourt, do Instituto de Biociências desta Universidade, pela competência na condução dos trabalhos, incentivo e acolhida nos momentos difíceis.

Aos colegas do Laboratório de Ecologia da Paisagem e Conservação (LEPaC/IB/USP) pelo auxílio nas ferramentas de geoprocessamento e ao ótimo astral proporcionado ao ambiente de trabalho, especialmente à Paki, Kitaro, Felipe, Wellington e Luiz.

Aos professores Vladimir Bartalini e Yuri Tavares Rocha pelas discussões e sugestões fornecidas na qualificação.

À professora Mercedes Bartolomé da Universidade de Madrid pela colaboração e interesse no desenvolvimento da pesquisa social.

Aos professores desta Faculdade Paulo Bruna e Silvio Macedo pela cessão de informações e mapas.

À equipe do Herbário Municipal por possibilitar a visita aos vários parques municipais e a percepção sobre as questões envolvidas na sua gestão. 
Ao Flávio Fatigatti pela disponibilidade de material e pela elaboração de mapas e esquemas.

Aos amigos Dalva Mota, Margarete Hora, Joás Menezes, Arilda Neves, Lelo, Simone J. De Sordi e Adeliana Barbedo pelo estímulo e companheirismo.

À amiga Vandineide por todas as discussões sobre o aterro Sapopemba e seus arredores.

Aos entrevistados Fábio, Sérgio e Sylvio pela valiosa colaboração.

Ao Edimilsom Peres Castilho do Departamento de Parques e Áreas Verdes (Depave) da Secretaria do Verde e Meio Ambiente pelas discussões, cessão de fotos e projetos dos parques.

À Valéria Tiveron pelas discussões mantidas sobre resíduos e bibliografias disponibilizadas.

Aos colegas Francisco A. N. da Silva e Acauã Rodrigues dos Santos que me levaram a assumir a coordenação do GTAC e, por mudanças administrativas, a escolher outro posto de trabalho, favorecendo a definição do tema da Tese.

Aos colegas da Divisão de Meio Ambiente e Patrimônio (Demap) da Secretaria de Negócios Jurídicos (SNJ), pelo incentivo e apoio e, especialmente a minha chefe, Rosana Loberto pela compreensão e flexibilidade nos momentos em que precisei de maior dedicação à pesquisa. 

Margens do Rio Jacu, retificado, ao longo da Av. Jacu-pêssego, limite leste do futuro Parque Jardim Primavera, zona leste do município de São Paulo.

Foto da autora em 2007. 


\section{RESUMO}

BARROS, Luzia Helena dos Santos. Requalificação dos Aterros Desativados (Brownfields) no Município de São Paulo: Parques (Greenfields) Raposo Tavares e Jardim Primavera. 2011. 350 p. Tese (Doutorado). Faculdade de Arquitetura e Urbanismo, Universidade de São Paulo, São Paulo, 2011.

Orientador: Prof. Dr. Paulo Renato Mesquita Pellegrino

Co-orientadora: Prof. Dr ${ }^{\mathrm{a}}$. Marisa Dantas Bitencourt

O processo de industrialização e urbanização brasileiro está caracterizado por uma dinâmica de abandono (degradação) e reuso de áreas, que podem apresentar histórico de atividades com potencial de contaminação dos solos e águas superficiais e subterrâneas, concentrados em centros industriais, dentre os quais desponta o município de São Paulo. A disposição de resíduos sólidos urbanos está entre as atividades que contribuem para o surgimento de áreas contaminadas e apresenta algumas especificidades para a sua recuperação. $O$ objetivo desta pesquisa compreende a identificação e avaliação da adequação técnica, ambiental e paisagística dos processos de conversão de aterros desativados, existentes no município de São Paulo, em parques urbanos. O trabalho aborda as origens dessas áreas, passando pelas fases de sua implantação e desativação, os processos envolvidos na sua efetiva requalificação como parques, dentro de suas respectivas inserções urbanas, assim como a avaliação de suas condições atuais, quanto à contaminação, ao potencial de conectividade na paisagem e aos projetos paisagísticos e planos de gestão propostos. A pesquisa trata de dois estudos de caso: o antigo aterro Raposo Tavares, situado na Subprefeitura do Butantã, zona oeste, atual Parque Raposo Tavares e o antigo aterro Jacuí, situado na Subprefeitura de São Miguel Paulista, zona leste, hoje em processo de requalificação como o Parque Jardim Primavera. $O$ estudo dos conceitos e das classificações dos sistemas de gestão de áreas contaminadas e de áreas verdes permitiu a proposição dos termos área contaminada requalificada e parqueaterro. A análise espacial da paisagem dos parques-aterros, através do modelo de tomada de decisão por multicritérios (Multi Criteria Evaluation - MCE), deu origem aos mapas de potencial de conectividade, em dois diferentes cenários: mais otimista e mais conservador. Os resultados mostraram que a conexão da paisagem está mais favorecida junto ao Raposo Tavares. Observou-se, também, que as condições ambientais e a distância de influência dos critérios selecionados na avaliação são determinantes para a definição das zonas de amortecimento urbanas dos parques. Os estudos de caso representam duas épocas distintas do desenvolvimento tecnológico para a requalificação dessas áreas. O projeto paisagístico do parqueaterro Raposo Tavares não contemplou aspectos importantes para evitar problemas relacionados à sua gênese. Ao contrário, o projeto do parque-aterro Jardim Primavera incorporou os quesitos técnicos e ambientais atuais e incluiu a participação da comunidade. A particularidade da gênese dos parques-aterros e suas restrições orientaram as diretrizes propostas para os seus planos de gestão, especialmente quanto à revegetação e definição das suas zonas de amortecimento. Dessa forma, conclui-se que a implantação de parques-aterros deve ser encarada com precaução, em razão dos possíveis riscos à saúde dos trabalhadores da obra como dos seus futuros usuários e à flora e fauna locais.

Palavras-chave: áreas contaminadas, recuperação ambiental, aterros desativados, parques urbanos. 


\section{ABSTRACT}

BARROS, Luzia Helena dos Santos. Rehabilitation of Deactivated Landfills (Brownfields) in São Paulo Municipality: The Raposo Tavares and Jardim Primavera Parks (Greenfields). 2011. 350 p. Thesis (PhD). College of Architecture and Urbanism, University of São Paulo, São Paulo, 2011.

Supervising professor: Prof. Dr. Paulo Renato Mesquita Pellegrino

Co-supervisor: Prof. Dr. Marisa Dantas Bitencourt

The process of industrialization and urbanization of Brazil is characterized by a dynamic of abandonment (degradation) and reuse of areas, which may have a history of activities that could contaminate the soils and surface and ground water. These areas tend to be concentrated in industrial centers, one of the most noteworthy of which is São Paulo. The disposal of solid waste is one of the activities that contribute to the emergence of contaminated areas and they have to be recovered in a specific manner. The aim of this research is to identify and assess the suitability from a technical, environmental and landscape standpoint of processes of converting abandoned landfills into urban parks in the municipality of São Paulo. The study discusses the origins of these areas, from the stages of their implementation and deactivation, to the processes involved in their effective redevelopment as parks, within their respective urban insertions. It also evaluates their current situation in terms of contamination, their potential for connectivity in the landscape and examines their landscaping design and proposed management plans. The research includes two case studies: the former landfill site Raposo Tavares, located in the Subprefecture of Butantã in the West District, which is currently the Raposo Tavares Park; and the former landfill site Jacuí, located in São Miguel Paulista, in the Eastern District, currently under redevelopment as the Jardim Primavera Park. The study of the concepts and classifications of the management systems of contaminated areas and green areas led to the proposal of the terms requalified contaminated area and landfill-park. Spatial analysis of the landscape of the landfill-parks, using the Multi Criteria Evaluation - MCE model, enabled the creation of connectivity potential maps, with two different scenarios: one more optimistic and the other conservative. The results showed that the landscape connectivity is more favourable in Raposo Tavares. It was also found that the environmental conditions and distance of influence of selected criteria in the evaluation are crucial to the definition of urban buffer zones of the parks. The case studies represent two different eras of technological development for the requalification of these areas. The landscape project of the Raposo Tavares landfill-park did not include important aspects to avoid problems related to its genesis. On the contrary, the design of the Jardim Primavera landfill-park incorporated current environmental and technical issues and included community participation. The particularity of the genesis of landfill-parks and their constraints oriented the proposed guidelines for their management plans, especially regarding the definition of revegetation and their buffer zones. Thus, it was concluded that the implementation of landfill-parks should be viewed with caution because of possible health risks to construction workers, future users and their flora and fauna.

Keywords: contaminated sites, environmental restoration, deactivated landfills, urban parks. 


\section{SUMÁRIO}

INTRODUÇÃO.

\section{PARTE I}

\section{Dos LIXÕES Às ÁREAS CONTAMINADAS: DEGRADAÇÃo AMBIENTAL NA PAISAGEM PAULISTANA}

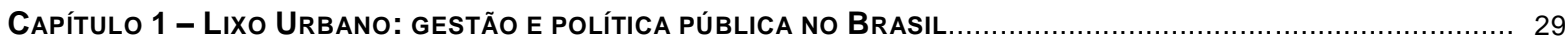

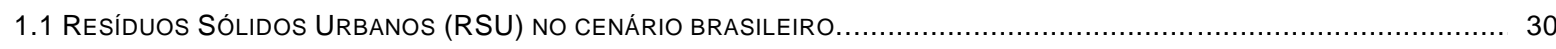

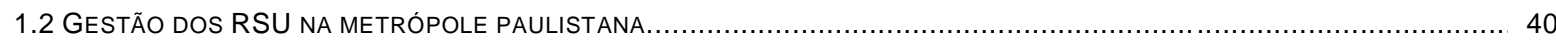

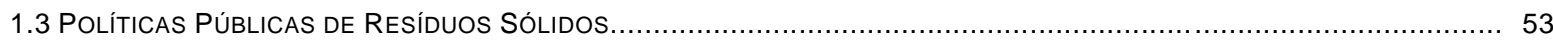

Capítulo 2 - BrownfieldS e Áreas Contaminadas: Histórico e ReVISÃo teórica............................... 57

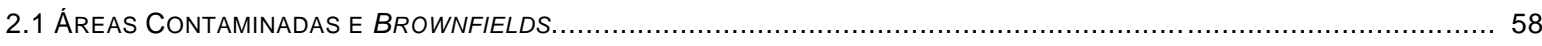

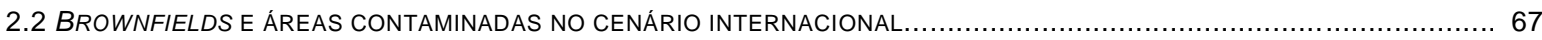

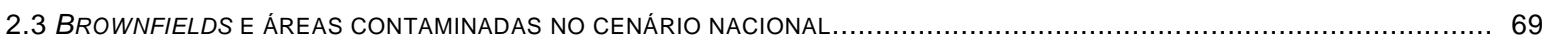

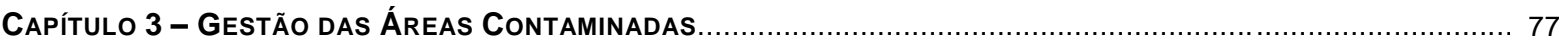

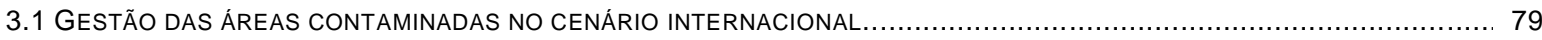

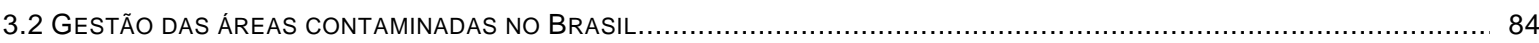

CAPÍtUlo 4 - Riscos AMBIENTAIS e À SAÚde humanA ASSOCIAdOS AOS LIXõeS E ATERROS............................119

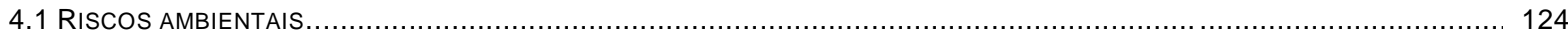

4.2 RISCOS SOCIOAMBIENTAIS PROVOCADOS POR LIXÕES E ATERROS....................................................... 128

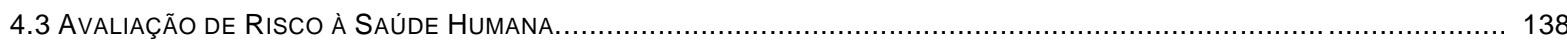

4.4 RISCOS SOCIOAMBIENTAIS E DE SAÚDE CONSTATADOS EM ALGUNS ATERROS BRASILEIROS DESATIVADOS.................. 143

Capítulo 5 - Lixões e aterros desativados no Município de São Paulo................................................. 149

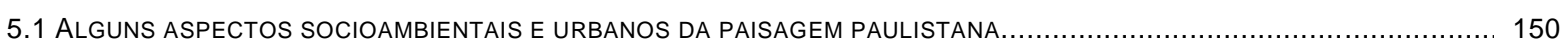

5.2 SitUAÇÃO dOS LIXÕES E dOS ATERROS DESATIVAdOS NO MUNICÍPIO DE SÃo PAULO........................................... 166

5.3 REFLEXÕES PRELIMINARES SOBRE O POTENCIAL DE REVEGETAÇÃO DOS ATERROS MUNICIPAIS...............................197 


\section{PARTE II}

\section{Processo de REQUALIFICAÇÃo dos liXões e ATERROS desativadoS NA PAISAGEM PAULISTANA}

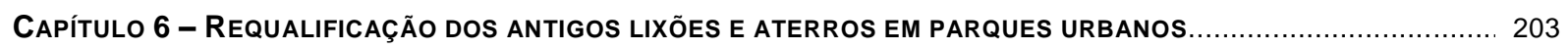

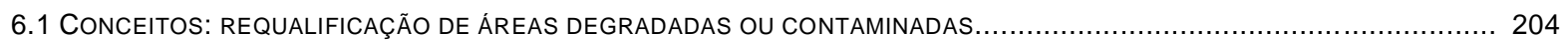

6.2 Requalificação de Áreas Degradadas por Contaminação, no MunicíPIO de SÃo Paulo............................. 207

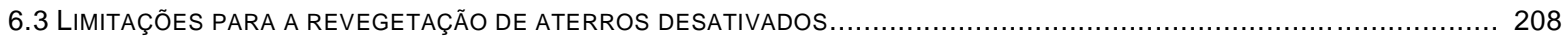

6.4 MÉTODOS DE REMEDIAÇÃO DE ÁREAS CONTAMINADAS POR RESÍDUOS SÓLIDOS.................................................212

Capítulo 7- Parques-aterros no Sistema de Áreas Verdes do Município de São Paulo - novos

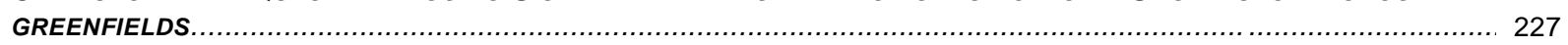

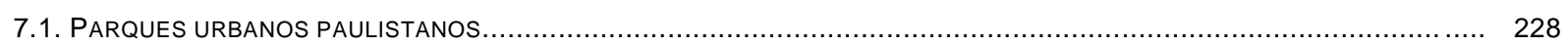

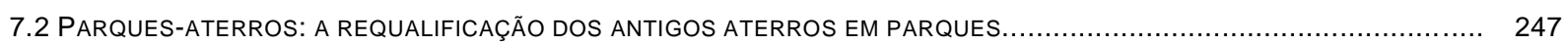

\section{PARTE III}

IMPLANTAÇÃo dOS PARQUES-ATERROS NO MUNICíPIO dE SÃo PAULO POR MEIO DE DOIS ESTUDO DE CASOS

Capítulo 8 - Contexto urbano e socioambiental dos parques-aterros Raposo Tavares e Jardim PrimaVera e O SEU POTENCIAL de CONEXÃo NA PAISAGEM PAULISTANA...

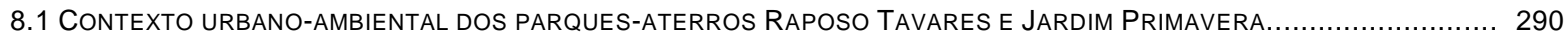

8.2 Potencial de Conectividade dos Parques-Aterros Raposo TaVARES E Jardim Primavera........................ 315

8.3 CONTRASTES URBANO-AMBIENTAIS NOS ARREDORES DOS PARQUES-ATERROS ESTUDO DE CASO............................. 326

Capítulo 9 - Análise dos parques-aterros Raposo Tavares e Jardim Primavera 331

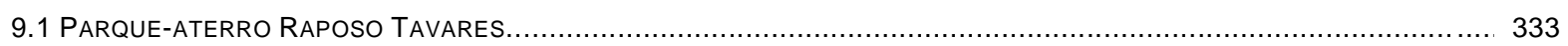

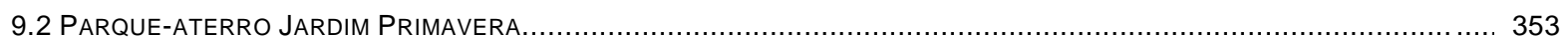

9.3 AdEQUAÇÃO TÉCNICA, AMBIENTAL E PAISAGÍSTICA DOS PROJETOS IMPLANTADOS E PROPOSTOS NOS PARQUES-

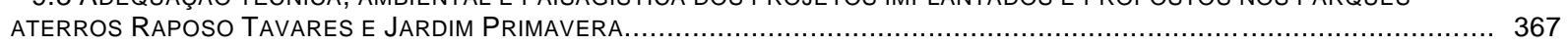

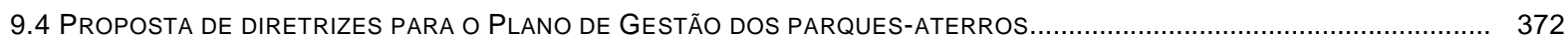

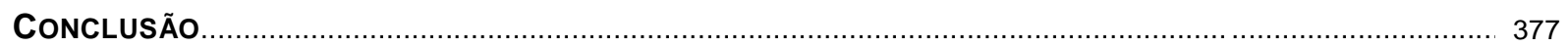

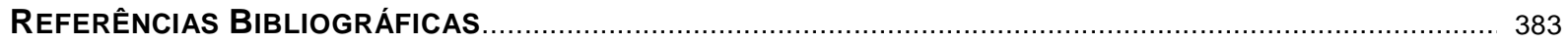

ApÊNDICES E ANEXos (CD ROM) 


\section{INTRODUÇÃO}

O município de São Paulo caracteriza-se por apresentar desigualdade socioambiental: pobreza, degradação dos recursos naturais, maiores contingentes populacionais, nas zonas periféricas; renda mais alta, elevado valor venal dos terrenos e implantação de sistema de infra-estrutura, na região do eixo centrosudoeste; qualidade do ar, taxa de impermeabilização do solo e temperaturas aparentes diferenciadas, que, não por acaso, estão relacionadas aos aspectos geológico-geomorfológico-geotécnicos e ao processo de urbanização acelerado, desencadeado pela industrialização, no século XX.

Nas últimas décadas, tem-se evidenciado uma modalidade de poluição ambiental pouco visível, relacionada à contaminação do solo e das águas subterrâneas, gerada por diferentes fontes, como processos industriais, armazenamento de produtos tóxicos e disposição inadequada de resíduos sólidos. O histórico de evolução e a caracterização da disposição de resíduos no município de São Paulo mostram que esses locais recebiam todo e qualquer tipo de lixo. Tanto esses antigos locais de disposição de resíduos, sem nenhum controle, quanto os atuais, clandestinos ou operados irregularmente, caracterizam-se como áreas degradadas, configurando-se hoje ou no futuro como passivos ambientais, ou seja, como áreas suspeitas ou contaminadas, os chamados brownfields.

Neste mês de setembro os problemas oriundos das áreas contaminadas retornaram às manchetes. Os jornais de circulação nacional e a televisão noticiaram a inclusão da área onde estão localizados o Shopping Center Norte, o Lar Center e o Carrefour, na Vila Guilherme, zona norte do município, na lista da Companhia Ambiental do Estado de São Paulo (Cetesb) como área crítica contaminada (Figura 1) . Na área há acumulação de gás metano proveniente de antigo lixão existente no 
subsolo $^{1}$, apresentando risco de explosividade. Anteriormente, o Shopping foi autuado para providenciar a remediação do terreno (instalação de sistema de extração de gases) sem, no entanto, cumprir com todas as exigências, mesmo após a aplicação de multas. A situação de risco fez com que a Secretaria Municipal do Verde e Meio Ambiente (SVMA) interditasse a área. A ação foi anulada pela assinatura de um Termo de Ajustamento de Conduta (TAC) com o Ministério Público e por liminar concedida pela Justiça de São Paulo à administração do Shopping. No dia 2 de outubro a administração do Shopping publicou na Folha de S. Paulo ${ }^{2}$ nota de esclarecimento à população no intuito de resgatafr a imagem do empreendimento. A presença de metano foi, também, constatada no conjunto habitacional Zachi Narchi (Projeto Cingapura), mas sem risco de explosividade, na mesma região. O conjunto residencial Barão de Mauá, Mauá - SP está, também, sujeito à situação semelhante ao Shopping, tendo a Cetesb recomendado aos moradores o abandono das suas residências.

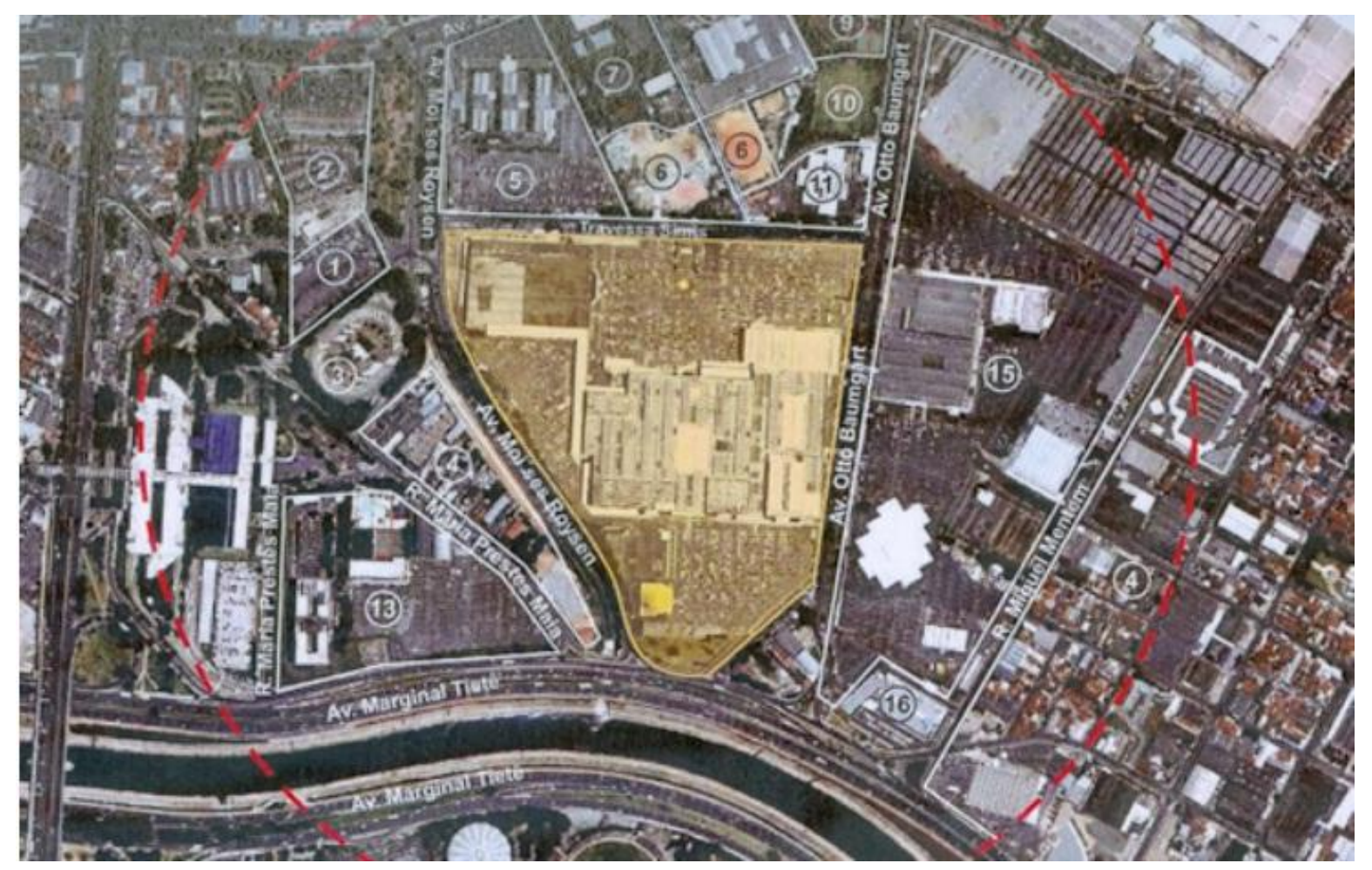

Figura 1 - Delimitação da área contaminada crítica (em vermelho) e no centro perímetro (em amarelo) do Shopping Center Norte e Supermercado Carrefour.

Fonte: Cetesb (2011). Disponível em www.cetesb.gov.br. Acesso em: 20set.2011.

\footnotetext{
${ }^{1}$ A ocorrência do lixão, na região da Coroa, foi destacada no estudo sobre a problemática dos resíduos sólidos na cidade de São Paulo, realizado por Ogata (1978, 1983), apresentado no Capítulo 1. Na década de 1970, foi prevista a implantação do Centro Administrativo Municipal (CAM). Os lixões estão dispersos na antiga planície do Rio Tietê, estendendo-se do Clube da Coroa (Capítulo 4) até o atual Parque da Juventude (Capítulo 7), antigo aterro Carandiru (Capítulo 5).

${ }^{2}$ FOLHA DE S. PAULO. Cotidiano. C1-C13. Domingo, 2 de outubro de 2011, p. C1.
} 
O ano de criação da Política Nacional de Resíduos Sólidos (PNRS), que prevê a extinção dos lixões até 2014, foi marcado por retrocessos nos indicadores de produção e destinação final do lixo no Brasil. Em 2010, a população brasileira gerou 195 mil toneladas de resíduos sólidos diárias, um aumento de 6,8\% em relação a 2009. Deste total, 42,4\% (22, 9 milhões de toneladas/ano) receberam destinação inadequada: lixões ou aterros controlados (Abrelpe, 2010). No estado de São Paulo, em 2010, foram produzidas 26 mil toneladas de resíduos sólidos diárias, registrando-se, nesses últimos 14 anos, melhora significativa da situação dos locais de disposição e tratamento de resíduos domiciliares (Cetesb, 2010). Os últimos dados disponíveis para o município de São Paulo são relativos a 2009, quando foi registrada a produção total de 17 mil toneladas de resíduos sólidos, diárias, correspondendo aos resíduos urbanos cerca de 10 mil toneladas (SES, 2010). Todos esses dados indicam que ainda há muito trabalho a ser feito para requalificar essas áreas.

Essa autora tem se deparado com os vários processos de degradação ambiental e as tentativas para sua recuperação, em algumas regiões do país, nordeste e sudeste, bem como, na Alemanha. A observação desses fatos já se fez presente na década de 1960, durante a sua infância, quando vivenciou muito de perto as famosas enchentes e deslizamentos de encostas ocorridos na cidade do Rio de Janeiro. Durante os seus estudos na graduação em geologia, na Universidade de Brasília, pelos cerrados do centro-oeste, registrou tanto a beleza dos afloramentos rochosos, corredeiras e biodiversidade, quanto a dureza e a precariedade das atividades cotidianas nos pequenos povoados.

Ao longo da sua vida profissional, primeiramente no sertão sergipano, constatou os danos causados pela seca e participou dos projetos de construção de poços e barragens para abastecimento da população e irrigação de culturas. Posteriormente, nos estudos desenvolvidos mais sistematicamente, no período entre 1988 a 1992, durante a pesquisa de mestrado intitulada: Os Condicionantes geológico-geotécnicos na instabilidade das encostas da Serra da Carioca, Maciço da Tijuca - RJ, pode se inteirar, com base científica, sobre o histórico dos escorregamentos, suas graves conseqüências e possibilidades de ação, tão conhecidos dos cariocas. A experiência na Alemanha deu-se, no período de 1999 a 
2000, mediante formação e aperfeiçoamento profissional na área de Gestão de Infra-estrutura Urbana, promovida pela Carl Duisberg Gesellschaft (CDG).

A vivência mais contínua como profissional técnica se dá como geóloga efetiva da Prefeitura do Município de São Paulo (PMSP), após um breve período na Prefeitura Municipal de Petrópolis, RJ. Inicialmente, em 1991, na Administração Regional, atual, Subprefeitura da Penha, a partir de 1993, na SVMA e a partir de 2008, na Secretaria de Coordenação das Subprefeituras (SMSP); atuando nas áreas de risco geológico-geotécnico, cartografia geotécnica, educação ambiental, controle ambiental, recuperação ambiental e gestão de áreas contaminadas, produtos perigosos e de parques e áreas verdes. Em 2010, ingressa na Secretaria de Negócios Jurídicos (SNJ) passando a atuar na defesa do patrimônio municipal e ambiental, presenciando as tendências de mudanças de uso do solo paulistano. Toda essa experiência é caracterizada pela observação de conflitos diversos, no planejamento e na gestão dos espaços livres, da vegetação e das áreas degradadas; entre os vários profissionais envolvidos no trato dessas questões e nas várias instâncias de decisão, desde o município até a União. Esses conflitos são responsáveis pela aplicação desarticulada da legislação, dos instrumentos de incentivo existentes para a sua implantação ou recuperação, pela deficiência na comunicação dos riscos à população, resultando em ações parciais, insuficientes ou contraditórias que, em geral, implicam em aumento da degradação ou em ações imediatistas, desperdício de dinheiro público e perda de credibilidade na ação pública.

O questionamento sobre a forma de intervenção dos setores públicos e privados na construção da cidade e a necessidade de entender a linguagem e o pensamento dos profissionais ligados à análise da paisagem urbana levou essa autora a se aproximar dos conceitos sobre urbanização, espaço e paisagem, mediante a participação, inicialmente, como aluna ouvinte, em algumas disciplinas das áreas de planejamento urbano e paisagem e ambiente, desta Faculdade de Arquitetura e Urbanismo (FAU) e de Filosofia, Letras e Ciências Humanas (FFLCH), desde 2005 e, posteriormente, ingressando no doutorado. As disciplinas, os trabalhos realizados e publicados, além da participação em eventos nacionais e internacionais e a própria pesquisa propiciaram a compreensão e o aprofundamento no entendimento da dinâmica da paisagem urbana e nos processos envolvidos para a sua requalificação ambiental. 
As áreas contaminadas, dentre elas os locais de disposição de resíduos sólidos, além de se tornarem um problema de saúde pública, podem ser consideradas como problema urbano-ambiental devido à complexidade, ao tempo e aos custos envolvidos na sua requalificação. E tal como afirma Valentim (2010, p. 186) as áreas contaminadas na paisagem urbana "(...) são testemunho do vigor social do passado e abrigam, silenciosamente, uma herança que se anuncia em algum momento como risco, uma herança que se levanta contra o viver coletivo com saúde." O mesmo autor observa que a concentração dos impactos de diversas naturezas (poluição do ar, água e solo) característicos da Região Metropolitana de São Paulo (RMSP), oriundos de um uso intenso do solo faz dessa conurbação de cidades um núcleo preferencial para a concentração de áreas contaminadas.

No Estado de São Paulo até dezembro de 2010 foram cadastradas 3.675 áreas contaminadas, sendo 1.199 (33\%) localizadas no município de São Paulo e 599 (16\%) na RMSP (excluindo São Paulo). Desse total, apenas 163 (4\%) foram reabilitadas (Cetesb, 2010).

Os aterros desativados são áreas geralmente extensas e situadas nas zonas periféricas, com carência de espaços públicos e de lazer. Rotineiramente, recomenda-se a sua requalificação como parques, áreas de recreação e para prática de esportes, de forma compatível com o entorno. Essa forma de reuso foi, primeiramente, aplicada no município de São Paulo na década de 1980 e, nos tempos recentes, há ações concretas para a conversão desses aterros em parques urbanos, os greenfields. No entanto, o reaproveitamento dessas áreas exige uma série de cuidados e conhecimentos técnicos específicos, tanto na fase de investigação da contaminação, como na elaboração de projetos, na implantação de obras e na sua manutenção.

Apesar disso, não se reproduzem nas práticas dos setores, público e privado, o necessário planejamento e a aplicação de procedimentos que garantam a utilização segura de áreas que apresentem problemas de contaminação do solo e das águas subterrâneas, com a elaboração de projetos adequados e a sua implantação, mediante o emprego de técnicas apropriadas. Para tanto era preciso responder às questões: Como se processa a conversão de lixões e aterros em parques? Quais os instrumentos necessários para a gestão e manutenção dessas áreas? Como esse tipo de parque pode contribuir para a conexão da paisagem urbana? Dessa forma, foram tomadas como hipóteses que: 
a. A criação de uma tipologia específica de parque urbano para o Sistema de Espaços Livres e Áreas Verdes - SELAV do município permitirá a identificação imediata da sua gênese e a aplicação de procedimentos técnico-científicos especiais, de longo prazo, imprescindíveis à implantação e manutenção desse tipo de parque;

b. A transformação dos lixões/aterros em parques urbanos, desconsiderando toda a complexidade desse processo e sem compromisso concreto com a qualidade ambiental e com a responsabilidade social, responde de forma insuficiente às pressões de parte da sociedade quanto à requalificação ambiental;

c. Apesar das limitações para revegetação de lixões/aterros, essa tipologia de parque pode apresentar potencial para conexão da paisagem, quando se configurar como trampolim ecológico e favorecer a formação de corredores ecológicos.

Para verificar as hipóteses relacionadas, partiu-se do tema geral de áreas contaminadas urbanas, tendo como objeto específico de estudo os processos de recuperação de antigos lixões/aterros no município de São Paulo para a implantação de parques urbanos públicos, com base em dois estudos de caso, a saber:

- O antigo lixão/aterro Raposo Tavares, situado na Subprefeitura do Butantã, zona oeste do município, onde foi implantado o parque municipal de mesmo nome, em 1981, sem critérios técnicos específicos necessários, oficializado recentemente;

- O antigo lixão/aterro Jacuí, situado na Subprefeitura de São Miguel Paulista, na zona leste do município, hoje em processo de requalificação para parque, com reuso estabelecido pela Lei 13.308/2002, que criou o Parque Primavera.

A fim de identificar e avaliar a adequação técnica, ambiental e paisagística dos processos de conversão de lixões/aterros desativados, existentes no município, em parques urbanos; a pesquisa aborda as origens dessas áreas, passando pelas fases de sua implantação e desativação como lixões/aterros, nos processos 
envolvidos na sua efetiva transformação em parques, dentro de suas respectivas inserções urbanas, até uma avaliação de suas condições atuais.

Com o intuito de alcançar o objetivo geral pretendido pela pesquisa são listados a seguir os seus objetivos específicos principais:

- Levantar as ações realizadas para proceder aos trabalhos de requalificação dos aterros em parques urbanos, tais como: investigação do potencial de contaminação, métodos para remediação implantados, critérios técnicos adotados nos projetos paisagísticos e nos planos de gestão;

- Discutir os aspectos técnicos, científicos, sociais e administrativos envolvidos na requalificação dessas áreas degradadas;

- Analisar o potencial de conexão da paisagem, nos estudos de caso, com base na ecologia da paisagem.

Objetivos específicos secundários também foram necessários, como complemento, aos principais:

- Levantar as condições técnicas de implantação e desativação dos antigos lixões/aterros;

- Estudar os métodos para a remediação da contaminação em aterros de resíduos sólidos;

- Diagnosticar as condições sócio-econômicas e ambientais atuais do entorno dos antigos lixões/aterros transformados ou não em parques e seu potencial de revegetação;

- Diagnosticar, por sensoriamento remoto, o uso e ocupação do solo no município, especialmente as tipologias de vegetação.

Inicialmente, buscou-se entender a inserção dos lixões/aterros no sistema de disposição final dos resíduos sólidos realizando-se uma revisão sobre as diversas classificações e os conceitos existentes na literatura especializada, com destaque para a definição de lixão, aterro controlado e aterro sanitário. A consulta à Pesquisa Nacional de Saneamento Básico (IBGE, 2000) e ao Diagnóstico do Manejo de Resíduos Sólidos Urbanos - 2007 (MCidades/SNSA, 2009) permite apresentar 
uma visão geral da situação dos lixões/aterros no Brasil e, mediante informações do Inventário Estadual de Resíduos Sólidos Domiciliares (Cetesb, 2011), a situação no estado de São Paulo. A dissertação de mestrado sob o título Gestão de Resíduos Sólidos no Município de São Paulo (Tiveron, 2001) e dados obtidos no Departamento de Limpeza Pública (Limpurb), Secretaria de Serviços (SES) são fontes de informação sobre a gestão dos resíduos sólidos no município. O estudo sobre a história do lixo e sobre a evolução da disposição de resíduos sólidos no município foi realizado nas seguintes dissertações de mestrado: Nos Rastros dos Restos: As Trajetórias do Lixo na Cidade de São Paulo (Lopes, 1998) e Os Resíduos Sólidos na Organização do Espaço e na Qualidade do Ambiente Urbano: Uma Contribuição Geográfica ao Estudo do Problema na Cidade de São Paulo (Ogata, 1978).

A revisão bibliográfica sobre a conceituação de áreas degradadas, brownfields e áreas contaminadas e a sua situação no panorama internacional e nacional; bem como dos termos relacionados à sua recuperação foi baseada, principalmente, em literaturas de referência e nas pesquisas: Gerenciamento de Áreas Contaminadas na bacia hidrográfica do reservatório Guarapiranga (Gloeden, 1999), Avaliação da Gestão de Sítios Contaminados por Resíduos Perigosos nos EUA, Canadá, Países europeus e Brasil, e Exemplo de um Manual Simplificado de Avaliação de Saúde Ambiental destes Sítios para o Brasil (Magalhães, 2000), Avaliação Ambiental Preliminar de Antigas Áreas de Disposição de Resíduos Sólidos Urbanos do Município de São Paulo (Silva, 2001), Requalificação urbana e o risco à saúde devido à contaminação do solo por substâncias perigosas: um estudo de caso na cidade de São Paulo (Valentim, 2005), Refuncionalização de Brownfields: Estudo de Caso na Zona Leste de São Paulo - SP (Vasques, 2005), Entraves Espaciais: Brownfields Caracterizados por Aterros de Resíduos Sólidos Urbanos Desativados no Município de São Paulo/SP (Leite, 2005), Recuperação de Áreas Contaminadas. Um novo desafio para projetos paisagísticos (Morinaga, 2007), Áreas contaminadas e os Riscos Socioambientais em São Paulo (Ramires, 2008) e Geotecnologias nos Estudos sobre Brownfields: Identificação de Brownfields em Imagens de Alta Resolução Espacial e Análise da dinâmica da Refuncionalização de Antigas Áreas Fabris em São Paulo (Vasques, 2009). 
Requalificação dos Aterros Desativados (BROWNFIELDS) no MunicíPIO de SÃo PAULO: PARQUES (GREENFIELDS) RAPOSO TAVARES E JARDIM PRIMAVERA

LUZIA HELENA DOS SANTOS BARROS

O estudo do tema das áreas contaminadas contou com o levantamento da legislação federal, estadual e municipal sobre o assunto. No âmbito do município de São Paulo foram estudados os projetos e os procedimentos internos desenvolvidos pela SVMA, bem como os relatórios das Comissões Parlamentares de Inquérito (CPI's), publicados pela Câmara Municipal. Contribuição valiosa foi fornecida também pelo Manual de Áreas Contaminadas (Cetesb, 2001) essencial ao entendimento dessa problemática.

Instrumentos de planejamento e gestão urbano-ambiental do município também foram levantados, destacando-se o Plano Diretor Estratégico (Lei 13. 430/2002), os Planos Regionais Estratégicos das Subprefeituras (Lei 13.885/2004), o Atlas Ambiental do Município (SVMA, 2004), o Informe GEO Cidade de São Paulo (SVMA, 2004) e, mais recentemente, o estudo para construção de um indicador socioambiental sintético: Indicadores Ambientais e Gestão Urbana (SVMA/CEM, 2008).

Os conceitos de paisagem e de fragmentação, trampolins e corredores ecológicos, relacionados à Ecologia da Paisagem também foram tratados, mediante literaturas fundamentais: Paisagem e geografia física local global: esboço metodológico (Bertrand, 1971); Landscape Ecology (Forman; Godron, 1986), Land Mosaics: The Ecology of Landscapes and Regions (Forman, 1995) e Landscape Ecology Principles in Landscape Architecture and Land-Use Planning (Dramstad et al., 1996).

As bases cartográficas digitais do município foram obtidas com o auxílio do arquiteto Flávio Fatigatti, nos arquivos do Atlas Ambiental (SVMA, 2004) e o Mapa Digital da Cidade - 2004, escala 1: 1.000, da Intranet da Prefeitura de São Paulo. As aerofotos de diferentes épocas e escalas, também foram consultadas, na intranet, na SVMA e na Secretaria de Habitação (Sehab), a saber: ano de 1940, escala 1: 20.000; ano de 1954, escala 1:25.000; ano de 1972/74 e 1977, escala 1:8.000; ano de 1996, escala 1:5.000; ano de 2000/2001, escala 1:5.000 e ano de 2004, escala 1:1.000. Outros documentos cartográficos também foram consultados: Carta Geotécnica do Município de São Paulo - 1992 (Sempla, 1992), escala 1:10.000; Mapa Topográfico do Município de São Paulo - Levantamento Sara Brasil - 1930, escala 1:5.000 e as sérias temáticas Município em Mapas - 2008 e Panorama e Olhar São Paulo - 2008. 
No Departamento de Parques e Áreas Verdes - Depave/SVMA foram obtidas as plantas e projetos referentes aos dois estudos de caso, incluindo-se, no caso do parque Raposo Tavares o projeto de plantação - adubação e correção do solo, piso e elementos arquitetônicos e drenagem de chorume, modificados em abril de $1980 \mathrm{e}$ do futuro parque Jardim Primavera foram obtidos: o projeto executivo - planta de piso, escala 1:500, abril/1980, o projeto paisagístico, escala 1:500, de 1987 e o projeto paisagístico - fase 1, escala 1:500, acompanhado do seu memorial descritivo, elaborado em 2007. Adicionalmente, obteve-se o projeto de parque elaborado para o antigo aterro Sapopemba, em 2009.

O levantamento da situação de implantação e desativação dos antigos aterros foi realizado, principalmente, mediante consulta à dissertação de mestrado de Silva (2001). Como base para a pesquisa também foram utilizados os relatórios internos: Avaliação Preliminar da Viabilidade ambiental da Implantação de Parques Municipais em Aterros Sanitários Desativados (SVMA, 2001) e Análise, Caracterização e Proposta de Ação para Revitalização dos Aterros Desativados no Município de São Paulo (SVMA, 2005). Informações obtidas no Departamento de Controle da Qualidade Ambiental - Decont e no Depave/SVMA e nos processos administrativos municipais e da Cetesb, além de visitas à campo e entrevistas permitiram verificar o histórico das práticas e a situação atual, especialmente, nos dois estudos de caso. Particularmente, para o Parque Jardim Primavera destaca-se o Relatório de Avaliação Ambiental e Análise de Risco Tier 2 - Fase 2. Antigo Aterro Municipal Jacui (SVMA, 2008), que trata das investigações quanto à contaminação da área e da avaliação de risco à saúde humana. Esses dados juntamente com as informações demográficas, sócio-econômicas e ambientais e o mapa de uso e ocupação do solo elaborado, possibilitaram identificar o contexto urbano-ambiental no qual estão inseridos os parques-aterros estudados, do ponto de vista político, administrativo e social.

O mapa de uso e ocupação do solo, um dos produtos desenvolvidos no Departamento de Ecologia Geral, Instituto de Biociências da Universidade de São Paulo (IB/USP) - Laboratório de Ecologia da Paisagem e Conservação (LEPaC), foi obtido por meio da geomática e destacou com maior detalhamento a classe da vegetação, incluindo um levantamento expedito em campo, visto que ela é um elemento determinante para a implantação dos parques-aterros. No estudo da vegetação do município, ressaltam-se as pesquisas: Florística e Estrutura de 
Requalificação dos Aterros Desativados (BrownfieldS) no MunicíPIO de SÃo PAULO: PARQUES (GREENFIELdS)

RAPOSO TAVARES E JARDIM PRIMAVERA

LUZIA HELENA DOS SANTOS BARROS

Trecho Remanescente de Floresta no Planalto Paulistano (SP) (Aragaki, 1997), Composição florística dos estratos arbóreo e arbustivo da mata do Parque Santo Dias (Garcia, 1995), Proteção e Fomento da Vegetação no Município de São Paulo: possibilidades, alcance e conflitos (Silva Filho, 2005) e, também, o Atlas Ambiental. Quanto às limitações da implantação de vegetação em aterros, destacam-se: Vegetação em aterros sanitários de resíduos sólidos urbanos: estudo do caso do aterro de Santo Amaro (Andrade, 2000) e Fitotransporte de metais em espécies arbóreas e arbustivas de resíduos sólidos urbanos (Andrade, 2005).

Adicionalmente foram levantados trabalhos relacionados ao estudo das áreas verdes, destacando-se aqueles que tratavam do conceito, da classificação e da análise de parques urbanos, tais como: A evolução dos parques urbanos na Cidade de São Paulo (Kliass, 1989), Parques públicos municipais de São Paulo. Ação da municipalidade no provimento de áreas verdes (Bartalini, 1999) e Parques Urbanos no Brasil (Macedo e Sakata, 2003).

A análise espacial do potencial de conectividade dos parques-aterros na paisagem paulistana, desenvolvida, também no LEPaC, com base num modelo de tomada de decisão por multicritérios (Multi Criteria Evaluation - MCE), resultou na construção dos mapas de potencial de conectividade, em dois diferentes cenários, mais otimista e mais conservador, para os estudos de caso e suas zonas de amortecimento urbanas.

Os projetos paisagísticos dos parques-aterros Raposo Tavares e Jardim Primavera são apresentados e analisados frente à sua adequação às especificidades do substrato do terreno, ao potencial de conexão na paisagem e às demandas sociais da população. São propostas, também, algumas diretrizes para os planos de gestão desse tipo especial de parque.

A presente Tese está estruturada em três partes, compondo-se de vários capítulos. A Parte I - Dos Lixões às Áreas Contaminadas: dedradação ambiental na paisagem paulistana trata dos fundamentos da pesquisa, analisando desde a origem dos lixões até a sua configuração como brownfields ou áreas contaminadas, evidenciando os riscos ambientais e à saúde humana a eles associados e a sua inserção no contexto do uso e ocupação do solo e no sistema de gestão de áreas contaminadas. Cinco capítulos respondem pelo seu conteúdo. 
O Capítulo 1 - Lixo urbano: gestão e políticas públicas discorre sobre os conceitos e as classificações dos resíduos sólidos e apresenta um panorama da situação da sua gestão no Brasil e, em especial, no município de São Paulo. É apresentado, também, o histórico sobre a evolução da disposição final do lixo no município, destacando-se os lixões/aterros. A situação das áreas contaminadas e dos brownfields no nível internacional e nacional, bem como os vários conceitos relacionados ao assunto são abordados no Capítulo 2 - Brownfields e áreas contaminadas: histórico e revisão teórica.

O gerenciamento das áreas contaminadas no nível internacional e nacional até o diagnóstico da sua gestão no município de São Paulo é tratado no Capítulo 3 Gestão das Áreas Contaminadas que identifica os diferentes enfoques dessas áreas (econômicos, políticos, ambientais, administrativos, de saúde pública) e os conflitos existentes entre as diversas esferas de governo, descrevendo seus marcos legais, bem como os procedimentos implantados ou em desenvolvimento, na gestão municipal. Os riscos ambientais e à saúde da população humana desencadeados pela presença de antigos lixões/aterros no meio urbano e os seus principais contaminantes e indicadores são apresentados no Capítulo 4 - Riscos ambientais e à saúdle humana associados aos lixões e aterros. A situação urbano-ambiental dos aterros desativados existentes no município e suas zonas de amortecimento urbanas foi descrita com base nos graus de contaminação e nos princípios da ecologia de paisagem, no Capítulo 5 - Lixões e aterros desativados no município de São Paulo - os brownfields.

A Parte II - Processo de requalificação dos lixões e aterros desativados - parques-aterros na paisagem paulistana, composta por dois capítulos, se refere propriamente ao estudo da transformação desses lixões e aterros em parques urbanos. Para tanto aborda os aspectos envolvidos no processo de requalificação dessas áreas e as alternativas de remediação aplicáveis aos projetos paisagísticos e analisa a criação desses parques especiais no sistema de classificação das áreas verdes. O Capítulo 6 - Requalificação dos antigos lixões e aterros em parques urbanos apresenta os vários conceitos relacionados à recuperação ambiental de áreas degradadas, em especial contaminadas. Aborda a problemática de implantação de vegetação sobre aterros e relaciona os métodos de remediação, dando-se destaque a uma das tipologias emergentes, a fitorremediação e às zonas alagadas construídas. Os conceitos e as classificações de parques urbanos são 
discutidos e uma nova classe foi proposta, parque-aterro, para o Sistema de Áreas Verdes do município de São Paulo no Capítulo 7 - Parques-aterros no Sistema de Áreas Verdes do município de São Paulo - os greenfields. O capítulo aborda a importância da vegetação, especialmente nos parques urbanos, como elemento de conexão da paisagem e, descreve os vários exemplos de parques implantados sobre aterros, tanto estrangeiros quanto nacionais.

Por último a Parte III - Implantação dos parques-aterros no município de São Paulo por meio de dois estudos de caso apresenta os dois estudos de caso analisados na Tese, compondo-se de dois capítulos. O Capítulo 8 - Contexto urbano e socioambiental dos parques-aterros Raposo Tavares e Jardim Primavera e o seu potencial de conexão na paisagem paulistana levanta os dados demográficos, urbanos e socioambientais da região nas quais se inserem os parques-aterros, o estágio de gerenciamento da contaminação, a situação da vegetação e os problemas decorrentes da origem dessas áreas. Analisa-se, também, o potencial de conectividade desses parques-aterros incluindo-se as suas respectivas zonas de amortecimento urbanas, por intermédio de um modelo de tomada de decisão. A análise da viabilidade da incorporação dos antigos lixões e aterros à malha urbana do município e da sua conversão em parques foi realizada no Capítulo 9 - Análise dos parques-aterros Raposo Tavares e Jardim Primavera, por meio da crítica aos seus projetos paisagísticos, à gestão desses parques-aterros e às formas de atuação da população neste processo. Foram sugeridas diretrizes para o plano de gestão dos parques-aterros a fim de embasar as ações da Administração Pública no caso de reformas e novas obras. 


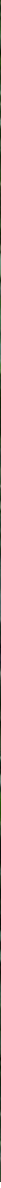


Afloramento do lixo em sub-superfície no Parque Raposo Tavares, zona oeste do município de São Paulo.

Foto da autora em 2008.

Drenos de gás no antigo aterro Vila Albertina, zona norte do município de São Paulo. Fonte: SES (2009).

Poço de monitoramento no antigo aterro Jacuí, futuro Parque Jardim Primavera, zona leste do município de São Paulo.

Fonte: SVMA (2007) 


\title{
CAPÍTULO 1
}

\section{LIXO URBANO: GESTÃO E POLÍTICA PÚBLICA NO BRASIL}

\author{
Nas favelas, no Senado \\ Sujeira pra todo lado \\ Ninguém respeita a Constituição \\ Mas todos acreditam no futuro da nação \\ Que país é este - Renato Russo
}

A geração de lixo é uma atividade inerente ao ser humano. Está presente na moradia, na indústria, no comércio, na agricultura e nas unidades de saúde. Outrora, a existência de pequenos aglomerados urbanos que produziam pequena quantidade de resíduos, compostos, principalmente, por materiais degradáveis, não representava grandes problemas para a sua disposição final. Mesmo assim, já no século XIV (1.345 - 1.349), segundo Figueiredo (1992¹; apud Silva e Donaire, 2007), registrou-se o surto da peste bubônica ou peste negra, que matou milhares de pessoas, provocada pela proliferação de ratos, devido ao acúmulo de lixo nas ruas das cidades européias.

A produção do lixo depende de fatores geográficos, sociais e produtivos. $O$ aumento da geração desses resíduos e sua inadequada administração, principalmente na etapa de destinação final, são percebidos pela predominância da disposição a céu aberto (lixões), que tem provocado efeitos indesejáveis e, muitas vezes, irreversíveis do ponto de vista sanitário e ambiental (AIDIS/IDRC, 2006).

\footnotetext{
${ }^{1}$ FIGUEIREDO, Paulo Jorge Morais. A Sociedade do Lixo. São Paulo: Editora Unimep.1992. p.24-183.
} 
Essas mesmas instituições relatam que na América Latina e Caribe tem prevalecido a gestão de resíduos sólidos pelo sistema convencional, isto é, coleta de resíduos orgânicos e inorgânicos misturados e disposição em aterros sanitários, controlados ou lixões. Comentam sobre a insuficiência dessa prática como solução ambiental, social e economicamente sustentável. Destacam que as áreas apropriadas para disposição de resíduos estão cada vez mais distantes dos locais de geração, implicando no aumento dos custos de transporte.

Nas sociedades contemporâneas a questão dos resíduos sólidos tornou-se um dos temas emergentes e de grande complexidade para a gestão das metrópoles, devido ao grande volume de resíduos produzidos e à escassez de áreas para disposição final. Aliados a esses fatos destacam-se os lixões e aterros desativados, que muitas vezes despontam na paisagem urbana como áreas abandonadas, estigmatizadas ou mesmo descaracterizadas como outros usos, sem atender aos critérios técnicos exigidos.

\subsection{Resíduos Sólidos URBanos (RSU) NO CENÁRIO BRASILEIRO}

\subsubsection{CONCEITOS E CLASSIFICAÇÕES}

O gerenciamento dos resíduos sólidos envolve uma série de etapas: acondicionamento, coleta, transporte, transbordo, tratamento e disposição final; além de exigir espaços, equipamentos e estruturas específicos para o seu funcionamento. Quanto maior a dimensão da cidade, maiores serão os volumes de resíduos gerados e a estrutura necessária para a sua gestão. Várias são as instalações para a disposição final dos resíduos urbanos: lixão, aterro controlado, aterro sanitário, aterros de inertes e depósitos clandestinos. Tais instalações localizam-se no interior da área urbana ou nas áreas periféricas (Ruberg, 2005). 
Requalificação dos Aterros Desativados (Brownfields) no Município de São Paulo: Parques (GREENFIELDS) RAPOSO TAVARES E JARDIM PRIMAVERA

LUZIA HELENA dos SANTOS BARROS

O presente trabalho tratará especialmente dos lixões e aterros controlados definindo-se, para melhor entendimento, as várias tipologias a seguir:

a) Lixões - são locais onde houve o lançamento de resíduos diversos sobre o solo, sem quaisquer critérios técnicos, medida de proteção ao meio ambiente ou à saúde pública (IPT/CEMPRE, 2000). São também conhecidos como vazadouros à céu aberto.

b) Aterros controlados - diferenciam-se dos lixões por contarem com uma cobertura de camada de terra após o descarregamento do caminhão de lixo. Esta medida evita a proliferação de vetores de doenças e a atividade de catação.

c) Aterros sanitários - "forma de disposição final de resíduos urbanos no solo, através de confinamento em camadas cobertas com material inerte, geralmente solo, segundo normas operacionais específicas, de modo a evitar danos ou riscos à saúde pública e à segurança" segundo a NBR 13.896 (ABNT, 1997).

A Política Nacional de Resíduos Sólidos (Lei 12.305/10) define os resíduos sólidos como:

[...] material, substância, objeto ou bem descartado resultante de atividades humanas em sociedade, a cuja destinação final se procede, se propõe proceder ou se está obrigado a proceder, nos estados sólido e semissólido, bem como gases contidos em recipientes e líquidos cujas particularidades tornem inviável o seu lançamento na rede pública de esgotos ou em corpos d'água, ou exijam para isso soluções técnica ou economicamente inviáveis em face da melhor tecnologia disponível (Art.3oㅡㄴ inciso XVI).

A Norma Brasileira 10.004 (ABNT, 2004) estabelece como definição:

[...] Resíduos nos estados sólido e semi-sólido, que resultam de atividades da comunidade de origem: industrial, doméstica, hospitalar, comercial, agrícola, de serviços e de varrição. Ficam incluídos nesta definição os lodos provenientes de sistemas de tratamento de água, aqueles gerados em equipamentos e instalações de controle de poluição, bem como determinados líquidos cujas particularidades tornem inviável seu lançamento na rede pública de esgotos ou corpos de água, ou exijam para isso soluções técnicas e economicamente inviáveis, em face à melhor tecnologia disponível. 
Tal como Merbach (1998 apud Leite, 2005) apontava para a definição de aterros sanitários, contida na NBR 8.419 (ABNT, 1984), as NBR's 13.896 e 10.004, também não incluíram a questão do uso futuro da área do aterro.

Para o Manual de Saneamento (MS/FNS, 1999, p. 203) os resíduos sólidos são constituídos de substâncias degradáveis e não degradáveis de composição bastante variada, que depende de diversos fatores: hábitos, costumes, renda e nível educacional da população, número de habitantes, clima, nível de desenvolvimento e variações sazonais e, definidos como:

[...] materiais heterogêneos (inertes, minerais e orgânicos), resultante das atividades humanas e da natureza, que podem ser parcialmente utilizados, gerando, entre outros aspectos, proteção à saúde pública e economia de recursos naturais. Os resíduos sólidos constituem problemas sanitário, econômico e principalmente estético.

Lopes (1998), citando Ogata (1978, p.51), destacou que o termo "resíduo" está associado a um contexto tecnológico, de aprimoramento da produção, ou seja, cultural e histórico, de acordo com Ariane Kuhnen. A autora também informa que a expressão: "resíduos sólidos e salubridade" já aparecia no Código de Posturas de 1886, artigo VI, sem, entretanto, ser utilizada nem pelas autoridades sanitárias, àquela época. Rocha (1992) apud Lopes (1998, p.163) observa que a expressão "resíduos sólidos" passa a ser utilizada pelos sanitaristas a partir de meados da década de 1960 e, segundo Lopes, esta expressão está associada à transformação da intolerância social em relação ao lixo.

Ogata (1978) afirma que o espaço da cidade registra traços das suas dinâmicas, resultantes da confrontação de energias políticas, sociais e econômicas, traduzindo-se num sistema de acumulação e fixação de atividades da sociedade ao longo dos tempos. Cita Medam $^{2}$ (1971) que relaciona a estrutura acumulada de uma memória à estrutura acumulada de uma materialidade física.

A referida autora relata que os aterros de lixo são sinais ocultos da materialidade urbana e que os resíduos sólidos urbanos depositados em aterros ("lixões" ou aterros sanitários) se destacam na materialidade física. Esses aterros são registros no espaço a serem desvendados. Outras formas de disposição dos resíduos (incineração, industrialização) não se caracterizam

\footnotetext{
${ }^{2}$ MEDAM, A. La ville-censure. Paris. (Societé et Urbanisme). Ed. Anthrópodos, 1971. 245 p.
} 
Requalificação dos Aterros Desativados (Brownfields) no Município de São Paulo: Parques (GREENFIELDS) RAPOSO TAVARES E JARDIM PRIMAVERA

LUZIA HELENA dOS SANTOS BARROS

como marcas na materialidade física. Ressalta, também, que os aterros de resíduos (1978, p.24), no sentido semiológico, representam um significante, uma linguagem, uma forma de comunicação da materialidade física. Aponta que essa materialidade física pode apresentar, entre outros, valor arqueológico, no caso dos depósitos de sambaquis (depósitos antigos de tribos que habitavam o litoral americano, constituídos de conchas, restos de cozinha e esqueletos).

Lopes (1998, p.33) destaca a expressão "aterro de lixo", utilizada por Ogata (1978), comentando que o termo "aterro" não era comum no século XIX, apesar do lixo servir, àquela época, para aterramento das áreas alagadiças da cidade.

Depósitos irregulares de resíduos, locais (terrenos baldios, praças, parques, ruas, etc.) onde a população ou as empresas habitualmente lançam os resíduos, preferencialmente de construção e demolição (entulho), mas podendo ser encontrados resíduos industriais e de saúde, são comuns. Sua localização muitas vezes é desconhecida ou conhecida como "ponto viciado", pois persiste mesmo com a sua retirada rotineira.

A classificação dos resíduos sólidos depende do seu local de produção, da sua origem, do teor de umidade, da sua capacidade de biodegradação (Quadro 1.1) bem como da periculosidade (Quadro 1.2). Segundo Moreira $(2009$, p. 3) as classes de periculosidade II e III foram agrupadas, mais recentemente, sendo renomeadas para Classe Ila (nãoinertes) e Ilb (inertes). Outra classificação importante foi estabelecida pela Resolução Conama no 5, de 05 de agosto de 1993, que se baseia no potencial de contaminação dos resíduos ao meio ambiente (Tabela 1.1). A nova "Lei do Lixo" (Lei 12.305/10) reclassificou os resíduos sólidos segundo a origem e a periculosidade (Tabela 1.2). 
Quadro 1.1: Classificação dos resíduos sólidos quanto à biodegradação

\begin{tabular}{|c|c|c|}
\hline Classificação & De acordo com & Caracterização \\
\hline Resíduos sólidos em geral & Local de produção & $\begin{array}{l}\text { Urbanos } \\
\text { Rurais }\end{array}$ \\
\hline \multirow{3}{*}{$\begin{array}{l}\text { Resíduos sólidos urbanos } \\
\text { (RSU) }\end{array}$} & Umidade & $\begin{array}{l}\text { Seco } \\
\text { Molhado }\end{array}$ \\
\hline & Origem & $\begin{array}{c}\text { Domiciliar } \\
\text { Comercial } \\
\text { Público } \\
\text { Hospitalar } \\
\text { Terminais de transporte } \\
\text { Industrial } \\
\text { Entulho }\end{array}$ \\
\hline & Capacidade biodegradação & $\begin{array}{c}\text { Facilmente degradáveis } \\
\text { Degradação moderada } \\
\text { Degradação lenta } \\
\text { Não degradáveis }\end{array}$ \\
\hline
\end{tabular}

Fonte: Rafael (2006, p.57).

Quadro 1.2: Classificação dos resíduos quanto à periculosidade (ABNT, 2004)

\begin{tabular}{|l|l|}
\hline \multicolumn{1}{|c|}{ Classe } & \multicolumn{1}{c|}{ Características } \\
\hline I - Perigosos & $\begin{array}{l}\text { Apresentam risco à saúde pública ou ao meio ambiente, caracterizando-se por } \\
\text { ter uma ou mais das seguintes propriedades: inflamabilidde, corrosividade, } \\
\text { reatividade, toxicidade e patogenicidade }\end{array}$ \\
\hline II - Não-inertes & $\begin{array}{l}\text { Podem ter propriedades, como inflamabilidde, biodegrabilidade ou solubilidade; } \\
\text { porém, não se enquadram como resíduo I ou III }\end{array}$ \\
\hline III - Inertes & $\begin{array}{l}\text { Não têm constituinte algum solubilizado, em concentração superior ao padrão de } \\
\text { potabilidade de águas }\end{array}$ \\
\hline
\end{tabular}

Fonte: Tressoldi e Consoni (1998, p.344).

Tabela 1.1: Classificação dos resíduos sólidos segundo a Resolução Conama ํำ 5/1993.

\begin{tabular}{|c|l|}
\hline Classe & \multicolumn{1}{|c|}{ Características } \\
\hline A & $\begin{array}{l}\text { Resíduos que apresentam risco potencial à saúde pública e ao meio ambiente } \\
\text { devido à presença de agentes biológicos. São resíduos dos hospitais, das clínicas } \\
\text { médicas e veterinárias, e dos bancos de sangue. }\end{array}$ \\
\hline B & $\begin{array}{l}\text { Resíduos que apresentam risco potencial à saúde pública e ao meio ambiente } \\
\text { devido às suas características químicas. São os resíduos farmacêuticos, drogas } \\
\text { quimioterápicas e demais resíduos perigosos. }\end{array}$ \\
\hline C & $\begin{array}{l}\text { Rejeitos radioativos: enquadram-se neste grupo os materiais radioativos ou } \\
\text { contaminados com radionuclídeos, provenientes de laboratórios de análises } \\
\text { clínicas, serviços de medicina nuclear e radioterapia, segundo Resolução CNEN } \\
6.05 .\end{array}$ \\
\hline D & $\begin{array}{l}\text { Resíduos comuns são todos os demais que não se enquadram nos grupos } \\
\text { descritos anteriormente. Os resíduos urbanos, em geral, se enquadram nesta } \\
\text { classe. }\end{array}$ \\
\hline
\end{tabular}

Organização: Luzia Helena dos S. Barros (2011) 
Requalificação dos Aterros Desativados (Brownfields) no Município de São PaUlo: Parques (GREENFIELDS) RAPOSO TAVARES E JARDIM PRIMAVERA

LUZIA HELENA dOS SANTOS BARROS

Tabela 1.2: Classificação dos resíduos sólidos segundo a Lei 12.305/10

\begin{tabular}{|c|c|c|}
\hline De acordo com & Classificação & Características \\
\hline Origem & $\begin{array}{l}\text { Domiciliar } \\
\text { Limpeza urbana } \\
\text { RSU } \\
\text { Serviços públicos e saneamento básico } \\
\text { Industriais } \\
\text { Serviços de saúde } \\
\text { Construção civil } \\
\text { Agrossilvopastoris } \\
\text { Serviços de transportes } \\
\text { Mineração }\end{array}$ & $\begin{array}{l}\text { Atividades domésticas em residência } \\
\text { urbanas } \\
\text { Varrição e vias públicas } \\
\text { Engloba os anteriores } \\
\text { Exceto os RSU } \\
\text { Processos produtivos e instalações } \\
\text { industriais } \\
\text { Equipamentos de saúde, etc. } \\
\text { Construções, reformas, reparos e } \\
\text { demolições } \\
\text { Atividades agropecuárias } \\
\text { silviculturais e } \\
\text { Portos, aeroportos, terminais } \\
\text { alfandegários, rodoviários, } \\
\text { ferroviários, passagens de fronteira } \\
\text { Atividades de pesquisa, extração ou } \\
\text { beneficiamento de minérios }\end{array}$ \\
\hline Periculosidade & Não-perigosos & $\begin{array}{l}\text { Possuam inflamabilidade, } \\
\text { corrosividade, reatividade, toxicidade, } \\
\text { patogenicidade, carcinogenicidade, } \\
\text { teratogenicidade e mutagenicidade } \\
\text { com risco significativo à saúde } \\
\text { pública ou à qualidade ambiental. } \\
\text { Exceto os anteriores }\end{array}$ \\
\hline
\end{tabular}

Organização: Luzia Helena dos S. Barros (2011).

\subsubsection{SITUAÇÃO DA DISPOSIÇÃO FINAL DOS RESíDUOS} SÓLIDOS NO BRASIL

Os serviços de limpeza pública constituem-se, basicamente, da coleta de resíduos domiciliares e da varrição de ruas e de seu conseqüente transporte e disposição. Outros serviços também podem estar associados, dependendo do perfil de cada município, tais como: limpeza de bocas de lobo, coleta de entulho, limpeza e coleta de resíduos das feiras livres, limpeza de córregos e margens de rios, etc. Aos municípios foi determinado, pela Constituição Federal (1988, Art. 30), a competência para legislar sobre os assuntos de interesse local, dentre eles os serviços de limpeza pública.

A Pesquisa Nacional de Saneamento Básico (PNSB) (IBGE, 2002) apontou a seguinte distribuição da destinação final do lixo coletado, em peso (Figura 1.1): 47,1\% em aterros sanitários, 22,3\% em aterros controlados e $30,5 \%$ em lixões, considerando que mais de $63,6 \%$ do lixo coletado no País possuía destinação final adequada. 


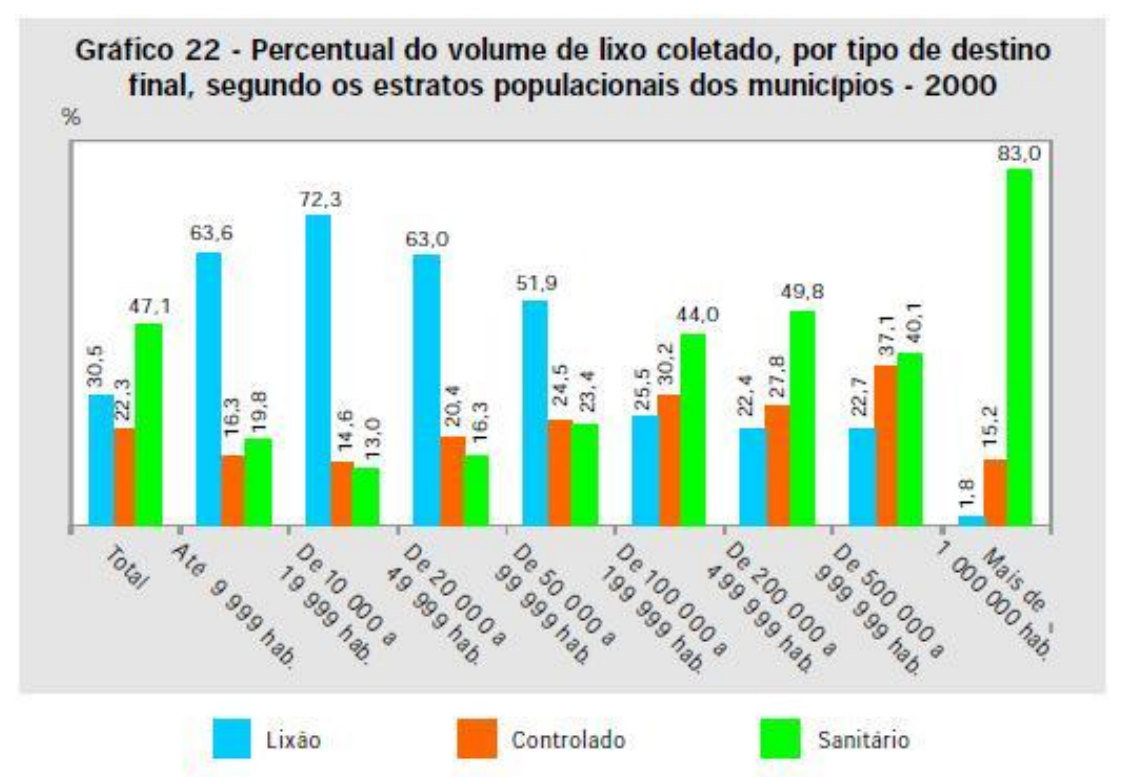

Fonte: IBGE, Diretoria de Pesquisas, Departamento de População e Indicadores Sociais, Pesquisa Nacional de Saneamento Básico 2000.

Figura 1.1: Percentual do volume de lixo coletado, por tipo de destino final, segundo os estratos populacionais dos municípios.

A pesquisa destacou, entretanto, que ao se considerar em números de municípios a situação se altera, com $63,6 \%$ dos municípios brasileiros utilizando como destinação final os lixões. Os aterros controlados e sanitários são utilizados por, respectivamente, 18,4 e 13,8\% dos municípios. Observa-se, também, que os municípios que utilizam os lixões respondem apenas por $12,8 \%$ do total de lixo produzido no País, configurando uma situação menos grave.

O relatório "Diagnóstico de Manejo de Resíduos Sólidos Urbanos 2007" (MC, 2007), referente ao levantamento de 291 municípios, possuindo o total de 87.701.749 habitantes, sendo 83.806.317 de população urbana, indicou que foram coletadas 29.629 .735 toneladas de resíduos domiciliares e públicos no País. Do total de resíduos coletados 31,1\% foram dispostos em lixões, 31,9 em aterros controlados e $37,1 \%$ em aterros sanitários. Considerando os resíduos exclusivamente domiciliares, foram coletados cerca de 0.73 $\mathrm{Kg} / \mathrm{habitante}$ atendido/dia.

A Associação Brasileira de Limpeza Pública e Resíduos Especiais (Abrelpe, 2009) realizou uma pesquisa, em 2009, em 364 municípios, que correspondem a 81,6 milhões de habitantes $(51,4 \%$ da população urbana total 
Requalificação dos Aterros Desativados (Brownfields) no Município de São Paulo: Parques (GREENFIELDS) RAPOSO TAVARES E JARDIM PRIMAVERA

Luzia Helena dos Santos Barros

brasileira ${ }^{3}$ ) nos quais foram gerados cerca de 57 milhões de toneladas de RSU, com a relação per capita de 359,4 Kg/hab/ano. Deste total, cerca de 50 milhões de toneladas foram coletadas $(316,7 \mathrm{Kg} / \mathrm{hab} / \mathrm{ano})$, correspondendo a 161 toneladas/dia, com maior índice registrado na região sudeste. Com os dados obtidos foi feita uma projeção para todo o País. Assim, destaca-se da pesquisa o fato de mais da metade dos RSU possuírem destinação adequada. No entanto, cerca de 22 milhões de toneladas (43\%) continuam sendo destinadas aos aterros controlados ou lixões (Figura 1.2). Do total de resíduos coletados diariamente mais de $43 \%$ foram dispostos em aterros controlados ou lixões (Figura 1.3). Foi verificado, também, que nos lixões foram depositados 13,2\% do total de resíduos de serviços de saúde coletados. Considerando-se as diferentes unidades para disposição final de resíduos constatou-se que o lixão predomina nos municípios do nordeste e o aterro sanitário e controlado nos do sudeste (Quadro 1.3).
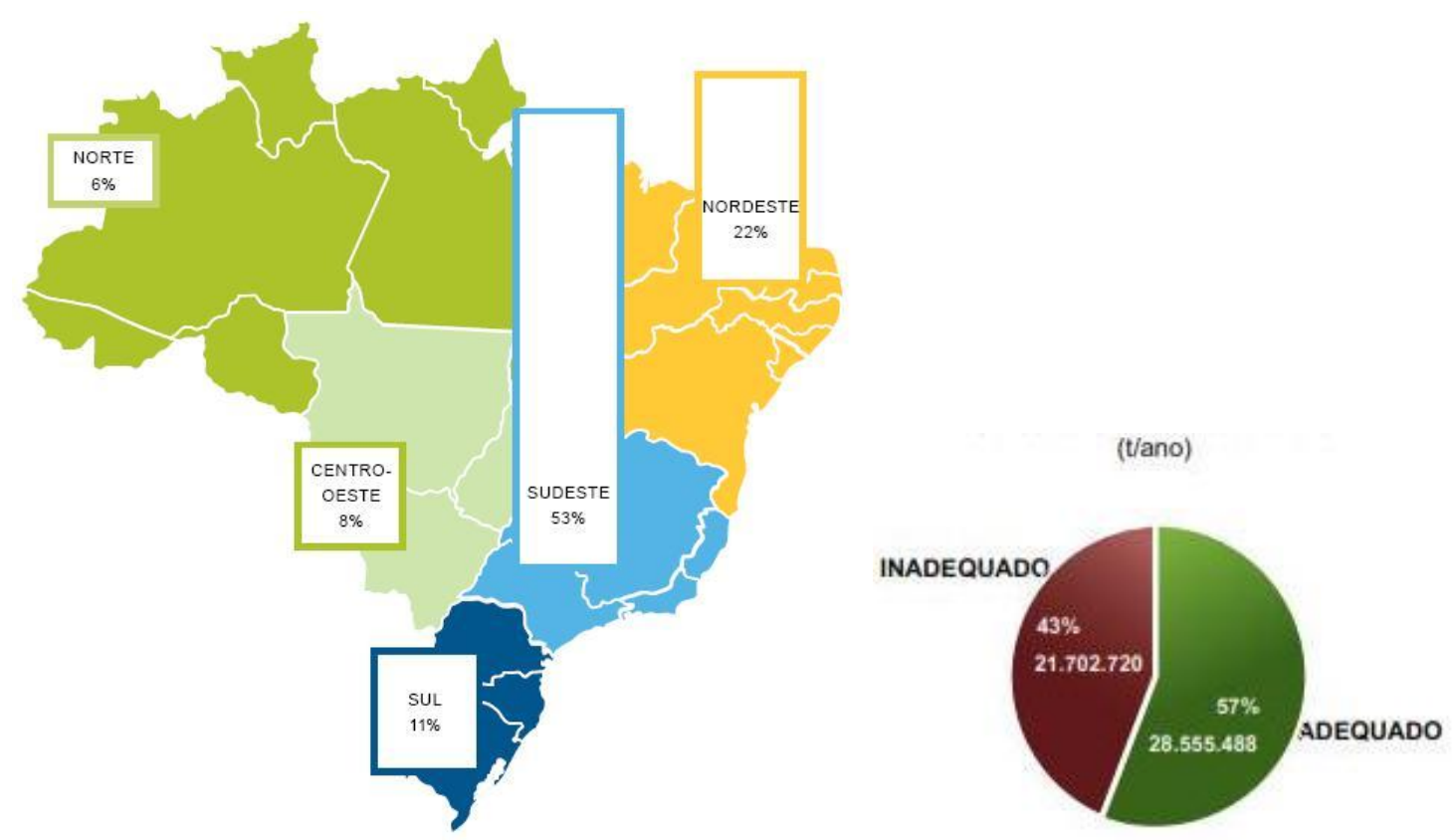

Figura 1.2 - Distribuição percentual por regiões dos RSU coletados no Brasil e situação da destinação final, em 2009.

Fonte: Abrelpe, 2009

${ }^{3}$ IBGE (2009) 


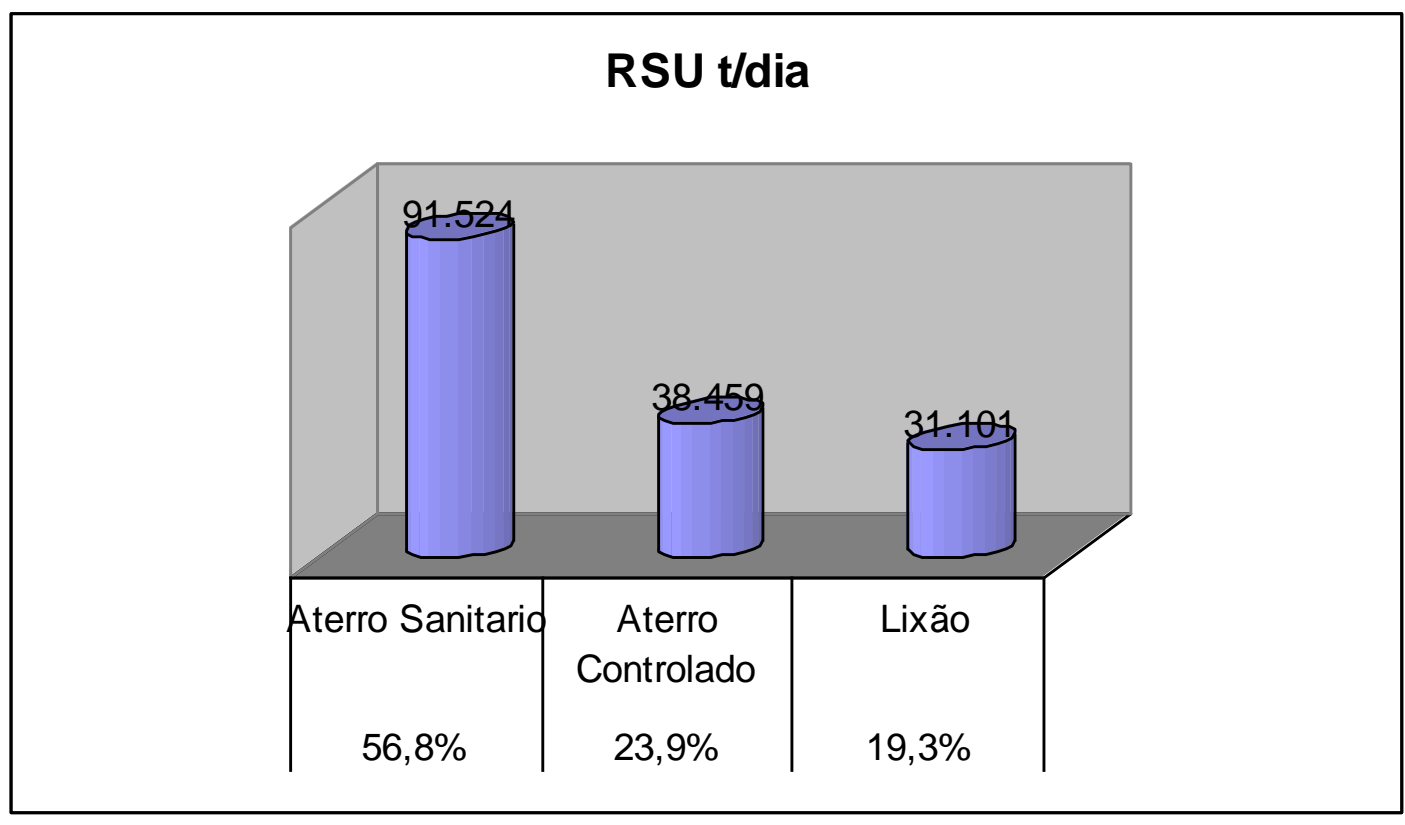

Organização: Luzia Helena dos S. Barros (2011)

Figura 1.3 - Resíduos sólidos urbanos coletados diariamente por tipo de disposição no Brasil, em 2009.

Fonte: Abrelpe (2009).

Quadro1.3 - Disposição final de RSU nos municípios brasileiros, por modalidades e regiões (os números no quadro correspondem ao total de municípios).

\begin{tabular}{|l|c|c|c|c|c|c|}
\hline \multirow{2}{*}{ Disposição Final } & \multicolumn{6}{|c|}{ Regiões e Brasil } \\
\cline { 2 - 7 } & Norte & Nordeste & Centro-Oeste & Sudeste & Sul & BRASIL \\
\hline Aterro Sanitário & 81 & 431 & 146 & 793 & 687 & 2.138 \\
\hline Aterro Controlado & 105 & 497 & 146 & 630 & 361 & 1.739 \\
\hline Lixão & 263 & 866 & 174 & 245 & 140 & 1.688 \\
\hline BRASIL & 449 & 1.794 & 466 & 1.668 & 1.188 & $\mathbf{5 . 5 6 5}$ \\
\hline
\end{tabular}

Fonte: Pesquisa ABRELPE 2009

Tiveron (2001) ressalta que a geração de resíduos diária produzida por habitante, nos municípios, pode ser considerada um dado pouco preciso, pois a pouca quantidade de lixo existente nos vários pequenos municípios dispensa a implantação de balança para sua pesagem. Afirma ainda que a grande discrepância no tamanho populacional dos municípios brasileiros (Quadro 1.4) se relaciona as diversas realidades que necessitarão de soluções bastante diferenciadas para a gestão dos resíduos sólidos. 
Requalificação dos Aterros Desativados (Brownfields) no Município de São Paulo: Parques (GREENFIELDS) RAPOSO TAVARES E JARDIM PRIMAVERA

LuZia Helena dos Santos BarRos

Quadro 1.4: População dos municípios brasileiros no ano de 2000

\begin{tabular}{|c|c|c|c|}
\hline $\begin{array}{c}\text { População } \\
\text { (habitantes) }\end{array}$ & $\begin{array}{c}\text { Número de } \\
\text { municípios }\end{array}$ & $\begin{array}{c}\text { \% em número de } \\
\text { municípios }\end{array}$ & \% população \\
\hline Até 20 mil & 4.022 & 73 & 20 \\
\hline$>100$ mil & 224 & 4 & 50 \\
\hline$>200$ mil & 107 & 2 & 41 \\
\hline$>500$ mil & 31 & 0.5 & 28 \\
\hline$>1$ milhão & 13 & 0.2 & 20 \\
\hline Total & 5.507 & 100 & 100 \\
\hline
\end{tabular}

Fonte: IBGE, 2002

\subsubsection{DisPoSIÇÃo FINAL DOS RESídUOS SÓLIDOS NO} Estado de São Paulo e alguns aspectos

METROPOLITANOS

O Inventário Estadual de Resíduos Sólidos Domiciliares 2010 (Cetesb, 2011), constatou a crescente melhoria na situação da disposição do lixo nos 645 municípios, que compõem o estado de São Paulo, e onde são gerados 26.300 toneladas diárias de RSU. A situação pode ser identificada mediante os índices de qualidade de aterro - IQR, apresentados em 1997 e 2010 (Figura 1.4).

As áreas metropolitanas se caracterizam por apresentarem um extraordinário volume de resíduos, favorecendo a degradação ambiental, que, segundo Hilst (1972 ${ }^{4}$ apud Ogata, 1983, p.19), pode ser explicado pelas seguintes situações:

- $\quad$ [...] a elevada densidade demográfica e a variedade de atividades que conduzem a uma produção de poluição muito maior e mais variada que a de um espaço rural;

- $\quad$ enquanto o índice de produção é elevado, a capacidade da atmosfera e das águas superficiais de assimilarem os detritos líquidos e gasosos é essencialmente imutável e a superfície terrestre, para a deposição dos resíduos sólidos, encontra-se muito reduzida por outras demandas do uso de espaço.

\footnotetext{
${ }^{4}$ HILST, G.R. Poluição: outra dimensão da urbanização. In: MOYNIHAN, D.P. (Org.). Desafio Urbano. São Paulo, Cultrix.1972. Cap. 8, p.105-118.
} 
Meyer et al. (2004) afirmam que a disposição final do lixo nas regiões metropolitanas implica em conflitos de uso e ocupação do solo e que a sua gestão extrapola os limites municipais; além de expor a população a riscos socioambientais.

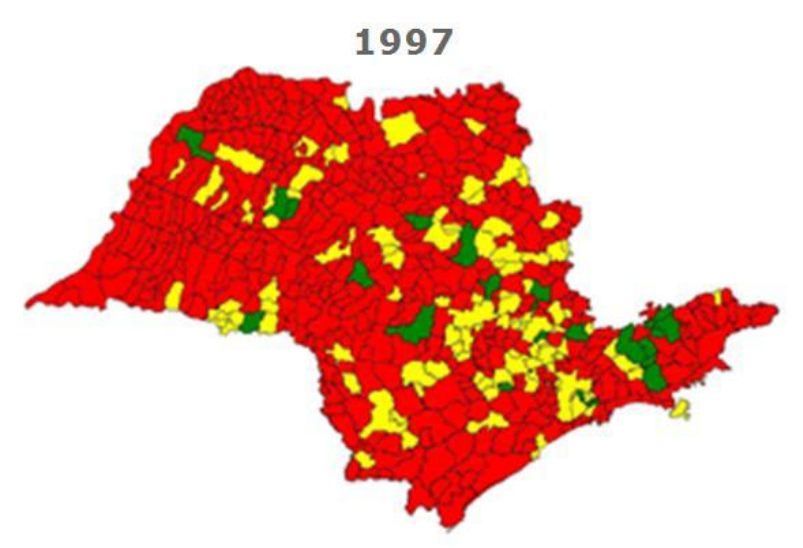

Inadequado

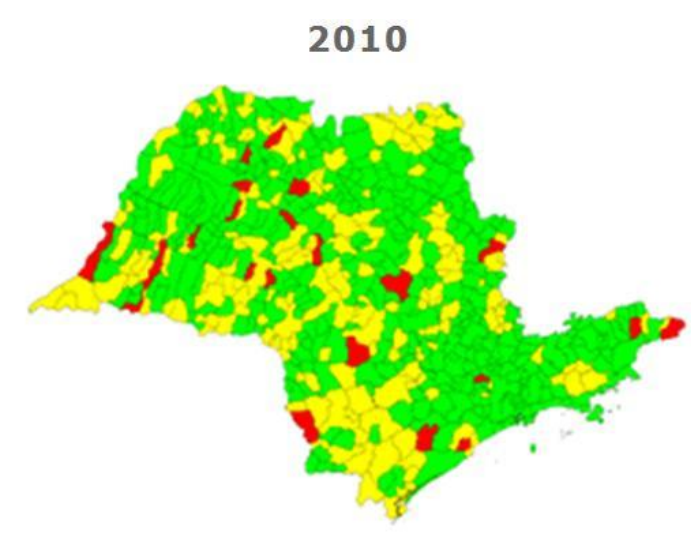

Adequado

Figura 1.4 - IQR - Índice de Qualidade de Aterro de Resíduos no Estado de São Paulo em 2010.

Fonte: Cetesb (2011).

\section{2 GESTÃo dos RSU NA METRÓPOLE PAULISTANA}

\subsubsection{HistóRICO dO destinO dO LIXO NO PERÍOdO de 1800}

A 1976

O destino do lixo no município de São Paulo historicamente se revela como um símbolo das suas dinâmicas físicas e sócio-econômicas e do nível de desenvolvimento técnico-científico e político. Lopes (1998, p. 19) afirma que

[...] a história do lixo exige uma reflexão não só sobre seu aspecto ou valor simbólico, mas também sobre a realidade técnica e científica das ações políticas e econômicas que 0 transformam, progressivamente, numa mercadoria rentável, num objeto de disputas de setores públicos e privados, num tema estratégico para as campanhas para a ordem social, [...], e ainda num assunto de grande importância para as instituições ligadas ao planejamento urbano. Por isso fazer a história do lixo é também repensar os limites da cidade e mergulhar num campo de disputas locais. 
Requalificação dos Aterros Desativados (Brownfields) no Município de São Paulo: Parques (GREENFIELDS) RAPOSO TAVARES E JARDIM PRIMAVERA

Luzia Helena dos Santos Barros

A evolução histórica aqui apresentada, limitada ao período de 1800 a 1976, justifica-se, pois é nesse intervalo da evolução da cidade que se originam muitos dos lixões e aterros controlados que ainda hoje permanecem visíveis ou invisíveis como manchas na matriz urbana, funcionando como registros das mudanças ocorridas na paisagem paulistana.

A regulamentação da destinação do lixo na cidade já se evidenciava no texto do Edital de 15 de outubro de 1722 (Lopes,1998, p.29 e Silva, 2001, p.34):

[...] Os oficiais do Senado da Câmara desta cidade de São Paulo que presente servimos pela ordenação de sua majestade que Deus guarde, fazemos saber a todos os moradores desta cidade, de qualquer qualidade ou condição que em diante façam botar os cisco e os lixos de suas casas nas paragens, declaradas, a saber, nas covas que estão atrás da misericórdia nova e nas covas que estão de fronte de Santa Tereza e somente o façam nestas paragens e as pessoas que fora destes lugares botarem os tais lixos serão condenadas por cada vez em seis mil réis sem que lhes sirva de desculpa o ignorarem onde seus servos botam os tais lixos, pois o deverão examinar e fazer escutar como pelo que o presente quartel ordenamos.

Lopes (1998, p.34), reproduzindo mapa (Figura 1.5) de Ogata (1978), afirma que até meados do século XIX os depósitos de lixo estavam identificados às pessoas (próximos ao rio, fundos de casa, etc.) dispostos num aro concêntrico, a menos de um quilômetro do centro da vila, no convívio das pessoas. Ainda não representavam um perigo.
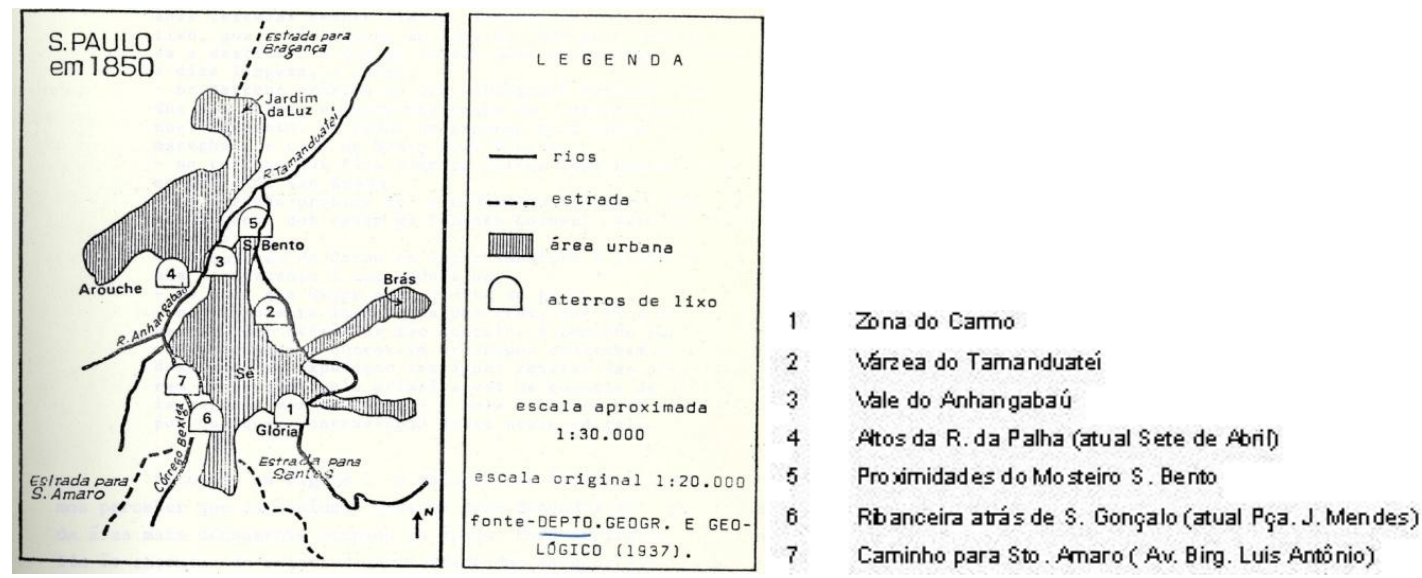

Figura 1.5: Localização dos depósitos dos lixões no período de 1800-1850 Fonte: Ogata (1978, p.50).

Nesta fase, conforme Ogata (1978), não havia coleta residencial do lixo, mas a municipalidade estabelecia locais destinados ao seu lançamento pela própria população, situados na periferia da época. Situavam-se nas 
encostas das margens esquerda e direita do Rio Anhangabaú e esquerda do Rio Tamanduateí, correspondendo aos terraços fluviais do nível intermediário. Esses terraços, definidos por Aziz Ab'Sáber, em 1958 (Ab'Sáber, 2007), possuem altitudes médias muito constantes $(745-750 \mathrm{~m})$, estendendo-se da área central da cidade até as colinas do Tatuapé, passando pelos baixos terraços (725-730 m) do Brás, Canindé e Pari. Relacionam-se a um nível de terraceamento antigo da calha-eixo dos vales do Tietê e Pinheiros.

As ameaças de epidemia, especialmente, a de febre amarela, transformaram o lixo em alvo de preocupação das autoridades, associados aos danos à saúde pública. O Código de Posturas do Município de 1886, no seu Título VII "Da higiene e salubridade pública” (Lopes, 1998, p.40) com o intuito de proteger a população quanto à ameaça das epidemias trata de regulamentar a disposição do lixo para a periferia da cidade: "Art. 98 - A Câmara designará os lugares próprios para neles ser feito o depósito de lixo e terra, afastando o mais possível das proximidades da cidade [...]".

A cidade apresentou um grande crescimento a partir de meados do século XIX, principalmente após 1875, quando São Paulo se tornava um pólo industrial (Ogata,1978). Nesta época, além de se dispor o lixo era necessário transformá-lo. Assim, o método de incineração foi implantado, de acordo com o princípio básico de não-desperdício de energia. A energia produzida no processo de queima no incinerador abasteceria alguns locais da cidade (Lopes, 1998). Os resíduos, então, passam a ser depositados sempre na periferia (Figura 1.6), a oeste da cidade, nos terraços fluviais do nível intermediário, em Santa Cecília e às margens do Rio Tietê, na ilha Capirunduva, formada pelos seus meandros, e onde estava instalado o incinerador da Ponte Pequena (Ogata , 1978).

Em 1914, a Postura Municipal decretada pelo então Prefeito Washington Luiz definiu o que era lixo e o que não era (Lopes, 1998, p.91):

- [...] lixo, para efeitos de remoção pela limpeza pública, abrange todos os detrictos, animaes, vegetaes, minerais e industriais encontrados nas ruas públicas e também todos os detritos domiciliares sólidos resultantes da limpeza de qualquer prédio, estabelecimento ou casa de habitação inclusive jardisn, páteos, cozinha e quaisquer dependências;

- [...] os objetos de uso doméstico que pelas suas dimensões e peso, não caibam nos recipientes destinados a conter os detritos domiciliares, os resíduos industriais de qualquer natureza, os objetos e artigos imprestáveis ou condenados para o consumo, que pela sua 
Requalificação dos Aterros Desativados (Brownfields) no Município de São Paulo: Parques (GREENFIELDS) RAPOSO TAVARES E JARDIM PRIMAVERA

Luzia Helena dos Santos Barros

quantidade não caibam nos recipientes destinados a conter os resíduos domiciliares; os restos de materiais de obras e construções e o produto de demolição e entulho de qualquer natureza. Esses produtos, resíduos e objetos não serão removidos pela limpeza pública, mas esta é obrigada a aceitá-los nos lugares de destino final do lixo.

O impulso na industrialização devido à $1^{\text {a }}$ Guerra Mundial e o conseqüente crescimento populacional, no começo do século $\mathrm{XX}$, trouxe vários problemas à administração pública, dos quais, a poluição do Rio Tietê, que além do lixo, recebia, também, os esgotos da cidade. Nesta fase, a principal forma de destinação do lixo eram os lixões. Segundo declaração do Prefeito Washington Luiz Pereira de Souza, os lixões deveriam ser extintos, pois o crescimento urbano logo os englobavam (Ogata, 1978). Petrone (1958 apud Ogata, 1978) distinguia três zonas funcionais na cidade. A zona comercial, correspondendo ao centro velho, e a industrial, aos bairros de várzea, próxima à ferrovia (Brás, Mooca e Belenzinho). A zona residencial incluía os bairros aristocráticos (Campos Elísios até a Av. Paulista e a nascente do Jardim América), os bairros de classe média, na periferia e, os bairros operários junto à zona industrial.

O mapa dos locais de disposição do lixo no período de 1925 a 1950 (Figura 1.6), elaborado por (Ogata, 1978), mostra que os mesmos se situavam na periferia, nas porções oeste, norte e leste da cidade, formando um semicírculo. Estes locais situavam-se nos compartimentos geomorfológicos do espigão central (incinerador Araçá), nas altas colinas e espigões secundários (aterro da Rua Galeno de Almeida), nos baixos terraços fluviais do vale do Tietê (lixão da 4⿳亠丷 Parada, no Belenzinho) e na várzea do Rio Tietê (lixão da Rua Anhanguera, na Barra Funda e compressor de latas, na Ponte Pequena).

O espigão central, as altas colinas e os espigões secundários, são elementos topográficos, também, definidos por Ab'Saber, em 1958. O primeiro, com direção SE-NW, se constitui na principal plataforma interfluvial do sistema de colinas paulistanas, estendendo-se do Jabaquara até o Sumaré (790-820 $\mathrm{m})$. As altas colinas dos rebordos dos espigões principais são regiões relativamente acidentadas onde estão as cabeceiras dos afluentes da margem esquerda do Rio Tietê e direita do Rio Pinheiros, com altitudes entre 780-830m. 
Os espigões secundários são patamares elevados e planos, descontínuos e decrescentes, perpendiculares ao eixo do divisor Tietê-Pinheiros, com altitudes variando entre 750 e 800 m (Ab'Saber, 2007, p.105-107).

Em meados do século XX, conforme relata Ogata (1978), houve o incremento da industrialização associada à crise do café transformando São Paulo em pólo de atração de população e numa grande cidade. É nesta época que já se projetava a retificação do Tietê, intensificando-se o lançamento de resíduos nas suas margens. O fato contribuiria para o lançamento dos resíduos próximo ao centro produtor, por propiciar um longo período para sua deposição e com a valorização de grandes e antigos alagados, próximo ao centro. Além disso, surgem as estações zimotérmicas, pelo processo Beccare, precurssoras das usinas de compostagem. Neste período, também, é implantado o primeiro aterro sanitário de São Paulo, de acordo com depoimento de Ribeiro da Luz ${ }^{5}$, na Rua Pedro de Toledo, próximo ao Ibirapuera, onde se encontra o Centro Recreativo do Bem Estar Social.

A autora destaca, ainda, que na fase de 1925-1950 os resíduos são racionalmente utilizados, evitando-se o desperdício de recursos naturais e que os locais de disposição ultrapassam as margens dos rios Tietê e Pinheiros (Figura 1.6). Situam-se nos terraços fluviais de nível intermediário, nos baixos terraços fluviais dos vales do Tietê e Pinheiros e na várzea dos rios Tietê, Pinheiros e Tamanduateí.

No estado de São Paulo o período de 1956 a 1970, segundo Negri (1996 ${ }^{6}$ apud Morinaga, 2007) foi marcado pela industrialização pesada e pela "consolidação dos materiais de uma sociedade urbana e industrial".

Quanto à disposição dos resíduos Ogata (1978) afirma que no período de 1950 -1975 (Figura 1.6) houve o predomínio dos lixões, mas outras formas se fazem presentes como o aparecimento da usina de compostagem, em 1970 e do primeiro aterro, reconhecido como sanitário, em Lauzane Paulista, em 1974.

É importante observar, no entanto, que a nomenclatura aterro sanitário utilizada na época, corresponde na verdade ao que hoje denominamos aterro controlado. São considerados como aterros sanitários, tal

\footnotetext{
${ }^{5}$ Rocha, A.A. A história do lixo. In: Resíduos sólidos e meio ambiente no Estado de São Paulo. São Paulo: Coordenadoria de Educação Ambiental, 1992.

${ }^{6}$ NEGRI, B. concentração e desconcentração industrial em São Paulo. Campinas, Editora da Unicamp. 1996.
} 
Requalificação dos Aterros Desativados (Brownfields) no Município de São Paulo: Parques (GREENFIELDS) RAPOSO TAVARES E JARDIM PRIMAVERA

LuZia Helena dos Santos BarRos

como definidos anteriormente, no município de São Paulo, apenas os aterros Bandeirantes e São João, hoje encerrados.

$\mathrm{Na}$ década de 1950, as indústrias avançaram para o vale do rio Pinheiros (Vila Leopoldina, Jaguaré, Jurubatuba), periferia da área metropolitana. Em seguida, devido à mudança do transporte ferroviário para rodoviário, elas começaram a ocupar os terrenos mais altos, na direção de Guarulhos, São Bernardo do Campo e Diadema. Este deslocamento foi acompanhado pela mudança de uso do solo, onde os bairros industriais passaram a mistos e estes a residenciais. Este processo também acarretou alteração na localização das áreas de disposição de resíduos, mostrando uma nova tendência para se localizarem nas colinas. Os lixões serão expulsos da várzea, pois já terão cumprido o seu papel de valorização imobiliária dos antigos alagados (Ogata, 1978).

Entretanto, tal como observa, também Ogata, a várzea ainda será por muito tempo o local preferencial para a disposição do lixo. O Projeto de Recuperação de Áreas com Resíduos Sólidos (RARES) criado pelo Prefeito Miguel Colassuono (1973 - 1975), tinha o objetivo de aterrar, com resíduos sólidos, todas as áreas adjacentes do rio Tietê, a ser retificado. Assim, nesta fase, as áreas de disposição de resíduos situavam-se em diferentes compartimentos geomorfológicos (Ogata, 1978): altas colinas e espigões secundários, altas colinas da periferia e várzea do Rio Tietê, Pinheiros e outros rios (Anexo $A)$.

Após 1975, Ogata (1978) informa que o município adotava quatro formas de destinação dos resíduos sólidos: o aterro sanitário, mais expressivo, o lixão, a usina de compostagem e a incineração (Figura 1.7). Destas, as duas primeiras predominaram por várias décadas (Figura 1.8), sendo responsáveis por cerca de 80 \% da disposição de todos os resíduos coletados em 1976. Afirma que o lixão está em vias de extinção, persistindo somente o lixão do Itaim Paulista. 


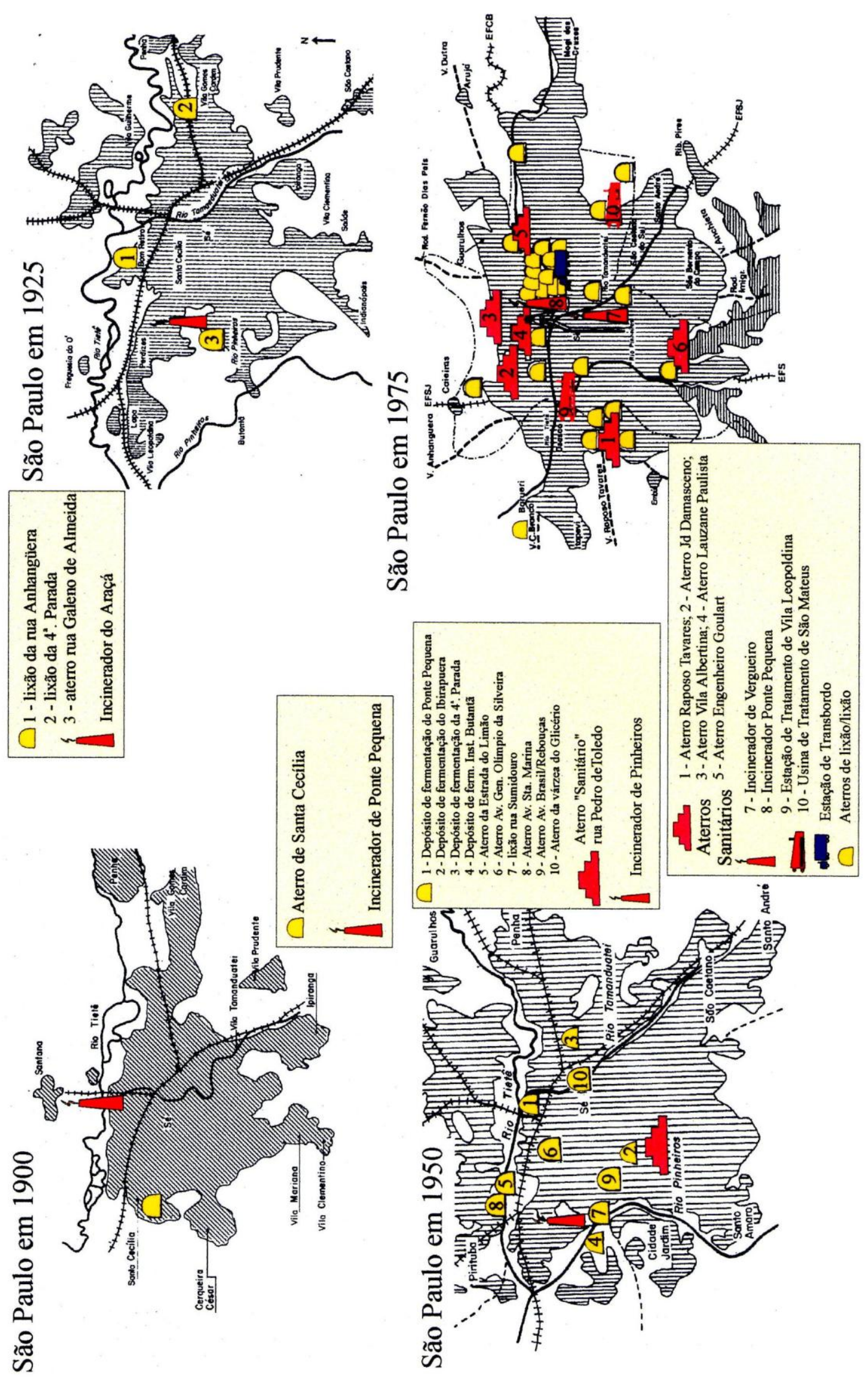

Figura 1.6- Áreas de disposição de lixo no município de São Paulo entre 1850 a 1975.

Fonte: Rodriguez (1998, p.92), reproduzido de Ogata (1983) 


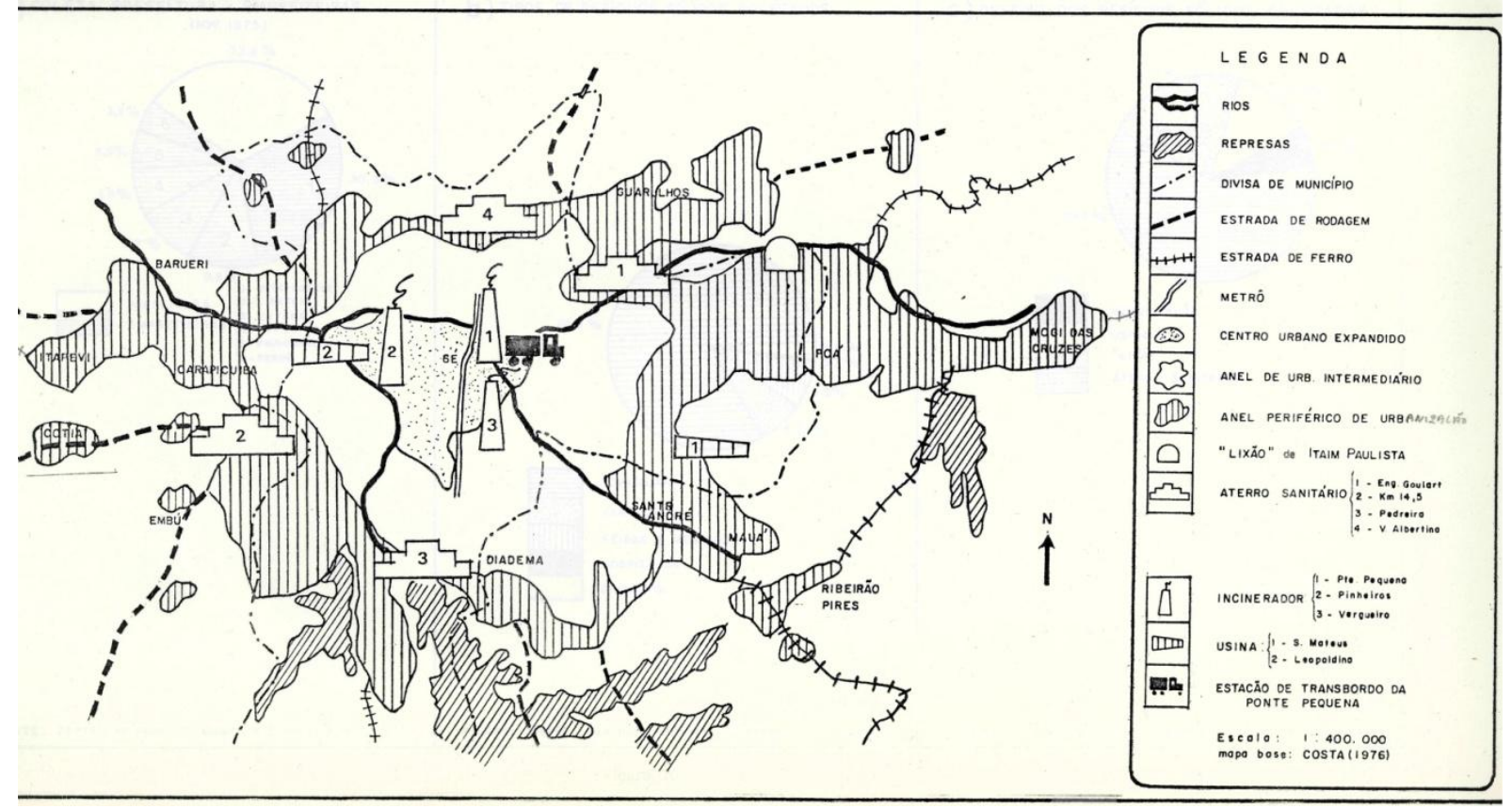

Figura 1.7 - Localização das áreas de disposição de lixo no período de 1975 - 1976 Fonte: Ogata $\left(1978, s / n^{\circ} p\right)$.

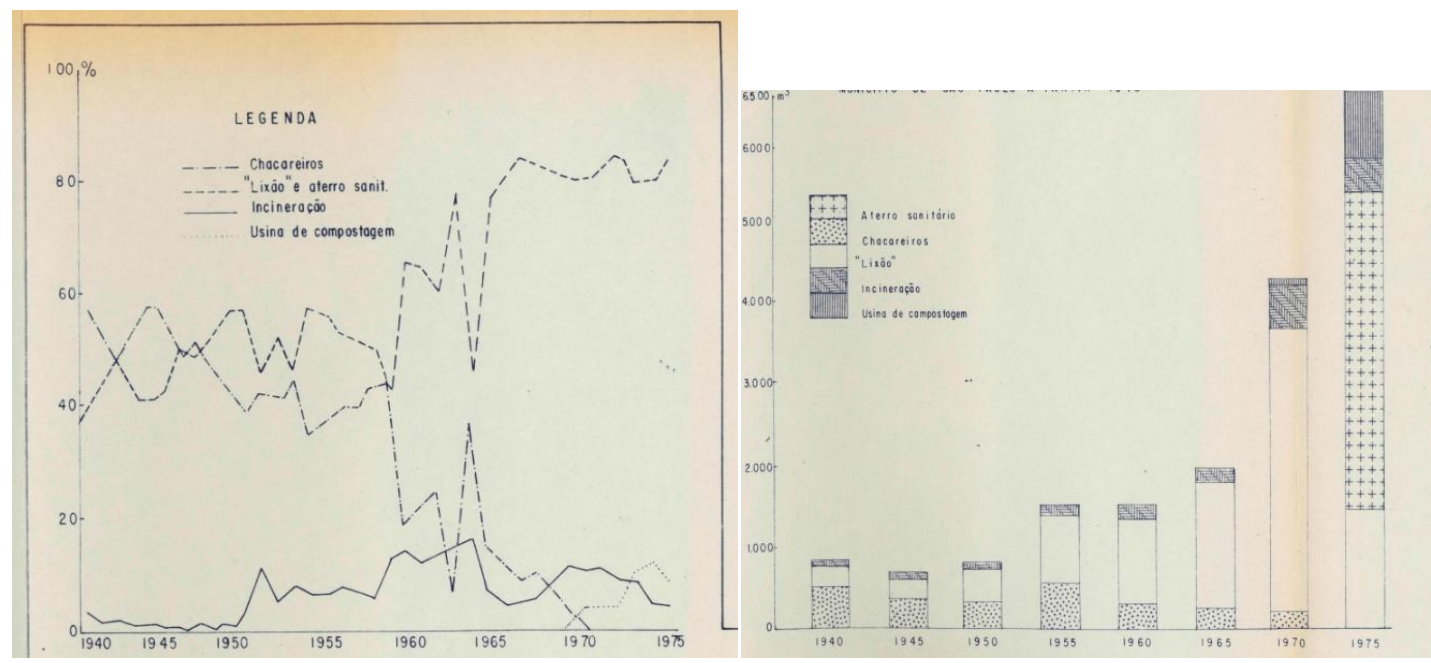

Figura 1.8 - A evolução dos resíduos sólidos no município de São Paulo no período de 1940 a 1975: fases de disposição, quantidade e formas de destino final.

Fonte: Anuários da Limpeza Pública da Prefeitura do Município de São Paulo apud Ogata (1978, Prancha II).

A autora no seu estudo sobre a evolução da disposição dos resíduos sólidos no município de São Paulo no período de 1800 a 1976 aponta que os lixões e os aterros sanitários necessitam de grandes áreas para se instalarem, disponíveis, em geral, na periferia. A localização dessas áreas na periferia faz com que as mesmas não sejam percebidas pela maioria dos cidadãos. Somente a população do seu entorno é que percebe a dimensão clara e visível 
dessas áreas na materialidade física da cidade. Mediante o seu estudo concluiu, então, que o problema dos resíduos sólidos afeta diretamente os elementos da "cidade pressão" e não a população como um todo. Portanto, essa característica, leva a pouca importância dada ao tema na formalização das políticas públicas. Considerou, também, que os resíduos sólidos serviriam como indicador do grau de eficiência da urbanização de São Paulo.

O histórico de disposição final do lixo no município mostra que aqueles locais relacionavam-se às antigas atividades de mineração, sejam as cavas de extração de areia, ao longo das planícies aluvionares dos rios Tietê e Pinheiros ou, as pedreiras, junto às encostas dos maciços de solos/rochas do embasamento cristalino, zonas mais periféricas ao centro urbano.

Tammemagi $\left(1999^{7}\right.$ apud Ruberg, 2005) comenta que as áreas de mineração, em geral, são inadequadas à disposição de resíduos, pois possuem baixa estabilidade estrutural e, preferencialmente, taludes mais íngremes; além da concepção do seu projeto estar restrita à vida útil da mina, sem considerar o seu reuso como depósito de resíduos, por mais 20 ou 30 anos. Adiciona, ainda, que são áreas geologicamente complexas, podendo conter estruturas que favorecem a condução das águas subterrâneas, exigindo barreiras mecânicas adicionais para garantir a impermeabilização do solo.

Silva (2001, p.37) informa que, em 1974, a Prefeitura publicava o primeiro edital para execução de aterros sanitários ${ }^{8}$. O edital incluía algumas especificações para os projetos a serem desenvolvidos nos locais indicados pela Prefeitura, tais como: incluir eventual sistema de drenagem; receber todo e qualquer tipo de resíduo, com exceção de animais mortos de grande porte e resíduos patológicos, que deveriam ser incinerados, construção de células de 2 a 4 metros de altura, a serem recobertas diariamente por uma camada com 15 a $30 \mathrm{~cm}$ de espessura e implantar uma camada de recobrimento final com no mínimo $60 \mathrm{~cm}$. Essas especificações, no entanto, não determinavam as medidas necessárias à implantação de um aterro sanitário, tal como definido anteriormente. Desta forma, foram executados nesta época, na verdade, um total de oito aterros controlados: Lauzanne Paulista, Vila São Francisco, Jardim

\footnotetext{
7 TAMMEMAGI, H. The waste crisis: landfills, incinerators and the search for a sustainable future. New York: Oxford, 1999.

${ }^{8}$ Processo administrativo no $073.038 / 1974$.
} 
Requalificação dos Aterros Desativados (Brownfields) no Município de São Paulo: Parques (GREENFIELDS) RAPOSO TAVARES E JaRdiM PRIMAVERA

Luzia Helena dos Santos Barros

Damaceno,.Pedreira Itapuí, Pedreira City, Carandiru, Engenheiro Goulart e Raposo Tavares.

Ao longo da história, os diversos tipos de resíduos produzidos no município, vêm se modificando. Entretanto, a geração de papel, papelão e jornal mostra-se relativamente constante, assim como permanece uma alta taxa de geração de matéria orgânica (Figura 1.9, Anexo B).

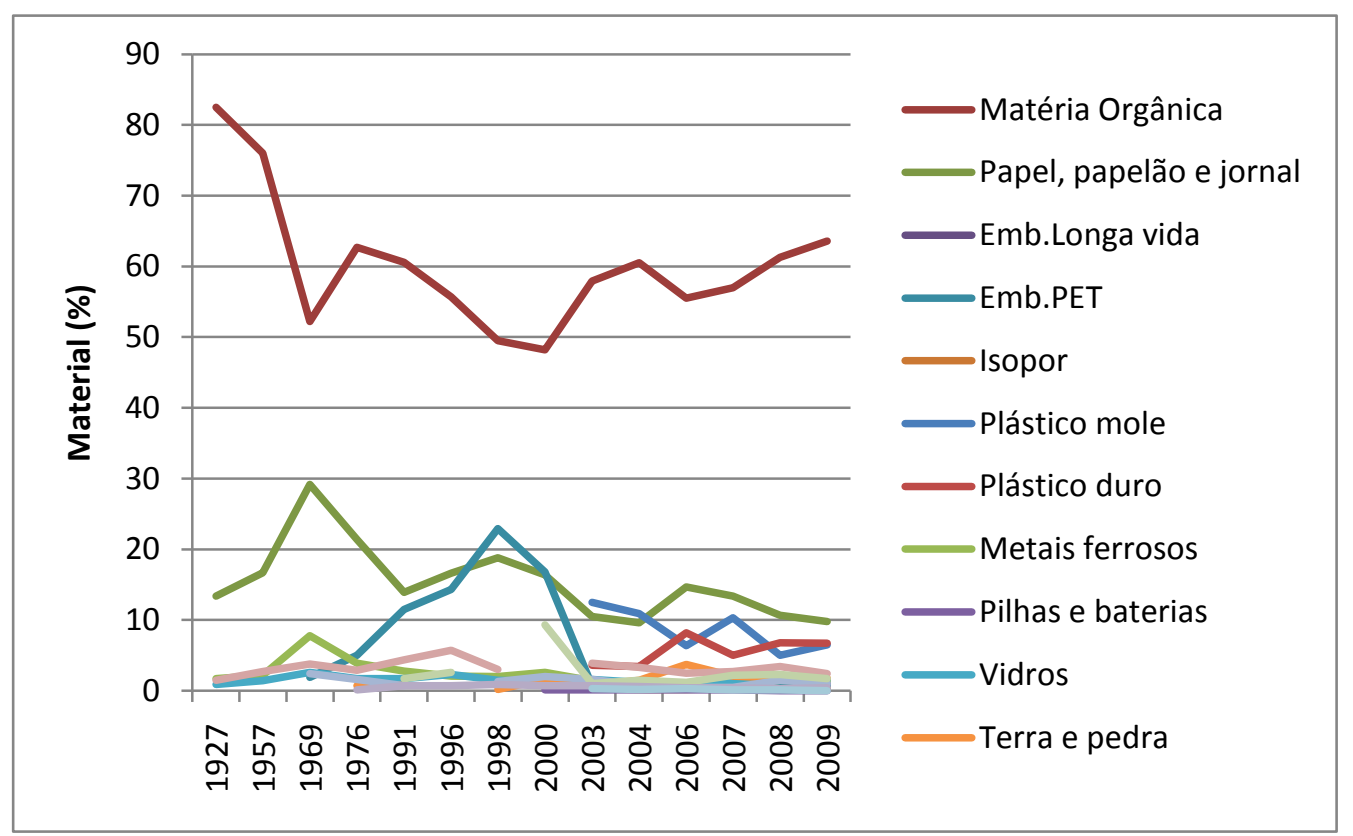

Elaboração: Luzia Helena dos S. Barros (2011)

Figura 1.19 - Evolução histórica da caracterização dos resíduos coletados no município. Fonte:Tiveron (2001); Grimberg (2009); SES/Limpurb (2004; 2010).

\subsubsection{SISTEMA DE DISPOSIÇÃo FINAL DOS RSU NO MUNICÍPIO dE SÃo PAULO}

No município de São Paulo, a gestão dos serviços de limpeza pública (Lei 13.478/2002) está a cargo do Departamento de Limpeza Urbana (Limpurb), pertencente à Secretaria Municipal de Serviços (SES). Entretanto, alguns serviços como limpeza de bocas de lobo e galerias de águas pluviais, poda e remoção de árvores e corte de grama em áreas públicas, estão sob a responsabilidade da Secretaria da Coordenação das Subprefeituras ou das próprias Subprefeituras. 
Atualmente, o município conta com as seguintes unidades de disposição final dos resíduos sólidos urbanos: transbordos Ponte Pequena, Vergueiro, Santo Amaro e São João e os aterros sanitários de Pedreira e Caieiras, este último situado no município de Caieiras (Figura 1.10). Os resíduos inertes, principalmente os entulhos de construção, são destinados aos aterros de inertes de Itaquera, Lumina, Vila Brasilândia e Riuma. Integra também o sistema, a unidade de desativação eletrotérmica, para tratamento dos resíduos de saúde e 37 ecopontos. Os aterros Bandeirantes e São João foram encerrados, respectivamente, em 2007 e 2008 (SES/Limpurb, 2010).

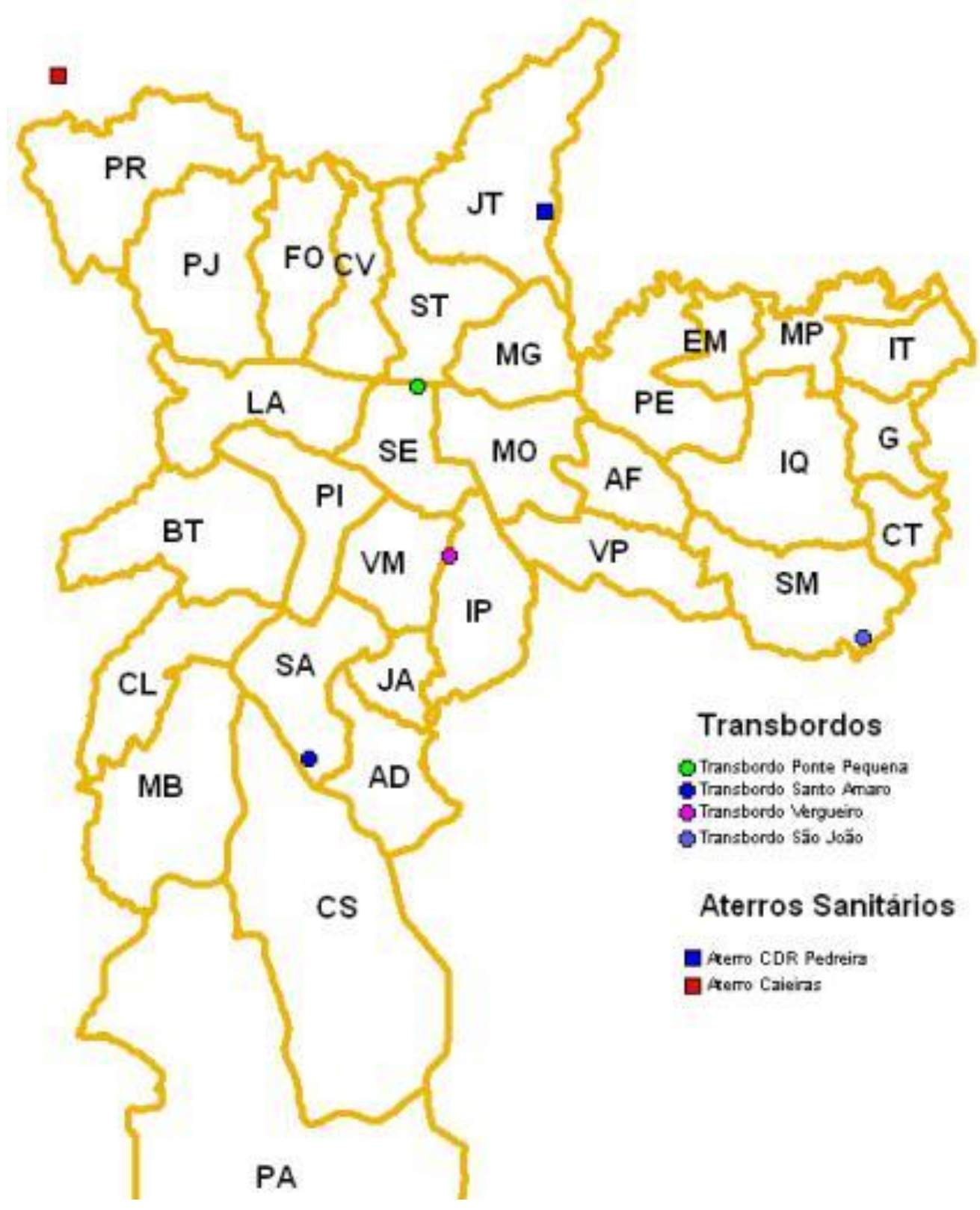

Figura 1.10: Unidades de disposição final dos resíduos sólidos urbanos no município. Fonte: SES/Limpurb (2010). 
Requalificação dos Aterros Desativados (Brownfields) no Município de São Paulo: Parques (GREENFIELDS) RAPOSO TAVARES E JARDIM PRIMAVERA

LUZIA HELENA dos SANTOS BaRRos

De acordo com a SES/Limpurb (2010), em 2009, foram coletadas diariamente cerca de 9.900 toneladas de resíduos sólidos domiciliares. Desse total, 4.230 toneladas são enviadas para a estação de transbordo Ponte Pequena, 1.500 para Vergueiro, 2.500 para Santo Amaro e 1.040 para São João, as quais são dispostas no CTR Caieiras (5.000 t.) e no CTR Pedreira (4.900 t.). A coleta de serviços de saúde totaliza 91 toneladas/dia, enquanto que a coleta seletiva 94 toneladas/dia. A coleta de resíduos realizada pelas subprefeituras corresponde ao total de 487 toneladas/dia. Do total de resíduos coletados $70 \%$ correspondem aos resíduos sólidos domiciliares e de feiras livres. Os resíduos dispostos em aterros totalizam 16.815 toneladas/dia, sendo que $12.485 \mathrm{em}$ aterros sanitários e $4.330 \mathrm{em}$ aterros de inertes (Figura 1.11).

A grande desigualdade socioambiental do município explica a variedade na distribuição da geração de resíduos encontrada. Os índices variam de 0,3 a $1,7 \mathrm{Kg} / \mathrm{hab} / \mathrm{dia}$, com os índices mais baixos ocorrendo nas zonas sul e leste e os mais altos na zona central (Figura 1.12).

Conforme apontado anteriormente, desde a década de 70 , os lixões e aterros controlados foram abandonados como forma institucionalizada de disposição final dos resíduos sólidos urbanos e praticamente inexistem no sistema de gestão, dificultando as atividades de manutenção e vigilância. Atualmente, estão sob manutenção ou vigilância da Prefeitura os seguintes aterros controlados: Sapopemba, Santo Amaro, Vila Albertina e Itatinga (inertes). No próximo capítulo se apresenta uma descrição sucinta dos aterros desativados municipais.

Inicialmente, o lixo era disposto nos lixões que ao longo do tempo deram lugar aos aterros controlados e, por último, aos aterros sanitários. Segundo Benvenuto e Cunha $(1992)^{9}$ e Schmidell e Vitoratto $(1992)^{10}$, citados por Pellogia (1998), os aterros sanitários representam a melhor solução técnica e econômica para a disposição da maior parte dos resíduos urbanos. Porém, fazem ressalvas aos projetos geotécnicos implantados em São Paulo e no Brasil.

\footnotetext{
${ }^{9}$ BENVENUTO, C. ; CUNHA, M.A. A estabilidade geotécnica de aterros sanitários. Construção (2314). 1992. p. $23-26$. ${ }^{10}$ SCHIMIDELL, W.; VITORATTO, E.O. O desafio do lixo urbano. Revista Politécnica. 1992. (204 - 205). p. 40-42.
} 


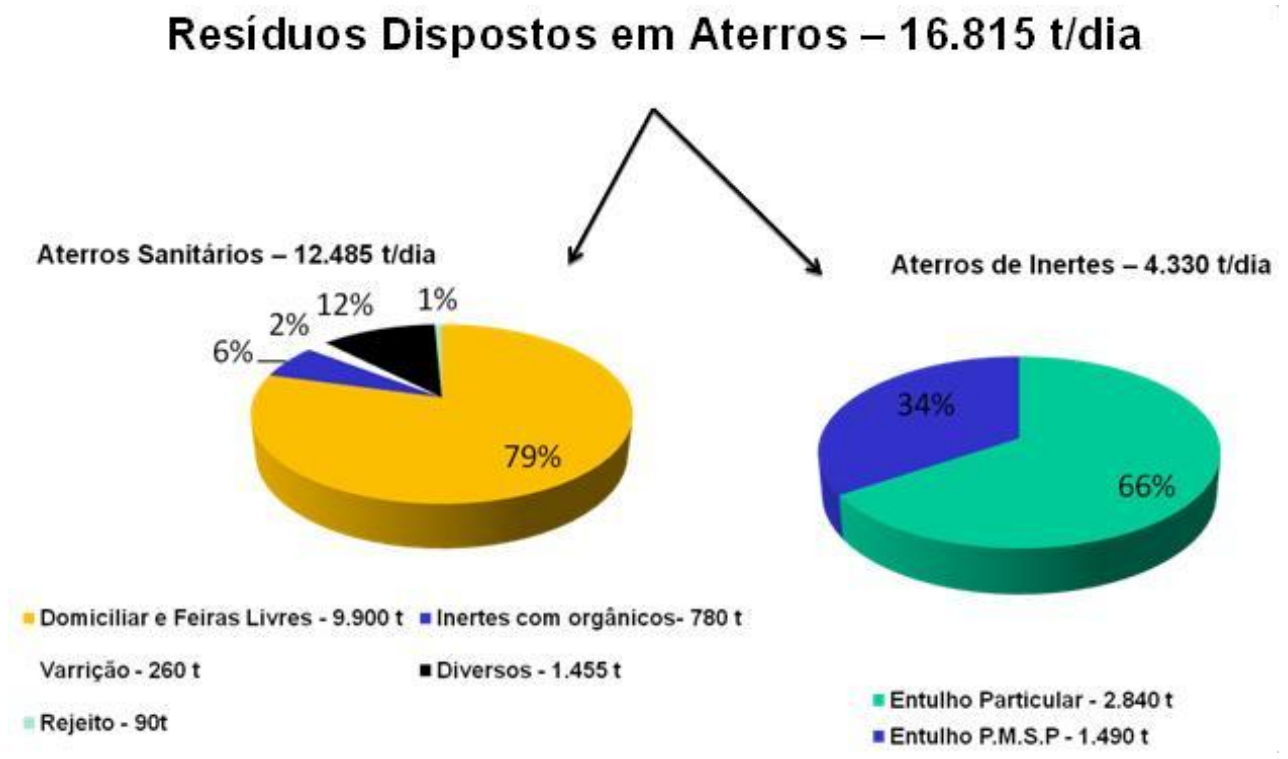

Figura 1.11: Volume de resíduos sólidos urbanos no município dispostos em aterros. Fonte SES/Limpurb (2010).

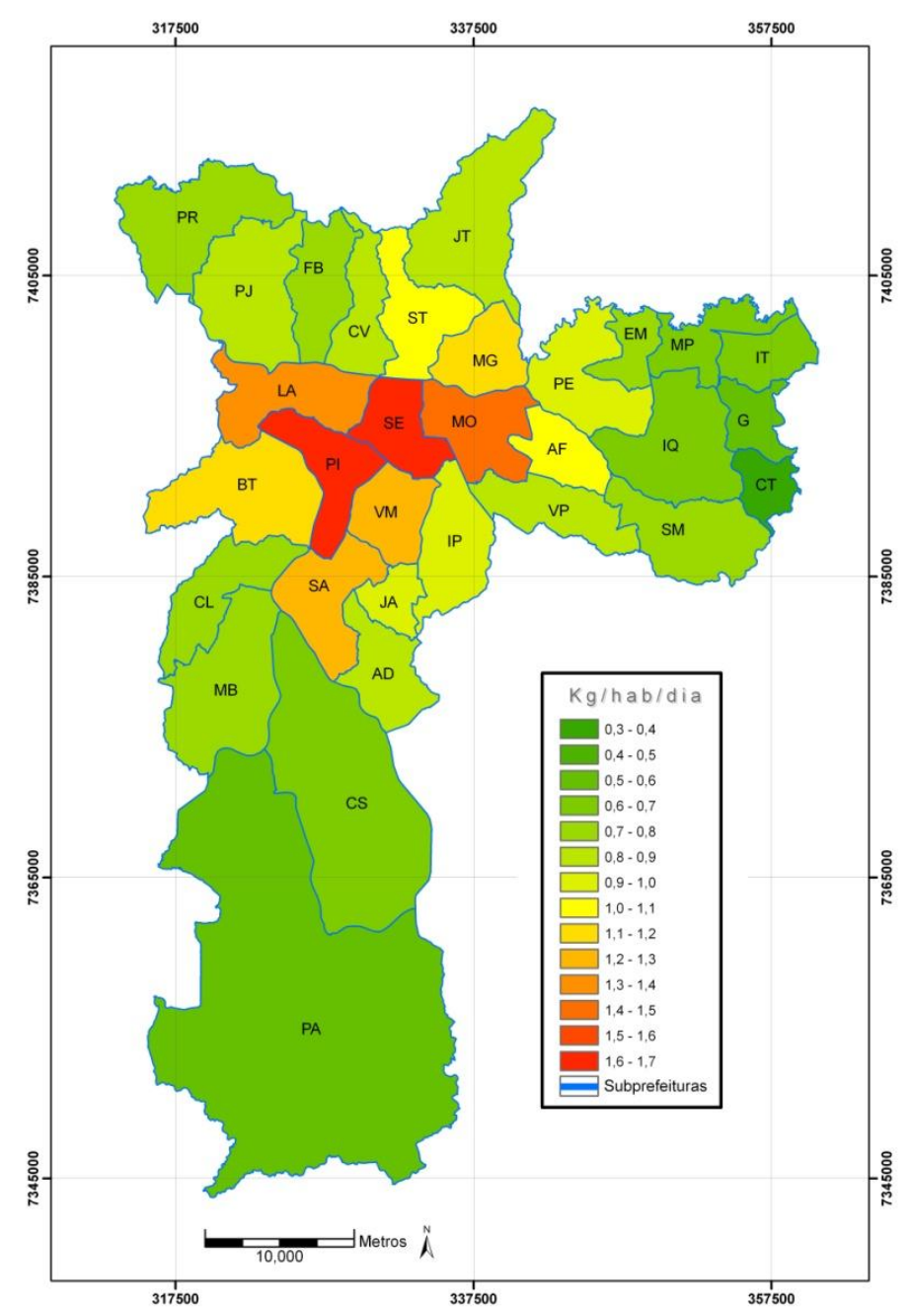

Elaboração: Luzia Helena dos S. Barros (2011)

Figura 1.12: Coleta per capita de RSU por Subprefeituras no município de São Paulo (2009) Fonte: SES/Limpurb (2010) e SMS (2009). 
Requalificação dos Aterros Desativados (Brownfields) no Município de São Paulo: Parques (GREenfiELDS) RAPOSO TAVARES E JARDIM PRIMAVERA

Luzia Helena dos Santos Barros

A gestão dos resíduos sólidos, em regime de concessão desde 2004, demonstra que o município hoje passa por uma fase crítica, operando com dois aterros sanitários, sendo um deles situado fora dos seus limites. Ainda coexistem no sistema muitos pequenos lixões (pontos viciados) e os antigos lixões ou aterros desativados dispersos na sua malha urbana. Não há menção clara sobre as ações desenvolvidas nesses antigos aterros. A obtenção de informações sobre a gestão dos resíduos é difícil, pois não há produção de relatórios periódicos pelo Limpurb, antes comuns, tal como relatou Grimberg (2009). Concomitantemente existe uma desestruturação geral do Limpurb, que dificulta a integração e a continuidade das ações. Esta situação atesta a precariedade com que o tema é tratado, tal como já afirmava Ogata (1978, p.110-111).

[...] O problema dos resíduos sólidos não afeta diretamente moradores da cidade como um todo, como no caso da poluição do ar que atinge dos subúrbios operários até os bairros de classe A. Nosso tema de estudo afeta principalmente os elementos da "cidade pressão", o que favorece com que ele seja tratado como um tema marginal no quadro da política urbana. (....) É nesse sentido que consideramos os resíduos sólidos como um indicador de verificação do grau de eficiência da urbanização atual de São Paulo.

\subsection{Políticas Públicas de Resíduos Sólidos}

\subsubsection{Política Nacional de Resíduos Sólidos (PNRS)}

Há quase duas décadas vinha sendo discutida uma política pública de resíduos sólidos no Congresso Nacional. Finalmente, em agosto de 2010, foi sancionada a Lei 12.305 que institui esta política no âmbito nacional.

A Lei relaciona dentre os seus princípios a prevenção, a precaução e a responsabilidade compartilhada pelo ciclo de vida dos produtos e dentre os seus objetivos, a proteção da saúde pública e da qualidade ambiental, bem como a disposição ambientalmente adequada ${ }^{11}$ de rejeitos (Art. 6 e 7).

\footnotetext{
${ }^{11}$ Destinação de resíduos que inclui a reutilização, a reciclagem, a compostagem, a recuperação e o aproveitamento energético ou outras destinações admitidas pelos órgãos competentes do Sisnama, do SNVS e Suasa, entre elas a
} 
Determina um prazo de quatro anos, a partir da sua publicação, para a implantação desse último objetivo (Art. 54). Institui a obrigação de implementar a logística reversa ${ }^{12}$, independente do serviço público, aos fabricantes, importadores, distribuidores e comerciantes de uma série de produtos (Art. 33).

Quanto à destinação ou disposição final de resíduos sólidos ou rejeitos proíbe (Art. 47) o lançamento em praias, no mar, nos corpos hídricos e in natura a céu aberto (exceto os resíduos de mineração) e, dentre outras, as atividades de fixação de habitações temporárias ou permanentes (Art. 48).

A lei estabelece os planos de resíduos sólidos, relacionando como um dos conteúdos mínimos para os planos nacional e estaduais (Arts. 15 e 17), metas para a eliminação e recuperação de lixões. Nos planos municipais de gestão integrada (Art. 19) e no plano de gerenciamento (Art. 20) de resíduos sólidos especifica a necessidade de identificação dos passivos ambientais relacionados aos resíduos sólidos, incluindo áreas contaminadas, e respectivas medidas saneadoras.

\subsubsection{Política de Resíduos Sólidos do Estado de São PaUlo}

A Lei 12.300, de 16/03/2006, instituiu a Política Estadual de Resíduos Sólidos que definiu os princípios, as diretrizes, os objetivos e os instrumentos para a gestão integrada e compartilhada dos resíduos sólidos no estado. O artigo 13 da Lei estabeleceu a responsabilidade dos municípios pela gestão integrada e regionalizada dos RSU, em cooperação com o Estado e organismos da sociedade civil. Criou o plano metropolitano de resíduos sólidos, instituindo a gestão compartilhada entre Estado, Municípios e a sociedade civil (Parágrafo único). No Art. 14 proíbe uma série de formas de destinação e utilização de resíduos sólidos, dentre elas o lançamento "in natura" a céu aberto e a deposição inadequada no solo. No Art. 16 exige a recuperação ou remediação da degradação ou contaminação provocada pelos RSU. No Art. 62

\footnotetext{
disposição final, observando normas operacionais específicas de mopdo a evitar danos ou riscos à saúde pública e à segurança e a minimizar os impactos ambientais adversos (Lei 12.305/2010, Art. 3으, inc. VIII).

12 Instrumento de desenvolvimento econômico e social caracterizado por um conjunto de ações, procedimentos e meios destinados a viabilizar a coleta e a restituição dos resíduos sólidos ao setor empresarial, para reaproveitamento em seu ciclo ou em outros ciclos produtivos, ou outra destinação final ambientalmente adequada (Lei 12.305/2010, Art. $3^{\circ}$, inc. XII).
} 
instituiu o termo de compromisso de ajustamento de conduta ambiental, com força de título executivo extrajudicial, com a finalidade de cessar, adaptar, recompor, corrigir ou minimizar os impactos ambientais provocados pela disposição inadequada, independentemente das sanções cabíveis.

A exigência contida na nova "Lei do Lixo" quanto à identificação dos seus passivos ambientais e à implementação de medidas saneadoras está relacionada às medidas de controle ambiental e de engenharia, aplicadas à fase de encerramento do aterro. Desconsidera a importância da reconversão dessas áreas no contexto urbano e socioambiental onde estão inseridas. A exigência da sua requalificação para um uso futuro determinado poderia ter sido utilizada para garantir a efetiva inserção dessas áreas na paisagem urbana, conforme as especificidades locais. 


\section{BROWNFIELDS E ÁREAS CONTAMINADAS: HISTÓRICO E REVISÃO TEÓRICA}

A ocorrência de brownfields no tecido intra-urbano é um fenômeno decorrente da sua evolução. São marcas na paisagem que registram a transformação da economia industrial em pós-industrial, resultantes do fechamento de indústrias no período da desindustrialização (Vasques, 2009). Os brownfields abrangem não apenas as indústrias desativadas, mas, também, uma série de outras atividades: minas, comércio, sistemas de transportes, lixões, etc..

Os lixões e aterros de resíduos são incorporados à malha urbana pelo avanço da ocupação do espaço, e quando encerrados, na maioria dos casos, permanecem esquecidos, abandonados, sem tratamento adequado, configurandose em espaços subutilizados, transformando-se, então, nos chamados brownfields e em áreas suspeitas de contaminação ou contaminadas. Essas áreas podem sofrer apropriação por parte da população do entorno, como áreas informais de lazer ou até mesmo serem destinadas a espaços institucionais, de moradia ou de trabalho precário (catação), para a sobrevivência.

A reversão desses processos de degradação ambiental exige, além de políticas preventivas, ações concretas para reparação dos danos causados no 
passado - o passivo ambiental ${ }^{1}$. Dentre as evidências mais significativas desse passivo apontam-se a contaminação do solo provocada por atividades industriais e o despejo de resíduos (Sánchez, 2004).

No Brasil, acidentes de grande repercussão, especialmente em São Paulo, tais como os casos de "Cubatão", "Barão de Mauá" e "Vila Carioca", acordaram a população e os órgãos públicos, para a gravidade da questão das áreas contaminadas. Estas áreas permanecem estigmatizadas, desencadeando sérios prejuízos materiais e pessoais à população do entorno, bem como, desvalorização do preço da terra, impactos aos bens a proteger e à economia local, que dificultam a criação de novas atividades e empregos e inibem a ação de possíveis investidores.

A escassez de novos espaços nas áreas urbanas leva à busca pela revalorização dessas áreas, que, no entanto, depende da promoção de medidas para o controle da contaminação e a recuperação ambiental adequadas, que favoreçam a sua requalificação, considerando os aspectos socioambientais e culturais do local.

\section{1 Áreas Contaminadas e BrownfieldS}

A degradação ambiental pode se originar de processos naturais ou antrópicos, destacando-se dentre as suas conseqüências a transformação da paisagem. Araujo et al. (2005, p. 19) argumentam que a degradação do solo é mais grave, pois os processos de formação e regeneração dos solos são lentos e, portanto, de difícil reversão. Definem degradação ambiental como o processo que:

[...] envolve a redução dos potenciais recursos renováveis por uma combinação de processo agindo sobre a terra. Tal redução, levando ao abandono ou "desertificação" [...], pode ser por processos naturais, tais como o ressecamento do clima atmosférico, [...] erosão, alguns outros de formação do solo ou uma invasão natural de plantas ou animais nocivos. Pode também ocorrer por ações antrópicas diretamente sobre o terreno ou indiretamente em razão das mudanças climáticas adversas induzidas pelo homem $[\ldots]$.

A degradação ambiental, então, está relacionada à redução da qualidade ambiental, envolvendo o solo, a vegetação e ás águas superficiais e subterrâneas.

\footnotetext{
${ }^{1}$ É o acúmulo de danos ambientais que devem ser reparados a fim de que seja mantida a qualidade ambiental de um determinado local. (Sánchez, 2001)
} 
Segundo Sánchez (2006, p. 27), ela corresponde ao impacto ambiental negativo, sendo definida como

[...] qualquer alteração adversa dos processos, funções ou componentes ambientais, ou como uma alteração adversa da qualidade ambiental, correspondendo ao impacto ambiental negativo. Afirma que a expressão "área degradada" sintetiza os resultados da degradação do solo, da vegetação e muitas vezes das águas.

\subsubsection{BROWNFIELDS - CONCEITUAÇÃO}

Kivell (1992 ${ }^{2}$ apud Vasques, 2009) relaciona o surgimento dos brownfields com as mudanças econômicas, tecnológicas e sociais responsáveis pelas readaptações na utilização dos espaços. Vasques (2009) sintetiza as causas desse aparecimento em duas escalas: geral (global e nacional) e específica (regional e local). Considera como fatores gerais a reestruturação industrial, desindustrialização, desconcentração industrial, desinvestimento e exurbanização ${ }^{3}$. Relaciona como fatores específicos o fechamento por falência, o comportamento especulativo, as realocações mais rentáveis, o desacordo entre proprietários e a obsolescência funcional.

As áreas abandonadas ou subutilizadas fruto, principalmente, da dinâmica urbana contemporânea vêm recebendo denominação específica em diversos países. O emprego do termo brownfield inicialmente ocorre, na década de 1970, no processo de modernização de plantas da indústria de aço estadunidense como "brownfield expansion" (US Office of Technology Assessment, 1980; Cranndall, 1981). O seu uso passou a incorporar a existência de atividades pré-desenvolvidas, podendo apresentar contaminação, tal como destacam Ferber e Grimski ${ }^{5}$ (2002), segundo Vasques (2009, p.31).

De acordo com Vasques (2005, p.8) e laochite $(2005$, p.10) a definição de brownfields aparece, em 1980, na lei federal americana Comprehensive

\footnotetext{
${ }^{2}$ KIVELL, P.T. Les friches et Le déclin industrial Dan lês ville britanniques. Revue Belge de Geographie, Bruxelles: societé Royale Belge de Geographie , 116éme Anne (1-4). 1992. P. 117-128.

${ }^{3}$ É o processo de formação dos distritos industriais, devido à realocação das atividades econômicas para re-agrupamentos pré-determinados, geralmente, especializados. Ocorre por diversos fatores, dentre eles, os menores preços dos terrenos nas periferias, tráfego intenso, problemas de estacionamento e dificuldade para expansão física das empresas, nas zonas centrais (Mérenne-Schoumaker, 1996 apud Vasques 2009, p. 29).

${ }^{4}$ Refere-se à instalação de equipamentos que elevem a produtividade da fábrica, devido a algum impedimento que limita sua capacidade de uso completo (Vasques, 2009, p. 31).

${ }^{5}$ FERBER, U.; GRIMSK, D. Brownfields and Redevelopment of Urban Areas. Viena: Umweltbundersamt (Austrian Federal Environment) CLARINET. 2002.
} 
Environment Response, Compensation, and Liability Act - CERCLA, seção 101, primeira a tratar de áreas contaminadas, como: "instalações industriais ou comerciais abandonadas, ociosas e subutilizadas cujo redesenvolvimento é dificultado devido à contaminação real ou percebida, mas que tem um potencial ativo para reuso". A agência ambiental americana (EPA) recepcionou esta definição, assim como a lei pública americana, de 2002, "Small Business Liability Relief and Brownfields Revitalization Act.. Também é utilizado o termo wastelands (áreas residuais).

Tal como relata Vasques (2009), os brownfields, no Reino Unido, são denominados como brownland, blackfields, derelict land, fallow land e previously developed land. Na França são utilizados os termos friches urbaines e industrielles (Macquat $^{6}$, 2006; Bruyelle ${ }^{7}, 1992$; Cabanne $\left.{ }^{8}, 1992\right)$, bem como, terrains vagues $\mathrm{e}$ terrains abandonnés. Em italiano, área dismessa ou fabbrica dismessa. No espanhol, o termo mais utilizado é ruínas e baldios industriales. Segundo Ihobe $^{9}$ (1998) a expressão "emplazamientos industriales contaminados" é utilizada para identificar restrições de uso, na etapa de recuperação. Na Alemanha são usados industriebrächen e brachfläche (Vasques 2009, p. 31 a 33). Sánchez (2001, p. 129) aponta os termos alemães altstandorte e altlasten.

Nos estudos sobre brownfields realizados por Vasques $(2005 ; 2009)$ e Leite (2005) foram encontrados, além da utilização do próprio termo, uma série de outros nomes: áreas degradadas, pontos negros, espaços opacos, espaços residuais, espaços de reconversão, paisagens estragadas, cicatrizes/fraturas urbanas, cinturão ou anel de ferrugem ou, ainda ferradura (áreas industriais concentradas), espaços de inércia, terrenos vagos, rugosidades, aos quais estão associados diferentes conceitos. Leite (2005, p. 12) se refere a essas áreas como

\section{[...] entraves espaciais, obstáculos que provocam descontinuidades urbanas, dificultando o uso mais eficiente do espaço, e dando a eles a aparência ultrapassada ou de abandono bastante característica, proporcionando um impacto visual negativo do ponto de vista urbanístico.}

Souza C. (2002, p. 110-111), nos seus estudos sobre novas territorialidades ao longo da orla ferroviária paulistana, trata essas áreas como "terrenos vagos" que se constituem em "rupturas no tecido urbano". São "espaços residuais" que

\footnotetext{
${ }^{6}$ MACQUAT, A. Processus du Réabiltation des friches industrielles. Cinc cas das des friches industrielles en Ville Délemont. Neuchatel: Universite Nêuchatel/Institut de Geografie, October, 2006.

7 BRUYELLE, P. Les friches industrielles. Revue Belge du Géographie. Bruxellas: Sociète rRuyale Belge du Géograohie, 116ème anné, n1-4, 1992 p. 113-137.

${ }^{8}$ CABANE, C. Lexique du Géographie Humaine et economique. $2^{\mathrm{a}}$ ed. Parris, Dalloz. 1992

${ }^{9} \mathrm{HHOBE}$
} 
registram as transformações do capitalismo no território urbano. Por outro lado, destaca que podem se transformar em oportunidades

[...] uma área disponível, cheia de expectativas, com forte memória urbana, a memória de seu uso anterior parece maior que seu uso atual, potencialmente única, o espaço do possível, do futuro, a possibilidade do novo.

A Universidade Estadual de São Paulo (UNESP) em convênio com as universidades americanas University of Pittsburgh (UP) e Carnegie Mellon University (CMU) estabeleceu, em 2001, em Rio Claro, o Grupo de Análise Territorial com Suporte de Geotecnologias, que elaborou, em 2003, o seguinte conceito para brownfields, conforme laochite (2005, p. 29 e Vasques (2005, p. 34): "[...] arcabouço físico-territorial abandonado, contaminado ou não, de uma atividade sócio-econômica relevante em um determinado período de tempo, passível de redesenvolvimento".

Alker et al ${ }^{10}$ (2000 apud Vasques, 2009, p. 39) propõem uma definição para o termo, aceita por vários autores que trata de "terreno ou parte dele, sem uso ou parcialmente utilizado, onde houve atividade ou uso anterior; podendo estar desocupado, desamparado ou contaminado e disponível para reuso, exigindo, porém, em muitos casos, intervenções". Essa definição é fruto de uma síntese, realizada pelos autores, sobre os fatores inclusos nas várias definições do termo, criando um modelo do que pode ser considerado um brownfield.

Vasques (2009) elabora uma tentativa de classificação do que é e do que não é brownfield (Anexo C) e afirma que a análise das várias tipologias de brownfields (2005), facilita a compreensão sobre as suas origens e características e organiza um organograma (Anexo D) com as principais categorias de brownfields encontradas na literatura estrangeira.

Leite (2005, p.114) nos seus estudos sobre brownfields especifica que "aterros de resíduos sólidos urbanos desativados, sem recuperação, apartados da dinâmica urbana e, conseqüentemente, contribuindo para a desvalorização do entorno podem ser considerados brownfields ou entraves espaciais". São denominados também como espaços desperdiçados, pois o uso do espaço é pouco eficiente originando descontinuidades urbanas, como no município de São Paulo. Concluiu que dos seis aterros desativados no município de São Paulo, com área

\footnotetext{
${ }^{10}$ ALKER, S.A.J.V. et al. The Definition of Brownfield. Journal fo Enviromental Planning and Management. Abgdom, v. 43, n 1, 2000. p. 49-69.
} 
total de $1.200 .000 \mathrm{~m}^{2}$, sob a fiscalização do Departamento de Limpeza Urbana (Limpurb); os aterros Sapopemba, Jacuí e São Mateus podem ser classificados como brownfields, enquanto os aterros de Santo Amaro, Vila Albertina e Itatinga (inertes) como brownfields em processo de recuperação, apesar de não possuírem projetos definidos e oficializados de refuncionalização ${ }^{11}$.

De acordo com Sánchez (2004, p.85) "[...] alguns brownfields são áreas contaminadas, enquanto que nem toda área contaminada é um brownfield, caso de áreas contaminadas situadas em indústrias ativas, por exemplo - denominado como "terreno industrial contaminado" (Figura 2.1). Compreende-se, então, que as áreas contaminadas são casos especiais de áreas degradadas.

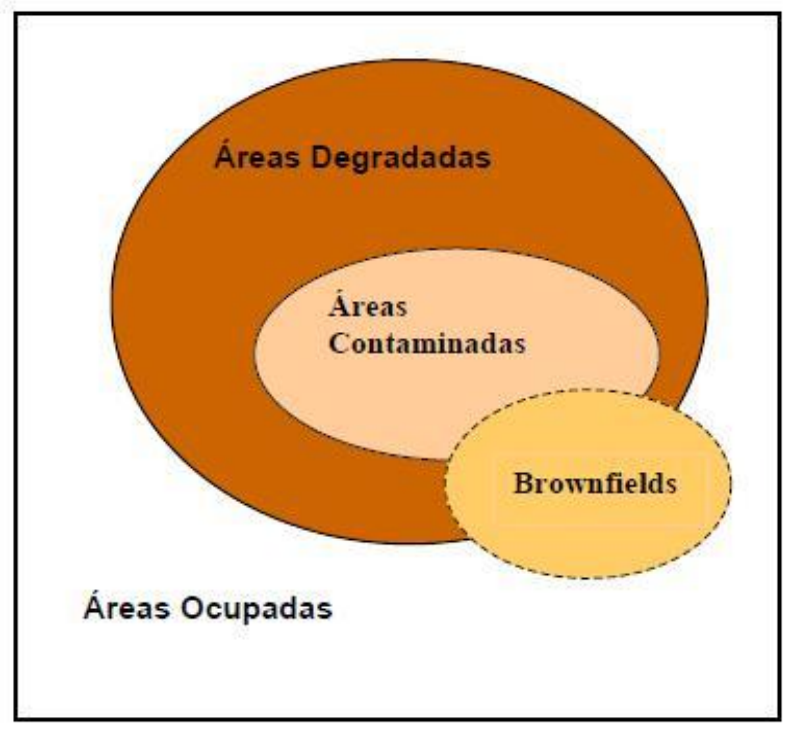

Figura 2.1- Tipologia de áreas degradadas Fonte: Sánchez (2004, p. 85)

As diferentes definições para o termo brownfield dificultam sobremaneira a sua identificação e quantificação. Yount ${ }^{12}$ (2003 apud Vasques, 2009) ressalta a importância de um conceito padrão para permitir a realização de inventários de brownfields, que os identifiquem e os restituam ao ciclo produtivo. Aponta, também, a inexistência de termos que expressem quando uma propriedade se torna um brownfield e quando deixa de sê-lo. Vasques $(2009$, p.36) relata que alguns autores delimitam o mínimo de dois anos, sendo dez anos como tempo médio para abandono.

\footnotetext{
${ }^{11}$ Refuncionalizar segundo Evaso (1999 apud Vasques 2005:36; Vasques 2009:49 "implica na alteração da função de uma determinada coisa/elemento, atribuindo-lhe um novo valor de uso. [...] Tais acomodações requerem, às vezes, adequações por parte do espaço construído: demolições (supressões), reformas (superposições) e acréscimos (acumulações). [...] As alterações a serem feitas reordenam o conteúdo, atribuindo a cada elemento uma nova posição hierárquica, que é, essencialmente, de cunho funcional".

${ }^{12}$ YOUNT, K.R. What are Brownfields? Finding a Conceptual Definition. Environmental Practice, v. 5, n.1 2003. P. 25-33.
} 
Greenberg $^{13}$ (1991 apud Vasques, 2009, p. 41) e Greenberg et al. ${ }^{14}$ (1999 apud Magalhães, 2000, p. 41) propôs a expressão TOADS - Temporaly Obsolete, Abandoned or Derelict Sites para conceituar um tipo especial de brownfield, tratando-se de um local abandonado e obsoleto, temporariamente, capaz de desvalorizar as propriedades vizinhas e influenciar uma mudança no zoneamento local. O espaço passa a ser associado à insegurança, à criminalidade, à falta de empregos e serviços e ao vandalismo. Adquire um estigma negativo com a contaminação de terrenos e estruturas.

Outro termo, derivado deste último, HI-TOADS - High-impact Temporaly Obsolete, Abandoned or Derelict Sites, foi criado por Hollander ${ }^{15}$ (2009 apud Vasques, 2009, p. 42) para se referir a brownfields mais perigosos, apontados em algumas cidades americanas (New Bedford - Massachusetts, Pittsburg Pennsylvania, Richmond - Virginia, Trenton - New Jersey e Youngstown - Ohio), onde foram observadas áreas poluídas e perigosas, destruídas, contaminadas, abandonadas e arruinadas.

Outra expressão “Locally Unwanted Land Uses - LULUs” é encontrada para definir espaços problemáticos, que traduzida significa 'usos do solo localmente não desejados'. Designa espaços desejados e necessários à sociedade ou legalmente exigidos, mas pelos quais ninguém quer se responsabilizar, tais como os aterros de lixo, os abrigos para sem-tetos e incineradores (Vasques, 2009, p. 42).

A mesma autora identifica esses espaços como 'terras de ninguém'. Cita como exemplo o estudo de Greenberg e Schneider ${ }^{16}$ (1994), em Nova Jersey, que observaram concentrações de áreas TOADs e LULUs, onde taxas de mortes violentas de jovens do sexo masculino relacionavam-se à injustiça social, produzindo violência urbana estrutural. A autora cita os autores Bowman e Pagano $^{17}$, 2004, p. 1-2), que se remetem aos dangerous brownfields (brownfields perigosos), indicadores de declínio intra-urbano, materializados nos lotes desocupados; desencadeando o aparecimento das expressões dead space (espaço morto) e disturbed space (espaço alterado) para se referir a solos improdutivos,

\footnotetext{
${ }^{13}$ GREENBERG, M. American Cities: Good and Bad News about Public Healthy. Bulletin of New York Academy of Medine. New York, V. 67 n1. 1991. p. 17-21

; Schneider, Violenca in American City: Young Black malls is the Answer, but what was the question? Social Science Medicine. V. 39, n2. 1994, p.179-184.

${ }^{15}$ HOLLANDER, J.B. Polluted and dangerous: America's worst abandoned properties and what can e done about them. Burlington: The University of Vermont Press; Hannover: University Press of New England, 2009.

${ }^{16}$ GREENBERG, M.; SCHENEIDER D. Violence in America cities: Young Black Males is the Answer, but what was the Question? Social Science and Medicine, v. 39, n. 2. 1994. P. 179-187.

${ }_{17}$ BOWMAN, A.O.; PAGANO, M.A. Terra Incognita: Vacant Land and Urban Strategies. Washington: Georgetown Uiverty Press, 2004.
} 
edifícios degradados ou usos temporários como depósitos de lixo ou de material de construção.

As três expressões citadas anteriormente englobam sérios problemas sociais relacionados à criminalidade, comércio de drogas, roubos, prostituição, etc., sendo reconhecidos por Leite (2005, p.14) como espaços marginais.

Berger ${ }^{18}(2006)$ nos seus estudos sobre brownfields, considerados subprodutos das mutações econômicas, apresenta uma classificação para as diversas paisagens: Landscape of Dwelling - LODs, terrenos vagos em conjuntos residenciais; Landscape of Transition - LOTs, armazéns temporários; Landscape of Infrastructure - Lins, paisagens de infra-estrutura de transporte; Landscape of Obsolescense - LOOs, depósitos e aterros de lixo; Landscape of Exchange - LEXs, centros comericiais abandonados e Landscape of contamination - LOCOs, bases militares e outros tipos de brownfields (Vasques, 2009, p. 43).

\subsubsection{TERMOS CORRELATOS AOS BROWNFIELDS}

O termo brownfields ("campos marrons") é utilizado em contraposição ao termo greenfields ("campos verdes"), que se refere a áreas rurais agrícolas, em boas condições, ou a áreas de florestas e parques, onde não houve prévio uso ou atividade desenvolvida (Silva, 2001; Vasques, 2009).

Vasques (2009) afirma que os greenfields, em geral, são áreas naturais, situadas fora da área urbana e que deveriam ser preservadas, estando, entretanto, sob constante pressão devido ao crescimento desordenado das cidades (urban spraw $^{19}$ ). O reuso, refuncionalização ou requalificação dos brownfields pode desestimular o fenômeno de urban spraw, favorecendo a preservação dos greenfields. Aponta que brownfields não contaminados podem ser revitalizados como parques, campos de recreação e lazer.

Neste trabalho, o termo greenfield terá um significado mais abrangente, situando-se na malha urbana e referindo-se às áreas vegetadas naturais ou implantadas com potencial para preservação, conservação ou manutenção, que

\footnotetext{
${ }^{18}$ BERGER, A. Drosscape: Wasting Land in Urban America. New York: Princeton Architectural Press. 2006.

${ }^{19}[. .$.$] expansão territorial das cidades, diminuição das densidades populacionais, aumento da dependência por transportes$ automotivos de uso individual, padões de ocupação residencial e não- residencial nas regiões metropolitanas [...] Trata-se da difusão da edge city (cidades de contorno)., com a formação de verdadeiros simulacros de cidades em áreas distantes do contexto dos centros urbanos consolidados (Ojima, 2006, p. 6 apud Vasques, 2009, p. 46).
} 
necessitam de manejo constante, incluindo-se os parques urbanos, parques naturais, as unidades de conservação, etc.

Outro termo surgiu para designar estabelecimentos exclusivamente comerciais: greyfields (campos cinzentos), cor característica dos estacionamentos asfaltados. São definidos por Sobel ${ }^{20}$ (2001, p.1) como "centros comerciais obsoletos economicamente". Também recebem a denominação de dead malls (centros comerciais mortos) ou ghostboxes (boxes comerciais fantasmas). Suas características, boa localização, infra-estrutura construída e subjacente e grandes praças de estacionamento, favorecem o seu reuso, assim como os menores custos para a sua reativação. A reativação desses espaços tem como conseqüência a valorização dos subúrbios urbanos e a diminuição do fluxo de deslocamento para áreas mais valorizadas (Vasques, 2009, p.43). A autora cita exemplos de greyfields, no Brasil: o Shopping Center de Limeira (SP) e o Outlet Center, em Nova Odessa (SP), situados na Rodovia Anhanguera.

\subsubsection{CONCEITOS E CLASSIFICAÇÃo DAS ÁREAS CONTAMINADAS NO BRASIL}

A origem da contaminação de uma área pode estar relacionada aos processos produtivos, ao armazenamento de matérias-primas ou à disposição de resíduos das atividades anteriormente abrigadas pelo terreno.

A classificação das áreas contaminadas foi estabelecida, no Brasil, primeiramente, em 1999, no Manual de Gerenciamento de Áreas Contaminadas (Cetesb, 2001), resultado do convênio com a Alemanha, mediante a Deutsche, Gesellschaft für Technische Zumammenarbeit (GTZ). Algumas adaptações foram introduzidas, posteriormente, nos instrumentos legais específicos do município de São Paulo. Mais recentemente essa classificação foi aperfeiçoada pela lei estadual das áreas contaminadas (Lei 13.577/2009) que incluiu, também, outras definições.

Dessa forma, para melhor compreensão dos conceitos serão a seguir listadas algumas das principais definições:

- $\quad$ Área Potencialmente Contaminada é aquela onde estão sendo ou foram desenvolvidas atividades que por suas próprias características podem

\footnotetext{
${ }^{20}$ SOBEL, L.S. Greyfield Mall Revitalization: Evaluating the Economic Impact to the Host Community. Miami Knight Program Fellow, Scholl of Architecture, Univerty of Miami. 2001.
} 
acumular quantidades ou concentrações de matéria em condições que a tornem contaminada;

- Área Suspeita de Contaminação é aquela na qual, após a realização de avaliação preliminar, foram observadas ou obtidas informações técnicas que induzam à suspeição de contaminação;

- $\quad$ Área Contaminada é aquela onde comprovadamente há poluição causada por quaisquer substâncias ou resíduos que nela tenham sido depositados, acumulados, armazenados, enterrados ou infiltrados, e que causem impacto negativo à saúde humana, ao meio ambiente e a outro bem a proteger;

- Área Contaminada Crítica é aquela que em função dos danos causados ou dos riscos que impõe aos receptores ou aos compartimentos de interesse, gera inquietação na população ou conflitos entre os atores envolvidos, havendo a necessidade de um procedimento de gerenciamento, diferente, que contemple a definição de estratégias de intervenção, de comunicação dos riscos e de gestão da informação, envolvendo, normalmente, outros órgãos ou entidades;

- $\quad$ Área Contaminada sob Investigação é a área contaminada onde estão sendo realizados procedimentos para determinar a extensão da contaminação e os receptores afetados;

- Área Remediada para Uso Declarado é a área contaminada submetida às técnicas de remediação a fim de re-estabelecer nível de risco aceitável para um uso declarado;

- $\quad$ Avaliação Preliminar objetiva encontrar indícios de uma possível contaminação do solo e água subterrânea através do levantamento de informações obtidas sobre o histórico da área, análise temporal de fotos aéreas e observações de campo;

- Investigação Confirmatória é a etapa de investigação onde são feitos estudos e análises para comprovar a existência de contaminação;

- Investigação Detalhada é a etapa seguinte à investigação confirmatória, que objetiva definir os limites da pluma de contaminação, determinar as concentrações das substâncias ou contaminantes de interesse e caracterizar o meio físico onde se insere a área contaminada sob investigação;

- $\quad$ Avaliação de Risco é a quantificação dos riscos gerados pelas áreas contaminadas à saúde da população e aos ecossistemas, edificações, 
instalações de infra-estrutura urbana, produção agrícola, e outros, baseadas em princípios físicos, químicos e biológicos;

- Remediação é a técnica aplicada a uma área contaminada, visando a remoção, redução ou contenção dos contaminantes, de modo a assegurar a sua utilização, em níveis aceitáveis, para um uso declarado.

Na Política Nacional de Resíduos Sólidos, Lei 12.305/2010, recentemente promulgada, área contaminada foi definida como o "local onde há contaminação causada pela disposição, regular ou irregular, de quaisquer substâncias ou resíduos". Além disso, a Lei introduziu o conceito de área contaminada órfã: "aquela cujos responsáveis não são identificáveis ou individualizáveis".

\subsection{BROWNFIELDS E ÁREAS CONTAMINADAS NO CENÁRIO INTERNACIONAL}

\subsubsection{NOS ESTADOS UNIDOS E EUROPA}

A inexistência de um padrão global para o conceito de brownfields pode gerar imprecisão nos dados estatísticos. Entretanto, alguns países apresentam as suas estimativas para essas áreas. Na Alemanha existem cerca de 128.000 hectares, nos Países Baixos entre 9.000 e 11.000 e na Bélgica/Wallonia, cerca de 9.000 (Grimisk e Ferber ${ }^{21}, 2001$ apud Vasques, 2005, p. 30).

Mckeehan (200022 apud Vasques, 2006), informa que nos Estados Unidos existiam até o ano de 2000, cerca de 600.000 áreas identificadas como brownfields; que totalizaram 81.568 acres em 201 cidades. Segundo Vasques (2005) a agência ambiental européia - European Environment Agency (EEA), em 2000, disponibilizou um estudo sobre a caracterização e identificação de locais contaminados em vários países - Management of Contaminated Sites in Western Europe (Prokop et al., $2000^{23}$, p.11). Os dados apresentados a seguir (Tabelas 2.1 e 2.2) mostram o total

\footnotetext{
${ }^{21}$ GRIMSK, D.; FERBER, U. Urban Brownfields in Europe. Land contamination \& Reclamation. London: EPP Publication, v. 9, n. 1 2001. P. 143-148.

${ }_{22}$ MCKEEHAN, P. Brownfields: the Financial, Legislative and social aspects of the Redevelopment of contaminated Commercial and Industrial Properties. Cambridge Scientific Abstracts. 2000. Disponível em: http://www.csa.com/hotopics/brow/overvew.html. acesso em : Maio 2004.

${ }_{23}$ PROKOP, G. et al. Management o contaminated sites in Western Euroe. Copenhagen: European environmental Agency. 2000.
} 
de áreas potencialmente contaminadas e contaminadas existentes nos vários países abrangidos pelo estudo.

Silva (2001, p.20-21) relata que, segundo Lee e Jones-Lee. ${ }^{24}$ (1995), nos Estados Unidos são estimados mais de 50.000 aterros inativos dos quais $80 \%$ são responsáveis pela poluição das águas subterrâneas. E, de acordo com Walsh e LaFleur $^{25}$ (1995), numa pesquisa realizada em Nova York, no período entre 1844 e 1994, para identificar os antigos aterros (não só de resíduos) foi constatada uma área total de 45.650 acres, correspondendo a $20 \%$ da área abrangida pelo estudo. Esses aterros situam-se na maioria em áreas de influência da maré, úmidas, juntos a grandes corpos d'água, facilitando a migração lateral do percolado e a descarga local para a água subterrânea.

Tabela 2.1: Relação das áreas potencialmente contaminadas e contaminadas na União Européia

\begin{tabular}{|l|c|c|c|}
\hline \multirow{2}{*}{ Países } & \multicolumn{2}{|c|}{$\begin{array}{c}\text { Potencialmente Contaminadas } \\
\text { Identificados }\end{array}$} & Contaminadas \\
& 202.880 & 240.000 & s.d. \\
\hline Alemanha & 28.000 & $\sim 80.000$ & 135 \\
\hline Áustria & 7.728 & 14.000 & 8.020 \\
\hline Bélgica & 37.000 & $\sim 40.000$ & 3.673 \\
\hline Dinamarca & 4.902 & s.d & 370 \\
\hline Espanha & 10.396 & 25.000 & 1.200 \\
\hline Finlândia & s.d. & 800.000 & 896 \\
\hline França & s.d. & $\sim 2.000$ & s.d. \\
\hline Irlanda & 8.873 & s.d. & 1.251 \\
\hline Itália & 2.121 & s.d. & s.d. \\
\hline Noruega & s.d. & 120.000 & \\
\hline Países Baixos & 7.000 & s.d. & 2.000 \\
\hline Suécia & 35.000 & 50.000 & $\sim 3.500$ \\
\hline Suíça & &
\end{tabular}

Organização: Luzia Helena dos S. Barros

[s.d.: sem dados]

Fonte: Prokop et al. (2000, p. 11 apud Vasques, 2005, p. 32)

\footnotetext{
${ }^{24}$ LEE, G.F.; JONES-LEE, A. Overview of Landfill Post Closure Issues. Presented at American Society of civil engeneers session: "Landfill Closures - environmental Protection and Land Recovery". New York,N.Y. 1995

${ }^{25}$ WALSCH, D.C.; LAFLEUR, R.G. Landfills in New Yor City: 1844-1994. In: Ground Water, v. 33, no 4, 1995. p. 556-560.
} 
Requalificação dos Aterros Desativados (BrownfieldS) no MunicípIo de SÃo PaUlo: PARques (GreenfieldS) RAPOSO TAVARES E JARDIM PRIMAVERA

LuZia Helena dos Santos BarRos

Tabela 2.2: Áreas potencialmente contaminadas no Reino Unido

\begin{tabular}{|c|c|c|c|c|c|}
\hline Região & Total & $\begin{array}{c}\text { Área } \\
\text { (ha) }\end{array}$ & Uso da terra/tipos & Ano & Fonte \\
\hline Inglaterra/Gales & s.d. & 40.495 & Derelict land - Brownfields & 1989 & DoE \\
\hline Gales & 749 & 3.900 & $\begin{array}{c}\text { Potencialmente contaminados, } \\
\text { excluindo os em operação e }>0,5 \text { ha }\end{array}$ & 1988 & $\begin{array}{c}\text { Welsh } \\
\text { Office }\end{array}$ \\
\hline Escócia & 2.551 & 8.297 & Derelict land - Brownfields & 1992 & $\begin{array}{c}\text { Scottish } \\
\text { Office }\end{array}$ \\
\hline $\begin{array}{c}\text { Condado de } \\
\text { Cheshire }\end{array}$ & 1.577 & s.d & Depósitos de resíduos (wastes sites) & 1990 & DoE \\
\hline Londres & 68 & s.d. & Gasworks & 1991 & $\begin{array}{c}\text { Friends of } \\
\text { the Earth }\end{array}$ \\
\hline
\end{tabular}

Organização: Luzia Helena dos S. Barros

[s.d.: sem dados]

Fonte: Prokop et al. (2000, p. 112 apud Vasques, 2005,p. 32) ao citar Bardos et al. (1994).

\subsection{BROWNFIELDS E ÁREAS CONTAMINADAS NO CENÁRIO NACIONAL}

\subsubsection{NO BRASIL}

Duran $^{26}$ (2001 apud Leite, 2005) comenta que a desindustrialização de São Paulo, levou ao esvaziamento de vários galpões que permanecem desocupados, a exemplo do que ocorre nos bairros de Santo Amaro, na zona sul e Vila Leopoldina, na zona oeste. Esse intenso processo de desindustrialização juntamente com as características de crescimento urbano e industrial descontrolados, segundo Cunha (1997 ${ }^{27}$ apud Vasques (2005, p.33), resultou em:

[...] áreas de conflito, onde a ocupação destas áreas é partilhada por usos incompatíveis entre si, como os de natureza industrial e residencial ou regiões onde o uso atual do solo mostra-se não condizente com os níveis de contaminação apresentado em decorrência de antigas fontes de poluição, desativadas ao longo do processo de transformação ocorrido no perfil industrial da região.

\footnotetext{
${ }^{26}$ DURAN, S. Plano director prevê reindustrialização de SP. São Paulo, 25Out.2001. Folha Online. Disponível em: http://www1.folha.uol.com.br/folha/cotidano/ult95u37572.shl. Acesso em: 12Jul2003.

${ }^{27}$ CUNHA, R.C. Avaliação de risco em áreas contaminadas por fontes industriais desativadas - estudo de caso. Tese. (Doutorado em Geologia). Instituto de Geociências - IG. Universidade de São Paulo - USP. 1997
} 


\title{
2.3.2 No Estado de São Paulo
}

As exigências ambientais surgidas no início da década de 1980 e a mudança de perfil industrial de muitas cidades levaram-nas a se depararem com os seus passivos ambientais. No entanto, para Sánchez (2001, p.166):

\begin{abstract}
[...] ainda que o governo pudesse prover um aumento significativo de recursos financeiros para os órgãos ambientais, seria virtualmente impossível fiscalizar de perto as cerca de 117 mil fontes fixas de poluição hoje cadastradas no Estado de São Paulo.
\end{abstract}

O Sistema Estadual de Análise de Dados (Seade), de São Paulo, computou 93 mil estabelecimentos industriais, com 49 mil deles situados na sua Região Metropolitana (Vasques, 2005, p.34). No entanto, "não há, no Brasil, estatísticas sobre o fechamento de indústrias" (Sánchez, 2001, p.32), o que impossibilita conhecer o tamanho desse problema e dificulta o estabelecimento de políticas públicas específicas.

O estado de São Paulo registrou, na última divulgação da lista de áreas contaminadas (Cetesb, 2009), em novembro de 2009, um total de 2.904 áreas contaminadas, distribuídas conforme as regiões do estado e por atividade (Quadro 2.1). A grande maioria das áreas contaminadas refere-se a postos de combustíveis (79\%). Este fato pode ser explicado pela aplicação da legislação estadual específica (Resolução SMA 05/2001), que permitiu constatar a existência de contaminação nessas atividades; elaborada a partir da publicação da Resolução Conama 273/2000, que trata do licenciamento de postos de abastecimento de combustíveis novos e antigos. Além da exigência de cadastro e avaliação dessa atividade também é exigida a troca dos antigos equipamentos (tanques) com mais de 15 anos de operação. Do total de áreas contaminadas cadastradas relacionadas a todas as atividades registradas (industrial, comercial, resíduos, acidentes, posto de combustível e indeterminada) encontram-se $28 \%$ em monitoramento, $20 \%$ sob investigação e $4 \%$ reabilitadas. Avaliando a situação dessas áreas ao se excluir os postos de combustíveis (2.279), restando, portanto, o total de 625 áreas verifica-se que os percentuais pouco se modificam, estando $23 \%$ em monitoramento, $22 \%$ sob investigação e apenas $5 \%$ reabilitadas.

O sistema de gestão das áreas contaminadas também permitiu a identificação dos vários contaminantes encontrados, onde predominam os solventes 
Requalificação dos Aterros Desativados (BrownfieldS) no MunicípIo de SÃo PaUlo: PARques (GreenfieldS) Raposo TAVAREs e Jardim Primavera

LuZia Helena dos Santos BarRos

aromáticos, os combustíveis líquidos e os $\mathrm{PAHs}^{28}$, relacionados à atividade dos postos de combustíveis.

A implantação da gestão com a disponibilização anual da listagem de áreas contaminadas no estado de São Paulo permite observar a evolução do número de áreas identificadas no período de 2002 a 2009, que passou de 255 para 2.904. O aprimoramento da gestão das áreas contaminadas certamente levará ao aumento do número de áreas cadastradas.

\begin{tabular}{|l|c|c|c|c|c|c|}
\hline \multicolumn{7}{|c|}{ Áreas Contaminadas no Estado de São Paulo- novembro de 2009 } \\
\hline \multirow{2}{*}{ Região } & \multicolumn{7}{c|}{ Atividade } \\
\cline { 2 - 7 } & Comercial & Industrial & Resíduos & $\begin{array}{c}\text { Postos de } \\
\text { combustiveis }\end{array}$ & $\begin{array}{c}\text { Acidentes/ } \\
\text { Desconhecida }\end{array}$ & Total \\
\hline São Paulo & 32 & 83 & 25 & 675 & 3 & 818 \\
\hline RMSP - outros & 23 & 108 & 17 & 375 & 5 & 528 \\
\hline Interior & 53 & 129 & 33 & 900 & 13 & 1128 \\
\hline Litoral & 13 & 34 & 20 & 199 & 2 & 268 \\
\hline Vale do Paraiba & 2 & 28 & 1 & 130 & 1 & 162 \\
\hline \multicolumn{1}{|r|}{ Total } & 123 & 382 & 96 & 2.279 & 24 & 2.904 \\
\hline
\end{tabular}

Para a distribuição das áreas contaminadas foram consideradas as seguintes regiões:

- São Paulo: Capital do Estado;

- RMSP - outros: 38 municipios da Região Metropolitana de São Paulo, excluindo-se a Capital;

- Litoral: municípios do Litoral Sul, Baixada Santista, do Litoral Norte e do Vale do Ribeira;

- Vale do Paraíba: municipios do Vale do Paraiba e da Mantiqueira;

- Interior: Os municipios não relacionados anteriormente.

Quadro 2.1 Áreas Contaminadas por região do estado de São Paulo (Cetesb, 2009, p. 1).

\subsubsection{No MunicíPIO de SÃo PaULO}

A transformação do uso do solo na cidade de São Paulo pode ser verificada no registro da alteração do Imposto Predial e Territorial Urbano (IPTU). Sepe e Silva (2004) apresentam um levantamento dessa alteração no período de 1996 a 2004 (Figura 2.2). Apontam que do total de 2.070 áreas onde houve alteração do uso, 180 passaram a ser tributadas como "terrenos", ou seja, o uso anterior industrial foi apagado pela demolição das edificações.

\footnotetext{
${ }^{28}$ Hidrocarbonetos aromáticos
} 


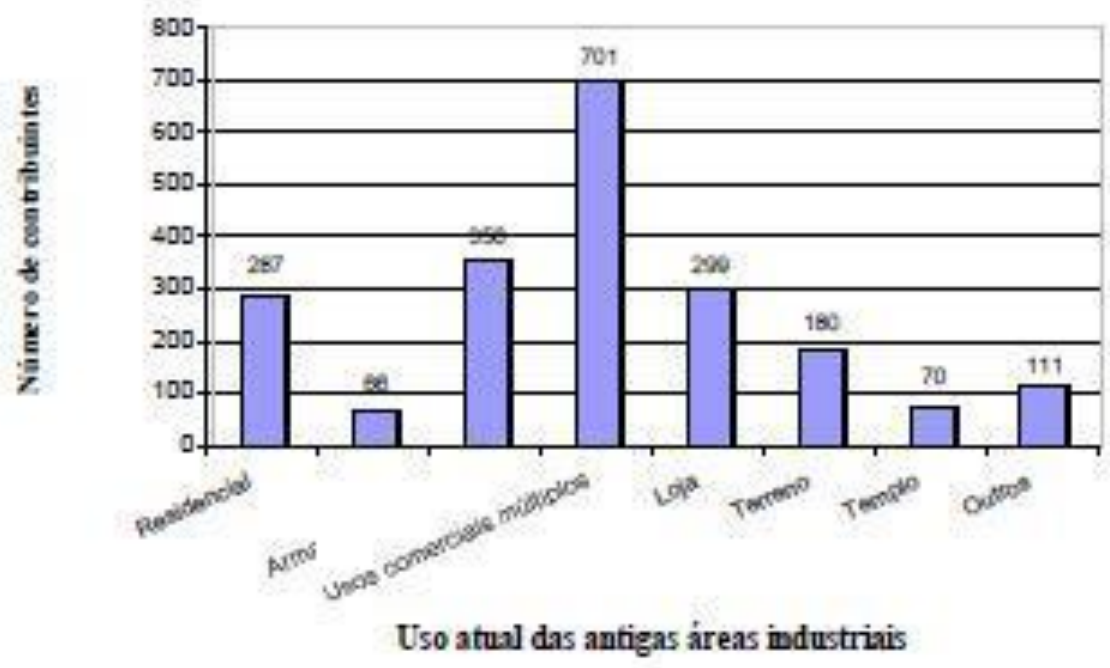

Figura 2.2 - Áreas com alteração de IPTU industrial para outros usos no período de 1996 -2004 no Município de São Paulo Fonte: Sepe e Silva (2004, p. 46).

Meyer e Grostein (2010) observaram que no Vetor Leste do Centro (VLC) ${ }^{29}$ existem 195 mil m² de terrenos vazios; além de galpões, armazéns e a orla ferroviária, com vocação para transformação urbanística, onde a questão das áreas contaminadas amplia o rol de preocupação com os vários brownfields constatados.

No município de São Paulo, até novembro de 2008, estavam cadastradas 790 áreas contaminadas, incluindo tanto as áreas identificadas pelo município quanto pela Cetesb (Figura 2.3). Os postos de combustíveis representam a grande maioria das áreas contaminadas no Município ${ }^{30}$. Este fato é reflexo, como explicado anteriormente, da atuação legal específica do Estado sobre essa atividade.

Ramires (2008) apresenta a evolução do número de áreas contaminadas no período de 2002 a 2007 (Figura 2.4), onde houve um aumento de 791\% de áreas identificadas em cinco anos. Reporta que para mais de 50\% das áreas não há projeto de remediação e que apenas $4 \%$ foram remediadas.

\footnotetext{
${ }^{29}$ O VLC é dominado pelo Parque D. Pedro II e pelo sistema hidrológico do rio Tamanduateí (Meyer \& Grostein, 2010, p.67)

${ }^{30}$ Estão instalados no Município de São Paulo aproximadamente 2.000 postos de combustíveis (Secretaria Municipal de Habitação - Departamento de Controle do Uso de Imóveis - Contru, 2006 apud Ramires, 2008)
} 
Requalificação dos Aterros Desativados (BrownfieldS) no Município de SÃo PaUlo: Parques (GreenfieldS) Raposo TAVARES e Jardim Primavera

LuZia Helena dos Santos BarRos

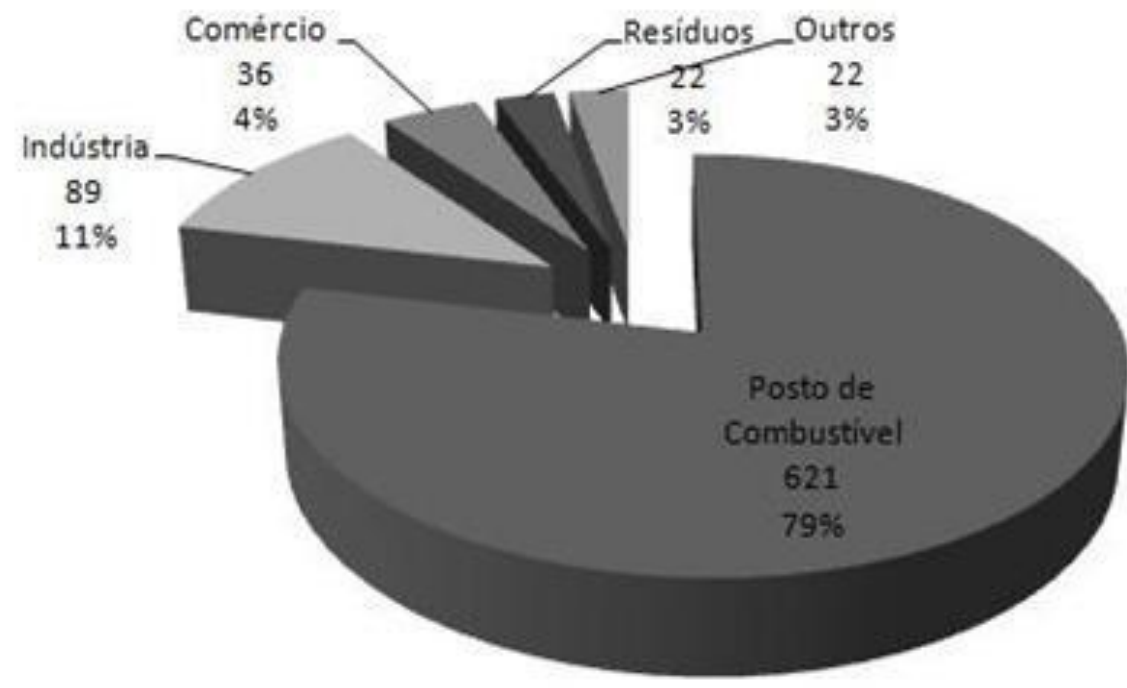

Organização: Morinaga, C.M. (2009)

Figura 2.3: Áreas contaminadas no Município de São Paulo por atividade geradora dos impactos ambientais.

Fonte: SVMA/Cetesb (informação verbal) ${ }^{31}$.

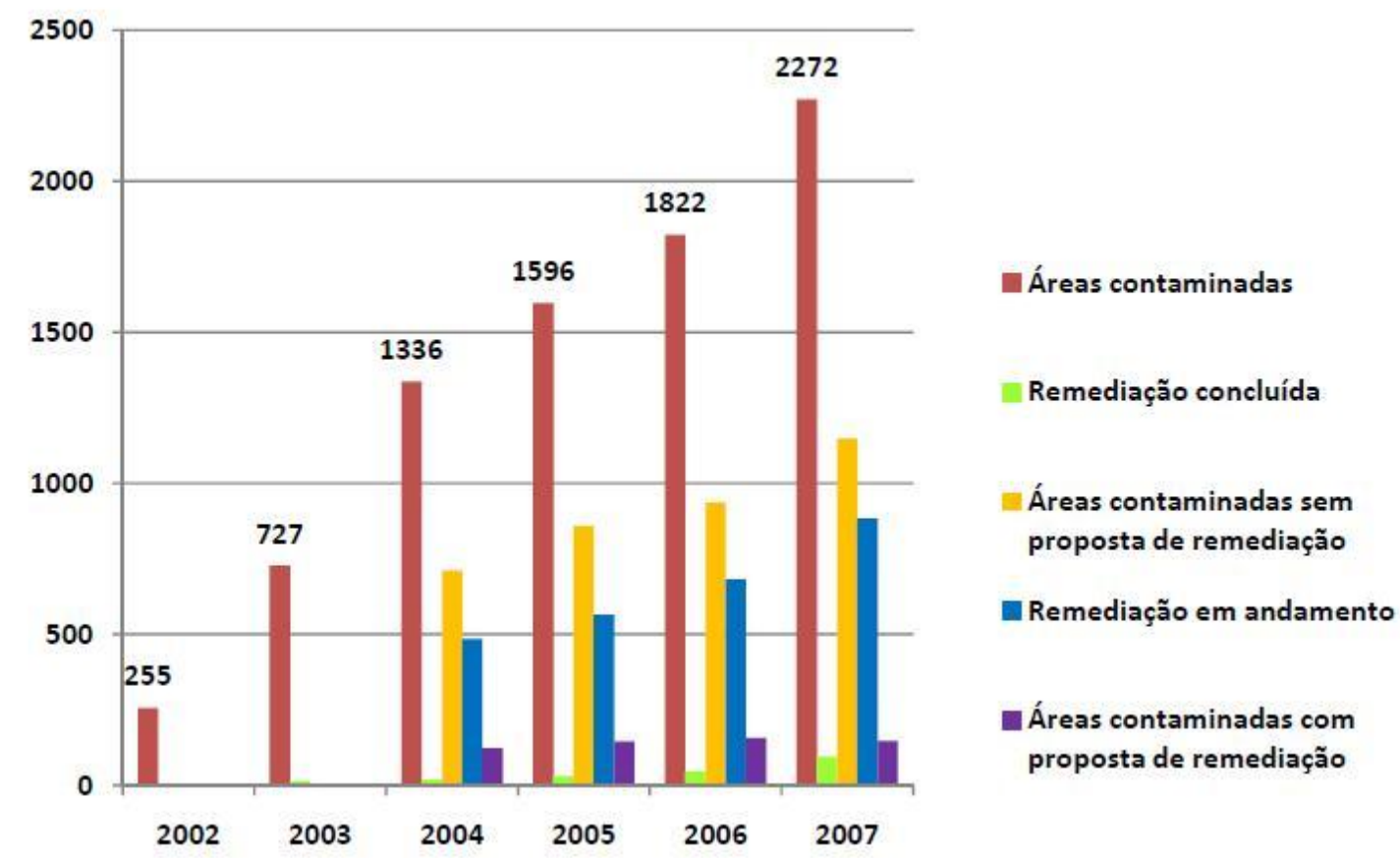

Figura 2.4 - Situação das áreas contaminadas no município de São Paulo, 2002 - 2007. Fonte: Ramires (2008, p.111).

Quanto às áreas suspeitas de contaminação, até novembro de 2007, havia um total de 84 áreas, predominando as caracterizadas por ocorrência de disposição de resíduos (Figura 2.5). Essas áreas correspondem a 56\% do total e são formadas pelos antigos aterros municipais, bem como por disposição irregular. As áreas

\footnotetext{
${ }^{31}$ Informações fornecidas pelo GTAC em 2008.
} 
suspeitas de contaminação, segundo Ramires (2008), localizam-se, principalmente, na periferia (zona rural) onde existe dificuldade para identificação do proprietário. Ramires comenta que muitos terrenos públicos são suspeitos de contaminação e deixados em segundo plano no orçamento financeiro, favorecendo projetos de maior visibilidade, pois os custos da avaliação confirmatória são altos e a contaminação pode permanecer "invisível".

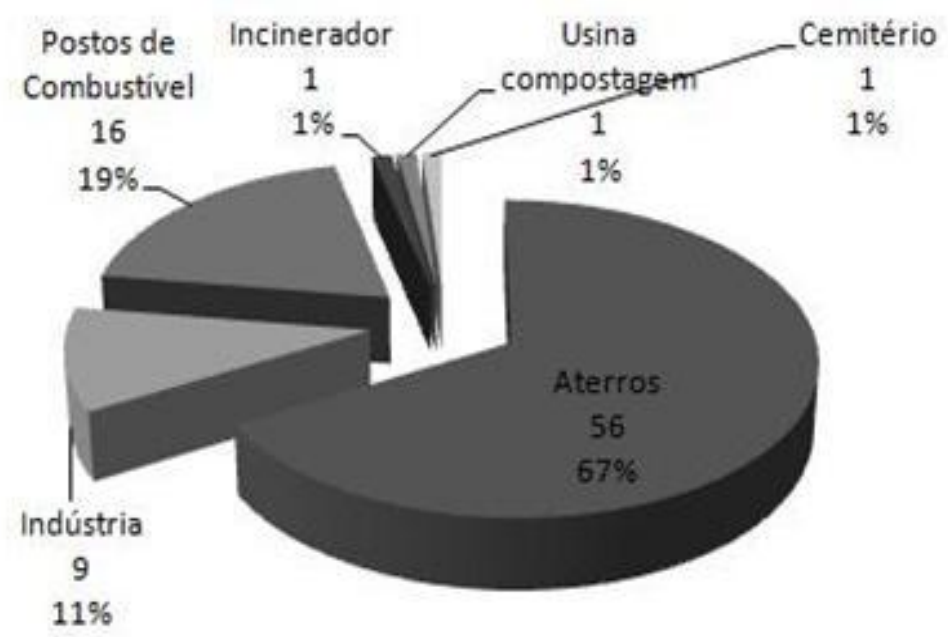

Organização: Morinaga, C.M. (2009)

Figura 2.5 - Áreas suspeitas de contaminação no município de São Paulo por atividade geradora de impactos ambientais em 2007

Fonte: SVMA (informação verbal) ${ }^{32}$.

As estatísticas sobre as áreas contaminadas e suspeitas de contaminação que mostram a predominância das atividades, postos de combustíveis e disposição de resíduos, coincidem com as observações de Sales (2004, p.9), quando relata a tramitação de casos na promotoria do meio ambiente da capital:

[...] o maior número de casos, em trâmite na promotoria do meio ambiente da capital, é relativo à degradação de solo, envolvendo tanto disposição irregular de resíduos inertes, os chamados "bota-fora", quanto aos casos de vazamento em postos de gasolina, [...].

Ramires (2008) relata, também, que as áreas potencialmente contaminadas (Figura 2.6) estão representadas basicamente por antigos terrenos industriais, situados na zona industrial demarcada pela antiga lei de zoneamento do Município (1972) e, posteriormente por lei estadual (Lei no 1.817/78). Abrangem os distritos da Lapa, Vila Leopoldina, Freguesia do Ó, Casa Verde, Limão, Barra Funda e Vila Maria, zona oeste e norte do município. Na zona centro-sul e sul, os distritos do

\footnotetext{
32 Informação fornecida pelo GTAC em 2007
} 
Ipiranga, Jabaquara, Santo Amaro, Campo Grande e Socorro. Na região sudeste os distritos do Tatuapé, Belém, Mooca, Água Rasa e Vila Prudente. Ainda segundo Ramires o novo zoneamento municipal (Lei 13.885/2004) transformou muitas das antigas zonas industriais em zonas de uso misto de baixa, média e alta densidade e, em zonas de centralidade polar, refletindo a mudança de perfil da cidade. A observação das regiões de concentração das áreas potencialmente contaminadas juntamente com o novo zoneamento aponta para um problema atual, quando há uma demanda por mudança de uso dessas áreas e uma forte ação do mercado imobiliário. Muitas destas regiões também estão abrangidas pelas Operações Urbanas $^{33}$, denominadas de Vila Leopoldina, Diagonal Sul, Celso Garcia e Carandiru-Vila Maria, no Plano Diretor (Lei 13.430/2002).

O perfil socioeconômico da RMSP e, particularmente, do município de São Paulo indica a sua tendência de funcionar como um núcleo de produção de áreas contaminadas. Atualmente os postos de combustíveis predominam como atividades contaminadoras, seguidos pelos empreendimentos industriais.

O controle da situação dos postos de combustíveis se torna relativamente mais fácil, pois, geralmente, têm menores dimensões, favorecendo a ocorrência de contaminação mais pontual; além de apresentarem contaminantes específicos dessa atividade com comportamento conhecido. Nesses casos, também, a exigência legal de troca dos tanques de combustíveis antigos por novos tanques, estanques, mostra a tendência de redução dessa atividade como principal fonte contaminadora no município.

Ao contrário, as áreas potencialmente contaminadas, representadas, na maior parte, por terrenos de antigas indústrias, quando sujeitas às investigações ambientais serão, muito provavelmente, responsáveis pelo aumento acentuado da relação das áreas contaminadas. Esses terrenos se caracterizam por apresentarem grandes dimensões, favorecendo a dispersão da contaminação e, uma diversidade de contaminantes, que podem reagir entre si, aumentando a complexidade dos processos de contaminação da área.

As áreas suspeitas de contaminação estão representadas, na sua maioria, pelos antigos lixões e aterros municipais. São áreas, em geral extensas, e, que, mediante investigações ambientais preliminares, recentemente realizadas,

\footnotetext{
33 "[...] o conjunto de intervenções e medidas coordenadas pelo Poder Público municipal, com participação dos proprietários, moradores, usuários permanentes e investidores privados, com o objetivo de alcançar em uma área transformações urbanísticas estruturais, melhorias sociais e a valoriazação ambiental" (Lei Federal n 10.257/2001)
} 
confirmam a sua contaminação e indicam a sua transferência para o cômputo das áreas contaminadas. Essas áreas, até bem pouco tempo, permaneciam invisíveis para o poder público e grande parte da população. Entretanto, com as exigências contidas na nova Lei do Lixo, o seu passivo ambiental terá que ser identificado e saneado.

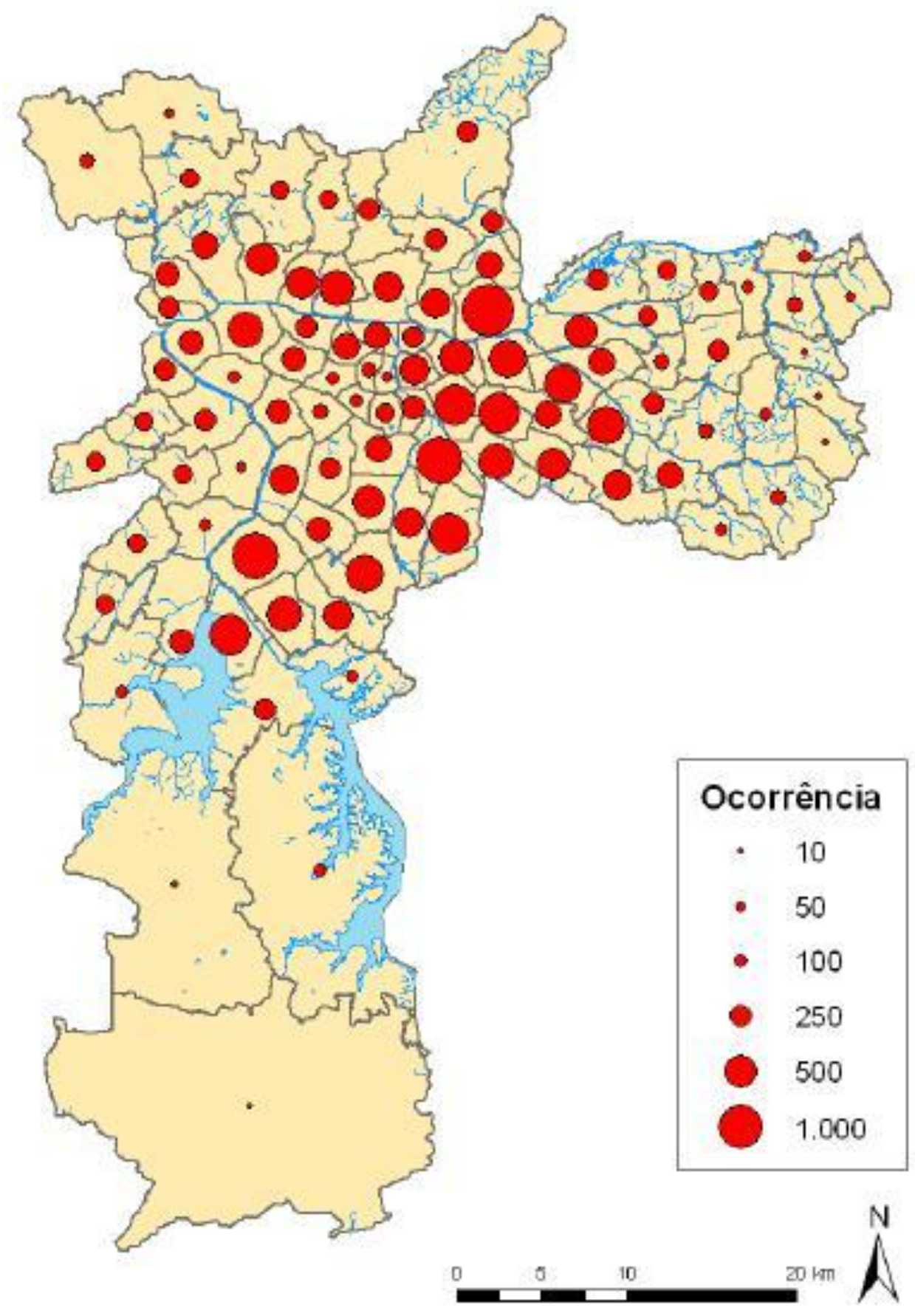

Figura 2.6: Concentração de áreas com potencial de contaminação por distrito no Município de São Paulo.

Fonte: Ramires (2008, p. 115). 


\section{CAPÍTULO 3}

\section{Gestão das Áreas ConTAMINADAS}

Nos países desenvolvidos e mais industrializados, desde meados dos anos 60 , aumentava a preocupação com a qualidade ambiental, sobretudo motivada por acidentes ambientais e episódios extremos de contaminação, em especial do ar e das águas, com conseqüências graves sobre a saúde humana, em algumas populações, bem como sobre espécies da flora e fauna das áreas atingidas. A abrangência dessa preocupação era local, sem ultrapassar, muitas vezes, as fronteiras de estados e províncias, limitando-se a regiões restritas, sob influência direta da fonte dos problemas ambientais registrados. Mesmo assim, nesta época, políticas públicas foram elaboradas estabelecendo-se regras gerais para o uso dos recursos naturais.

Nos anos 70, assiste-se à evolução das políticas públicas ambientais recémcriadas, ainda focadas em controle ambiental, em especial de empreendimentos industriais que se constituíam em fontes de degradação ambiental. O instrumento da Avaliação de Impacto Ambiental (AIA), fundamentada nos Estudos de Impacto Ambiental (EIA) surge como o marco nas políticas ambientais e nas ações regulatórias. 
No Brasil, a preocupação com a qualidade ambiental já despontava nos Códigos das Águas (1934) e Florestal (1965). A criação da Secretaria Especial do Meio Ambiente (SEMA) ${ }^{1}$, no nível federal, institucionalizou as ações ambientais no país com dois grandes objetivos: controle da poluição, principalmente industrial e proteção ambiental, por meio da criação de áreas protegidas. Várias medidas legais surgiram, posteriormente, com o objetivo de controlar a poluição e preservar e conservar os recursos ambientais.

É importante resgatar Pádua (2004, p. 30) quando afirma que a crítica sobre a destruição ambiental, preocupação no Brasil, desde o século XVIII, era tema de discussão da elite local que o utilizou como forma de se contrapor ao colonialismo e em defesa da independência.

[...] os esforços de crítica ambiental [...] podem ser vistos como momentos no processo de tomada de consciência dos dilemas ambientais no universo da modernidade. Eles foram capazes de enunciar uma questão política global que apenas, hoje, em plena mudança de milênio, está sendo percebida em toda a sua radicalidade.

No entanto, o autor argumenta que as idéias da elite local estavam relegadas a uma "ilha de letrados num mar de analfabetos", e que eram minoritárias mesmo dentro dessa "ilha" e assim que o enfrentamento efetivo da destruição ambiental estava restrito a uma parte da sociedade que não conseguiu concretamente implantá-las, com exceção da restauração da Floresta da Tijuca, entre 1861 e 1874. "[...] Se as preocupações ambientais estavam longe de conquistar o seu conjunto da elite, mais distante ainda estavam de influenciar a realidade socioeconômica sobre a qual essa última erguia o seu domínio" (Carvalho, $1981^{2}$ apud Pádua, 2004, p. 31).

Sánchez (2001) apontou diferentes níveis de abordagem para o tema da contaminação. A abordagem negligente caracteriza uma atitude de omissão, na qual se aguarda a manifestação do problema ou se deseja o seu permanente desconhecimento. Ações desarticuladas e solucionadas caso a caso são características da forma reativa. A atuação corretiva inclui a identificação, diagnóstico e recuperação planejada e sistemática; utilizada há tempos pelos países industrializados e que avançam para ações preventivas. A prevenção inclui a regulação do encerramento e desativação apropriada de empreendimentos ou

\footnotetext{
${ }^{1}$ Decreto no 73.030/1973.

${ }^{2}$ CARVALHO, J.M. A construção a ordem. 1981, p. 51.
} 
atividades que contribuem para o problema. O conceito de ciclo de vida, que avalia a origem até o reuso da contaminação está na base da visão proativa.

O processo de industrialização e urbanização brasileira está caracterizado por uma dinâmica de abandono e reuso de áreas, que podem representar histórico de desenvolvimento de atividades com potencial de contaminação dos solos e águas superficiais e subterrâneas, concentrados nos núcleos urbanos, o que faz dos municípios entes importantes para o gerenciamento desse tema, preferencialmente, compartilhado com os estados.

A utilização e a incorporação das áreas contaminadas, situadas tanto em zonas centrais como em zonas periféricas do município, sem a avaliação de risco e as devidas medidas de remediação ou de controle, pode acarretar vários riscos à saúde da população e ao meio ambiente. Da mesma forma, uma área contaminada pode representar problemas de gestão urbano-ambiental como desvalorização do entorno, cortes no tecido urbano, ocupação clandestina, abandono, subutilização de terrenos, contribuindo para a sua degradação urbana, paisagística e ambiental.

\subsection{GESTÃo dAS ÁREAS CONT AMINADAS NO CENÁRIO INTERNACIONAL}

Os problemas relativos à contaminação de solos e águas subterrâneas são, cada vez mais, objeto de preocupação da sociedade. Nos países mais industrializados tal preocupação remonta a década de 1980 do século passado, quando se iniciaram as primeiras ações para estruturação do sistema de gestão dessas áreas.

\subsubsection{Na AmÉRICA do NoRTE}

Os Estados Unidos foi um dos primeiros países a implementar as ações em área contaminadas, como visto no capítulo 2. A lei Comprehensive Environmental Response, Compensation and Liability Act (CERCLA) definiu critérios para a 
declaração da contaminação, investigação e remediação. Nesta oportunidade foi, também, instituído o Superfund, fundo constituído de recursos provenientes de taxas aplicadas sobre o óleo cru e outros produtos químicos e imposto cobrado de empresas, que eram utilizados nas áreas mais críticas. Posteriormente, o Superfund Amendments and Reauthorization Act (SARA) complementou os recursos e as áreas de atuação do CERCLA (Cunha, 1997 apud Silva (2001); Morinaga (2007).

No início da década de 1990, a fim de incentivar o reaproveitamento dos brownfields foi promulgado o Environment Protection Agency (EPA) Brownfields Program. Já neste século, em 2002, a lei federal The Small Business Liability Relief and Brownfield Revitalization Act estabelece critérios mais maleáveis para a responsabilização legal e financeira, permitindo a isenção dos custos das medidas reparadoras aos pequenos geradores de brownfields, às organizações sem fins lucrativos e aos geradores falidos. São isentos, também, de responsabilidade novos proprietários de terrenos que promoveram as investigações obrigatórias e, que posteriormente constatem contaminação (Morinaga, 2007).

$\mathrm{O}$ autor informa também que adicionalmente às exigências relativas à identificação e à recuperação das áreas contaminadas, a lei CERCLA determina à Agency for Toxic Substances and Disease Registry (ASTDR) e à EPA a elaboração de uma lista, em ordem de prioridade, das substâncias encontradas, com maior freqüência, nas áreas incluídas na National Priorities List ( NPL), quanto à toxicidade dos contaminantes e o seu potencial de risco. O autor apresenta, ainda, uma compilação das informações da ASTDR sobre as dez primeiras substâncias químicas (arsênio, chumbo, mercúrio, cloreto de vinila, bifenilas policloradas (PCBs), benzeno, hidrocarbonetos policíclicos aromáticos (PHAs), cádmio, benzo-pireno e benzo-fluoranteno) constantes na lista, em 2005.

A ASTDR visa prevenir ou reduzir a exposição a substâncias perigosas e os efeitos adversos na saúde humana. A avaliação de saúde pública realizada pela agência é predominantemente qualitativa, em contraste, com a avaliação quantitativa tradicional aplicada pela EPA. A agência identifica ações relativas à saúde pública a serem empreendidas pela EPA e por outras instituições. Em caso de urgência emite, ela própria, advertência de perigo para a saúde pública (Magalhães, 2000). 
Em 1989, o Canadá implantou o seu Programa Nacional de Recuperação de Áreas Contaminadas (National Contaminated Sites Remediation Program, NCSRP), incluindo padrões de qualidade dos solos contaminados e o Sistema Nacional de Classificação (NCS) que identificou áreas prioritárias para intervenção (CCME, 1993; Martin et al., 1997 apud Magalhães, 2000; Morinaga, 2007). O NCS, segundo Andrade (1996 apud Magalhães, 2000), mediante informações obtidas nas investigações preliminares, especifica três categorias de risco: alto, médio e baixo, de acordo com os seguintes fatores: características dos contaminantes, rotas de exposição e receptores ou bens a proteger.

\subsubsection{NA EUROPA}

Destacam-se diversos países na Europa com experiências no gerenciamento de áreas contaminadas. Segundo Magalhães (2000) alguns grupos de países foram constituídos para compartilhar informações e tecnologias e incrementar a gestão dos sítios contaminados na Europa. Dentre estes grupos, são citados: o AD HOC Internationalworking Group for Contaminated Land, iniciado em 1993, com mais de 20 países e organizações internacionais (FAO e OECD), o Common Forum for Contaminated Land in the European Union, formado em 1994, e a Network for Industrially Contaminated Land in Europe (NICOLE), rede criada em 1996, com a participação de companhias industriais, pesquisadores, universidades e organizações governamentais. Morinaga (2007) informa que a remediação das áreas contaminadas está contemplada em fundos públicos da União Européia, tais como, - European Regional Development Fund (ERDF) e o URBAN, além dos fundos específicos de cada país. A revitalização de sítios contaminados ganha incentivo, nos anos 90, com a criação dos programas: Contaminated Land Rehabilitation Network for Environmental Technologies (CLARINET), o Regeneration of Eupean sites incities and Urban Environments (RESCUE) e o Concernet Action on Brownfield and Economic Regeneration Network (CABERNET). E relata experiências de gestão dessas áreas na Alemanha, Holanda e Reino Unido que serão sucintamente descritas a seguir. 
A Alemanha, desde 1998, consta com a lei federal de Proteção do Solo e sua regulamentação, que estabeleceu os valores-limite de concentração das substâncias tóxicas no solo para investigação e remediação de áreas contaminadas, de acordo com os seus usos futuro: play-grounds, residências, parques, indústria e comércio. A responsabilização do proprietário da área, quanto aos custos para a sua remediação, na Alemanha, caso este não seja o poluidor, está limitada ao valor de mercado do terreno. Vários incentivos para a revitalização existem nos seus estados, dentre elas cita-se as Landesetwicklungsgesechaften (LEGs), sociedades de economia mista financiadas por recursos públicos e privados.

A Holanda trata a questão mediante a lei de limpeza do solo - Soil Cleanup $A c t$, de 1983, posteriormente incorporada à lei de proteção do solo, que exigia, às províncias, um programa anual de remedição das áreas mais críticas. Foi o primeiro país a adotar padrões de qualidade para solo e águas subterrâneas. O "Sistema ABC" (Lista Holandesa) fixava três classes de valores de referência de acordo com os usos previstos. Posteriormente, em 1994, mediante um aperfeiçoamento da classificação os níveis passaram a S, T e I, respectivamente: referência (permite qualquer tipo de uso do solo), alerta (risco à saúde e ao meio ambiente com necessidade de investigação) e intervenção (necessidade de remediação).

O Reino Unido promoveu o incentivo ao reuso de áreas urbanas abandonadas, desde meados da década de 1950, como conseqüência da sua política de instituição de cinturões verdes nas zonas periféricas das cidades. Além disso, foram criados instrumentos específicos, a saber: a Derelict Land Grant, que estipulava subvenção aos terrenos abandonados, as Enterprize Zones (EZ), zonas de empreendimento, que autorizou a isenção de impostos à implantação de empresas em áreas específicas e as Urban Development Corporations (UDC), corporações de desenvolvimento urbano. 


\subsubsection{Na AMÉRICA LATINA}

No programa de cooperação técnica implantado, em 1993, entre a Cetesb e a Deutsche Gesellschaft für Technische Zuzammenarbeit (GTZ), surgiu a iniciativa de construir uma rede regional para a troca de experiências e discussão dessa problemática no âmbito da América Latina. Em julho de 2008, a Rede Latina Americana de Prevenção e Gestão de Sítios Contaminados (ReLASC) ${ }^{3}$ foi operacionalizada. A descrição das experiências e ações de alguns países pode ser encontrada na sua plataforma virtual, sendo reproduzidas a seguir.

Na Argentina a gestão das áreas contaminadas é tratada no Programa para Gestão Ambiental de Áreas Contaminadas (PROSICO) com o objetivo de identificar, sistematizar, qualificar e quantificar processos de degradação por contaminação. Além de desenvolver estratégicas para a sua prevenção, controle e recuperação; assim como os instrumentos regulatórios. Em 2007, foi elaborado o Manual PROSICO.

No Chile foram desenvolvidos vários manuais e guias sobre pesquisas de áreas, identificação e confirmação da contaminação, listados a seguir: Identificação Sistemática de Sítios Contaminados; Identificação e Confirmação de Áreas com Presença de Contaminantes, na Região Metropolitana, Região do Bio-Bio, Região de Valparaíso e Região dos Lagos; Análise Técnico-Jurídica da Gestão de Sítios Contaminados no Chile e elaboração de uma lista com as Áreas Prioritárias com Potencial Presença de Contaminantes, em base digital.

No México a gestão das áreas contaminadas está associada à política geral de resíduos perigosos, atribuição da Diretoria Geral de Gestão Integral de Materiais e Atividades de Risco, integrante da Sub-secretaria de Gestão da Proteção Ambiental, vinculada à Secretaria de Meio Ambiente e Recursos Naturais, órgão nacional, criado em 2000. Muitos projetos foram desenvolvidos e outros estão em andamento, destacando os seguintes: Guia técnico para orientar a elaboração de estudos de risco ambiental em sítios contaminados; Programa de Remediação de Sítios Contaminados; Lei Geral de Equilíbrio Ecológico, Lei para Prevenção e Gestão Integral de Resíduos.

\footnotetext{
${ }^{3}$ ReLASC (<http://www.relasc.org>)
} 
Na Colômbia, em 2005, foi promulgada a Politica Ambiental para la Gestión Integral de Resíduos o Desechos Peligrosos. Algumas publicações foram elaboradas, a saber: Consolidación del Inventario de Plaguicidas, Guia Técnica de Evaluación y Manejo de Sítios Contaminados com COPS; Manual Técnico para a Ejecución de Análisis de Riesgos para Sítios de Distribuición de Derivados de Hidrocarburos. Investigações ambientais foram realizadas em algumas localidades, assim como implantação de projetos de remediação.

\subsection{GESTÃo dAS ÁREAS CONTAMINADAS NO BRASIL}

Só muito recentemente o gerenciamento das áreas contaminadas tem sido preocupação de alguns estados e municípios brasileiros. Nacionalmente esse instrumento tem sido pouco explorado e somente em dezembro de 2009 foi promulgada, pelo Conama, uma resolução normativa sobre o tema.

No nível estadual essa preocupação começa a aparecer com ênfase em São Paulo, certamente por se caracterizar como um estado industrial, onde, nos últimos tempos, o seu perfil econômico tem se voltado para o setor terciário, ou mesmo à modernização do seu parque industrial. Isso faz com que o fechamento de muitas indústrias aconteça e, por conseqüência, ocorra o abandono das suas instalações, reformas do seu parque industrial ou reutilizações desses mesmos terrenos.

Não por acaso, é em São Paulo, na Baixada de Santos, na década de 1980, que ocorre o primeiro registro de acidente de grande repercussão, devido à contaminação de solos por resíduos, provenientes da fabricação de agrotóxicos da Rhodia S.A., antiga Clorogil, objeto de uma das primeiras ações civis públicas ambientais (Sánchez, 2001). Outros casos são registrados na literatura: Indústrias Matarazzo, São Caetano do Sul, SP; Barão de Mauá, Mauá, SP; Keralux e Vila Carioca, São Paulo, SP e Cidade dos Meninos, Baixada Fluminense, RJ. Esses casos, via de regra, foram tratados com enfoque no controle ambiental por ações reativas e corretivas, geralmente apenas emergenciais. 


\subsubsection{Primeiras atividades desenvolvidas no estado e municíPIo de São PaUlo}

Em São Paulo, a questão do gerenciamento, se inicia dentro da cooperação técnica Brasil-Alemanha, mediante consultoria prestada pela agência alemã de cooperação técnica GTZ, à Companhia de Tecnologia de Saneamento Ambiental (Cetesb), no início da década de 1990, com o Projeto Recuperação dos Solos e das Águas Subterrâneas em Áreas de Disposição de Resíduos Industriais (Weber, 1996), no qual constava como meta principal a elaboração de um cadastro de áreas contaminadas e suspeitas de contaminação. O projeto resultou na elaboração do Manual de Gerenciamento de Áreas Contaminadas (Cetesb, 2001), no estabelecimento dos valores de intervenção para solos e águas subterrâneas do estado de São Paulo (Cetesb, 2002) e, desde 2002, na disponibilidade, via Internet, da relação das áreas contaminadas (Cetesb, 2009).

A Cetesb, por intermédio da GTZ, realizou reuniões com vários órgãos municipais, para apresentação daquele projeto, visando promover trabalhos em parceria com a Prefeitura do Município de São Paulo (PMSP). Uma iniciativa pioneira de trabalho conjunto entre a Cetesb e a Secretaria do Verde e Meio Ambiente (SVMA) ocorreu, em 1997, no loteamento Jardim Keralux ${ }^{4}$, na zona leste, conforme relato de Magalhães (2000) e a descrição de um dos estudos de caso, apresentados na dissertação de Ramires (2008).

O loteamento irregular foi implantado na várzea do Rio Tietê, em 1994, com área aproximada de $221.000 \mathrm{~m}^{2}$, sobre as estruturas da antiga indústria Keralux (Figura 3.1). Em 1995, a Secretaria Municipal da Habitação (Sehab) notificou os responsáveis pelo loteamento, os órgãos fiscalizadores e o Ministério Público Estadual solicitando a paralização das atividades e o desfazimento do loteamento. A SVMA, em abril de 1997, vistoriou a área para verificar suposta disposição de resíduos perigosos, por solicitação da Administração Regional de Ermelino Matarazzo, constatando indícios da ocorrência de BHC (Hexaclorociclohexano); confirmada, posteriormente, por avaliação ambiental realizada pela própria SVMA. Em novembro deste mesmo ano, em ação conjunta Cetesb-SVMA, após delimitação da área impactada e quantificação dos resíduos, foram retiradas 122 toneladas de

\footnotetext{
${ }^{4}$ O Jardim Keralux está situado na Av. Assis Ribeiro, altura do oㅜ 7.300, Subprefeitura de Ermelino Matarazzo e, atualmente, contido em Zona de Especial Interesse Social (ZEIS).
} 
BHC $\left(65 m^{3}\right)$ e levados, provisoriamente, para o aterro São João, local esse que passou a ser de disposição definitiva. Posteriormente, outras intervenções ocorreram na área do loteamento com poucos resultados satisfatórios. ${ }^{5}$

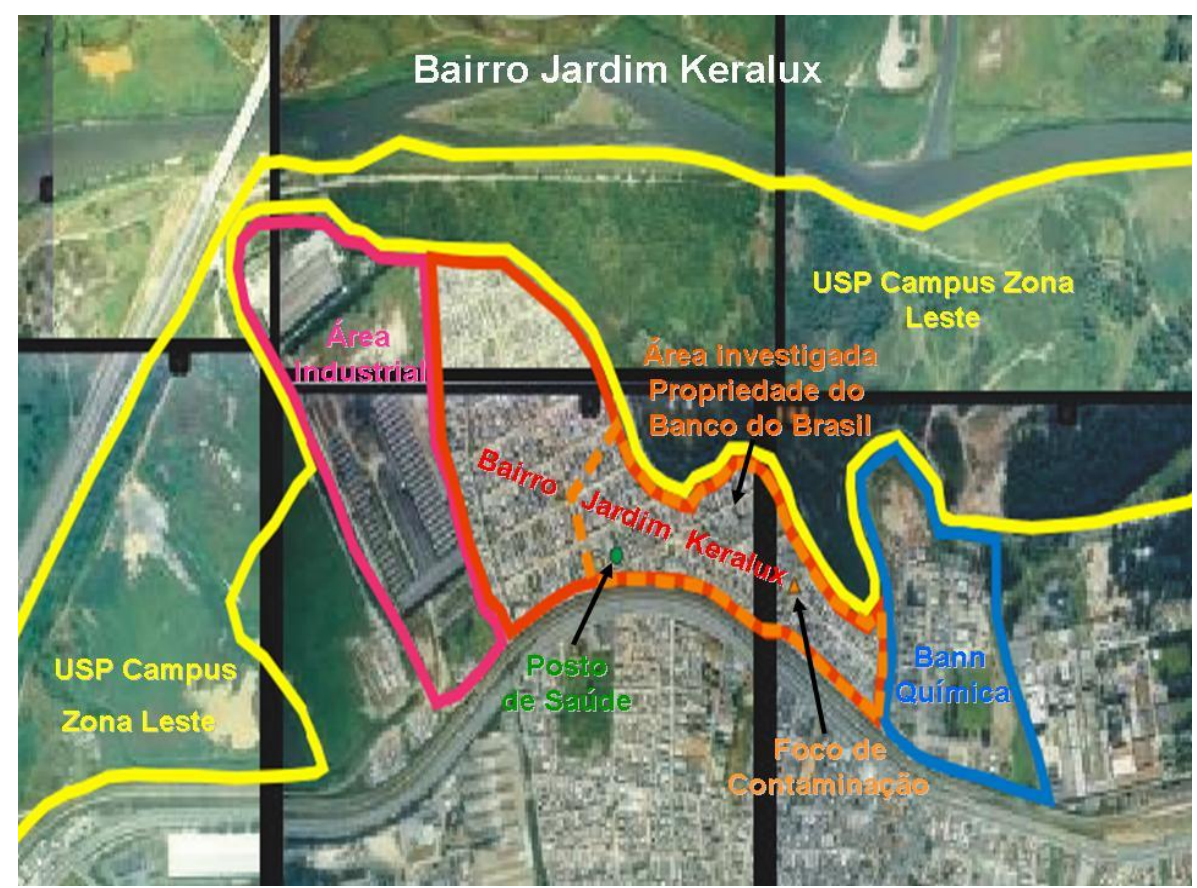

Figura 3.1: Localização do loteamento Jardim Keralux e seu entorno.

Fonte: Aerofoto BASE, 2001, escala original 1:6.000. Sehab/Resolo - SVMA/Decont/GTAC.

Em 1999, foi celebrado um termo de cooperação técnica entre a SVMA e a Cetesb , com previsão de validade até 2002. O objetivo principal da cooperação era estabelecer o cadastro compartilhado de áreas contaminadas. No âmbito da SVMA, - Departamento de Controle da Qualidade Ambiental (Decont), era a unidade responsável pelo desenvolvimento dos trabalhos, mediante as Divisões de Controle Ambiental (Decont -1) e de Projetos Especiais (Decont - 3). O Decont-1 tratava das áreas degradadas por resíduos sólidos, erosão, escorregamentos; de favelas e loteamentos irregulares ou clandestinos, bem como das propostas para a recuperação ambiental. Ao Decont-3 competia analisar os planos de emergência de transporte de produtos perigosos e a degradação ou contaminação em áreas de mananciais.

\footnotetext{
${ }^{5}$ Após a remoção do foco de contaminação da área, foram realizadas outras investigações, mas que, entretanto, não atenderam a todas as exigências da Cetesb, para a sua remediação. Em janeiro de 2007, a SVMA emitiu Auto de Intimação/Notificação aos responsáveis, Banco do Brasil e Massa Falida Construtora Alfredo Mathias, exigindo a realização de investigação ambiental detalhada e análise de risco. O Banco do Brasil não realizou as investigações exigidas por SVMA, pois conseguiu a suspensão de todas as autuações aplicadas. A Massa Falida Construtora Alfredo Mathias celebrou um Termo de Ajustamento de Conduta - TAC para promover a investigação, realizada, entretanto, por equívoco, em outro local (Ramires, 2008).
} 
Requalificação dos Aterros Desativados (BrownfieldS) no MunicíPIO de SÃo Paulo: Parques (GreenfieldS) RAPOSO TAVARES E JARDIM PRIMAVERA

LuZia Helena dos Santos BarRos

Para o desenvolvimento dos trabalhos inerentes ao convênio foram criados três grupos que tratariam das indústrias, resíduos sólidos e postos de gasolina. Os dois primeiros subgrupos efetivamente realizaram a análise preliminar das indústrias situadas na antiga Administração Regional de Santo Amaro e nas bacias hidrográficas do córrego Franquinho e do Rio Aricanduva, na zona leste e, de alguns antigos aterros da década de 1970. Esses trabalhos conjuntos, entretanto, foram interrompidos, por solicitação da Cetesb, em 2000, para a reestruturação do setor de áreas contaminadas internamente àquela Companhia. Neste mesmo ano, foi criada a Coordenadoria de Áreas Contaminadas na Cetesb.

Em 2002, o Grupo Técnico Permanente de Áreas Contaminadas (GTAC) foi criado no Decont/SVMA, tendo início o projeto Modelo de Gerenciamento para Revitalização de Áreas Degradadas por Contaminação, integrante do Projeto de Gestão Ambiental Urbana - ProGAU, do Ministério de Meio Ambiente - MMA, parte da Cooperação Técnica Brasil-Alemanha, com a Agência Alemã de Cooperação Técnica - GTZ. Além do MMA, no nível nacional, havia a participação do Instituto Brasileiro de Administração Municipal - IBAM.

O objetivo principal desse projeto compreendia a implementação de procedimentos técnicos e administrativos com vistas à revitalização de espaços urbanos contaminados subutilizados. Como área piloto foi selecionada o antigo incinerador Sumidouro, localizado na Rua do Sumidouro, em Pinheiros, atual Praça Victor Civita, que será apresentado no Capítulo 7.

Como resultados desse projeto constam vários relatórios. Em 2003, os seguintes relatórios foram finalizados: A revitalização de áreas urbanas degradadas - políticas, instrumentos e incentivos no cenário internacional e Instrumentos legais e econômicos existentes no Município de São Paulo para recuperação de áreas contaminadas. Em 2004, os relatórios: A revitalização de áreas urbanas degradadas por contaminação - experiências nacionais, Estudos de instrumentos e mecanismos de cooperação relevantes e Análise dos stakeholders públicos e privados. O relatório de síntese do projeto Consolidação Preliminar dos Produtos e Perspectivas para a Continuidade do Projeto foi finalizado no início de 2005.

Outro avanço no tema, no âmbito do estado, em 2003, foi promovido pelo Ministério Público do Estado de São Paulo - Centro de Apoio Operacional de Meio 
ambiente, Urbanismo e Patrimônio Cultural (CAOUMA/MP), com a criação do Grupo Interinstitucional de Áreas Contaminadas (GIAC) $)^{6}$. O trabalho objetivava avaliar o "estado da arte" do tema nas várias instituições, bem como, estabelecer procedimentos integrados para o gerenciamento das áreas contaminadas no Estado, mediante a experiência piloto com o município de São Paulo. As áreas potencialmente contaminadas foram o foco de preocupação, principalmente do Ministério Público, além da participação dos Cartórios de Registros de Imóveis no controle desses imóveis. Como resultado obteve-se o consenso sobre a obrigatoriedade da publicidade registrária, em cartório, das áreas confirmadas como contaminadas, possibilitando a notificação ao proprietário ou interessado da existência de restrições ambientais no local. Ramires (2008) informa que na última reunião do GIAC, em abril de 2007, não foi possível obter o cadastro de áreas potencialmente contaminadas e nem garantir a participação dos cartórios no controle dessas áreas.

A publicidade registrária da contaminação foi aprovada pela Corregedoria Geral da Justiça de São Paulo ${ }^{7}$, o que permitirá a averbação nas matrículas dos imóveis atingidos, de termo ou declaração de área contaminada, oficialmente emitido pela Cetesb. A publicidade funcionará como mais um instrumento de controle e de troca de informações, objetivando esclarecer ao empreendedor ou interessado ou, mesmo, à sociedade a situação da área. Deve-se ressaltar que a atuação dos cartórios estaria restrita à notificação ao interessado sobre existência de contaminação no imóvel, cabendo aos órgãos ambientais, a partir daí, todos os demais procedimentos relativos ao gerenciamento de áreas contaminadas. A informação sobre a contaminação na matrícula imobiliária serve de exemplo ao comentário de Melo (2004, p.116), sobre o novo código civil brasileiro contemplar a função social como elemento marcante do direito de propriedade e, desta forma, tal como o autor reconhece:

[...], o direito de propriedade pode e deve limitar-se em benefício de uma finalidade superior que mereça proteção, proteção que pode advir da lei ou através da consciência social [...].

\footnotetext{
${ }^{6}$ Relatório das Atividades do Grupo Interinstitucional para Estabelecimento de Procedimentos em Áreas Contaminadas (GIAC) - São Paulo. Fevereiro 2005. p. O GIAC contou com a participação dos seguintes órgãos: Cetesb, Prefeitura de São Paulo (SVMA, Sehab e SMSP), Junta Comercial do Estado de São Paulo - Jucesp, Secovi, Sinduscon, AELO, Instituto de Registro Imobiliário (IRIB) e Companhia de Processamentos de Dados do Estado de São Paulo (Prodesp).

7 Decisão da Corregedoria Geral da Justiça do Tribunal de Justiça do Estado de São Paulo - CG N. 167/2005 - Capital, publicada no Diário Oficial do Estado de 12 de junho de 2006.
} 
Em março de 2005, a cooperação técnica Brasil-Alemanha foi retomada, mediante o Programa Energia e Meio Ambiente - Projeto de Gestão Ambiental Urbana - ProGAU, havendo a substituição do IBAM pela Caixa Econômica Federal e a integração da Secretaria Municipal de Planejamento (Sempla), atual Secretaria de Desenvolvimento Urbano (SMDU).

O projeto, então, foi denominado Revitalização de Áreas Urbanas Degradadas por Contaminação no Município de São Paulo prevendo a continuidade das intervenções necessárias à efetiva revitalização do antigo incinerador Sumidouro e a seleção de outras áreas. No âmbito propriamente deste projeto foi selecionada a região correspondente a futura Operação Urbana Diagonal Sul, abrangendo as Subprefeituras da Sé, Mooca, Ipiranga e Vila Prudente, principal eixo de antiga ocupação industrial, atualmente em franco processo de alteração de usos. Em 2007, foi elaborado o relatório Instrumentos para a revitalização de áreas urbanas degradadas por contaminação (Brownfields).

Novo termo de cooperação entre a SVMA e a Cetesb foi estabelecido em maio de 2005, com o objetivo de implementar um sistema integrado para o gerenciamento das áreas contaminadas no município de São Paulo ${ }^{8}$, encerrado em abril de 2009, prazo máximo de prorrogação acordado. Ramires (2008) relata, que no âmbito desse termo, a Cetesb disponibilizou o Sistema de Fontes de Poluição (SIPOL) com dados de 36.086 indústrias contidas no Município, que foram sendo inseridos no sistema de dados sobre imóveis (Boletim de Dados Técnicos - BDT), recebendo a classificação de áreas com potencial de contaminação.

Motta relata que, em maio de 2009, a SVMA propõe à Cetesb a prorrogação do termo de cooperação (Informação verbal) ${ }^{9}$ sem receber resposta daquela Companhia até o momento. Como primeiro trabalho para desenvolvimento, neste novo período de cooperação, foi indicada a análise da qualidade do solo de alguns parques municipais (Aclimação, Alfredo Volpi, Buenos Aires, Ibirapuera, Luz, Raposo Tavares, Trianon), onde foram encontradas elevadas concentrações de metais pesados $^{10}$ (informação verbal) ${ }^{11}$. Avalia-se que a proposta está desarticulada dos

\footnotetext{
${ }^{8}$ Processo Administrativo 2005-0.116.703-6

9 Ofício 089/SVMA-G/2009, de 29/05/09, encaminhado pelo Secretário Eduardo Jorge ao Diretor Presidente da Cetesb, informação fornecida por Milton Motta/GTAC em 2010.

${ }^{10}$ Figueiredo, A.M.G.; Enzweiler, J.; Camargo, S.P.; Sígolo, J. Metal contamination in urban park soils of São Paulo. Journal of Radioanalytical and Nuclear Chemistry, Vol. 280, No. 2. 2009. p. 423-429.

${ }_{11}$ Informação fornecida por Motta no Decont/SVMA em setembro de 2010. Rezende, em setembro de 2011, informa que ainda não foi estabelecido novo termo de cooperação.
} 
objetivos dos trabalhos do GTAC e, era necessário elaborar um novo termo de cooperação, pois o anterior não comportava prorrogação.

No âmbito da Cetesb, mediante a Decisão de Diretoria no 103 (Cetesb, 2007) que dispõe sobre o procedimento para gerenciamento de áreas contaminadas, foi aprovado o documento intitulado Procedimento para Gerenciamento de Áreas Contaminadas e criado o Grupo Gestor de Áreas Críticas (GAC), este vinculado à sua Presidência. O GAC tem como objetivo fundamentar as decisões nos campos institucional e técnico, sendo responsável pela gestão das informações e por estabelecer estratégias de comunicação dos riscos, além de definir o tipo de intervenção a ser aplicada.

Em 2009, houve a reestruturação da SVMA (Lei 14.887) ficando o GTAC subordinado à Divisão de Licenciamento Ambiental do Decont, extinguindo-se a Divisão de Projetos Especiais, à qual o mesmo estava vinculado, desde 2003. Entretanto, a formalização do Grupo não foi incluída no corpo da Lei, como sugestão feita anteriormente, mas apenas por meio de portaria interna ${ }^{12}$, a exemplo da época de sua criação ${ }^{13}$. Ressalte-se que nessa oportunidade havia todas as condições para concretizar uma necessidade antiga do GTAC: interesse político de promover mudança na estrutura da SVMA, capacitação da equipe técnica, trabalhos concretos realizados e publicados, participação e experiências adquiridas em fóruns de discussão nacional e internacional, crescente demanda para avaliação de mudanças de uso em áreas potencialmente, suspeita e contaminadas; justificativas mais do que essenciais às necessidades de estrutura administrativa e técnica (recursos humanos e financeiros), apontadas desde a criação do Grupo.

A Câmara Municipal de São Paulo (CMSP) também se reportou ao assunto, inicialmente, instaurando uma Comissão Parlamentar de Inquérito (CPI), em novembro de 2002, para apurar a responsabilidade por contaminação e passivo ambiental no âmbito do Município (CMSP, 2002-2003). O relatório final foi concluído em junho de 2003 solicitando a execução de projetos de Lei aprovados e o encaminhamento do referido relatório ao Ministério Público.

Em março de 2006, foi instaurada a CPI da Poluição (CMSP, 2006), com o objetivo de averiguar as responsabilidades pela poluição sonora, atmosférica, da

\footnotetext{
${ }^{12}$ Portaria 11/Decont-G/09.

${ }^{13}$ Portaria 97/SMMA-G, cria no Decont/SMMA, atual SVMA, o GTAC atribuindo-Ihe uma série de atribuições. Diário Oficial da Cidade, 16 de julho de 2002.
} 
água, do solo e do subsolo, além dos passivos ambientais. O relatório final do mesmo ano constatou a complexa situação do Município quanto à questão dos resíduos sólidos e sua destinação adequada, destacando a necessidade de viabilizar novos locais para instalação de aterros sanitários, visto que os em operação estavam muito próximos do esgotamento. O relatório também incluiu algumas proposições e sugestões, das quais se destacam:

a) À Mesa da Câmara Municipal

- criação da Comissão Extraordinária Permanente para controle da Poluição e dos Danos Ambientais;

- Aprovação do Projeto de Lei n16/2003, que dispõe sobre medidas preventivas e de proteção ao meio ambiente e de segurança, aplicáveis a estabelecimentos públicos e privados dotados de equipamentos e sistemas destinados ao armazenamento e à distribuição de combustíveis automotivos;

- Consolidar e aprimorar a legislação municipal sobre meio ambiente especialmente no que tange ao controle da poluição e suas fontes;

- Dotar o quadro de pessoal da CMSP de profissionais das áreas de geologia, química, biologia e engenharia, com especialização em meio ambiente para assessorar as atividades dos parlamentares.

b) À Administração Municipal:

- Redefinição institucional da SVMA, congregando na sua estrutura as diversas áreas de exercício do poder de polícia municipal, como licenciamento, [...] e monitoramento sobre os temas de emissões e contaminação: sonora, atmosférica, da água, do solo e subsolo, bem como dos passivos ambientais;

- Readequar de imediato o quadro funcional e os suportes técnicos, administrativos e laboratoriais no sentido de assegurar eficácia, eficiência e efetividade no exercício das competências municipais na defesa do meio ambiente;

- Estruturação legal da COVISA - Coordenação de Vigilância em Saúde do Município;

- Desenvolvimento de proposta ao planejamento integrado de resíduos que deverá contemplar e privilegiar, em especial a coleta seletiva de lixo domiciliar e suas cooperativas;

c) Ao Ministério Público:

- Providências para concretizar os Termos de Ajustamento de Conduta $\mathrm{TAC}^{14}$ para os casos apurados pela CPI;

d) Ao Governo do Estado:

- Que a Secretaria Estadual do Meio Ambiente - SMA determine às empresas, avaliadas pela Cetesb como suspeitas de contaminação, a apresentação dos relatórios ambientais em suas respectivas áreas.

\footnotetext{
${ }^{14}$ Termo de Ajustamento de Conduta - TAC é um instrumento legal destinado a colher do causador do dano ao meio ambiente, entre outros interesses difusos e coletivos, um título de obrigação de fazer e não fazer, mediante o qual o responsável pelo dano ao meio ambiente assume o dever de adequar sua conduta às exigências legais, sob pena de sanções fixadas no próprio termo (Lei 7.347/1985, Art. 5우 6 .
} 
Em março de 2009, a CPI sobre Danos Ambientais (CMSP, 2009) foi instaurada, baseada nos diagnósticos da CPI anterior, com a finalidade de apurar e investigar os danos ambientais e seus respectivos passivos, decorrentes do exercício de atividades e práticas industriais e econômicas inadequadas, irregulares e ilegais. Dentre os vários assuntos tratados foram incluídos os lixões ou aterros ativos e desativados. Mediante questionamentos sobre a existência de lixões ou aterros, os mesmos foram constatados nas seguintes subprefeituras: Capela do Socorro, Casa Verde, Freguesia do Ó, Itaquera, Jaçanã-Tremembé, Santo Amaro, São Miguel Paulista e Perus. Destaca-se das muitas providências enumeradas, a sugestão ao Executivo para "elaboração de projeto de lei que defina mecanismos de incentivos a investidores privados para viabilizar a recuperação de áreas sem interesse mercadológico para os empreendedores imobiliários - as denominadas "Áreas Órfãs".

As várias CPI's instaladas na CMSP pecam pela amplidão dos temas abordados e das inúmeras discussões, que na maioria das vezes divagam sobre o problema ou o tangenciam. Um dos fatores que pode explicar essa forma de abordagem é o próprio perfil profissional dos consultores parlamentares. O quadro de recursos humanos da CMSP não possui a diversidade técnica necessária à atuação multidisciplinar exigida na esfera do meio ambiente. A última CPI (2006) inclusive relacionou a recomendação para dotar a CMSP de profissionais com experiência na área ambiental. No caso do Ministério Público tem sido exigido do poder municipal e do poluidor o enfrentamento do problema, com freqüência, utilizando-se do TAC, mas muitas vezes sem compreender todas as nuances técnicas, administrativas e políticas, envolvidas no assunto, que ocasionam o seu descumprimento. Neste sentido a mesma CPI sugeriu a concretização dos TAC's para os casos por ela apurados. No entanto, alguns TAC's incluem tantas ações conflituosas e desconexas da realidade, que parecem ter sido elaborados com 0 propósito de apenas cumprir um procedimento administrativo e, previamente sem a intenção de efetivá-lo. 


\subsubsection{ATUAÇÃO DOS SETORES IMOBILIÁRIO E FINANCEIRO}

No setor imobiliário, o tema tem sido objeto de crescente interesse, em virtude das responsabilidades inerentes ao empreendedor imobiliário. O setor solicitou à Câmara Ambiental da Indústria e Construção Civil do Estado de São Paulo a discussão da questão, instituindo-se, em 2002, o Grupo de Trabalho de Áreas Contaminadas, sob coordenação da Cetesb com participação do Secovi, Sinduscon, AELO, CDHU, AESAS, IPT ${ }^{15}$, Universidade de São Paulo (USP), SVMA e Secretaria de Meio Ambiente de Santo André (Moliterno, 2006). O trabalho do grupo resultou na elaboração do Guila para Avaliação do Potencial de Contaminação em Imóveis (Cetesb, 2003), ferramenta orientadora aos empreendedores imobiliários e outros profissionais da área, quanto às precauções e procedimentos a serem adotados, para evitar intervenções que coloquem em risco a saúde humana (trabalhadores, moradores, usuários e vizinhos do empreendimento, dentre outros).

Na página da Internet do Secovi encontrava-se, em 2006, o Mapa das Áreas Contaminadas, tendo como fonte a Cetesb, no qual está representado o número de áreas contaminadas por distritos do Município, além da relação dos tipos de contaminantes mais encontrados (benzeno, tolueno, xileno - BETEX, hidrocarbonetos poliaromáticos - PAHs, metais e solventes halogenados) e as suas conseqüências para o organismo humano. A contaminação por postos de combustíveis destacava os distritos de Santana, Santo Amaro e Vila Maria.

Outro setor que vem se organizando para tratar do assunto é o financeiro, principalmente nas operações de concessão de crédito e de seguro, visto as conseqüências do passivo ambiental no patrimônio empresarial. Carvalho e Ribeiro (2000 apud Melo, 2004) destacam que a incorporação da variável ambiental na avaliação da concessão de crédito poderá contribuir com a proteção do próprio patrimônio e com a preservação do meio ambiente. No mercado segurador, está em desenvolvimento estudo para incorporar o passivo ambiental de postos de combustíveis na composição de apólice de seguro dessas atividades (Scorsin et al., 2006).

\footnotetext{
${ }^{15}$ Secovi - Sindicato das Empresas de Compra, Venda, Locação e Administração de Imóveis Residenciais e Comerciais de São Paulo; Sinduscon - Sindicato da Indústria e Construção Civil; AELO - Associação de Empresas de Loteamento e Desenvolvimento Urbano; CDHU - Companhia de Desenvolvimento Habitacional e Urbano; AESAS - Associação das Empresas Brasileiras de Consultoria e Engenharia Ambiental; Instituo de Pesquisa Tecnológicas do Estado de São Paulo IPT.
} 
A Caixa Econômica Federal (CEF) mediante o Projeto REVITA Revitalização de áreas urbanas degradadas por contaminação, no âmbito do acordo de cooperação técnica entre o Ministério do Meio Ambiente e a Agência Alemã de Cooperação Técnica (GTZ) elaborou um guia com informações relevantes à orientação do seu corpo técnico. O Guila Caixa: Sustentabilidade Ambiental vem "[...] para dar maior segurança aos seus negócios de crédito imobiliário ou de aplicações de recursos públicos em desenvolvimento urbano” (Marker, 2008). O autor destaca que "os instrumentos e procedimentos desenvolvidos visam a evitar a ocupação em terrenos contaminados". Esclarece, por outro lado, que em caso de contaminação constatada, a Caixa poderá ter mais segurança para aplicação das medidas necessárias à eliminação ou mitigação desses riscos, dentro das normas legais e técnicas de gerenciamento dos riscos.

\subsubsection{INSTRUMENTOS LEGAIS}

\subsubsection{INSTRUMENTOS LEGAIS NO ÂMBITO NACIONAL}

O tema contaminação já aparece no Brasil, em 1975, no Decreto-Lei 1.413, alertando para as possíveis degradações provocadas pelo setor industrial obrigando as indústrias instaladas ou a se instalarem no País a promover as medidas necessárias a prevenir ou corrigir os inconvenientes e prejuízos da poluição e da contaminação do meio-ambiente. Sánchez (2004) aponta que o reconhecimento do tema se dá a partir da década de 1980, mediante a repercussão do caso de contaminação por disposição inadequada de resíduos, pela empresa Rhodia, na Baixada Santista.

Posteriormente, a Lei 6766/79 (Leahmn)), que dispõe sobre o parcelamento do solo urbano, incorporou alguns cuidados quanto às condições ambientais do solo e subsolo ao proibir o parcelamento, sob certas condições, entre elas:

- $\quad$ em terrenos aterrados com materiais nocivos à saúde pública, sem prévio saneamento;

- em terrenos onde as condições geológicas não aconselham a edificação; 
- $\quad$ em áreas de preservação ecológica ou naquelas onde a poluição impeça condições sanitárias suportáveis, até sua correção (Lei 6766/1979, Art. $3^{\circ} \$$ único).

A Lei no 6.938/81, que instituiu as bases da Política Nacional do Meio Ambiente (PNMA), criou o Sistema Nacional de Meio Ambiente (Sisnama), com o objetivo de integrar e articular os três níveis de governo e, o Conselho Nacional de Meio Ambiente (Conama), órgão consultivo e deliberativo, com representação da sociedade civil e dos municípios, caso esse possua órgão ambiental estruturado e Conselho de Meio Ambiente deliberativo. Essa lei introduziu mudanças significativas à política nacional, como observa Sánchez (2006, p. 78).

[...] Essa lei trouxe diversas inovações. No plano dos instrumentos de ação, instituiu, entre outros, a avaliação de impacto ambiental e o licenciamento ambiental, até então existente apenas na legislação de alguns Estados. No plano institucional, a lei inovou ao criar uma estrutura articulada de órgãos governamentasi dos três níveis de governo, o Sisnama - Sistema Nacional de Meio Ambiente. Inovou também ao criar o Conama (Conselho Nacional de Meio Ambiente), composto por representantes de diferentes órgãos federais, estaduais e por representantes da sociedade civil, incluindo o setor empresarial, sindical e organizações não-governamentais [...].

Outro avanço introduzido foi o princípio da responsabilidade objetiva do poluidor, que determina que os danos ambientais e a terceiros provocados por atividades exercidas pelo poluidor deverão ser indenizados ou reparados, independente da existência de culpa. A lei estabeleceu também que os municípios, observada a legislação federal e estadual, poderão elaborar normas supletivas e complementares, bem como padrões relacionados ao meio ambiente, princípio recepcionado, posteriormente, pela Constituição Federal (1988), no seu Artigo 23. Os municípios, assim, passam a ser entes fundamentais à proteção ambiental, conforme declara Antunes (2001 ${ }^{16}$ apud Reis, 2004, p. 361):

[...] Está claro que o meio ambiente está incluído entre o conjunto de atribuições legislativas e administrativas municipais e, em realidade, os Municípios formam um elo fundamental na complexa cadeia de proteção ambiental [...].

Além da existência de instrumentos legais, que delegam aos municípios, a competência para o início da gestão ambiental local, observa-se, por parte de alguns setores da sociedade, uma forte corrente em direção à descentralização. Alega-se que haveria melhor tratamento dos problemas locais e que a sociedade estaria

\footnotetext{
${ }^{16}$ ANTUNES, P.B. Direito Ambiental. Rio de Janeiro: Lumen Juris, 2001. 657 p
} 
protegida contra a centralização de poder, o que proporcionaria maiores chances de participação pública nos processos decisórios. Por outro lado, como aspectos contrários à descentralização da gestão ambiental, poderiam ser apontados a falta de cooperação entre os municípios e o fato de que o município, nem sempre, é a esfera mais apropriada para determinadas ações, do ponto de vista ambiental, econômico, social e político.

Bezerra e Ribas (2005) afirmam que as gêneses da problemática urbana e ambiental são diferentes, a saber: do privado e do público, dos recursos naturais como bens finitos e como bens ilimitados, da descentralização e centralização da regulação, respectivamente; o que explicaria a dicotomia no trato dessa questão. Os mesmos autores apontam, também, que a legislação brasileira não incorpora a dimensão ambiental nos instrumentos de gestão urbana, remetendo o uso do solo a uma ação setorial limitada à eficiência dos valores econômicos. Há de se considerar ainda os comentários de Costa e Braga (2002) sobre a implementação setorializada das políticas públicas e o pouco diálogo existente entre os vários órgãos.

A Lei de Interesses Difusos (Lei 7.347/1985) merece menção, pois como afirma Sánchez (2006) ela ampliou o conceito de dano ambiental, quando definiu os interesses difusos ${ }^{17}$, instrumentando o Ministério Público na matéria ambiental.

A Lei no 9.605/1998 (Crime Ambiental), no Art. 54, define como crime o ato de causar poluição de qualquer natureza, qualificando o delito, quando uma área urbana ou rural, torna-se imprópria para a ocupação humana ( $2^{\circ}$, inciso I) ou, por lançamento de resíduos sólidos, líquidos ou gasosos, ou detritos, óleos ou substâncias oleosas, em desacordo com as exigências, estabelecidas em leis ou regulamentos ( $\S 2^{\circ}$, inciso V). O Art. $56, \S 1^{\circ}$, define como crime "o ato de produzir, processar, embalar, importar, exportar, comercializar, fornecer, transportar, armazenar, guardar, ter em depósito ou usar produto ou substância tóxica, perigosa ou nociva à saúde humana ou ao meio ambiente, em desacordo com as exigências estabelecidas em leis, ou nos seus regulamentos, assim como a conduta de abandoná-los ou utilizá-los em desacordo com as normas de segurança".

O Conama que, desde 2004, discutia a política nacional para a gestão de sítios contaminados, promulgou a Resolução 420, em dezembro de 2009, que trata dos critérios e valores orientadores de qualidade do solo e do gerenciamento de

\footnotetext{
${ }^{17}$ Interesses difusos são aqueles comuns a um grupo indeterminado ou indeterminável de pessoas, como ocorre com os moradores de uma região, os freqüentadores de um espaço público, os consumidores de certos produtos e as minorias raciais (Sánchez, 2006, p.79).
} 


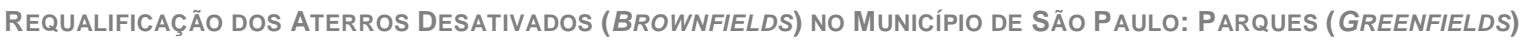
RAPOSO TAVARES E JARDIM PRIMAVERA

LUZIA HELENA dOS SANTOS BARROS

áreas contaminadas. O Art. 3o estabelece que, a proteção do solo deverá ser realizada de forma preventiva, mantendo a sua funcionalidade ou corretiva, restaurando a sua qualidade ou recuperando-a, de forma compatível com os usos previstos. Adota no seu Art. 60 vários termos e definições. Dentre as ações de gerenciamento do órgão ambiental competente, relaciona a necessidade de ampla publicidade e comunicação da situação da área ao proprietário, ao possuidor, ao Cartório de Registro de Imóveis da Comarca onde se insere o imóvel, bem como ao cadastro imobiliário das prefeituras e do Distrito Federal (Art. 31, inciso VIII). Instituiu no Art. 38, inciso X, o Banco de Dados Nacional sobre Áreas Contaminadas, a ser alimentado a partir das informações exigidas em relatório citado no seu caput. Inclui como anexos: o Procedimento para o Estabelecimento de Valores Orientadores de Referência de Qualidade de Solos, a Lista de Valores Orientadores para Solos e para Águas Subterrâneas e o Fluxograma das etapas de gerenciamento de áreas contaminadas. Mediante a Resolução 273/2000, estabeleceu a obrigatoriedade do licenciamento ambiental dos sistemas de armazenamento de combustíveis, exercida no estado de São Paulo pela Cetesb, desde 2001, quando foi instituída a Resolução/SMA no 5.

\subsubsection{InStRumentos LEGAIS NO ESTAdo DE SÃo PAULO}

A Política Estadual do Meio Ambiente (Lei 9.509/1997) estipula algumas ações em matéria de degradação ambiental: medidas para a prevenção da degradação e a sua recuperação, junto ao setor privado; controle e fiscalização de obras, atividades, processos produtivos e empreendimentos que causem degradação e a comunicação à população, entre outros, sobre a existência de substâncias nocivas e potencialmente nocivas à saúde e ao solo. No âmbito da lei foi criado o Sistema Estadual de Administração da Qualidade Ambiental (SEAQUA), integrante do Sisnama, tendo como órgão central a Secretaria Estadual de Meio Ambiente (SMA).

Até muito recentemente o estado lidava com a questão da contaminação através da Lei 997/1976, que trata do controle da poluição no meio ambiente, e o seu decreto regulamentador $8.468 / 1976$. Para algumas situações particulares, a lei 9.999/98 estabeleceu que nas Zonas de Uso Predominantemente Industrial (ZUPI) 
poderão ser admitidos os usos residencial, comercial, de prestação de serviços e institucional, quando se tratar de zona que tenha sofrido descaracterização significativa do uso industrial e não haja contaminação da área, mediante parecer técnico do órgão ambiental estadual, desde que o uso pretendido seja permitido pela legislação municipal. Nos casos de encerramento de atividades sujeitas ao licenciamento ambiental o Decreto Estadual 47.400/02 solicita a apresentação de um Plano de Desativação que contemple o passivo ambiental e as necessárias medidas de recuperação.

A Lei 12.300/2006, que instituiu a Política Estadual de Resíduos Sólidos, especifica que os responsáveis pela degradação ou contaminação de áreas em decorrência das suas atividades deverão promover a sua recuperação ou remediação, em conformidade com procedimentos específicos, estabelecidos em regulamento.

Mais recentemente foi promulgada a Lei 13.577/2009, que dispõe sobre diretrizes e procedimentos para a proteção da qualidade do solo e gerenciamento de áreas contaminadas. Dentre os objetivos da lei destacam-se as medidas preventivas à geração de áreas contaminadas, o incentivo à reutilização de áreas remediadas e a garantia à informação e à participação da população afetada nas decisões relacionadas com as áreas contaminadas. A Lei (Art. 30) criou o Fundo Estadual para Prevenção e Remediação de Áreas Contaminadas (FEPRAC), vinculado à SMA e destinado à proteção do solo contra alterações prejudiciais às suas funções, bem como à identificação e à remediação de áreas contaminadas. Foi definida a classe área remediada para uso declarado ${ }^{18}$ e exigido ao seu responsável que proceda à averbação desta informação na matrícula imobiliária (Art. 26 e 27). A alteração do uso dessa classe fica submetida à avaliação de risco para o novo uso pretendido e à avaliação do órgão ambiental competente (Art. 28). O Decreto no $54.544 / 2009$ regulamenta os seus incisos, XIII e VIII (Art. $4^{\circ}$ e $31^{\circ}$ ), que tratam da compensação ambiental.

\footnotetext{
${ }^{18}$ É a área contaminada onde foi restabelecido um nível de risco aceitável para um uso declarado.
} 


\subsubsection{INSTRUMENTOS LEGAIS NO MUNICÍPIO DE SÃO PAULO}

Antecipando-se a outros entes da Federação, o município de São Paulo já incluiu, na sua Lei Orgânica (1992), o tema das áreas degradadas e da recuperação ambiental (Art. 148 e 182). Mas somente, em 2002, reconhece oficialmente o problema das áreas contaminadas, promulgando legislação específica para o tratamento das mesmas, sendo a SVMA responsável pela sua aplicação. Ao Decont/SVMA, tal como dispunha a Lei $11.426 / 1993$ e hoje a Lei 14.887/2009, compete:

[...] orientar, planejar, ordenar e coordenar as atividades de controle, monitoramento e gestão da qualidade ambiental, nos termos das atribuições da Secretaria como órgão local do Sistema Nacional do Meio Ambiente Sisnama e promover o acompanhamento, avaliação e controle da qualidade das águas, do solo, do ar e dos resíduos, em todas as suas formas [...].

Desta forma, o Decreto 42.319/2002 instituiu o cadastro de áreas contaminadas e suspeitas de contaminação, com a possibilidade de sua localização em base cartográfica adequada. O cadastro subsidiará os processos de aprovação, licenciamento ou regularização de parcelamento, uso e ocupação do solo na Secretaria das Subprefeituras (SMSP) e na de Habitação (Sehab); além da definição de rotas de exposição de populações aos contaminantes existentes. Remeteu às Subprefeituras a fiscalização preventiva dessas áreas e informação à SVMA sobre quaisquer ocorrências. Inovou ao garantir a participação da população atingida no processo de decisão sobre a reabilitação dessas áreas, mediante cadastramento a ser regulamentado.

A Lei 13.564/2003 complementou o decreto anterior, pois incluiu as áreas potencialmente contaminadas na atuação do poder público e exigiu a apresentação de Laudo Técnico de Avaliação de Risco, comprovando a existência de condições ambientais aceitáveis para o uso pretendido.

O Plano Diretor Estratégico (PDE) do Município de São Paulo, Lei 13.430/02, estabelece dentre seus objetivos o controle e a redução dos níveis de poluição e de degradação, controle da poluição da água, do ar e da contaminação do solo e subsolo. Determina que o controle da poluição da água, do ar e a contaminação do solo e subsolo constituem diretrizes da Política Ambiental do Município (Art. 56). Dentre os objetivos da Política de Resíduos Sólidos, 
apresentados no Art. 70, relaciona a recuperação de áreas públicas degradadas ou contaminadas e no Art. 71 determina a criação de mecanismos para que o mesmo ocorra em áreas particulares. Menciona a necessidade de instituir o zoneamento ambiental, por legislação específica (Art. 248), que deverá considerar o cadastro de áreas contaminadas existente na época da sua elaboração (Art. 249).

A Lei 13.885/2004, que complementa a anterior, instituiu os Planos Regionais Estratégicos (PRE) e as diretrizes para o parcelamento e ordenamento do uso e ocupação do solo, especificando, no seu Art. 201, que as áreas contaminadas ou suspeitas de contaminação só poderão ser utilizadas após investigação e análise de risco específico. $O$ artigo incluiu também uma listagem das atividades classificadas como suspeitas de contaminação: indústria química, petroquímica, metalúrgica, farmacêutica, montadoras, têxtil, tinturaria, depósitos de resíduos, materiais radioativos, matérias provenientes de indústrias químicas, aterro sanitário, cemitérios, mineração, hospitais e postos de combustíveis.

O Código Sanitário do Município de São Paulo (Lei 13.725/2004) estabelece que, os órgãos de vigilância em saúde deverão monitorar as atividades potencialmente contaminadoras, garantir a remediação de áreas contaminadas e a manter o cadastro dessas áreas.

\subsubsection{CONFLITOS NA ATUAÇÃO DO MUNICÍPIO E ESTADO}

A criação da SVMA e seu respectivo Conselho de Meio Ambiente e Desenvolvimento Sustentável (CADES), em 1993, forneceu ao Município a competência legal para atuar na prevenção, conservação, manutenção, controle, gestão e planejamento ambiental, o que inclui a gestão das áreas contaminadas. Contudo até hoje persistem alguns conflitos devido, em muitas situações, à existência de competência concorrente ou à resistência para definir os seus limites.

Os principais conflitos se originam, conforme afirma Ramires (2008), nas zonas das antigas indústrias (ZUPI's), delimitadas pela lei estadual 1.817/1978 e alteradas pela lei municipal $13.885 / 2004$, que passaram a zonas de uso misto ou de centralidade polar. A lei estadual determinou que a mudança de uso oficializada pelo município implica a sua automática reclassificação (Art. $8^{\circ}, \$ 1^{\circ}$ ). Apesar disso, a Cetesb continua a exigir os estudos ambientais e a emitir parecer técnico, 
considerando na análise, prioritariamente, o uso pretérito da área, não havendo uma segurança específica quanto aos novos usos possíveis, visto que estes estão sob a aprovação do município. Essa prática acarreta uma duplicidade de ações ou mesmo soluções inadequadas de intervenção, desconectadas com os projetos de uso futuro pretendidos.

Mesmo com todos esses conflitos, alguns trabalhos conjuntos vêm sendo desenvolvidos e são experiências valiosas para o aprimoramento de todo o sistema de gestão. Neste sentido, a Lei Estadual 13.577/2009, incluiu entre os seus objetivos a promoção da articulação entre as instituições, relacionou o Plano Diretor como um dos instrumentos para o gerenciamento dessas áreas e determinou para a composição do Cadastro de Áreas Contaminadas a inclusão das informações registradas nos órgãos públicos estaduais e municipais.

\subsubsection{PoSSIBILIDADES DE APLICAÇÃo DE ALGUNS INSTRUMENTOS URBANíSTICOS, AMBIENTAIS E ECONÔMICOS NA REQUALIFICAÇÃO DAS ÁREAS CONTAMINADAS NO MUNICÍPIO DE SÃo PAULO}

As políticas públicas urbanas brasileiras recentes incorporaram a componente ambiental e estabeleceram estratégias econômicas para promover a requalificação de espaços vazios ou subutilizados. Especialmente no município de São Paulo pode-se citar o Plano Diretor Estratégico (PDE) e os Planos Regionais Estratégicos das 31 Subprefeituras (PRE). Esses instrumentos incluem vários dispositivos com potencial para incentivar a requalificação das áreas contaminadas, cujas diretrizes e conceitos têm origem no Estatuto da Cidade (Lei 10.257/01).

O PDE instituiu o Programa de Intervenções Ambientais (Art. 253), coordenado pela SVMA e a SMDU, a ser regulamentado por Decreto, pelo Executivo. Estipulou algumas ações a serem empreendidas, entre elas: a ampliação e preservação do sistema de áreas verdes; a recuperação de áreas degradadas e a identificação e reabilitação para novos usos de áreas contaminadas. Priorizou para atendimento do programa as áreas do Sistema de Áreas Verdes e as áreas públicas ou privadas de importância para recuperação e melhoria da qualidade ambiental. Apontou a possibilidade de utilização de instrumentos já previstos no Estatuto da 
Cidade: o Termo de Compromisso Ambiental (TCA $)^{19}$ e o Termo de Ajustamento de Conduta (TAC) ${ }^{20}$.

Grimski (2004) considera que os projetos de revitalização de áreas degradadas possuem características diferenciadas (uso pretérito, dimensão da área, antecedentes regionais e econômicos, mercado imobiliário e custos da intervenção), agrupando-os em três categorias, quanto ao fator econômico (Figura 3.2). Os terrenos atraentes ao mercado imobiliário e nos quais não há necessidade de financiamento, os situados em locais menos interessantes ao mercado e que podem ser objeto de investimento público e privado e aqueles sem interesse do setor imobiliário, sendo impossível a sua revitalização sem o aporte financeiro público. Do mesmo modo, Marker (2003) afirma que a experiência internacional mostra que a revitalização dessas áreas depende não somente dos investimentos privados e da dinâmica do mercado, mas também dos investimentos públicos.

A revitalização das áreas contaminadas, segundo Gramegna $\left(2007^{21}\right.$ apud Morinaga et al, 2008) deve se basear em instrumentos tributários e urbanísticos não necessariamente incluídos no Estatuto da Cidade. Para tanto, agrupa esses instrumentos em três tipos: os localizados em terrenos com interesse do mercado imobiliário e possibilidade de aplicação das parcerias público-privadas, áreas sem interesse do mercado nas quais o poder público deve ser indutor da intervenção necessária e os locais onde é necessária a aplicação de instrumentos de coerção.

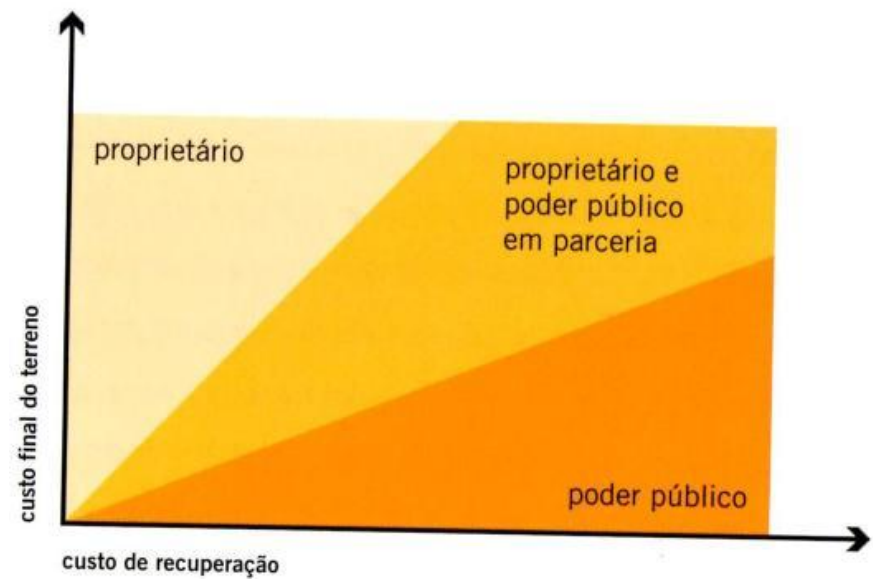

Figura 3.2 Relação dos custos de revitalização de áreas degradadas.

Fonte: Meyer e Grostein (2010, p.178), adaptado de Grimski (2004, p.12).

\footnotetext{
${ }^{19}$ Termo de Compromisso Ambiental - TCA é o documento firmado entre o poder público e pessoas físicas ou jurídicas, resultante da negociação de contrapartidas nos casos de autorização prévia para a supressão de espécies arbóreas (Art. 251).

${ }^{20}$ Termo de Ajustamento de Conduta - TAC é o instrumento com força de título extrajudicial, que tem como objetivo precípio a recuperação do meio ambiente degradado ou o condicionamento de situação de risco potencial à integridade ambiental, por meio da fixação de obrigações e condicionantes técnicas, estabelecidas pela SVMA, as quais deverão ser rigorosamente cumpridas, pelo infrator, em relação à atividade degradadora a que deu causa, de modo a prevenir, cessar, adptar, recompor, corrigir ou minimizar seus efeitos negativos sobre o meio ambiente (Decreto 42.833/2003, Art. 15).

${ }^{21}$ GRAMEGNA, M.V. Instrumentos rbanísticos passíveis de apicação nas áreas contaminadas: São Paulo. 2007. p.1-18.
} 


\subsubsection{OUTORGA ONEROSA}

Morinaga et al (2008, p.73-74) comentam que a outorga onerosa do direito de construir já vinha sendo utilizada, antes mesmo do PDE (2002), em operações urbanas e interligadas. Está baseada no direito de construir até o limite máximo do Coeficiente de Aproveitamento $(\mathrm{CA})^{22}$, com o direito adicional de construir sendo autorizado pela municipalidade mediante contrapartida financeira. Os autores entendem que pode se isentar, parcial ou integralmente dos valores adicionais de construção, o proprietário atual (não poluidor) de uma área contaminada, em contrapartida à remediação da área. Consideram que a sua aplicação está associada às áreas de interesse do mercado e à disponibilidade de estoque de potencial construtivo adicional nos distritos.

\subsubsection{TransferÊnCIA DO DiREITO DE CONSTRUIR}

A Transferência do Direito de Construir poderá ocorrer mediante autorização, em lei municipal específica, ao proprietário privado ou público para transferir o seu direito de construir para local diverso; ou alienar esse direito com o fim de preservar um imóvel de interesse histórico, ambiental, cultural, paisagístico ou social. No caso das áreas contaminadas, Morinaga et al (2008), apontam que a remediação de um imóvel pode restringir o seu uso, sendo possível então que o seu proprietário resgate esse direito em outro local. Propõem que após a realização da remediação, pelo proprietário, mediante um contrato, se proceda à doação do terreno ao município para a implantação de parque ou praça e, como contrapartida, Ihe seja restituído o direito de edificar em um novo local. Ressaltam, contudo, que a aplicação desse instrumento, no município, restringe-se a imóveis específicos situados nas seguintes zonas especiais: Zona Especial de Preservação Cultural (ZEPEC), Zona Especial de Proteção Ambiental e Zona Especial de Interesse Social (ZEIS).

\footnotetext{
${ }^{22}$ Coeficiente de Aproveitamento - CA é relação entre a área edificável e a área do terreno (Lei13.430/02, Art. 28 \$ 1º).
} 


\subsubsection{OpERAÇÕES URBANAS CONSORCIADAS}

Esse instrumento é regido por um conjunto de medidas para provocar transformações urbanísticas estruturais, melhorias sociais e valorização ambiental em perímetros determinados, mediante parceria público-privada, exigindo-se uma lei específica com definição das regras de cada operação urbana proposta. Morinaga et al. (2008) consideram que no caso de uma operação urbana abarcar áreas industriais ou passíveis de contaminação, a sua remediação poderá ser incentivada por alguns instrumentos urbanísticos ou pelo CEPAC ${ }^{23}$, para cobrir os seus custos. Os autores indicam as operações urbanas, Diagonal Sul e Vila Leopoldina, já previstas no PDE, como as mais promissoras, necessitando de identificação, diagnóstico e avaliação dos imóveis contaminados contidos nos respectivos perímetros.

\subsubsection{Fundo DE DESENVOLVIMENTO URBANO (FUNDURB)}

O FUNDURB foi criado pela mesma lei do PDE e regulamentado pelo Decreto 43.231/2003 com o objetivo de fornecer recursos financeiros à implantação dos vários dispositivos urbanísticos e ambientais instituídos no PDE. A utilização desses recursos na investigação e remediação de áreas públicas municipais (antigos aterros, lixões, bota-foras, etc) e áreas órfãs, foi sugerida por Morinaga et al. (2008).

\subsubsection{Fundo Especial do MEIO Ambiente (FEMA)}

O FEMA e o CONFEMA - Conselho Especial do Meio Ambiente e Desenvolvimento Sustentável foram aprovados pela Lei 13.155/2001, vinculado à SVMA e regulamentados pelo Decreto 41.713/2002. O FEMA é alimentado com

\footnotetext{
${ }^{23}$ CEPAC - Certificados de Potencial Adicional de Construção são títulos colocados no mercado primário de ações, por meio de leilão, que originam os recursos financeiros depositados no "Fundo da Operação Urbana Consorciada".
} 
recursos provenientes do orçamento municipal e de multas por infrações ambientais. Sua função é viabilizar financeiramente os planos, projetos e programas que visem o uso racional e sustentável de recursos naturais e, dentre outros, a recuperação da qualidade ambiental. Os seus recursos podem ser aplicados direta ou indiretamente pela SVMA ou transferidos a terceiros: órgãos públicos, Organizações da Sociedade Civil de Interesse Público (OSCIP) e Organizações não Governamentais (OnG). Os recursos serão prioritariamente destinados às linhas temáticas definidas pelo CONFEMA. As características desse fundo permitem a sua utilização também em áreas contaminadas, entendendo-se que devam ser priorizadas as áreas contaminadas municipais ou as áreas órfãs, mas até o momento essa linha temática ainda não foi objeto do CONFEMA. Destaca-se que a base de todos esses possíveis incentivos está condicionada à flexibilização das diretrizes estabelecidas no Plano Diretor, tratando de favorecer espaços intra-urbanos específicos e, muitas vezes, desconsiderando alguns problemas críticos do Município.

Villaça (2004) ressaltou que, a partir da década de 1990, os planos diretores tentavam incluir nos seus dispositivos os princípios da justiça social, dentre eles, o coeficiente de aproveitamento único e igual a um para toda a cidade (solo criado), ao qual se associavam as idéias da outorga onerosa, do potencial construtivo e a criação de fundo municipal de urbanização. Sendo assim, se faz necessária atenção ao alerta do autor quando discorre sobre a história do planejamento urbano no Brasil, demonstrando que os vários planos elaborados incorporaram a ideologia de esconder os problemas das maiorias e os interesses das classes dominantes na produção do espaço urbano. E ao que afirma Rolnik (1992 ${ }^{24}$ apud Pellogia, 1998, p.144-145) sobre as intervenções governamentais não representarem necessariamente $\mathrm{o}$ interesse coletivo

[...] Muitas vezes a intervenção do Estado não representa a melhor defesa do interesse coletivo, pelo contrário, por detrás de uma aparência de garantia, proteção e defesa do interesse público [se] escondem mecanismos de interação com o mercado, que acabam provocando efeitos contrários ao pretendido [...]

.Ou ainda quanto ao âmbito das tomadas de decisão mais importantes a que se referem vários autores

\footnotetext{
${ }^{24}$ ROLNIK, R. Política ambiental e gestão da cidade (Apresentação). In: PREFEITURA DO MUNICÍPIO DE SÃO PAULO/SECRETARIA MUNICIPAL DO PLANEJAMENTO. Cadernos de Planejamento, Diário Oficial do Município de São Paulo, Ano 37, no 243 (Suplemento). 1992 (24/12/92). p. 24.
} 
[...] as decisões de maior importância, que direta ou indiretamente afetam a economia local, se dão fora do âmbito do poder público municipal. Os agentes econômicos, geralmente decidem sob as pressões de mercado, dos interesses do lucro e de diretrizes políticas regionais ou nacionais de competências da União. A autonomia econômica de espaços subnacionais, descolada dos processos econômicos nacionais, é incompatível com a integração espacial do mercado capitalista [...] (Lojikne, Castells e Preteceille apud Oliveira, 1996).

\subsubsection{Manual de Gerenciamento de Áreas Contaminadas}

O gerenciamento de áreas contaminadas (Cetesb, 2001) é definido como um conjunto de medidas com o objetivo de assegurar o conhecimento das suas características e dos impactos causados pelas mesmas, propiciando a utilização de instrumentos adequados, necessários à tomada de decisão quanto à otimização das intervenções para minimizar os riscos à população e ao meio ambiente (Figura 3.2).

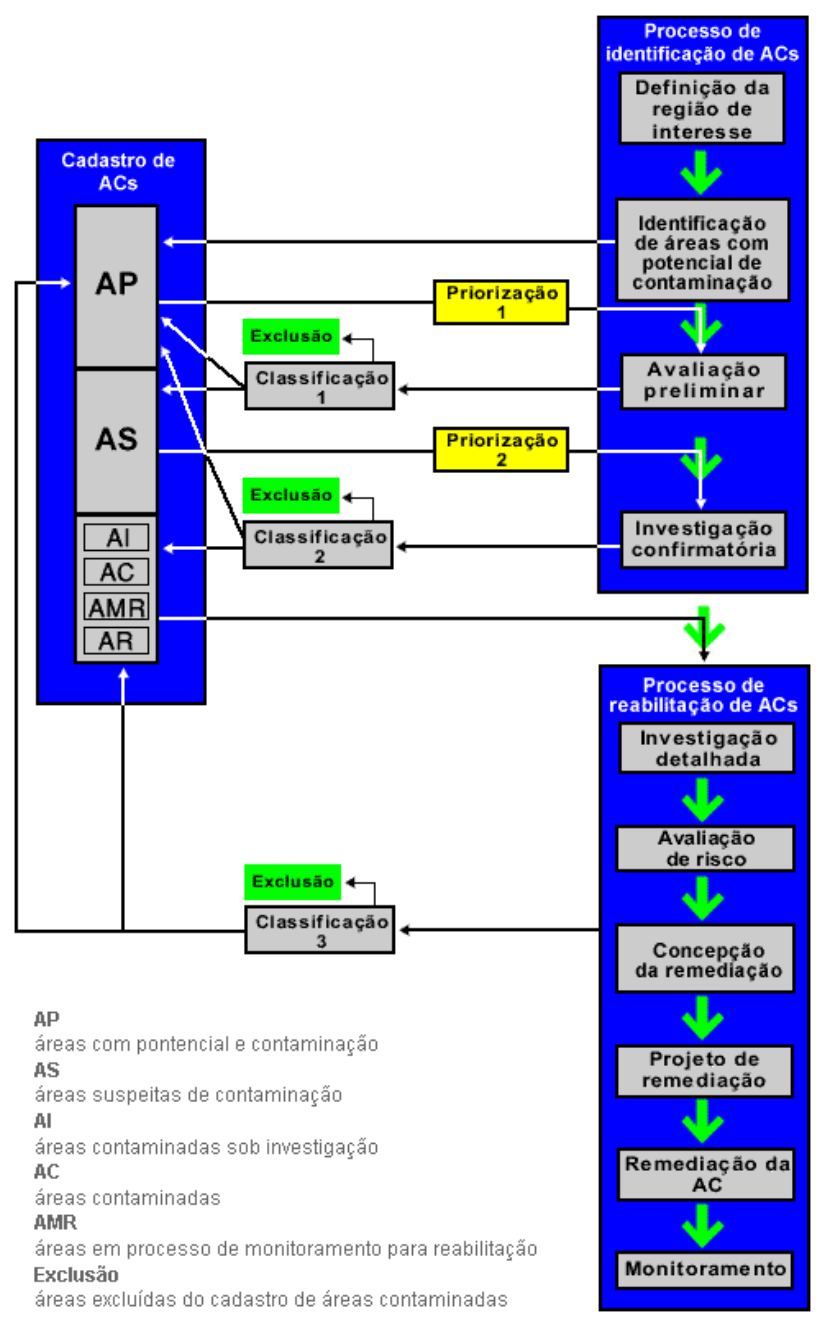

Figura 3.2: Fluxograma do Gerenciamento de Áreas Contaminadas.

Fonte: Cetesb (2007). 
O cadastro das áreas contaminadas, composto pelas suas diferentes tipologias, é o elemento fundamental para o gerenciamento dessas áreas. A partir das informações cadastradas, são definidas as etapas de estudos ambientais a serem empreendidas em cada caso de interesse. Após cada etapa de estudos a área recebe uma classificação específica. As etapas de investigação continuam até a área ser excluída do cadastro ou, caso confirmada a contaminação, até que se obtenham dados suficientes sobre o grau de concentração das substâncias presentes no meio (solo e água), bem como a sua abrangência, ou seja, até que seja estabelecido o modelo conceitual ${ }^{25}$ do caso analisado. Este modelo servirá de base para a análise de risco e, quando constatado o risco, providenciar as devidas ações com vistas ao seu gerenciamento.

O gerenciamento do risco corresponde à etapa de elaboração das propostas de intervenção. As diferentes possíveis medidas de intervenção, tais como: monitoramento, controle institucional ou de engenharia, remediação, ação emergencial e reabilitação para uso declarado, são definidas conforme o nível de risco constatado: risco aceitável, risco à saúde ou ecológico e perigo (Figura 3.3).

As medidas de controle institucional poderão substituir ou complementar a aplicação das técnicas de remediação, caracterizando-se por restrições: ao uso do solo, ao uso das águas superficiais e subterrâneas, ao uso de edificações e ao consumo de alimentos.

A seqüencialidade das etapas do gerenciamento de áreas contaminadas, parte da análise macro de uma área de interesse até alcançar dados analíticos complexos, em alguns casos; acompanhada pelo aumento dos custos para a investigação (Figura 3.4). Segundo Marker (2008, p.46) o procedimento seqüencial traz alguns benefícios:

- Otimização dos recursos: cada etapa leva a um resultado que orienta um melhor planejamento com maior objetividade;

- Criação de momentos de decisão e planejamento: no fim de cada etapa se gera uma conclusão que influencia o andamento da próxima, se for o caso, na forma de uma sequência lógica;

- Transparência sobre decisões e clareza dos objetivos das intervenções a serem implementadas.

\footnotetext{
${ }^{25}$ É o instrumento síntese do conhecimento adquirido sobre a área após a etapa de investigação detalhada. Deverá identificar as fontes primárias e secundárias de contaminação, os mecanismos de transporte e os caminhos preferenciais de movimentação dos contaminantes, as vias de exposição e os receptores potencialmente afetados; registrando todas as incertezas remanescentes e discutir a aceitabilidade das mesmas na execução da próxima etapa do gerenciamento (Cetesb, 2007)
} 


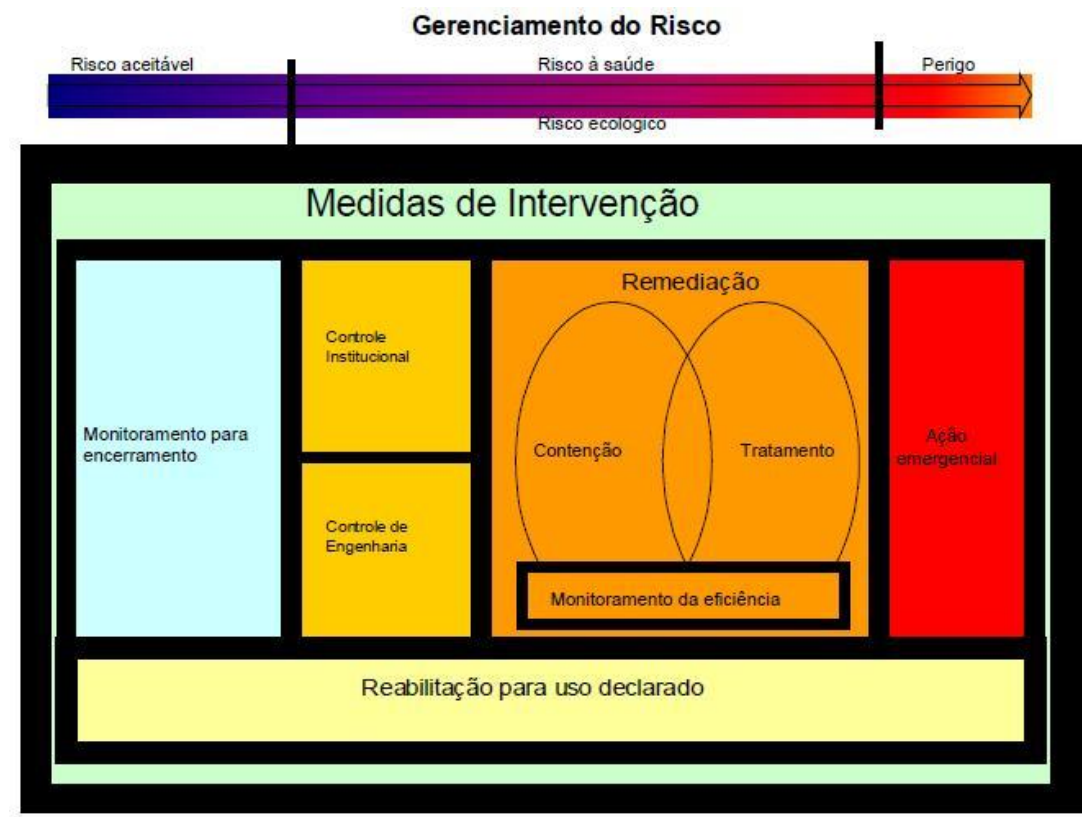

Figura 3.3: Ações de intervenção a serem adotadas no gerenciamento de risco. Fonte: Cetesb (2007, p.22).

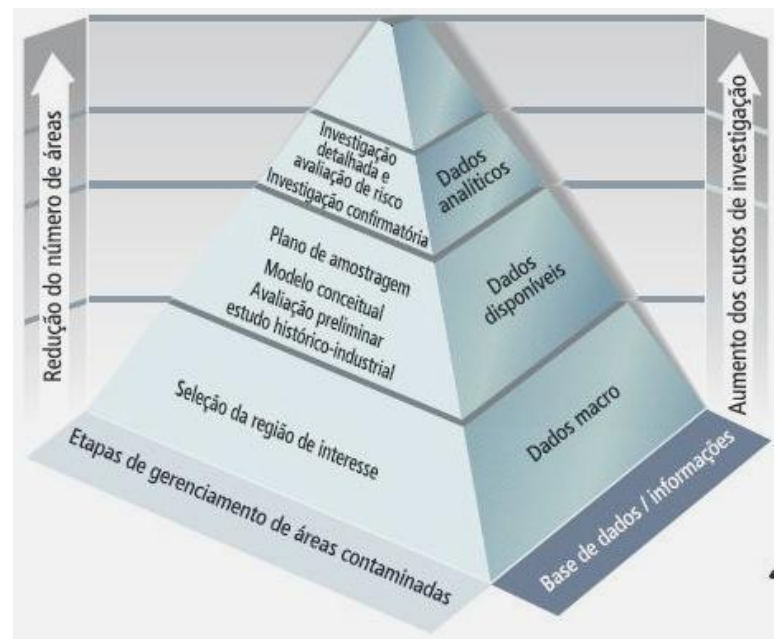

Figura 3.4: Relação entre a seqüência das etapas do gerenciamento e os custos de investigação. Fonte: Marker (2008, p.46).

O autor apresenta um gráfico (Figura 3.5) que mostra a relação não-linear entre a margem de erro inerente às etapas de investigação e o seu nível de evidências. Ou seja, as etapas iniciais: levantamento de informações e vistoria ao terreno, de fácil aplicação e baixo custo, já possuem pequena margem de erro, favorecendo o controle e o gerenciamento de riscos inerentes ao negócio imobiliário. Contudo pode-se extrapolar a aplicação desse comportamento para outros tipos de empreendimento (negócio). 


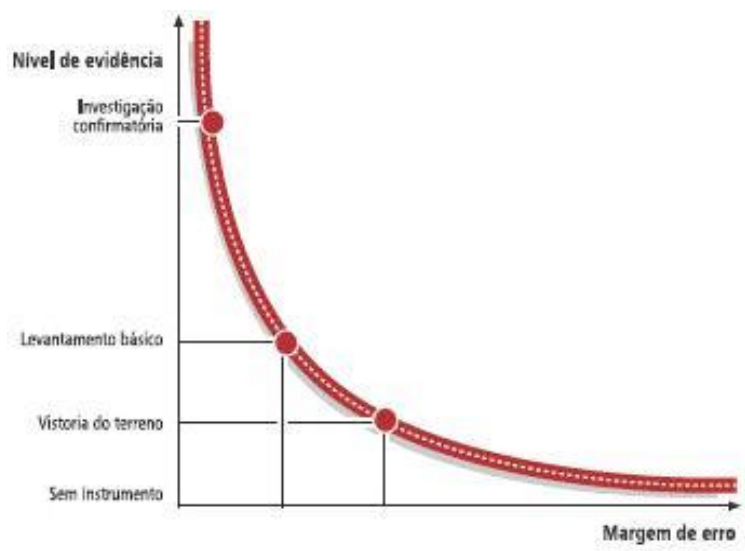

Figura 3.5: Relação entre a margem de erro e a complexidade de investigação Fonte: Marker (2008, p.48).

\subsubsection{Gestão das ÁReAs Contaminadas no municípIo de SÃo PaUlo}

A SVMA/Decont é o principal órgão municipal responsável pelas necessárias intervenções nas áreas contaminadas no Município. A criação do Grupo Técnico Permanente de Áreas Contaminadas (GTAC), em 2002, com a formação de uma equipe técnica especializada, aliada aos instrumentos legais instituídos e às discussões de casos práticos, possibilitaram a efetiva atuação na gestão dessas áreas. A Secretaria possui, dentre suas atribuições, a criação e a implementação do cadastro de áreas contaminadas e suspeitas de contaminação, preferencialmente em conjunto com o órgão ambiental estadual e a sua disponibilização a todos os órgãos municipais (Decreto 42.319/2002). Recentemente, foi exigida a publicação do relatório das áreas contaminadas na imprensa oficial e na Internet (Lei 15.098/2010; Decreto 51.436/2010). O cadastro, então, foi uma das primeiras atividades desenvolvidas pelo GTAC. Inicialmente, agregou-se à listagem de áreas contaminadas disponibilizadas pela Cetesb outras áreas reconhecidas pelo Município. Ao mesmo tempo elaborou-se uma listagem das áreas suspeitas de contaminação. As duas primeiras listagens, assim, foram enviadas, em março de 2004, aos órgãos municipais afins (Subprefeituras, Sehab, Sempla, SNJ, etc), via Memorando, pois em muitas unidades não havia disponibilidade para acesso à Intranet e Internet, àquela época. Uma atualização dessas listagens foi elaborada em fevereiro de 2005.

A implantação do cadastro digital, propriamente dito, foi viabilizada, mediante modificações indicadas pelo GTAC, no Sistema Integrado de Informações 
Urbanas (SIIU), desenvolvido pela Companhia de Processamentos de Dados Prodam para a Prefeitura, orientado pela Sehab, com o intuito de disponibilizar as informações para todos os órgãos municipais afins (Prodam, 2005). Além disso, assegura a alimentação e alteração dos dados pelas suas respectivas competências institucionais. O sistema utiliza como base o Boletim de Dados Técnicos (BDT) ${ }^{26}$, transferindo o legado de sistemas tradicionais de cadastro do município aos sistemas informatizados, facilitando o acesso aos seus dados, inclusive pela WEB, no futuro. Desta forma, a partir de junho de 2005, começaram a ser incluídos, on line, os dados sobre as áreas contaminadas identificadas pelo Município ou Estado. No final do segundo semestre de 2005, iniciou-se a inclusão das áreas classificadas como suspeitas e, em 2007, as potencialmente contaminadas.

Ramires (2008, p.124) informa que o sistema, até 2008, contava com um total de 11.000 áreas cadastradas, estimando-se que apenas as áreas potencialmente contaminadas cheguem a 36.000. Ressalta-se, entretanto, que 0 sistema ainda não foi georreferenciado e permite apenas a inclusão de dados sobre áreas urbanas, ou seja, que possam ser identificadas por SQL (Setor, Quadra, Lote). Deste modo, as áreas situadas em antigas zonas rurais, bem como áreas públicas, que não possuem SQL, ainda não poderiam ser cadastradas. O GTAC, considerando as especificidades para armazenar e tratar os dados gerados, desde 2002, solicitou ao Decont, em abril de 2007, a implantação de um banco de dados específico. Assim, a PRODAM foi contratada para a elaboração do Sistema de Informações de Gestão de Áreas Contaminadas (SIGAC) ${ }^{27}$. Mas somente no início de 2011 houve a disponibilização do cadastro eletrônico das áreas contaminadas, atualizado pela ultima vez em julho de 2011.

\footnotetext{
${ }^{26}$ Série de informações sobre os lotes utilizadas pelos órgãos municipais nos procedimentos de aprovação de alvarás solicitados.

${ }^{27}$ Processo Administrativo 2007-0.121.731-2
} 


\subsubsection{ATIVIDADES PIONEIRAS DESENVOLVIDAS PELO GTAC}

Uma das primeiras atividades sistemáticas desenvolvidas pelo grupo constituiu-se no projeto intitulado Avaliação ambiental preliminar, quanto ao potencial de contaminação, nas garagens e postos de abastecimento de combustíveis da Prefeitura do Município de São Paulo. O trabalho tinha como objetivo o treinamento da equipe, a atuação preventiva em áreas municipais, quanto ao atendimento à Resolução do Conama 273/2000 e SMA 5/2001; além de verificar os conflitos e dificuldades de integração advindos dessas ações. Foram avaliadas 34 unidades municipais possuidoras de garagens e postos de abastecimento de combustíveis, identificando-se 8 áreas suspeitas de contaminação, para as quais foi indicada a realização da investigação confirmatória e apresentação do plano de intervenção.

Uma das áreas classificadas como área contaminada suspeita, Garagem Prates, situada no Bom Retiro, onde havia registro de ocorrência de vazamento de óleo, nos anos 90, e previsão de mudança de uso, foi selecionada como projeto piloto, realizando-se a avaliação confirmatória e a análise de risco. $\mathrm{Na}$ área foram encontrados níveis de criseno acima dos valores aceitáveis, caracterizando uma via de exposição por emissão volátil em ambiente aberto, mas que não se completava devido ao recobrimento do solo por pavimento em bom estado. No entanto, para a execução de qualquer movimentação no terreno deveria ser exigida a utilização, pelos trabalhadores, de equipamentos de proteção individual especiais.

Esse projeto resultou, também, na elaboração do curso Manipulação Segura de Produtos com Potencial de Contaminação do Ambiente e da Saúde ministrado, em 2004, aos funcionários da Subprefeitura de São Mateus, pela equipe técnica do GTAC e profissionais que atuavam na Seção Técnica de Produtos Perigosos do Decont-3/SVMA. Uma cartilha foi elaborada, como material didático do curso, em quatro fascículos, que criou alguns personagens: a Ecolídia, a Regina Cicla e o Nico Ciente.

Os primeiros estudos de casos práticos referentes a parcelamento de solo (desdobro) e aprovação de mudança de uso, sob a análise do GTAC, advindos das determinações do Decreto 42.319/2002, exigiram pareceres técnicos, que demandaram grandes discussões, principalmente quanto aos procedimentos 
internos e de integração com outros órgãos municipais e estaduais. As secretarias diretamente envolvidas nos debates eram a de Planejamento, Saúde, Coordenação das Subprefeituras e as próprias Subprefeituras. Nesses debates despontavam o desconhecimento da questão da contaminação, os diferentes enfoques de cada setor e a dificuldade de se estabelecer ações de cooperação. Essa situação é descrita por Marker (2003, p.11).

[...] Frequentemente existem conflitos entre as secretarias de meio ambiente por um lado e de planejamento e habitação por outro, em função das diferentes atribuições e interesses destas entidades. Não é raro que as restrições ambientais entrem em conflito com os objetivos do desenvolvimento urbano [...].

De acordo com exigências legais, foi instituído um grupo intersecretarial para a elaboração de uma proposta para a regulamentação da Lei $13.564 / 03^{28}$. A minuta de regulamentação, finalizada em agosto de 2004, procurou solucionar os principais conflitos, existentes à época, entre a legislação municipal específica, além de propor procedimentos básicos para análise dos processos, que tratavam da questão nos órgãos envolvidos. A regulamentação efetiva da Lei dependeria do encaminhamento da minuta de regulamentação, para a Secretaria de Governo e posterior envio à Câmara Municipal, o que não ocorreu até o momento.

No grupo intersecretarial estavam representadas as seguintes Secretarias: Verde e Meio Ambiente, responsável pela sua coordenação, Habitação, Coordenação das Subprefeituras, Negócios Jurídicos, Planejamento, Saúde e Serviços; todas com participação efetiva. A Sehab estava representada pelos Departamentos de Parcelamento do Solo (Parsolo) e de Aprovação (Aprov). Os procedimentos, propostos para aprovação de empreendimentos ou intervenções em terrenos com potencial de contaminação, suspeitos de contaminação, ou contaminados estão representados em um fluxograma (Figura 3.6), elaborado a partir das discussões do Grupo.

As exigências solicitadas ao interessado, durante todo o processo de análise técnica do Município, eram emitidas mediante um "Comunique-se" (comunicado publicado no Diário Oficial). Quando a área era confirmada como contaminada, o Departamento de Aprovação (Aprov) exigia parecer técnico da Cetesb o qual poderia incluir restrições de uso a serem incorporados ao pedido de aprovação do projeto

\footnotetext{
${ }^{28}$ Processo Administrativo 2001-0.257.811-3
} 
pelo interessado. No período de 2003 a 2006, os responsáveis pelos imóveis classificados como contaminados eram comunicados e a análise prosseguia na Cetesb, devido à experiência daquela Companhia no tema e à sua complexidade. Com contínuo treinamento especializado da equipe técnica do GTAC, a partir de 2007, segundo Ramires (2008) todos os imóveis abrangidos pela legislação municipal passaram a ser analisados, pelo GTAC/Decont, em todas as etapas constituintes do processo de gerenciamento.

Segundo Ramires (2008), a partir do final de 2005, por demanda da Sehab os procedimentos relacionados aos processos de solicitação de certidão de diretrizes foram alterados. Nestes casos, o interessado passou a apresentar a Avaliação Ambiental Preliminar ao GTAC/Decont/SVMA, enquanto o prosseguimento normal da análise ocorria junto à Sehab. Entretanto, a emissão da certidão ficava condicionada ao parecer ambiental da SVMA.

A mesma autora comenta que o fluxograma de procedimentos nunca foi utilizado na sua totalidade, pois não havia exigência legal, já que a sua regulamentação não se efetivou. A Sehab, mediante o Aprov, além disso, se mostrou arredia quanto à sua implementação, pois isso alteraria procedimentos internos, impraticáveis do seu ponto de vista, devido a sua dinâmica e ao número de processos a serem analisados.

As solicitações para mudança de uso, abrangidas pela legislação estadual (Lei 9.999/1998 e Decreto 47.400/2002) são analisadas pela Cetesb que emite parecer técnico final, acompanhado do plano de intervenção. Esses documentos são encaminhados ao GTAC/Decont que, no caso de discordar das ações propostas, poderá solicitar estudos complementares e modificações no plano de intervenção (Ramires, 2008).

É importante apontar que, no geral, o início de todo o processo de gerenciamento dessas áreas, se caracteriza por alguma forma de intervenção, solicitada pelo proprietário ou empreendedor. Essas solicitações são protocoladas, comumente, em Sehab ou nas Subprefeituras e tratam do parcelamento do solo, de reformas até as mudanças do tipo de uso do terreno com execução de novas construções.

O GTAC também desenvolveu um método para identificação e priorização de áreas potencialmente contaminadas, de acordo com as atividades poluidoras desenvolvidas, elegendo como piloto o perímetro da Operação Urbana Diagonal Sul 
(Ramires et al, 2008). O trabalho partiu da análise do Cadastro de Contribuintes Imobiliários (CCM), de 2004, da Secretaria Municipal de Finanças, com 54.870 contribuintes, dos quais foram selecionados 644 , contidos no perímetro e passíveis de contaminação. Deste total 204 atividades industriais com maior potencial de contaminação foram priorizadas ${ }^{29}$, sendo 129 áreas vistoriadas, em 2005. As vistorias demonstraram que $40 \%$ das áreas estavam desativadas e $18 \%$ subutilizadas.

Áreas públicas com passivos ambientais (antigos aterros, usinas de compostagem e incineradores) estão também incluídas nas ações municipais. Dentre elas destaca-se a contratação pela SVMA dos estudos ambientais para subsidiar a implantação do Parque Jardim Primavera (Ramires et al, 2008), a ser tratado no Capítulo 8.

A integração efetiva das Subprefeituras e outras Secretarias (Habitação, Desenvolvimento Urbano, Saúde, Serviços, Infra-estrutura, Negócios Jurídicos, Esportes, etc.) ao sistema de gerenciamento dessas áreas poderá contribuir para a difusão do tema na Administração Pública e nas suas populações do entorno, favorecendo o debate sobre as decisões de intervenção.

O aprimoramento da gestão urbano-ambiental desses passivos implicará o aumento do número de áreas confirmadas como contaminadas e, conseqüentemente, do custo envolvido e a necessidade de maiores investimentos e de aperfeiçoamento das tecnologias e estratégias para promover a sua requalificação.

Os avanços de atuação verificados serão importantes no processo de revisão do Plano Diretor, destacando-se a necessidade de inclusão das áreas potencialmente contaminadas, na revisão da Lei 13.564/2003 e sua necessária regulamentação, a fim de especificar os procedimentos intersecretariais e, até interinstitucionais, e nos fluxos das ações entre as diversas instâncias, na tentativa de minimizar os conflitos existentes.

A publicidade registrária das áreas contaminadas é uma grande conquista para a sociedade, no entanto, independente da sua importância para a gestão ambiental será fundamental garantir o direito aos municípios de emitirem, também, a referida declaração, quando comprovada a capacitação técnica da sua equipe.

\footnotetext{
${ }^{29}$ As atividades poluidoras priorizadas foram obtidas mediante a análise das listas de atividades integrantes da Lei Federal 10.165/2000 - Anexo VIII e Instrução Normativa IBAMA no 10, de 17/08/2002 - Anexo II.
} 


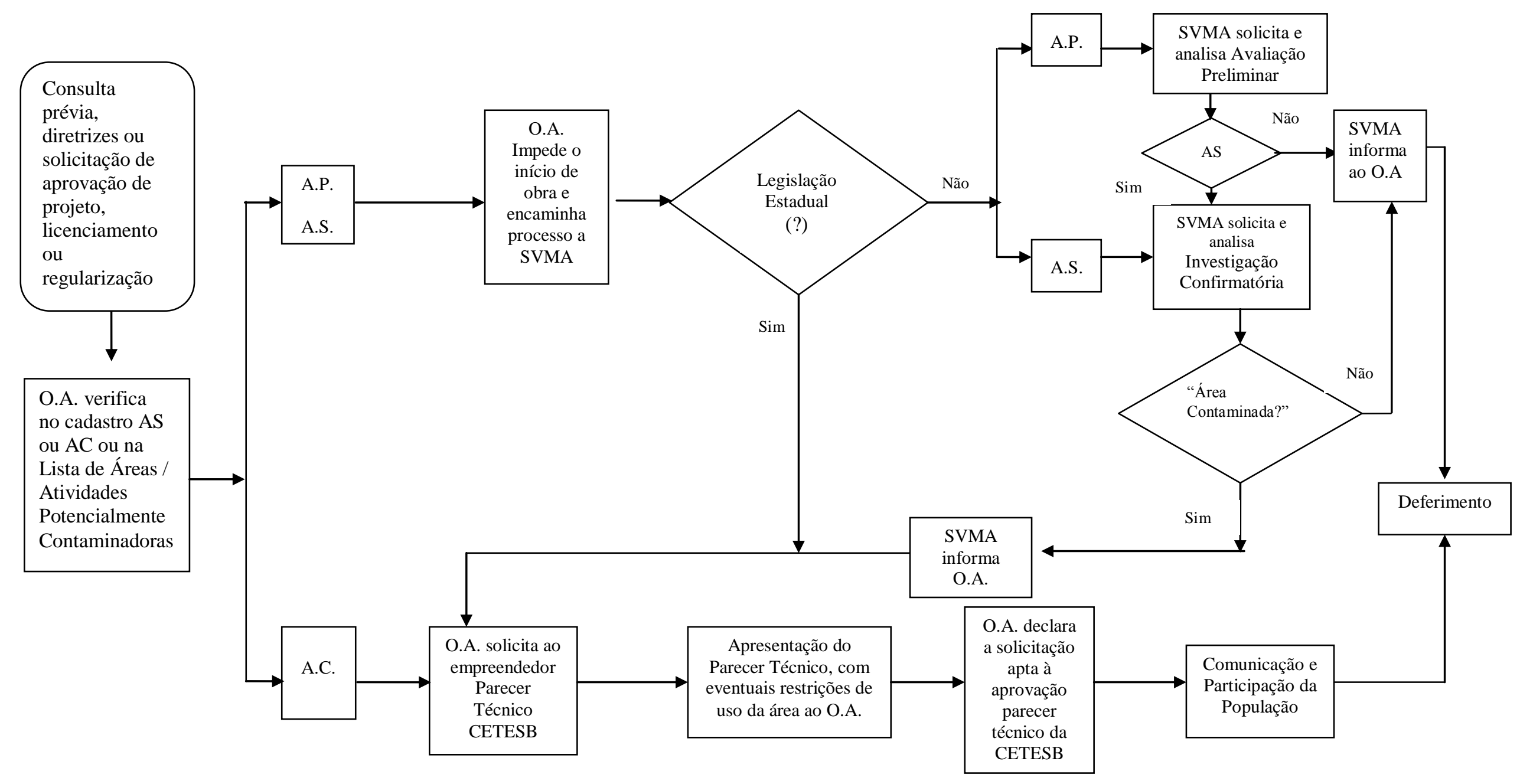

AP - área potencialmente contaminada; AS - área suspeita de contaminação; AC - área contaminada; AO - órgão de aprovação

Figura 3.6: Fluxograma dos procedimentos propostos, em 2004, para o gerenciamento de áreas contaminadas no município de São Paulo.

Fonte: SVMA (2004) 


\subsubsection{COMPOSIÇÃO E DEMANDAS DO GTAC}

O GTAC, criado em julho de 2002, era composto pela mesma equipe da Seção Técnica de Recuperação Ambiental (Decont-13), vinculada à Divisão de Controle Ambiental (Decont-1), possuindo como coordenadora a presente autora, que passou a acumular a chefia da Seção. Naquela época o grupo era constituído de arquiteto (1), biólogos (2), geógrafos (2) e geólogos (2). Em 2003, algumas mudanças internas ao Departamento ocorreram, sendo o GTAC e o Decont-13 transferidos para a Divisão Técnica de Projetos Especiais (Decont-3). Ao mesmo tempo, uma equipe técnica específica para o GTAC foi constituída ${ }^{30}$, composta por 8 profissionais: arquiteto (1), biólogos (1), engenheiro químico (1), estatístico (1), geógrafos (2) e geólogos (2); com o profissional estatístico prestando serviços ao GTAC e ao Departamento. A coordenação agora era acumulada com a direção da Divisão. Em outubro de 2003, a geógrafa Jane Zilda dos S. Ramires passou a coordenar o Grupo. Ao longo de 2003-2004 a equipe técnica foi ampliada com a entrada de biólogo (1), engenheiro químico (1) e químico (1).

Com a mudança administrativa de governo, deixei de integrar o Decont, em meados de 2005, permanecendo como coordenadora do GTAC, até meados de 2006, a geógrafa Jane Ramires, quando foi substituída, pelo geólogo Milton Tadeu Motta, o atual coordenador. Em julho de 2006, o arquiteto Carlos Minoru Morinaga, que compunha a equipe do Grupo, desde a sua criação, deixou o Decont.

Em junho de 2009, com a reestruturação da SVMA, o GTAC (Decont-23) passou a constituir a Divisão de Licenciamento Ambiental - Decont- $2^{31}$, com a seguinte equipe técnica, segundo Motta (2010, 2011): biólogo (2), engenheiro químico (4), geógrafo (2), geólogo - coordenador (1). Em meados desse mesmo ano, a geógrafa Jane Ramires e a bióloga Joana D’Arc Vítor, integrantes da primeira equipe do Grupo, também deixaram o Decont. Atualmente, setembro de 2010, o GTAC é composto por biólogo (1), engenheiro químico (6) ${ }^{32}$, geólogo (1) e químico (2), sendo que cinco engenheiros químicos e dois químicos ingressaram na SVMA, respectivamente, em 2009 e 2010, mediante a chamada do concurso para a carreira de especialista de meio ambiente. Apenas a engenheira química Rosimeire Lobato e

\footnotetext{
${ }^{30}$ Portaria 1/ Decont-G/03, de 25/03/03

${ }^{31}$ Portaria 11/DECONT-G/09

${ }^{32}$ O Eng. Químico Amós Carneiro, no início de 2010, ingressou na Companhia de Saneamento Ambiental do Estado de São Paulo (Sabesp).
} 
o geólogo Milton Motta permanecem na equipe, desde 2002. Ressalta-se que o coordenador do Grupo acumulou a função de diretor do Decont-2, nos períodos de janeiro de 2008 a abril de 2009 e de março de 2010 até o momento, setembro 2011 (informação verbal) ${ }^{33}$.

As demandas de trabalho do Grupo se ampliaram e se diversificaram bastante desde a sua criação. Segundo Ramires et al (2008) houve um aumento das solicitações do setor privado para mudanças de uso, registrando-se, no período de agosto de 2006 a outubro de 2007, um total de 158 processos administrativos que tratavam de intervenções em imóveis que necessitavam de estudos ambientais. A tendência de demandas crescente também pode ser verificada, no registro da entrada de 483 processos administrativos a serem analisados, entre maio de $2009 \mathrm{e}$ julho de 2010, perfazendo uma média mensal de 32 processos, sem levar em conta os outros tipos de documentos tramitados. Nesse mesmo período, registrou-se a saída mensal média de 21 processos. Destaca-se que para cada um dos meses de setembro de 2009 e junho de 2010 foi registrada a entrada de 63 processos (informação verbal) ${ }^{34}$.

A composição técnica do GTAC merece atenção especial. A análise do perfil e do número de profissionais integrantes da sua equipe técnica mostrou que, anteriormente, havia uma melhor diversidade de perfis e que praticamente permaneceu inalterado o número total de profissionais. Atualmente, no entanto, existe uma forte tendência de concentração de perfis profissionais associados ao entendimento dos processos produtivos tecnológicos (engenheiros químicos e químicos), em geral, formados para atuação com enfoque no controle ambiental. Assim, considerando a competência exclusiva do município, no que tange ao uso e ocupação do solo, e a premência de difundir a problemática da contaminação nesse âmbito, é fundamental o resgate do perfil de profissionais envolvidos na problemática do espaço urbano-ambiental (arquitetos, engenheiros civis, geógrafos, geólogos, etc.), à composição da equipe técnica do GTAC, condição imprescindível à melhoria da atuação multidisciplinar do Grupo.

\footnotetext{
${ }^{33}$ Informação fornecida por Motta no Decont/SVMA em 2010 e 2011.

34 Informação fornecida por Motta no Decont/SVMA em 2010.
} 


\section{RISCOS AMBIENTAIS E À SAÚDE HUMANA ASSOCIADOS AOS LIXÕES E ATERROS}

A problemática da destinação final do lixo, nas grandes metrópoles, vem se agravando a cada ano e se configura como um aspecto da degradação ambiental. Os lixões, aterros controlados e até os aterros sanitários são uma das formas de destino final que mais contribuem para a exposição da população a problemas de saúde pública, visto que podem desencadear graves impactos ambientais ${ }^{1}$. A probabilidade de ocorrência desses impactos com perdas e danos sociais e econômicos se define como risco ${ }^{2}$.

Situações de risco são vivenciadas pela sociedade ao longo da sua existência variando do enfrentamento de fenômenos naturais (terremotos, secas, inundações), antrópicos (poluição, incêndio) ou mesmo de condições inerentes à vida (doenças, epidemias, acidentes, etc.). O significado e a percepção do risco dependem também de questões culturais e subjetivas, sendo considerado por Veyret (2007) como uma construção social, que independe de fatos ou processos objetivos. Os riscos associados aos antigos lixões ou aterros, situados

\footnotetext{
${ }^{1}$ Impacto ambiental é a alteração da qualidade ambiental que resulta da modificação de processos naturais ou sociais provocada por ação humana (Sánchez, 2006, p.42)

2 Risco designa tanto um perigo potencial quanto sua percepção e indica uma situação percebida como perigosa na qual se está ou cujos efeitos podem ser sentidos (Veyret, 2007, p.25)
} 
especialmente nas metrópoles, são muitas vezes despercebidos pela população em geral, podendo atingir grande número de pessoas com graves conseqüências e complexidade para a sua gestão. Recentemente situações desta natureza ocorreram nas duas principais regiões metropolitanas nacionais, São Paulo e Rio de Janeiro.

O Diário Oficial da Cidade de São Paulo autorizou a transferência dos alunos da Escola Municipal de Ensino Fundamental - EMEF Clovis Graciano para outra unidade (Decreto no 50.899, 02/10/ 2009). A escola, situada à Rua Mendonça Junior 60 (Figuras 4.1 e 4.2), na Vila Nova Cachoeirinha, Subprefeitura da Casa Verde, fundada em 1988, será desativada devido à concentração de gás metano constatada num antigo lixão ${ }^{3}$, sobre o qual a unidade foi construída. A existência desse lixão foi identificada, em meados da década de 90, pelo Departamento de Controle da Qualidade Ambiental (Decont)/SVMA, que notificou a ocorrência às várias outras instâncias municipais. O Cemitério da Vila Nova Cachoeirinha, área suspeita de contaminação, agrava as condições ambientais da região.

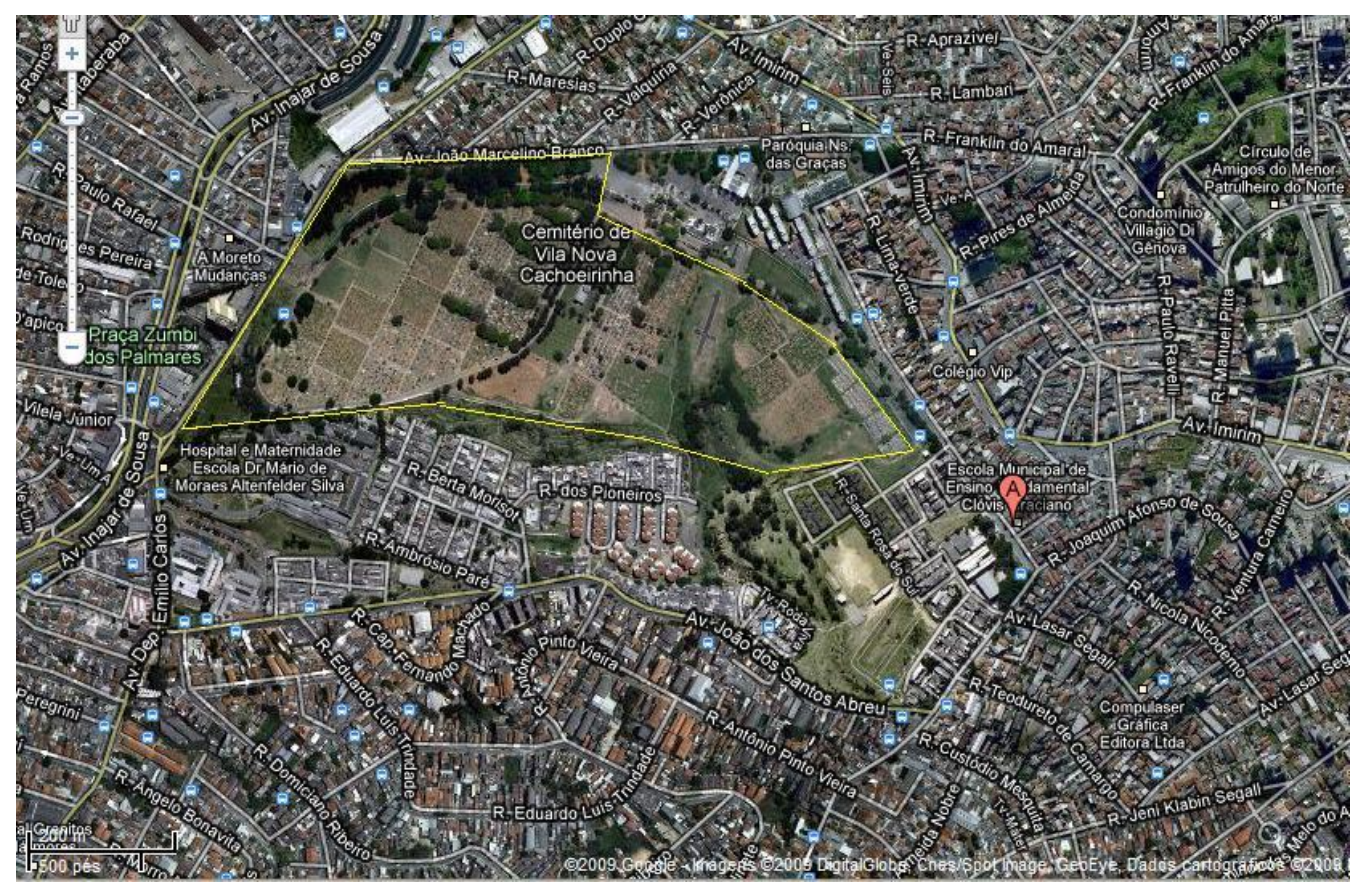

Figura 4.1 - Vista geral da região onde está localizada a EMEF Clovis Graciano.

Fonte: Google Earth, 2010. Acesso em março 2010.

\footnotetext{
${ }^{3}$ O lixão/aterro funcionou do final da década de 1960 até o início da década de 1980, com a ocupação por residências iniciada em 1991. Sobre a área foi construído o Conjunto Habitacional Nossa Senhora da Penha, de propriedade da Companhia Metropolitana de Habitação de São Paulo (Cohab) e as escolas Municipal de Ensino Infantil - EMEI Vicente Paulo da Silva e EMEF Clovis Graciano. A Cetesb constatou, em 2006, altas concentrações de metano nas imediações das escolas oriundas do Conjunto, identificado como área fonte. Em seguida, para prevenir as escolas dos riscos de explosão, a Secretaria Municipal da Educação - SME contratou, por meio do Departamento de Edificações - EDIF, da Secretaria Municipal de Infraestrutura Urbana e Obras - Siurb um sistema para extração dos vapores de metano do solo. Em 2007, se iniciou o monitoramento das concentrações de metano e compostos orgânicos voláteis - VOC's nas escolas e no seu entorno, por solicitação da Promotoria de Justiça do Meio ambiente da Capital - PJMAC. As avaliações realizadas, até setembro de 2009, constataram concentrações dentro da faixa de explosividade com risco para os usuários das escolas (SVMA, 2010).
} 


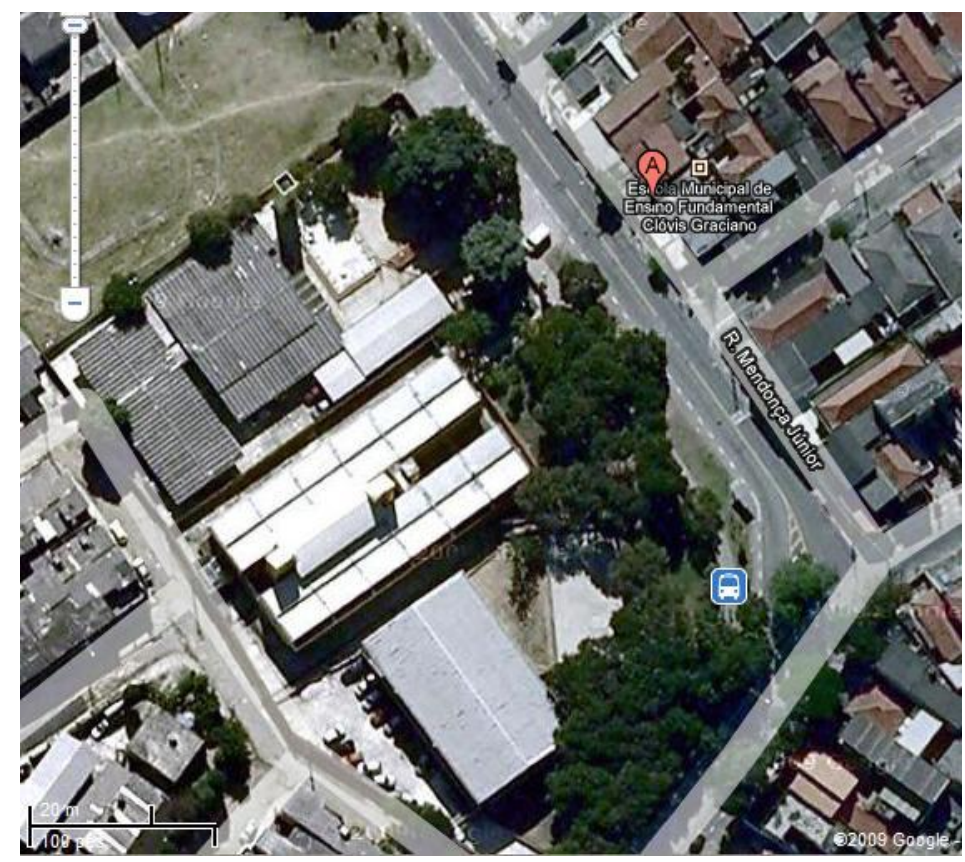

Figura 4.2 - Detalhe das vizinhanças da EMEF Clovis Graciano.

Fonte: Google Earth, 2010.

A imprensa noticiou a tragédia do Morro do Bumba, em Niterói, Rio de Janeiro, ocorrida no dia 7 de abril de 2010. O escorregamento se deu após fortes chuvas que acometeram a cidade desde o dia anterior, causando soterramento de moradias e pessoas e muitas mortes (Figura 4.3). O local havia sido utilizado em anos anteriores como um lixão municipal.
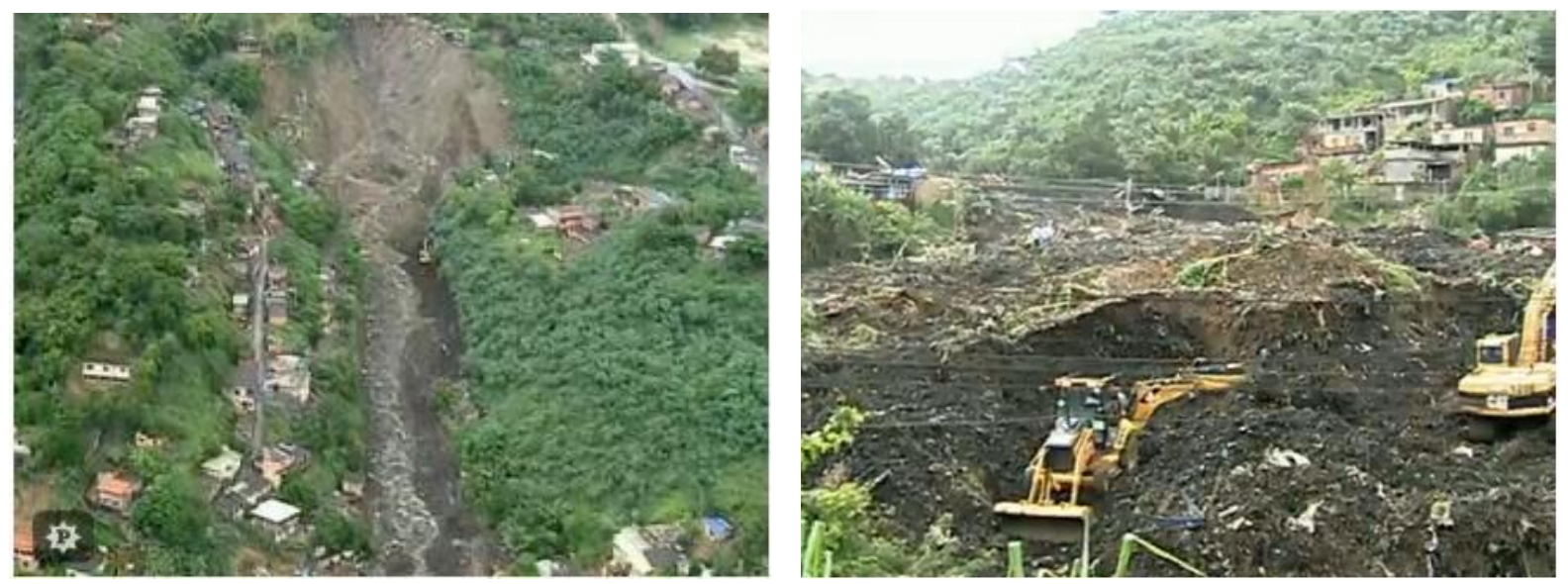

Figura 4.3 - À esquerda, visão geral do escorregamento no lixão desativado no Morro do Bumba, Niterói, RJ. À direita, Defesa Civil Estadual a procura de sobreviventes. Disponível em <http:IVvideos.glob.com/vídeos/Player/Noticias/O...G/M 12444580-7823-PR>. Acesso em 28/09/2010. 
Grellet e Lobato (2010) noticiam que o lixão funcionou de 1970 a $1985^{4}$, sendo posteriormente ocupado por mais de 100 moradias das quais cerca de 50 foram soterradas. Depoimento de morador, entretanto, informa que, em 2000, caminhões ainda depositavam lixo no local. A Universidade Federal Fluminense, em estudo realizado em 2004, que constatou apenas 12 casas construídas sobre 0 lixão, segundo Maniero $(2010)^{5}$, já alertava para os altos riscos existentes na área, a necessidade de monitoramento e sobre os riscos de ocupação da área, recomendando a remoção daquelas moradias. Segundo relatos havia escape de fumaça em partes do morro. A secretária estadual do Meio Ambiente, Marilene Ramos, admitiu que a ocorrência de uma explosão, provocada pelos gases acumulados no lixão, poderia ter contribuído para o acidente. $O$ prefeito Jorge Roberto da Silveira, na sua quarta administração da cidade, declarou "[...] que não havia qualquer sinalização de que isso ocorreria. O lixão estava desativado. Ninguém poderia imaginar. Lamentavelmente, isto ocorreu e estamos estudando as causas e as conseqüências no entorno".

Um ano depois do acidente, que ocasionou 47 mortes, após a retirada de 86 mil toneladas de material, para contenção e estabilização da área, algumas intervenções estão em andamento. A área foi cercada, retaludada, gramada, havendo previsão para a plantação de árvores, com o objetivo de implantar uma praça moderna (Figura 4.3); tendo o governo do Estado do Rio de Janeiro investido o montante de $R \$$ de 53 milhões. Apesar do corte da energia elétrica e do abastecimento de água, efetuado pelo Estado, o topo e os arredores do local voltaram a ser reocupados por alguns antigos moradores, que alegam vários motivos para a sua permanência: aluguel social atrasado, demora para construção, distância do local e tamanho dos apartamentos prometidos e, necessidade de cuidar das criações de gado, cabrito, porcos, galinhas, etc., que mantém no Bumba (Brasil, 2011).

\footnotetext{
${ }^{4}$ O documentário L.X.O, com direção de Ronaldo German, realizado no lixão em 1980, mostra os diversos tipos de resíduos lançados no local, onde já aparecem focos de fogo e fumaça, provenientes da decomposição do metano, além da presença de muitos catadores e urubus. G1/rio de janeiro/chuva. Filme mostra Morro do Bumba quando o local ainda era lixão. 09/04/2010. Disponível em http://globo.com. Acesso em 28/09/2010.

5 MANIERO, V. Morro do Bumba: em 2004, apenas 12 casas sobre o lixão. 09/04/2010. Disponível em <http://oglobo.globo.com/economia/miriam/posts/2010/. Acesso em 28/09/2010.
} 
Requalificação dos Aterros Desativados (BrownfieldS) no MunicípIo de SÃo PaUlo: Parques (GreenfieldS) Raposo TAVARES E Jardim PrimaVera

Luzia Helena dos Santos Barros

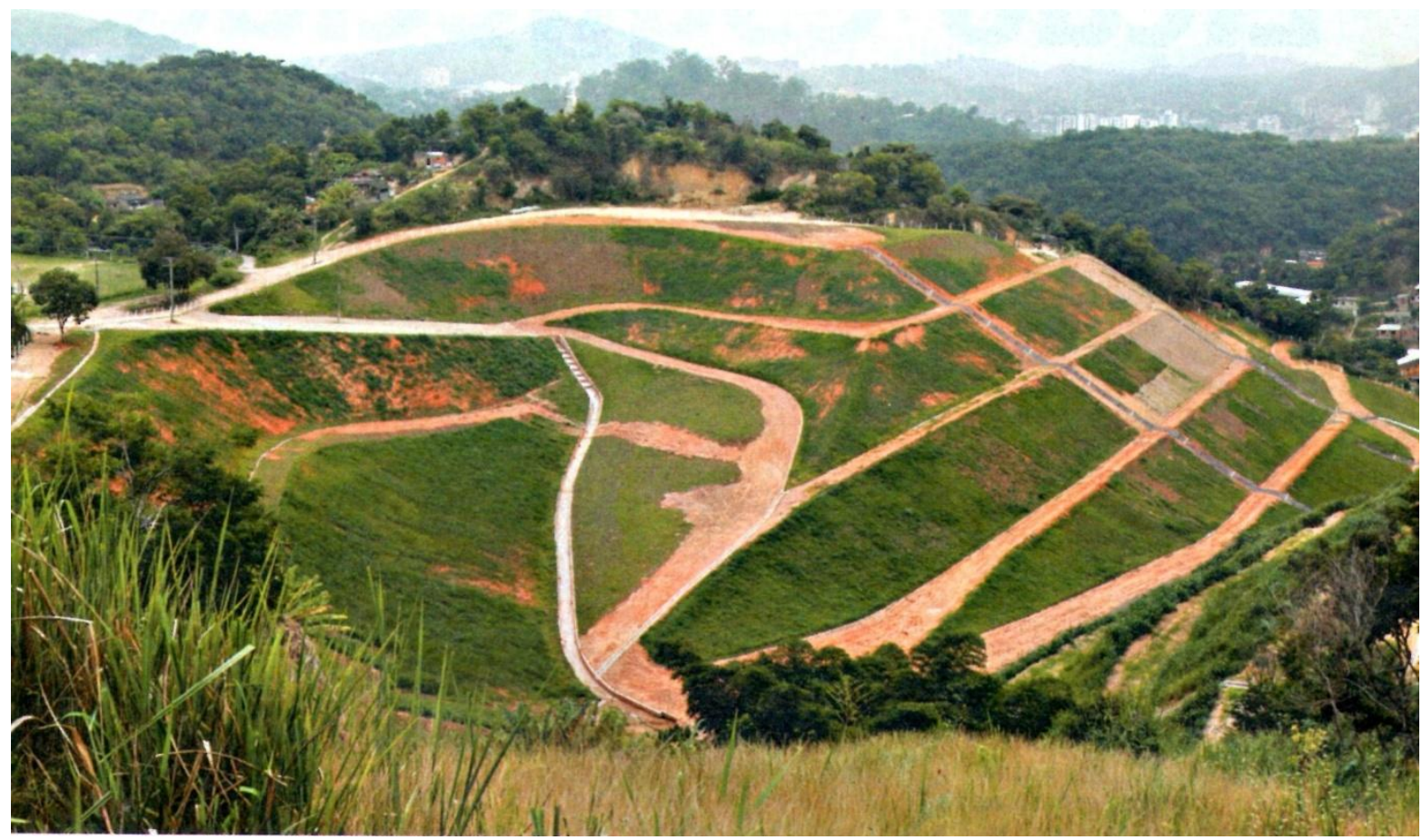

Figura 4.4 - Parte da área urbanizada no Morro do Bumba, Niterói, RJ, em abril de 2011. Fonte: Brasil (2011, p. 26).

A tragédia do Morro do Bumba, como sempre, resgatou a lembrança de algumas outras situações de ocupação de lixões no País. O portal do Estadão (2010) ${ }^{6}$ revela que há 17 mil pessoas morando sobre lixões desativados na Grande São Paulo. Sobre o Sítio Joaninha, lixão desativado há 29 anos, situado na divisa de São Bernardo do Campo e Diadema, onde já houve escorregamentos e explosões, vivem cerca de 5.000 habitantes. Na favela do Espírito Santo, em Santo André, 5.600 pessoas ocupam uma área parcialmente liberada pelo Instituto de Pesquisas Tecnológicas (IPT). No condomínio, de classe média, Barão de Mauá, em Mauá, ocupado desde 1994, estão 6.800 moradores, onde, há cerca de 10 anos, houve uma explosão causando a morte de um funcionário. No local foi registrada a presença de gás metano e mais 43 substâncias, inclusive cancerígenas. No município de São Paulo são conhecidas favelas situadas sobre lixões na Freguesia do Ó e no lpiranga.

Outras ocorrências foram relembradas pelo portal MS (2010) ${ }^{7}$. Em Foz do Iguaçu, Paraná, sobre um lixão encerrado há 14 anos foram construídas 70 casas,

\footnotetext{
6 ESTADÃO.COM.BR/Opinião. Lições do Morro do Bumba. 15/04/2010. Disponível em $<$ http://www.estadao.com.br/noticia_imp.php?req=not_imp538467,0.php.>. Acesso em 28/09/2010.

PORTALMS. Em todo o Brasil, milhares de pessoas vivem sobre lixões. Disponível em <http://www.portalms.com.br/noticias/detalhe.asp?cod=959578832>. Acesso em 28/09/2010.
} 
que estão sofrendo abatimento, pela acomodação do substrato, com formação de trincas. Casos semelhantes foram apontados no interior do estado de São Paulo: Ribeirão Preto, Franca e Mauá, este último citado anteriormente.

O jornal O Globo $(2010)^{8}$, também, destaca a construção de 300 casas, no bairro Clube dos Engenheiros, sobre um lixão desativado, na década de 1980, em Araruama, Região dos Lagos, no Estado do Rio de Janeiro.

\subsection{Riscos AMBIENTAIS}

Aos riscos podem ser relacionados diferentes significados, tipologias e relações com o território, a escala e a sua gestão como apresentado no artigo de Zanirato et al (2008), que trata das interpretações teóricas dos riscos baseado em diversos autores: Beck (1999 e 2006), Calvo Garcia-Tornel (1997 e 2001), Douglas (1976 e 1992), Giddens (1991 e 2002), November (2002), Renn (1992 e 2003), Slovic (1987) e Veyret (2007). Zanirato et al (2008) ressalta que esses vários autores comungam do entendimento do surgimento, postulado por Beck, da Sociedade de Risco que se caracteriza pela globalização, individualização e reflexividade. Pode ser representada por uma fratura na modernidade, como estabeleceu o alemão Ulrich Beck (2002, p.16), em 1986.

[...] la idéia de que somos testigos (sujeto y objeto) de uma fractura dentro de la modernidad, la cual se desprende de los contornos de la sociedad industrial clásica y acuña uma nueva figura, a la que aquí llamamos sociedad (industrial) del riesgo .

A sociedade industrial que proporcionou o desenvolvimento científico e tecnológico também foi responsável pela produção dos passivos ambientais, destacando-se a contaminação do solo e das águas subterrâneas, com o surgimento dos seus respectivos riscos ambientais, que caracterizam a sociedade contemporânea ou Sociedade de Risco, tal como coloca Ramires (2008, p.166).

[...] O avanço que presenciamos, neste início de século, no campo da ciência e da tecnologia, não conseguiu atender as expectativas de nossa sociedade quanto ao ideal de segurança e qualidade de vida. Contrariando as expectativas do projeto da modernização, vivenciamos a onipresença das situações de riscos, perigos e catástrofes de toda ordem.

A degradação de áreas pela contaminação dos solos e das águas subterrâneas é um legado da modernização, é o resultado da negligência às questões ambientais no avanço e expansão da indústria e, hoje,

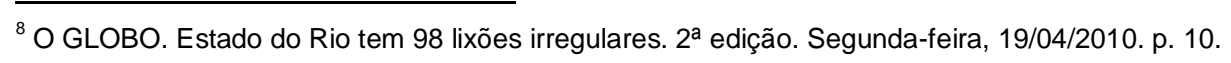


Requalificação dos Aterros Desativados (BrownfieldS) no MunicípIo de SÃo PaUlo: Parques (GreenfieldS) Raposo Tavares e Jardim Primavera

Luzia Helena dos Santos Barros

sabemos, representa riscos à sociedade e aos ecossistemas. Indiscutivelmente os riscos derivados da contaminação, vêm se somar a gama dos riscos socioambientais presentes na sociedade contemporânea, também denominada Sociedade de Risco [...].

A reflexão de Beck (2002) sobre as mudanças sociais e políticas advindas da destruição provocada pela industrialização, das bases ecológicas e naturais da vida, concluiu que não há mais que se falar em contraposição entre natureza e sociedade. No final do século XX a natureza se converteu num produto histórico no interior do mundo civilizado destruído ou ameaçado pelas condições naturais de sua reprodução. O autor justifica o conceito de sociedade de risco quando afirma que o desafio do presente e do futuro está relacionado à transformação das ameaças civilizatórias da natureza em ameaças sociais, econômicas e políticas do sistema.

Souza (2000, p.316) nos seus estudos sobre o desafio metropolitano brasileiro reconheceu que São Paulo e Rio de Janeiro tipificam a "sociedade de risco" definida por Beck, mas potencializada. Isto porque nessas metrópoles de país "industrializado subdesenvolvido" coexistem necessidades básicas (fome, desemprego, saneamento, etc.), já superadas nos países desenvolvidos, com temores de catástrofes ecológicas e de outros eventos.

Os riscos, como dito anteriormente, podem ser classificados de diversas formas, podendo ser considerados os riscos ambientais, segundo Amaral e Cerri (1998) como uma classe ampla que compreende os riscos tecnológicos (químicos, radioativos, etc.), naturais (físicos e biológicos) e os riscos sociais (assaltos, conflitos, atentados, etc.).

Segundo Veyret (2007, p.30) os riscos se relacionam à percepção de um perigo ou de uma ameaça potencial que podem provocar danos às pessoas, aos bens e à organização do território. Definiu então o risco como: "a representação de um perigo ou álea ${ }^{9}$ (reais ou supostos) que afetam os alvos e que constituem indicadores de vulnerabilidades".

A vulnerabilidade de um indivíduo, de um grupo, de um território está relacionada a uma análise complexa das perdas e danos constatados e suas possibilidades de reversão. Conforme Dauphiné ${ }^{10}$ (2001, apud Veyret 2007, p.42), a

\footnotetext{
${ }^{9}$ Álea é o acontecimento possível; pode ser um processo natural, tecnológico, social, econômico, e sua probabilidade de realização. O equivalente em inglês é hazard (para definir a álea natural). Alguns autores utilizam o termo "perigo", especialmente quando se trata de riscos tecnológicos (Veyret, 2007, p.24).

${ }^{10}$ DAUPHINE, A. Risques et catastrophes. Paris, Armand Colin, coll. $<<U>>.2001$.
} 
vulnerabilidade revela "a fragilidade de um sistema em seu conjunto e sua capacidade para superar a crise provocada por uma álea".

Veyret (2007, p.43) informa que a vulnerabilidade depende de inúmeros fatores e que varia no espaço e no tempo. E afirma que

[...] ser vulnerável é estar fisicamente exposto a uma álea (natural ou outra), é apresentar certa fragilidade diante do sinistro [...]. É, de igual modo, não ter em vista os meios disponíveis para enfrentar a crise que pode sobrevir. [...] Reduzir a vulnerabilidade não consiste em tentar reduzir a freqüência da álea, o que é, em certos casos, totalmente impossível (terremotos, vulcanismos, inundações [...], mas em diminuir os efeitos possíveis da crise por meio do conhecimento dos processos e pela instalação de dispositivos adequados [...].

Porto (2007, p.205) considera que a vulnerabilidade é um conceito essencial para realizar análises complexas integradas de riscos, numa abordagem transdisciplinar, pois favorece o discurso entre diferentes especialistas e o entendimento sobre os paradigmas dos problemas ambientais.

[...] O conceito de vulnerabilidade contribui para o desenvolvimento de novas formas integradas e contextualizadas na análise de problemas envolvendo riscos ocupacionais e ambientais, pois permite a construção de pontes conceituais e metodológicas entre áreas de conhecimento e facilita o diálogo interdisciplinar. Ao mesmo tempo, estimula o levantar dos aspectos éticos dos problemas, integrando o mundo institucional e técnico-científico ao mundo das pessoas e da política [...].

O autor (2007, p.189) ainda comenta que as relações de poder geradas pelos riscos estão situadas no espaço político-institucional, por exclusão da população atingida das decisões que as afetam, e no território pela segregação entre áreas ricas e 'salubres' daquelas pobres, perigosas e insalubres ('zonas de sacrifício').

[...] As estruturas de poder dentro das instituições, organizações e corporações técnico-científicas podem formar culturas técnicas fechadas que produzem o pior tipo de postura em relação aos riscos: filtros políticos e bloqueios cognitivos que classificam e rejeitam informações contrárias aos seus interesses particulares. De certo modo, toda forma de olhar é também uma forma de não olhar. Mas estruturas e organizações rígidas, autoritárias e submetidas aos interesses particulares de certas elites radicalizam esse problema e incorporam um certo tipo de ignorância institucional como característica da organização: quando não se quer saber - que não se sabe, inviabilizando, desta forma, o processo de aprendizagem coletiva e institucional $[\ldots]$.

Outro princípio destacado pelo autor (2007, p.193) é a importância da consideração dos riscos ambientais como fenômenos multidimensionais e cíclicos 
Requalificação dos Aterros Desativados (Brownfields) no Município de São Paulo: Parques (GreenfieldS) Raposo TAVAREs e Jardim Primavera

Luzia Helena dos Santos Barros

que acontecem na conjunção de tempo, lugar e pessoas nas diferentes escalas espaciais, temporais e populacionais.

\begin{abstract}
[...] Abordagens integradas para a compreensão e enfrentamento dos riscos pressupõem considerar e articular as dimensões essenciais dos três pilares que constituem qualquer fenômeno de saúde, trabalho e ambiente: o 'lugar' ou território onde os riscos são produzidos e atuam, com seus ecossistemas e sistemas sócio-técnico-ambientais, sejam eles produtivos ou de outros tipos, como ambientes urbanos com suas infra-estruturas e instalações; as 'pessoas', representadas por indivíduos, grupos populacionais, organizações e comunidades envolvidas no ciclo dos riscos, em especial os expostos aos mesmos, cujas vontades, interesse e clamores podem conformar consciências individuais e coletivas e políticas públicas voltadas à preservação da vida; e o 'tempo', compreendido seja enquanto tempo histórico que configura tais populações e territórios onde os perigos são produzidos, seja como tempo físico dos ciclos geração-exposição-efeitos, incluindo o tempo futuro para o caso das gerações futuras [...].
\end{abstract}

Marcelino (2008, p.22 a 24) discute as diferenças entre os conceitos de perigo, desastre e risco. Afirma que o termo perigo, tradução de hazard, é definido, por ISDR (2004) ${ }^{11}$ e UNDP $(2004)^{12}$, como "[...] um fenômeno físico ou um processo natural potencialmente prejudicial, que pode causar sérios danos sócio-econômicos as comunidades expostas [...]", estando de acordo com o conceito estabelecido pela ONU. Ao citar Tobni e Montz (1997) ${ }^{13}$ esclarece que desastre "[...] é a materialização do perigo [...]". Resume risco como a "[...] probabilidade (mensurável) de um perigo transformar-se em desastre [...]".

Para a Cetesb (2007), perigo é uma ou mais condições, físicas ou químicas, com potencial para causar danos às pessoas, à propriedade, ao meio ambiente ou à combinação desses.

Marcelino (2008) declara também que o risco apresenta-se sob diversos aspectos em função dos elementos naturais e sociais envolvidos no processo, exigindo-se a sua gestão de forma a alcançar níveis aceitáveis. A gestão do risco envolve a avaliação e a percepção de risco, etapas definidoras das medidas preventivas (estruturais e não-estruturais) a serem adotadas.

Para Valentim (2010, p.57) o risco no contexto da saúde pode ser percebido quando existe um potencial de distúrbio no desenrolar natural da vida.

[...] risco é palavra fugidia, que comporta conceitos múltiplos; polissêmica, ora resvala pelas sensações das incertezas coletivas, ora pelas convicções, amparadas pelas ciências probabilísticas, dos destinos

\footnotetext{
${ }^{11}$ ISDR - International Stratgies for Disasters Reduction. Living with risk: a global review of disasters reduction initiatives. Geneva: UN/ISDR, 2004.

${ }_{12}$ UNDP - United Nations Development Programme. Reducing Disasters risk: a challenge for development. New York, USA: UNDP, 2004. 129 p.

${ }^{13}$ TOBNI, G.A.; MONTZ, B.E. Natural Hazards: explanation and integration. New York: The Guilford Press, 1997. 388 p.
} 
individuais. O risco é um conceito que no campo da saúde remete à ameaça à vida, embora seja uma condição inata ao ato de viver.

As áreas contaminadas relacionam-se aos "riscos tecnológicos difusos", definidos por Garcia-Tornel (2001) e Veyret (2007), conforme informa Ramires (2008), pois podem implicar em efeitos graves, imprevisíveis e de longa duração. A exposição aos riscos advindos dessas áreas, ou seja, a vulnerabilidade ao risco, de acordo com Garcia, é conseqüência da percepção que se tem do risco e da sensibilidade da população exposta.

O risco de contaminação dos ecossistemas e da população oriundos das áreas contaminadas está relacionado às suas características intrínsecas, às do meio físico onde estão inseridas e às formas de exposição dos receptores (população e bens a proteger). Sánchez (2001, p.85) afirma que a existência de solos ou águas contaminados

[...] ocasiona riscos à saúde das pessoas e dos ecossistemas cujas conseqüências são em geral, cumulativas e só se manifestam no futuro e não de forma espetacular, como explosões e incêndios, mas por meio do aumento da incidência de doenças ou da concentração de substâncias tóxicas no meio.

\subsection{RISCOS SOCIOAMBIENTAIS PROVOCADOS POR LIXÕES E ATERROS}

A disposição inadequada de resíduos provoca os seguintes impactos ao meio ambiente e à saúde humana: poluição ou contaminação das águas superficiais e subterrâneas; devastação da vegetação; poluição atmosférica; poluição ou contaminação do solo; abrigo para animais sinantrópicos ${ }^{14}$, queimas e riscos de explosões; transmissão de doenças, odores, erosão, escorregamentos, recalques, poluição visual, poluição sonora (provocada pelo trânsito dos veículos) e desvalorização dos imóveis do entorno.

Em geral a instalação dos lixões ou aterros é realizada com o simples lançamento dos diversos tipos de resíduos diretamente sobre o terreno, sem critérios técnicos adequados, acarretando problemas sérios de estabilidade

\footnotetext{
${ }^{14}$ Animais sinantrópicos são aqueles que se adaptaram a viver junto ao homem, à despeito de sua vontade, podendo transmitir doença e causar agravos à saúde humana ou a outros animais. São eles; rato, pombo, morcego, barata, mosca, mosquito, pulga, carrapato, fromiga, escorpião, aranha, taturana, lacrais, abelha, vespa e marimbomdo. SMS (s/d:2)
} 
Requalificação dos Aterros Desativados (BrownfieldS) no MunicípIo de SÃo PaUlo: Parques (GreenfieldS) Raposo TAVAREs e Jardim Primavera

Luzia Helena dos Santos Barros

geológico-geotécnica e de contaminação do solo e das águas subterrâneas. Mori (1992, p.232) destaca que

[...] Uma significativa parcela dos acidentes [geotécnicos urbanos] ocorre em aterros. Geralmente os aterros urbanos são simplesmente lançados ou compactados apenas pelo tráfego de equipamentos de terraplanagem, sem maiores rigores de densidade e umidade. Muitas vezes contêm lixo ou entulho misturado e quase sempre [são] construídos sem encaixe com o terreno natural em degraus escavados, sem ao menos se retirar a vegetação, e com drenagem superficial mal dimensionada. Drenagem interna simplesmente não existe.

Enquanto que Fanning e Fanning ${ }^{15}$ (1998 apud Pellogia, 1998, p.133) reportam que

[...] "os solos criados pelo homem", quando detritos orgânicos são soterrados, provavelmente, provocarão muitos problemas no futuro: subsidências das superfícies do terreno, riscos de explosões em função da geração de gases naturais sob condições anaeróbicas e contaminação das águas subterrâneas por substâncias químicas.

Araujo $^{16}$ (1996 apud Lima, 2003) informa que dentre as várias fontes de contaminação dos recursos hídricos cadastradas pela EPA (agência ambiental americana), os lixões foram identificados em mais de 35 estados, dos quais 15 apresentam alto grau de contaminação.

A construção de aterros é regulada pela agência americana desde 1991. Leis federais estipulam que o operador/proprietário deve instalar uma cobertura adequada, para minimizar a infiltração de água e a erosão, no prazo máximo de seis meses após o encerramento do aterro. Deve-se, também, colocar uma camada drenante para o gás e uma camada de pedra ou material geossintético para evitar animais cavadores. Exige-se ainda a manutenção da integridade da cobertura final, o monitoramento da contaminação da água subterrânea e o manejo da produção de gás e do chorume ${ }^{17}$ por 30 anos, após o seu fechamento. Para tanto, foi criado um fundo financeiro para custear os cuidados de pós-fechamento e a limpeza da água subterrânea contaminada, se ocorrer (Harnik et al, 2006b).

Tressoldi e Consoni (1998) apresentam os principais grupos de contaminantes e seus indicadores encontrados em diversas fontes de contaminação. Os cloretos, nitratos e metais pesados são os elementos mais comuns encontrados

\footnotetext{
${ }^{15}$ FANNING, D.J.; FANNING, M.C.B. Soil: morphology, genesis and classification. New York, John Willey \& Sons. 1998. ${ }^{16}$ ARAUJO, G.N.R. Estudo Geoquímico da Contaminação dos Recursos Hídricos e sua propagação nas Adjacências do Aterro de Resíduos sólidos Jockey Club - DF. Instituto de Geociência, Universidade de Brasília (UnB), DF. 1996. Dissertação. (Mestrado em Hidrogeologia)

${ }^{17}$ Chorume é o líquido contaminante, de cor escura, odor nauseante e de elevada Demanda bioquímica de Oxigênio (DBO), originado de processos biológicos, químicos e físicos da decomposição de orgânicos (Bortolin, 2009, p.8)
} 
na maior parte das fontes de contaminação. Enquanto que os contaminantes orgânicos e os metais pesados são marcadores de fontes específicas.

O Decont/SVMA (SVMA, 2004) no seu banco de dados sobre Áreas Degradadas por Disposição de Resíduos Sólidos da Seção Técnica de Recuperação Ambiental indicou os principais impactos ambientais relacionados à disposição irregular, no qual predominavam a poluição do solo e das águas (47\%).

Os principais subprodutos de um lixão ou aterro controlado, responsáveis pelos riscos à saúde humana e ao ecossistema, são a geração do chorume e as emanações de gases, tratados aqui com maior profundidade. Outro aspecto que merece ser apontado se refere à estabilidade geotécnica desses maciços de resíduos.

\subsubsection{IMPLICAÇÕES DO CHORUME E DO PERCOLADO (OU LIXIVIADO)}

A contaminação provocada pelos resíduos domiciliares e urbanos está relacionada à decomposição da matéria orgânica aí presente, responsável pela formação do percolado ${ }^{18}$ e do chorume, que devido a sua acidez pode carrear metais existentes no lixo aumentando ainda mais o seu poder poluidor. Os resíduos industriais se caracterizam por apresentarem substâncias muito tóxicas (compostos orgânicos e metais pesados), mesmo em baixas concentrações, que conferem ao seu percolado maior poder contaminante do que os dos resíduos domiciliares. Os resíduos de saúde constituem-se dos microrganismos patógenos que podem se proliferar e atingir a biota (Tressoldi e Consoni, 1998).

As características do chorume estão relacionadas à especificidade da massa de resíduos (composição, espessura, densidade, teor de umidade, índice de vazios), bem como às atividades químicas, físicas e biológicas que ocorrem no seu interior. Uma série de fatores contribui para a quantidade, qualidade e a concentração do chorume, tais como: precipitação, evapotranspiração, infiltração; temperatura; método operacional, tempo de exposição dos resíduos sem cobertura, tempo de maturação ${ }^{19}$, grau de compactação, características do solo, nível d'água do terreno,

\footnotetext{
${ }^{18}$ Percolado é o líquido composto pelo chorume e por águas de chuva e subterrâneas, que lixiviam compostos orgânicos presentes nos aterros para o ambiente. Em muitas situações é utilizado como sinônimo de chorume (Bortolin, 2009, p.8).

${ }_{19} \mathrm{O}$ tempo de maturação dos resíduos, ou seja, a sua idade, afeta a composição do chorume, como observado nos valores médios obtidos em aterros recentes e antigos no Brasil (Anexo E).
} 
RequalificaÇÃo dos Aterros Desativados (Brownfields) no Municíío de São PaUlo: PARques (GreenfieldS) Raposo Tavares e Jardim Primavera

Luzia Helena dos Santos Barros

drenagem superficial do aterro, sistemas de drenagem do chorume, e tipo da cobertura final (declividade e material impermeabilizante).

As características do percolado, segundo Torres et al.(1997 ${ }^{20}$ apud Oliveira, 2001), dependem também do período climático (verão ou inverno), com presença ou ausência de chuva. Na estação seca há maior concentração dos seus constituintes (matéria orgânica e metais pesados) que são diluídos na estação chuvosa provocando um aumento da quantidade gerada.

De acordo com Schalch (1984 ${ }^{21}$ apud Oliveira, 2001) o chorume, quando puro, apresenta alguns parâmetros com teores elevados. A Demanda Bioquímica de Oxigênio (DBO) varia da ordem de 9.400 a 20.000 mg/L e a Demanda Química de Oxigênio (DQO) fica por volta de $35.200 \mathrm{mg} / \mathrm{L}$, enquanto o esgoto doméstico possui DBO entre 200 a $300 \mathrm{mg} / \mathrm{L}$.

Tressoldi e Consoni (1998), apresentando os resultados de análises físicoquímicas e bacteriológicas procedidas em algumas amostras de chorume de lixões e aterros situados na Região Metropolitana de São Paulo, verificaram que são muitas as variações encontradas nos aterros de Santo Amaro e Vila Albertina (São Paulo), Santo André e São Bernardo do Campo e nos lixões de Mauá e Cama Patente.

Os principais poluentes originados nos aterros sanitários segundo Chistensen et al. (2000²2 apud Lima, 2003) são os cátions e ânions inorgânicos, metais pesados, matéria orgânica e compostos orgânicos específicos (hidrocarbonetos e fenóis), apresentando concentração bastante variável.

A avaliação da qualidade do chorume, mediante a medição da razão $\mathrm{DBO} / \mathrm{DQO}^{4}$, pode indicar o estágio da sua decomposição e o potencial para a geração de gás. O decréscimo dessa razão indica o avanço do processo de degradação. Por outro lado, baixas taxas podem apontar, também, a ocorrência de metais tóxicos, inibidores da degradação (Smith, $1993^{23}$ apud Silva, 2001).

A estimativa da geração de chorume está associada a uma gama de fatores, conforme relatado anteriormente, variando ao longo dos dias, das estações e dos anos, se transformando em um grande problema para a operação e manutenção

\footnotetext{
${ }^{20}$ TORRES, P. et al. Tratabilidade biológica de chorume produzido em aterro não controlado. Eng. Sanit. e Amb., v.2, p.55-62, 1997.

${ }^{21} \mathrm{SCHALCH}$, V. Produção e características do chorume em processo de decomposição de lixo urbano. São Carlos, Dissertação (Mestrado em Hidráulica e Saneamento). Escola de Engenharia de São Carlos, Universidade de São Paulo.1984. $103 p$.

${ }^{22}$ CHRISTENSEN, H.T.; BJERG, P.L., BANWART, A.S.; JAKOBSEN, R.; GORM, H.; HANS-JORGEN, A. Characterization of redox conditions in groundwater contaminant plumes. Journal of Contaminant Hydrology, DK-2800, Lyngby, Denmark. Accepted 29 May 2000.

${ }^{23}$ SMITH, M.V. Landfill Gases. In: Contaminated Land - Problems and Solutions. Blackie Academic and Professional. 1993. $351 \mathrm{p}$.
} 
dessas áreas. Segundo a Cetesb (1993 apud Lima, 2003) a metodologia do balanço hídrico ${ }^{24}$, proposta por Henry e Geare (1975), é a mais adequada para estimar a produção de chorume.

Bagchi (1990 25 apud Silva, 2001) ressalta que em estudos realizados sobre a produção de chorume foram verificadas diferenças de 83 a $1543 \%$ nos valores previstos aos efetivamente medidos. Tal fato tem implicações diretas no controle ambiental, bem como na estimativa dos custos e na previsão dos métodos e da duração da etapa obrigatória de monitoramento. Nos Estados Unidos exige-se a reserva de fundos para manutenção do aterro por 30 anos após o seu encerramento.

A contaminação causada pela disposição de resíduos sólidos se processa mediante a migração (transporte) dos contaminantes através do solo e das águas subterrâneas, meios geológicos, podendo ocorrer na zona não-saturada e alcançar a zona saturada. Os contaminantes em contato com a água subterrânea, no caso do chorume, interagem formando compostos miscíveis, solúveis, em uma única fase. As características do solo (composição, granulometria, permeabilidade) e do próprio contaminante determinam diferenças no seu comportamento durante o processo de migração através do solo ou da água (Mattos, 2005). Caracterizam-se como plumas de contaminação ${ }^{26}$ com concentrações variáveis no espaço e no tempo, podendo alcançar grandes áreas e longas distâncias, dependendo das condições hidrológicas e hidrogeológicas locais (Figura 4.5).

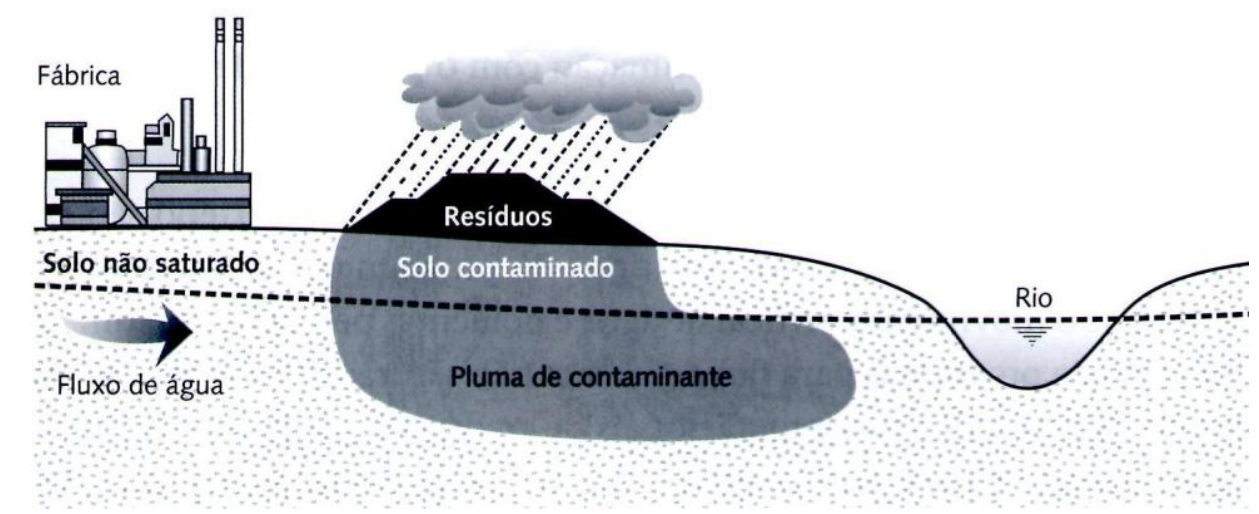

Figura 4.5 - Formação da pluma de contaminação.

Fonte: Boscov (2008, p.89).

\footnotetext{
${ }^{24} \mathrm{O}$ balanço hídrico consiste no cálculo, mês a mês, da diferença entre as parcelas de entrada e saída de água na massa de resíduos. Segundo Lima (2003) pode ser calculado por programas computacionais que mantém bancos de dados meteorológicos, considerados, entretanto, inaplicáveis à realidade brasileira, pois são programas importados.

${ }^{25}$ BAGCHI, A. Design, construction and monitoring of sanitary landfill. John willey \& sons, Inc. 1990. $284 \mathrm{p}$.

${ }^{26}$ Pluma de contaminação é a região contaminada por um ou mais poluentes a partir da fonte, que pode ser obtida através da modelagem computacional (Boscov, 2008).
} 
Requalificação dos Aterros Desativados (Brownfields) no Município de SÃo PaUlo: Parques (GreenfieldS) Raposo TAVAREs e Jardim PrimaVera

Luzia Helena dos Santos Barros

No estudo de Guiguer Junior (1987 ${ }^{27}$ apud Tressoldi e Consoni, 1998), realizado no aterro de Taubaté, situado sobre sedimentos argilo-arenosos da Formação Caçapava, em aqüífero livre, o alcance longitudinal da pluma de contaminação chegou a 200 m, após cinco anos da sua implantação.

Apesar da evolução tecnológica, o tratamento do chorume ainda pode ser considerado um grande desafio, inclusive para os atuais aterros sanitários. Segundo Benvenuto (2010), o tratamento do chorume in loco não é prática comum; na maioria dos casos ele é recolhido e levado para tratamento nas estações de esgoto, em troca da disposição do lodo gerado na estação, na sua planta ${ }^{28}$. Ainda estão em desenvolvimento técnicas para possibilitar o seu descarte em águas superficiais próximas ou mesmo para reuso.

\subsubsection{EMANAÇÕES DE GASES}

A degradação anaeróbica da matéria orgânica é responsável pela produção de gases tóxicos ao meio ambiente e à saúde humana. Dentre eles destacam-se o metano e o dióxido de carbono. Em geral a produção de gás ocorre por toda a vida útil do aterro com seu pico ocorrendo na fase de fechamento. Segundo Heimlich (s/d apud USEPA, 2002) o início da produção de metano ocorre após um a dois anos da disposição dos resíduos e pode perdurar por dez a sessenta anos.

Conforme relato de Silva (2001) o biogás já foi detectado à distância de até 1.500 m (Gandolla, Acaia e Fischer, 1998 ${ }^{29}$ ). A sua presença pode ser indicada pela morte da vegetação, que ocorre devido à redução da quantidade de oxigênio no solo, por oxidação do metano. Além disso, podem ocorrer riscos de explosividade e inflamabilidade.

A explosividade de um aterro é determinada pelos Limites de Explosividade Inferior (LEL) e Superior (UEL), que correspondem à porcentagem do gás no ar em volume. Nesse intervalo, com a presença de uma fonte de ignição, pode ocorrer

\footnotetext{
${ }^{27}$ GUIGUER JUNIOR, N. Poluição das águas subterrâneas causadas por aterros sanitários: uma abordagem matemáticoexperimental. Escola Politécinica. Universidade de São Paulo (EPUSP). São Paulo. 1987. 250 p. (dissertação de Mestrado). ${ }^{28} \mathrm{O}$ aterro sanitário S. João, encerrado a muito pouco tempo, depois de coletar o chorume nas lagoas de acumulação, transportava-o, via caminhões especiais, para a Estação de Tratamento de Suzano da Sabesp (Enterpa Ambiental, S.A, s/d). Folheto de divulgação. 4 p.

${ }^{29}$ GANDOLLA, M.; ACAIA, C.; FISCHER, C. Landfill gas migration in the subsoil - experiences of control and remediation. International Directory of Solid Waste Mangement. The ISWA Yearbook, James \& James (science Publischers), London. 1998. p. 237-245.
} 
explosão. O gás metano é explosivo entre o LEL de 5\% em volume e UEL de $15 \%$ em volume. No interior do aterro o metano ocorre com concentrações típicas de 50\% (muito mais alta do que o UEL), fora das condições de explosividade. Entretanto, ao migrar e diluir-se, especialmente em áreas próximas e confinadas, pode atingir as condições ideais para atingir os níveis de explosividade (Brito Filho, 2005). O gás de aterro pode percorrer diferentes caminhos potencias: pelo ar, solo, águas subterrâneas, edificações (Figura 4.6).

Brito Filho (2005) relaciona alguns acidentes com explosão do gás de aterro. Na Carolina do Norte, Winston-Salem, em 1969, houve a explosão de gás, confinado em um porão, adjacente a um aterro, provocada por um cigarro aceso, que causou a morte de três homens e feriu outros cinco. Num aterro em Sheridan, Colorado,em 1975, houve acúmulo de gás na tubulação de drenagem das águas pluviais, onde crianças brincavam com uma vela acesa, que resultou em sérios ferimentos em todas as crianças. Em Cincinnati, Ohio, em 1983, uma residência nas proximidades de um aterro foi destruída. Em 1984, agora em Akron, outra casa foi destruída e dez temporariamente evacuadas. Num parque construído sobre um aterro em Charlotte, Carolina do Norte, em 1994, uma mulher foi queimada na explosão ocorrida durante uma partida de futebol.

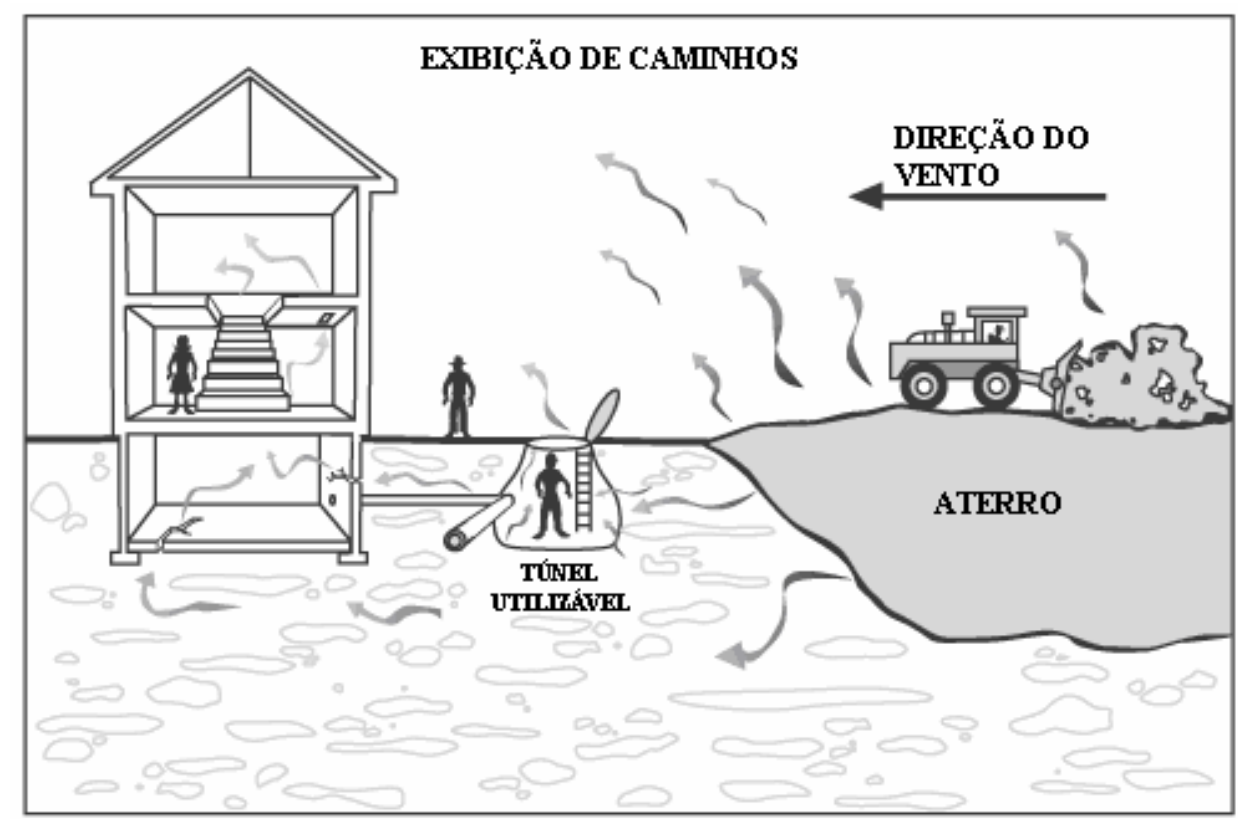

Figura 4.6 - Caminhos potenciais do gás de aterro.

Fonte: ASTDR (2005 ${ }^{30}$ apud Brito Filho, 2005, p. 73).

${ }^{30}$ AGENCY FOR TOXIC SUBSTANCES AND DISESE REGISTRY (ATSDR). Chapter 2: Landfill Gas Basics. Disponível: <http://www.atsdr.cdc.gov/HAC/landfill/html/ch2.html>. Acesso: 18 Jul. 2005. 
Garvin, Hartless e Tedd $^{31}$ (1998 apud Silva, 2001) comentam que a concentração de gás no solo é extremamente variável em um curto período de tempo, dificultando a avaliação dos riscos de emissão de gás; recomendando-se, então, a medição da taxa de emissão de gás. No entanto, existe indefinição sobre o seu significado, além de existirem diferentes métodos, geralmente inadequados para a sua medição.

Lima (1986 apud Brito Filho, 2005), verificou que ao aumento da altura da célula de lixo (maior grau de adensamento ou compactação) corresponde a um aumento da velocidade no processo de digestão e um acentuado aumento na fração molar do metano, havendo maior produção de gás.

Leuenberger e Brandsch (2008, p.194) alertam para a diferença marcante entre os processos de migração de gás e de águas subterrâneas, pois aqueles migram muito mais rapidamente e seus riscos podem ser desconsiderados, dependendo do momento de sua medição.

[...] Aterros/depósitos inspiram e expiram de maneira que riscos podem ser subestimados. Se essas emissões gasosas são medidas durante uma inspiração, as concentrações comprovadas e os seus respectivos riscos serão por muitas vezes menores do que se a análise fosse feita durante a expiração.

Não são conhecidas muitas informações sobre a taxa de emissão de metano nos aterros brasileiros. O tempo de degradação também é muito variável, pois se relaciona às características do lixo e às condições meteorológicas de cada local (Oliveira e Mahler, $1998^{32}$ apud Silva, 2001).

Ainda, conforme citação do mesmo autor, o estudo de diferentes aterros, em Wiscosin, mostrou que o Cloreto de Vinila (substância carcinogênica), ocorria em todos os aterros municipais, provavelmente, originado da biodegradação de um solvente muito comum, o Tricloroetileno (Chazin et al., 1987 apud Bagchi, $1990^{33}$ ). A presença de compostos orgânicos voláteis (VOC's) também foi constatada nas emissões gasosas de aterros da Califórnia, sendo muito comum ocorrer migração de gás para o entorno (Hodgson et al.,1992 apud Lee e Jones-Lee, 1994).

\footnotetext{
${ }^{31}$ GARVIN, S. L. HARTLESS, R. TEDD, P. Building on Contaminated Lands: The Risks. In: Contaminated Soil'98. Thomas Telford, London. 1998. p. 641-650.

${ }^{32}$ OLIVEIRA, F.J.P.; MAHLER, C,F. Proposta de monitoramento ambiental para operação de aterros sanitários. Encontro Nacional de Limpeza Pública. Anais. Associação Brasileira de Limpeza Pública. 1998. p. 145-163.

${ }^{33} \mathrm{BAGCHI}$ A. Design, construction and monitoring of sanitary landfill. John Willey \& sons, Inc. 1990. $284 \mathrm{p}$.
} 
As diferentes situações de risco relacionadas às concentrações de gás no solo e em edifícios configuraram dez classes específicas de riscos de gás (Quadro 4.1), definidas por Leuenberger e Brandsch (2008). As classes se baseiam na presença e nas condições do metano no maciço do aterro, que poderão desencadear ou não medidas especiais, estabelecendo-se prioridades de ação.

Lee e Jones-Lee (s/d apud USEPA, 2002) relatam que, em muitos casos, o aproveitamento do metano como fonte de energia não é economicamente viável devido a sua baixa produção e qualidade, quando comparada às fontes naturais. Por outro lado, tecnologias de coleta, filtragem e limpeza existentes hoje, permitem a sua queima e a sua transformação em eletricidade (USEPA, 2002). Esse processo reduz os impactos ambientais e estéticos provocados pelo gás (Eren, 2000 apud USEPA, 2002). Nos Estados Unidos, existem muitos exemplos de sucesso da aplicação dessa tecnologia em aterros ativos e inativos (Ewall, 1999 apud USEPA, 2002).

Quadro 4.1 - Classes de riscos de gás

\begin{tabular}{|c|c|c|c|c|c|}
\hline \multirow[b]{2}{*}{ Classe } & Aterro antigo & \multicolumn{4}{|c|}{ Boa proteção } \\
\hline & $\begin{array}{l}\text { Condições Metano } \\
\left(\mathrm{CH}_{4}\right)\end{array}$ & $\begin{array}{l}\text { Metano } \\
\text { presente? }\end{array}$ & Risco & $\begin{array}{c}\text { Ações } \\
\text { necessárias }\end{array}$ & $\begin{array}{l}\text { Urgência/ } \\
\text { Prioridade }\end{array}$ \\
\hline 1 & $\mathrm{CH}_{4}$ inexiste & não & baixo & nenhuma & $1 \times / 2$ anos \\
\hline 2 & $\begin{array}{c}\mathrm{CH}_{4}<5 \mathrm{Vol} \% \text {, em } \\
\text { profundidade }\end{array}$ & não & baixo & observação & $1 x /$ ano \\
\hline 3 & $\begin{array}{c}\mathrm{CH}_{4}<5 \mathrm{Vol} \% \text {, inexiste } \\
\text { rota de migração }\end{array}$ & não & baixo & observação & $1 x /$ ano \\
\hline 4 & $\begin{array}{c}\mathrm{CH}_{4}<5 \mathrm{Vol} \% \text {, existe } \\
\text { rota de migração }\end{array}$ & não & médio & observação & $1 \times /$ ano \\
\hline 5 & $\begin{array}{c}\mathrm{CH}_{4}>5 \mathrm{Vol} \% \text {, inexiste } \\
\text { rota de migração e } \\
\text { pressão de gás }\end{array}$ & não & médio & observação & 1-2x /ano \\
\hline 6 & $\begin{array}{l}\mathrm{CH}_{4}>5 \mathrm{Vol} \% \text {, existe } \\
\text { rota de migração e alta } \\
\text { pressão de gás }\end{array}$ & não & $\begin{array}{l}\text { potencial } \\
\text { (probabi- } \\
\text { lidade?) }\end{array}$ & observação & \\
\hline 7 & $\begin{array}{c}\mathrm{CH}_{4}>5 \mathrm{Vol} \% \\
\text { quantidade relevante } \\
\text { de gás, existe rota de } \\
\text { migração e alta } \\
\text { pressão de gás }\end{array}$ & não & potencial & $\begin{array}{l}\text { Medidas de } \\
\text { segurança }\end{array}$ & urgente \\
\hline 8 & idem & $\begin{array}{l}\text { traços } \mathrm{CH}_{4} \\
\quad(\mathrm{ppm})\end{array}$ & alto & $\begin{array}{l}\text { medidas } \\
\text { urgentes, } \\
\text { remediação }\end{array}$ & urgente \\
\hline 9 & idem & $\mathrm{CH}_{4} 5-15 \mathrm{Vol} \%$ & urgente & evacuação & urgente \\
\hline 10 & idem & $\mathrm{CH}_{4} 5-15 \mathrm{Vol} \%$ & acidente & $\begin{array}{l}\text { Socorro após } \\
\text { o acidente }\end{array}$ & \\
\hline
\end{tabular}

Fonte: Leuenberger e Brandsch (2008, p.195, tradução nossa). 


\subsubsection{ESTABILIDADE GEOTÉCNICA DO MACIÇO DE RESÍDUOS}

A variabilidade dos materiais constituintes de um lixão ou aterro, descrita no Capítulo 1, os procedimentos inadequados de lançamento desses materiais, a operação dessa atividade (compactação incorreta das camadas de resíduos, espessura inadequada da camada de cobertura, inexistência ou insuficiência da drenagem interna); bem como a redução do volume do maciço, causado pela degradação natural da matéria orgânica, está diretamente relacionada ao comportamento geotécnico complexo desses maciços, de difícil modelagem. Neste sentido, Wolle ${ }^{34}$ (1992 apud Pellogia, 1998, p.134) declara:

[...] a estabilidade dos assim chamados 'aterros sanitários' é tipicamente uma questão geotécnica, com dificuldades e complexidades especiais (não é possível, por exemplo, modelar tais aterros ou seus materiais constituintes através dos ensaios convencionais em laboratório, como é praxe na maioria dos problemas que envolvem a Mecânica dos Solos) [...].

Boscov (2008) aponta a permeabilidade como uma das propriedades geotécnicas que influenciam a estabilidade do maciço de resíduos. Em permeabilidades baixas há formação de gás e chorume, com desenvolvimento de pressões neutras $^{35}$, que desencadeiam os deslocamentos da massa de resíduos. Os valores do coeficiente de permeabilidade dos RSU brasileiros situam-se entre $10^{-8} \mathrm{e}$ $10^{-6} \mathrm{~m} / \mathrm{s}$, menores que o dos países desenvolvidos, muito provavelmente, devido à maior quantidade de materiais putrescíveis.

Quanto aos recalques observados em aterros de resíduos, a autora comenta que eles são mais elevados do que os que ocorrem em maciços de solos, citando alguns autores (Sowers, 1973; Wall e Zeis, 1995; Van Meerten et al., 1995; Coumoulos e Koryalos, 1997; Abreu, 2000) que registraram uma variação da ordem de 10 a 50\% em relação a espessura total original do aterro. A complexidade dos mecanismos de compressão, atuantes nos aterros, e da sua quantificação dificultam a previsão dos recalques.

A pouca capacidade de carga $^{36}$ desses resíduos e a forma inapropriada de implantação dos lixões ou aterros condicionam os processos de deformação, ruptura, subsidência, colapso, escorregamento, erosão, etc. A ocorrência desses

\footnotetext{
${ }^{34}$ WOLLE, C.M. Veias abertas na Serra. Téchne, I (I): 26-31.

${ }^{35}$ Pressão neutra ou poropressão é a " [...] pressão no interior das descontinuidades das rochas ou nos poros de um solo, que corresponde à altura que a água ascende no interior de um piezômetro colocado neste ponto. [...] é expressa pelo produto entre a massa específica da água e a altura alcançada pela água." (Azevedo e Albuquerque Filho, 1998).

${ }^{36}$ Termo utilizado para avaliar o comportamento geotécnico dos maciços de solo, definido pela resistência ao cisalhamento e compressibilidade do solo e a posição do nível d'água. É a carga que provoca a ruptura, neste caso, do aterro.
} 
problemas aparece com mais freqüência após o seu encerramento. Dependem da manutenção existente e do regime e intensidade de chuvas na região.

A implantação de estruturas rígidas sobre os antigos aterros pode intensificar situações de estresse no maciço, provocando recalques diferenciais devido às diferentes cargas e compressibilidades. Abrahão e Velloso (1998, p.386, grifo dos autores) ao tratarem do estudo das fundações de edificações em solos afirmam que "[...] Uma edificação que se apóie sobre materiais que tenham rigidez (módulos de deformabilidade) diferente, está sujeita a recalques diferenciais que podem comprometer a estrutura.

\subsection{Avaliação de Risco à Saúde Humana}

Segundo a Cetesb (2001) a avaliação de risco, etapa constituinte do gerenciamento das áreas contaminadas, discutido no Capítulo 3, objetiva identificar e quantificar os riscos à saúde humana, provenientes de uma área contaminada. Ela fornece subsídios às etapas posteriores de remediação e controle de uso do solo (Figura 4.7). Os princípios de toxicologia humana, o conhecimento das propriedades físico-químicas e o comportamento ambiental dos contaminantes são a base das metodologias utilizadas.

A caracterização do risco inclui as etapas: avaliação de toxicidade e de exposição ${ }^{37}$. A avaliação de toxicidade verifica a magnitude da exposição, o tipo de efeito adverso e a possibilidade de um composto produzir câncer no indivíduo ao longo da exposição. Ela compreende a identificação dos efeitos adversos (carcinogênicos e não carcinogênicos) à saúde humana, provocados por um agente tóxico específico e, a determinação da dose-resposta, que é a dose do contaminante recebida, pelo indivíduo ou população exposta, responsável pela incidência de efeitos adversos à saúde humana. As informações são obtidas de estudos epidemiológicos, estudos clínicos e experimentos em animais. A Dose de Referência deve ser determinada para cada via de ingresso (via de exposição) considerada na Avaliação de Risco.

\footnotetext{
${ }^{37}$ Contato de um organismo receptor com um agente físico ou químico (contaminante). A exposição é quantificada como o montante do contaminante na interface de contato com o organismo (pele, pulmões, intestino) e disponível para absorção (EPA, 1989 apud Cetesb, ).
} 
Requalificação dos Aterros Desativados (BrownfieldS) no MunicípIo de SÃo PaUlo: Parques (GreenfieldS) Raposo TAVAREs e Jardim Primavera

Luzia Helena dos Santos Barros

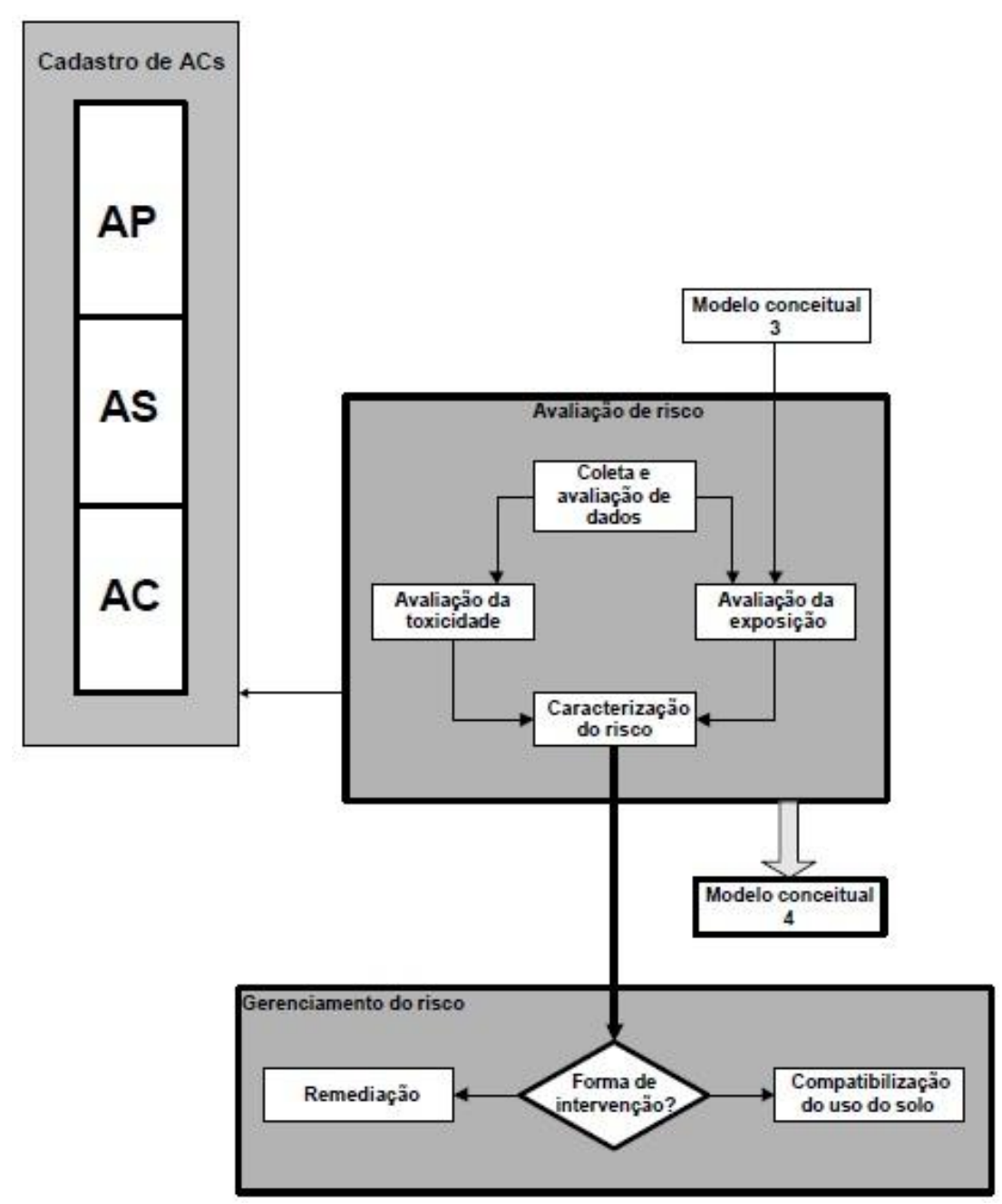

Figura 4.7 - Avaliação de Risco Fonte: Cetesb (2001- 2007).

A avaliação de exposição é a determinação da intensidade, freqüência, duração e caminhos da exposição humana, atual ou futura, a um determinado contaminante. Para tanto, é necessário entender os mecanismos de liberação e transporte do contaminante no meio físico; identificar as populações expostas e todas as vias potenciais de exposição ${ }^{38}$ e estimar as concentrações nos pontos de exposição ${ }^{39}$, para cada via específica (Figura 4.8) (Cetesb 2001-2007).

- O objetivo da caracterização de risco é quantificar a capacidade de desenvolver câncer ou de sofrer um efeito adverso não carcinogênico agudo, crônico ou subcrônico, baseado na exposição aos contaminantes no local. Os riscos carcinogênicos e não carcinogênicos são calculados para cada cenário (atual, futuro, hipotético) de interesse definido na avaliação de risco.

\footnotetext{
${ }^{38}$ Modo como um composto químico entra em contato com o organismo exposto: ingestão, contato dérmico e inalação (EPA, 1989 apud CETESB, ) .

${ }^{39}$ Ponto de contato entre o receptor (organismo ou população exposta) e o composto químico (EPA, 1989 apud CETESB, ) .
} 
PASSO 1

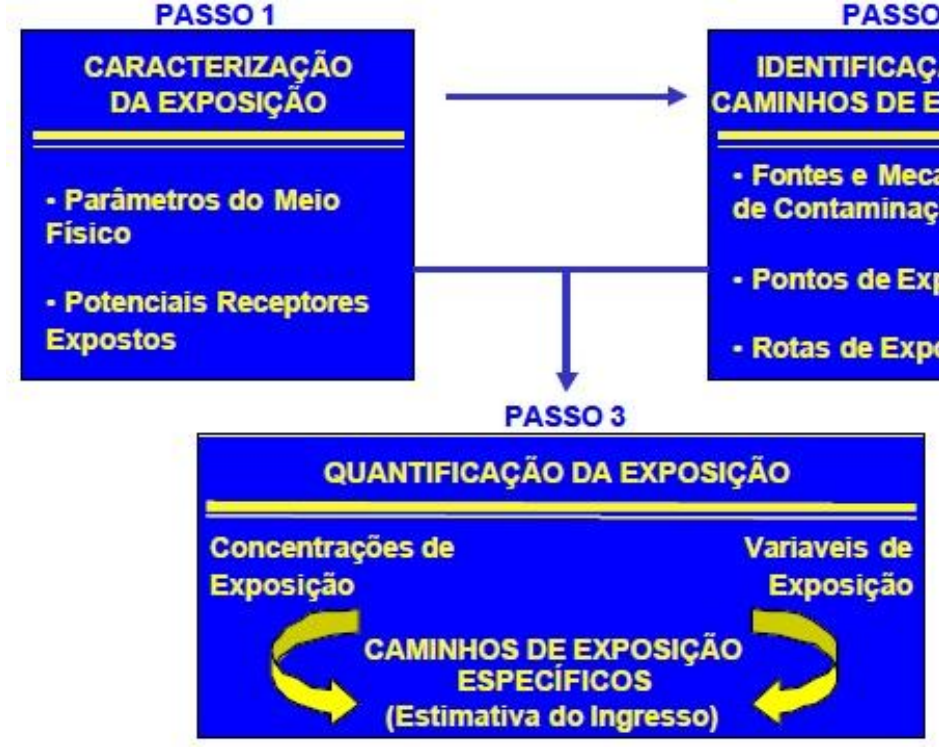

Figura 4.8 - Estágios da avaliação de exposição (modificado de EPA, 1989) Fonte: Cetesb (2001-2007)

A quantificação do risco é determinada para exposições individuais e simultâneas, respectivamente, para cada composto e múltiplos compostos químicos de interesse ${ }^{40}$. Deve ser realizada individualmente para efeitos carcinogênicos e não carcinogênicos, considerando cada contaminante e caminho de exposição ${ }^{41}$ identificado no Modelo Conceitual de Exposição da área de estudo.

Para a quantificação dos riscos é preciso estabelecer valores limites que possibilitem identificar os seus diferentes níveis de tolerância. A Cetesb (20012007), a partir de levantamento bibliográfico internacional, definiu o limite de $10^{-5}(1 \mathrm{x}$ $10^{-5}$ ), para o risco carcinogênico, ou seja, um caso de câncer em excesso em uma população de 100.000 pessoas. Se esse limite for ultrapassado será necessário implantar medidas de remediação, remoção emergencial da população exposta ou até mesmo a eliminação da rota e exposição. Caso o risco obtido seja inferior a esse limite, ele é considerado gerenciável, onde ações de médio e longo prazo devem ser executadas a fim de reduzir emissões e exposições ou deve ser implantado um monitoramento da qualidade ambiental do sítio. Para o risco de toxicidade (não carcinogênico) é utilizada a comparação com o índice de

\footnotetext{
${ }^{40}$ Composto ou substância química detectada no meio físico, que está relacionada à fonte primária ou secundária de contaminação, por exemplo a matéria-prima ou produto final do processo produtivo ou de suporte operacional na área de estudo. Deve possuir perfil toxicológico e físico-químico suficientes para ser utilizado na quantificação do risco toxicológico e no estabelecimento de metas de remediação. Como exemplos temos : chumbo no solo, benzeno ou cloreto de vinila nas águas subterrâneas, estireno no ar atmosférico (EPA, 1989 apud Cetesb, 20).

${ }_{41}$ Percurso do composto químico, da fonte ao receptor. Uma via de exposição descreve um único mecanismo pelo qual um indivíduo ou população está exposta a um agente químico. Cada caminho inclui uma fonte de contaminação, uma rota de exposição e um ponto de exposição. Se o ponto de exposição difere do ponto de localização da fonte, o meio físico de transporte do contaminante também é incluído.
} 
Requalificação dos Aterros Desativados (BrownfieldS) no MunicípIo de SÃo PaUlo: Parques (GreenfieldS) Raposo Tavares e Jardim Primavera

Luzia Helena dos Santos Barros

periculosidade de meta 1, calculado para cada caminho de exposição e o tempo de exposição definidos no modelo conceitual .

O comportamento da migração dos contaminantes no solo e nas águas subterrâneas, segundo Tressoldi e Consoni (1998), depende de uma série de condicionantes do meio físico, dos quais se destacam: os geológicos, os hidrogeológicos, os geotécnicos e os geomorfológicos.

Para uma dada via de contato, os mecanismos de liberação, de transporte, de transferência e de transformação serão importantes na determinação das concentrações dos contaminantes no local de exposição do receptor. Para que um efeito na saúde do receptor possa ser observado é necessário que a concentração da substância química seja tóxica ou perigosa e que possua mobilidade e biodisponibilidade.

Valentim (2010, p.137-138) destaca que é na cidade que "o social pressiona os recursos naturais muito além de sua capacidade de regeneração e autodepuração". O seu território é o local dos impactos, advindos da concentração dos agentes químicos que viabilizam a produção e o consumo de base fabril. Ao citar Barreto e Carmo (2007) ${ }^{42}$, afirma que no Brasil, na última década, foi verificado um intenso crescimento da participação dos cânceres no conjunto das internações hospitalares, exigindo-se a atuação nos determinantes ambientais da doença, tais como a exposição a agentes químicos no trabalho ou no ambiente em geral.

A Organização Mundial da Saúde $\left(2000^{43}\right.$ apud Gouvea e Prado, 2010) apontou que a exposição a contaminantes advindos de aterros, provavelmente, está inserida num raio de $1 \mathrm{Km}$ para a via aérea e de $2 \mathrm{Km}$ para a via água.

As etapas da avaliação de risco incluem muitas incertezas, devido informações insuficientes ou superestimadas. Em geral são usados parâmetros conservadores que tendem a gerar valores superestimados de risco e de índice de periculosidade.

Pivato (2003 ${ }^{44}$ apud Real, 2005), na revisão bibliográfica realizada, compilou os resultados de trabalhos sobre o tema e elaborou uma síntese da probabilidade de

\footnotetext{
42 BARRETO, Maurício Lima e CARMO, Eduardo Hage. Padrões de adoecimento e de morte da população brasileira: os renovados desafios para o Sistema Único de Saúde. Ciência \& Saúde Coletiva 2007; 12 (sup.): 1779-1790.

${ }^{43}$ World Health Organization. European Centre for Environment and Health. Methods of assessing risk to health from exposure to hazards released from waste landfi Ils. Report from a WHO Meeting Lodz, Poland, 10 - 12 April, 2000. Bilthoven; 2000.

${ }^{44}$ PIVATO,A. An Overview of the Fundamentals of RIsk Assesment Applied to the Aftercare Landfill Impact. In: Proceedings of the Nieth International Landfill Symposium. Sardinia, S. Margherita di Pula, Cagliari, Italy. 2003.
} 
ocorrência da contaminação, decorrente de aterros de resíduos sólidos urbanos. (Quadro 4.2).

Quadro 4.2 - Síntese da revisão bibliográfica sobre riscos à saúde humana decorrentes de aterros desativados.

\begin{tabular}{|c|c|c|c|c|c|}
\hline \multicolumn{6}{|c|}{ Riscos à saúde humana decorrentes de aterros desativados } \\
\hline \multirow[t]{2}{*}{$\begin{array}{c}\text { Meio } \\
\text { contaminante }\end{array}$} & \multirow[t]{2}{*}{ Mecanismo } & \multirow[t]{2}{*}{$\begin{array}{c}\text { Fonte } \\
\text { contaminante }\end{array}$} & \multirow[t]{2}{*}{ Vias de exposição } & \multicolumn{2}{|c|}{$\begin{array}{c}\text { Probabilidade de } \\
\text { ocorrência da } \\
\text { contaminação } \\
\text { Pós fechamento } \\
\text { (anos) }\end{array}$} \\
\hline & & & & $0-50$ & $>50$ \\
\hline \multirow{2}{*}{ Gasoso } & \multirow{2}{*}{$\begin{array}{l}\text { Fluxo de } \\
\text { biogás }\end{array}$} & Biogás & $\begin{array}{l}\text { Inalação de gás no } \\
\text { interior e exterior das } \\
\text { residências }\end{array}$ & 2 & 0 \\
\hline & & Poeiras & $\begin{array}{l}\text { Inalação de poeiras } \\
\text { no interior e exterior } \\
\text { das residências }\end{array}$ & 1 & 0 \\
\hline \multirow{13}{*}{ Líquido } & \multirow{13}{*}{$\begin{array}{l}\text { Fluxo de } \\
\text { percolado }\end{array}$} & \multirow{7}{*}{$\begin{array}{c}\text { Água } \\
\text { subterrânea }\end{array}$} & Ingestão & 3 & 2 \\
\hline & & & Contato dérmico & 3 & 2 \\
\hline & & & $\begin{array}{l}\text { Inalação de vapores } \\
\text { no interior e exterior } \\
\text { das residências }\end{array}$ & 3 & 2 \\
\hline & & & $\begin{array}{l}\text { Ingestão de vegetais } \\
\text { irrigados }\end{array}$ & 2 & 1 \\
\hline & & & $\begin{array}{l}\text { Ingestão de água de } \\
\text { irrigação }\end{array}$ & 2 & 1 \\
\hline & & & $\begin{array}{l}\text { Contato dérmico com } \\
\text { água de irrigação }\end{array}$ & 1 & 1 \\
\hline & & & $\begin{array}{l}\text { Inalação de sprays } \\
\text { de água de irrigação }\end{array}$ & 0 & 0 \\
\hline & & \multirow{6}{*}{ Água superficial } & Ingestão & 1 & 1 \\
\hline & & & Contato dérmico & 1 & 1 \\
\hline & & & $\begin{array}{l}\text { Ingestão de vegetais } \\
\text { irrigados }\end{array}$ & 2 & 1 \\
\hline & & & $\begin{array}{c}\text { Ingestão de água de } \\
\text { irrigação }\end{array}$ & 1 & 1 \\
\hline & & & $\begin{array}{l}\text { Contato dérmico com } \\
\text { água de irrigação }\end{array}$ & 1 & 1 \\
\hline & & & $\begin{array}{l}\text { Inalação de sprays } \\
\text { de água de irrigação }\end{array}$ & 0 & 0 \\
\hline \multirow{5}{*}{ Sólido } & \multirow{5}{*}{ Solos } & \multirow{4}{*}{ Solos } & Contato dérmico & 1 & 1 \\
\hline & & & Ingestão & 1 & 2 \\
\hline & & & $\begin{array}{c}\text { Ingestão de vegetais } \\
\text { plantados }\end{array}$ & 1 & 3 \\
\hline & & & $\begin{array}{l}\text { Organismos } \\
\text { microbiológico }\end{array}$ & 0 & 0 \\
\hline & & Vapores & $\begin{array}{c}\text { Inalação de vapores } \\
\text { no interior e exterior } \\
\text { das residências }\end{array}$ & 1 & 1 \\
\hline
\end{tabular}

Fonte: Pivato (2003 apud Real, 2005), modificado. 


\subsection{RISCOS SOCIOAMBIENTAIS E DE SAÚDE CONSTATADOS EM ALGUNS} ATERROS BRASILEIROS DESATIVADOS

Silva (2001) na avaliação ambiental de oito aterros, situados no município de São Paulo, encerrados, àquela época, entre 21 e 26 anos atrás, verificou a existência de significativos impactos ambientais, quanto à contaminação e estabilidade geotécnica. Relatou como principais vias de exposição o contato direto com os resíduos e o percolado e as emanações de gases em áreas ocupadas.

Os riscos mais graves, quanto ao contato com os resíduos e o chorume, foram observados nos aterros Jardim Damaceno, ocupado por favela e, Raposo Tavares, onde foi implantado um parque. As emanações de gases ocorreram nos aterros (Jardim Damaceno, Pedreira Itapuí, Carandiru e Lauzanne Paulista) sobrepostos por edificações (residências, shopping, supermercado). Nestas áreas foi recomendada a investigação sobre o grau de explosividade, bem como, a ocorrência de substâncias tóxicas voláteis, aspecto este a ser investigado, também, nos aterros Raposo Tavares e Eng. Goulart. No que se refere à contaminação das águas subterrâneas observou que esta via de exposição não foi importante, pois os aterros situam-se em áreas de descargas locais. Apontou que problemas significativos quanto à estabilidade geotécnica foram constatados nos aterros de encostas: Raposo Tavares e Jardim Damaceno, este último, com o agravante de apresentar situações de riscos às moradias.

O autor afirma que os aterros avaliados devem ser considerados áreas contaminadas passíveis de recuperação, em um sistema de gerenciamento. Ressaltou a importância da implantação do gerenciamento das áreas contaminadas, preferencialmente integradas entre estado e município, onde estas áreas seriam incluídas juntamente com outras, possivelmente mais críticas, para priorização.

Em 2003, durante a perfuração de um poço cacimba no terreno do Centro da Coroa Futebol Clube, situado na Subprefeitura de Vila Maria/Vila Guilherme, foi detectada a presença de gás com risco de explosão, medido pela Cetesb, proveniente de antigo lixão. Algumas orientações foram fornecidas pelo GTAC/Decont, àquela Subprefeitura (Figura 4.9). A existência de lixão instalado sobre antigo porto de areia, na região denominada Coroa, foi apontada por Silva 
(2001) no entorno antigo aterro Carandiru mediante fotointerpretação realizada (Figura 4.10).

O antigo lixão na verdade se dispersa por uma grande área, conhecida há muito tempo pela Prefeitura ${ }^{45}$. Em 1974, a antiga Emurb, atual São Paulo Urbanismo, proprietária de parte da área, contratou a Promon, para diagnosticar os problemas geotécnicos e ecológico-sanitários, com vistas à implantação do Centro Administrativo Municipal - CAM. Os resultados indicaram a viabilidade técnica do projeto, mas apontavam dois problemas principais: alto custo para a construção e custos permanentes de manutenção, controle e proteção do ambiente por várias décadas (Emurb,1974). Muito provavelmente, os custos elevados para a implantação do CAM e a mudança administrativa, ocorrida nos meados da década de 1970, fizeram com que se abandonasse a proposta.

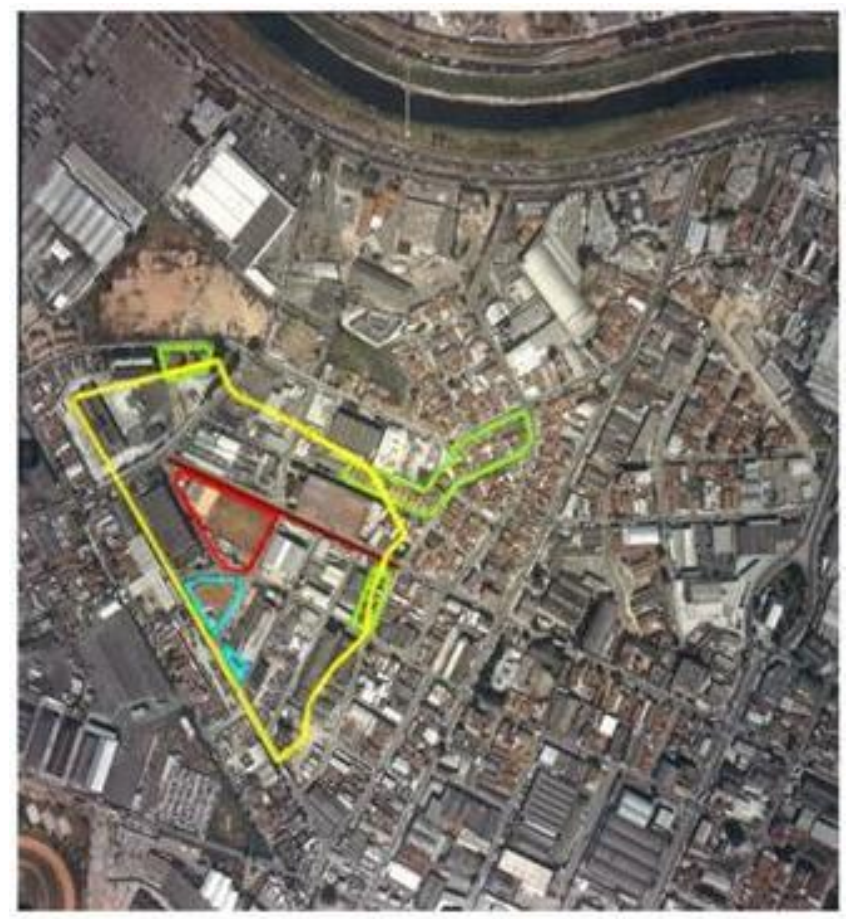

Sub prefeitura de Vila Maria e Vila Guilherme

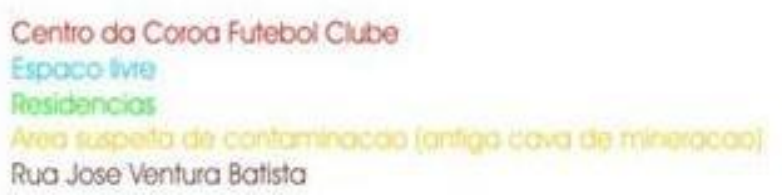

Figura 4.9 - Delimitação da área suspeita de contaminação (antigo lixão), que extrapola os limites do Clube.

Fonte: SVMA (2003)

\footnotetext{
${ }^{45}$ O local constituía-se por uma várzea meandrante com solos orgânicos (turfas) de baixa resistência e elevada compressibilidade. Durante cerca de 30 anos foi utilizado como lixão da cidade. No início da década de 1970, devido aos problemas oriundos do lixão e a necessidade de alocar os materiais provenientes do bota-fora das obras do Metrô, foi recoberto por esses materiais. O gás que emanava do lixão era usado como combustível por operários e moradores das favelas próximas, que desconheciam os riscos de explosão associados (Emurb, 1974).
} 

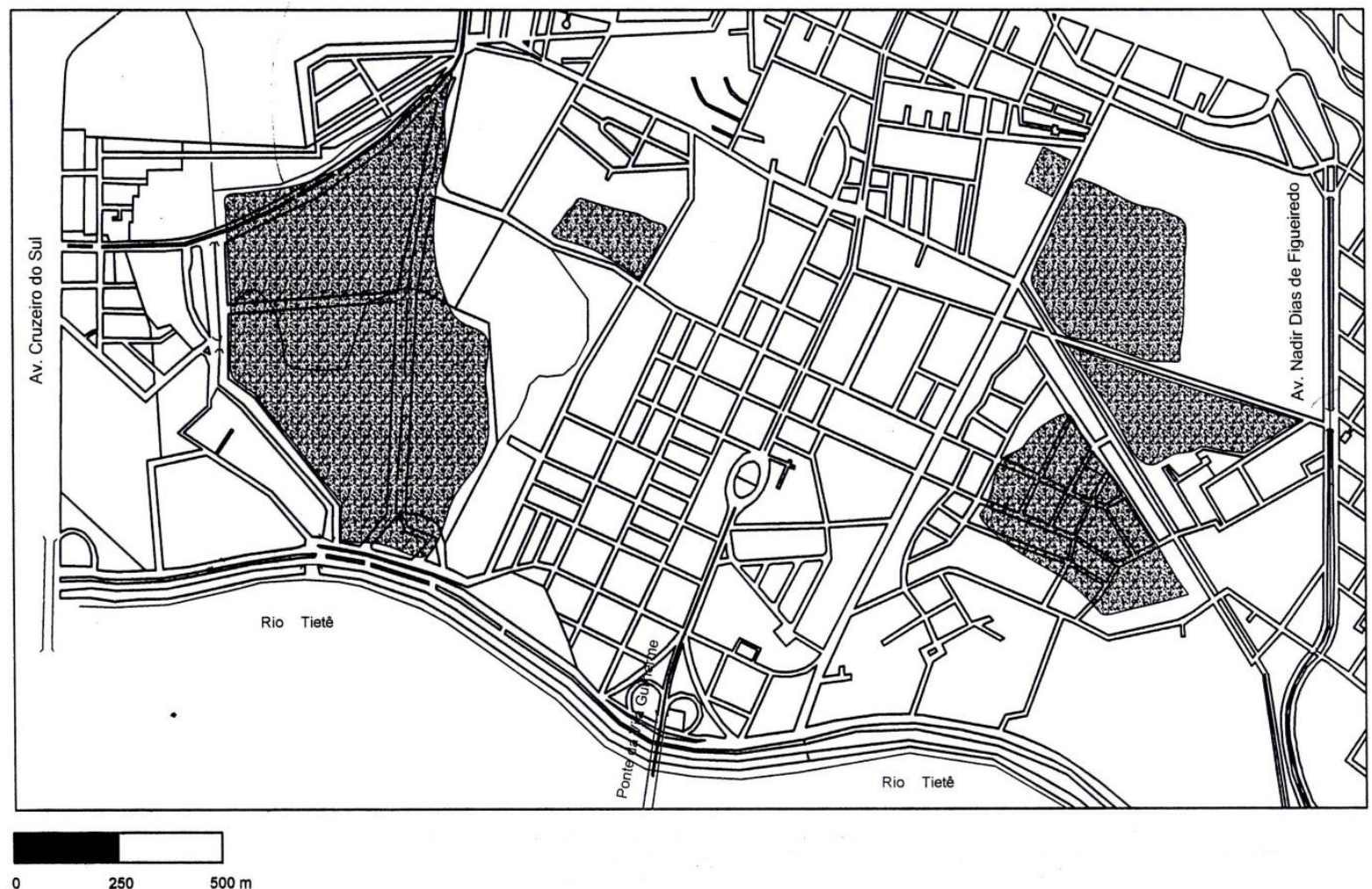

Figura 4.10 - Localização dos antigos lixões na região do Carandiru sobre base digital (GEOLOG/PRODAM) a partir de fotointerpretação de fotoaérea de 1973.

Fonte: Silva (2001, p. 65)

O Decont/SVMA (SVMA, 2005; Ramires et al., 2005) com intuito de implementar ações para revitalização dos aterros desativados situados no município, propôs uma priorização, quanto ao risco à saúde pública e ao ambiente, baseada no índice de qualidade dos aterros. A situação das áreas estudadas por Silva (2001) foi atualizada e outras áreas foram adicionadas. Entretanto, para o cômputo da priorização foram elencados apenas os aterros que estavam sob responsabilidade da administração municipal, a seguinte ordem decrescente de priorização para intervenção: Vila S. Francisco, Raposo Tavares, Jacuí, Sapopemba, S. Mateus e Santo Amaro.

Leo (2006) nos estudos desenvolvidos nos aterros desativados no município de São Paulo (Bandeirantes, Jacuí, Itatinga, Santo Amaro, São Mateus, Sapopemba, Vila Albertina e Vila São Francisco $)^{46}$, relacionou as suas condições ambientais com os dados sobre leptospirose, mapeados em 2002, pelo projeto São

\footnotetext{
${ }^{46}$ O estudo baseou-se no geoprocessamento de imagens CIBERS I (junho 2002, bandas 2, 3, 4; INPE), com resolução espacial de $20 \mathrm{~m}$, de aerofotos do ano de 2000, nas escalas de 1:5.000 e 1:6.000 e, dos padrões predominantes de uso construtivo no município, elaborados por Sempla, em 2002.
} 
Paulo PROTEJE, inferindo que há possibilidade de correlação apenas nos seguintes aterros: Bandeirantes, Vila Albertina e Vila São Francisco. Não obstante, salienta que a incidência de casos de leptospirose, também, foi verificada em regiões nas quais predominam o uso residencial de médio e alto padrão, como nas Subprefeituras do Butantã, Ipiranga, Lapa, Pinheiros e Santo Amaro. Recomenda a realização de estudos mais profundos e multidisciplinares para analisar a possibilidade de correlação direta da doença com a presença desses aterros.

Gouvea e Prado (2010) estudaram a associação entre a ocorrência de câncer e malformações congênitas nas populações residentes num raio de $2 \mathrm{Km}$ ao redor de 15 aterros (S. João, Bandeirantes, Vila Albertina, Jardim Damaceno, Lauzanne Paulista, Carandiru, Eng. Goulart, Jacuí, Pedreira Itapuí, S. Mateus, Sapopemba, S. Amaro, Vila S. Francisco, Raposo Tavares e Pedreira City) no município de São Paulo. Concluíram, entretanto, que não houve evidências suficientes para estabelecer uma relação causal. Mesmo assim, alertam que apesar da dificuldade para realizar uma avaliação epidemiológica precisa dessa exposição na saúde, as evidências de contaminação do solo e águas subterrâneas e seus efeitos nas populações do entorno dessas áreas, determinam a necessidade de planejamento e elaboração de políticas para gerenciamento dessas situações, incluindo o acompanhamento das populações expostas.

Em região propícia ao avanço da urbanização, em Fortaleza, Ceará, foi construído o aterro denominado Jangurussu, encerrado em 1998. De acordo com os resultados obtidos pelas análises dos parâmetros físico-químicos do chorume ${ }^{47}$, foi observado que muitos deles superam os limites estipulados pela Resolução Conama № 20. Quanto às águas subterrâneas os valores resultantes do estudo apresentam, em termos gerais, um acréscimo elevado se comparado aos poços de referência (Lima, 2003).

Nos estudos da avaliação hídrica no entorno do antigo lixão da Marambaia, situado no município de Nova Iguaçu, Rio de Janeiro, realizados por Mattos (2005) não foi constatada contaminação das coleções de águas superficiais, a não ser em períodos de transbordo como ocorrido em janeiro de 2005. Quanto ao lençol subterrâneo foi estimada a direção sul/sudeste para a pluma de contaminação. A

\footnotetext{
${ }^{47}$ Entre os parâmetros físico-químicos considerados nas análises de chorume estão a presença de metais, o pH, DQO, DBO, etc.
} 
autora sugere a implantação de um plano de monitoramento no aterro, além de complementação das análises para alguns parâmetros.

Em pesquisa realizada na região sul do estado de Santa Catarina (Possamai et al., 2006) foi constatada a existência de 51 lixões inativos, localizados em 38 municípios de um total de 44 pertencentes à região. Destes, 43 possuem idade inferior a 15 anos com grande potencial produtor de chorume. A situação foi considerada crítica, pois em nenhum dos lixões identificados ocorreu coleta e tratamento do chorume; em 50 deles inexistia sistema de drenagem e em 47 não se realizava o monitoramento ambiental. Acrescente-se, ainda, a presença de catadores nos lixões de 10 municípios visitados.

Aos lixões ou aterros desativados estão associados cenários de risco à saúde pública e ao ambiente. São reproduções do modelo técnico-científicoindustrial da sociedade contemporânea que caracterizam a sociedade de risco. Os cenários de risco se distribuem desigualmente no território e afetam também desigualmente a população. Ressalta-se que os cenários também se alteram no tempo. Além disso, geralmente, os indivíduos mais afetados são alijados das decisões sobre a gestão dos riscos que os atingem e, muitos, desconhecem a dimensão do perigo ou são incapazes de lidar com todas as variáveis envolvidas na percepção, prevenção, controle e minimização dos riscos.

Marcelino (2008), ao tratar dos conceitos envolvidos nos estudos de risco estabeleceu que Perigo x Vulnerabilidade $=$ Risco. Porto (2007) alertou que o conceito de vulnerabilidade permite o enfrentamento do tema mediante o diálogo de diferentes especialistas e a integração entre as instituições técnico-científicas e políticas e os indivíduos. Sendo assim, considera-se que o reconhecimento dos contextos vulneráveis (ambientais, sócio-econômicos e humanos) e as práticas coletivas e individuais para transformar essas situações poderão evitar ou ao menos reduzir a reprodução dos riscos ambientais e as suas conseqüências. 


\section{LIXÕES E ATERROS DESATIVADOS NO MUNICÍPIO DE SÃO PAULO}

O histórico de evolução da destinação final do lixo e a sua caracterização no município de São Paulo, apresentados no Capítulo 1, mostram que esses locais recebiam todo e qualquer tipo de lixo (domiciliares, de serviços de saúde, de indústrias e de outras fontes). Tanto esses antigos locais de disposição de resíduos, sem nenhum controle, quanto os atuais, clandestinos ou operados irregularmente, caracterizam-se como áreas degradadas, configurando-se hoje ou no futuro como passivos ambientais. Conhecidos como brownfields muitas vezes estão relacionados às áreas contaminadas, assunto tratado nos Capítulos 2 e 3. Essas áreas podem ser apropriadas pela população para lazer, moradia ou mesmo como produto de sobrevivência, acarretando graves riscos à saúde humana, os quais foram discutidos no Capítulo 4, quando inexiste um sistema eficaz de gestão.

Considerando a importância da requalificação desses antigos aterros, preferencialmente como parques e as dificuldades para revegetação dessas áreas, esse Capítulo tratará da inserção dessas áreas na metrópole paulistana, por intermédio do uso e ocupação do solo, dos princípios da ecologia de paisagens e da análise das suas condições socioambientais atuais. 


\subsection{ALGUNS ASPECTOS SOCIOAMBIENTAIS E URBANOS DA PAISAGEM PAULISTANA}

São Paulo, capital do estado de São Paulo, perfaz $8.051 \mathrm{Km}^{2}$ (menos de 1\% do território nacional) e possui população de 10.998 .813 habitantes. Funciona como núcleo central (metrópole) de uma área conurbada com outros 39 municípios (Figura 5.1), denominada Região Metropolitana de São Paulo (RMSP). A RMSP possui população de 19,7 milhões de habitantes, correspondendo a cerca de $10 \%$ da população nacional e constituindo-se no quarto maior aglomerado urbano mundial. Mesmo se constituindo no maior pólo de riqueza nacional agrega municípios bastante diversos, com variados níveis de qualidade de vida, reproduzidos nos seus interiores (Emplasa, 2011). Meyer, Grostein e Biderman (2004, p.19-20) definem a metrópole, do ponto de vista funcional como

[...] uma congregação de unidades administrativas autônomas que apresentam problemas urbanos comuns. [...] é a forma de estruturação urbana que o desenvolvimento econômico contemporâneo tende a produzir em todo o mundo. Historicamente, a metrópole moderna esteve associada a processos de industrialização e urbanização aceleradas.

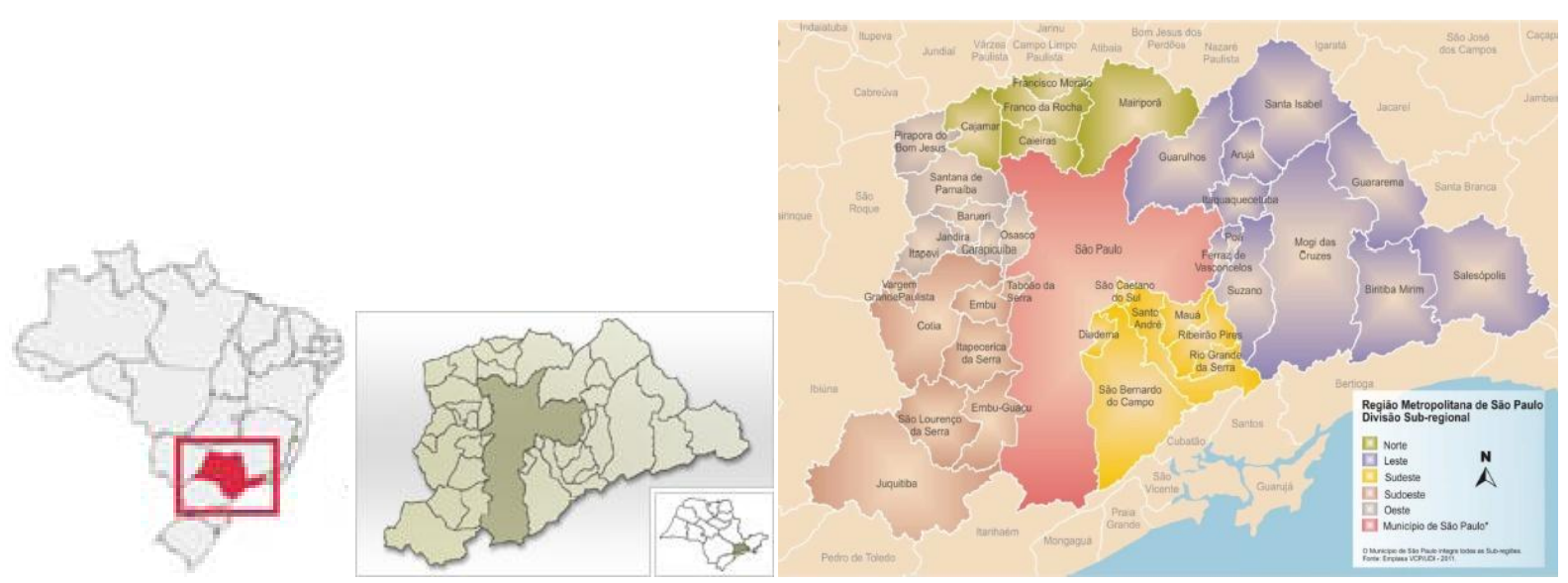

Figura - 5.1 Localização da RMSP e do município de São Paulo no estado de São Paulo e no Brasil. Fonte: Emplasa (2011).

Villaça (2001, p.12) no estudo dos espaços intra-urbano das metrópoles brasileiras conceitua estrutura como um conjunto de elementos interrelacionáveis "[...] um todo constituído de elementos que se relacionam entre si de tal forma que a alteração de um elemento ou de uma relação altera todos os demais elementos e todas as demais relações [...]" composto por quatro elementos: o centro principal, os subcentros e os conjuntos de bairros residenciais e industriais. Observa que 
[...] Essa estrutura está imbricada a outras estruturas territoriais, como os sistemas de transporte e de saneamento. Entretanto, consideramos ser a primeira mais importante, pois inclui, incorpora e subjuga as demais, mais do que o contrário, embora não possa existir sem elas. [...] Essa estrutura territorial, mais importante está também articulada a outras, não territoriais, como a econômica, a política e a ideológica.

Utilizando o modelo de Hoyt (1959) ${ }^{1}$, por setores de círculo, que representa a estruturação do espaço metropolitano através de seus elementos mais essenciais, Villaça (2001) definiu tipologias de desenvolvimento para algumas metrópoles brasileiras, entre elas São Paulo (Figura 5.2), com 360ํำ de possibilidade para evolução; estabelecendo que, desde meados do seulo XIX, as classes de renda mais alta (dominantes) tendem a se segregar no quadrante sudoeste. $O$ autor comenta que a segregação acentuada provoca a divisão das metrópoles em duas partes distintas, mais pobre e mais rica e, o surgimento de dois centros, o velho, tradicional, que já foi dos mais ricos, mas hoje está tomado pela classe mais pobre e o centro novo, dos mais ricos.

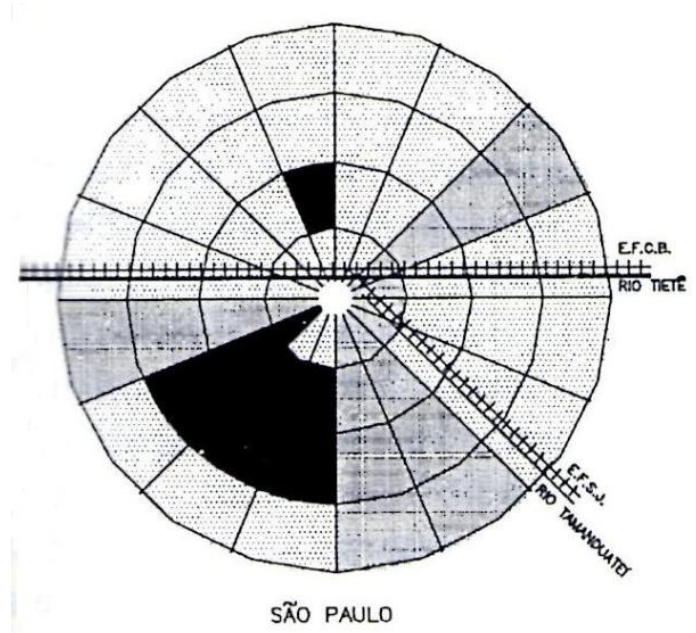

Figura 5.2 - Estruturas espaciais de São Paulo segundo o modelo de Hoyt. Fonte: Villaça (2001, p.115).

A estrutura da metrópole paulistana no Plano Diretor (2002) foi instituída pelos elementos estruturadores e integradores. Como elementos estruturadores foram considerados a rede hídrica estrutural, a rede viária estrutural, a rede estrutural de transporte coletivo e a rede estrutural de eixos e pólos de centralidade. Enquanto que os integradores foram definidos como as habitações, os equipamentos sociais, as áreas verdes e os espaços públicos.

\footnotetext{
${ }^{1}$ HOYT, H. The pattern of movement of residential rental neighborhoods. In: MAYER, H.M.; KOHN, C.E. (Eds.). Readings in Urban Geography. Chicago, The University of Chicago Press, 1959. P. 499-510.
} 
Valentim (2010) ressalta que muitos dos elementos estruturantes do espaço urbano estão relacionados diretamente à ocorrência de áreas contaminadas, destacando, primeiramente, as áreas industriais, responsáveis por grande produção de passivos ambientais. Secundariamente, indica as áreas residenciais, pois são locais potencialmente preferenciais à exposição humana às substâncias tóxicas. $\mathrm{Na}$ mesma linha de raciocínio do autor, incluem-se, nesse segundo grupo, as áreas verdes, especialmente os parques urbanos implantados sobre aterros.

No final do século $X X$, se observa a transformação do modo de produção essencialmente mecânico para o modo de produção tecnológico, que corresponde à passagem da metrópole moderna para a contemporânea. A metrópole moderna, com seus problemas urbanos acumulados, coexiste com a contemporânea, criando um cenário urbano de descompasso acentuado com conflitos entre os setores urbanos pobres e ricos. Outro padrão de organização urbana na metrópole contemporânea - "espaços de fluxos", definido por Castells (1999) ${ }^{2}$, no qual os fluxos (de capital, da tecnologia, de informação, de imagens, etc.) são a forma predominante de relação. E, ainda segundo os autores, esse tipo de território permite a articulação de trechos aparentemente descontínuos e desarticulados (Meyer, Grostein e Biderman, 2004).

A constituição geológico-geomorfológica do município de São Paulo está representada, sinteticamente, por rochas cristalinas pré-cambrianas, que sustentam as serras, os morros e os morrotes e por sedimentos cenozóicos, terciários e quaternários, que correspondem às colinas e às planícies aluvionares, respectivamente (Figura 5.2).

As rochas do embasamento pré-cambriano, representadas pelas suítes graníticas indiferenciadas (granitos, granodioritos, monzogranitos e granitóides diferenciados) predominam ao norte do município, formando a Serra da Cantareira (Hasui e Carneiro, $1980^{3}$ apud SVMA, 2004a). As rochas metassedimentares e metavulcânicas dos Grupos São Roque e Serra do Itaberaba (filitos, metarenitos, quartzitos, anfibolitos, metacalcários, dolomitos, xistos, calciossilicatadas) aparecem a norte e a noroeste. O Complexo Embu (xistos, filitos, migmatitos, gnaisses, quartzitos lenticulares, calciossilicatadas) ocorre expressivamente, especialmente,

${ }^{2}$ CASTELLS, M. A Sociedade em Rede. São Pauio: Paz e Terra. 1999. p. 435-436

${ }^{3} \mathrm{HASUI}$, Y.; CARNEIRO, C.D.R. Origem e evolução da Bacia Sedimentar de São Paulo. In: MESA REDONDA: ASPECTOS GEOLÓGICOS E GEOTÉCNICOS DA BACIA SEDIMENTAR DE SÃO PAULO. Publicação Especial. São Paulo, ABGE/SBG. 1980, p. 47-52. 
ao sul e, secundariamente, a leste (SVMA, 2004a). Essas formações caracterizam relevos acidentados e rochas susceptíveis à erosão e escorregamentos, sendo menos favoráveis à ocupação.

Os sedimentos terciários (argila, areia, silte, conglomerado) da Bacia Sedimentar de São Paulo, de maior abrangência no município, ocorrem por todo o seu substrato central, ao longo dos Rios TieTê e Pinheiros e em manchas isoladas ao norte, sul e sudoeste (SVMA, 2004a). Os sedimentos da Bacia conformam relevos suaves, com menor suceptibilidade à erosão, mas apresentando dificuldade de escavação e possibilidade de ocorrência de recalques diferenciais.

Os depósitos quaternários, aluvião (areia, silte, argila) e o colúvio (silte a grânulos), ocorrem ao longo das planícies fluviais (Tietê, Pinheiros e Tamanduateí) e junto às encostas, respectivamente. Ab'Saber (1980) comenta que essas planícies fluviais meândricas sofreram fortes intervenções (retificação e inversão da correnteza), sem comparação no mundo tropical. As planícies apresentam lençol freático raso e recalques em solos moles, características que favorecem a ocorrência de inundação, contaminação e danos às estruturas e fundações. Os colúvios, com espessuras entre $0,5 \mathrm{~m}$ e $3,0 \mathrm{~m}$ e alta porosidade (SVMA, 2004a), apresentam alta susceptibilidade a escorregamentos, quando saturados.

Ao sul do município, em Paralheiros, se destaca uma depressão circular, preenchida por depósitos quaternários, a Cratera de Colônia, considerada um registro deposicional de informações paleoclimáticas (SVMA, 2004a).

Pellogia (1994, 1998) e Oliveira (1990), nas reflexões sobre as formações superficiais e sub-superficiais, corroborando com outros autores, colocam que os impactos desencadeados pelas ações antrópicas sobre a natureza podem ser correlacionados aos impactos provocados por fenômenos naturais ou geológicos, só que mais acelerados; implicando em efeitos geológicos e geomorfológicos específicos, que levaram a caracterizar o período geológico 'Quinário' ou 'Tecnógeno'. Oliveira (1995) resumindo o tema esclarece "as novas coberturas pedológicas e as novas formações geológicas, que se encontram em processo de geração, estão fortemente influenciadas pela ação do homem", enquanto que Pellogia (1998, p.11) afirma 


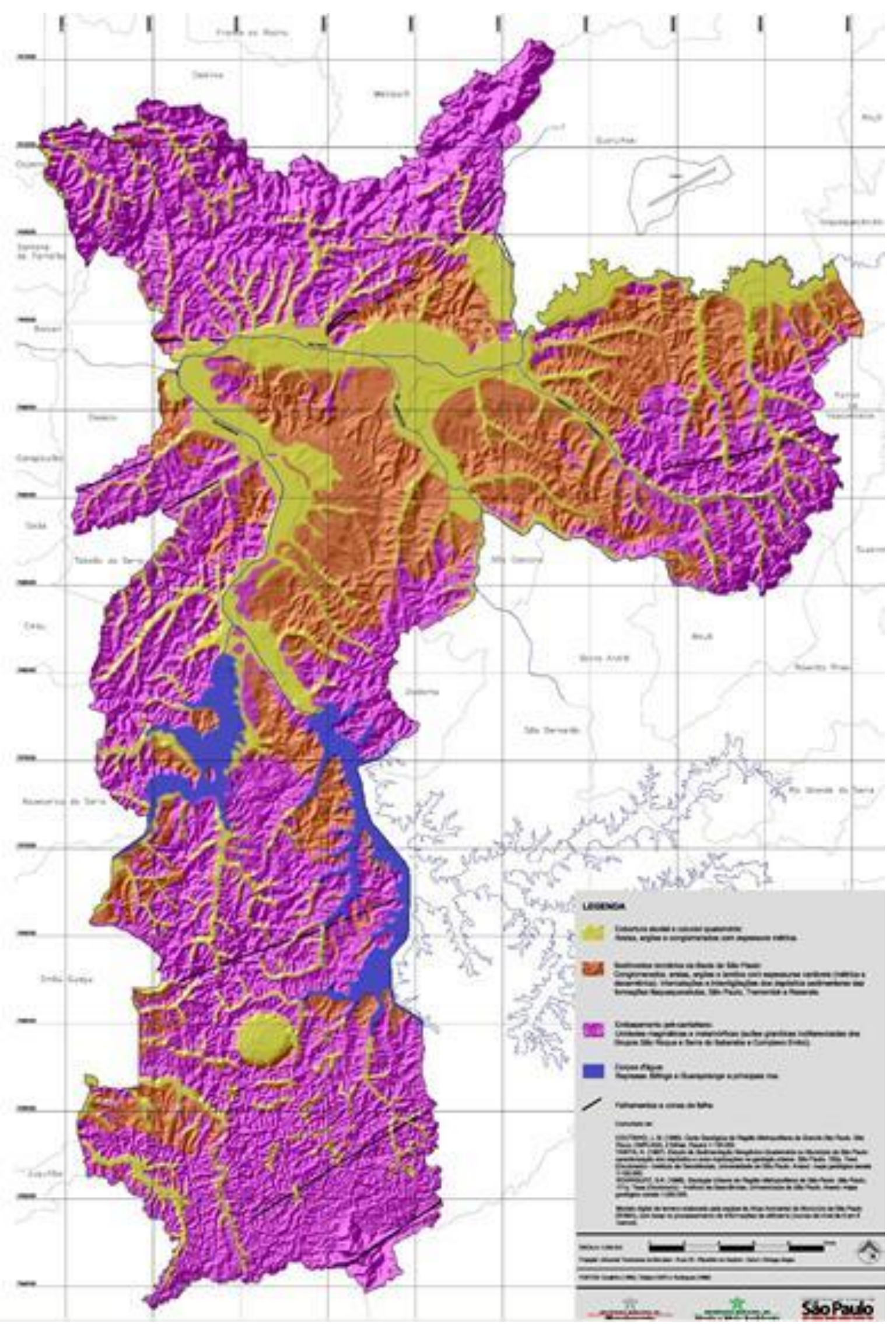

Figura 5.2 - Principais domínios geológico-geomorfológicos do município de São Paulo Fonte: SVMA (2004b) 
[...] A Geologia do Tecnógeno concentra-se, então, no estudo dos produtos (depósitos e feições do relevo, ditos "tecnogênicos") gerados diretamente ou influenciados pela atividade humana, mas também de seus processos geradores específicos, estes que atuam sobre maciços e relevos préexistentes assim como sobre os próprios depósitos tecnogênicos. E é nas concentrações urbanas que tal ação modificadora do homem sobre o ambiente, por assim dizer geológico, se amplia e diversifica, ganhando imediato interesse prático em função de afetar, direta e imediatamente, a vida de grandes quantidades de seres humanos.

O estudo da evolução dos sistemas tecnogênicos (S.T.) no município, realizado por Figueira (2007), considerado essencial à origem e desenvolvimento da metrópole, identificou a dinâmica, interação e transição de um sistema para outro a fim de fomentar propostas para a solução dos seus problemas urbano-ambientais. Nesta abordagem foram relacionados três principais sistemas: de Canais e Reservatórios, de Mineração e de Ocupação Urbana.

No S.T. de Canais e Reservatórios se destaca a retificação dos rios Tietê e Pinheiros para a geração de energia elétrica, no qual há produção de assoreamento, denominado como depósitos tecnogênicos induzidos, por Chemekov ${ }^{4}$ (1982 apud Figueira, 2007). Ao S.T. de Mineração corresponde a lavra de areia aluvionar, em extinção, e de brita, obtida da exploração do manto de alteração de rochas graníticognáissicas, utilizadas como matérias primas para promover o crescimento urbano da cidade. Esse sistema relaciona-se diretamente aos subsistemas de disposição de resíduos e de áreas contaminadas. A transformação da paisagem e a dinâmica superficial definem o S.T. de Ocupação Urbana ou Urbanização que, ao se expandir para além da região central, sobre terrenos pouco favoráveis à ocupação, desencadeiam uma série de impactos e remobilização de materiais. Esse sistema foi subdividido em sistemas tecnogênicos: de infra-estrutura urbana, de resíduos, de áreas contaminadas e de movimentos de massa.

As diferentes condições socioambientais existentes no município podem, também, serem demonstradas pelos indicadores sintéticos ${ }^{5}$ municipais de meio ambiente (SVMA, 2008a). Dos cinco indicadores obtidos, destacam-se os de pressão, Adensamento Vertical e Precariedade Urbana e o de estado, Cobertura

\footnotetext{
${ }^{4}$ CHEMEKOV,Y. Technogenic deposits. In: INQUA CONGRSSI, 11, V. 3. Anais...1982. p.62.

${ }^{5}$ Indicadores sintéticos [...] são importantes para a disseminação das informações e para o debate público, uma vez que sintetizam, num único índice, uma complexidade de fatores que são, muitas vezes, de difícil apreensão para um público mais amplo (SVMA, 2008, p. 36).
} 
Vegetal $^{6}$. A partir da aplicação da técnica de análise estatística de agrupamentos sobre os indicadores sintéticos foi possível classificar os distritos municipais em quatro tipos socioambientais (Figura 5.3 e Tabela 5.1).

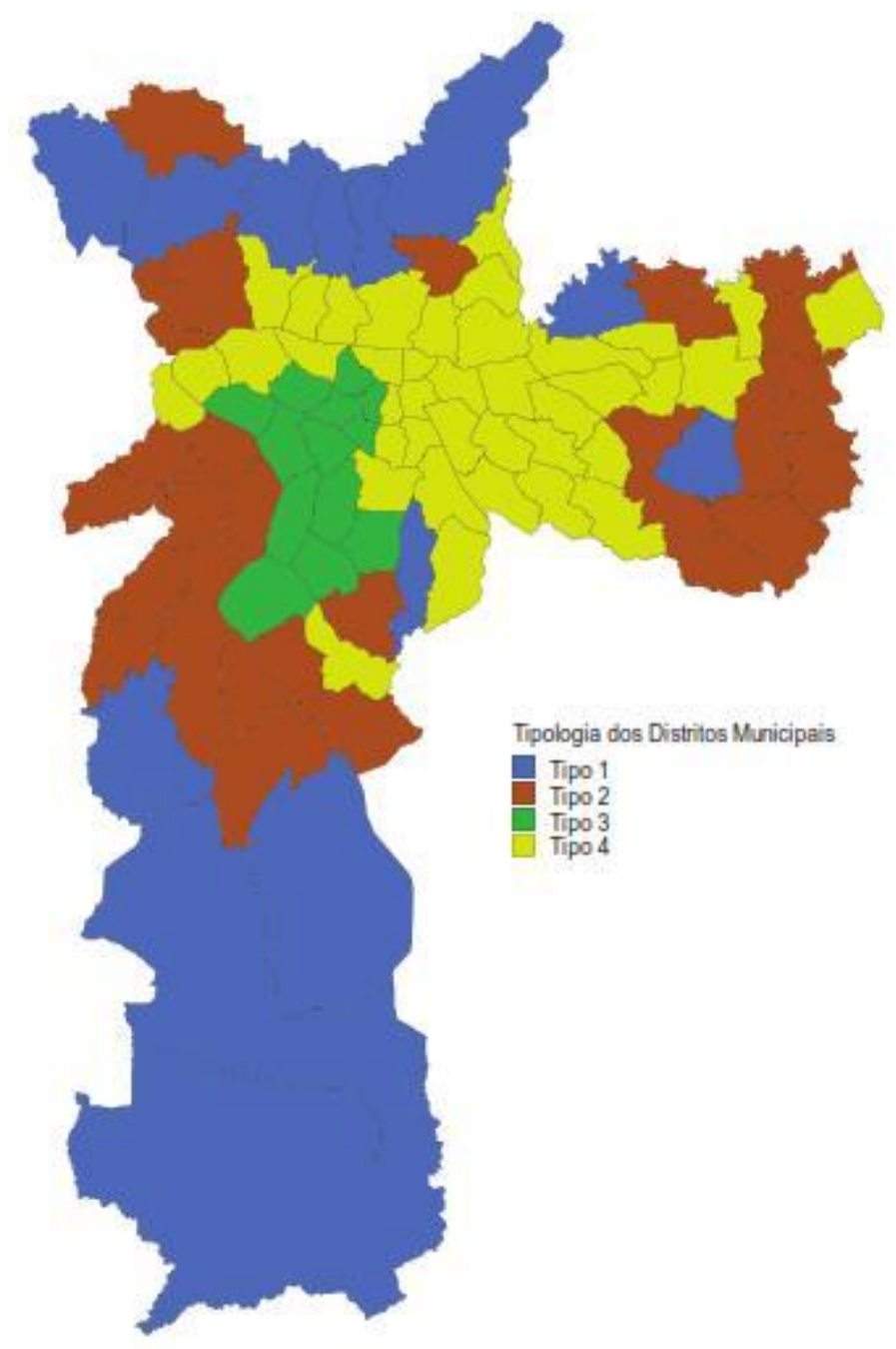

Figura 5.3 - Distribuição das tipologias socioambientais de distritos no município de São Paulo Fonte: SVMA (2008, p. 109)

Tabela 5.1- Tipos socioambientais de distritos no município de São Paulo

\begin{tabular}{|c|l|}
\hline Distritos & \multicolumn{1}{|c|}{ Descrição } \\
\hline Tipo1 & $\begin{array}{l}\text { Áreas prestadoras de serviços ambientais, com altos valores de cobertura vegetal. Estão } \\
\text { contemplados com ações de controle e conservação da biodiversidade, mas sob forte pressão de } \\
\text { ocupação urbana, altamente precária }\end{array}$ \\
\hline Tipo 2 & $\begin{array}{l}\text { Alta precariedade urbana em áreas com remanescentes de vegetação, sob pressão de ocupação } \\
\text { urbana desordenada. São densamente ocupados mas com baixo controle urbano. }\end{array}$ \\
\hline Tipo 3 & $\begin{array}{l}\text { Alto adensamento vertical e boas condições de infra-estrutura urbana e onde se concentra o } \\
\text { controle urbano. Localmente, podem apresentar altos valores de cobertura vegetal (parques, } \\
\text { arborização viária e intralote). }\end{array}$ \\
\hline Tipo 4 & $\begin{array}{l}\text { Baixíssima presença de cobertura vegetal em áreas de ocupação urbana consolidada e boa } \\
\text { infra-estrutura, com processo de "esvaziamento" populacional. }\end{array}$ \\
\hline
\end{tabular}
Organização: Luzia Helena dos S. Barros (2011)

Fonte: SVMA (2008, p. 108).

\footnotetext{
${ }^{6}$ Duas variáveis que compõe esse indicador foram obtidas pelo processamento digital de imagens do satélite LANDSAT, com resolução espacial de $30 \mathrm{~m}$, captando alvos com resposta espectral compatível com fragmentos de vegetação superiores a 900 $\mathrm{m}^{2}$ (SVMA, 2008).
} 


\title{
A constituição geológico-geomorfológica, a evolução dos sistemas
} tecnogênicos, os indicadores sintéticos de meio ambiente e os aspectos do município-metrópole são instrumentos que permitem diagnosticar os conflitos e as vulnerabilidades intra-urbanas a que estão expostos os seus moradores. Neste sentido, Meyer, Grostein e Biderman (2004, p.99 e 102) argumentam

\begin{abstract}
[...] O desconhecimento dos aspectos relacionados com a capacidade de suporte do meio natural e suas fragilidades por um processo de urbanização desordenada resultou na multiplicação das áreas de risco, com problemas de inundações, erosão e deslizamentos. As opções de projeto adotadas na ocupação das várzeas, [...] geralmente ocupadas por avenidas, marcaram profundamente o destino urbano dessas áreas e a relação da cidade com os seus rios. A ocupação inadequada de fundos de vale estabeleceu uma relação predatória entre as formas de urbanizar e os recursos naturais. Desconheceu-se a diversidade de feições do sítio urbano e, conseqüentemente, dos condicionantes que deveriam pautar os avanços da urbanização em situações morfológicas diferenciadas. Como resultante, deu-se a ocupação indistinta das planícies aluviais do rio Tietê, do rio Pinheiros e seus afluentes e a ocupação de áreas inadequadas, com solos frágeis e de alta declividade e vulnerabilidade a processos erosivos, especialmente a partir do momento em que a urbanização extrapolou os limites físicos e geomorfológicos da bacia sedimentar de São Paulo, que ocorreu na década de 1960.
\end{abstract}

A percepção da paisagem urbana envolve a compreensão da sua dinâmica por meio da caracterização e interpretação dos processos naturais e antrópicos atuantes no meio. Segundo Forman (1999) a paisagem pode ser percebida, quando avistada em sobrevôo, como um mosaico composto de mancha-corredor-matriz, seja ele floresta, deserto, agrícola ou urbano. Para Dramstad et al. (1996) esses elementos, que compõe o padrão estrutural da paisagem, são os instrumentos de comparação entre diferentes paisagens e, também, de planejamento do solo e da arquitetura da paisagem; visto que o padrão espacial controla fortemente os movimentos, fluxos e mudanças. Bertrand (1971, p. 2) especifica que a paisagem está diretamente relacionada à noção de escala e que

[...] A paisagem não é a simples adição de elementos geográficos disparatados. É, numa determinada porção do espaço, o resultado da combinação dinâmica, portanto instável, de elementos físicos, biológicos e antrópicos que, reagindo dialéticamente uns sobre os outros, fazem da paisagem um conjunto único e indissociável, em perpétua evolução [...]

Christofoletti (1981, p. 14) afirma que a paisagem pode ser entendida, como subjetiva, o que decorre da percepção realizada pelo observador e, também, como um elemento objetivo, demarcado no espaço

[...] A paisagem surge como fato concreto, tendo por essência uma conotação espacial. Ela pode ser delimitada mais ou menos nitidamente, e 
sua extensão é cartografada. Ao contrário, a noção de ecossistema não possui dimensão, não é espacializada nem concreta. É mais uma formulação sistêmica de entrosamento funcional, analisando os processos atuantes entre várias categorias de elementos (seres vivos).

O termo paisagem foi utilizado inicialmente pelo geobotânico alemão Alexander Von Humbolt, no início do século XIX, correspondendo a "característica total de uma região terrestre" (Metzger, 2001). Em 1938, o ecologista e geógrafo alemão Carl Troll afirmou que os termos ecologia e paisagem se relacionavam intimamente e ao "meio ambiente do Homem" (Ndubisi, 2002), iniciando a linha de pesquisa da Ecologia de paisagens (Landshaftsökologie) e, retomando idéia proposta, em 1850, pelo filósofo e geógrafo Rozenkranz (Troppmair, 1985).

A ecologia de paisagens introduz uma forma de análise única que conjuga tanto as relações verticais (interna às unidades) como horizontais (entre as unidades espaciais), que compõem um complexo de sistemas (rocha, água, ar, plantas, animais e o homem) com fisionomia distinta e paisagem reconhecível (Forman e Godron, 1986).

Pellegrino (1995, p. 26) comenta que

[...] Com o reconhecimento de que o distúrbio, seja causado pelos seres humanos ou induzido por forças da natureza, é a condição normal de qualquer ecossistema, a ecologia da paisagem difere ideologicamente da maioria da literatura existente sobre ecologia, procurando uma posição mais balanceada, ainda que não antropocêntrica, na qual assume, que todas as paisagens, das matas às áreas centrais das cidades, compartilham de um modelo estrutural similar. A ecologia da paisagem ao traduzir para uma linguagem comum de estrutura, função e mudança oferece um papel mediador entre as ciências ambientais e os interventores na paisagem, criando uma estrutura analítica que permite um entendimento mais integral da dinâmica espacial das paisagens.

O uso e ocupação do solo determinam as possíveis pressões ou impactos advindos das intervenções antrópicas sobre os ambientes naturais, possibilitando a integração entre os dados sobre o meio biofísico e socioeconômico, bem como é fundamental à análise de fontes de poluição (Santos, 2004).

Como visto, as diversidades socioambientais, funcionais, econômicas e estruturais da paisagem paulistana podem ser observadas por vários instrumentos e analisadas por diferentes pontos de vista e linhas de pesquisa. Dentre alguns instrumentos, foi selecionado, como base de estudos, o mapa de uso e ocupação do solo (Figura 5.4), obtido pelo processamento digital da imagem do satélite japonês ALOS. 
Requalificação dos Aterros Desativados (BrownfieldS) no MunicípIo de SÃo PaUlo: Parques (GreenfieldS) RAPOSO TAVARES E JARDIM PRIMAVERA

LUZIA HELENA DOS SANTOS BARROS

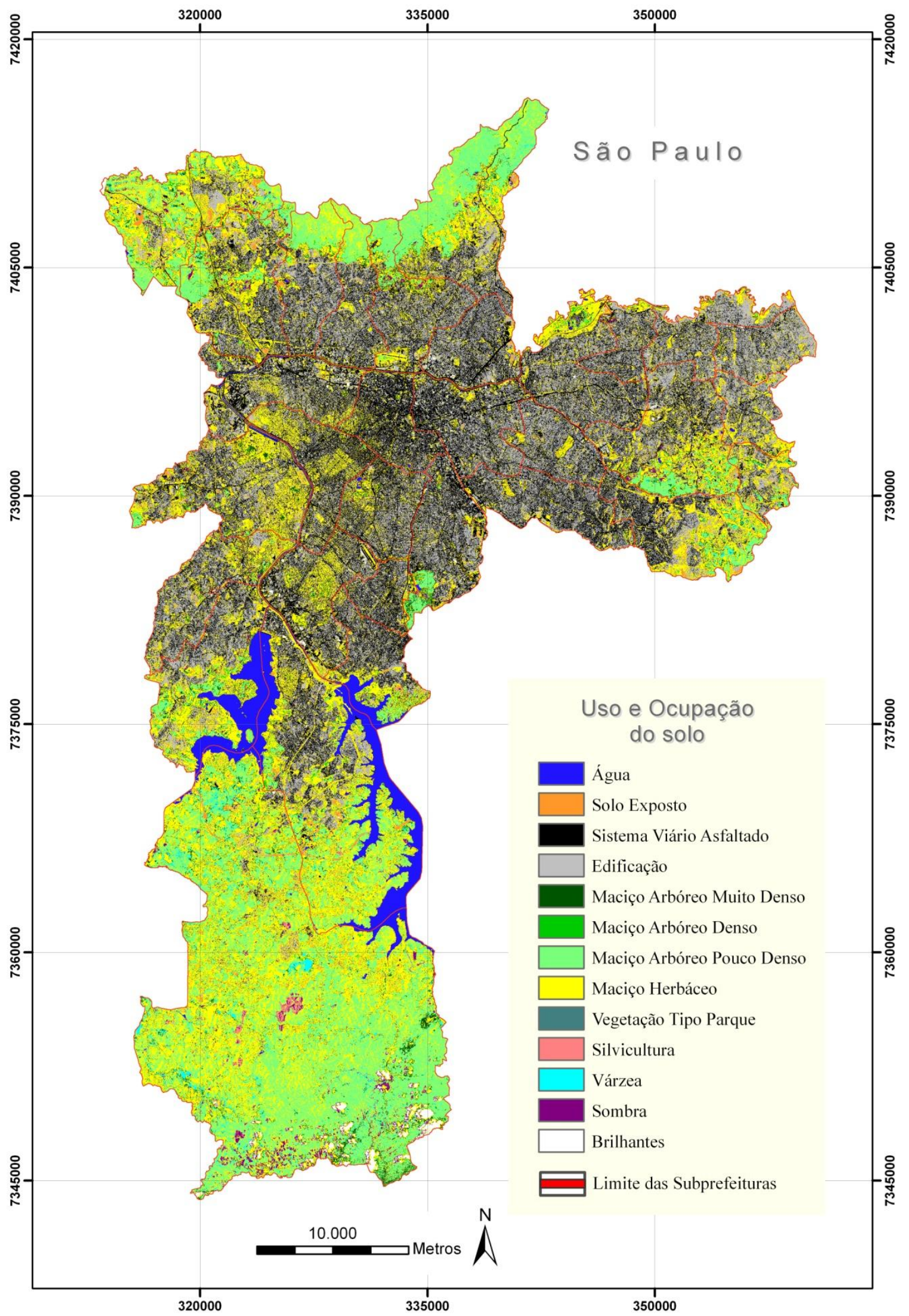

Figura 5.4 - Mapa de uso e ocupação do solo do Município de São Paulo, elaborado a partir de processamento de imagem ALOS/2007 
O mapa de uso e ocupação do solo destaca a consolidação da urbanização (edificação e sistema viário asfaltado) na parte central do município, que se estende para sudoeste e leste. A classe maciço arbóreo pouco denso ocorre no extremo norte e sul, enquanto que a classe maciço herbáceo aparece com expressão na sua porção sul, ao longo do trecho médio do Rio Pinheiros, no extremo leste e, mais rarefeita, na porção noroeste. A classe água destaca as represas Billings e Guarapiranga, enquanto que a silvicultura, que corresponde à plantação de eucaliptos, está restrita ao extremo sul do município.

\subsubsection{Metodologia para obtenção do Mapa de Uso e Ocupação do Solo no MuNICÍPIO DE SÃo PAULO}

A elaboração do mapa de uso e ocupação do solo do município, foi fruto do compartilhamento de estudos realizados no $\mathrm{LEPaC}-\mathrm{IB}_{\mathrm{USSP}}{ }^{7}$ e, de acordo com Barros et al. (2011), fundamentou-se na aplicação da metodologia, desenvolvida por Novack e Kux (2009), nas imagens do satélite japonês ALOS (Advanced Land Observing Satellite), de 12 de dezembro de 2007, com resolução espacial de $10 \mathrm{~m}$, realizada por (Bitencourt, 2009). Inicialmente, foi obtida uma imagem, resultado de uma análise de principais componentes $(\mathrm{APC})^{8}$ das quatro bandas originais do sensor AVNIR-2 (Advanced Visible and Near-infrared Radiometer - Type 2), com faixas espectrais: azul $(0,42-0,50 \mu \mathrm{m})$, verde $(0,52-0,60 \mu \mathrm{m})$, vermelho $(0,61-0,69 \mu \mathrm{m})$ e infravermelho próximo $(0,76-0,89 \mu \mathrm{m})$ e, uma imagem de índice de vegetação $(\mathrm{NDVI})^{9}$. Essas imagens definiram as assinaturas espectrais e sua correspondente classificação Fuzzy ${ }^{10}$. Adicionalmente, um refinamento da classe de vegetação foi realizado, sobrepondo-a as imagens originais, utilizadas na primeira classificação, criando novas imagens multiespectrais, APC e NDVI. Em seguida, foi aplicado o algoritmo de classificação Maxlike ${ }^{11}$. Algumas classes foram reunidas para simplificar e melhorar a sua visualização no mapa. Foi realizada, então, a sobreposição das duas classificações, substituindo-se as áreas mal definidas na

\footnotetext{
${ }^{7}$ Laboratório de Ecologia da Paisagem e Conservação, Instituto de Biociências da Universidade de São Paulo

${ }^{8}$ APC é uma das funções mais poderosas na manipulação de dados multiespectrais (Crosta, 1992)

${ }^{9}$ NDVI (Normalized Difference Vegetatation Index) desenvolvido por Rose et al. (1974), é muito utilizado, expressando a diferença entre as faixas do infra-vermelho próximo e do vermelho, normalizada pela soma das mesmas (Thiam e Eastman, 1999).

${ }^{10}$ Classificação "soft" que cria uma imagem para cada classe a ser obtida, exibindo a probabilidade de cada pixel pertencer a essa classe (Eastman, 2006).

${ }^{11}$ Classificação "hard" que obrigatoriamente designa uma das classes desejadas para todos os pixels da imagem (idem).
} 
classificação Fuzzy, pela Maxlike, mais precisa. Posteriormente, um filtro foi aplicado nessa imagem, para reduzir o ruído, obtendo-se o mapa de uso e ocupação do solo, conforme mostra o Fluxograma 5.1.

O programa de processamento de imagens utilizado, Idrisi ${ }^{\mathrm{TM}}$ Andes (Clark Labs, 1987 - 2006), permitiu quantificar a área e a proporção das classes definidas. Para a análise do contexto urbano no qual se inserem os referidos aterros, foram identificadas, espacializadas e quantificadas as tipologias de uso e ocupação, que predominam no interior e nos suas vizinhanças (considerando-se as distâncias de 500,1000 e 2.000 m). Nos estudos de caso, as classes de uso e ocupação do solo foram, também, quantificadas nos limites das Subprefeituras, Distritos e bacias hidrográficas. O mapa de uso e ocupação do solo elaborado, associado aos princípios da ecologia de paisagens, foi utilizado como base para avaliar a potencialidade relativa da revegetação dos aterros estudados.

\section{CLASSIFICAÇÃO PRELIMINAR}

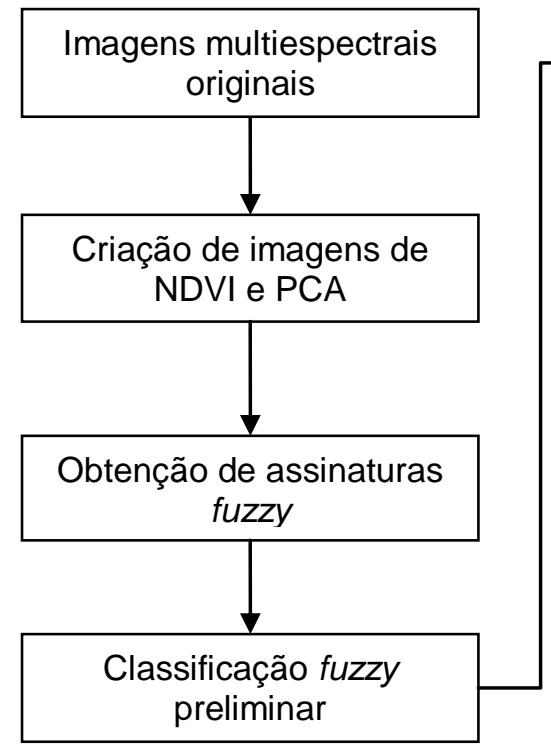

REFINAMENTO

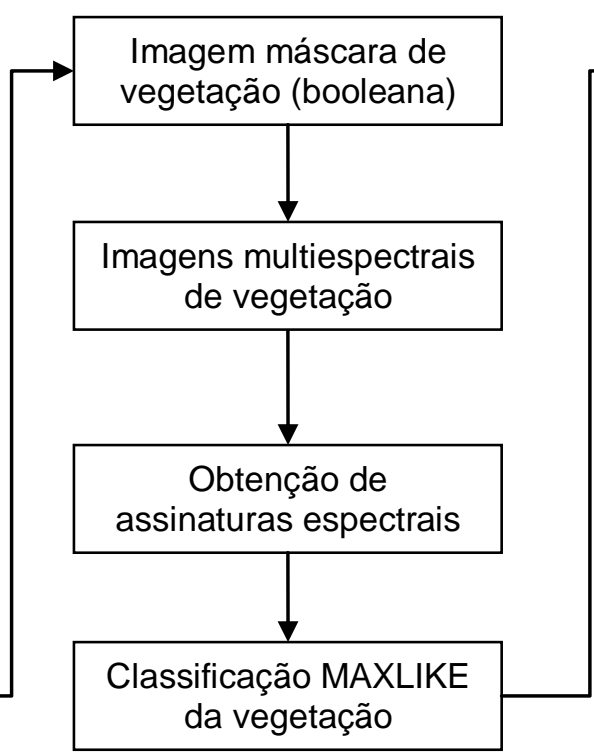

CLASSIFICAÇÃO FINAL

Combinação das duas classificações
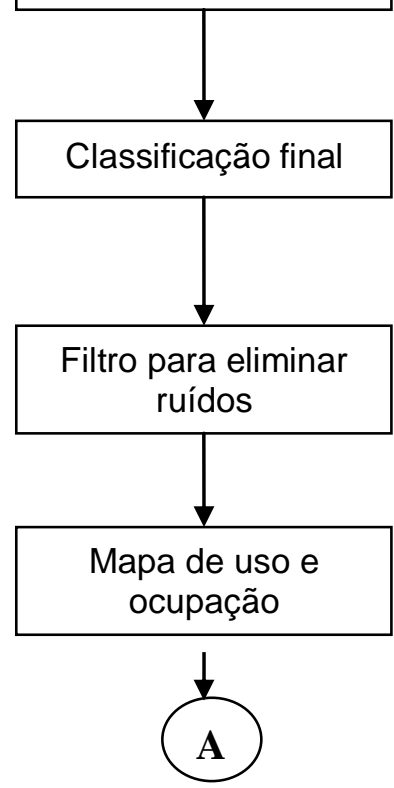

Fluxograma 5.1 - Representação do processo de classificação por sensoriamento remoto, aplicado na imagem $A L O S / 2007$, para obtenção do mapa de uso e ocupação do solo preliminar.

Fonte: (Bitencourt, 2009). 


\subsubsection{1- DEFINIÇÃO DAS CLASSES DE VEGETAÇÃO}

O levantamento mais recente do recobrimento da vegetação do município foi realizado no âmbito do Atlas Ambiental do Município São Paulo (SVMA, 2004a), obtido a partir de processamento digital de imagens do satélite $L A N D S A T$, com resolução espacial de $20 \mathrm{~m}$, insuficiente para os propósitos da presente pesquisa.

A quantificação e a identificação da cobertura vegetal, implantada sobre os aterros desativados e suas imediações, são informações essenciais à análise do potencial de revegetação dessas áreas, necessitando de dados espaciais de alta resolução e da obtenção das respectivas assinaturas espectrais ${ }^{12}$. Adicionalmente, a identificação de tipologias de vegetação típicas de uma área composta por remanescente de vegetação natural, foi necessária, para verificar as diferenças ou semelhanças entre essas últimas e os tipos implantados sobre aterros, ao serem captados pelo satélite.

Sendo assim, de posse do mapa de uso e ocupação do solo preliminar (Fluxograma 5.1), obtido nessa primeira etapa, foi realizado, posteriormente, um maior detalhamento da classe vegetação, a partir da sua identificação em campo. A fim de atender as exigências anteriores, foram selecionados dois parques urbanos municipais, situados na zona oeste, Subprefeitura do Butantã: o Alfredo Volpi, implantado a partir de remanescentes de vegetação original, de acordo com estudo de Aragaki (1997) e, o Raposo Tavares, implantado sobre aterro desativado. As etapas de campo foram realizadas nos dias 16/02/09 e 03/06/09.

A identificação da vegetação nos parques foi realizada pelo Biólogo Dr. Ricardo José F. Garcia, do Herbário Municipal (SVMA). No caso do parque Alfredo Volpi, o levantamento, também, foi acompanhado pelo seu então Administrador, Eng. Florestal Dr. Rubens Chagas. O campo constou da marcação de pontos chaves (edificações, arruamentos, vegetação de interesse, feições especiais, etc) com GPS $^{13}$, que possibilitou o georeferenciamento da imagem e contribuiu para estabelecer uma classificação da vegetação mais ajustada à realidade urbana do município.

Com base nas informações de campo e nos dados de bibliografia foram definidas, a priori, as seguintes classes de uso e ocupação nos parques de estudo:

\footnotetext{
${ }^{12}$ Assinatura espectral é a capacidade de cada corpo refletir ou emitir radiação nos diversos comprimentos de onda.

${ }^{13} \mathrm{O}$ GPS (Global Position System) utilizado, cedido pelo LEPaC, possibilita maior precisão das leituras, sob vegetação, possuindo as seguintes especificações: GARMIN's GPSMAP 60 CSx with sensors and maps.
} 
mata secundária, bosque, bosque heterogêneo, capoeirinha, capinzal, vegetação tipo parque, solo exposto e quadra de cimento. Outras classes foram incluídas, floresta, capoeira e gramado, para atender à classificação do território de todo o município.

A descrição das categorias de vegetação está baseada no estudo de padrões de vegetação e uso do solo do município, realizado por Vasconcelos e Garcia (2007, p. 54 e 55). Também foram utilizados alguns conceitos definidos para a Mata Atlântica no compêndio sobre preservação, recuperação e benefícios da Mata Atlântica (Schäffer e Prochnow, 2002, p. 35).

Mata secundária - é aquela resultante de um processo natural de regeneração da vegetação, onde houve corte raso ou seletivo da floresta primária, ou mesmo, aquelas descaracterizadas por causas naturais (erosão, escorregamentos, etc.). As matas secundárias possuem árvores com diferentes estratos (alturas), arbustos, trepadeiras, ervas e epífitas.

Bosque - corresponde ao maciço arbóreo, composto de diferentes espécies ou não, implantado pelo homem, podendo apresentar sub-bosque com menor diversidade do que as matas. Possuem padrão mais homogêneo que as matas.

Capoeirinha - é o estágio inicial de regeneração da mata secundária, com duração média de 6 anos. Ocorre a presença de capins e samambaias de chão. Predominam grandes quantidades de árvores pioneiras de poucas espécies (vassouras e vassourinhas), com padrão homogêneo e menor altura relativa em relação às matas. Campo antrópico - são áreas com cobertura herbácea, geralmente composta por grama, eventualmente, com árvores ou arbustos isolados em terrenos mais secos e em topografias variadas.

Vegetação tipo parque - são áreas de vegetação implantada pelo homem composta de gramados entremeados por árvores, de diferentes espécies ou não, isoladas entre si ou formando pequenos maciços. Tansley e Chipp (1926 apud Veloso, 1991, p.45) empregaram o termo como um tipo de vegetação (Parkland) e sinônimo de savana arborizada. As suas características podem ser correlacionáveis aos montados, observados sobre substratos sedimentares do terciário e quaternário, de extensa ocorrência ao sul do Rio Tejo, em Portugal. Pena e Cabral (1996, p. 65) definem os montados como "[...] povoamento arbóreos relativamente abertos, constituídos por quercíneas, ou seja, árvores do gênero Quercus (carvalhos)", com 
dominância do sobreiro e pequenas manchas do pinheiro-manso, que alguns autores associam à implantação pelo homem (Figura 5.5).
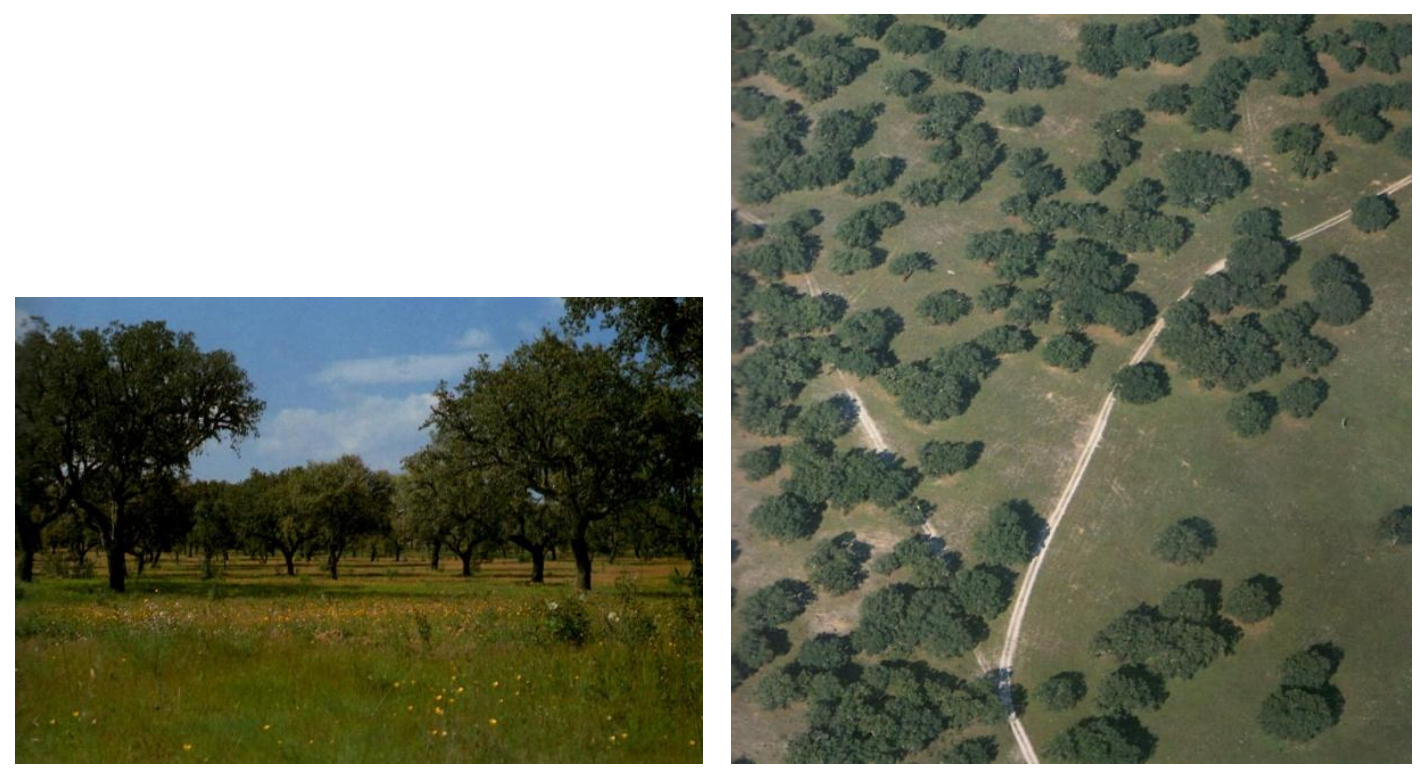

Figura 5.5 - Vegetação tipo montados encontrada ao sul do Rio Tejo, em Portugal. Fonte - Pena e Cabral (1996, p. 65 e 67).

A análise da vegetação, pelo método de sensoriamento remoto adotado, está baseada na medição da quantidade de folhas verdes do maciço vegetal. Desta forma, tipologias diferentes de vegetação podem apresentar densidade de folhas verdes semelhantes, sendo impossível, neste caso, individualizá-las. A análise mostrou que, espectralmente, a Mata secundária e o bosque muito denso são iguais, ou seja, possuem muitas folhas verdes, sendo então reunidos na classe 'maciço arbóreo muito denso'. A mesma explicação se aplica ao bosque pouco denso e à capoeirinha, com menos quantidade de folhas verdes que a classe anterior, correspondendo à classe 'maciço arbóreo pouco denso'. A vegetação de bosque denso apresenta uma densidade intermediária de folhas verdes, sendo denominada como 'maciço arbóreo denso'. As tipologias de vegetação campo antrópico, campo natural e capoeirinha também mostraram assinatura espectral semelhante, pois possuem muito poucas folhas verdes, correspondendo à classe 'maciço herbáceo'. Assim, foram individualizadas no mapa final treze (13) classes de uso e ocupação do solo (Fluxograma 5.2): água; solo exposto; sistema viário asfaltado; edificação; 
maciço arbóreo muito denso, denso, pouco denso; maciço herbáceo; vegetação de parque; silvicultura, várzea, sombra e brilhantes ${ }^{14}$.

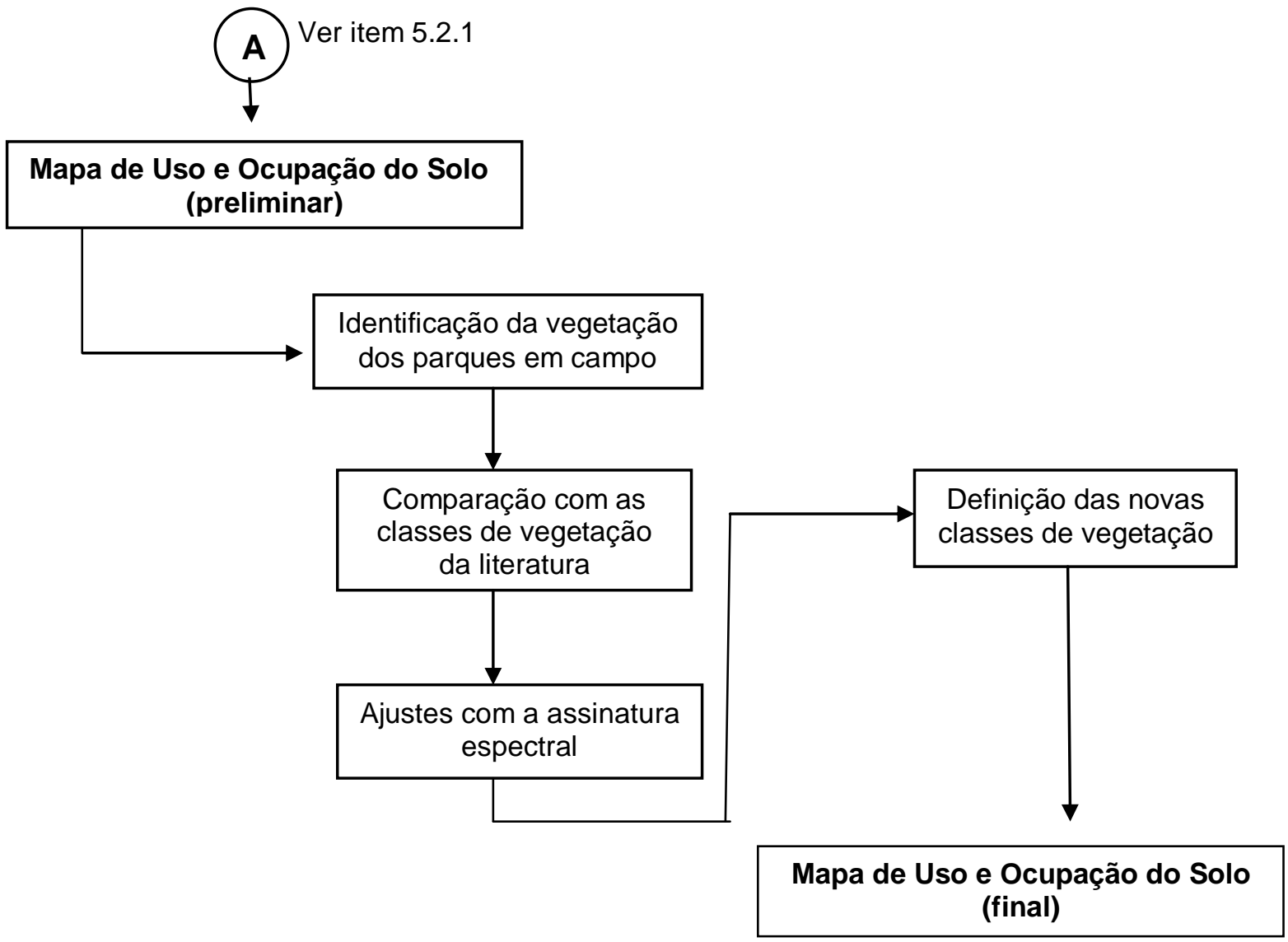

Fluxograma 5.2 - Representação do processo de refinamento da classificação da vegetação para obtenção do mapa final de uso e ocupação do solo.

A correspondência entre a assinatura espectral e a tipologia de vegetação identificada, no campo, poderá ser aferida com certeza absoluta mediante uma amostragem de cada classe aleatoriamente e geração do índice Kappa ${ }^{15}$. Considerando, entretanto, que essa aferição foge ao escopo desta pesquisa e que a assinatura espectral das classes 'maciço arbóreo muito denso' e 'maciço herbáceo' são diametralmente opostas, justifica-se a adoção da classificação de vegetação ora apresentada (Informação verbal) ${ }^{16}$.

\footnotetext{
${ }^{14}$ Inclui todos os alvos de grande refletância para quase todas as bandas da imagem, tais como: telhados de metal, solos muito arenosos, etc. (Bitencourt, 2009).

${ }^{15}$ Cálculo estatístico utilizado para testar a concordância entre os resultados observados e os classificados em uma tabela de contigência (matriz de erro), conforme definido por Landis e Koch (1977).

${ }^{16}$ Informação fornecida por Bitencourt em 25/02/10.
} 


\subsection{SiTUAÇÃO DOS LIXÕES E dOS ATERROS DESATIVADOS NO MUNICÍPIO DE SÃo PaUlo}

O município conta com quatorze (14) antigos lixões ou aterros controlados desativados $^{17}$, sendo muitos deles remanescentes da década de 1970 (Tabela 5.2); além de dois aterros sanitários, recentemente encerrados, Bandeirantes e São João (Figura 5.6). Os aterros foram incorporados ao tecido urbano, onde há escassez de áreas de lazer ou verdes, o que leva a população a apossar-se deles para ocupação por moradias ou outras atividades. No entanto, nenhuma medida de controle ambiental efetiva foi implantada, a não ser no caso do aterro Vila Albertina. Algumas dessas áreas foram convertidas em parques (Raposo Tavares, Eng. Goulart, Juventude, Vila-Lobos). Outras apresentam propostas de requalificação para este mesmo uso: Jacuí, Sapopemba, São Mateus, Santo Amaro e Vila Albertina.

Em geral, recomenda-se a reutilização das áreas dos antigos aterros como recreação e de forma compatível com o entorno. Conforme o IPT/Cempre (2000) o uso futuro de aterros desativados deverá

[...] harmonizar-se com a ocupação nos entornos. Grandes construções, sobretudo para moradias, deverão ser evitadas, utilizando-se o local, preferencialmente, para áreas de recreação comunitárias (parques e campos para práticas esportivas).

Atendendo as recomendações e exigências técnicas e, ainda, considerando os menores custos para reuso desses antigos aterros, está prevista a requalificação dessas áreas, como parques urbanos, nas legislações municipais, especialmente, no Plano Diretor Estratégico ou nos Planos Regionais Estratégicos. Essas áreas, de grande extensão, situam-se, na sua maioria, nas zonas mais periféricas (Figura 5.7), que ao serem requalificadas, deverão ser incorporadas ao Sistema Municipal de Áreas Verdes, assunto a ser tratado no Capítulo 7.

Contudo, tal como afirma Vaques (2005), atualmente, a prioridade das ações governamentais está voltada para a recuperação de centros históricos e seus patrimônios, deixando de lado as áreas periféricas. Como exemplo, pode-se citar o

\footnotetext{
${ }^{17} \mathrm{O}$ total de aterros estudados se refere aos aterros desativados que foram oficialmente utilizados, outrora, como áreas de destinação final de resíduos pela administração municipal. Outras áreas de lixões ou aterros, contudo, são conhecidas ou, mesmo desconhecidas pelo poder público.
} 
Requalificação dos Aterros Desativados (BrownfieldS) no MunicíPIO de São PaUlo: Parques (GreenfieldS) Raposo TAVARES E Jardim PrimaVera

LUZIA HELENA dos SANTOS BARROS

"Projeto Nova Luz", na zona central da cidade, em fase de licitação ${ }^{18}$. O efetivo reconhecimento da periferia como cidade, depende de alguns fatores, como destaca a autora, citando Gonzalez (1995, p. 55) ${ }^{19}$.

[...] a diversificação funcional de atividades econômicas e especialização naquelas de maior arrecadação; o fomento da descentralização produtiva e do equilíbrio entre residência - emprego; uma coesão de um mercado único de solos, igualando as oportunidades em infra-estrutura e equipamentos de todo o tipo, educacionais, sanitários, culturais, espaços verdes; uma política de solo global em escala metropolitana, incluindo os espaços urbanizados, os que necessitam de "reabilitação" e os que estão por urbanizar; e, por fim, uma gestão intermunicipal e parceria público-privada.

O GTAC/SVMA inicialmente classificou esses antigos aterros como áreas suspeitas de contaminação, determinando a realização das investigações técnicas imprescindíveis à sua requalificação (estimativa da produção de gás, estabilidade do maciço e presença de contaminantes na água subterrânea e no maciço de resíduo). O estágio de desenvolvimento dessas ações será mostrado no item 5.3.2.

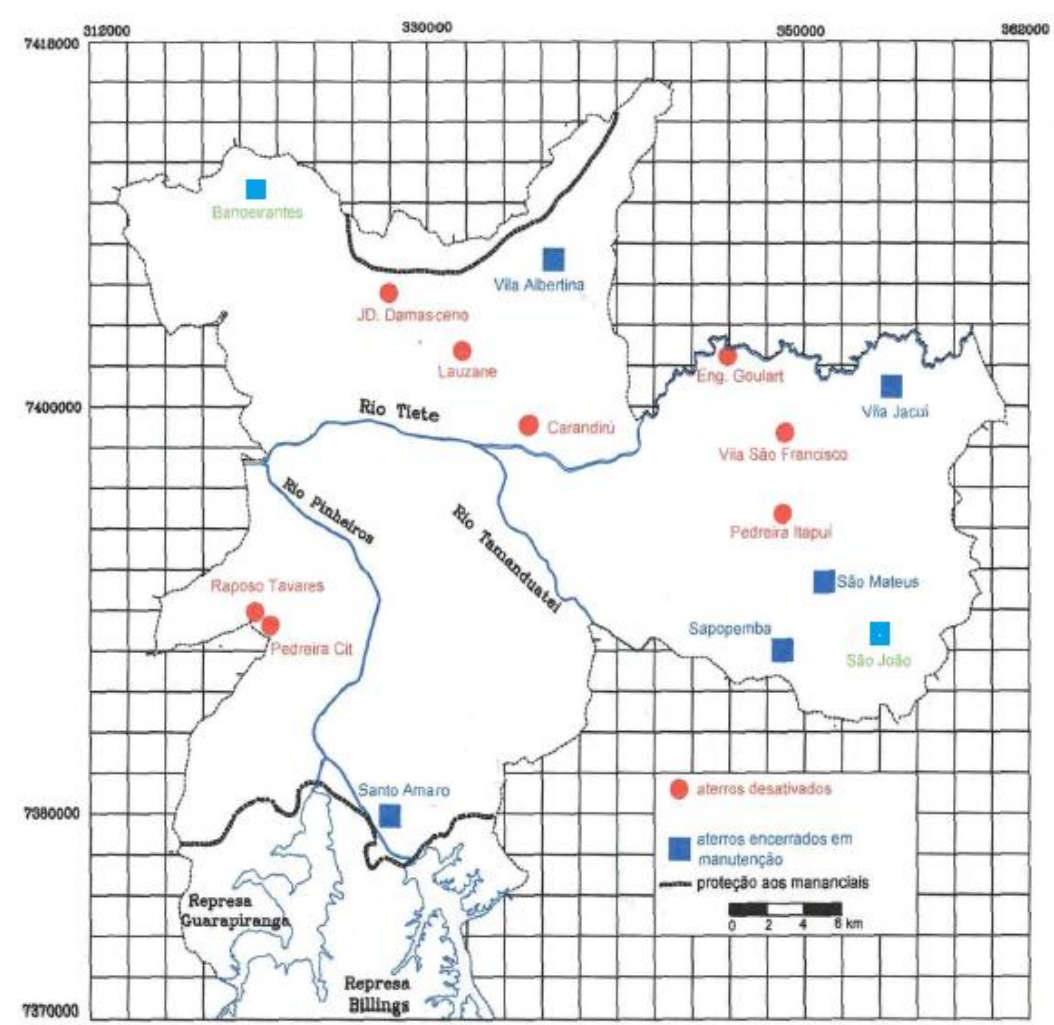

Figura 5.6 - Localização dos aterros desativados no município de São Paulo Fonte: SVMA, modificado

\footnotetext{
${ }^{18}$ A Prefeitura do Município de São Paulo anunciou, em 18/11/10, as diretrizes básicas para o projeto preliminar de reurbanização da Nova Luz, região formada pelas Av. Ipiranga, São João, Duque de Caxias, Cásper Líbero e Rua Mauá, totalizando $500 \mathrm{mil} \mathrm{m}^{2}$. O projeto possui como objetivos: o incentivo ao comércio; a diversificação dos perfis habitacionais e das atividades; a recuperação de áreas degradadas; a ampliação de áreas destinadas a praças e ao convívio social; melhorias da mobilidade e infraestrutura; recuperação do patrimônio histórico; cultural e artístico; e a criação de ambiente social para promover o desenvolvimento social e econômico da região, atraindo novos moradores, empreendedores e freqüentadores (PMSP, 2010).

${ }_{19}$ GONZALEZ, R.M. Politicas Metropolitanas en España: Enre urbanismo y ordenación dl território. In: Geographicalia, 32, diciembre de 1995. p.53-62
} 
Tabela 5.2: Aterros desativados existentes no município de São Paulo

\begin{tabular}{|c|c|c|c|c|c|c|}
\hline Aterros & Início & Fim & Inativo & Área $\left(\mathrm{m}^{2}\right)$ & Vol.(Ton.) & Situação Atual \\
\hline J. Damaceno & Fev 1975 & Nov 1975 & 35 & 22.000 & 187.000 & Favela, AC \\
\hline L. Paulista* & Fev 1974 & Nov1974 & 36 & 22.100 & 215.000 & $\begin{array}{l}\text { Supermercado, } \\
\text { Investigação } \\
\text { confirmatória }\end{array}$ \\
\hline Carandiru** $^{\star *}$ & Jan 1977 & Nov 1977 & 33 & 30.000 & 23.000 & $\begin{array}{l}\text { Parque da } \\
\text { Juventude }\end{array}$ \\
\hline Vila Albertina & Mar 1977 & Mar1993 & 17 & 224.000 & 9,2 milhões & $\begin{array}{c}\text { Manutenção, } \\
\text { Monitoramento e } \\
\text { Vigilância; AS }\end{array}$ \\
\hline Eng. Goulart ${ }^{\star \star}$ & 1975 & 1979 & 31 & 748.600 & 1,8 milhão & Parque Ecológico \\
\hline Jacuí & Mar 1979 & Abr 1988 & 22 & 122.000 & 2,5 milhões & Vigilância; AC \\
\hline V.S.Francisco & Jun 1976 & Jun1976 & 33 & 19.000 & 51.000 & $\begin{array}{c}\text { Creche e favela, } \\
\text { AC }\end{array}$ \\
\hline Ped. Itapuí ${ }^{*}$ & 1978 & 1979 & 31 & 125.350 & 576.000 & Loteamento \\
\hline S. Mateus & Fev 1984 & Dez 1985 & 25 & 85.000 & 1 milhão & Vigilância; AC \\
\hline Sapopemba & 1979 & Fev1984 & 26 & 222.000 & 2,7 milhões & Vigilância; AC \\
\hline S. Amaro & 1976 & Fev 1995 & 15 & 370.000 & 16 milhões & $\begin{array}{c}\text { Manutenção e } \\
\text { Monitoramento; } \\
\text { ÁS }\end{array}$ \\
\hline $\begin{array}{l}\text { Itatinga } \\
\text { (inertes) }\end{array}$ & 1990 & 1999 & 11 & 157.000 & 5,2 milhões & Vigilância \\
\hline Pedreira Cit & 1977 & 1978 & 32 & 13.460 & 566.000 & Favela \\
\hline $\begin{array}{l}\text { Raposo } \\
\text { Tavares }\end{array}$ & 1967 & 1979 & 31 & 206.000 & 1,9 milhão & $\begin{array}{c}\text { Parque Raposo } \\
\text { Tavares; AS }\end{array}$ \\
\hline
\end{tabular}

Obs: Administração * particular e ** estadual; AS - Área suspeita de contaminação; AC - Área contaminada.

Organização: Luzia Helena dos S. Barros (2011)

Fonte: De Leo (2000); Silva (1991); SVMA (2001; 2008 a,b; 2009 a,b; 2010 a,b); Ramires et al. (2005); Leite (2005), SES (2009 a,b,c; 2010). 
Requalificação dos Aterros Desativados (BrownfieldS) no MunicípIo de São Paulo: Parques (GreenfieldS) RAPOSO TAVARES E JARDIM PRIMAVERA

LUZIA HELENA dos SANTOS BaRRos

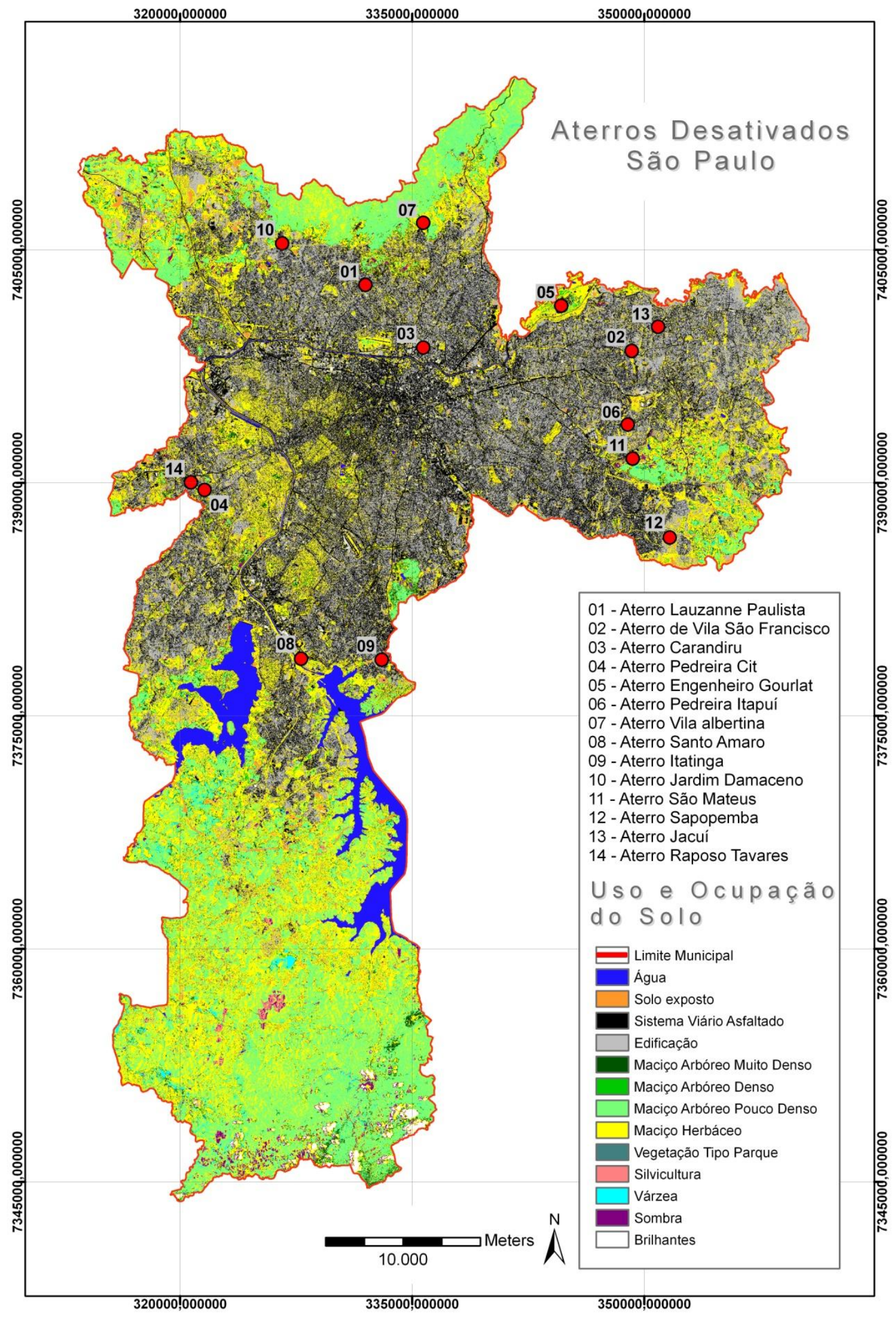

Figura 5.7: Localização dos lixões e aterros controlados desativados (mais antigos) sobre o mapa de uso e ocupação do solo do município de São Paulo 


\subsubsection{USO E OCUPAÇÃO DO SOLO NO ENTORNO DOS LIXÕES E DOS ATERROS}

DESATIVADOS

Esse item apresenta o contexto urbano de uso e ocupação do solo no qual se inserem os 14 lixões mostrados na Figura 5.7, de acordo com a metodologia descrita no item 5.2.1, a fim de avaliar a potencialidade relativa da revegetação dessas, áreas, segundo a presença de vegetação e, secundariamente, de água.

A vegetação, especialmente a arbórea, mesmo em pequenas manchas, quando em condições ecológicas apropriadas, pode promover a conectividade da paisagem. Assim, as pequenas manchas de vegetação podem funcionar como ponto de passagem para algumas espécies, permitindo o fluxo entre manchas maiores sendo denominadas stepping stones_(Forman, 1999) ou trampolins ecológicos (Metzger, 2001); que quando interconectados favorecem o estabelecimento de corredores ecológicos, definidos por Schäffer \& Prochnow (2002, p. 28) como "áreas que unem os remanescentes florestais possibilitando o livre trânsito de animais e a dispersão de sementes das espécies vegetais. Permite o fluxo gênico entre as espécies da flora e fauna e a conservação da biodiversidade".

Os aterros foram agrupados para facilitar a apresentação dos resultados. No primeiro grupo encontram-se os aterros desativados (Pedreira Cit, Lauzanne Paulista, Jardim Damaceno, Vila São Francisco e Pedreira Itapuí) ocupados por edificações e o aterro de inertes Itatinga (Figuras 5.8, 5.9 e 5.10). Compõem o segundo grupo os aterros, sob administração estadual, Engenheiro Goulart e Carandiru, atualmente convertidos em parques. No terceiro grupo foram incluídos os aterros com propostas de transformação em parques municipais: Vila Albertina, Santo Amaro, São Mateus e Sapopemba. Os estudos de caso, Raposo Tavares e Jacuí, compõem o quarto grupo.

Do total das treze classes de uso e ocupação do solo, identificadas, sete correspondem a $80 \%$, permitindo a simplificação da classificação para a análise pretendida. As classes denominadas edificação e sistema viário asfaltado foram reunidas na classe urbanização e a classe maciço herbáceo incluiu a classe vegetação tipo parque. 

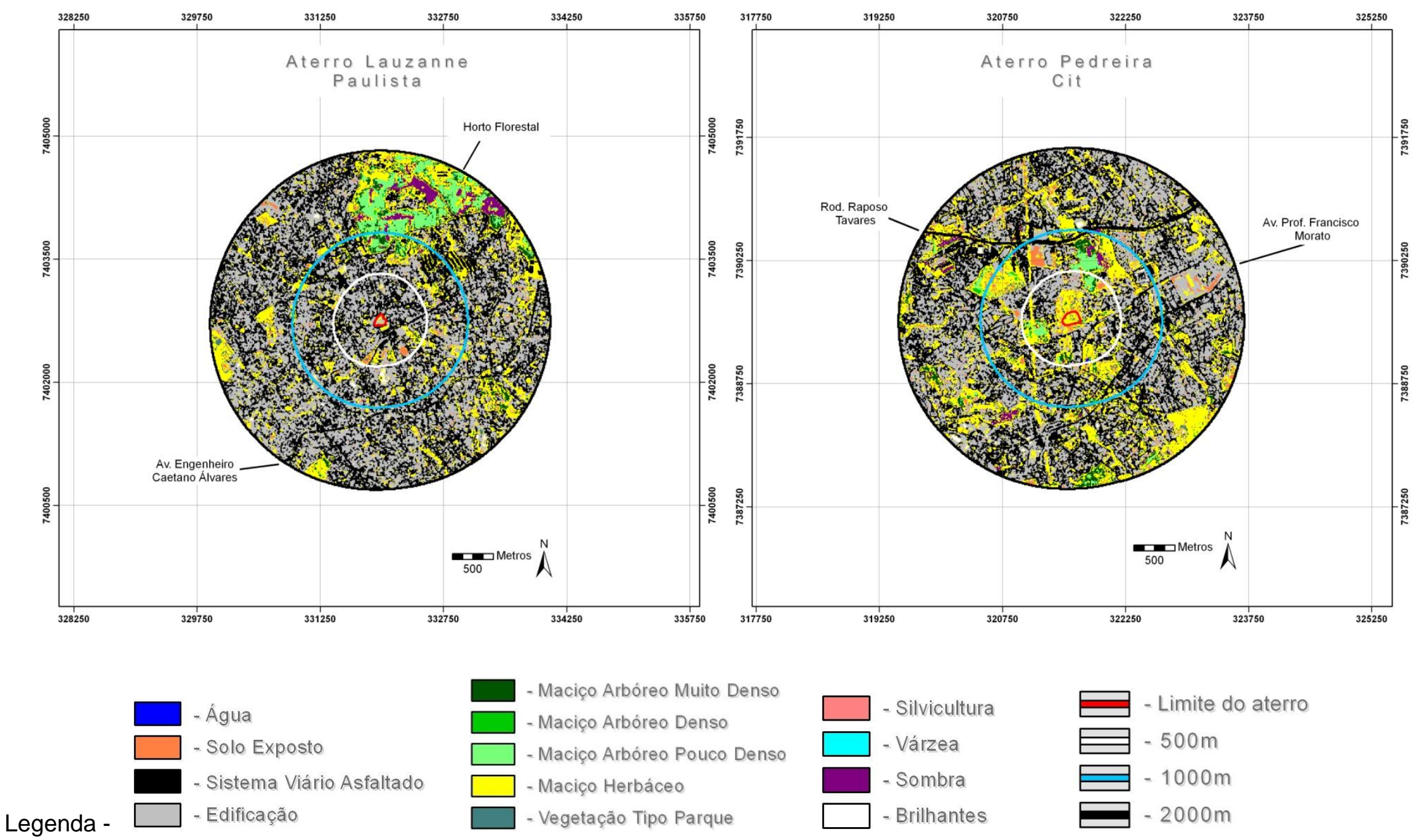

Figura 5.8 - Uso e ocupação do solo no entorno dos aterros desativados Lauzanne Paulista e Pedreira City no município de São Paulo 

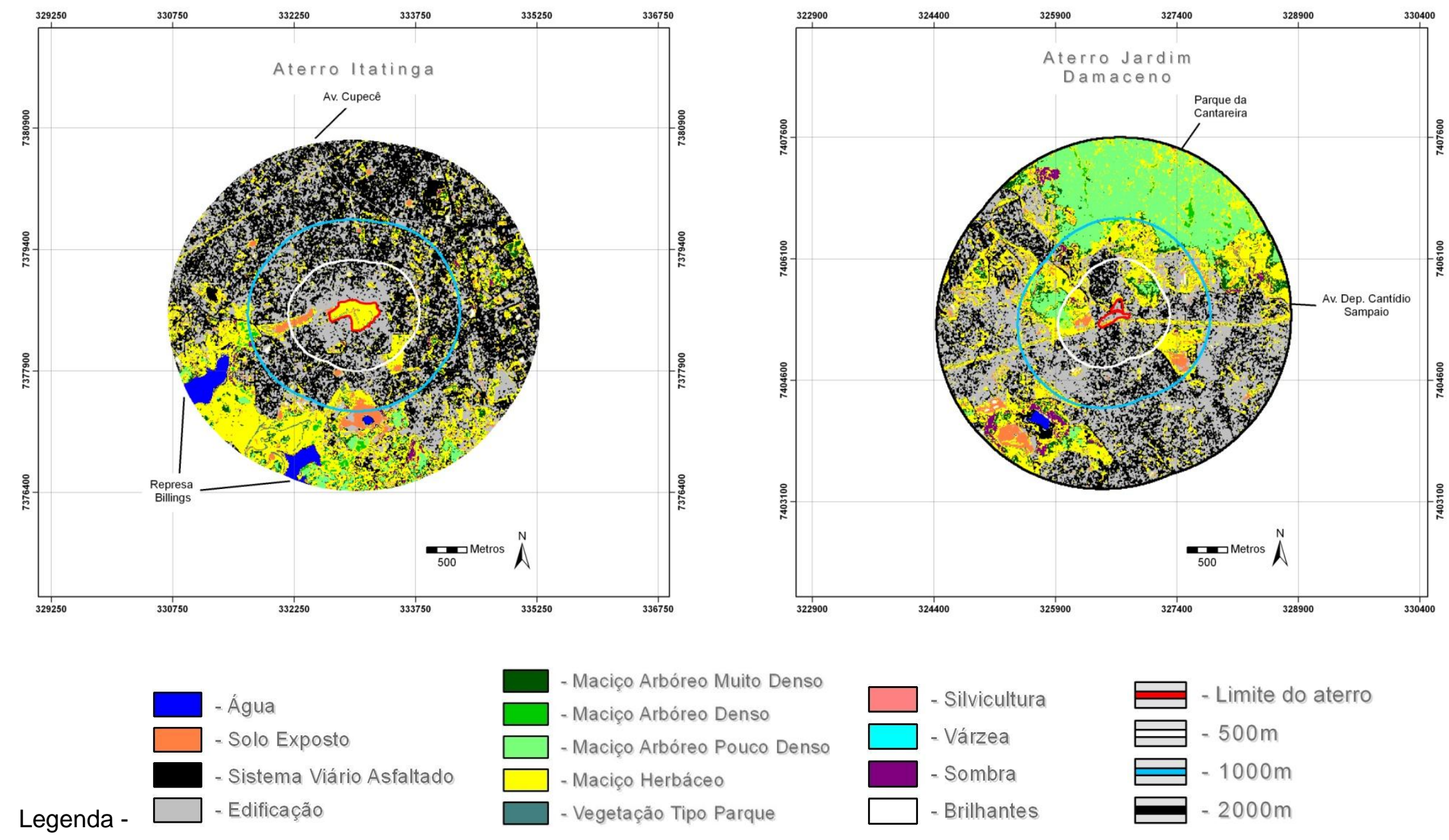

Figura 5.9 - Uso e ocupação do solo no entorno dos aterros desativados Itatinga e Jarim a no município de São Paulo 

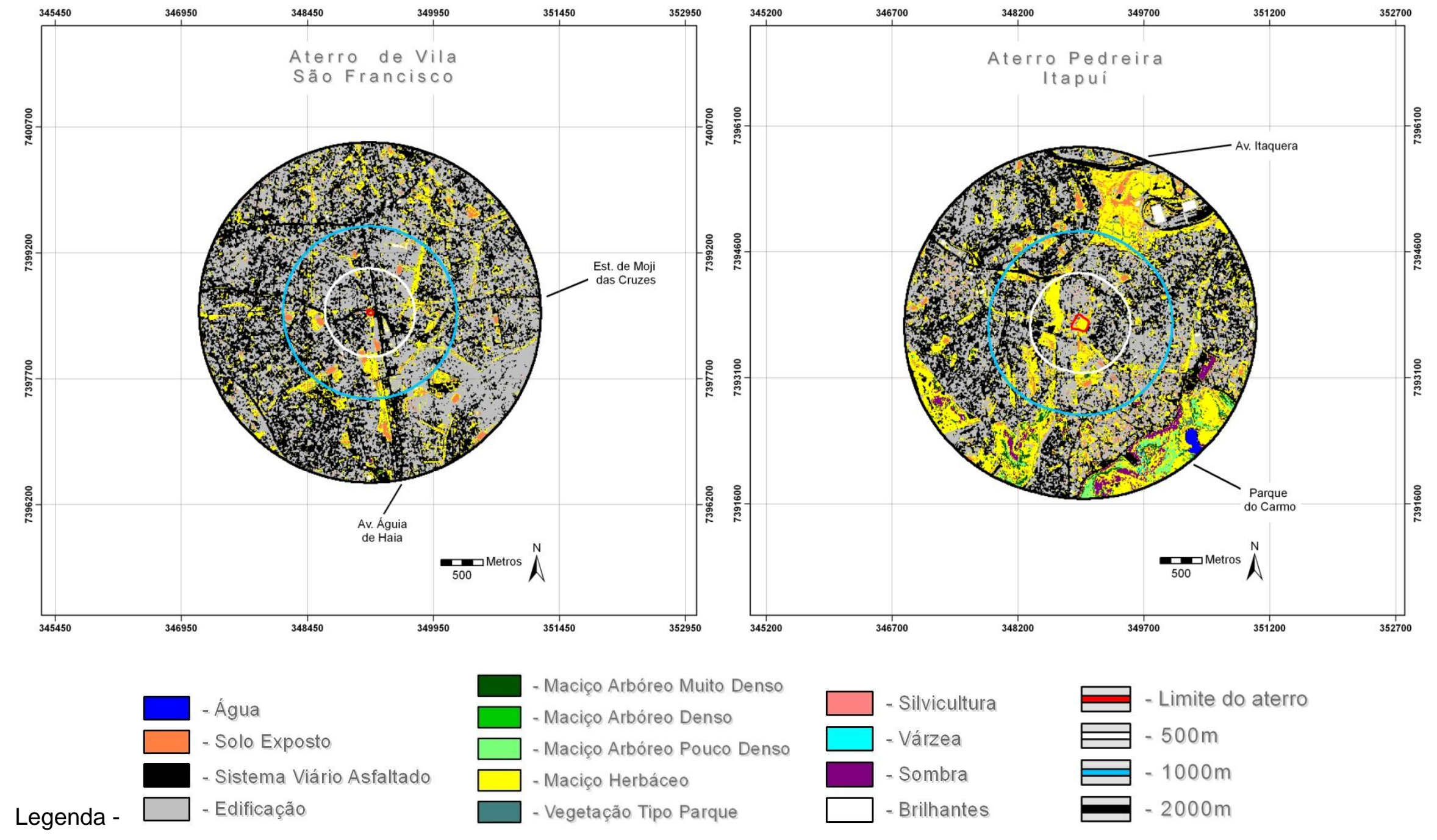

Figura 5.10 - Uso e ocupação do solo no entorno dos aterros desativados Vila São Francisco e Pedreira Itapuí no município de São Paulo 
A Tabela 5.3 mostra os dados obtidos para os aterros do Grupo 1 (Apêndice A). A classe urbanização ocupa mais de $50 \%$ das diferentes áreas de entorno consideradas, chegando a mais de $82 \%$ nas imediações do Lauzanne Paulista e Vila São Francisco. O maciço arbóreo muito denso tem ocorrência restrita, inexistindo nas proximidades do aterro Vila São Francisco e, possuindo alguma expressão, junto aos aterros Pedreira City e Jardim Damaceno. Já o maciço arbóreo denso e a água não possuem significância, enquanto que o maciço arbóreo pouco denso, está restrito ao entorno do Jardim Damaceno, numa mancha contínua, relacionada à Serra da Cantareira (Figura 5.8). O maciço herbáceo (8 a 32\%) é dominante, possuindo menor expressão no entorno do Lauzanne Paulista e Vila São Francisco.

Tabela 5.3 - Quantificação (\%) simplificada das classes de uso e ocupação do solo nas áreas de entorno (500, 1.000 e $2.000 \mathrm{~m})$ dos aterros do Grupo 1.

\begin{tabular}{lrrrrrrrrrr}
\hline \multicolumn{1}{c}{ Classes } & \multicolumn{3}{c}{ P.City } & \multicolumn{3}{c}{ L.Paulista } & \multicolumn{3}{c}{ Itatinga } \\
& 500 & 1000 & 2000 & 500 & 1000 & 2000 & 500 & 1000 & 2000 \\
Urbanização & 54 & 62 & 71 & 88 & 82 & 75 & 80 & 81 & 69 \\
M. A. m. Denso & 4 & 3 & 2 & 1 & 2 & 2 & 0,2 & 0,5 & 2 \\
M. A. Denso & 0,2 & 0,2 & 0,1 & - & - & - & - & 0,1 & 0,5 \\
M. A. p. Denso & 4 & 0,2 & 1 & - & - & 3 & - & - & 0,1 \\
M. Herbáceo & 32 & 26 & 22 & -9 & 13 & 16 & 17 & 15 & 22 \\
Água & 0,2 & 0,1 & - & - & - & - & - & - & 2 \\
\multicolumn{1}{c}{ Classes } & J.Damaceno & V.S.Francisco & P.Itapuí & \\
& 500 & 1000 & 2000 & 500 & 1000 & 2000 & 500 & 1000 & 2000 \\
Urbanização & 66 & 57 & 52 & 89 & 85 & 87 & 72 & 76 & 67 \\
M. A. m. Denso & 3 & 4 & 3 & - & - & - & 0,2 & 0,2 & 1 \\
M. A. Denso & 0,5 & 0,5 & 0,5 & - & - & - & - & - & - \\
M. A. p. Denso & 3 & 7 & 16 & - & - & - & - & - & 1 \\
M. Herbáceo & 23 & 27 & 23 & 8 & 12 & 10 & 24 & 20 & 24 \\
Água & - & - & 0,2 & - & - & - & - & - & 0,3 \\
\hline
\end{tabular}

Os resultados obtidos aliados a ocupação por edificações, bem como as limitações para o desenvolvimento de vegetação nessas áreas, desfavorecem o seu potencial para uma possível requalificação como parque urbano.

A Figura 5.11 apresenta o uso e ocupação do solo no entorno dos aterros estaduais, Engenheiro Goulart (Parque Ecológico do Tietê) e Carandiru (Parque da Juventude). 

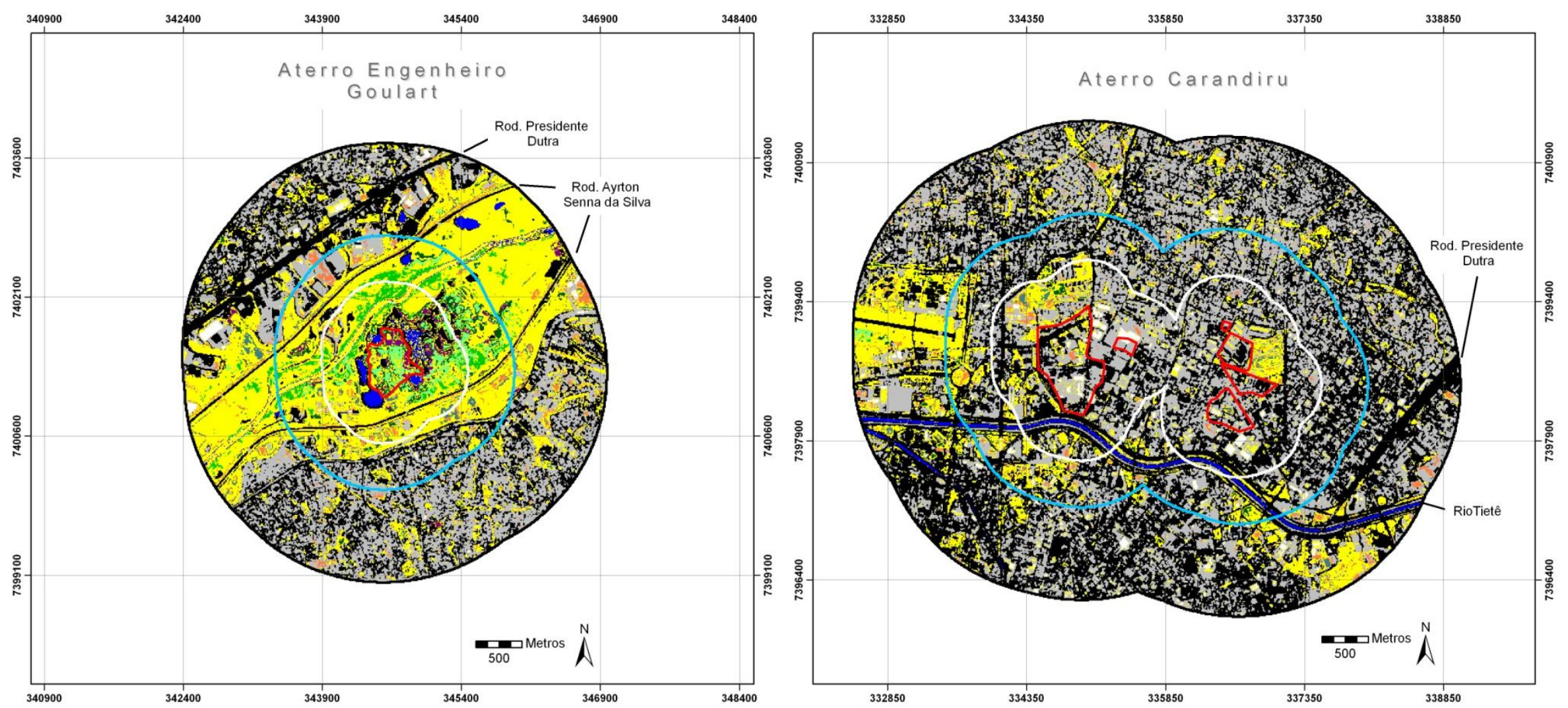

Legenda -
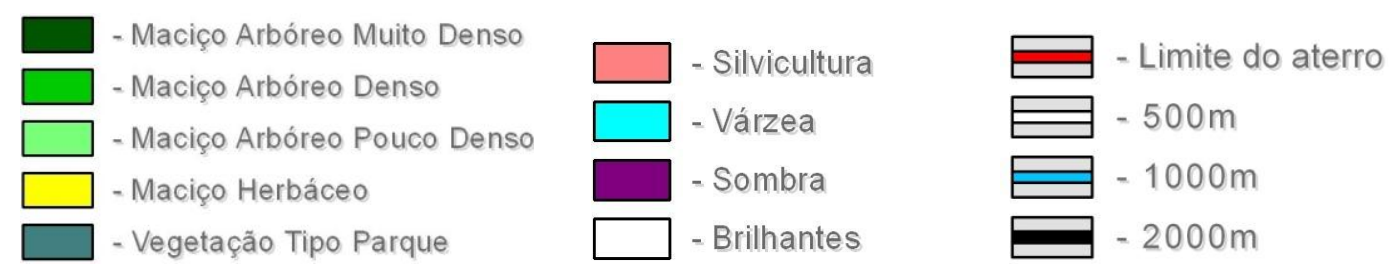

Figura 5.11 - Uso e ocupação do solo no entorno dos aterros desativados Engenheiro Goulart e Carandiru no município de São Paulo 
A Tabela 5.4 sintetiza os resultados obtidos para os antigos aterros do Grupo 2 (Apêndice B), atuais parques estaduais, nos quais foi realizada, também, a quantificação das classes no seu interior (Int.). A classe urbanização predomina no aterro Carandiru, ocupando cerca de $80 \%$ das diferentes áreas do seu interior e do entorno, enquanto que a vegetação arbórea está quase ausente. No interior do aterro Engenheiro Goulart predominam as classes de vegetação (78\%), com a vegetação arbórea superando um pouco a herbácea. Nas áreas de entorno de 500 e $1.000 \mathrm{~m} \mathrm{o}$ maciço herbáceo possui maior proporção e no entorno de $2.000 \mathrm{~m}$ predomina a urbanização. A água apresenta-se com 5\%, no entorno de $500 \mathrm{~m}$.

Tabela 5.4 - Quantificação (\%) simplificada das classes de uso e ocupação do solo nas áreas de entorno $(500,1.000$ e $2.000 \mathrm{~m})$ dos aterros do Grupo 2.

\begin{tabular}{lrrrrrrrr}
\hline \multicolumn{1}{c}{ Classes } & \multicolumn{3}{c}{ E.Goulart } & \multicolumn{4}{c}{ Carandiru } \\
& Int. & $\mathbf{5 0 0}$ & $\mathbf{1 0 0 0}$ & $\mathbf{2 0 0 0}$ & Int. & $\mathbf{5 0 0}$ & $\mathbf{1 0 0 0}$ & $\mathbf{2 0 0 0}$ \\
Urbanização & 5 & 13 & 26 & 50 & 84 & 82 & 83 & 83 \\
M. A. m. Denso & 17 & 7 & 5 & 2 & - & 0,3 & 0,4 & 0,4 \\
M. A. Denso & 0,5 & 7 & 6 & 2 & - & - & - & - \\
M. A. p. Denso & 24 & 9 & 5 & 2 & - & - & - & - \\
M. Herbáceo & 36 & 49 & 48 & 37 & 11 & 12 & 13 & 13 \\
Água & 0,6 & 5 & 2 & 1 & - & 0,8 & 0,9 & 0,7 \\
\hline
\end{tabular}

O mapa de uso e ocupação do solo no entorno desses aterros indica que o 'parque/aterro'20 Engenheiro Goulart apresenta características mais favoráveis ao desenvolvimento e manutenção da vegetação, pois está inserido no Parque Ecológico do Tietê e possui predominância da vegetação arbórea e herbácea no seu interior e nas suas proximidades (500 e 1.000 m). A presença da classe 'água', correspondendo às lagoas meândricas do rio Tietê, também contribui para o maior potencial de re-vegetação da área. Ressalta-se que os limites do aterro Carandiru correspondem a porções fragmentadas na Figura 5.10 e que o Parque da Juventude foi implantado sobre uma dessas manchas, onde predomina a vegetação herbácea.

As Figuras 5.12 e 5.13 mostram a classificação de uso e ocupação do solo no entorno dos aterros Vila Albertina e Santo Amaro e São Mateus e Sapopemba, respectivamente.

\footnotetext{
${ }^{20}$ Essa denominação será discutida no Capítulo 7.
} 


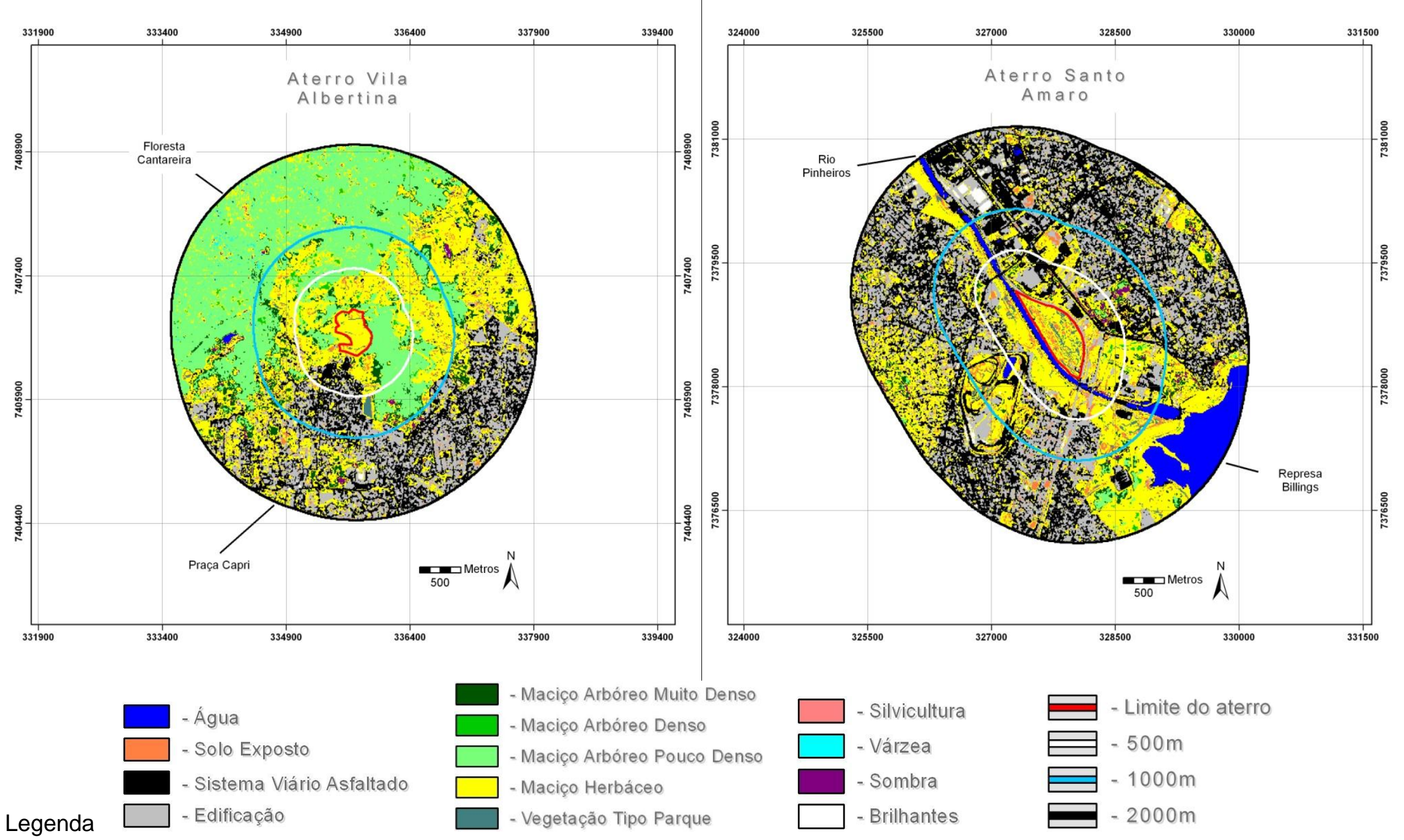

Figura 5.12 - Uso e ocupação do solo no entorno dos aterros desativados Vila Albertina e Santo Amaro no município de São Paulo 


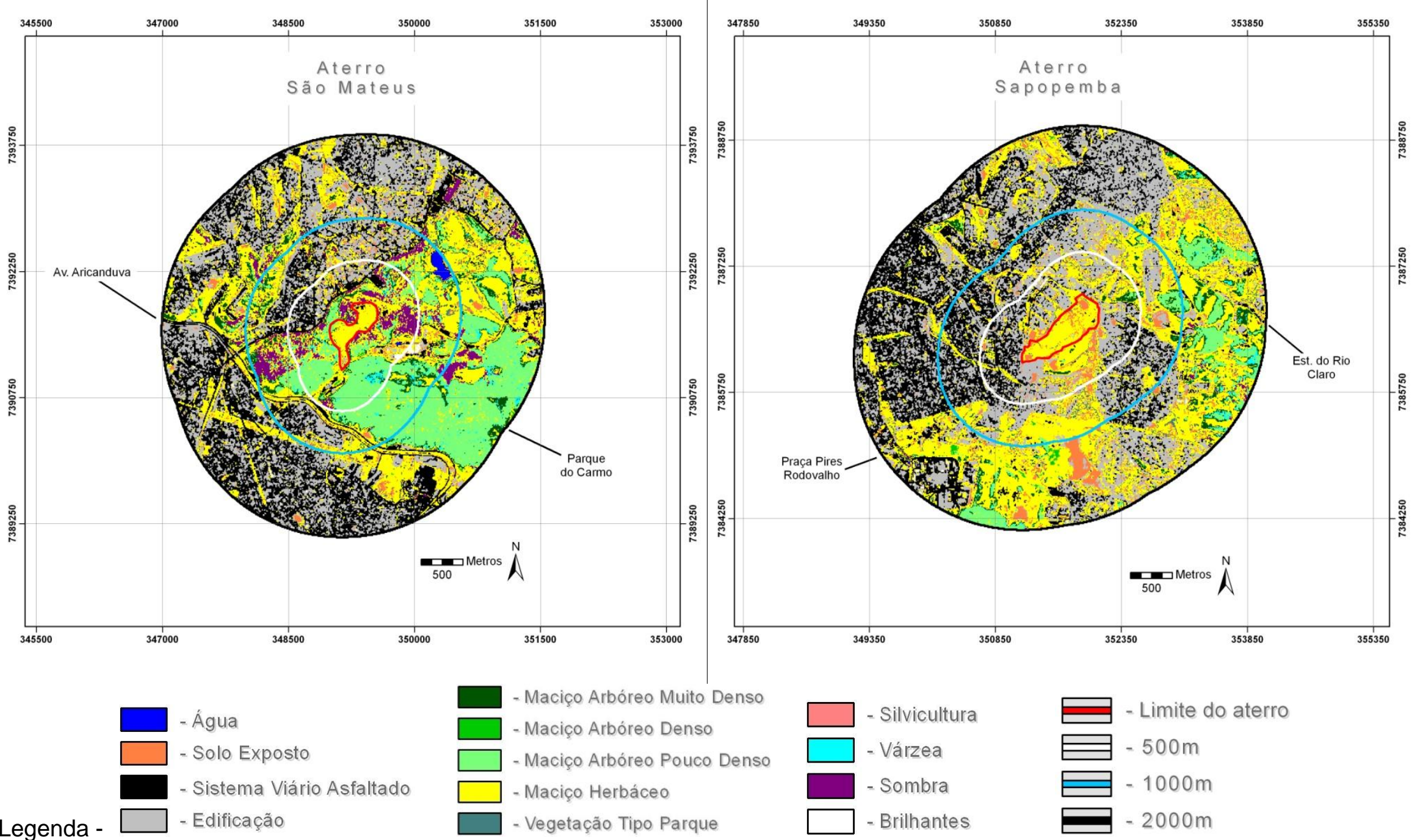

Figura 5.13 - Uso e ocupação do solo no entorno dos aterros desativados São Mateus e Sapopemba no município de São Paulo 
$\mathrm{Na}$ Tabela 5.5 apresenta-se a síntese dos dados obtidos para os antigos aterros do Grupo 3 (Apêndice C). Nesse grupo as classes foram, também, quantificadas no interior (Int.) dos aterros e incluiu-se o solo exposto, pois ele favorece os processos de erosão e contaminação.

A classe maciço herbáceo predomina no interior de todos os aterros de grupo, com média de $84 \%$, apresentando no seu entorno variação entre 28 a $49 \%$, sendo um pouco superior no entorno (500 e $1.000 \mathrm{~m}$ ) dos aterros Vila Albertina (48 e $41 \%$ ) e Santo Amaro (49 e 38\%). A vegetação arbórea está ausente no interior dos aterros Santo Amaro e Sapopemba, com pouca significância no seu entorno, onde predomina a urbanização, ocorrendo, secundariamente, o maciço herbáceo (34 a 37\%), com exceção do entorno próximo (500 m) do Santo Amaro, no qual, essa última classe é dominante (49\%). Considerando-se apenas as classes maciço arbóreo muito denso e maciço arbóreo denso constata-se que elas são muito pouco significativas em todos os aterros desse grupo, apresentando valores superiores nos aterros Vila Albertina (média de 4\%) e São Mateus (média de 3\%). No entorno desses mesmos aterros, predomina o maciço herbáceo (32 a 48\%), excetuando-se a envoltória de $2.000 \mathrm{~m}$, do primeiro, no qual o maciço arbóreo pouco denso ocorre em maior proporção $(34 \%)$ e, do segundo, no qual a urbanização (45\%) é dominante. Destaca-se que a classe maciço arbóreo pouco denso configura-se como uma mancha contínua, nas imediações desses dois aterros (Figuras 5.11 e 5.12) e como fragmentos no Sapopemba (Figura 5.12). A classe água está presente em maior proporção no entorno do Santo Amaro (média de $5 \%$ ) e o solo exposto com maior expressão nos aterros Sapopemba e Santo Amaro (média de 15\%).

A vegetação herbácea do interior desses aterros é típica dos projetos de engenharia para revegetação de aterros ${ }^{21} \mathrm{e}$, predomina, também, no entorno mais próximo (500 e $1.000 \mathrm{~m}$ ) do aterro Vila Albertina e do Santo Amaro. A vegetação arbórea é pouco expressiva, sobressaindo-se a classe maciço arbóreo pouco denso no entorno do Vila Albertina e do São Mateus, relacionadas, respectivamente, à Serra da Cantareira e à APA/Parque do Carmo.

\footnotetext{
${ }^{21} \mathrm{Em}$ geral, os projetos de recuperação dessas áreas objetivam apenas o seu nivelamento e a sua estabilidade, indicando comumente o revestimento vegetal com gramíneas, mais simples e eficiente, sem nenhuma preocupação paisagística. Andrade (2000) relaciona os motivos para a utilização das gramíneas: a) ausência de dados sobre implantação de vegetação nas condições adversas dos aterros; b) falta de interesse e/ou condições financeiras do poder público em investir na recuperação dessas áreas; c) insuficiência de conhecimentos e falta de investimentos em métodos de adaptação do ambiente às espécies vegetais paisagísticas.
} 
Tabela 5.5 - Quantificação (\%) simplificada das classes de uso e ocupação do solo nas áreas de entorno $(500,1.000$ e $2.000 \mathrm{~m})$ dos aterros do Grupo 3

\begin{tabular}{lrrrrrrrrr}
\hline \multicolumn{1}{c}{ Classes } & \multicolumn{4}{c}{ V.Albertina } & \multicolumn{4}{c}{ S.Amaro } \\
& Int. & 500 & 1000 & 2000 & Int. & 500 & 1000 & 2000 \\
Urbanização & 0,9 & 11 & 15 & 26 & 6 & 36 & 51 & 58 \\
M. A. m. Denso & 1 & 7 & 7 & 5 & 0,1 & 2 & 1 & 1 \\
M. A. Denso & 0,1 & 1 & 1 & 0,7 & - & 0,2 & 0,2 & 0,1 \\
M. A. p. Denso & 0,4 & 29 & 33 & 34 & - & 0,2 & 0,2 & 0,5 \\
M. Herbáceo & 93 & 48 & 41 & 31 & 79 & 49 & 38 & 29 \\
Água & - & - & - & 0,1 & - & 5 & 3 & 6 \\
Solo exposto & 5 & 3 & 2 & 2 & 14 & 6 & 5 & 3 \\
\multicolumn{1}{c}{ Classes } & & S.Mateus & & & Sapopemba \\
& Int. & 500 & 1000 & 2000 & Int. & 500 & 1000 & 2000 \\
Urbanização & 3 & 19 & 27 & 45 & 2 & 52 & 58 & 53 \\
M. A. m. Denso & 5 & 5 & 6 & 4 & - & 2 & 1 & 3 \\
M. A. Denso & 0,1 & 0,2 & 0,1 & 0,1 & - & - & - & 0,2 \\
M. A. p. Denso & 4 & 23 & 19 & 14 & - & 0,3 & 1 & 3 \\
M. Herbáceo & 81 & 33 & 32 & 28 & 83 & 37 & 33 & 34 \\
Água & - & 0,1 & 1 & 0,3 & - & - & - & - \\
Solo exposto & 3 & 2 & 2 & 3 & 16 & 9 & 7 & 6 \\
\hline
\end{tabular}

O aterro Vila Albertina foi o que apresentou maior potencial para revegetação, pois está sob menor pressão da urbanização, com alguma expressão das classes maciços herbáceo e arbóreo pouco denso e com presença do maciço arbóreo muito denso, em todos os cenários de entorno; além de se situar nas proximidades da Serra da Cantareira. Dentre os aterros menos favoráveis à revegetação, Sapopemba e Santo Amaro, o primeiro está sob forte pressão da urbanização. O segundo possui como diferencial a classe água, associada ao Rio Grande e à Represa Billings, elementos potencialmente promotores da revegetação.

A Figura 5.14 apresenta a classificação de uso e ocupação do solo no entorno dos antigos aterros Raposo Tavares, hoje um parque urbano de mesmo nome e Jacuí, futuro Parque Jardim Primavera. 

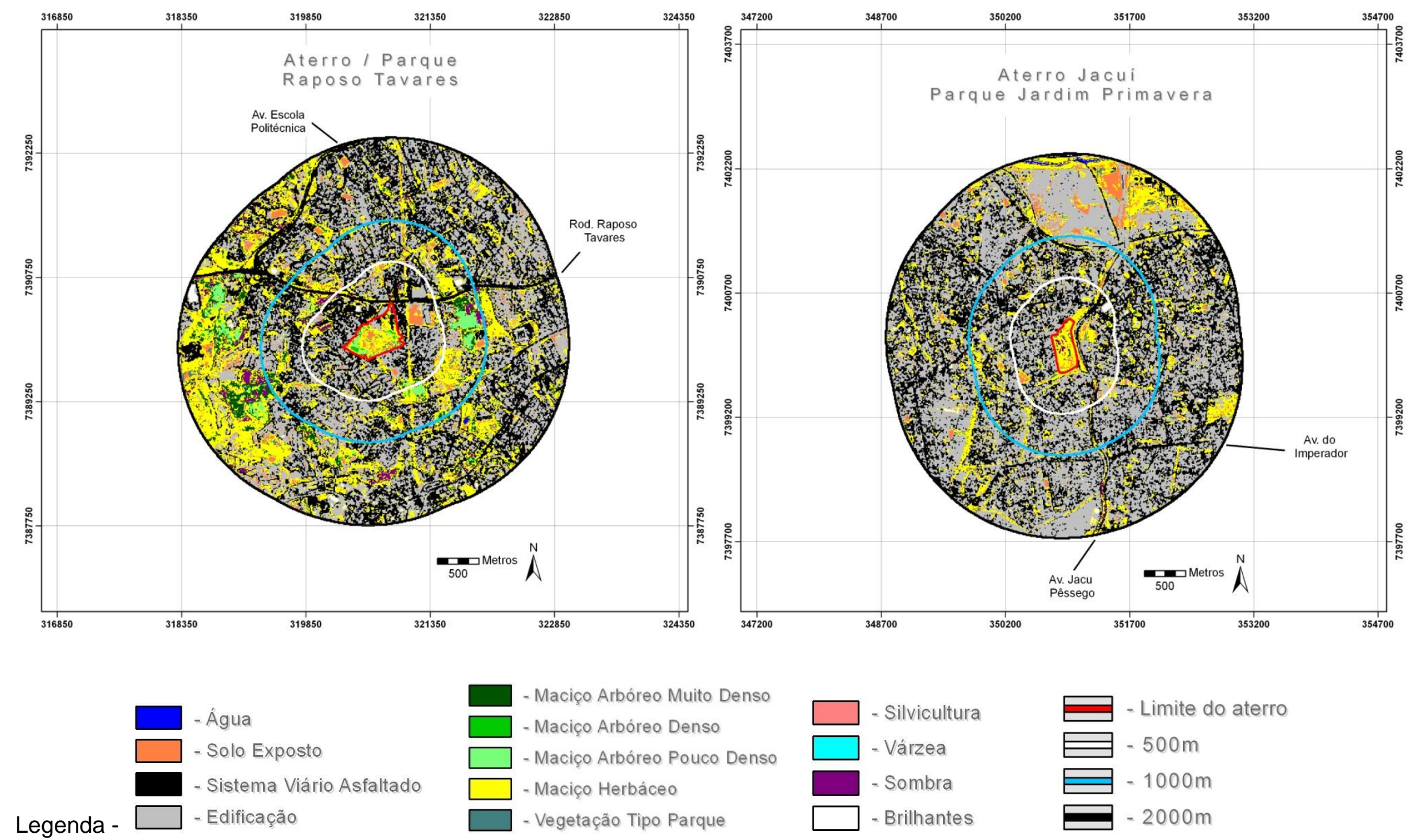

Figura 5.14 - Uso e ocupação do solo no entorno dos aterros desativados Raposo Tavares e Jacuí no municjípio de São Paulo 
A Tabela 5.6 sintetiza os resultados da classificação de uso do solo aplicada aos aterros Raposo Tavares e Jacuí (Apêndice D). A classe maciço herbáceo (média de 70\%) predomina nos seus interiores e a urbanização (média de $75 \%$ ) nos seus arredores. O maciço arbóreo possui pouca significância, destacando-se os maciços arbóreo denso e pouco denso, no Raposo Tavares e o maciço arbóreo muito denso, no Jacuí. A água está ausente no interior e nos arredores de ambos os aterros e o solo exposto presente com maior significância nos seus interiores.

Tabela 5.6 - Quantificação (\%) simplificada das classes de uso e ocupação do solo nas áreas de entorno $(500,1.000$ e $2.000 \mathrm{~m})$ dos aterros selecionados como estudo de caso

\begin{tabular}{lrrrrrrrrc}
\hline \multicolumn{1}{c}{ Classes } & \multicolumn{3}{c}{ Raposo Tavares } & \multicolumn{4}{c}{ Jacuí } \\
& Int. & 500 & 1000 & $\mathbf{2 0 0 0}$ & Int. & 500 & 1000 & 2000 \\
\cline { 2 - 9 } Urbanização & 13 & 71 & 68 & 67 & 1 & 77 & 83 & 83 \\
M. A. m. Denso & 3 & 1 & 2 & 3 & 6 & 0,6 & 0,3 & 0,2 \\
M. A. Denso & 5 & 0,5 & 0,2 & 0,1 & - & - & - & - \\
M. A. p. Denso & 6 & 1 & 2 & 1 & - & - & - & - \\
M. Herbáceo & 63 & 20 & 23 & 24 & 78 & 18 & 14 & 14 \\
Água & - & - & - & - & - & - & - & - \\
Solo exposto & 9 & 4 & 3 & 3 & 8 & 3 & 2 & 3 \\
\hline
\end{tabular}

O predomínio da vegetação herbácea está associado, muito provavelmente, às técnicas de engenharia preconizadas para recuperação de aterros, como observado nos aterros do Grupo 3, ou ainda, às dificuldades encontradas para desenvolvimento de vegetação de maior porte nesse tipo de maciço. Salienta-se, que no parque/aterro Raposo Tavares, desde a década de 1980, foi implantada vegetação vinculada ao novo uso como parque urbano.

A comparação dos dados obtidos sobre os aterros dos grupos 3 e 4 denotam que há forte pressão da urbanização sobre o Jacuí e, secundariamente, sobre o Raposo Tavares; enquanto que a maior presença de solos expostos nos aterros Sapopemba e Santo Amaro, favorecem a ocorrência de processos de erosão e contaminação. Manchas contínuas de vegetação se destacam nas imediações dos aterros Vila Albertina e São Mateus. A análise geral desses dois grupos de aterros, quanto à re-vegetação, permitiu ordená-los do maior potencial para o menor: Vila Albertina, São Mateus, Santo Amaro, Sapopemba, Raposo Tavares e Jacuí. 


\subsubsection{CONDIÇÕES SOCIOAMBIENTAIS DOS LIXÕES E DOS ATERROS DESATIVADOS E SUAS IMEDIAÇÕES}

A seguir será apresentado um resumo da situação ambiental atual de quatro aterros desativados municipais a serem transformados em parques urbanos, conforme determinação dos instrumentos urbanísticos municipais e do Termo de Compromisso Ambiental entre a Prefeitura do Município de São Paulo e a Secretaria do Meio Ambiente do Estado de São Paulo (SMA). O antigo aterro Jacuí, com reúso para parque legalmente definido por lei municipal e o parque-aterro Raposo Tavares, serão abordados nos Capítulos 8 e 9.

\subsubsection{Aterro Vila Albertina}

O aterro localiza-se na Rua Capitão José Aguirre de Camargo 400 (Figura 5.15) e integra a Subprefeitura de Jaçanã-Tremembé, distrito de Tremembé (Tipo 1, Tabela 5.1), com população estimada em 185.731 habitantes (SMS, 2010), zona norte do município, fazendo parte da Zona Especial de Proteção Agrícola e de Extração Mineral (ZEPAG/03), conforme a Lei 13.885/04, perfazendo uma área de cerca de 214.000 m² $^{2}$ (SVMA, 2008c; 2010a). O aterro iniciou suas atividades em 29 de março de 1977, sobre antiga cava de mineração de brita, em maciço granítico, com cerca de 80 m de altura; encerrando-se em março de 1993, com a disposição de cerca de 9,2 milhões de toneladas de resíduos (SVMA, 2001; Leite, 2005; SES, 2009). Desde então vem sendo monitorado quanto à estabilidade, produção de percolados e de gases e, ainda, às características físico-químicas do chorume e às condições de qualidade ambiental das águas subterrâneas (Jorge et al., 2004; Leite, 2005). A sua recuperação está prevista para 2012 no Plano Diretor Estratégico e definido o seu novo uso como parque urbano no Plano Regional Estratégico da Subprefeitura de Jaçanã-Tremembé.

Apresenta taludes inclinados ( $1 \mathrm{~V}: 2 \mathrm{H}$ ou menores) com altura de cerca de 5 metros, re-vegetados com gramíneas e alguns exemplares arbóreos e arbustivos esparsos (paineira, suína, guapuruvu), com alturas de 3 metros. A sua face sul apresenta-se densamente ocupada por habitações de baixa renda e algumas indústrias (Figura 5.16), enquanto que a leste encontra-se a Fazenda Santa Maria e 
ao norte o Parque Estadual da Cantareira, onde existem remanescentes de mata preservados (SVMA, 2001).

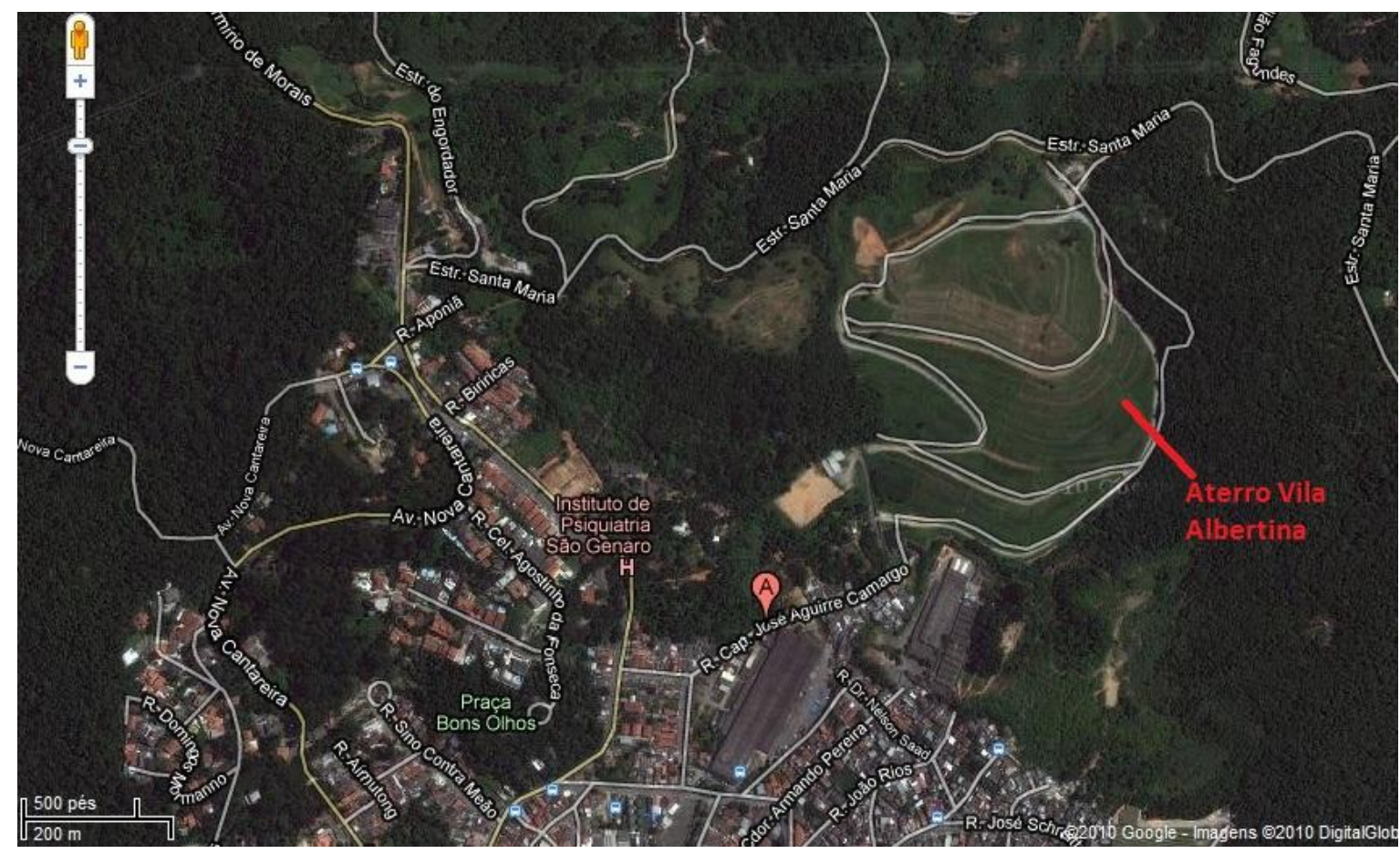

Figura 5.15 - Localização do antigo aterro Vila Albertina

Fonte: Googlemaps, imagem de 22/12/09, acesso em 15/11/10

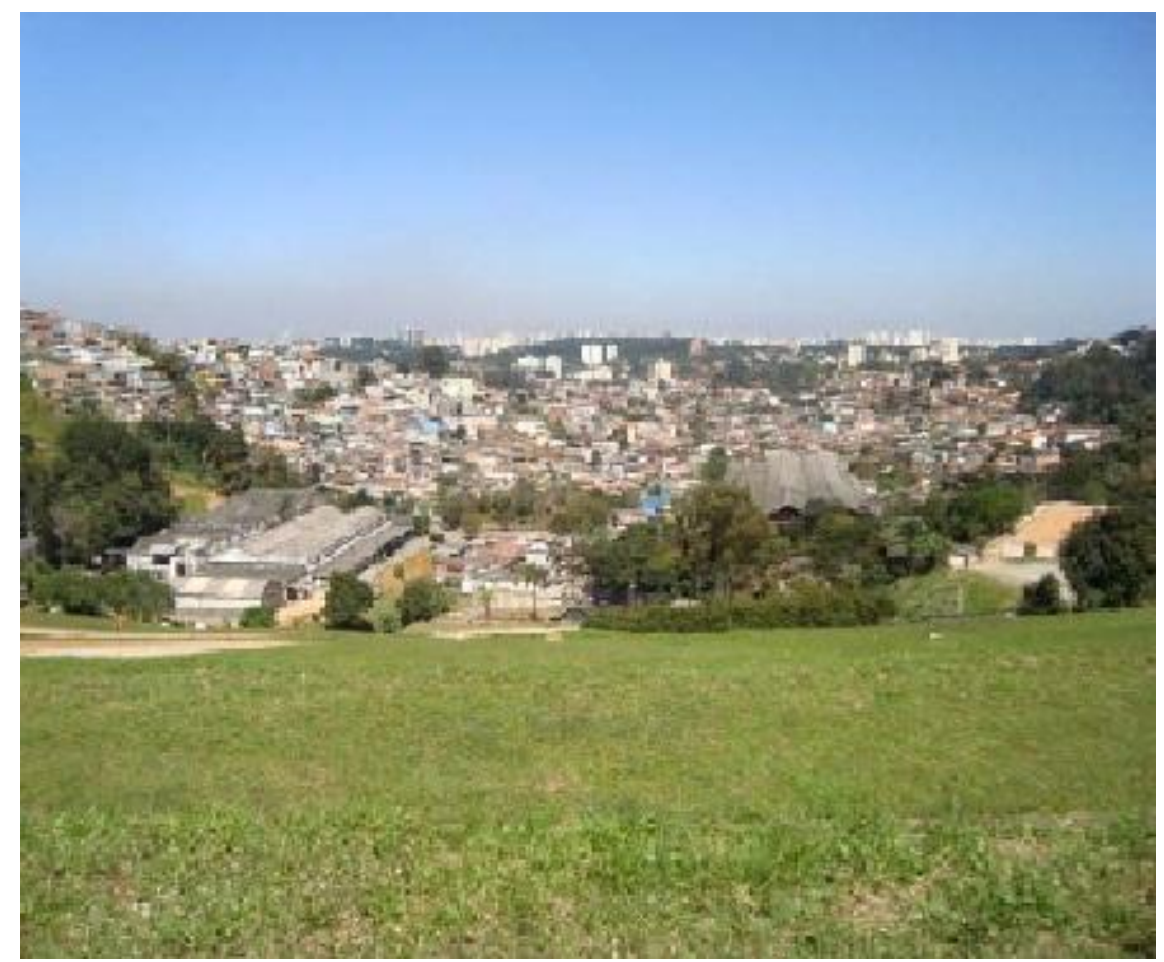

Figura 5.16 - Face sul do antigo aterro Vila Albertina contígua à residências e indústrias Fonte: SES (2009; v. 1, p. 21) 
A região constitui-se geologicamente por rochas magmáticas e metamórficas do embasamento pré-cambriano, formadas pelas unidades dos Grupos São Roque, Serra do Itaberaba e Complexo Embu, sendo cortada por extensas falhas transcorrentes. A hidrogeologia local está representada pelo aqüífero livre, onde predominam material silto-arenoso, com variação do nível d'água de 0,60 a 6,0 m de profundidade. $O$ fluxo da água subterrânea tem direção preferencial para o córrego Tremembé e $\mathrm{o}$ afluente existente na área. $\mathrm{O}$ aterro foi implantado sobre o divisor de águas entre os vales dos rios Cassununga e Tremembé e, parcialmente, sobre o divisor entre os rios Tremembé e Santa Maria. (SES, 2009).

A SVMA (2001) e Borella (2004) comentam sobre as medições de gases realizadas nesse aterro, pela USEPA $(1996)^{22}$, no âmbito de processo licitatório empreendido pela SVMA, para aproveitamento do biogás dos aterros municipais, prevendo-se o término da sua produção para 2030 (Figura 5.17).

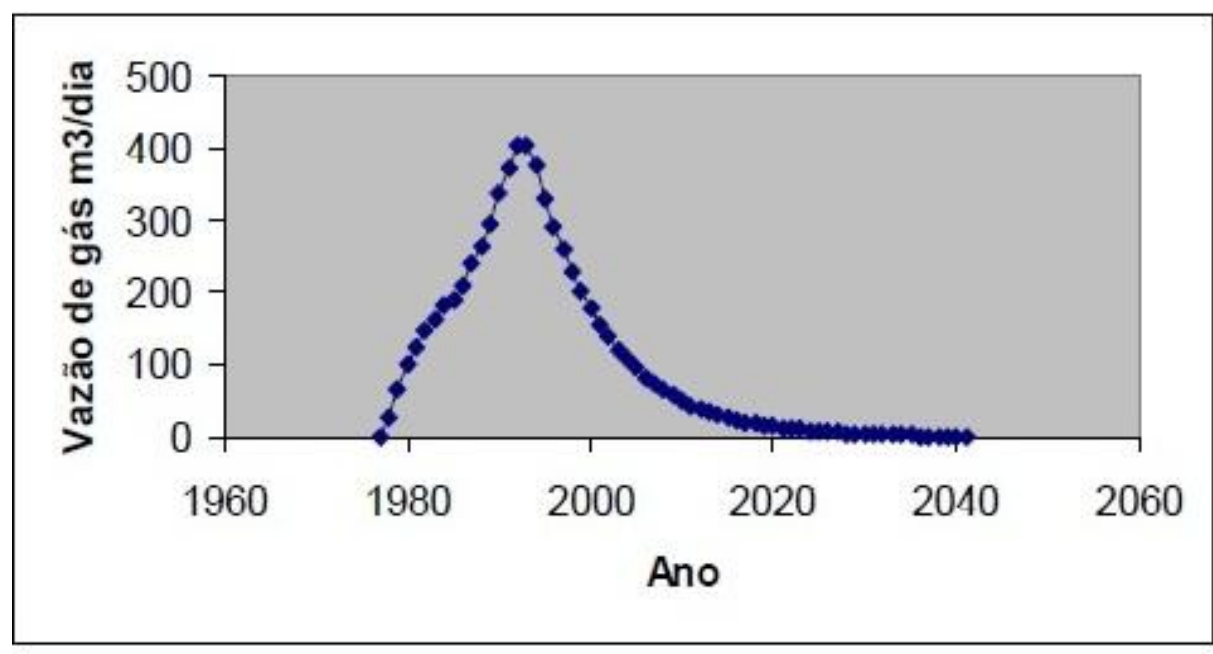

Figura 5.17 - Variação da vazão de gás no antigo aterro Vila Albertina Fonte - Borella (2004)

Os estudos, contratados pela SES/Limpurb, para avaliação do potencial de contaminação da área e do seu entorno, segundo o modelo conceitual previsto e a sua devida revisão, consideraram dois cenários hipotéticos de exposição aos receptores. O cenário 1 trata da ingestão de água subterrânea (onsite) para os receptores transeuntes e moradores do local e do entorno, trabalhadores do aterro e de obras. O cenário 2 diz respeito à exposição ao corpo d'água (córrego Tremembé e afluente, off-site) para o contato dérmico e ingestão de

\footnotetext{
${ }^{22}$ UNITED STATES ENVIRONMENTAL PROTECTION AGENCY - USEPA. Feasibility assessment for gas-toenergy at selected landfills in São Paulo, Brazil. Public Review Draft. EPA 68-W6-0004, 1996.
} 
água superficial. Os resultados obtidos detectaram no solo concentrações superiores aos valores de intervenção apenas para Bifenilas Policloradas (PCB's) ${ }^{23}$. Para a água subterrânea foram encontradas concentrações elevadas de metais (alumínio, bário, chumbo, cobalto, ferro, manganês e níquel) e de organismos microbiológicos (coliformes fecais e totais) e nitratos (SES, 2009).

A análise da investigação de contaminação, realizada pelo GTAC/Decont/SVMA, verificou que há risco cumulativo tóxico para a via de exposição ingestão de água subterrânea, recomendando-se restringir o seu uso para qualquer fim. Os resultados obtidos para a contaminação do solo e das águas subterrâneas e superficiais por metais não indicam que ela esteja diretamente associada à disposição de resíduos, assim como a contaminação do solo por PCB's. Constatou-se ainda que a contaminação da água subterrânea deve-se muito mais ao lançamento de esgoto por residências e indústrias do que propriamente pelo maciço de resíduos. De acordo com as especificidades da área indicou-se a proibição de qualquer construção sobre o maciço de resíduos, alertando-se que para a realização de qualquer obra será necessário aguardar a queima total do metano nos drenos existentes (Figura 5.18). Recomendou-se, também, o monitoramento das águas subterrâneas no interior do aterro, especialmente, na divisa sul, junto à ocupação por residências e industriais, avaliando-se os parâmetros metais, PCB's, TPH e di(etilexil)ftalato (SVMA, 2010a).

Leite (2005), na sua pesquisa de doutorado sobre os aterros desativados no município de São Paulo, avaliou as expectativas da população nas imediações do aterro Vila Albertina quanto ao reuso efetivo da área, por meio de entrevistas aplicadas aos moradores dos bairros mais próximos, concluindo que a população percebe a possibilidade de apropriação pública desses espaços, com novos usos como o lazer, mas desconhece os processos para viabilizar a sua implantação efetiva.

\footnotetext{
${ }^{23}$ Esse composto, cancerígeno à saúde humana, antigamente era utilizado na fabricação de óleos e lubrificantes, podendo ser encontrado em isolamento para cabos elétricos e fios. Contudo, o local onde foi encontrado o composto está recoberto por concreto e, portanto, as vias de exposição (contato dérmico e ingestão acidental de partículas de solo) não se completam deixando, então de serem calculados os riscos à saúde humana (SES, 2009).
} 


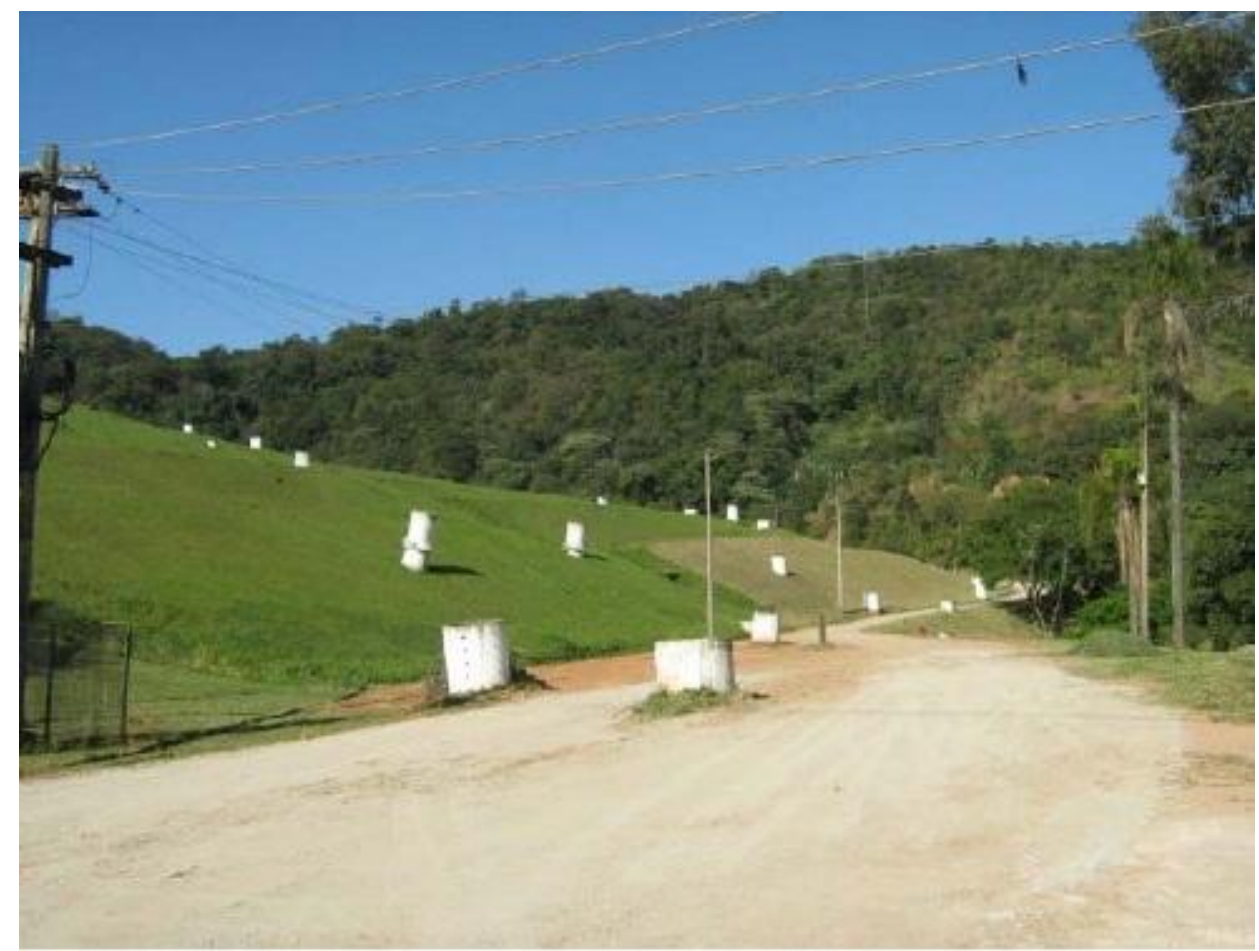

Figura 5.18 - Talude e drenos de gás do antigo aterro Vila Albertina Fonte - SES (2009; V. 1, p. 20).

\subsubsection{Aterro Santo Amaro}

O aterro localiza-se na margem direita do canal do Rio Grande (ou Jurubatuba), contribuinte da Represa Billings, em frente ao Autódromo Ayrton Senna, limitado pela faixa de domínio da ferrovia da Fepasa (Figura 5.19), integrando a Subprefeitura de Santo Amaro, distrito de Pedreira (Tipo 2, Tabela 5.1), estimando-se um total de 158.656 de habitantes (SMS, 2010), com área total de $370.000 \mathrm{~m}^{2}$ (Andrade, 2000; 2005; SVMA, 2001; 2005; Ramires et al, 2005), em Zona Mista de Alta Densidade (ZMa/03), estabelecida pela Lei 13.885/04. A geologia local está representada pelos sedimentos quaternários do Rio Grande.

A sua implantação foi iniciada em 1975, a partir da drenagem de duas lagoas resultantes da extração de areia e a construção de uma camada de base de argila compactada, com cerca de um metro de espessura. A disposição de resíduos iniciou-se em abril de 1976, constituindo-se de resíduos industriais (10\%), domésticos, restos de construção e material inerte (90\%). Uma rede interna de drenos de gases e de chorume foi instalada, sendo esse último encaminhado para estação de tratamento de esgoto. Na camada final de cobertura foi instalado, também, um sistema de drenagem superficial que coleta e encaminha as águas 
pluviais para o canal do Rio Grande. Seu projeto original, com cota de 80 metros, sofreu sucessivas ampliações (Oliveira, s/d ${ }^{24}$ apud Andrade, 2000; 2005), atingindo, no encerramento das suas atividades, em 20 de janeiro de 1995, um volume total de 16 milhões de toneladas de resíduos depositados (Andrade, 2000; 2005; SVMA, 2001; 2005; Ramires et al, 2005), conformando-se como um morro, com taludes acentuados, gramados, que se sobressai na margem do rio (Figura 5.20).

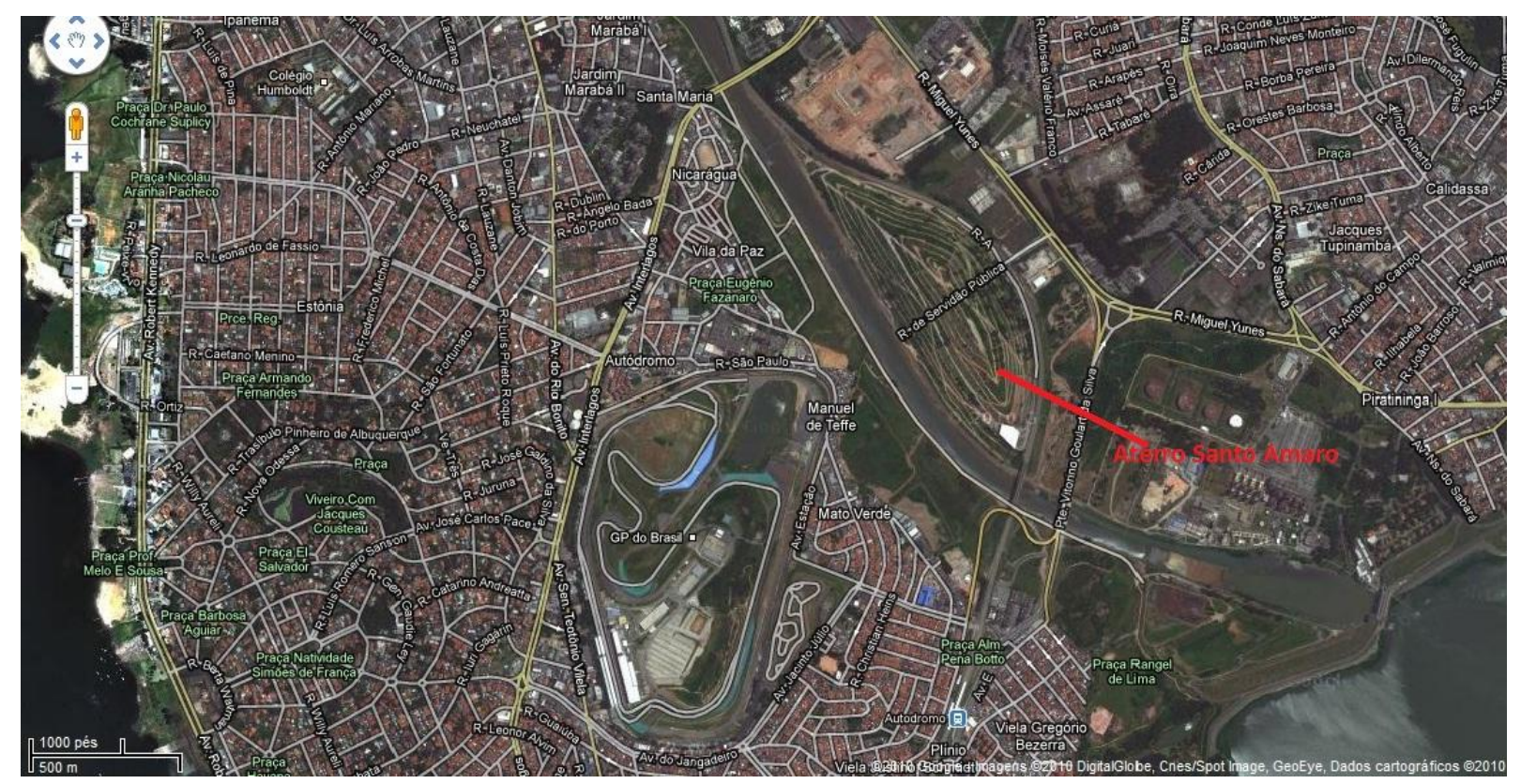

Figura 5.19 - Localização do antigo aterro Santo Amaro

Fonte: Googlemaps, imagem de 22/12/09, acesso em 15/11/10.

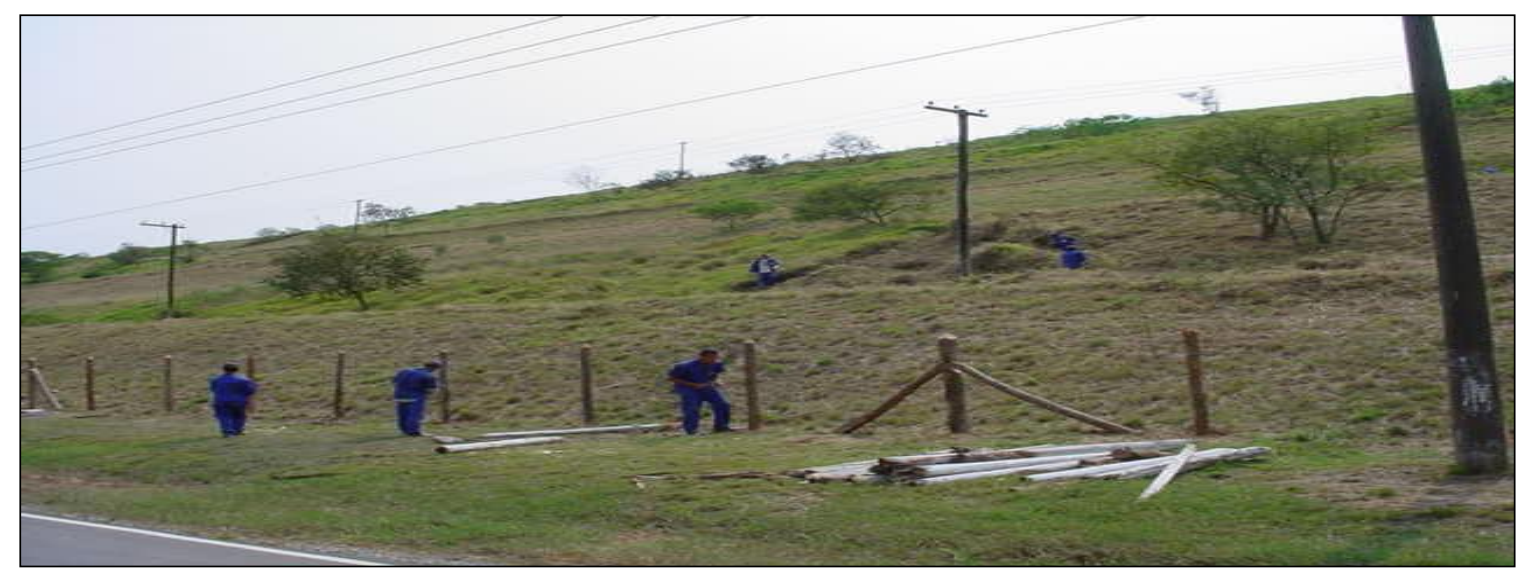

Figura 5.20 - Talude e bermas revegetadas do aterro Santo Amaro, em 09/04 Fonte: Ramires et al.(2005)

\footnotetext{
${ }^{24}$ OLIVEIRA, F.J.P. Aterro Sanitário de Santo Amaro: estudo de estabilidade visando aumento da capacidade de deposição. São Paulo: EPAL, s/d. 17 p. (Relatório Interno).
} 
Segundo Silva (2001), na década de 1980, o aterro foi objeto de experiência pioneira para a exploração do biogás como combustível, em 40 ônibus municipais (Módulo $4000-4000 \mathrm{~N} \mathrm{~m} 3 /$ dia). $\mathrm{O}$ autor ainda comenta sobre as medições de gases realizadas pela USEPA (1996) ${ }^{25}$, do mesmo modo que no aterro Vila Albertina, no qual a projeção da sua produção, ao longo do tempo, define o seu término, na melhor das hipóteses, para 2035 (Figura 5. 21).

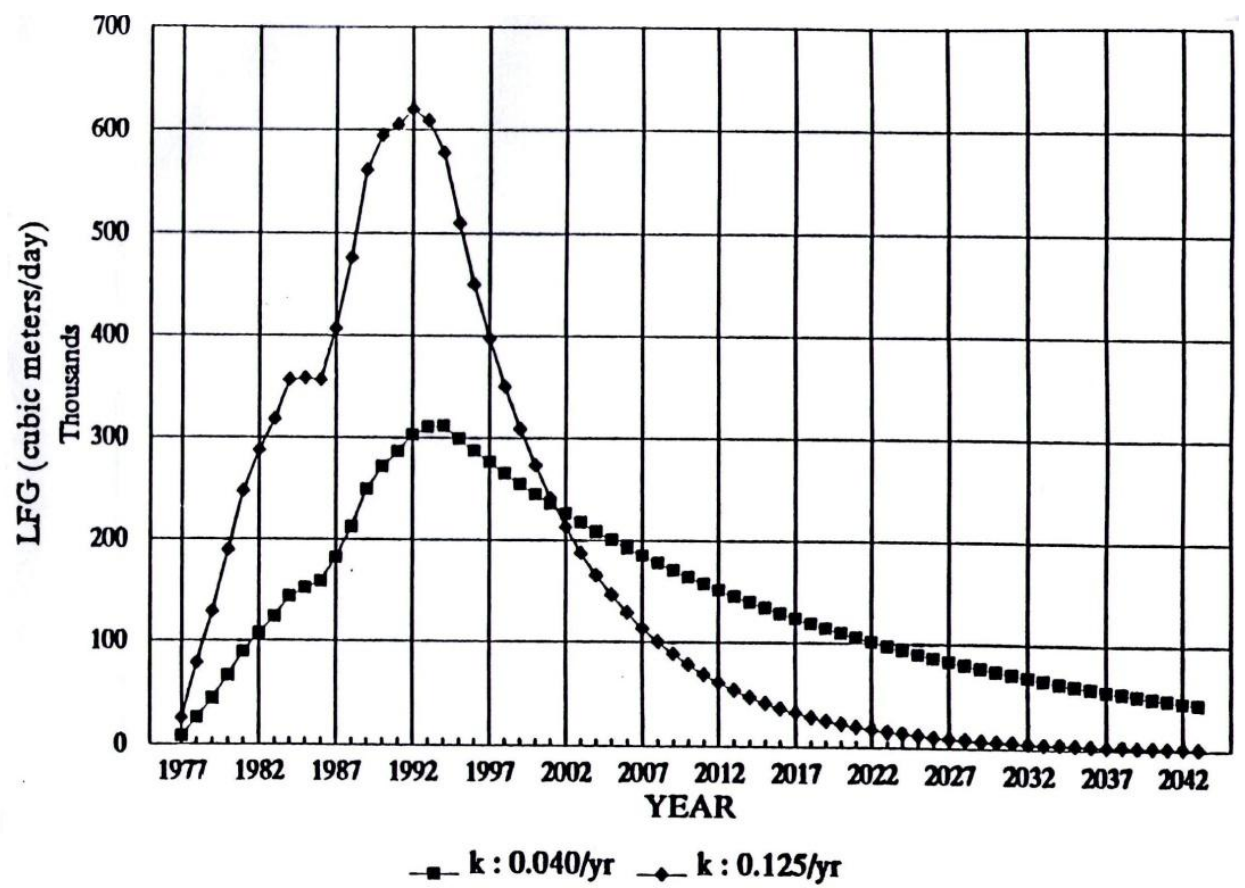

Figura 5.21 - Variação da vazão de gás no antigo aterro Santo Amaro Fonte - USEPA (1996 apud SVMA, 2001).

A recuperação do aterro para parque está vinculada ao Termo de Compromisso Ambiental, firmado pela Prefeitura do Município de São Paulo (Secretaria Municipal de Serviços, SES) com a Secretaria do Meio Ambiente do Estado de São Paulo (SMA), no âmbito do licenciamento da Central de Tratamento de Resíduos Sólidos Leste (CTL). Essa destinação já está apontada no mapa de uso e ocupação do solo da Subprefeitura de Santo Amaro, com implantação prevista para 2012, conforme o Mapa da Rede Estrutural Hídrica Ambiental. Ressalta-se, entretanto, que os estudos específicos para avaliação do potencial de contaminação do aterro e seus arredores ainda não foram realizados (Informação verbal| ${ }^{26}$ ).

Todavia é importante salientar que a região na qual o aterro está inserido foi classificada, pela Cetesb, como área contaminada crítica do Jurubatuba (Cetesb,

\footnotetext{
${ }^{25}$ Idem referência 22.

${ }^{26} \mathrm{~A}$ informação foi fornecida pelos engenheiros Vasques (SES/Limpurb) e Rosimeire Lobato (SVMA/GTAC), em 18/11/2010.
} 
2010), anteriormente destinada como Zona de Uso Predominantemente Industrial (ZUPI 131), pelo zoneamento municipal. Hoje passa por grande transformação com as atividades industriais sendo substituídas por empreendimentos imobiliários de alto padrão e a instalação de empresas de prestação de serviços e comércio. A mudança de perfil da área propiciou a investigação dos passivos ambientais que constatou a contaminação por compostos organoclorados que atingiram poços de produção de águas subterrâneas (Cetesb, 2010) ${ }^{27}$.

No final da década de 1990, a Universidade Federal do Rio de Janeiro, iniciou pesquisa, com duração de seis anos, sobre a fertilidade do solo, a adaptabilidade e o desenvolvimento de vegetação arbórea e arbustiva e, do risco de fitotransporte e de biodisponibilidade de metais pesados, pela vegetação implantada sobre 0 aterro. Os resultados mostraram que as plantas podem se desenvolver em solo de cobertura, disposto diretamente sobre os resíduos. Também não foi constatado fitotransporte ou biodisponibilidade de metais pesados significativos. Destacaram-se pela boa adaptabilidade, elevada rusticidade e baixa manutenção para o cultivo as espécies: Acacia holosericea, Clitoria fair childiana, Enterolobium contorsiliquium, Mimosa binucronata, Mimosa caesalpiniaefoliana, Mimosa pellita, Mimosa pigra, Mimosa tenuiflora e Schinus terebinthifolius, com estabelecimento superior a $50 \%$ e constituindo $72 \%$ da população final. A espécie Enterolobium contorsiliquium mostrou o melhor desempenho com estabelecimento de $93 \%$ e bom desenvolvimento médio. Salienta-se que o período da pesquisa é insuficiente para avaliar todos os processos de interação dessa vegetação, nesse meio, visto o tempo necessário para o estabelecimento de uma nova ecodinâmica ambiental. Além disso, há que se considerar a ocorrência de possíveis mudanças nas condições ambientais do maciço de resíduos, ao longo da sua maturação; sendo recomendado o contínuo monitoramento da vegetação e o aprofundamento das pesquisas (Andrade, 2000; 2005).

\footnotetext{
${ }^{27}$ Um estudo realizado, pelo IG/SMA, numa área com cerca de $120 \mathrm{Km}^{2}$, constatou 84 áreas contaminadas, sendo 14 delas por etenos (EEC) ou etanos (EAC) clorados, que atingiram 46 poços com 31 apresentando concentrações superiores acima dos Valores Orientadores de Intervenção (VOI). Foram identificadas 2.490 atividades com índices de Elevado Potencial de Contaminação (AEPC). O aqüífero sedimentar possui vulnerabilidade de média a alta (DAEE/SMA-IG, 2009). A contaminação já alcançou o aqüífero cristalino, mais profundo ( Neto , 2010).
} 


\subsubsection{ATERRO SAPOPEMBA}

Está situado ao sul da APA do Carmo, com acesso pela Rua Bandeira de Aracambi e próximo da Estrada do Rio Claro e do Km 27 da Av. Sapopemba, na Subprefeitura de São Mateus, distrito de São Rafael (Tipo 2, Tabela 5.1), com população estimada em 151.017 habitantes (SMS, 2010), em Zona Mista de Baixa Densidade (ZMb), conforme a Lei 13.885/04, com área de $220.000 \mathrm{~m}^{2}$ (Figuras 5.22 e 5.23). Integra a sub-bacia do córrego Caaguaçu e caracteriza-se pela predominância dos maciços de rochas e solos de micaxistos com aluviões presentes junto ao córrego. A sua implantação deu-se em 1979, sobre um vale, encerrando-se em 1984, por pressão dos moradores do futuro conjunto da COHAB, onde foram dispostos 2,7 milhões de toneladas de resíduos. Ocorrem gramíneas, arbustos e, raramente, espécies arbóreas, com alguns eucaliptos. (SVMA, 2001; Ramires et al, 2005; Volpe-Filik et al, 2007). Está incluído na 'Gleba São Francisco'28, em projeto de urbanização, a cargo da Secretaria Municipal da Habitação (Ramires et al, 2005) e, de acordo com informações do GTAC (SVMA/2009a), em região com intenso e recente processo de expansão, na qual encontram-se vários conjuntos habitacionais e casas construídas por mutirão (Anexo F).

Segundo ainda informações do GTAC (SVMA,2009a) a recuperação do aterro, também, está vinculada ao Termo de Compromisso Ambiental, firmado pela Prefeitura do Município de São Paulo (Secretaria Municipal de Serviços - SES) com a Secretaria do Meio Ambiente do Estado de São Paulo (SMA), no âmbito do licenciamento da Central de Tratamento de Resíduos Sólidos Leste (CTL). Essa determinação está prevista para 2012 no Plano Diretor Estratégico, conforme implantação indicada no Plano Regional Estratégico da Subprefeitura de São Mateus, Mapa da Rede Estrutural Hídrica Ambiental. No mapa, corresponde ao Parque Central 1, no qual se prevê a conexão dessa área com o Rio Aricanduva e a região de Mauá, mediante a implantação de parque linear.

\footnotetext{
28 "[...] Foi declarada de utilidade pública (DUP) através do Decreto 15.879 de 14 de maio de 1979, que retificou o Decreto 15.411 de 27 de outubro de 1978, com a finalidade de viabilizar a implantação do aterro sanitário Sapopemba [...]", possuindo um total de $1.782 .014 \mathrm{~m}^{2}$. O uso da gleba foi permitido, posteriormente, à Cohab/SP para habitação de interesse social. Parte da área $\left(1.044 .392 \mathrm{~m}^{2}\right)$ foi transferida, em 1986, para a Sehab para o mesmo tipo de implantação anterior. Em 2004, fol implementado o "Plano Global de Intervenção da Gleba São Francisco" para urbanização da área, que indicou a necessidade de investigação ambiental para a implantação de melhorias nos arredores do aterro Sapopemba. (Sehab/HABI, p. 3)
} 


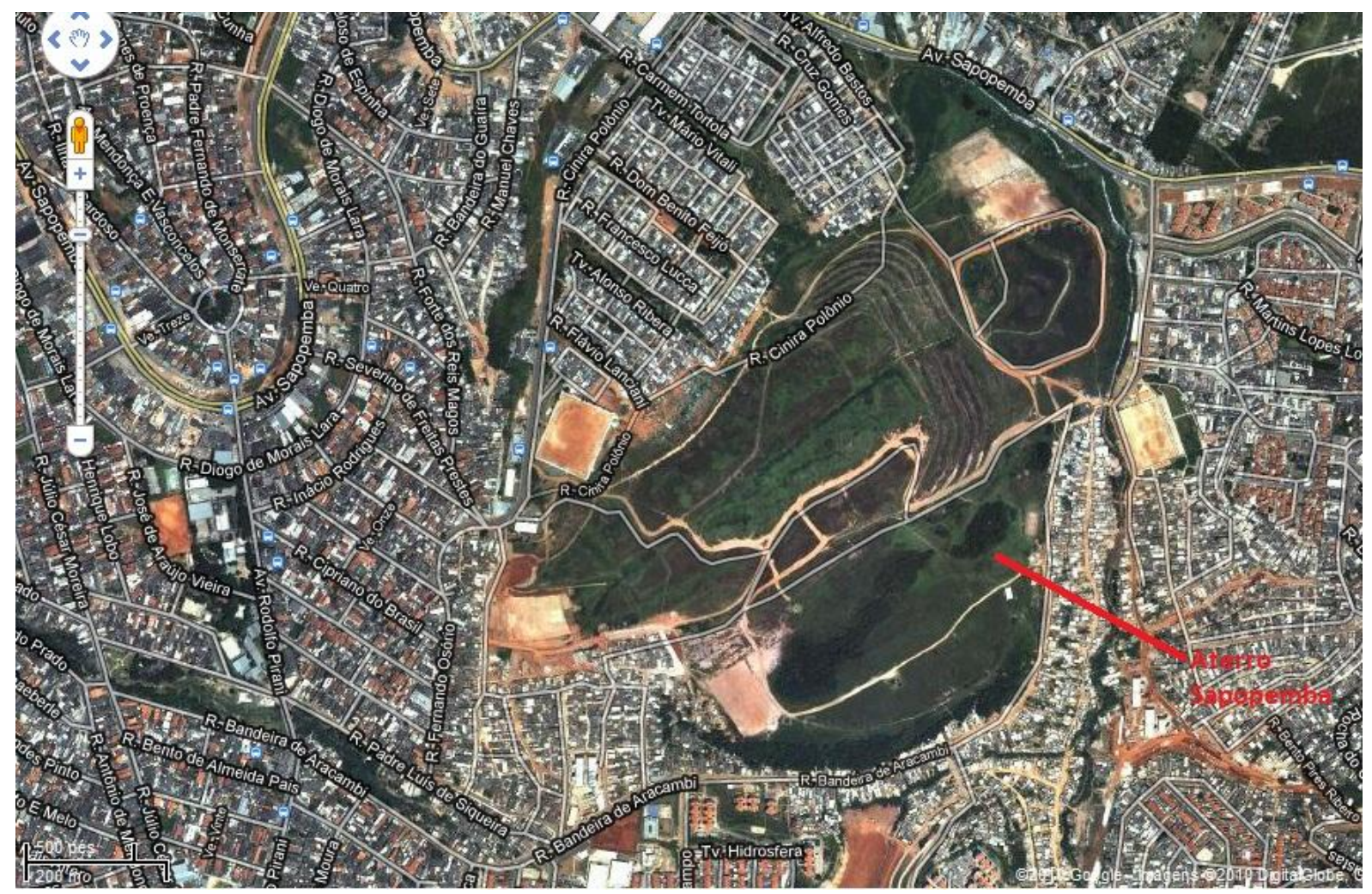

Figura 5.22 - Localização do antigo aterro Sapopemba Fonte: Googlemaps, imagem de 15/12/2008.

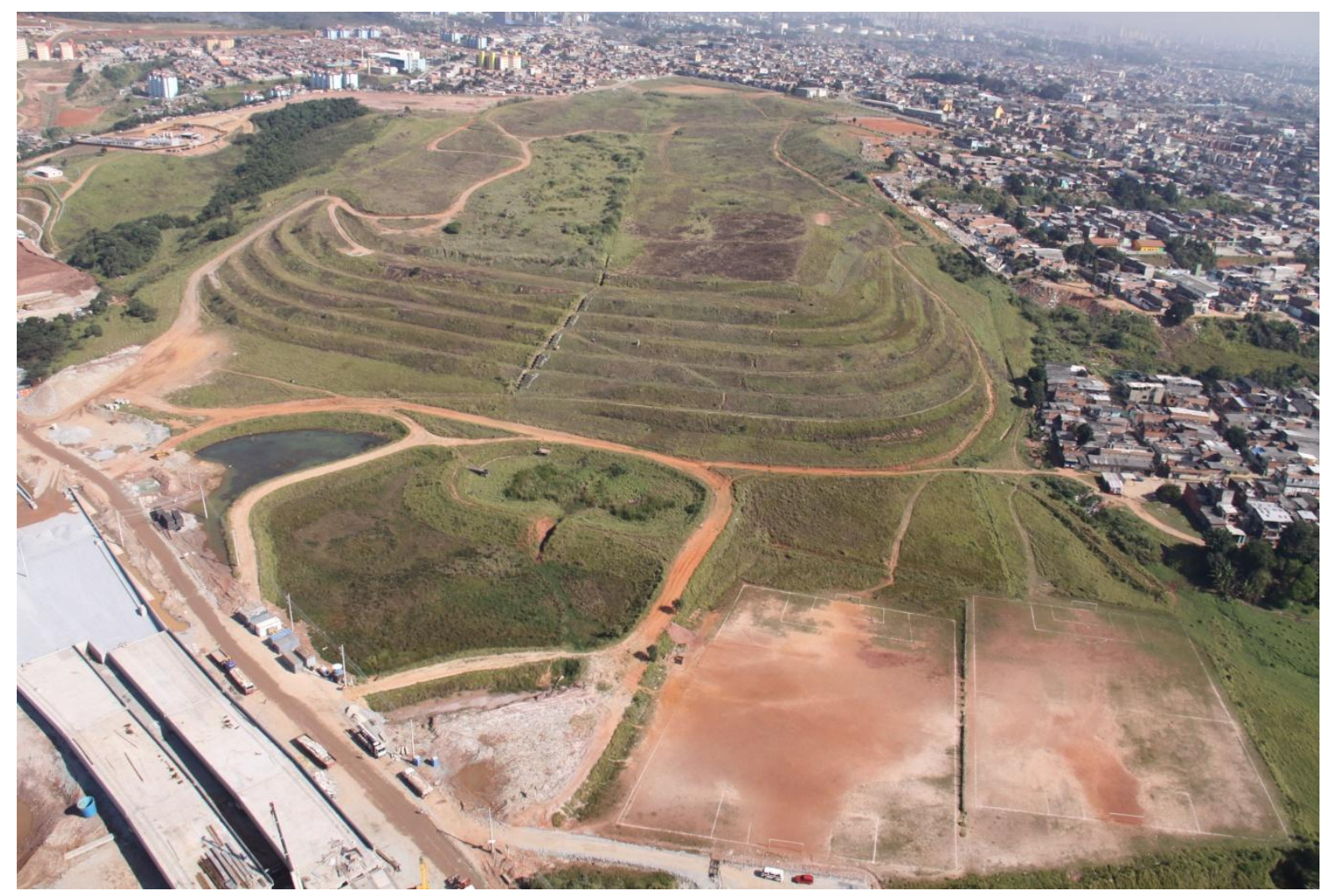

Figura 5.23 - Sobrevôo de helicóptero sobre o antigo aterro Sapopemba (15/junho/2010) Fonte: SVMA/Depave 
Em 2006, o GTAC verificou que o aterro apresentava boas condições geotécnicas e de conservação, odor proveniente de gás sulfídrico em alguns drenos de gás, indicando a presença de metano e pequeno volume d'água nas antigas lagoas de acumulação do percolado (SVMA, 2009a).

Investigação ambiental, contratada por Limpurb/SES, constatou contaminação do solo por metais, em profundidade, especialmente, arsênio e vanádio. Medições realizadas fora da massa de resíduos detectaram concentrações de metano de $20 \%$ de LEL (Limite Inferior de Explosividade) ${ }^{29}$, prevendo-se maiores concentrações na massa de resíduos. Outros estudos realizados em área lindeira, onde foram dispostos resíduos domiciliares também constataram a geração de metano (SVMA, 2009a). A água subterrânea está contaminada pelos metais: alumínio, bário, chumbo, ferro e manganês e apresenta altos valores para os parâmetros turbidez, coliformes fecais e totais. (SVMA, 2008c).

Considerando que a contaminação do solo se dá em profundidade estabeleceu-se que essa via de transporte, conforme o modelo conceitual previsto, não se completa, descaracterizando-se esse risco para os futuros usuários. Entretanto, conforme decisão do GTAC/SVMA, por medida de precaução, sugeriu-se o recobrimento de todo o maciço de resíduos com pelo menos $0,50 \mathrm{~m}$ de camada de solo, exceto os drenos e chaminés para eliminação de gases existentes. Além disso, a restrição de captação e uso da água subterrânea para qualquer fim. Investigação complementar também foi sugerida para algumas porções com resíduos, para avaliação detalhada da produção de metano (SVMA, 2009a).

\subsubsection{AterRo São MATEUS}

O aterro está inserido na Área de Proteção Ambiental (APA) do Carmo $^{30} \mathrm{e}$ na sub-bacia hidrográfica do Rio Aricanduva, limitando-se ao norte pelo Parque do Carmo, a sudeste pelo SESC Itaquera e a sudoeste pela Av. Aricanduva, perfazendo uma área de $85.000 \mathrm{~m}^{2}$ (Figura 5.24), em Zona Mista de Proteção Ambiental (ZMp/01), apontada pela Lei 13.885/04. Integra a Subprefeitura de Itaquera e o

\footnotetext{
${ }^{29}$ A USEPA (Municipal Solid Waste Disposal Facility Criteria) exige a redução da concentração de metano para $25 \%$ de LEL no subsolo acima do lençol freático, no caso de construções sobre aterros (SVMA/GTAC, 2009).

${ }_{30}$ Instituída pela Lei Estadual 6.409/1989 e com zoneamento ambiental definido pelo Decreto 37.679/1993, que criou cinco zonas de uso, estando o aterro São Mateus inserido na zona C. Essa zona se caracteriza por intensa alteração do ecossistema original, mas possuindo alguns remanescentes em áreas restritas. O decreto vedou a reativação do aterro e exigiu a sua recuperação (SVMA, 2001).
} 
distrito do Parque do Carmo (Tipo 1, Tabela 5.1), com o total de habitantes estimado em 69.630 (SMS, 2010). Caracteriza-se pela presença de micaxistos e, localmente, por aluviões quaternários do córrego Fazenda Velha. Foi implantado em fevereiro de 1984, sobre antiga cava de pedreira com $18 \mathrm{~m}$ de profundidade e sobre talvegue a sua montante, configurando-se em dois platôs contíguos, superior e inferior; como alternativa ao fechamento do aterro Sapopemba e iminente esgotamento do aterro Santo Amaro, encerrando suas atividades, por pressão da população ${ }^{31}$, em dezembro de 1985, com o total de um milhão de toneladas de resíduos depositados (SVMA, 2001; Ramires et al, 2005; SVMA, 2005, USP/ESALQ, 2006, SES/2009). A hidrogeologia local está representada pelo aqüífero livre com o nível da água subterrânea variando entre 1 e 19 metros e direção predominante de nordeste para sudoeste (SES/2009).

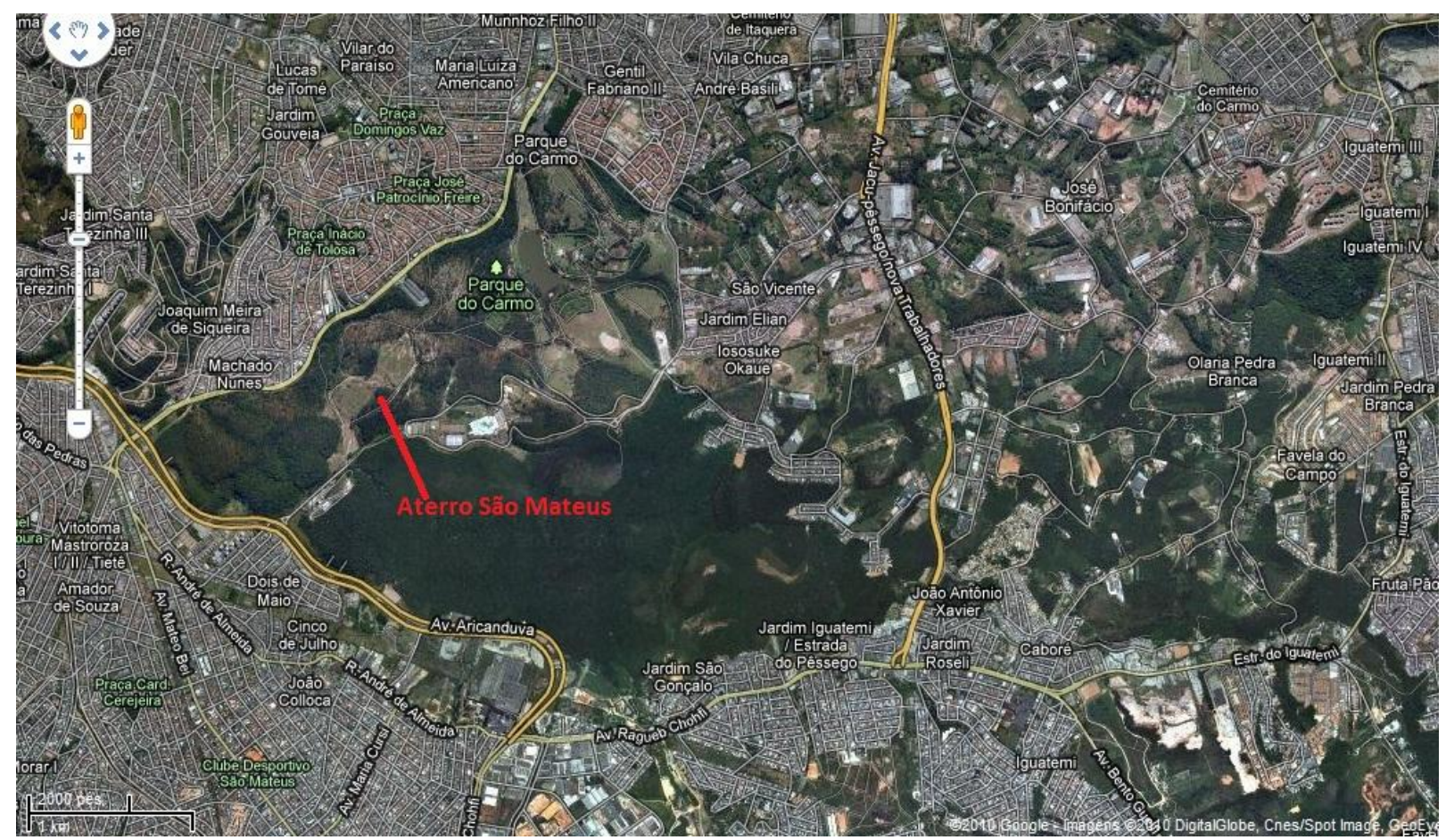

Figura 5.24 - Localização do aterro São Mateus

Fonte: Googlempas, imagem de 15/12/08, acesso em 15/11/10.

A cobertura vegetal está representada por gramíneas, arbustos e espécies arbóreas de pequeno porte, localizadas. Há presença de eucaliptos em faixa que se estende até o Parque do Carmo. (SVMA, 2001; Ramires et al, 2005; SVMA, 2005, USP/ESALQ, 2006). Segundo levantamento da USP/ESALQ (2006), contratado pela Ecourbis Ambiental, a vegetação original da APA do Carmo e dos fragmentos de

\footnotetext{
${ }^{31}$ O fechamento do aterro São Mateus (lixão do Parque do Carmo) foi fruto de intenso movimento social(Costa, 2000).
} 
vegetação nativa secundária do entorno do aterro pertencem ao tipo Floresta Ombrófila Densa (árvores de grande porte, epífitas, lianas) com elementos de Floresta Estacional Semidecídua, que está inserida no bioma Mata Atlântica, considerado um dos "hotspots" (áreas prioritárias para conservação da biodiversidade) mundiais (Myers et al. 2000) ${ }^{32}$.

A sua recuperação, em conjunto com os aterros Santo Amaro e Sapopemba, foi condicionada, também, ao Termo de Compromisso Ambiental, firmado pela Prefeitura do Município de São Paulo (Secretaria Municipal de Serviços - SES) com a Secretaria do Meio Ambiente do Estado de São Paulo (SMA) no âmbito do licenciamento da Central de Tratamento de Resíduos Sólidos Leste (CTL). Está prevista para 2012 no Plano Diretor Estratégico, não sendo indicada, entretanto, sua conversão para parque no Plano Regional da Subprefeitura de Itaquera.

Em 1996, no âmbito dessa recuperação, foi elaborado, pela mesma USP/ESALQ (2006), um projeto de restauração ecológica do aterro, o qual compreendeu o levantamento das diversas tipologias de vegetação, da avifauna e de alguns mamíferos (mastofauna), que será apresentado no Capítulo 7.

Investigação ambiental, contratada por Limpurb/SES, posteriormente, identificou áreas de revegetação e a presença de drenos de gás (Figura 5.25), além de verificar que em quase a totalidade dos limites do aterro foram dispostos resíduos (Figura 5.26). Nessa etapa o modelo conceitual revisado constatou que os resíduos (fonte primária) contaminam diretamente 0 solo $e$ as águas subterrâneas, detectando-se a contaminação de vapores em solo, com risco de explosividade para metano, de solo por arsênio e ferro e das águas subterrâneas por metais, 2,3,4,5tetraclorofenol (composto semi-volátil) e coliformes fecais e totais. A fim de verificar a evolução das concentrações de vapores de gás foi recomendado o monitoramento desses poços para avaliar a necessidade de implantação de sistema de extração. A contaminação do solo está associada ao solo exposto, indicando-se a sua impermeabilização para impedir o contato ou a ingestão pelos possíveis receptores. No caso das águas subterrâneas foi sugerido o monitoramento trimestral dos metais e do composto semi-volátil por dois ciclos hidrogeológicos para avaliar a possível realização de avaliação de risco (SES, 2009).

\footnotetext{
${ }^{32}$ MYERS, N.; MITTERMEIER, R.A.; MITTERMEIER, C.G. FONSECA, G.A.B.; KENT, J. Biodiversity hotspots for conservation priorities. NATIVE. V. 403, 2000. p. 853-858.
} 
A análise da investigação ambiental, realizada pelo GTAC/SVMA, corroborou com a sugestão de monitoramento da concentração dos vapores, para ambiente aberto, sem ocupação residencial. Recomendou o recobrimento da área de exposição dos resíduos com solo limpo e restrição à captação e consumo da água subterrânea em toda a região do aterro, concordando com a previsão anterior para o seu monitoramento. Além disso, notificou o Departamento de Águas e energia Elétrica (DAEE) e a Coordenação de Vigilância Sanitária (COVISA) sobre as inconformidades dos padrões de potabilidade encontrados nos poços de abastecimento do SESC. Adicionalmente, indicou a não utilização das águas do córrego e a instalação de drenagem do líquido percolado. No caso de reuso como parque, apontou a necessidade de realizar investigação detalhada com avaliação de risco à saúde humana e/ou adoção de medidas de controle institucional e de engenharia (SVMA, 2010b).
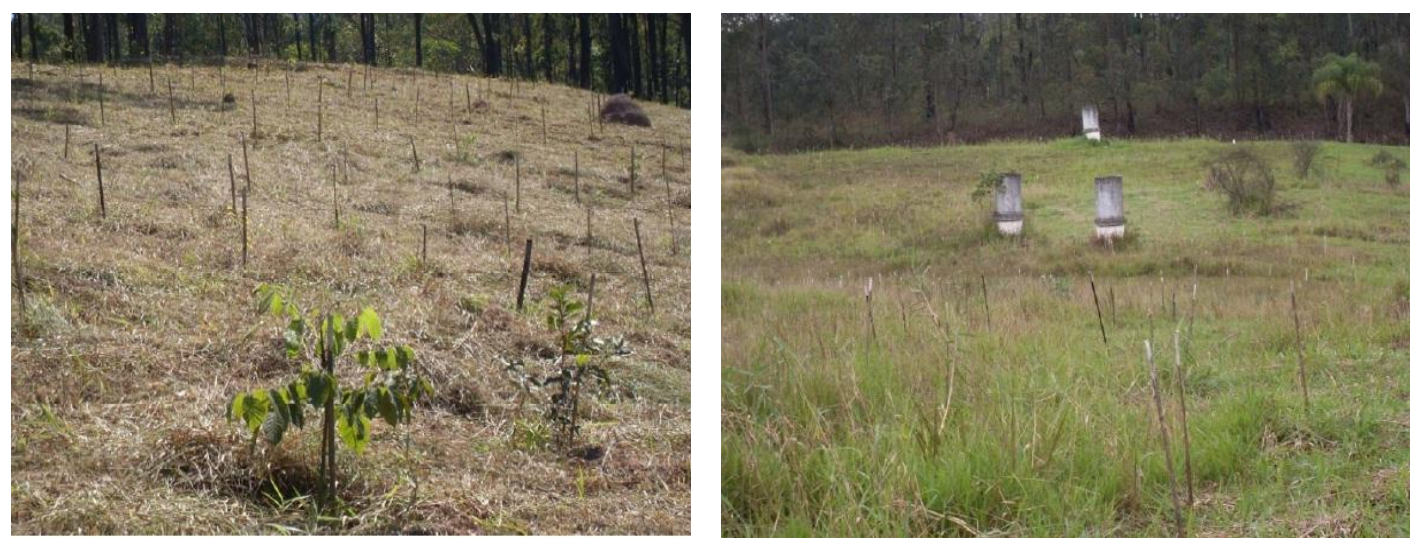

Figura 5.25 -Revegetação e drenos de gases existentes no aterro São Mateus e nos seus arredores. Fonte: SES (2009, p. 11-12).

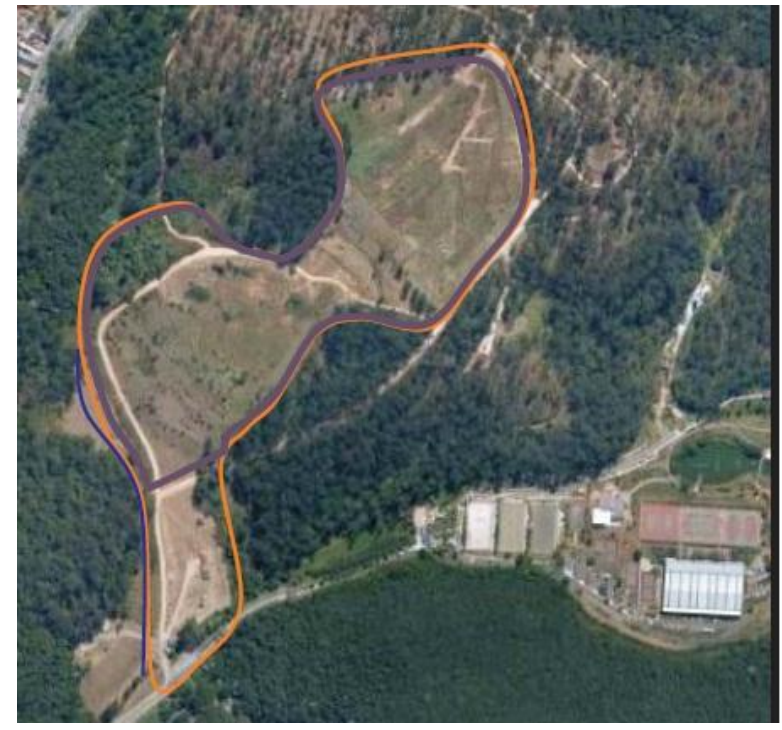

Legenda:

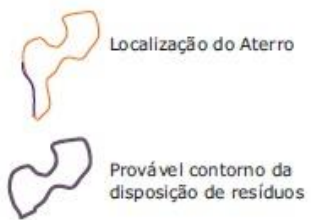

Figura 5. 26 - Localização do maciço de resíduos no aterro São Mateus

Fonte: Google Earth 2009 apud SES (2009, p. 49). 


\subsection{REFLEXões PRELIMINARES SOBRE O POTENCIAL DE REVEGETAÇÃo dOS}

ATERROS MUNICIPAIS

A análise do uso e ocupação do solo, usando as imagens fuzzy-maxlike ALOS, refinadas com a identificação da vegetação, em campo, associada aos princípios da ecologia de paisagens, no interior e nas imediações dos 14 aterros desativados no município de São Paulo; possibilitou a avaliação preliminar do potencial relativo de revegetação dessas áreas.

Considerando que a qualidade ambiental está relacionada ao tipo e à distribuição da cobertura do solo e à dinâmica da paisagem e, no caso específico de aterros, também, às limitações para o desenvolvimento de vegetação, a metodologia aplicada permitiu estimar os diferentes tipos de uso e ocupação do solo e as condições ambientais, no interior e no entorno (distâncias de 500, 1.000 e 2.000 m) desses antigos aterros.

Os resultados obtidos para os aterros do Grupo 1, ocupados por edificações, mostraram que esse grupo é o mais desfavorável à implantação de vegetação e ao seu potencial para uma possível requalificação como parque urbano. No caso dos parques-aterros Engenheiro Goulart e Carandiru (Parque da Juventude), Grupo 2, o primeiro, inserido no Parque Ecológico do Tietê, apresenta características mais favoráveis ao desenvolvimento e manutenção da vegetação. O Parque da Juventude está na zona central da cidade sob forte pressão da urbanização.

Os aterros dos Grupos 3 e 4, potenciais parques urbanos, à exceção do Parque Raposo Tavares, implantado desde 1981, apresentam o predomínio da vegetação herbácea no interior dos seus perímetros. A implantação desse tipo de cobertura está associada, muito provavelmente, às técnicas de engenharia preconizadas para recuperação de aterros, às limitações para implantação de vegetação de maior porte nesse tipo de maciço, ao desconhecimento ou falta de investimentos no desenvolvimento de métodos para seleção de espécies vegetais paisagísticas adaptadas às restrições desse tipo de ambiente e ao baixo custo perseguido pelas administrações públicas.

A vegetação arbórea é pouco significante nas imediações de todos os aterros desses dois grupos. Manchas contínuas de vegetação (maciço arbóreo pouco denso) se destacam nos arredores dos aterros Vila Albertina e São Mateus, 
associadas aos remanescentes existentes na Serra da Cantareira e na Área de Proteção Ambiental do Parque do Carmo, respectivamente.

A urbanização exerce forte pressão sobre o Jacuí e, secundariamente, sobre o Raposo Tavares. Os solos expostos, com maior presença nos aterros Sapopemba e Santo Amaro, favorecem a ocorrência de processos de erosão e facilitam a contaminação sub e superficial.

A análise geral desses dois grupos de aterros, quanto ao potencial de revegetação, de acordo com os princípios da ecologia de paisagem, permitiu ordená-los do maior potencial para o menor: Vila Albertina, São Mateus, Santo Amaro, Sapopemba, Raposo Tavares e Jacuí ${ }^{33}$. A essa condição associa-se, também, as maiores dificuldades para a formação de corredor verde interligando o Morro do Cruzeiro e a Baixada Santista, sugerida por Volpe-Filik et al. (2007), para o Sapopemba, do mesmo modo que há maiores restrições à conectividade da paisagem, previstas nos Planos Diretor e Regionais Estratégicos para o parqueaterro Raposo Tavares e o Jacuí (Parque Jardim Primavera).

Quanto às condições socioambientais, os aterros situam-se em distritos com quase o mesmo índice populacional, variando entre 151.000 e 186.000 habitantes, com exceção do distrito do Parque do Carmo, com menor índice (69.000 habitantes). A densidade demográfica, entretanto, apresenta valores variados com maiores taxas nos distritos São Rafael $(115,28)$ e Pedreira $(88,14)$ e menores no Parque do Carmo $(44,35)$ e Tremembé (32,30). Quanto aos tipos socioambientais dos distritos, os aterros Vila Albertina e São Mateus correspondem aos distritos Tipo 1 e o Santo Amaro e Sapopemba aos do Tipo 2. A descrição das características dessas classes de distritos, contida na Tabela 5.1, que representam as áreas mais periféricas do município, corrobora com o uso e ocupação do solo dessas áreas, analisados no item 5.3.1.

Os aterros foram implantados, na sua maioria, sobre antigas cavas de mineração, à exceção do Sapopemba e, em zona de recarga de aqüífero, no caso do próprio Sapopemba e do Vila Albertina, situações que favorecem a ocorrência de processos de contaminação do solo e das águas superficiais e subterrâneas.

Quanto à contaminação associada a esses aterros, as investigações realizadas confirmaram a contaminação do solo e das águas subterrâneas, por

\footnotetext{
${ }^{33}$ A avaliação do potencial de conectividade da paisagem será aprofundado nos estudos de caso, parque Raposo Tavares e aterro Jacuí, por meio do desenvolvimento de um modelo de tomada de decisão, a ser apresentado no Capítulo 8.
} 
metais, nos aterros inativos a mais de 20 anos, Sapopemba e São Mateus. No caso do Vila Albertina, segundo o GTAC, as contaminações constatadas não podem ser diretamente associadas ao seu maciço de resíduos. Esses resultados indicaram a necessidade de monitoramento do solo e das águas subterrâneas e a restrição à captação e ao consumo dessas últimas, também, pelos altos valores de coliformes fecais e totais encontrados. O aterro Santo Amaro ainda não foi submetido às avaliações ambientais, porém, o alto volume de resíduos depositados (16 milhões de toneladas) sobre antiga exploração de areia, nos sedimentos aluvionares do Rio Grande, num período de 19 anos, são fatores que contribuem sobremaneira para a confirmação de contaminação. As condições do entorno são ainda agravadas por ele se situar no polígono classificado como área contaminada crítica do Jurubatuba.

A geração de gás (metano) está presente em todos eles, sendo o Sapopemba merecedor de maior atenção, pois há migração do metano para o seu entorno, intensamente ocupado. As estimativas de produção do metano obtidas nos aterros Vila Albertina e Santo Amaro (40 anos após encerrados), quando extrapoladas aos outros aterros, apontam para um período de aproximadamente 15 anos para o término da sua produção no Sapopemba e no São Mateus.

Os resultados e discussões apresentados nos itens 5.3.1 e 5.3.2, quando associados às possibilidades efetivas de requalificação dos aterros para parquesaterros urbanos, corroboram a ordem do maior para o menor potencial, já indicada anteriormente: Vila Albertina, São Mateus, Santo Amaro e Sapopemba. 


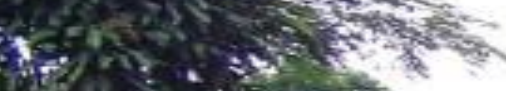

\%

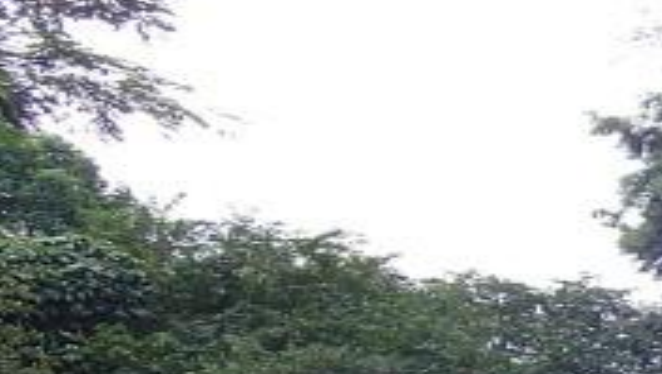

$5-4$

\section{Parte}

Processo de requalificação dos lixões e aterros desativados na paisagem paulistana

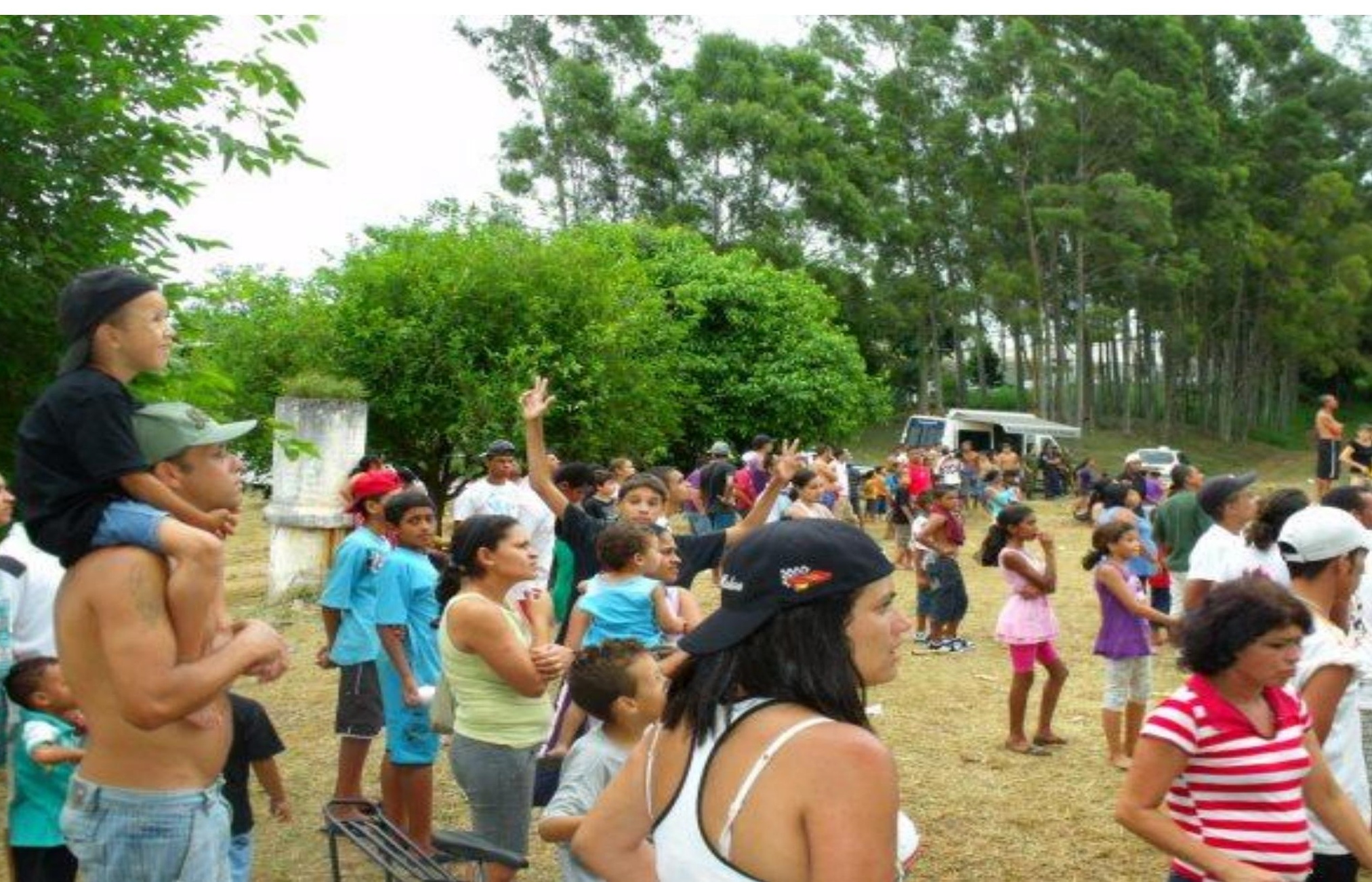


Antigo dreno de gás do aterro Jacuí, próximos a locais de circulação da população, futuro Parque Jardim Primavera, zona leste do município de São Paulo.

Foto da autora em 2007

2 Festival de pipas no futuro Parque Jardim Primavera (abril/2010), zona leste do município de São Paulo.

Foto cedida pelo morador Sylvio Sena. 


\section{REQUALIFICAÇÃO DOS ANTIGOS LIXÕES E ATERROS EM PARQUES URBANOS}

As mudanças na paisagem urbana das metrópoles, nos tempos contemporâneos, vêm sendo caracterizada pelo surgimento de várias áreas subutilizadas, abandonadas, degradadas e com potencial de contaminação do solo e das águas subterrâneas, que requerem a sua adequada requalificação. A requalificação de áreas contaminadas considerada do ponto de vista urbanopaisagístico e não apenas do controle de fontes de poluição, depende de uma série de fatores, dentre os quais se incluem aspectos legais, econômicos e políticos, além do envolvimento dos diversos setores interessados nesse processo, em especial a população dos seus arredores.

No que diz respeito aos empreendedores públicos e privados, a maior preocupação na reutilização desses espaços reside, principalmente, na responsabilização futura com relação ao tratamento do passivo ambiental existente, que ainda é um assunto juridicamente bastante controverso. Por outro lado, o desconhecimento a respeito do problema e das suas conseqüências ainda provoca uma série de resistências por parte de setores da própria municipalidade, 
especialmente aqueles ligados à aprovação de projetos de parcelamento, uso e ocupação do solo.

A pressão da urbanização incentivada pelo mercado imobiliário vem, nos últimos tempos, alcançando os antigos locais de disposição de resíduos, hoje desativados. O reuso preconizado para esses espaços, em virtude das restrições impostas pelo seu substrato e dos custos envolvidos, de modo geral, tem sido a implantação de parques com a inclusão de áreas verdes, de lazer e recreativas. A fim de assegurar o uso e ocupação seguros dessas áreas é necessário entender os conceitos envolvidos na sua recuperação e os métodos disponíveis para evitar, controlar e minimizar os possíveis danos socioambientais e materiais provocados pela disposição indiscriminada desses resíduos nos espaços urbanos.

Neste sentido, esse capítulo apresenta os vários conceitos estabelecidos para a recuperação das áreas degradadas, em especial contaminadas, sugerindo a criação de um novo termo no quadro do gerenciamento das áreas contaminadas. Além disso, discute as restrições impostas para a revegetação de maciços de resíduos sólidos urbanos. O capítulo descreve, também, os métodos de remediação da contaminação, aplicáveis aos RSU, especialmente a fitorremediação e as zonas alagadas. Esses elementos que possuem várias funções, dentre elas, a recomposição de habitats e a despoluição, ao mesmo tempo, podem ser incorporados aos projetos paisagísticos a serem desenvolvidos para os futuros parques.

\subsection{ConCEITOS: REQUALIFICAÇÃo dE ÁREAS DEGRADADAS OU}

CONTAMINADAS

O processo de urbanização crescente do Município ao englobar as áreas periféricas das cidades incorpora ao núcleo urbano, áreas destinadas às atividades industriais, à disposição de resíduos, à preservação e conservação da vegetação, etc. Concomitantemente, desde o início do século passado, vem ocorrendo o fechamento ou transferência das indústrias, o esgotamento das áreas utilizadas como descarte de resíduos e o desmatamento, processos de transformação que 
contribuem para o surgimento de áreas desativadas, abandonadas, desmatadas, ou seja, degradadas, os brownfields (Capítulo 2).

A degradação de uma área requer o re-estabelecimento de condições ambientais que promovam a sua recuperação ambiental. Essas intervenções na paisagem urbana são denominadas como recuperação, restauração, renovação, requalificação, revitalização, reabilitação, remediação, etc.. Esses termos muitas vezes se confundem, sendo cada qual, utilizado de acordo com os objetivos prioritários, atividades desenvolvidas ou os profissionais envolvidos no projeto.

Rodrigues e Gandolfi (2004, p. 235) afirmam que a Recuperação de Área Degradada (RAD) "é uma conseqüência do uso incorreto da paisagem e fundamentalmente dos solos por todo o país, sendo apenas uma tentativa limitada de remediar um dano que na maioria das vezes poderia ter sido evitado".

A recuperação ambiental "é um termo geral que designa a aplicação de técnicas de manejo visando tornar um ambiente degradado apto para um novo uso produtivo, desde que sustentável". Dentre os vários termos compreendidos pela recuperação encontra-se a restauração, que se refere ao processo de retornar uma área degradada às condições originais (Sanchez, 2006, p.41). A restauração sensu stricto, entretanto, é uma condição praticamente inatingível, pois, na grande maioria dos casos, não se dispõe de dados ou recursos suficientes para a reconstrução do sítio original (Oliveira, 2004). Nos casos específicos de conversão de lixões/aterros em parques considera-se que o termo é inadequado visto que é impossível restabelecer as condições originais.

O conceito de RAD, estabelecido pelo IBAMA (1990, p. 13), melhor se ajusta ao termo reabilitação, pois ele significa um novo uso a uma dada área, tornando-a estável ambientalmente, como destacado a seguir

[...] o processo de retornar o sítio degradado a uma forma de utilização de acordo com um plano preestabelecido para o uso do solo, o que implica em que uma condição estável será obtida em conformidade com os valores ambientais, estéticos e sociais da circunvizinhança. Significa, também, que o sítio degradado terá condições mínimas de estabelecer um novo solo e uma nova paisagem.

Segundo Box (1978) a reabilitação é o termo utilizado quando há o reuso do solo de um local alterado, de acordo com projeto prévio e em condições compatíveis com circunvizinhança, para outra finalidade. Sanchez (2006, p. 41) 
define a reabilitação como a forma de recuperação mais freqüente, relacionada à habilitação de uma área para um novo uso, denominada de redefinição ou redestinação (Rodrigues e Gandolfi, 2001, p. 238), originando um ecossistema alternativo (Cains Jr., 1986, p. 473). Valentim (2007) relaciona o termo às intervenções urbanas em áreas com passivos ambientais e econômicos, resultantes das externalidades negativas do processo industrial, com o objetivo de reintroduzir essas áreas ao ciclo econômico urbano com base no desenvolvimento sustentável.

Nos casos em que esse instrumento é utilizado em áreas degradadas, por contaminação, são usados os termos remediação e revitalização. As ações de remediação deverão constar de um projeto e, durante sua execução, a área deverá estar sob monitoramento, sendo definida como (Cetesb, 2001, p. 5)

[...] a técnica ou conjunto de técnicas aplicada a uma área contaminada, visando a remoção ou a contenção dos contaminantes presentes, de modo a assegurar a sua utilização futura, com limites aceitáveis de riscos aos bens a proteger.

A revitalização (Cetesb, 2001, p. 5), termo empregado usualmente pelos arquitetos e urbanistas, é "a reabilitação de uma área, onde possa ter havido alguma contaminação, que poderá ser remediada até o ponto em que seja seguro um novo uso pretendido".

Os meios urbanos podem ser degradados por processos socioeconômicos (redução de investimentos) ou físicos (poluição/contaminação); utilizando-se nestes casos os termos revitalização ou requalificação (Sanchez, 2006), termos opostos à renovação (ações de demolição/reconstrução), que na sua concepção incluem as interfaces com o ambiente do entorno, a tradição, cultura e laços sociais do local (Valentim, 2007).

Uma das formas de promover a recuperação ambiental ou a requalificação dos aterros desativados se faz pela implantação de vegetação ou revegetação. No processo para restabelecimento de mata ciliar, Crestana (1993 ${ }^{1}$ apud Oliveira, 2004) considera que a revegetação deve levar em conta o grau de degradação da área bem como a fisionomia da vegetação, características que podem ser extrapoladas para o caso da revegetação de aterros. Dentre os métodos utilizados, o autor propõe o reflorestamento heterogêneo com espécies nativas regionais. No entanto, Oliveira 
(2004) observa que os empreendedores em busca de resultados à curto prazo utilizam espécies exóticas de crescimento rápido (eucaliptos e pinus), que não contribuem para a conservação da fauna e flora locais. Segundo o IBAMA (1990), a seleção de espécies deverá contemplar as espécies arbóreas, arbustivas, herbáceas cultivadas e a serrapilheira. O uso de espécies exóticas dependerá da análise de possível interferência no desenvolvimento da flora nativa.

Vitalizar significa no dicionário (Ferreira, 1975) restituir à vida, dar nova vida, dar força, vigor, vitalidade a; e qualificar corresponde a atribuir qualidade, avaliar, apreciar, emitir opinião a respeito de. Considerando esses diferentes significados se utilizará o termo requalificação, do mesmo modo que Valentim (2007), mais apropriado para a análise dos casos de estudo, quanto à qualidade da paisagem e de vida nos parques urbanos e nos seus arredores.

\subsection{Requalificação de Áreas Degradadas por Contaminação, no MunicíPIO de SÃo PAULO}

A questão de contaminação de solo e água, principalmente subterrânea, no Município, vem sendo destacada desde a criação da Secretaria Municipal do Verde e Meio Ambiente - SVMA, em 1993. O Departamento de Controle da Qualidade Ambiental - Decont vem se deparando desde sempre com os impactos ambientais advindos de atividades industriais, comerciais e de disposição de resíduos sólidos que apresentam potencial para contaminação do solo e água, como visto no Capítulo 3.

Como produto da pressão por novos terrenos, especialmente em áreas urbanas ou suburbanas, os aterros desativados tornaram-se parcelas de terra, valiosas, com custo real e, começa a ser prioritário promover a remediação segura de quaisquer dos contaminantes in-situ (USEPA, 2002).

Borella (2004) comenta que é inevitável a existência de passivo ambiental advindo dos aterros sanitários, pois esse é o tratamento atual dado aos resíduos gerados no município de São Paulo e, que a recuperação dessas áreas é o meio de cumprir a política ambiental apregoada no Plano Diretor. 
O reconhecimento do passivo ambiental, pela sociedade, está diretamente relacionado ao nível de conhecimento tecnológico e científico, a sua percepção do risco e do perigo, à estrutura técnica e administrativa, das várias entidades, à existência de instrumentos legais e financeiros, aos efeitos à saúde e aos bens a proteger, ao mercado imobiliário, à pressão da população e ao desenvolvimento e evolução urbana, ao longo do tempo.

Tomando como concepção a importância de incorporar as áreas contaminadas ao tecido urbano, de modo a promover a melhoria da qualidade ambiental e reverter o processo de exclusão social, o Município, em 2002, iniciou o desenvolvimento do projeto Modelo de Gerenciamento de Revitalização de Áreas Degradadas por Contaminação, que selecionou a área do antigo lixão e incinerador do Sumidouro como projeto-piloto. Atualmente, o local está requalificado como Praça Victor Civita (vide Capítulo 7).

De posse de todas as definições apresentadas, do conhecimento sobre as etapas definidas no Manual de Gerenciamento das Áreas Contaminadas (Cetesb, 2001) e do reconhecimento do passivo ambiental pela sociedade, sugere-se a incorporação do termo área contaminada requalificada, no sistema de gestão de áreas contaminadas. Para tanto, propõe-se a definição para o novo termo como a área na qual foi empregado um conjunto de medidas (monitoramento, controle institucional e de engenharia e remediação) ajustadas aos projetos de requalificação específicos, que incorporem os aspectos socioambientais e culturais da paisagem do entorno. O projeto de requalificação deverá propiciar o envolvimento dos seus futuros usuários, desde o início das investigações ambientais e da concepção dos projetos de remediação, de engenharia, de arquitetura ou paisagísticos, para garantir a sua efetiva apropriação e manutenção.

\subsection{Limit AÇões PARA A REVEGETAÇÃo dE ATERROS DESATIVAdOS}

Os vários riscos socioambientais associados aos lixões ou aterros controlados, apresentados no Capítulo 4, restringem as formas de reuso desses espaços, incluindo especialmente a revegetação. 
A revegetação dessas áreas, no Brasil, utiliza comumente gramíneas de baixo porte, apesar da presença em seu território de uma das maiores biodiversidades do mundo. Andrade (2005) observa que a utilização das gramíneas protege a superfície da erosão, produz um bom efeito visual e funciona bem em projetos de campos de futebol e de golfe, sendo recomendadas pelos órgãos ambientais. $\mathrm{O}$ autor esclarece que o sistema radicular fasciculado da gramínea, com crescimento superficial, permite o uso de camada de solo agrícola pouca espessa para o seu desenvolvimento e evita o contato das suas raízes com o substrato e com os possíveis gases existentes em sub-superfície.

Lorenzi (1992 ${ }^{2}$ apud Andrade, 2000) considera que o plantio de gramíneas está relacionado à inexistência de estudos sobre o desenvolvimento da vegetação implantada em aterros brasileiros, o desinteresse ou a dificuldade financeira dos governos municipais na recuperação dessas áreas e o não investimento em técnicas para re-vegetação com fins paisagísticos.

O estabelecimento das espécies arbóreas e arbustivas exige maiores cuidados, pois, em geral, apresentam raízes mais profundas que as espécies herbáceas. A sua utilização, no entanto, deve ser ampliada devido às vantagens associadas à melhoria da qualidade do ar, à estabilidade solo, à manutenção de habitats, etc (vide Capítulo 7).

Gilman et al. (1981) ${ }^{3}$, Tchobanoglous et al. $\left(1993^{4}, 1994^{5}\right)$ apud Andrade (2000, 2005; Oliveira, 2004) relacionam uma série de condições que dificultam o plantio e o crescimento das plantas sob maciços de resíduos sólidos: toxicidade pelos gases gerados e pela presença de metais, movimentação diferencial da água, solos pobres em nutrientes e com capacidade de troca catiônica (CTC) limitada, temperaturas elevadas do solo, alta compactação e porosidade do solo, destruição da estrutura do solo, recalques diferenciais, saturação do solo de cobertura (drenagem deficiente), pouca espessura e salinidade ${ }^{6}$ do solo de cobertura. Andrade (2005) observa que a incorporação e o transporte (fitotransporte) dos poluentes pelos vegetais, ao mesmo tempo, podem disponibilizá-los para as cadeias tróficas,

\footnotetext{
${ }^{2}$ LORENZI, H. Árvores Brasileiras. Nova Odessa, SP: Ed. Plantarum, v.1, 1992. 368 p.

${ }^{3}$ GILMAN, E.F.; LEONE, I.A.; FLOWER, F.B. The adaptability o 19 woody species in vegetation a former sanitary landfill. Forest Science, Ohio, v. 27, n.1. 1981. p. 13-18.

${ }_{4}^{4}$ TCHOBANOGLOUS, G.; THEISEN, H.; VIRGIL, S.A. Integrated solid waste management: Engineering principles and managemt issues. New York: McGraw-Hill Inc. 1993. P. 778-790.

${ }^{5}$ TCHOBANOGLOUS, G.; THEISEN, H.; VIRGIL, S.A. Gestión integral de resíduos sólidos (tradução). 1ª ed. Madrid: McGrawHill Inc., v (s). 1-2, 1994.

${ }^{6}$ Andrade (2005) comenta que a salinidade é comum quando há recirculação do chorume para irrigação.
} 
favorecer o seu uso como bioindicadores ou nas técnicas de fitorremediação (vide ítem 6.5).

Quanto aos metais pesados, eles podem atuar na fisiologia do seres vivos como elementos essenciais ou tóxicos; dependo do tipo de metal e da sua dose. Quando os teores estão adequados ao bom desempenho fisiológico dos seres vivos são essenciais aos animais os metais $\mathrm{Cu}, \mathrm{Fe}, \mathrm{Mn}$, Mo e $\mathrm{Zn}$; às plantas o $\mathrm{Cu}, \mathrm{Fe}, \mathrm{Mn}$, Mo, Ni e Zn e o Co às bactérias fixadoras de nitrogênio. Teores excessivos destes mesmos elementos tornam-se tóxicos aos seres vivos. Alguns metais, entretanto, por não apresentarem nenhuma função fisiológica conhecida, são tóxicos em qualquer dose, caso do $\mathrm{Cd}, \mathrm{Pb}, \mathrm{Hg}$ Th; além do semi-metal As (Bustamante,19937; Kiehl, $1995^{8}$ e Berton, $2000^{9}$ apud Andrade, 2005).

A contaminação por metais pesados nas plantas apresenta alguns sintomas: folhas amareladas e com lesões, envelhecimento e desenvolvimento precoce (muitos frutos e poucas folhas), grande ramificação das raízes em sub-superfície, murchamento, nanismo, aridez da copa e engrossamento na base do tronco (Konold e Zeltner, $1983^{10}$ apud Andrade, 2000).

A propriedade de bioacumulação de alguns metais em seres vivos pode ocorrer por ingestão contínua de pequenas doses. O bioacúmulo do metal depende da quantidade ingerida e do mecanismo de sua eliminação (incluindo-se o decaimento radioativo ${ }^{11}$ ). Assim, a vegetação implantada sobre os RSU pode desencadear a contaminação dos seres vivos que circulam ou habitam essas áreas, por seu consumo ou mesmo pelo contato com a serrapilheira na camada de cobertura do solo.

As plantas tolerantes ${ }^{12}$ aos metais pesados (espécies metalófilas ${ }^{13}$ ) possuem a capacidade de acumulação dos metais na sua raiz e limitam sua

\footnotetext{
${ }^{7}$ BUSTAMANTE, M.M. da C. Biomonitoring of heavy metals using plants growing at former mining sites. Tese (Doutorado em ciências). Universität Trier, Trier. Alemanha. 1993.

${ }^{8}$ KIEHL, E.J. Utilização do composto de resíduos sólidos. In: Encontro Nacional de Reciclagem, Agricultura e Meio Ambiente. Campinas: CATI, 1995. p. 16-35.

${ }^{9}$ BERTON, R.S. Riscos de contaminação do agroecossistema com metais pesados. In: BETTIOL, W.; CAMARGO, A. (eds.). Impacto ambiental do uso agrícola do lodo de esgoto. Jaguariúna, SP. EMBRAPA-MA. 2000.

${ }^{10}$ KONOLD, W.; ZELTNER, G.H. Vegetation and rekultivierung von abgedeckten Mülldeponien. In: Beseitigung von Abfällen durch Ablagerung. 1983. p. 01-10.

11 Reação espontânea de transformação de átomo instável em estável (elemento-pai para elemento-filho). As taxas de decaimento radioativo (constantes de desintegração) independem das mudanças físicas ou químicas do ambiente e são expressas pelo conceito de meia-vida; que é o tempo decorrido para que a metade da quantidade original de átomos instáveis se transforme em estáveis (TEIXEIRA et al., 2003).

${ }_{12}$ A tolerância da vegetação aos metais pesados é caracterizada pela capacidade relativa de absorver, translocar e concentrar metais, sendo as plantas classificadas em acumuladoras, indicadoras e exportadoras, de acordo com as concentrações relativas de metais na raiz em relação à parte aérea (Marques, 1997 apud Andrade, 2005).

${ }^{13}$ Metalo+filo $=$ amiga dos metais.
} 
translocação (Marques, $1997^{14}$ apud Andrade, 2005). Os metais $\mathrm{Hg}, \mathrm{Pb}$ e As por se acumularem nas raízes e não serem translocados, em quantidades suficientes, para a parte aérea das plantas não causam risco à cadeia trófica. $O$ grupo dos metais insolúveis no solo e nas raízes das plantas, $\mathrm{Ti}, \mathrm{Cr}, \mathrm{Zr}, \mathrm{Y}, \mathrm{Ag}$ e $\mathrm{Sn}$, não são translocados e, por isso não se constituem em fonte de contaminação, mesmo em solo altamente contaminado. Os metais $\mathrm{Zn}, \mathrm{Cu}, \mathrm{Ni}, \mathrm{B}$ e $\mathrm{Mn}$, ao contrário, representam risco ambiental, pois a vegetação não é capaz de impedir a sua entrada na cadeia alimentar. Outros metais são absorvidos e constantemente responsáveis por toxicidade alimentar: $\mathrm{Se}$, Mo e $\mathrm{Cd}$. O Co, mesmo em níveis inferiores aos fitotóxicos, pode afetar a saúde de animais ruminantes (Chaney, $1980^{15}$ apud Berton, 2000 apud Andrade, 2005).

A qualidade do solo (forma de ocorrência, mobilidade dos íons metálicos, alcalinidade, etc.) de suporte da vegetação influencia diretamente a capacidade da absorção dos metais pelas plantas e os níveis de risco aos quais estarão expostos os seres vivos.

Os solos tropicais, bastante intemperizados, com predomínio de argilas do tipo 1:1 e óxidos de ferro e alumínio, possuem baixa seletividade e CTC. Essas características respondem pela ocorrência da atenuação dos metais no solo por precipitação, oclusão e retenção; funções relacionadas à presença dos altos níveis de hidróxidos e óxidos amorfos de ferro e de matéria orgânica (Labauve et al. $1988^{16}$, Pereira Neto, $1995^{17}$ apud Andrade, 2005). O comportamento dos metais em solos tropicais depende do teor de matéria orgânica presente, pois ela é responsável pela formação de complexos solúveis ou não, de acordo com a natureza dos ligantes orgânicos (Andrade, 2005).

No experimento de revegetação com espécies arbóreas e arbustivas (Figura 6.1), empreendido no aterro desativado Santo Amaro, por Andrade (2000, 2005), apresentado no Capítulo 5, foi constatado que as espécies testadas não trouxeram risco ambiental pela mobilização de metais pesados.

\footnotetext{
${ }^{14}$ MARQUES, V.S. Efeitos de zinco e cádmio em arroz (Oryza sativa L.) cultivado em solução nutritiva e em solo tratado com lodo de esgoto enriquecido. Dssertação (Mestrado em ciências). Universidade Federal Rural do Rio de Janeiro - UFRRJ, Rio de Janeiro. 1997

${ }^{15}$ CHANEY, R.L. Healthy risks associated with toxic metals in municipal sludge. In: BITTON, G. (ed.) sludge-Healthy risks of land application. An Arbor Sci. Publ., 1980. p. 59-83.

${ }_{16}$ LABAUVE, J.M., KOTOBY-AMACHER, J., GAMBRELL, R.P. The effect of soil properties and a synthetic municipal landfill leachate on the retention of $\mathrm{Cd}, \mathrm{Ni}, \mathrm{Pb}$ and $\mathrm{Zn}$ in soil and sediment materials. Journal WPCF, v. 60, n.3, Marsh, 1988. P. 379385.

${ }_{17}$ PEREIRA NETO, J.T. Reciclagem de resíduos orgânicos (compostagem). In: Encontro Nacional de Reciclagem, Agricultura e Meio Ambiente. Campinas, CATI, 1995. p. 55-81.
} 


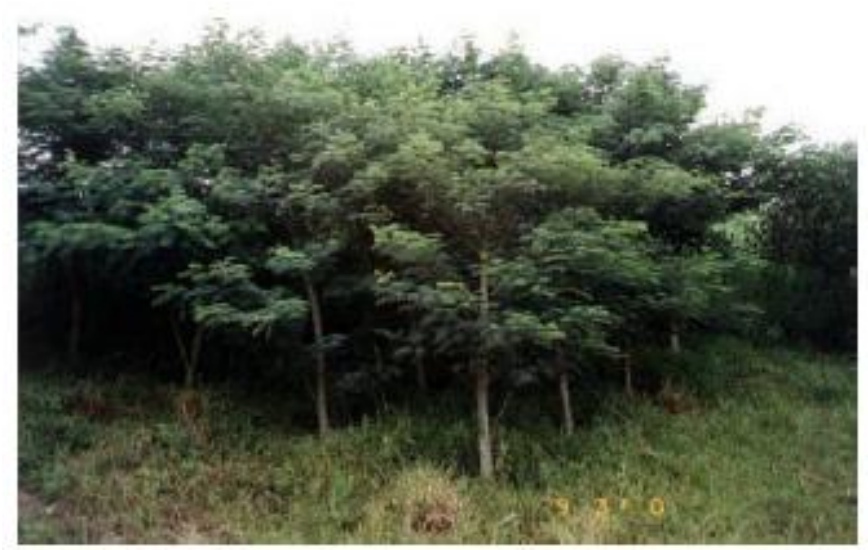

Figura 6.1- Enterolobium contorsiliquium, espécie vegetal introduzida no aterro desativado Santo Amaro, que se destacou pelos bons índices de estabelecimento e desenvolvimento.

Fonte: Andrade (2000, p. 154).

\subsection{MÉTODOS DE REMEDIAÇÃO DE ÁREAS CONTAMINADAS POR RESÍDUOS}

SóLIDOS

A remediação tem como objetivo a descontaminação ou a diminuição do seu risco, a níveis aceitáveis, à saúde humana e aos bens a proteger. As práticas de remediação são definidas a partir dos resultados obtidos na avaliação de risco e estão em constante evolução. Relacionam-se diretamente às características e ao comportamento do ambiente, do poluente, ao risco à saúde e aos bens a proteger, bem como aos aspectos econômicos. Basicamente as técnicas de remediação se dividem em: ex-situ, que se constitui na remoção e tratamento do solo contaminado, que posteriormente pode retornar ao local de origem e, in-situ, quando o tratamento do solo é realizado no próprio local, sem haver remoção.

A remediação de aterros se diferencia de outras áreas contaminadas. Nenhuma outra área contaminada possui uma proporção de contaminação tão grande, medidas em volume ou área. Além disso, a contaminação se espalha por toda a massa de resíduos, inviabilizando economicamente a remediação com a maioria das tecnologias de tratamento, isto é, não é possível tratar todo o solo contaminado nos aterros municipais (USEPA, 2002).

Furtado (1997 ${ }^{18}$ apud Vimieiro e Silva, 2007) afirma que os custos envolvidos nos projetos de remediação são muito altos. Relatou sobre um estudo

\footnotetext{
${ }^{18}$ FURTADO, M.R. Remediação - Controle Ambiental Chega ao Subsolo. Revista Química e Derivados. Outubro 1997.
} 
preliminar realizado no Estado de São Paulo envolvendo valores da ordem de US\$ 40 mil a US\$ 100 mil. Os custos dos estudos complementares e para o tratamento da área, foram estimados entre US\$500 mil a US\$ 5 milhões, com duração prevista para no mínimo dois anos.

Várias tecnologias de remediação estão disponíveis podendo cada uma ser utilizada isoladamente ou serem associadas. Não se tem a pretensão de uma descrição exaustiva dessas práticas, mas se apresenta um resumo das principais técnicas existentes (Tabela 6.1), compiladas de alguns autores: Silva (2001), Dinardi et al. (2003), Kurozawa (2005), Lima (2005), Vasques (2005) e Morinaga (2007).

Silva (2001) relata que a USEPA (1997) ${ }^{19}$, mediante a experiência do Superfund, estipulou para alguns casos, dentre eles, os aterros de resíduos, a remediação presumida, que contempla a redução de tempo e custo, principalmente, quanto à investigação detalhada. A utilização dos dados pré-existentes deve ser priorizada, a não ser que ocorram áreas com resíduos perigosos (hot-spots ou pontos quentes). Assim, a contenção foi o método de remediação presumida determinado para os aterros de resíduos, contemplando os seguintes elementos: sistema de cobertura, controle da fonte, para contenção da pluma, coleta e tratamento do percolado, coleta e tratamento do gás, controle institucional como complemento ao controle de engenharia. Nesses aterros, uma das principais medidas é a utilização do sistema de cobertura (Tabela 6.1) com drenagem de gases, a fim de evitar o contato de pessoas e animais, impedir a infiltração de água superficial, impedir a dispersão de partículas pelo vento e a formação de concentração de metano que dão origem às explosões (Figura 6.2).

O sistema de cobertura é mais eficiente quando há revestimento de base funcionando e quando os resíduos estão acima do nível d'água (CPEO, $1998^{20}$ apud USEPA, 2002). As coberturas geralmente são formadas pela compactação de argila e solo, combinada com uma membrana semi-permeável. O tipo mais sofisticado é conhecido por RCRA ${ }^{21}$, estimando-se um custo que varia de $U \$ 175$ milhões a mais de U\$ 225 milhões por acre (FRTR, 200022 apud USEPA, 2002).

\footnotetext{
${ }^{19}$ UNITED STATES ENVIRONMENTAL PROTECTION AGENCY (USEPA). Landfill Presumptive Remedy Saves Time and Cost. Office of solid Waste and Emergency Response. EPA540/F-96/017 (5202G).

20 Center for Public Environmental Oversight. Landfill Caps and Enhancements. $1998 . \quad$ Disponível em: <http://www.cpeo.org/techtree/ttdescript/landcap.html>.

${ }^{21}$ Resource Conservation Recovery Act, lei federal criada em 1976, que estabelece um sistema regulatório para as substâncias perigosas desde a sua origem até a sua disposição final. A lei exige o uso de procedimentos seguros no tratamento, transporte, estocagem e disposição final desses produtos (USEPA, 2002).

${ }_{22}$ Federal Remediation Technologies Roundtable. Landfill Cap. 2000. Disponível em: <http://www.frtr.gov/matrix2/section4/4 30.html>.
} 
Tabela 6.1 - Descrição sucinta das principais tecnologias de remediação

\begin{tabular}{|c|c|}
\hline Técnica & Definição \\
\hline $\begin{array}{l}\text { Sistemas de } \\
\text { cobertura }\end{array}$ & $\begin{array}{l}\text { Capas de diversos materiais dispostos, em ordem lógica, com função } \\
\text { específica, nem sempre só de impermeabilizar }\end{array}$ \\
\hline Lavagem de solos & $\begin{array}{l}\text { Jatos de água removem e separam as porções mais contaminadas. } \\
\text { Aditivos podem ser usados para aumentar a eficiência do processo. }\end{array}$ \\
\hline Incineração & $\begin{array}{l}\text { Queima de solos ou resíduos constituídos por produtos químicos } \\
\text { nocivos, em fornos, sendo eficiente para a destruição dos PCB's, } \\
\text { solventes e inseticidas. Contudo não elimina metais, necessitando que } \\
\text { as cinzas sejam enviadas para aterros especiais }\end{array}$ \\
\hline $\begin{array}{l}\text { Bombeamento } \\
\text { (Pump and Treat) }\end{array}$ & $\begin{array}{l}\text { A água subterrânea é bombeada através de poço para a superfície, onde } \\
\text { recebe tratamento para remoção dos contaminantes }\end{array}$ \\
\hline $\begin{array}{l}\text { Extração de } \\
\text { vapores (SVE) }\end{array}$ & $\begin{array}{l}\text { Técnica avançada aplicada na zona não saturada, que consiste na } \\
\text { injeção de vácuo continuamente no solo, para remoção e tratamento de } \\
\text { hidrocarbonetos adsorvidos no solo, em fase vapor }\end{array}$ \\
\hline Air sparging (AS) & $\begin{array}{l}\text { Injeção de ar na zona saturada para remoção de hidrocarbonetos } \\
\text { dissolvidos na água e adsorvidos no solo, através de volatilização }\end{array}$ \\
\hline $\begin{array}{c}\text { Extração } \\
\text { multifásica (MPE) }\end{array}$ & $\begin{array}{l}\text { Extração simultânea das fases vapores, dissolvida e livre das zonas } \\
\text { saturada e não saturada }\end{array}$ \\
\hline Oxidação química & $\begin{array}{l}\text { Promove a degradação dos compostos orgânicos através da injeção de } \\
\text { oxidantes (peróxido ou permanganato) }\end{array}$ \\
\hline Barreiras reativas & $\begin{array}{l}\text { São paredes permeáveis construídas no solo, constituídas de material } \\
\text { reativo (ferro, calcário ou carbono) que capturam os contaminantes e os } \\
\text { transformam em substâncias inofensivas }\end{array}$ \\
\hline Biorremediação & $\begin{array}{l}\text { Utilização de microorganismos para degradar componentes orgânicos no } \\
\text { solo ou nas águas subterrâneas. }\end{array}$ \\
\hline
\end{tabular}

Organização: Luzia Helena dos S. Barros

Fonte: Silva (2001), Dinardi et al. (2003), Kurozawa (2005), Lima (2005), Vasques (2005) e Morinaga (2007).

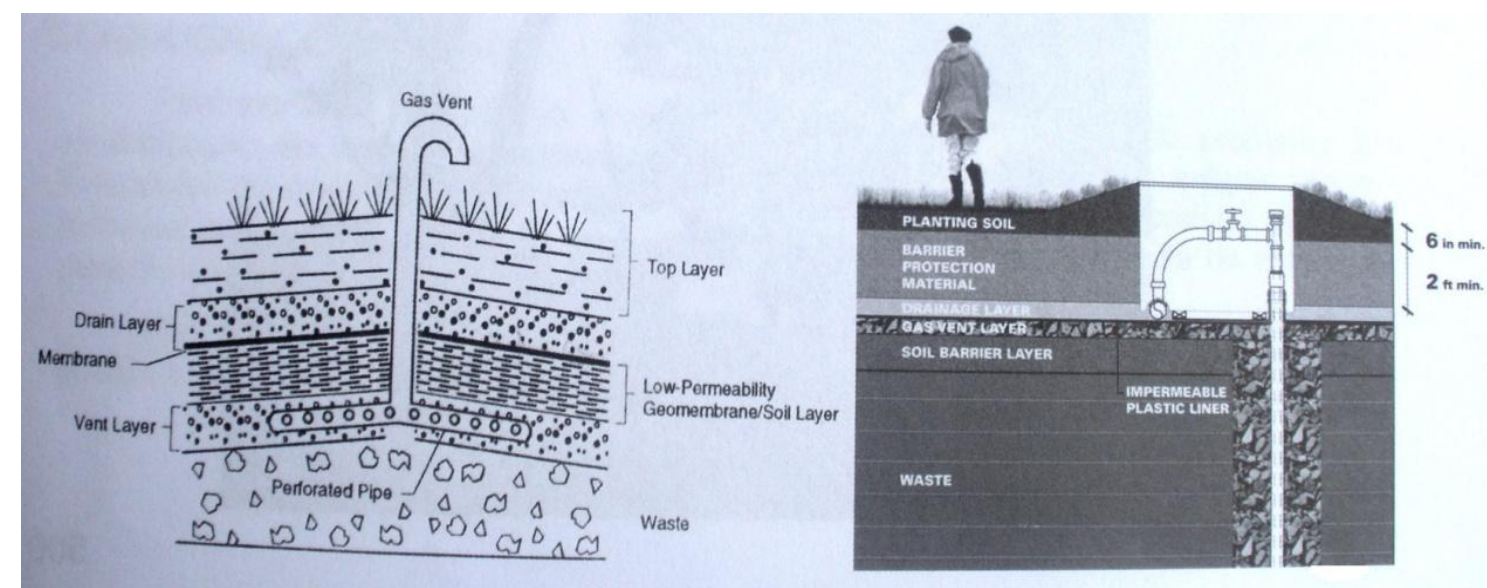

Figura 6.2 - Sistemas de cobertura com ventilação para gás: passivo, à esquerda e ativo, à direita, com bombeamento em poços profundos.

Fonte: USEPA (1991 apud Grube, $1992^{23}$ idem Silva, 2001, p. 29); NYC (2001 ${ }^{24}$ apud Silva e Sepe, 2009, p.499).

\footnotetext{
${ }^{23}$ GRUBE, W. Covers, slurry walls, grouting and dynamic compaction for RCRA corrective action stabilization. In:RCRA Corrective Action Stabilization Technologies, Proccedings, USEPA, EPA/625/R-92/014. P.29-40.

${ }^{24}$ NEW YORK CITY. Freshskill: Landfill to landscape. New York City Department of City Planning. 2001. Disponível em: $<$ http//:www.nycgovparks.org/sub_your_park/fresh_kills_park/html/fresh_kills_park/html>. Acesso em out. 2009.
} 
Gloeden (1999) identificou na bacia hidrográfica do Guarapiranga (área de proteção de mananciais da RMSP) nove antigas áreas de disposição de resíduos recomendando a implantação de, no mínimo, um sistema de cobertura ou a realização de obras para o seu isolamento, independente da constatação de contaminação; tal como a medida de remediação presumida, determinada pela EPA.

A revisão bibliográfica, realizada por Silva (2001), não identificou nenhuma área de aterro desativado, com passivo ambiental, recuperada, no território nacional, apenas casos onde foi executada a conversão de lixões em aterros controlados. Essa situação recentemente modificou-se, especialmente, no município de São Paulo com os exemplos da Praça Vitor Civita e do Parque Olímpico (vide Capítulo 7) e o Jardim Parque Primavera (vide Capítulos 8 e 9).

Segundo Lima (2005), a bioremediação, devido ao seu baixo custo, em relação às tecnologias mais tradicionais, obteve aceitação generalizada, a partir de 1993. Cita Devo (1993) que informa sobre programa governamental, nos Estados Unidos, que tratou 3.000 áreas degradadas por resíduos com a técnica. E ainda a EPA (1995) que, na década de 1990, computava cerca de 800 aterros sanitários e controlados tratados com a bioremediação. Comenta, também, que o mercado da bioremediação será incentivado em função das exigências, quanto à remediação do passivo ambiental de resíduos, contidas na ISO-14.001; além da necessidade de certificação com o Selo Verde. A bioremediação, em termos de processo, admite algumas variações (Tabela 6.2).

Tabela 6.2 - Descrição sucinta das principais tecnologias de bioremediação

\begin{tabular}{|c|c|}
\hline $\begin{array}{c}\text { Técnicas de } \\
\text { Bioremediação }\end{array}$ & \multicolumn{1}{c|}{ Definição } \\
\hline Biosparging & $\begin{array}{l}\text { Estimula (injeção de ar e micronutrientes) os microorganismos autóctones } \\
\text { para a biodegradação dos compostos orgânicos da zona saturada. }\end{array}$ \\
\hline Bioventing & $\begin{array}{l}\text { Aeração do solo com a injeção de nutrientes para estimular a atividade } \\
\text { biológica do meio com os microorganismos autóctones }\end{array}$ \\
\hline Fitorremediação & $\begin{array}{l}\text { Utiliza os processos naturais das plantas para remover os contaminantes } \\
\text { dos solos, dos lodos, dos sedimentos e das águas. }\end{array}$ \\
\hline $\begin{array}{c}\text { Atenuação } \\
\text { natural }\end{array}$ & $\begin{array}{l}\text { São processos de ocorrência natural. Digestão de contaminantes pela ação } \\
\text { de micróbios, a sua fixação no solo, que impede a sua migração e a } \\
\text { eliminação de gases pela radiação solar }\end{array}$ \\
\hline $\begin{array}{c}\text { Zonas alagadas } \\
\text { (Wetlands) }\end{array}$ & $\begin{array}{l}\text { São áreas úmidas, naturais ou construídas, com substrato saturado, pouco } \\
\text { oxigenado, que favorece a vegetação com funções para estabilizar o solo e } \\
\text { os sedimentos e remover os nutrientes da água }\end{array}$ \\
\hline
\end{tabular}

Organização: Luzia Helena dos S. Barros 


\subsubsection{FITORREMEDIAÇÃo}

A fitorremediação é uma técnica de tratamento in-situ, de baixo custo e fácil implantação, sendo recomendada para grandes áreas e pequenos níveis de contaminação; encontrados em pouca profundidade e que não ofereçam risco iminente à saúde. Pode ser empregada com finalidades estéticas em projetos paisagísticos. A espécie vegetal a ser selecionada estará condicionada ao tipo de contaminante, bem como às condições locais de clima e solo, ao seu rápido crescimento, à profundidade das suas raízes, à facilidade de plantio e manutenção e, ainda, à sua capacidade de captar grande quantidade de água, eliminando-a pela evapotranspiração. Essa técnica tem sido aplicada, nos Estados Unidos, em aterros industriais e municipais, em faixas de passagem de dutos, em campos agrícolas, em locais de tratamento de madeira, em postos de combustíveis, em bases militares, em estações de tratamento de esgoto e em minerações (Morinaga, 2007).

Conforme Vimieiro e Silva (2007) a fitorremediação pode ser classificada em diversos tipos (Figura 6.3) dependendo do comportamento do contaminante, quando sob a ação de processos de degradação, extração ou contenção, isolados ou em conjunto (Figura 6.4).

Dinardi et al. (2003) descreve a fitorremediação como a biotecnologia que emprega sistemas vegetais fotossintetizantes e sua microbiota para desintoxicar ambientes degradados ou poluídos. As substâncias alvos, nesse processo, são os metais ( $\mathrm{Pb}, \mathrm{Zn}, \mathrm{Cu}, \mathrm{Ni}, \mathrm{Hg}, \mathrm{Se})$; compostos inorgânicos $\left(\mathrm{NO}^{-3}, \mathrm{NH}_{4}, \mathrm{PO}_{4}^{-3}\right)$, elementos químicos radioativos $(\mathrm{U}, \mathrm{Cs}, \mathrm{Sr})$; hidrocarbonetos derivados de petróleo $\left(B T E X^{25}\right)$, pesticidas e herbicidas; explosivos; solventes clorados e resíduos orgânicos industriais $\left(\mathrm{PCB}^{\prime} \mathrm{s}^{26}, \mathrm{PAH}^{27} \mathrm{~s}^{27}\right.$ ), entre outros. Apresenta exemplo da aplicação da técnica no tratamento de chorume, utilizando o aguapé, na sua parte líquida (Figura 6.5), quanto pela irrigação, empregando tubérculos (beterraba, cenoura, rabanete) e espécies folhosas (alface).

\footnotetext{
${ }^{25}$ Benzeno, tolueno, estireno e xileno.

${ }^{26}$ Bifenilas policloradas

${ }^{27}$ Hidrocarbonetos poliaromáticos.
} 
Requalificação dos Aterros Desativados (BrownfieldS) no Município de SÃo PaUlo: Parques (GreenfieldS) RAPOSO TAVARES E JARDIM PRIMAVERA

LUZIA HELENA dos SANTOS BARROS

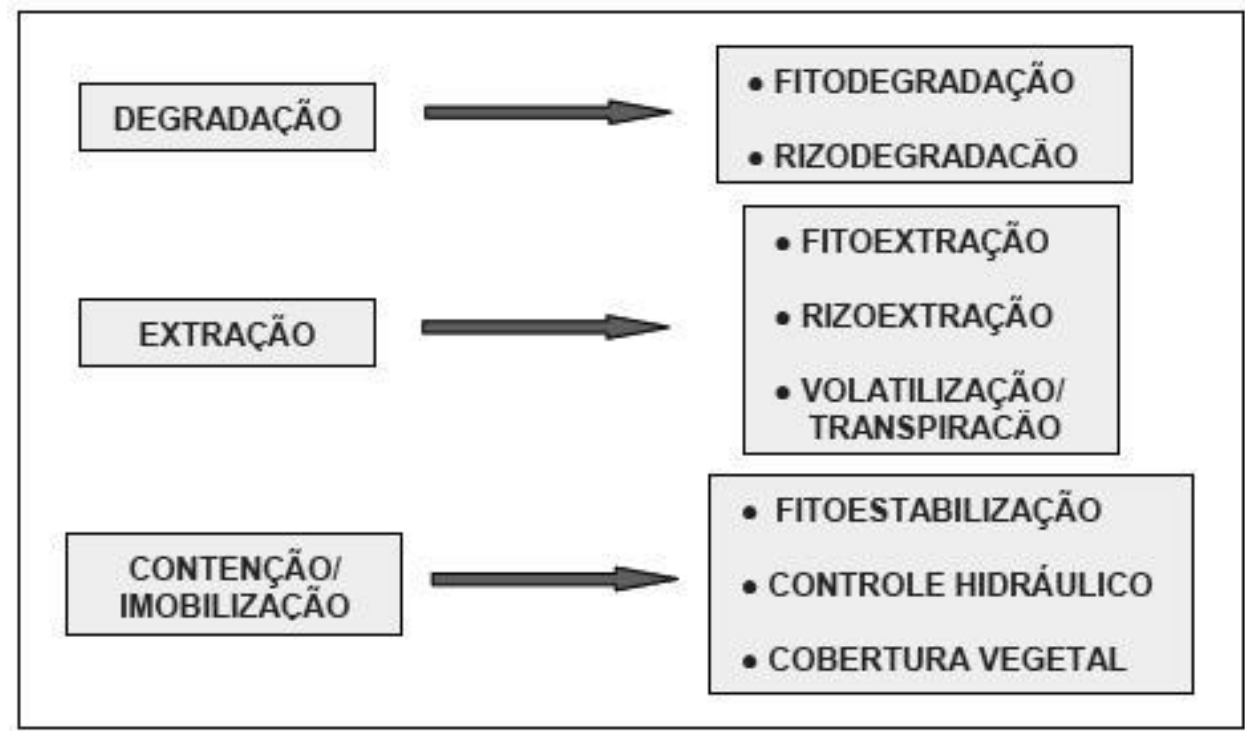

Figura 6.3 - Tipologias da fitorremediação, de acordo com os mecanismos de ação. Fonte: Vimieiro e Silva (2007, p.3)

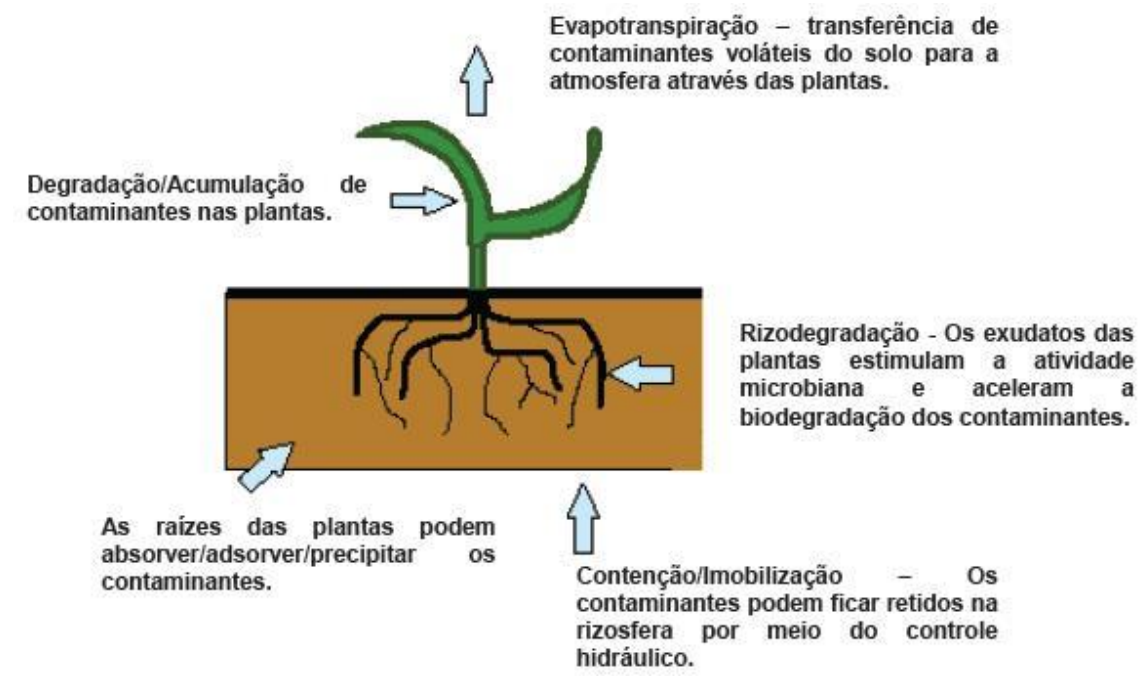

Figura 6.4 - Mecanismos de ação da fitorremediação.

Fonte: Vimieiro e Silva $(2007$, p.3)

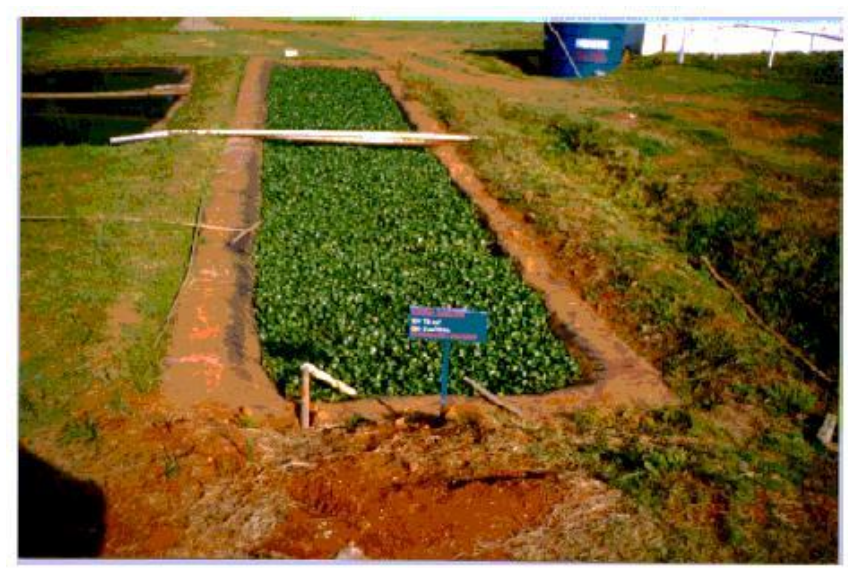

Figura 6.5: Aplicação da fitorremediação em chorume utilizando o aguapé Fonte: Dinardi et al. (2003, p.11) 
Segundo aqueles autores a fitorremediação pode ser aplicada, também, no controle da erosão e da disseminação de metais pesados no solo (Figura 6.6). A técnica consiste na retirada de solo contaminado de valas paralelas e da superfície de toda a área, substituindo-o por solo não contaminado. Sobre o solo contaminado, entre as valas, coloca-se uma camada de calcário (filtro químico) com $2 \mathrm{~cm}$ de espessura, dificultando a migração do metal e preservando a vegetação. Recomenda-se a implantação de dois tipos de vegetação: arbórea sobre as valas e herbácea (gramíneas) nos três metros que as separam uma da outra. Das árvores testadas destacaram-se duas espécies de eucalipto: a calaminácea e a crucífera, acumuladoras de cádmio. Foi testado, também, o desenvolvimento do eucalipto com e sem a colocação do filtro químico (Figura 6.7). Rodriguez (2007) recomenda a utilização do bambu na fitorremediação, espécie vegetal com sistema de raízes que favorece a atividade bacteriana e a degradação de contaminantes (Figura 6.8).

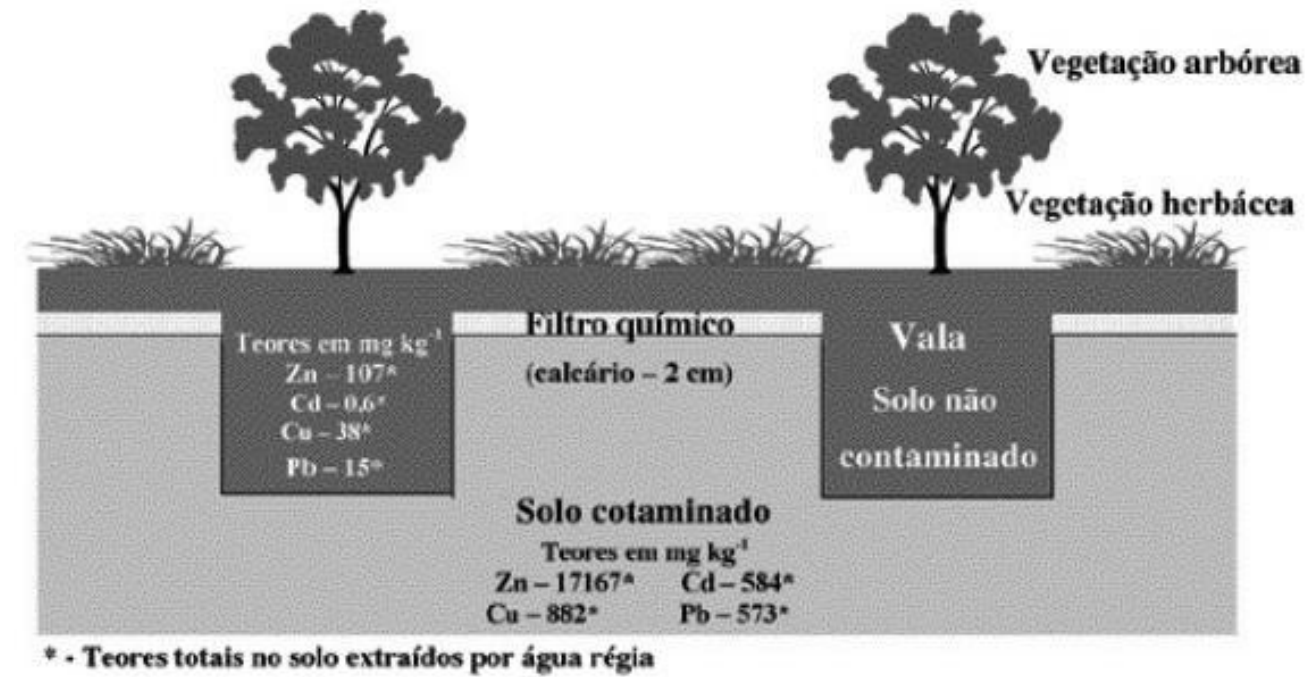

Figura 6.6 - Aplicação da fitorremediação em recuperação de solo contaminado.

Fonte: Dinardi et al. (2003, p.12).

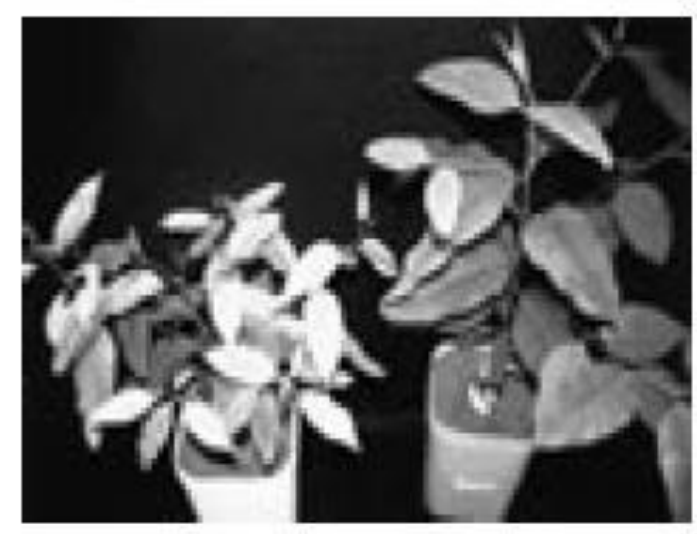

Figura 6.7 - Eucalipto em solo contaminado sem filtro de calcário, à esquerda, e com filtro, à direita, mais desenvolvido.

Fonte: Dinardi et al. (2003, p.13) 


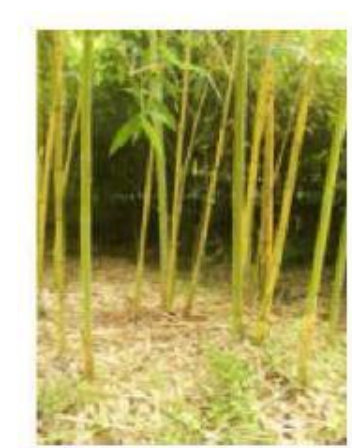

1. Phyllostachys sulphurea

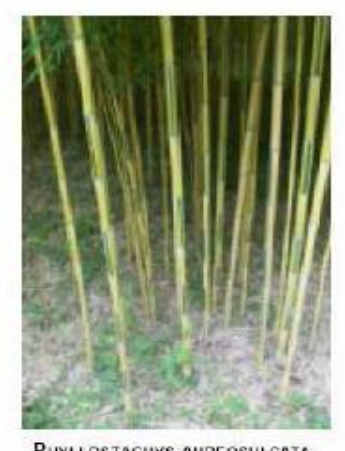

Phyllostachrs aureosulcata

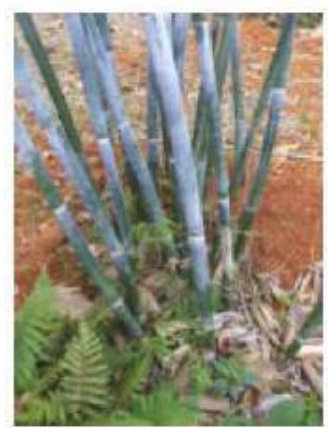

Merostachys spp.

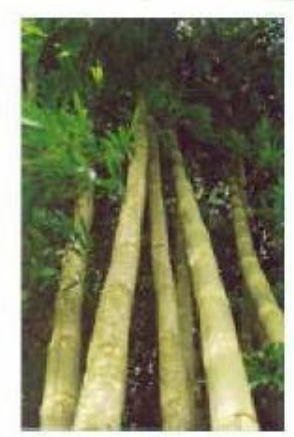

DENDROCALAMUS ASPER

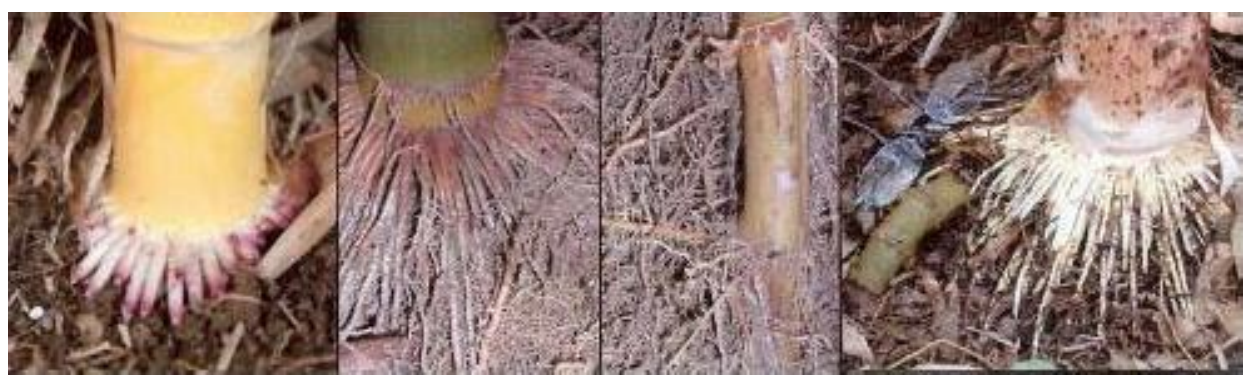

Figura 6.8 - Variedade de espécies de bambu e sistemas de raízes (rizomas e radicelas) Fonte: Rodrigues (2007).

De acordo com Accioly e Siqueira (2000 ${ }^{28}$ apud Vilhalva, 2008), as plantas fitorremediadoras são, na maioria das vezes, de clima temperado e, para o desenvolvimento da fitorremediação, estudos básicos sobre a fitoxicidade dos metais pesados e da tolerância das espécies ao estresse imposto pelo seu excesso são aguardados. Campos et al. (2005) ${ }^{29}$ e Alloway $(1990)^{30}$, citados pela mesma autora, relatam que contaminações ambientais com cádmio - Cd são freqüentes em áreas de mineração, resíduos sólidos e lodo de esgoto, indústria de plástico e lubrificante e em áreas com aplicação de fosfatados ricos em Cd.

Vilhalva (2008) identificou no cerrado paulista uma herbácea nativa, da família do café, Galianthe grandifolia - Rubiaceae (Figura 6.9), hiperacumuladora de $\mathrm{Cd}$, com potencial para fitorremediação, acumulando mais de $129 \mathrm{mg} \mathrm{kg}^{-1}$ do metal na sua parte aérea e quase três vezes mais nas raízes.

\footnotetext{
${ }^{28}$ ACCIOLY, A.M.A.; SIQUEIRA, J.O. Contaminação química e biorremediação do solo. In: NOVAES, R.F.; ALVAREZ, V.H.V.;SCHAEFER, C.E.G.R. (Ed.) Tópicos em Ciência do Solo, Viçosa, MG: Sociedade Brasileira de Ciência do Solo. 2000. P. 299-352

${ }^{29}$ CAMPOS, M.L.; ILVA, N.F.; ANTUNES, A.S.; GUILHERME, L.R.G.; MARQUES, J.J.G.S.E.M.; FUTINI NETO, A.E. Comparação de métodos na determinação de cádmio, cobre, cromo, níquel, chumboe zinco em fosfato de rocha. Pesquisa Agropecuária Brasileira, 40. 2005. p. 361-367.

${ }^{30}$ ALLOWAY, B.J. Heavy metals is soils. New York: John Wiley. 1990. p. 29-39.
} 


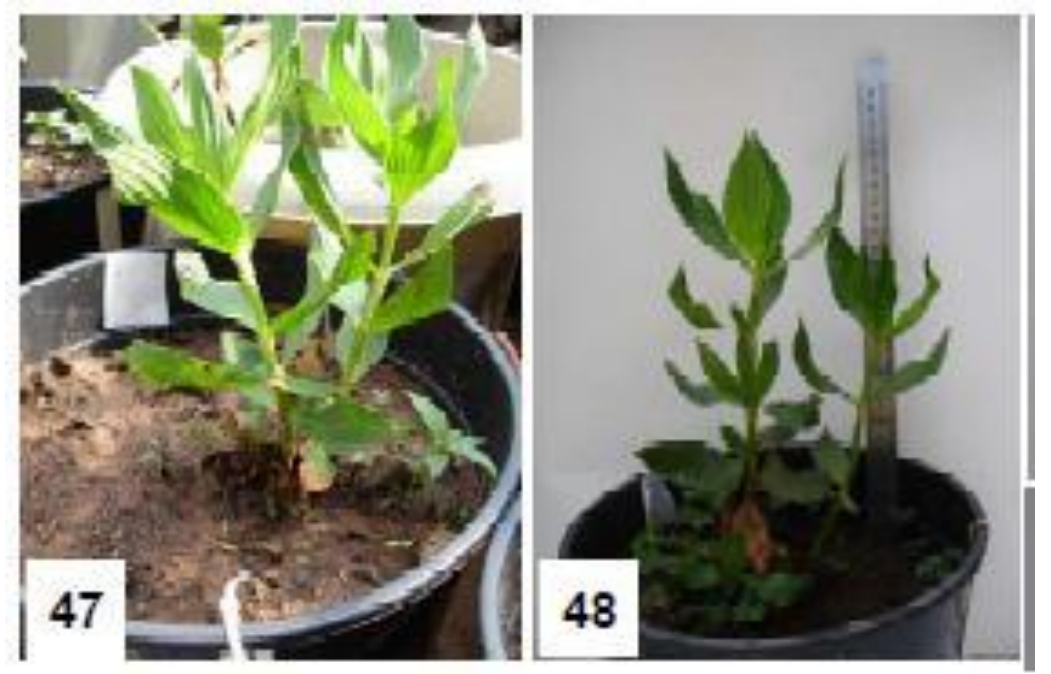

Figura 6.9 - Herbácea Galianthe grandifoilia (Rubiaceae) Fonte: Vilhalva (2008, p.45)

Raskin et al. (1997 31 apud Souza 2010b), verificaram que as plantas hiperacumuladoras são capazes de extrair e acumular mais de 10.000 mg.kg-1 de Zn e Mn, mais de 1.000 mg.kg-1 de Pb, Ni e Cu, e mais de 100 mg.kg-1 de Cd, demonstrando o seu uso promissor na fitorremediação de solos contaminados com metais.

Souza (2010a) investigou como a associação com o fungo micorrízico arbucular (FMA) Glomus etunicatum pode influenciar o crescimento e o potencial fitorremediador das plantas herbáceas, calapogônio (Calopogonium mucunoides), feijão espada (Canavalia gladiada) e mucuna preta (Stizolobium aterrimum) em solos contaminados por chumbo. Observou que o feijão espada e a mucuna preta apresentaram bom desenvolvimento e podem funcionar como fitoestabilizadoras. No caso do calapogônio, a associação com fungos micorrízicos foi fundamental para o crescimento e a ação fitoestabilizadora das plantas em solos contaminados pelo metal. Entretanto, a sua baixa produção de biomassa desfavorece a sua utilização na fitorremediação.

Souza (2010b) na sua pesquisa sobre o potencial fitorremediador de espécies arbóreas em solos contaminados com os metais pesados chumbo (Pb) e zinco $(\mathrm{ZN})$ concluiu que para $\mathrm{O} \mathrm{Pb}$ a espécie mais tolerante é a Mimosa caesalpiniaefolia (sansão do campo) e para o Zn a Erythrina speciosa. A autora esclarece que nestas espécies o metal se concentra nas raízes, não havendo

\footnotetext{
${ }^{31}$ RASKIN, I., SMITH, R. D., SALT, D. E. Phytoremediation of metals: using plants to remove pollutants from the environment. Curr. Opin. Biotec. 8. 1997. p. 221-226.
} 
translocação para as partes aéreas das plantas. A tolerância aos metais, apresentada por essas espécies, contribui paa a sua utilização no controle e revegetação de áreas contaminadas, pois elas favorecem o crescimento de outras espécies menos tolerantes nas vizinhanças.

A definição das práticas de remediação a serem adotadas, dentre outros fatores, deverá levar em conta também o tempo exigido para a finalização do processo de remediação em relação às concentrações de contaminantes no solo e nas águas subterrâneas (Figura 6.10) e às situações de risco do local.

A fitorremediação possui como desvantagem o longo tempo exigido para o processo de tratamento da área. Outra limitação básica, segundo Vimieiro (2007), se refere ao contato das plantas com o contaminante, em virtude das diferentes profundidades das raízes (Figura 6.11). As plantas precisam estender suas raízes até alcançar o contaminante ou o material precisa ser movido para o seu raio de ação. Ou ainda, deve-se promover a irrigação das plantas com as águas subterrâneas contaminadas. Recomenda sua aplicação nos casos de poluição mais difusa e com concentração moderada a baixa de contaminante.

O autor considera que uma das principais vantagens da fitorremediação é o seu baixo custo. Esclarece que os custos de manutenção são freqüentemente menores do que com as tecnologias tradicionais, mas em compensação, os custos de monitoramento podem ser muito mais altos, a exemplo da coleta e disposição apropriada das plantas contaminadas. Como exemplo, cita a sua aplicação ${ }^{32}$ na extração de césio e estrôncio dos pequenos lagos poluídos na região da usina nuclear de Chernobyl, na Ucrânia.

Por outro lado, os metais acumulados na planta, de interesse econômico, podem ser recuperados pela biomineração, ou, no caso de metais essenciais, utilizados como fertilizantes para plantas (Baker et al., 1981, 1994 apud Souza 2010b).

\footnotetext{
${ }^{32}$ Revista Química e Derivados (1997).
} 


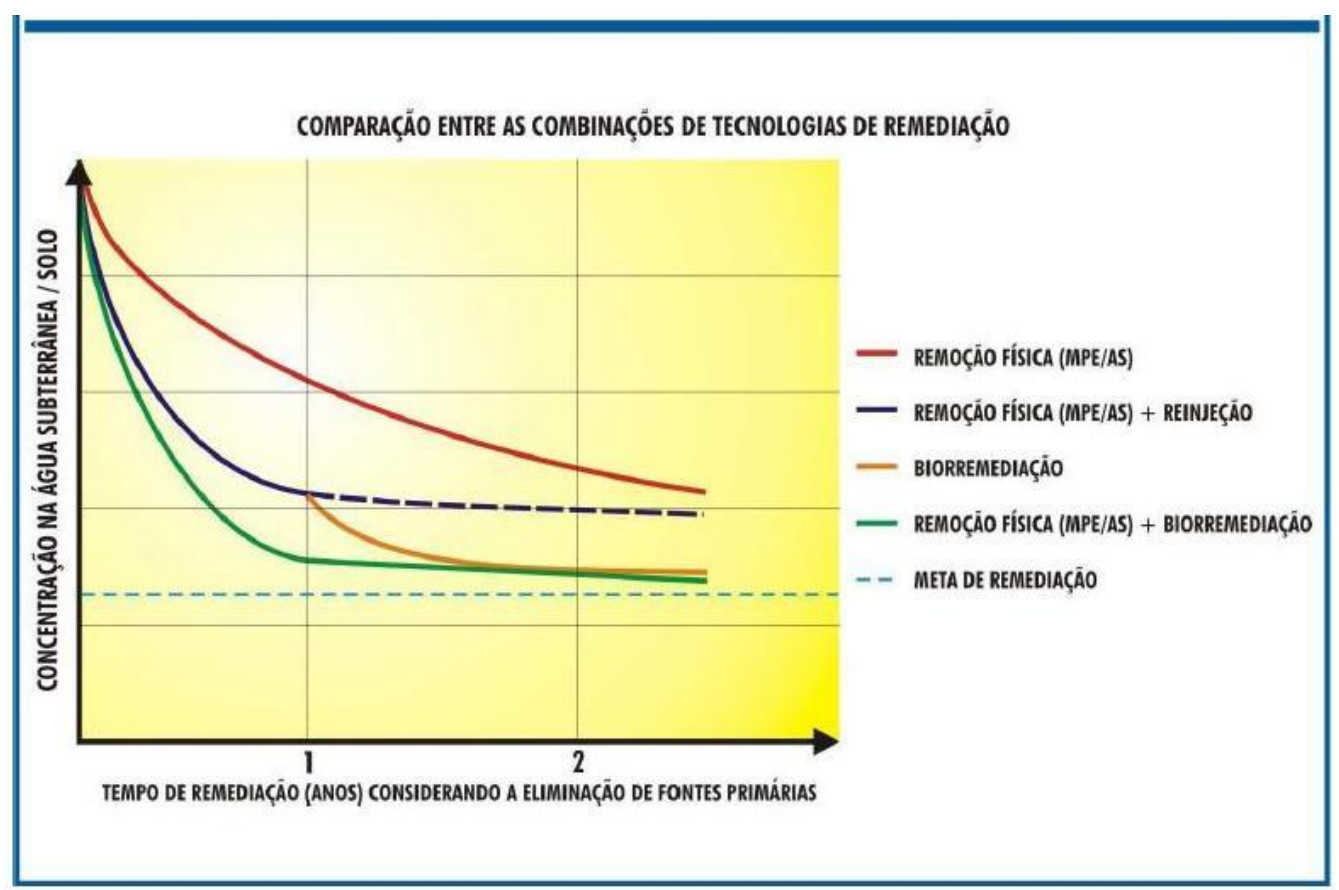

Figura 6.10 - Tempo de remediação em relação às várias tecnologias disponíveis Fonte: Moeri e Coelho (2005)

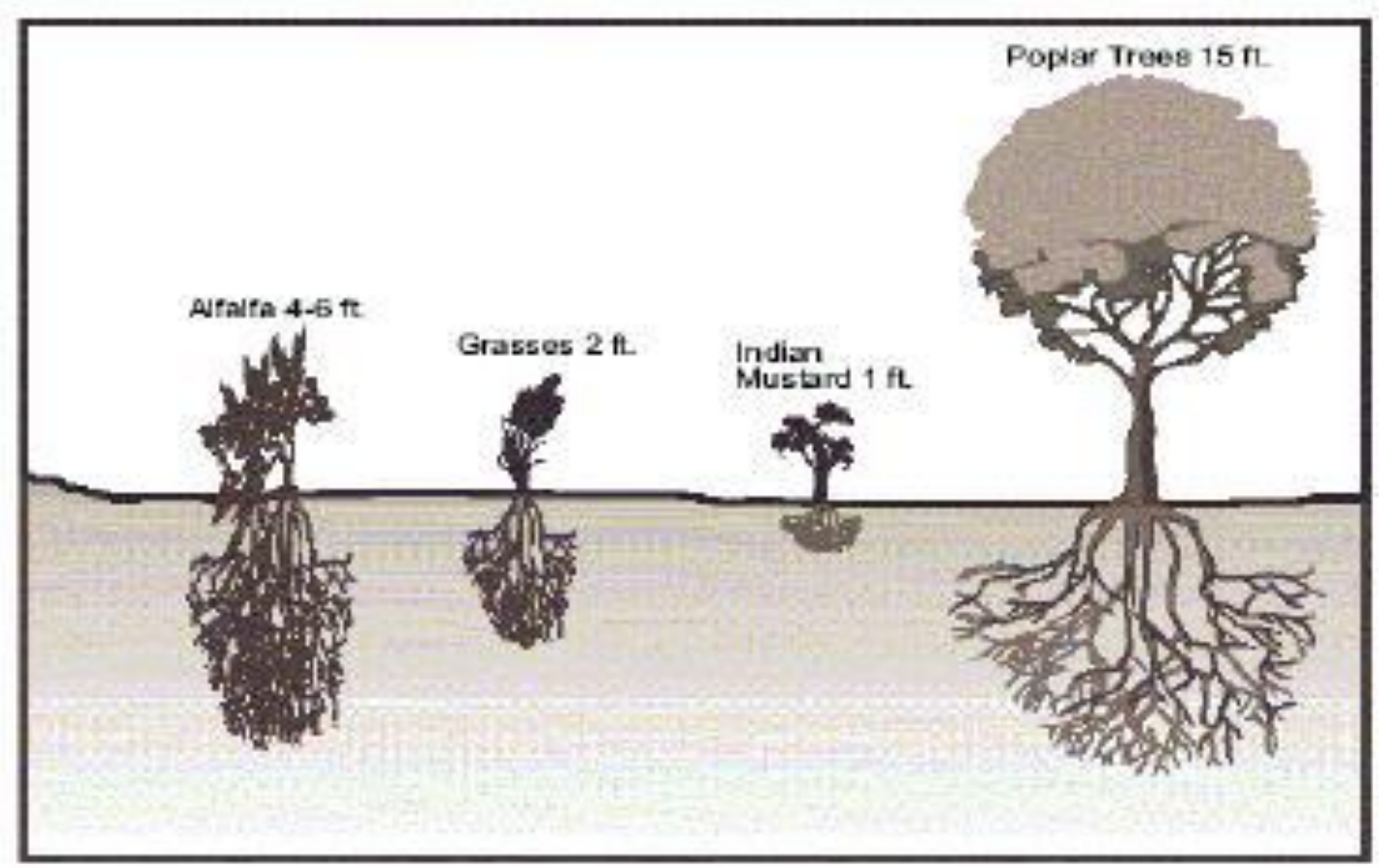

Figura 6.11 - Exemplos de profundidade de raízes de plantas $(1 \mathrm{ft}=30,5 \mathrm{~cm})$

Fonte: USEPA $\left(2000^{33}\right.$ apud Vimieiro, 2007, p.7)

\footnotetext{
${ }^{33}$ UNITED STATES ENVIRONMENTAL PROTECTION AGENCY (USEPA). Introduction to Phytremediation. Cincinnati, Ohio. National Risk Management Research Laboratory Office of Research and Development. 2000. EPA/600/R-99/107.
} 


\subsubsection{ZONAS ALAGADAS (WETLANDS)}

As zonas alagadas (Figura 6.12), segundo Boscov (2008), são ambientes de transição entre os ecossistemas terrestres (emersos) e aquáticos (submersos). Às zonas alagadas naturais correspondem os pântanos, brejos e manguezais. Esse elemento paisagístico, atenuador das cheias, além de propiciar a formação de habitats para diferentes espécies de animais e plantas, também, funciona como filtro de sedimentos, nutrientes, microorganismos, metais e poluentes carreados pelas águas. Campbell e Ogden (1999) destacam que o potencial de purificação dessas zonas alagadas é conhecido há séculos, citam os nativos das vilas sudanesas que utilizavam as plantas e os solos argilosos ao longo do Rio Nilo como purificadores das suas águas durante a estação chuvosa.

As zonas alagadas podem ser construídas artificialmente (Figura 6.13) para o tratamento de águas residuárias, chorume, drenagem ácida de minas, efluentes industriais e na atenuação de plumas de contaminação em aqüíferos rasos (Boscov, 2008). Possuem baixo custo operacional e eficiência energética. A sua implantação em parques e em sistemas recreacionais potencializam a integração de habitats, a qualidade estética e a melhoria da qualidade dos efluentes produzidos, que podem ser reciclados para a irrigação ou represados em lagoas (Campbell e Ogden,1999). Em geral são associadas à fitorremediação.

Nas zonas alagadas são encontradas espécies herbáceas e lenhosas. As espécies herbáceas se dividem em hidrófitas, total ou parcialmente submersas em águas rasas ou solos saturados, a exemplo, respectivamente, de algumas ervas aquáticas e do junco e papiro. Os lírios aquáticos possuem longas hastes fixadas ao fundo e folhas flutuantes na superficie. As espécies lenhosas, árvores e arbustos, possuem raízes adventícias, de escora e outras estruturas características, mas não são comumente utilizadas como filtradores de poluentes (Morinaga, 2007).

Alguns fatores influenciam a seleção de espécies para a construção de zonas alagadas, segundo Campbell e Ogden (1999). As espécies devem ser capazes de resistir à flutuação do nível d'água, podendo ser utilizadas tanto na sua porção emersa como submersa. Devem exibir sistema vigoroso de raízes, se estendendo tanto lateral como verticalmente, pois quanto maior a profundidade da raiz maior a área de contato dos microorganismos bacterianos e a oxigenação da 
zona anaeróbica. As plantas, preferencialmente nativas, devem ser capazes de se reproduzirem e se aglutinarem rapidamente.

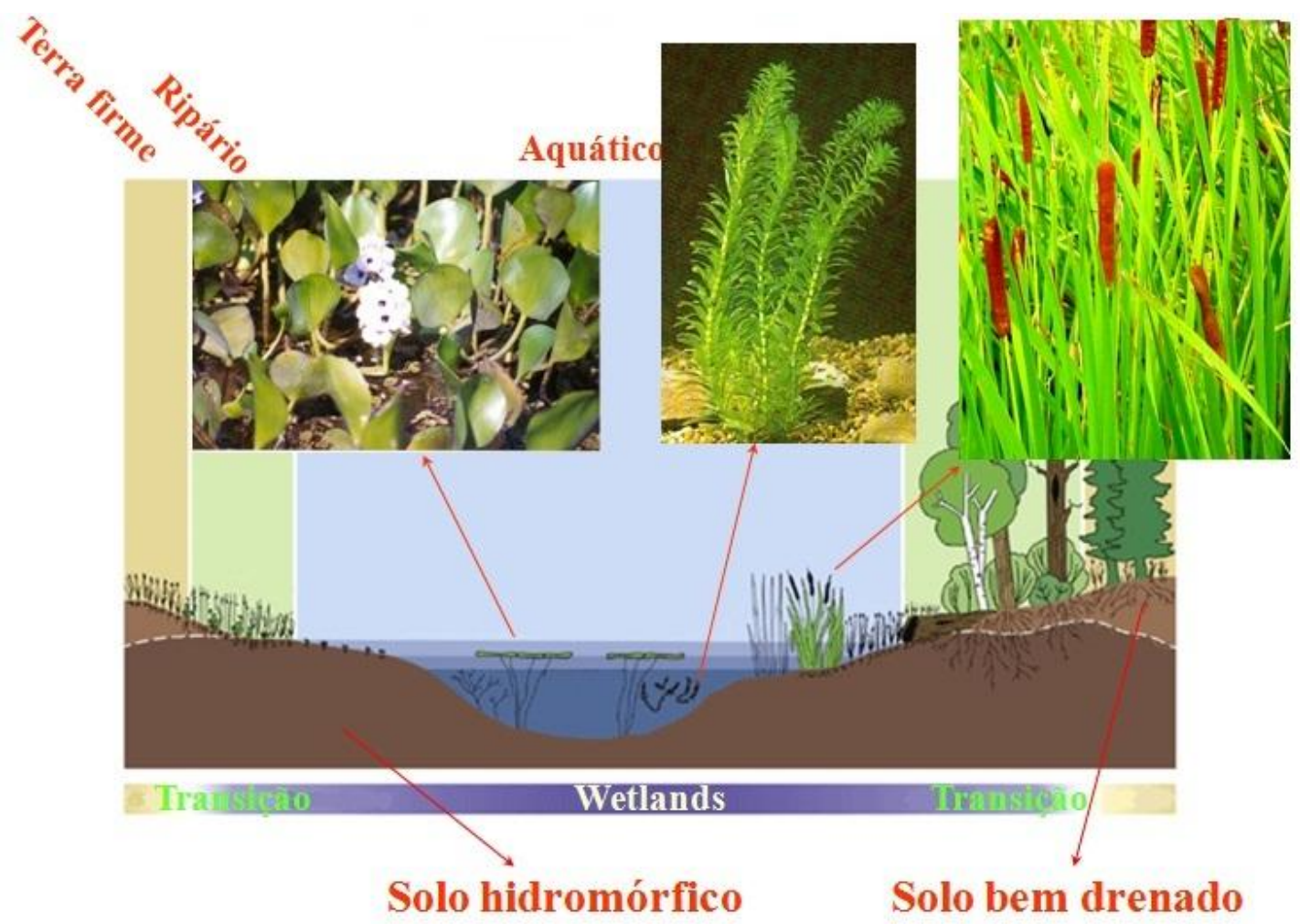

Figura 6.12 - Zonas alagadas naturais

Fonte:Tsuhako (2007).

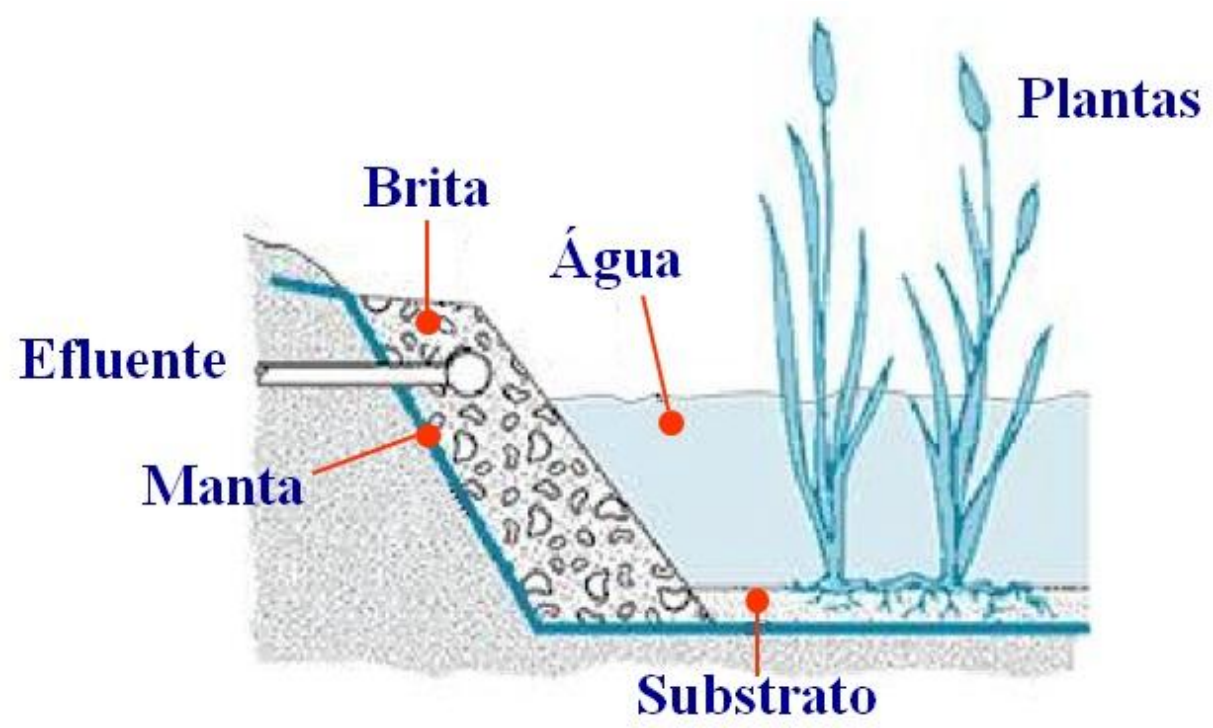

Figura 6.13 - Zonas alagadas construídas

Fonte:Tsuhako (2007). 
Lima (2008) analisou o tratamento de chorume em zonas alagadas construídas com macrófitas aquáticas emergentes na região de Campo Mourão, Paraná. Cinco espécies foram selecionadas para a construção das wetlands: $P$. parviflora, H. ranunculoides, C. nudiflora, Luziola peruviana e Ludwigia peploides. Os tratamentos apresentaram redução entre 72 e $76 \%$ na DQO, de 77 a $85 \%$ na DBO, de 69 a $73 \%$ de coliformes totais, de 98 a $99 \%$ de coliformes termotolerantes, de 82 a $100 \%$ de nitrogênio total, de 97 a $99 \%$ de ferro, de 86 a $99 \%$ de manganês, de 98 a 99 \% de chumbo e de 99 a $100 \%$ de cobre, além da redução de cádmio e cromo. Destacou-se pelo excelente desempenho a espécie Pontederia parviflora, com maior acúmulo de metais na raiz. A areia utilizada como substrato da zona alagada construída também acumulou os metais em estudo.

A construção de zonas alagadas apresenta limitações devido às suas dimensões que exigem áreas extensas e por isso precisam ser implantadas, preferencialmente, em terrenos disponíveis e de baixo custo. $O$ seu desempenho depende das condições ambientais, tais como as variações da precipitação e da carga e do tipo dos contaminantes. Outra preocupação é a ocorrência de mosquitos e pernilongos devido à presença de água estagnada a céu aberto. Para isso é necessário a limpeza constante do local, a manutenção do fluxo contínuo de água, a dispersão das massas de plantas flutuantes, a introdução de espécies para controle biológico e o sombreamento da superfície da água (Morinaga, 2007). 


\section{Parques-aterros no Sistema de Áreas Verdes do MUNICÍPIO dE SÃo PAULO - OS NOVOS GREENFIELDS}

A vegetação original do município já se apresentava bastante alterada por volta do início do século passado. Silva Filho (2005) destaca o trabalho pioneiro do professor Usteri $(1911)^{1}$, sobre a Flora dos Arredores da Cidade São Paulo, que indicou as florestas da região como, na verdade, matas secundárias, originadas da recuperação natural em terrenos abandonados, após a realização de queimadas e práticas de agricultura. $O$ professor identificou apenas um fragmento remanescente de floresta original, em terreno particular na Av. Paulista (atual Parque Trianon), juntamente com os campos, capoeiras, capoeirões, matas arbustivas e os brejos.

Ao longo dos anos, essa cobertura vegetal vem sofrendo acentuada redução com o registro, no período de 1991 a 2000, de uma perda de 5.345 ha, mais intenso nas suas regiões periféricas. A vegetação destaca-se, ao norte, no Parque Estadual da Cantareira e, ao sul, na Área de Proteção Ambiental Capivari-Monos. Apresentase, subordinadamente, nos parques municipais, cemitérios, jardins, clubes, etc. Essa cobertura correspondia, em 2001, a 39\% do território do município, com 20,6\% de vegetação nativa, $3,8 \%$ de reflorestamento e, $15,6 \%$ referente à pastagem, campo

\footnotetext{
${ }^{1}$ USTERI, P.A. Flora der Umgebung der Stadt São Paulo. Jena, Gustav Fischer. 1911. 271p.
} 
antrópico e natural (SVMA, 2004a). O uso e ocupação do solo associado à ocorrência de cobertura vegetal refletem-se nos diferentes micro-climas registrados na cidade.

Os parques são importantes elementos no mosaico da paisagem urbana, consolidada do Município e muito freqüentados pela população apesar de, em alguns casos, apresentarem situação crítica quanto à manutenção e conservação dos seus equipamentos e vegetação. O Sistema de Áreas Verdes do Município, atualmente, conta com oitenta parques municipais, nove reservas ecológicas e duas Áreas de Proteçao Ambiental - APA (SVMA, 2008); contendo apenas um parque implantado sobre antigo aterro, o Parque Raposo Tavares, com cerca de 200.000 $\mathrm{m}^{2}$. No território municipal estão também situados parques e áreas de proteção estaduais.

\subsection{PARQUes URBanOS PAULISTANOS}

A cobertura vegetal do município de São Paulo, condicionada pelo solo, clima e relevo, pode ser classificada, generalizadamente, como florestal e campestre. O componente florestal compreende as matas de planalto, nebular, de encosta, de turfeira e ciliar e o componente campestre, os campos alto-montano, naturais e as formações de várzea (Silva Filho, 2005). Essa vegetação se apresenta bastante fragmentada possuindo apenas alguns remanescentes de floresta em parques e áreas de preservação ambiental. Grande diversidade da flora e da fauna pode ser encontrada nessas áreas verdes.

Segundo SVMA (2004a), os parques paulistanos, na sua maioria, concentrados na zona urbana consolidada, cumprem diferentes funções: áreas de lazer, atenuantes das condições ambientais adversas até espaços de registro de remanescentes de matas nativas, que servem de banco genético e refúgio de fauna. Do ponto de vista ecológico, de acordo com SVMA (2008b), os parques urbanos são semelhantes às unidades de conservação (UC), pois possuem alta taxa de biodiversidade, no entanto, as suas características não estão abrangidas na legislação brasileira e nem na International Union for Conservation of Nature (IUCN). 
Os parques se destacam como instrumentos de controle da qualidade ambiental, de recreação, de refúgio de biodiversidade e de desenvolvimento de atividades educacionais (Garcia, 1995). São bastante utilizados pela população e seus usuários consideram como os aspectos mais relevantes a sua paisagem e 0 seu ambiente (Bartalini,1999). Oliveira e Santos (2004² apud Isernhagen; Bourlegat e Carboni, 2009) ressaltam a necessidade de um manejo adequado das zonas envoltórias dos parques urbanos e a responsabilidade do poder público na formulação de normas urbanísticas e de preservação ambiental.

Os Conselhos Gestores dos Parques Municipais (Lei 15.539/2003), diretamente ligados a SVMA, são compostos por diversas outras secretarias como: Cultura, Esportes Lazer e Recreação, Segurança e Saúde (SVMA, 2008b). Foram criados para ampliar e integrar as ações da administração pública e da população.

\subsubsection{CONCEITOS DE PARQUES URBANOS}

As definições de parque urbano apresentam grande diversidade dependendo do contexto urbano-cultural da região e dos objetivos estabelecidos nas pesquisas realizadas. Segundo Kliass (1989, p.18) os parques urbanos são

[...] aqueles espaços livres públicos urbanos, destinados à recreação, com dimensões significativas para as diferentes escalas consideradas, com tratamento paisagístico que os caracterize como áreas verdes, isto é, com predominância de elementos naturais, principalmente vegetação.

A revisão bibliográfica realizada por Albuquerque (2006) relaciona os conceitos de parque estabelecidos por vários autores. Lima et al. (1994) considera parque urbano a área verde com funções ecológicas, estéticas e de lazer com maior dimensão que as praças e jardins. Carneiro $(1998)^{3}$ observa que, no Brasil, os parques ampliam as suas tipologias de uso e o seu papel no contexto social e ambiental, funcionando como espaços educativos, sociais e relacionados a um ambiente saudável. Gilmet (2002) enumera as funções do parque: recreação, contemplação, esportes, educação (zoológicos, jardins botânicos), camping e estabelece que o projeto de elaboração do parque se baseia nestas funções.

\footnotetext{
${ }^{2}$ OLIVEIRA, C. A.; SANTOS, C. J. F. Florestas Urbanas: normas de uso e ocupação do solo para proteção de Unidades de Conservação na cidade. In: MILANO, M. S. (Coord.). Congresso Brasileiro de Unidades de Conservação, 4. Anais... Curitiba. 2004.

${ }^{3}$ CARNEIRO, A.R.S.;MESQUITA, I.b. Espaços Livres do recife. Recife: Prefeitura da Cidade do Recife. Universidade de Pernambuco - UFPE. 2000. 139 p.
} 
Segundo Scalise (2002) ${ }^{4}$ são grandes espaços abertos públicos, localizados em torno de acidentes naturais (ravinas, córrego, etc.) fazendo divisa com vários bairros. São limitados por ruas com organização espacial (paisagem) apresentando equilíbrio entre áreas pavimentadas e ambientes naturais, podendo conter usos informais: caminhos secundários de pedestres, esportes recreativos, centros comunitários, festivais, playgrounds, piscinas, etc. o autor especifica que o município é responsável por prover esses espaços e seus equipamentos e pela inclusão das recentes reivindicações por parques e áreas verdes nos planos urbanos. Nogueira $(2003)^{5}$ afirma que são espaços especificamente concebidos para facilitar a presença de vegetação nas cidades, compatível com o uso de intensidade moderada pelos cidadãos, possuindo configuração autônoma.

Macedo e Sakata (2003) definem o parque como espaço público destinado à recreação de massa, com estrutura morfológica auto-suficiente (sem influência direta, sobre a sua configuração, de estrutura construída no entorno) e podendo incluir, também, o propósito de conservação.

Melazo e Colesanti (2003) consideram que as finalidades mais comuns dos parques urbanos são o lazer/recreação e a conservação/preservação. No primeiro caso situam-se nas áreas centrais e de fácil acesso, estando os elementos naturais servindo de composição entre os espaços livres nos projetos arquitetônicos paisagísticos. No caso da conservação/preservação são mais funcionais quanto à qualidade ambiental e de vida da população. Ocorrem, em geral, nas zonas periféricas possuindo o significado de "espaço verde", essencial ao crescimento e desenvolvimento econômico e urbano.

Fontes e Shimbo (2003), mediante a revisão de literatura sobre a sistematização de categorias de espaços livres, propõem uma nova classificação para os espaços livres de lazer considerando suas áreas mínimas, potenciais raios de influência, restrições quanto às suas posições na malha urbana e funções. De acordo com as características das áreas quanto ao tamanho, posição, função e raio de influência, definem três categorias de parque: vizinhança, bairro e distrital.

Walker (2004) amplia o conceito tradicional de parque, de provedor de espaços abertos e recreacionais, ressaltando sua vital importância como instrumento para alcance dos extensos objetivos da política urbana, tais como: oportunidade de

${ }^{4}$ SCALISE, W. Parques Urbanos - evolução, projeto, função e uso. Revista Assentamentos Humanos. Marília, v. 4, n.1. 2002. P. 17-40.

${ }^{5}$ NOGUEIRA,J.E. La Ordenation urbanística: conceptos, herramientas y prácticas. Barcelona: Electa, 2003. 378 p. 
emprego, desenvolvimento da juventude, saúde pública e construção da cidadania, todos os quais ajudam a fortalecer a comunidade do seu entorno. Afirma que para os gestores de parque, essa visão reforça a importância crítica de reunir informações confiáveis para auxiliar na escolha criteriosa dos recursos, baseada nas principais demandas da comunidade sobre o parque e decidir a melhor forma de distribuí-los.

No levantamento quali-quantitativo dos espaços livres urbanos ${ }^{6}$ de Ribeirão Preto-SP, realizado para subsidiar o planejamento urbano-ambiental, Guzzo, Carneiro e Oliveira Jr. (2006, p.22) definiram parque urbano como

[...] espaço livre urbano público com dimensão quase sempre superior à de praças e jardins públicos, destinado ao lazer ativo e contemplativo, à conservação dos recursos naturais e à promoção da melhoria das condições ambientais da cidade. Alguns parques urbanos podem constituirse também como unidades de conservação. Os parques lineares são aqueles formados pelas faias de terra existentes ao longo dos rios e lagos, também com funções recreativas e conservacionistas.

\subsubsection{TIPOLOGIAS DE PARQUES URBANOS dO MUNICíPIO dE SÃo PAULO}

O município conta com parque urbano desde o final do século XVIII, época da criação do Jardim Público, atual Parque da Luz, que também responde como tantos outros às transformações inerentes à urbanização. A urbanização é um dos fatores responsáveis pelo avanço do desmatamento, resultando numa escassez de áreas verdes na cidade, especialmente nas zonas mais periféricas. Segundo SVMA (2004a) no período de 1991 a 2000, a perda de vegetação se concentrou em apenas 10 distritos periféricos, de um total de 96 existentes no município. Silva Filho (2005, p.46) relaciona a perda de vegetação à ineficácia da legislação e ao desencadeamento de outras modificações.

[...] A dimensão dessas perdas de área da cobertura vegetal leva a concluir que as normas legais foram ineficazes ou pouco eficazes na proteção da vegetação. As perdas, porém, não foram somente em quantidade, alterações profundas no meio físico (drenagens, canalizações de cursos d'água, terraplenagens, alteração do $\mathrm{pH}$ do solo, etc.) inviabilizaram a manutenção de determinadas formações vegetais, provocando perdas na diversidade de ambientes e de espécies.

\footnotetext{
${ }^{6}$ São todos os espaços da cidade em que não há edificações, ou espaços abertos para o céu. Termo mais abrangente que engloba os seguintes tipos: praça pública, parque urbano, área verde pública, cemitério e campus universitário. As áreas verdes devem ser constituídas de pelo menos 70\% de áreas vegetadas com solo permeável (Guzzo, 2006, p. 22).
} 
O Plano Diretor Estratégico, no seu Art. 131, estabeleceu que o Sistema de Áreas Verdes do Município se constitui do "conjunto de espaços significativos ajardinados e arborizados, de propriedade pública ou privada, necessários à manutenção da qualidade ambiental urbana tendo por objetivo a preservação, proteção, recuperação e ampliação desses espaços". No Art. 132 inclui o parque urbano na categoria de área verde pública de uso sustentável.

Posteriormente, a SVMA, por meio da consultoria da Fundação de Pesquisa Ambiental - FUPAM, elaborou um estudo para a classificação dos espaços públicos e as áreas verdes municipais, definindo o Sistema de Espaços Livres e Áreas Verdes do Município - Selav. O Selav "é o conjunto dos espaços públicos ou particulares vegetados, considerados de interesse público, para o satisfatório cumprimento de finalidades paisagísticas, ecológico-ambientais, funcionais, produtivas, de lazer e práticas de sociabilidade" (SVMA, 2006, p.7). Os parques urbanos, as praças, os jardins, pátios, largos, o sistema viário, áreas verdes, etc. são tipologias de espaço livre urbano com funções e formas diferentes, constituindo o Selav (Anexo G).

O sistema estabeleceu entre as tipologias de espaço livre e áreas verdes o Parque Nuclear Intraurbano e o Parque Linear. O Parque Nuclear Intraurbano foi definido como "a área verde inserida na malha urbana ou em suas bordas, com o objetivo de acolher atividades de lazer em ambiente predominantemente vegetado e com superfície predominantemente permeável" (SVMA, 2006, p.12). O Parque Linear da Rede Hídrica é a área verde contígua à rede hídrica, podendo ser composto por área core (área de preservação permanente), zona de amortecimento e zona equipada (recreação e lazer). A partir de dados de referência sobre os parques existentes na cidade e na bibliografia, se estabeleceram parâmetros de classificação e definição das categorias de parques nucleares intraurbanos (SVMA, 2006; Tabela 7.1).

As diferentes escalas e categorias de parques, com suas distintas funcionalidades e instalações, compondo um sistema de áreas verdes deveriam propiciar a interconexão de espaços vazios (zona rural) com a zona central da 
cidade formando um ambiente ecológico e esteticamente equilibrado (Eckbo, 1977 ${ }^{7}$; Bruck, $1982^{8}$ apud Rocha, 2007).

Tabela 7.1 - Parques Nucleares Intraurbanos do município de São Paulo

\begin{tabular}{|l|c|c|c|c|}
\hline Categoria & $\begin{array}{c}\text { Área Mínima } \\
\left(\mathbf{m}^{2}\right)\end{array}$ & $\begin{array}{c}\text { Raio de } \\
\text { Atendimento } \\
(\mathbf{m})\end{array}$ & $\begin{array}{c}\text { Superfície } \\
\text { Permeável } \\
(\%)\end{array}$ & $\begin{array}{c}\mathbf{m}^{2} \text { parque/ hab. } \\
\text { área atendimento }\end{array}$ \\
\hline $\begin{array}{l}\text { Parques de } \\
\text { Vizinhança }\end{array}$ & 6.600 & 500 & $>60-<70$ & $0,7-0,95$ \\
\hline $\begin{array}{l}\text { Parques de } \\
\text { Bairro }\end{array}$ & 44.000 & 1.500 & $>70$ & $1,0-1,7$ \\
\hline $\begin{array}{l}\text { Parques } \\
\text { Regionais }\end{array}$ & 468.000 & 5.000 & $>70$ & $0,7-1,4$ \\
\hline $\begin{array}{l}\text { Parques da } \\
\text { Cidade }\end{array}$ & 715.000 & 10.000 & $>70$ & $0,3-0,4$ \\
\hline
\end{tabular}

Organização: Luzia Helena dos S. Barros (2011).

Fonte: SVMA (2006).

No município de São Paulo a vegetação remanescente, do tipo Floresta Ombrófila Densa, predomina nos seguintes parques: Alfredo Volpi, Anhanguera, Carmo, Centro Municipal de Campismo (Cemucam), Chico Mendes, Guarapiranga, Jardim Herculano, Luiz Carlos Prestes, Pinheirinho d'água, Santo Dias, Severo Gomes, Trianon e Vila dos Remédios. Alguns parques apresentam lagos de diferentes dimensões e córregos com flora e fauna associados: Aclimação, Alfredo Volpi, Anhanguera, Carmo, Chácara das Flores, Chico Mendes, Cidade de Toronto, Guarapiranga, Ibirapuera, Jardim Felicidade, Jardim Herculano, Luz, Pinheirinho d'água, Piqueri, Raul Seixas, Santo Dais, São Domingos, Severo Gomes, Vila Guilherme e Vila dos Remédios. Espelhos d'água artificiais, com peixes ornamentais e aves domésticas, ocorrem nos parques Nabuco e Previdência; enquanto que o Parque Independência possui fontes e chafarizes com função apenas paisagística (SVMA, 2007b).

O Sindicato Nacional das Empresas de Arquitetura e Engenharia Consultiva (Sinaenco, 2008) realizou um levantamento de 41 parques situados no município para verificar o seu estado de manutenção e conservação, considerando os

\footnotetext{
${ }^{7}$ ECKBO, G. O paisagismo nas grandes metrópoles. Geografia e Planejamento/IGEO/USP. 1977. $24:$ 1-25.

${ }^{8}$ BRUCK, E.C. Proposta para um gerenciamento de áreas verdes. In: Congresso Nacional sobre Essências Nativas, I.

Anais... Instituto Florestal. São Paulo. 1982. P. 1900-1906.
} 
seguintes aspectos: vegetação, acessibilidade, equipamentos esportivos/lazer, banheiros e bebedouros. Da listagem geral, receberam melhor avaliação os parques: Burle Marx, Juventude, Ibirapuera e Villa-Lobos, destacando-se como os piores avaliados o Chico Mendes e o Raposo Tavares. A estimativa de freqüência mensal dos usuários também foi apresentada, despontando como o mais freqüentado o Ibirapuera (600.000 usuários/mês). Os parques Villa-Lobos, Juventude e Raposo Tavares, implantados sobre antigos aterros, apresentaram, respectivamente, as seguintes taxas de freqüência: $140.000,114.000$ e 3.300 usuários/mês.

As unidades de conservação existentes na região metropolitana de São Paulo (31) não são distribuídas de maneira a favorecer as conectividades, estando concentradas e isoladas, em áreas muito pequenas. Não existe arranjo estrutural que qualifique essas áreas. "[...] São encraves no meio urbano, sem elos de ligação e, quanto mais próximos de núcleos urbanos mais densos, maiores são as pressões humanas sobre seus recursos, apresentando muitos e diversos conflitos." (Santos, 2006).

\subsubsection{PRINCíPIOS DA ECOLOGIA DE PAISAGEM APLICADOS AOS PARQUES URBANOS}

A vegetação é responsável pela base de toda a cadeia trófica e, no meio urbano, seu registro mais significativo está associado aos maciços vegetais, encontrados, principalmente, nos parques públicos e unidades de conservação, devendo ser protegidos, conservados e mantidos, a fim de fornecer sustentação a todo um ecossistema. A manutenção e a preservação dos maciços vegetais estarão condicionadas, entretanto, ao potencial de conexão da paisagem, ou seja, ao grau com o qual a paisagem facilita ou impede os movimentos entre as manchas vegetadas.

Viana (1992 ${ }^{9}$ apud Lázzaro, 2008) destaca que a fragmentação da mata atlântica vem se acelerando originando fragmentos pequenos e isolados, considerados os últimos depositários da biodiversidade nativa das nossas florestas. Nesses fragmentos ocorre alta densidade de cipós e vegetação rasteira, que dificultam a regeneração natural de espécies arbóreas; alta freqüência de árvores

\footnotetext{
${ }^{9}$ VIANA, V. M.; TABANEZ, A. J. A., MARTINEZ, J. L. A. Restauração e Manejo de Fragmentos Florestais. In: Congresso Nacional sobre Essências Nativas, 2.1992, São Paulo. Revista do Instituto Florestal. Anais... São Paulo, 1992. p. 400 a 406.
} 
mortas e efeito de borda significativo e complexo (mudanças de luminosidade, temperatura, umidade e velocidade do vento). Essas características desfavorecem o processo de sucessão ecológica e explicam a necessidade de manejo adequado, a fim de reverter o processo de degradação dos fragmentos.

Schäffer e Prochnow (2002) afirmam que "a riqueza da biodiversidade e a velocidade da regeneração e crescimento das florestas secundárias" estão condicionadas a alguns fatores, dentre eles: "a existência de remanescentes florestais nos arredores para fornecer as sementes, a existência de dispersores de sementes e o grau de degradação do solo".

A observação do território do município de São Paulo, baseada nos princípios da ecologia de paisagem (mancha-corredor-matriz) (Forman, 1999) permite afirmar que, em sua grande parte, o município está representado por uma matriz de tecido urbano consolidado, representado pelos lotes, edificações e vias. Os parques urbanos municipais e estaduais, na sua maioria, despontam na paisagem do município como manchas de vegetação remanescentes ou introduzidas, simbolizando as transformações naturais ou induzidas pelo homem ao longo do tempo. Caracteristicamente como uma mancha, os parques apresentam formas, tamanhos, posição, função e origens diversas. Alguns deles funcionam ou apresentam potencial para funcionar como trampolins ecológicos, favorecendo a implantação de corredores ecológicos.

Forman (1995) destaca duas principais características e vantagens dos corredores: eficiência do movimento e proteção à matriz. Conforme Dramstad et al. (1996), apesar da polêmica sobre a efetividade dos corredores na preservação ou expansão da biodiversividade, muitos pesquisadores elencam uma rede de benefícios positivos na incorporação de ligações de alta qualidade entre as manchas de habitat. Afirmam, também, que os sistemas de drenagem são corredores de excepcional significância na paisagem. Conservar a sua integridade ecológica diante de intensa ação antrópica é tanto um desafio quanto uma oportunidade para os paisagistas e planejadores do uso do solo. Para Simi (2007), o corredor ecológico urbano com diversas interações ambientais pode ser construído pela arborização urbana, promovendo a movimentação da avifauna e a dispersão de sementes.

A conectividade da paisagem é vital para o conceito de efeitos de vizinhança (movimento de indivíduos entre manchas), pois ela define o entorno de uma mancha específica (Taylor et al.,1993). Os autores ressaltam que se o conceito de 
movimento não for explicitamente incorporado como concepção, os paisagistas e planejadores continuarão a ignorar a sua importância. Relatam as pesquisas de Sounders e Ingram (1987) ${ }^{10}$ e Fahrig e Paleoheimo $(1988)^{11}$ sobre muitos estudos terem demonstrado que o movimento é tão fundamental à viabilidade da população de espécies como à distribuição de recursos, mas que usualmente, os mapas produzidos por planejadores retratam a distribuição de recursos e não os padrões de movimento. E tal como afirmam Peterson $(1985)^{12}$ e Harris e Gallagher (1989) ${ }^{13}$, citados pelo autor, ignorar o movimento pode levar a conseqüências incorretas e potencialmente devastadoras para a conservação.

As manchas de vegetação, especialmente as remanescente de mata e de maior extensão, funcionam como bancos genéticos de espécies nativas, que necessitam de manejo adequado e proteção para garantir a sua integridade e fortalecer as paisagens. As manchas de vegetação arredondadas, contínuas e com bordas curvilíneas favorecem a conservação e proteção dos recursos naturais, pois minimizam os efeitos externos. As pequenas manchas de vegetação significativa com manejo adequado, podem se constituir como pontos para abrigo ou alimentação de espécies migratórias ou de apoio ao deslocamento de espécies na matriz urbana.

Os parques lineares, com implantação enfatizada mais recentemente, pela administração municipal, por outro lado, correspondem aos corredores. Conforme SVMA (2006, p.17) "estão associados às drenagens e têm por objetivos: proteger ou recuperar os ecossistemas lindeiros aos cursos e corpos d'água; conectar áreas verdes e espaços livres de um modo geral; controlar enchentes e prover áreas verdes para o lazer".

A matriz urbana consolidada se caracteriza, em geral, por apresentar as drenagens retificadas, canalizadas ou até mesmo aterradas. São utilizadas, também, como meio para disposição de lixo, entulho e esgoto. Portanto, os corredores de parques lineares, no interior da área urbana consolidada, representam uma tentativa de resgatar as funções ecológicas das drenagens na paisagem urbana.

\footnotetext{
${ }^{10}$ SOUNDERS,D.A. ; INGRAM, J.A. Factors affecting survival of breeding populations of Carnaby's cockatoo Calyptorhynchus funereus latirostris in remmants of native vegetation. 1987. p. 249-258. In: SOUNDERS,D.A. ; ARNOLD, G.W.; BURBIDGE, A.A.; HOPKINS, A.J.M. (Eds). Nature conservation: The role of remmants of native vegetation. Surrey Beatty \& Sons, Chipping Norton. 1987.

${ }^{11}$ FAHRIG, L.; PALEOHEIMO, J. Determinants of local population size in patchy habitats. Theor. Popul. Biol. V.34, 1988. p.194213.

${ }_{12}$ PETERSON, B. Extinction of an isolated population of the middle spotted woodpecker Dencrocopus medius (L.) in Sweden and its relation to general theories on extinction. Biol. Conserv. V. 32, 1985. p. 335-353.

${ }_{13}$ HARRIS, L.D ; GALLAGHER, P.B. New initiatives for wildlife conservation. The need for movement corridors. In: Preserving communities and corridors. Defenders of Wildlife, Washinton, 1989. P. 11-34.
} 


\subsubsection{Alguns Aspectos da INFLUÊnCIA dA VEGEtAÇÃo E dos PARQUES NA}

PAISAGEM URBANA

Oliveira (2006) comenta que a paisagem é dependente do homem, pois carrega a sua marca ao longo da história e que se deve aproveitar e potencializar a capacidade educadora da paisagem, nos parques, a fim de melhorar a compreensão do mundo. Os parques, no seu entendimento, são a recriação da natureza na cidade, contribuindo para uma nova ética de relação com o ambiente.

A vegetação na paisagem urbana, segundo Nucci (2001), é um atributo essencial que vem sendo preterido no desenvolvimento das cidades, progressivamente poluídas e, que quando preservada auxiliaria sobremaneira a despoluição do ar e dos rios.

A cobertura vegetal de uma região é função de vários fatores como clima, relevo, solo e tempo. A qualidade ambiental da paisagem urbana e, conseqüentemente, a qualidade de vida da população está diretamente relacionada à quantidade, qualidade, função e distribuição das áreas vegetadas, que no município de São Paulo, concentram-se, principalmente, nos parques e áreas de proteção ambiental. Bittencourt et al. (1993 ${ }^{14}$ apud Rocha, 2007) associam ao sistema de áreas verdes a capacidade de controle do clima, da circulação atmosférica, de redução dos agentes poluidores e de fornecer conforto promovendo a melhoria da qualidade de vida urbana. Cavalheiro (1991) observa que a vegetação pode funcionar como indicador biológico da qualidade ambiental nas cidades, citando como exemplo a presença de líquens. À sua maior ocorrência e diversidade corresponde um ambiente úmido e não poluído. A qualidade ambiental urbana para Guzzo, Carneiro e Oliveira Jr. (2006, p. 84)

[...] é dependente de processos socioambientais e está ligada ao conforto, em termos ecológicos, biológicos, econômicos, tipológicos, tecnológicos e estéticos, no ambiente urbano. Seu estudo pressupõe uma análise cuidadosa de caráter quanti-qualitativo. Acredita-se que um trabalho que aborde a questão da qualidade ambiental urbana deve apresentar especial atenção com a qualidade e a distribuição espacial das áreas verdes.

A vegetação tem a função de regular a temperatura ambiente, mitigando os efeitos das ilhas de calor nas áreas urbanas (Sherer, 2006). Spangenberg et al. (2008) apontam como os seus principais benefícios, nos climas quentes, a

\footnotetext{
${ }^{14}$ BITTENCOURT, J. A. et al. Green areas system of city of São Carlos (SP), Brazil. In: Seminário Internacional dos Problemas Ambientais dos Centros Urbanos, II. (ECOURBS) Anais... Biosfera, São Paulo. 1993. P. 47-48.
} 
capacidade de reduzir a radiação solar e diminuir a temperatura do ar devido ao sombreamento e a evapotranspiração, esclarecendo, de acordo com Yu e Hien $(2006)^{15}$, que os parques podem apresentar um significativo efeito de resfriamento. No estudo realizado no centro de São Paulo verificou-se que o Parque da Luz apresentou uma temperatura de cerca de $2{ }^{\circ} \mathrm{C}$ menor que as suas vizinhanças. Outros estudos realizados por Shinzato (2009) e os autores Santamouris $(2001)^{16}$ e Bruse $(2004)^{17}$, por ela citados, observaram diferenças de temperatura muito próxima entre as áreas verdes e as suas imediações, à saber, respectivamente: na cidade de São Paulo e num parque em Atenas, Grécia, a diferença encontrada foi de $3 \stackrel{\circ}{\circ}$ e em Melbourne, Austrália, o máximo de $2 \stackrel{\circ}{ } \mathrm{C}$. Duarte e Gonçalves (2006), no estudo da área da operação urbana Barra Funda, constataram uma variação entre 2 e $3 \stackrel{\circ}{\circ}$ comparando o interior do Parque Água Branca e os seus arredores.

Os resultados obtidos por Spangenberg et al. (2008) mostraram, além disso, que as árvores possuem grande potencial para melhorar o micro-clima e diminuir o estresse nos climas quente-úmidos. Quanto mais denso o dossel das árvores (maior LAl e LAD) ${ }^{18}$, menor a temperatura do ar e da superfície e melhor o conforto térmico nos climas quente-úmidos. Os autores citam Akbari, Pomerantz e Taha $(2001)^{19}$ ao comentarem que as árvores isoladas e enfileiradas possuem menor impacto na redução da temperatura do ar e aparentemente um potencial limitado para mitigar as ilhas de calor no meio urbano.

Os maciços arbóreos ou seus exemplares isolados reduzem parte da radiação incidente ou refletida pelo solo e edificações, contudo a contribuição de cada árvore varia com a densidade de seu dossel durante o ano (ciclo fenológico de cada espécie), com as condições de transparência do céu e com a posição relativa do sol (Satler, 1992 ${ }^{20}$ apud Bartholomei, 2003). Ao estudar a capacidade de atenuação da radiação solar de cinco espécies arbóreas, Bueno (1998 ${ }^{21}$ apud Bartholomei, 2003), concluiu que a Sibipiruna (média de 88,5\%), o Jatobá e a Chuva-de-Ouro mostraram os melhores resultados, seguidos da Magnólia e do Ipê

\footnotetext{
${ }^{15}$ YU, C.; HIEN, W.N. Thermal benefits of city parks. Energy and Buildings. Oxford, V. 38. 2006. p. 105-120.

${ }^{16}$ SANTAMOURIS,M. Energy and Climate in the Built Environment. James and James. London. 2001.

${ }_{17}^{17}$ BRUSE, M. ENVI-met implementation of the Jacobs A-gs Model to calculate the stomata conductance. Bochum. 2004

${ }^{18} \mathrm{LAI}$ - índice de área foliar; LAD - densidade de área foliar.

${ }^{19}$ AKBARI, H.; POMERANTZ, M.; TAHA, H. Cool Surfaces and shade trees to reduce energy use and improve air quality in urban areas. Solar Energy. V. 70, N3. Tampa. 2001. P. 295-310.

${ }^{20}$ SATLER, M. A. Arborização urbana e conforto ambiental. In: CONGRESSO DE ARBORIZAÇÃO DE CIDADES, 1. Anais...

Vitória, 1992. P. 15-28.

${ }^{21}$ BUENO, C. L. Estudo da atenuação da radiação solar incidente para diferentes espécies arbóreas. Universidade

Estadual de Campinas (UNICAMP). Dissertação (Mestrado em Engenharia Civil). 1998. 177 p.
} 
Roxo. Henke-Oliveira (2001) informa que áreas arborizadas extensas respondem por atenuação térmica não inferior a 2 e $3 \stackrel{\circ}{\circ} \mathrm{C}$, podendo atingir valores entre $6-8 \stackrel{\circ}{\circ} \mathrm{C}$. Destaca estudos de vários autores que verificaram que os parques afetam as variáveis climáticas nas suas redondezas, variando de $100 \mathrm{~m}$ até $2 \mathrm{Km}$ a partir da sua borda. Ao contrário, Shinzato (2009), nos seus estudos sobre o efeito da vegetação no micro-clima urbano, concluiu que a sua abrangência é limitada, pois a influência das árvores se restringe ao espaço abaixo das suas copas ou, no máximo, às áreas de projeção das suas sombras, indicando para o conforto do pedestre, a implantação de pequenos grupos de árvores ao invés de um único e grande parque.

A vegetação e o solo que a sustenta são filtros naturais, prevenindo a poluição das águas e contribuindo para a redução da percolação superficial (runoff), com diminuição da erosão superficial (Sherer, 2006). A cobertura vegetal também pode funcionar como modificadora da velocidade e trajetória dos ventos (Mascaró, $2005^{22}$ apud Shinzato, 2009) e, segundo Givoni (1991 23 apud Shinzato, 2009), como elemento atenuador de ruídos, pois absorvem o som de alta freqüência, excluindose os sons dos veículos, que são de baixa freqüência com ondas de grande amplitude, dificultando a sua absorção. Grey e Deneke (1978 ${ }^{24}$ apud Muneroli, 2009) informam que ela auxilia ainda a absorção de poluentes atmosféricos, por interceptação das partículas, possuindo as árvores de grande porte maior capacidade de remoção do ozônio e gás carbônico do que as de pequeno porte.

A vegetação também é fonte de alimentos e habitats para os animais e mesmo no meio urbano pode promover a ocorrência de uma rica fauna silvestre, como demonstrado pelo levantamento da biodiversidade faunística do município de São Paulo, no período de 1993 a 2005 (SVMA, 2007). Segundo Borcke (2006) a diversidade de animais está diretamente relacionada à diversidade de espécies vegetais nativas. As espécies nativas são mais atrativas do que as exóticas, pois seus frutos e flores são mais palatáveis aos animais locais.

Outro importante papel da vegetação é a função social, promovendo a saúde física e mental da população. Kandinski ( $1996^{25}$ apud Muneroli, 2009) relata que

[...] o verde absoluto é a cor mais calma que existe. Não se acompanha nem de alegria, nem de tristeza, nem de paixão. Esta imobilidade é uma qualidade preciosa, e sua ação é benfazeja sobre os homens e sobre as

\footnotetext{
${ }^{22}$ MASCARÓ, Vegetação Urbana. 2005

${ }^{23}$ GIVONI, B. Impact of Planted Areas on Urban Environmental Quality - A review. Atmosferic Environment. V. 25, n. 3, 1991. P. 289-299.

${ }^{24}$ GREY, G.; DENEKE, F. Urban Forestry. New York: John Wiley. 1978

${ }^{25}$ KANDINSKI, W. Curso da Bauhaus. São Paulo: Martins Fontes. 1996
} 
almas que aspiram ao repouso. A passividade é o caráter dominante do verde absoluto, mas esta passividade se perfuma de unção, de contentamento de si mesmo.

Valdir (2005 apud Muneroli, 2009) atribui à cor verde o efeito sedativo e relaxante. Essas características provêem as áreas verdes, em hospitais, de acordo com Ulrich (2003), como jardins de cura auxiliando na recuperação de doentes por meio da redução do estresse, da ansiedade e da depressão e com a diminuição da quantidade de medicamentos. Kuo et al. (1998 ${ }^{26}$ apud Shinzato, 2009) associam a proximidade das áreas verdes com a redução da fadiga mental e agressividade entre os moradores, gerando maior segurança aos ambientes.

Para Henke-Oliveira (2001) os parques urbanos dignificam a convivência intra-urbana, podem atrair turistas e negócios, além de favorecerem o aumento do valor das propriedades próximas. Relaciona os efeitos da vegetação, dos cursos d'água e das áreas de recreação ao valor das edificações, citando Tyrväinen $(1997)^{27}$ e, ainda um estudo de Kielbaso ( 1994$)^{28}$ sobre o valor agregado $5-15 \%$ superior dos imóveis no entorno das áreas verdes.

Santamouris (2001 ${ }^{29}$ apud Shinzato, 2009) também relaciona a presença de árvores à valoração imobiliária da vizinhança, relatando que, na Holanda, a proximidade com áreas verdes, lagos ou espelhos d'água acarreta, respectivamente, um aumento de $6 \%, 10 \%$ e $7 \%$ no valor da propriedade.

A revisão bibliográfica, realizada por Crompton (2001), sobre os estudos que avaliaram os impactos no valor da terra e das propriedades, na área de influência dos parques e espaços livres urbanos, que partiu de Olmsted, autor pioneiro desta discussão, destacou que seus efeitos dependem das características desses espaços e do perfil das propriedades vizinhas. Salientou que independentemente do tipo do parque ou dos serviços oferecidos, impactos negativos podem ocorrer quando não se tem um projeto paisagístico e manutenção adequados. Ademais, reconheceu a possibilidade dos parques influenciarem tanto positiva quanto negativamente no valor das propriedades dos seus arredores (Figura 7.2).

\footnotetext{
${ }^{26}$ KUO,F.E. ; SULLIVAN, W.C.; COLEY, R.L.; BRUSON, L. Fertile ground for community: inner-city neighborhood common spaces. American Journal of Community Psychology. V. 26, n. 6.1998. p. 823-859.

${ }^{27}$ TYRVÄINEN, L. The amenity of the urban forest: an application of the hedonic pricing method. Landscape and Urban Planning. V. 37, 1997. P. 211-222.

${ }_{28}$ KIELBASO,J. J. Urban forestry: the international situation. In: CONGRESSO BRASILEIRO SOBRE ARBORIZAÇÃO URBANA, 2. São Luis.1994. p. 3-12. Anais... Sociedade Brasileira sobre Arborização Urbana. 1994. 613 p.

${ }^{29}$ Vide 19.
} 
A porção superior do gráfico indica que o incremento de benefícios no valor da propriedade está associado à proximidade e à acessibilidade e decai com o aumento da distância do parque. A porção inferior mostra que os valores negativos estão provavelmente limitados às propriedades próximas ao parque e que diminuem com o aumento da sua distância, muito mais rapidamente que os impactos positivos.

Apontou, também, a existência de uma rede de efeitos diferenciados dos impactos positivos associados aos parques em relação aos limites impostos pelos conflitos de uso e acessibilidade (Figura 7.3).

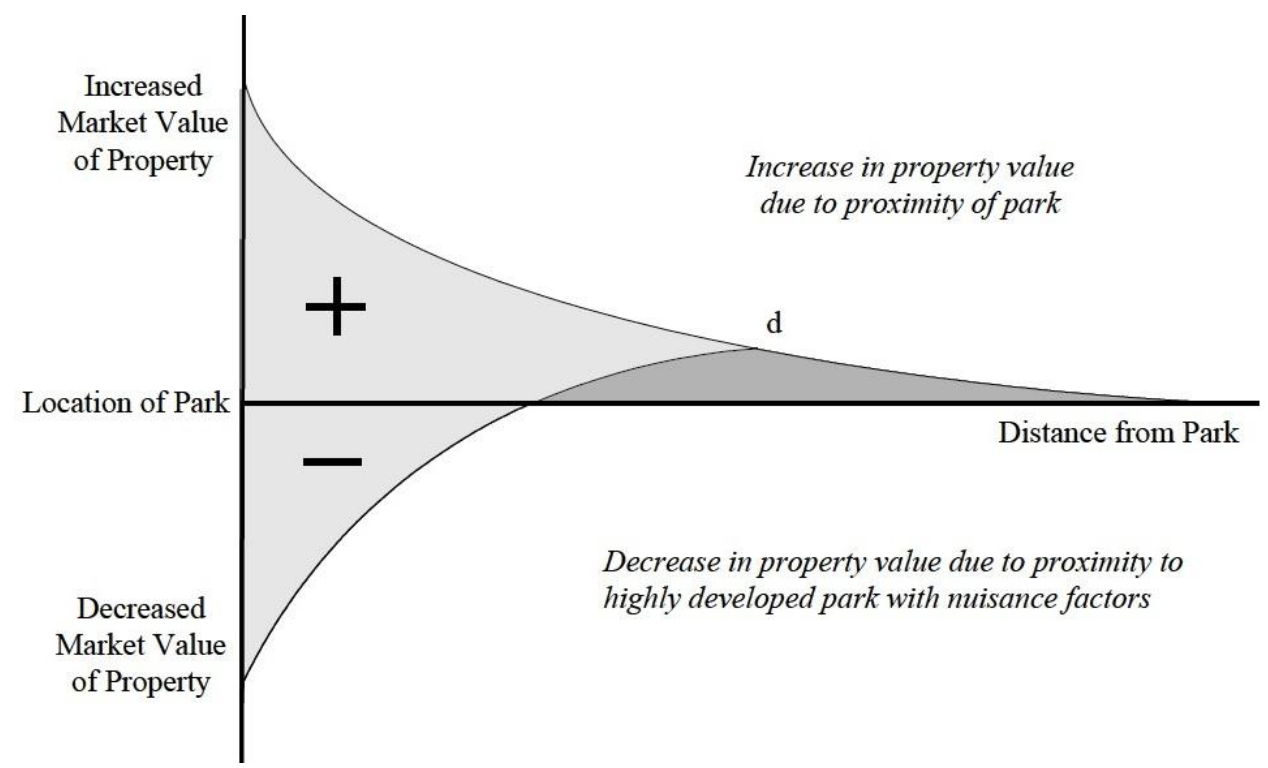

Figura 7.2 - Impactos positivos e negativos dos parques sobre o valor das propriedades residenciais. Fonte: Crompton (2001, p.15).

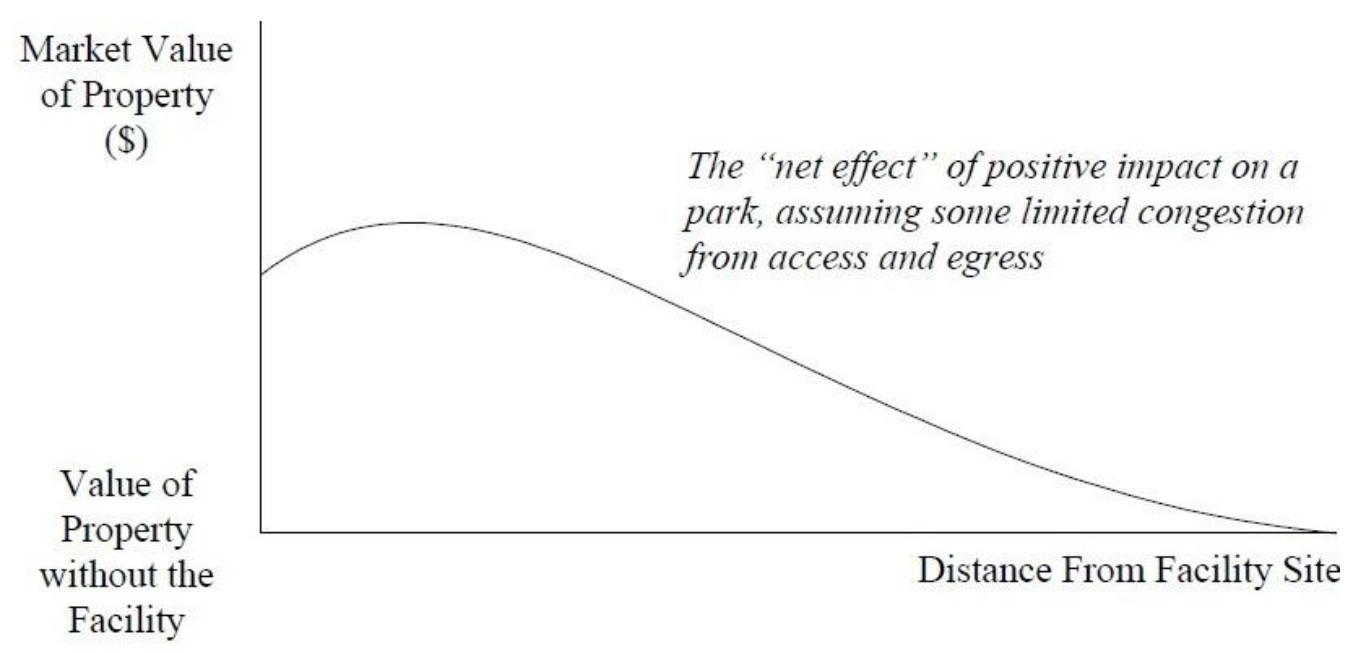

Figura 7.3 - Os efeitos de rede dos impactos positivos no parque.

Fonte: Crompton (2001, p.16). 
As residências situadas no entorno mais próximo dos parques recreativos ativos mostram um pequeno incremento de valor, explicado pelo barulho, pelos incômodos e ao fluxo de entrada e saída de veículos e pessoas. Mas os valores aumentam substancialmente, sendo improvável a ocorrência de impactos negativos, nas residências situadas além da primeira quadra adjacente ao parque. Ao contrário, a influência dos parques recreativos passivos se comporta como uma curva de decaimento clássica na qual as propriedades mais próximas dos parques apresentam os maiores valores de mercado.

$\mathrm{O}$ autor ainda identificou algumas evidencias de que o comportamento antisocial existente em alguns parques acarreta impacto negativo às propriedades contíguas e, que ele pode se intensificar quando o parque não é facilmente visível pelas ruas vizinhas. Entretanto, qualquer impacto negativo é provavelmente dissipado além da primeira quadra.

O aumento do valor das propriedades situadas nas imediações dos parques urbanos vem sendo muito bem explorado pelo mercado imobiliário. Mesmo nos casos em que os empreendedores são obrigados a rever seus projetos urbanísticos, perdendo áreas projetadas para edificação, de fato a perda se transforma em ganho. Barroso (2007, p.167-168), estudando o projeto urbanístico Panamby, na Vila Andrade, afirma

[...] A partir da negociação do parcelamento junto à Prefeitura de São Paulo, [...], nasceu o Parque Burle Marx, incorporando os jardins projetados por Burle Marx e a mata ao redor de uma pequena nascente. A dotação, ao contrário de ser perda, acabou sendo estratégia de valorização dos investimentos, pois a destinação de parte da gleba para a instalação de um parque público "[...] revelou-se um dos grandes atrativos imobiliários do Panamby, que passou a ser anunciado pelos agentes imobiliários como a "mais bela reserva verde da cidade"”' (Fix, 20010 ${ }^{30}$, p.22). [...] Nas estratégias de marketing dos promotores imobiliários, toda a cobertura vegetal, de gramíneas a árvores, é convenientemente trabalhada nas peças publicitárias, contando inclusive com apelos próprios do senso comum, como a idéia da "qualidade de vida". [...] ao parcelar a Chácara Tangará, perdeu-se a oportunidade de ter um pequeno, porém significativo, testemunho da mata atlântica na metrópole paulista, e o que restou funcionou apenas como uma encenação da natureza, reunida em um parque cuja função principal é elevar o preço dos imóveis vendidos ao seu redor [...]. O Parque Burle Marx é o principal item desse cenário [...] Comprar o apartamento em frente ao Parque Burle Marx - cujo prestígio advém da ausência de freqüentadores, o que the confere um status de privilégio - significa consumir um espaço desejado por todos e acessível a poucos, em função de sua escassez.

\footnotetext{
${ }^{30}$ FIX, M. Parceiros da exclusão: duas histórias da construção de uma "nova cidade" em São Paulo - Faria Lima e Água Espraiada. São Paulo: Boitempo. 2001.
} 
O verde, a natureza, a vegetação, as árvores, os parques e os jardins vem empregado, pelo mercado imobiliário, nos jornais de circulação nacional ou nos panfletos de lançamentos imobiliários, para atrair compradores aos seus empreendimentos, como se observa nas manchetes: "Jardins e bosques transformaram-se em atributos essenciais para os condomínios", 31 "[...] Venha viver junto à natureza, em meio a uma atmosfera de magia, rodeado de lazer e entretenimento [...]" ${ }^{32},[\ldots]$ More [...] ao lado de um lindo parque [...]" ${ }^{33}$, "[...] Um mundo melhor tem que ter muitas árvores", etc.. ${ }^{34}$

\subsubsection{Gestão pública da cobertura vegetal no município de SÃo Paulo}

A administração dos espaços livres e áreas verdes públicas é um importante segmento da gestão pública, pois a vegetação nos terrenos privados pode ser facilmente suprimida (Milano, $1988^{35}$ apud Rosseti, Pellegrino e Tavares, 2010). Entretanto, se intensifica na cidade a escassez de recursos e a não priorização das áreas livres públicas ao lazer, observando-se, desde a década de 1980, uma redução significativa dos investimentos públicos para a construção de novos parques e praças (Bartalini, 1999). Neste sentido o tratamento das áreas livres do município vem sendo relegado, conforme aponta Gonçalves (2002, p.23).

[...] É importante frisar que a cidade de São Paulo jamais teve um plano para suas áreas livres. $O$ máximo que existiu foram capítulos genéricos dedicados ao meio ambiente ou às áreas verdes dentro dos inócuos planos diretores. O poder público - o único responsável pela implantação, gestão e manutenção de espaços livres públicos como ruas, praças e parques - já realizou vários planos para São Paulo (viários, de abastecimento, de saneamento ou de canalização e drenagem de córregos). Contudo, não foi realizado um único plano ou projeto que tratasse dos espaços livres públicos. Nesse assunto, como em tantos outros, houve uma histórica e imperdoável omissão do Estado [...].

Silva Filho (2005, p.207) destaca que os conflitos nas relações entre os órgãos municipais, estaduais e federais têm raiz na divisão de poder e perda de

\footnotetext{
${ }^{31}$ FOLHA DE SÃO PAULO. Informe Publicitário. Viver São Paulo. Domingo, 15 out. 2006. p.2.

${ }^{32}$ FOLHA DE SÃO PAULO. Oásis Living Club. Caderno Ciência. Sábado, 17 out. 2009. p. A18.

${ }^{33}$ FOLHA DE SÃO PAULO. Central Home - Condominium Club. Caderno Imóveis. Domingo, 29 jul. 2007. p. 3

${ }^{34}$ FOLHA DE SÃO PAULO. Alameda Morumbi - Condominio Parque. Caderno Dinheiro. Domingo, 23 set. 2007. p. B12B13.

${ }_{35}$ MILANO, M.S. Avaliação quali-quantitativa e manejo da arborização urbana: exemplo de Maringá - PR. Universidade

Federal do Paraná (UFPR). Tese (Doutorado em Engenharia Florestal). Curitiba, PR, 1988. 120 p.
} 
privilégios e, aliados às deficiências que reduzem o poder de ação das instâncias de meio ambiente ou áreas verdes, não são apenas coincidências,

[...] Os conflitos e as deficiências são, pois, o resultado de uma correlação de forças, que atuam sobre a propriedade da terra: a preservação da vegetação, que busca a manutenção de determinadas qualidades, que são valores coletivos de uso, e setores do mercado imobiliário, que buscam a maior lucratividade da propriedade da terra e para os quais interessa somente o valor de troca da propriedade.

Burgos (2003, p.182), nos seus estudos na metrópole paulistana, concluiu que a esfera pública dos parques paulistanos se dá pelas formas de utilização e apropriação dos mesmos pela população. E que o caráter público desses parques não se realiza sem conflitos, mas manifestando a própria segregação espacial, seja negando ou afirmando seus significados.

Pode-se considerar como um marco, na identificação e controle da vegetação municipal, a elaboração do Cadastro dos Espaços Arborizados Significativos do Município de São Paulo, no período de 1984-1985, que se constitui de um conjunto de cartas articuladas, nas escalas de 1:5.000 e 1:10.000, nas quais estão mapeados os maciços ou exemplares arbóreos significativos, acompanhadas por fichas descritivas das suas características botânicas e do seu entorno. Esse documento originou a publicação do livro Vegetação Significativa do Município de São Paulo, em 1988, que serviu de base para a promulgação do Decreto Estadual 30.443/89, que decretou a vegetação ali mapeada como de patrimônio ambiental e/ou imune ao corte (Silva Filho, 2005).

Posteriormente, em 1993, quando foi elaborado o Diagnóstico Cartográfico Ambiental do Município de São Paulo (Sempla, 1985), a Carta 7, denominada Mancha Urbana e Áreas Verdes, constituía-se de uma imagem do satélite LANDSAT, datada de 1988, na escala aproximada de 1:250.000, apresentando os seguintes agrupamentos vegetais: Mata, Capoeira, Campo e Arborização, sem descrição dessas unidades. O objetivo do Diagnóstico foi subsidiar o planejamento da cidade e disponibilizar informações a fim de possibilitar a participação da população no processo de construção da cidade. Uma versão inicial foi apresentada na Conferência das Nações Unidas sobre Meio Ambiente e Desenvolvimento (ECO/92) e, posteriormente na Conferência Internacional sobre Meio Ambiente Urbano (ECO URBIS/93). Considera-se importante a visão global dos problemas ambientais municipais que o diagnóstico permite, no entanto, a escala e a sua estrutura dificultam o alcance dos seus objetivos (Silva Filho, 2005). 
O Atlas Ambiental de São Paulo, lançado em 2004, tem origem, em 1999, com um grupo de técnicos da SVMA empenhado em organizar a diversidade de informações dispersas, para consolidar o Sistema de Informações Ambientais do Município, incluído como instrumento de política urbana no Plano Diretor Estratégico. O Atlas Ambiental de Berlim e a disseminação da ferramenta Sistema de Informações Geográficas - SIG são instrumentos que norteiam a proposta. Posteriormente, técnicos da Sempla e professores da Universidade de São Paulo (USP) são incorporados ao projeto construindo-se uma equipe multidisciplinar e interinstitucional (SVMA, 2004a).

O tema vegetação foi priorizado para estudo, compondo-se pelo subprojeto Diagnóstico e Bases para a Definição de Políticas Públicas para as Áreas Verdes no Município de São Paulo, com o apoio da FAPESP, integrando o Programa BIOTA, no período de 2000 a 2002. A bacia do córrego Cabuçu-de-Baixo, excluindo-se o Parque Estadual da Cantareira e o Horto Florestal, foi selecionada como área piloto a fim de atualizar a publicação sobre a vegetação significativa e o uso e ocupação de áreas públicas, em escala de detalhe. Quanto à vegetação significativa verificou-se que houve importantes alterações, especialmente nas áreas de expansão e consolidação urbanas, quando em áreas particulares. As áreas públicas destinadas ao Sistema de Áreas Verdes foram ocupadas por favelas ou cedidas para outras finalidades, como áreas de uso institucional.

Quanto aos projetos de incentivo ao aumento da cobertura vegetal no município, a Prefeitura promulgou, em 2006, a Lei 14.186, que instituiu o Programa Municipal de Arborização Urbana, com vistas a efetuar ações para a implantação, gestão e conservação das áreas verdes urbanas. Relaciona dentre os principais objetivos: o estabelecimento da Política Municipal de Gestão de Áreas Verdes Urbanas, o conhecimento quali-quantitativo do patrimônio de áreas verdes, o incentivo à utilização do sensoriamento remoto na elaboração de inventário e manejo das áreas verdes e a conscientização pública sobre a importância dessas áreas, inclusive como indicador de qualidade de vida. Estipula que o Sistema de Áreas Verdes do Município deverá estabelecer as áreas que não serão urbanizadas e a forma de urbanização adequada para as demais. No caso dos parques, foi 


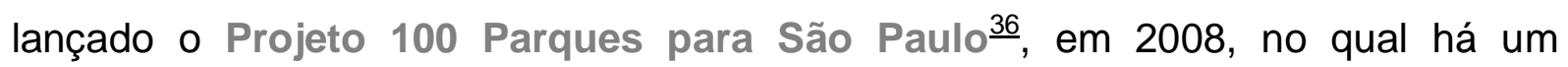
incentivo especial à implantação de parques lineares, conforme dispõe o Plano Diretor.

O Plano Diretor Estratégico (PDE), Lei 13.430/02, contém dispositivos para promover a ampliação e qualificação do Sistema de Áreas Verdes do município, destacando-se a proteção aos mananciais, à fauna e à flora remanescentes, mediante as sanções por infrações ambientais e pela criação de unidades de conservação e outras unidades semelhantes (SVMA, 2004b).

Gomes e Moretto (2009, p. 270-271) estudaram a utilização de indicadores ambientais, com base no documento GEO Cidade-SP (SVMA, 2004b), como ferramenta auxiliar na execução efetiva das políticas publicas referentes à implantação de parques lineares na zona leste do município, a fim de promover a conexão entre o Parque Ecológico do Tietê e o Parque do Carmo, presentes tanto no PDE como nos Planos Regionais Estratégicos (PRE's). Concluíram que eles foram utilizados apenas para definir as áreas prioritárias para implantação dos parques e que o seu planejamento não condiz com o conceito de processo cíclico e de etapas interligadas, apregoados como ações estratégicas, afirmando que as questões ambientais não podem ser tratadas de forma compartimentada na gestão urbana e sem a participação da sociedade

[...] Além da utilização dos indicadores não ter sido efetiva por parte dos agentes governamentais atuantes nos processos de elaboração das políticas e ações referentes à implantação de parques lineares estudados, é ainda menos efetiva a utilização desse instrumento como apoio à participação social, no que concerne a disponibilidade de informações adequadas para o melhor entendimento e envolvimento da sociedade. A participação pública durante o processo de planejamento é fundamental para que esse se complete. [...] não há integração com as outras secretarias e que para o caso específico dos parques lineares, existem conflitos com outras políticas do Plano Diretor, em especial a de habitação. E, que apesar desses aspectos, essas políticas e ações continuam a ser pensadas separadamente.

\footnotetext{
Gradwohl e Greimberg (1991 apud Lazzaro, 2008) afirmam que os conservacionistas e suas políticas de manutenção se decepcionarão, pois os parques e reservas convencionais não abrigarão mais do que $10 \%$ das florestas tropicais mundiais.
}

\footnotetext{
36 PREFEITURA DA CIDADE DE SÃO PAULO (PMSP). Projeto 100 Parques para São Paulo. Disponível em: <http://www.prefeitura.sp.gov.br/cidade/secretarias/meio_ambiente/pograms_e_projetos/index.php? $p=8443>$. Acesso em 30 nov. 2010
} 


\subsection{PARQUES-ATERROS: A REQUALIFICAÇÃO dOS ANTIGOS ATERROS EM}

PARQUES

As características intrínsecas aos lixões e aterros desativados, tais como, o comportamento geotécnico, os riscos ambientais associados, os custos para descontaminação ou remediação, em relação às tipologias de reúso (agricultura, residencial ou lazer) e a sua posição em relação ao seu entorno (geralmente imersos em áreas hoje densamente ocupadas e com pouca ou ausência de vegetação), descritas nos Capítulos 4, 5 e 6, indicam, invariavelmente, essas áreas à requalificação, como parque urbano, tanto no cenário internacional quanto no nacional. No entanto é preciso que as instituições estejam técnica e financeiramente preparadas para a requalificação dessas áreas, pois tal como observam Correia, Silva e Magnabosco $(2007$, p.4) "[...] Os graus de irreversibilidade nas atuações efetuadas na cidade são muito elevados. Caminhar para trás ou corrigir erros do passado é difícil, quando não impossível em muitos casos. Interferir para retificar é sempre muito caro!". Contudo os aterros tem se tornado uma das principais peças do mercado imobiliário no mundo, pois podem se transformar em abundantes áreas verdes com diversidades de animais (WebEcoist, 2009).

\subsubsection{PARQUE-ATERRO NO SISTEMA DE CLASSIFICAÇÃo de PARQUES URBANOS}

O Selav estabeleceu dentre as suas várias tipologias dois tipos de parques: nuclear intraurbano e linear, já definidos no item 7.2.2. Destacam-se as suas características tais como predominância de vegetação e superfície permeável, no primeiro caso, e presença de área de preservação permanente (APP), no segundo.

Nos parques implantados ou a serem implantados sobre os aterros desativados há limitações para implantação de vegetação sobre a camada de cobertura, além da necessidade de se promover a sua impermeabilização para evitar percolação de águas pluviais e conseqüente geração de chorume ou percolado (Capítulos 4, 5 e 6). Merecem cuidados especiais (monitoramento ou instalação de sistemas de extração) as possíveis emanações de gases. Nos casos 
em que eles se situem ao longo de córregos ou em áreas de várzeas, há que se considerar que a APP foi total ou parcialmente comprometida.

Tais especificidades e complexidades dos processos atuantes nestas áreas implicam ações de gestão ou manejo bastante diferenciadas, tanto internamente ao parque como nas suas imediações. Dentre essas ações podemos destacar a importância do conhecimento sobre a fragilidade da área para prever reformas, intervenções pontuais e introdução de vegetação adequada, utilização de equipamentos especiais pelos funcionários, restrição de acesso ou atividades, comunicação dos riscos aos usuários, além da possibilidade de promover um projeto de educação ambiental focado no tema, ações estas, que deverão ser incorporadas aos seus planos de gestão ${ }^{37}$.

Considerando as características dos aterros desativados, descritas acima, e a inexistência de uma classe a elas ajustadas, nas tipologias integrantes do Selav, propõe-se a criação da classe parque-aterro. Neste sentido, define-se o parqueaterro como a área verde inserida na malha urbana ou em suas bordas, com o objetivo de acolher atividades de recreação e lazer ou vegetação, adaptadas às restrições impostas pelo maciço de resíduos que o constitui. A implantação e a manutenção desse tipo de parque deverão atender às exigências do sistema de gerenciamento das áreas contaminadas. O parque-aterro poderá ser composto por área core (maciço de resíduos), zona equipada (recreação e lazer) e zona de amortecimento urbano ${ }^{38}$. A individualização de uma classe específica para os parques implantados sobre aterros permitirá a identificação imediata da sua gênese e a aplicação de procedimentos técnico-científicos-administrativos especiais, de longo prazo, imprescindíveis à implantação e manutenção criteriosa desse tipo de parque urbano. A criação da classe parque-aterro é, também, importante para garantir ações diferenciadas da administração pública na sua gestão, já que o município vem tratando todos os parques da mesma forma.

\footnotetext{
${ }^{37}$ Correlato ao plano de manejo, definido pelo SNUC, pode ser definido como um documento técnico onde se estabelece o zoneamento e as formas de uso do local e dos seus recursos naturais e construídos, inclusive nas intervenções físicas e de controle institucional necessárias à gestão da unidade.

${ }^{38}$ Sugere-se o termo zona de amortecimento urbano, pois não se trata do entorno de uma unidade de conservação, tal qual está definida pelo SNUC, mas, do mesmo modo, as atividades humanas poderão estar sujeitas a normas e restrições específicas, a fim de evitar prejuízos ao desenvolvimento da unidade ou riscos à manutenção dos ecossistemas e à saúde da população.
} 


\subsubsection{PARQUES-ATERROS NO CENÁRIO INTERNACIONAL}

Borella (2004), citando o guia de aterros do Ministério do Meio Ambiente da Nova Zelândia, apresenta a relação de alguns países onde os antigos aterros são convertidos em parques. Na Austrália, essas áreas na sua maioria se transformam em parques e jardins; ou áreas residenciais, sob controle rígido. No Canadá, em parques ou campos de golfe. Quando há projeto para controle de gás, são implantadas edificações. O pós-uso predominante, na Holanda, é de parque, campo de esportes e de golfe. No Japão, Hong Kong, são elencados três exemplos: o projeto de Parque Ecológico, pista de aeromodelismo e centro de educação ambiental no Jordan Valley; a implantação de campos de golfe no Shuen Wan e o projeto para construção de campo de baseball e futebol e área de recreação para crianças no Sai Tso Wan. Na Espanha, apresenta o exemplo do parque La Coruña (Figura 7.4).

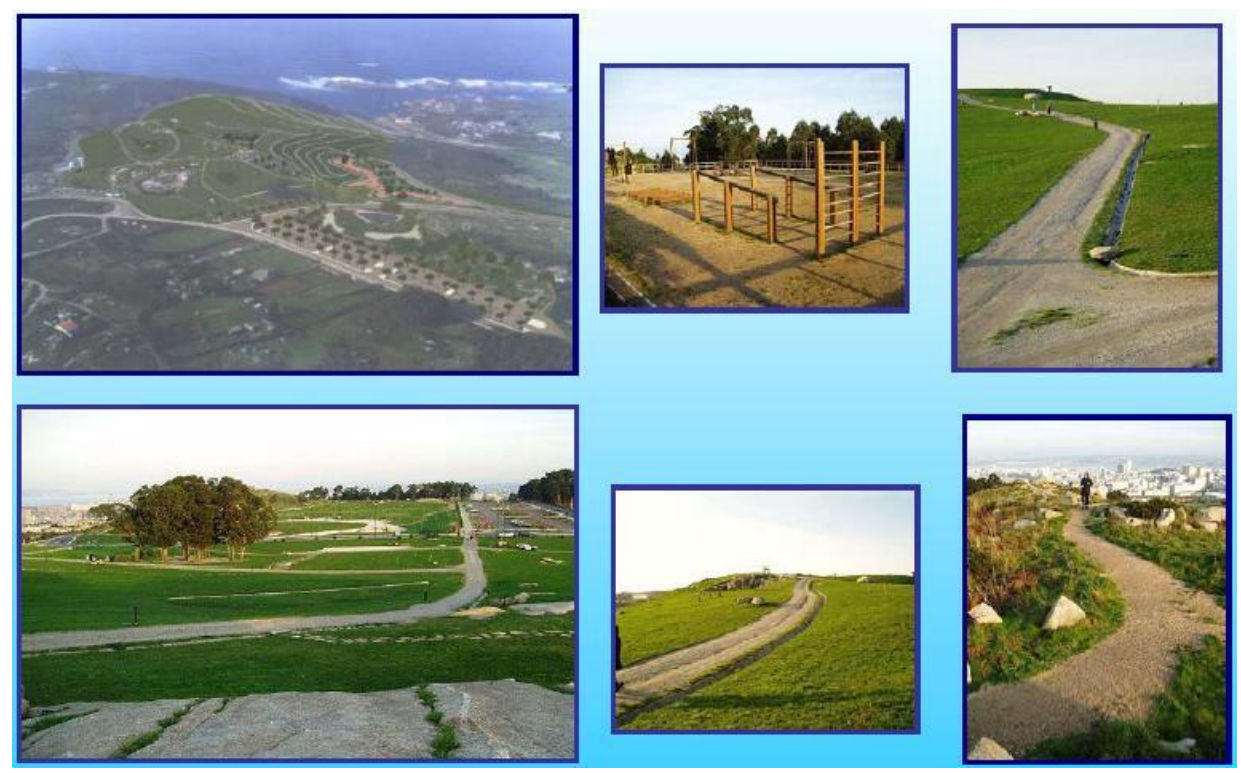

Figura 7.4 - Vista geral e de detalhe do Parque La Coruña, Espanha, implantado sobre antigo lixão. Fonte: Borella (2004).

\subsubsection{Parque Chambers Gully - Austrália}

Parque Chambers Gully (WebEcoist, 2009), localizado no subúrbio de Adelaide, na Austrália, foi uma ação de voluntários para a recuperação de um antigo aterro local, através de investimento de fundos governamentais. Atualmente é um santuário para os animais, incluindo os koalas, freqüentemente avistados sobre os eucaliptos. 
7.2.2.2 PARQUE AYALON - ISRAEL

O antigo aterro Hirya (Figura 7.5), uma enorme elevação situada próxima ao aeroporto de Ben Gurion, em Tel Aviv, Israel, iniciou o seu processo de recuperação em 2001 (WebEcoist, 2009). O aterro situa-se na confluência dos rios Ayalon e Shapirim e funcionou como local para disposição dos resíduos sólidos de toda a região metropolitana de Tel Aviv, no período de 1952 a 1998. Ocupa uma área de 40 hectares e 60 metros de altura com cerca de 16 milhões $\mathrm{m}^{3}$ de resíduos depositados (Isengerg, Peterson e Sternberg, 2004).

$\mathrm{O}$ arquiteto paisagista alemão Peter Latz foi selecionado num concurso nacional para desenvolver o projeto para reabilitação do aterro (Brandeis, s/d; www.alon.parkorg.il). Após a sua total recuperação, prevista para 2020, a área será incorporada a uma vasta área natural denominada Ayalon Park (Figura 7.6), transformando-se num dos maiores parques urbanos mundiais (WebEcoist, 2009).
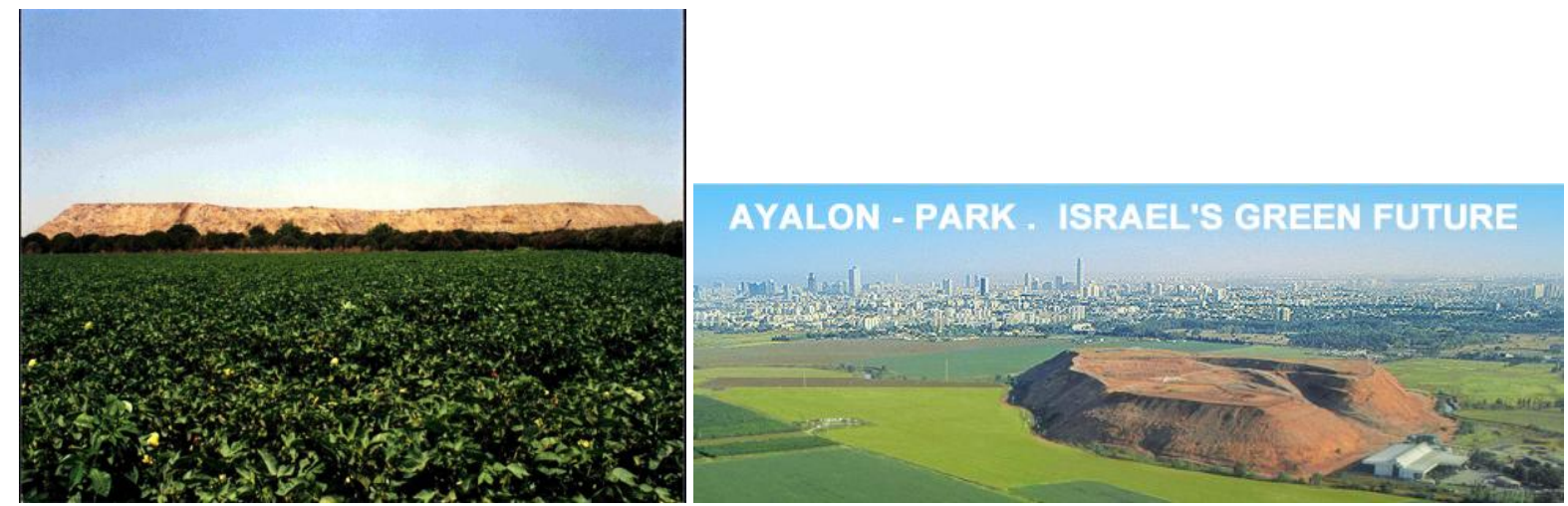

Figura 7.5 - Vista do antigo aterro Hirya situado na planície de Ayalon, Tel Aviv, Israel. Fonte: Brandeis (s/d); www.alon.parkorg.il

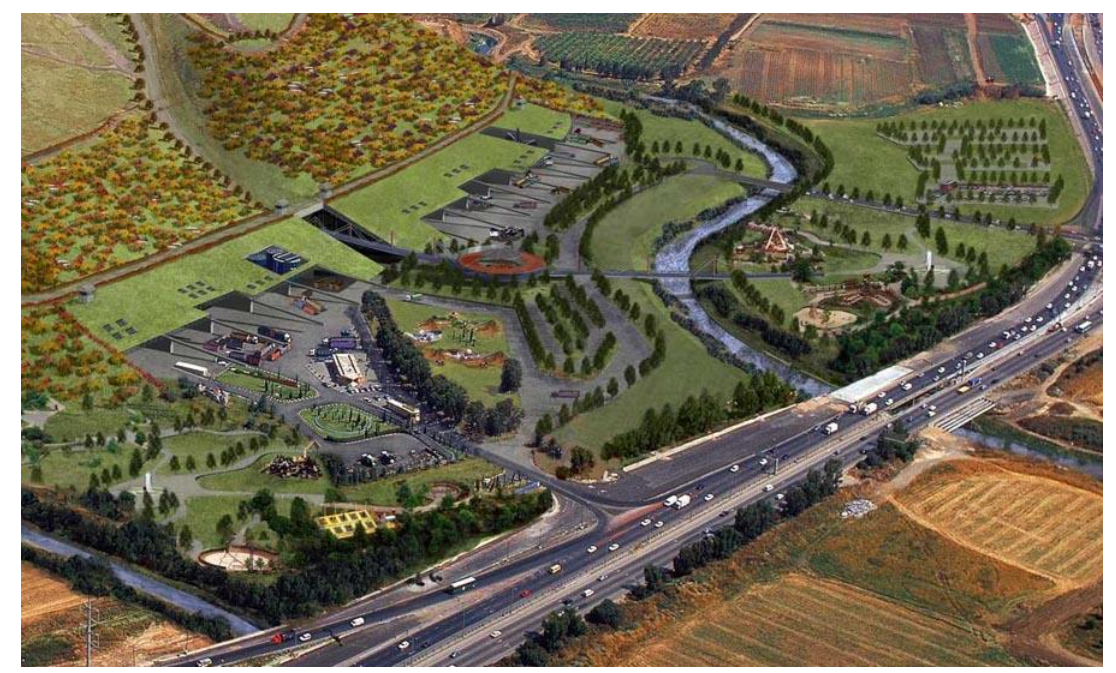

Figura 7.6 - Projeto do futuro Parque Ayalon em Tel Aviv, Israel.

Fonte: Brandeis (s/d). 


\subsubsection{Parque das Nações - Portugal}

A implantação do complexo do Parque das Nações (Figura 7.7), em Lisboa, Portugal, entre o rio Tejo e a estação ferroviária, na parte oriental da cidade, numa zona de transição entre os municípios de Lisboa e Loures, foi o resultado de um projeto de requalificação urbanística e ambiental de uma área de cerca de 340 hectares, com $5 \mathrm{~km}$ de frente para o rio, em região originalmente ocupada por uma refinaria de petróleo e pelas antigas docas de Olivais. A oportunidade do projeto foi viabilizada pela realização da Expo'98, a última grande exposição internacional do século XX. O projeto compreendia seis zonas com projetos detalhados por diferentes arquitetos. A zona verde, ao longo dos rios, foi delegada às atividades de lazer, esporte e educação ambiental (Morinaga, 2007).

No extremo norte do Parque das Nações situa-se o antigo aterro sanitário de Beirolas, entre o rio Trancão e a Estação de Tratamento de Águas Residuais de Beirolas, com área original de 17 hectares e 15 metros de altura. $O$ aterro serviu como depósito dos resíduos sólidos de Lisboa, no período de 1985 a 1990. Apresentou problemas com o sistema de drenagem de lixiados e biogás, além de instabilidade dos taludes, devido a sua operação por período superior ao previsto. A recuperação do aterro deu-se mediante as seguintes providências: suavização dos taludes para maior estabilidade, extração e tratamento dos lixiviados e do biogás, confinamento dos resíduos por meio de barreira impermeabilizante, instalação de sistema de drenagem das águas superficiais e colocação de camada de terra vegetal para o plantio de vegetação, constituindo-se no Parque Urbano do Tejo (Figuras 7.7 e 7.8). O solo contaminado por hidrocarbonetos, retirado dos terrenos das empresas petrolíferas, foi colocado em células isoladas, para re-conformação dos taludes do aterro, devido aos prazos curtos para execução do projeto e o baixo custo desta solução. Para cobertura do maciço de resíduos utilizou-se o biosólido ${ }^{39} \mathrm{e}$ o composto orgânico produzido na Estação de Tratamento de Resíduos Sólidos de Beirolas. O Plano de Monitoramento Ambiental do aterro compreende a avaliação dos seguintes indicadores: qualidade dos solos; águas subterrâneas; águas superficiais e sedimentos; poluição atmosférica; ruído; geotecnia; meteorologia; comunidades biológicas e outros aspectos sócio-econômicos (Morinaga, 2007).

\footnotetext{
${ }^{39}$ Solo manufaturado constituído de mistura de materiais, incluindo o composto de esgoto tratado.
} 

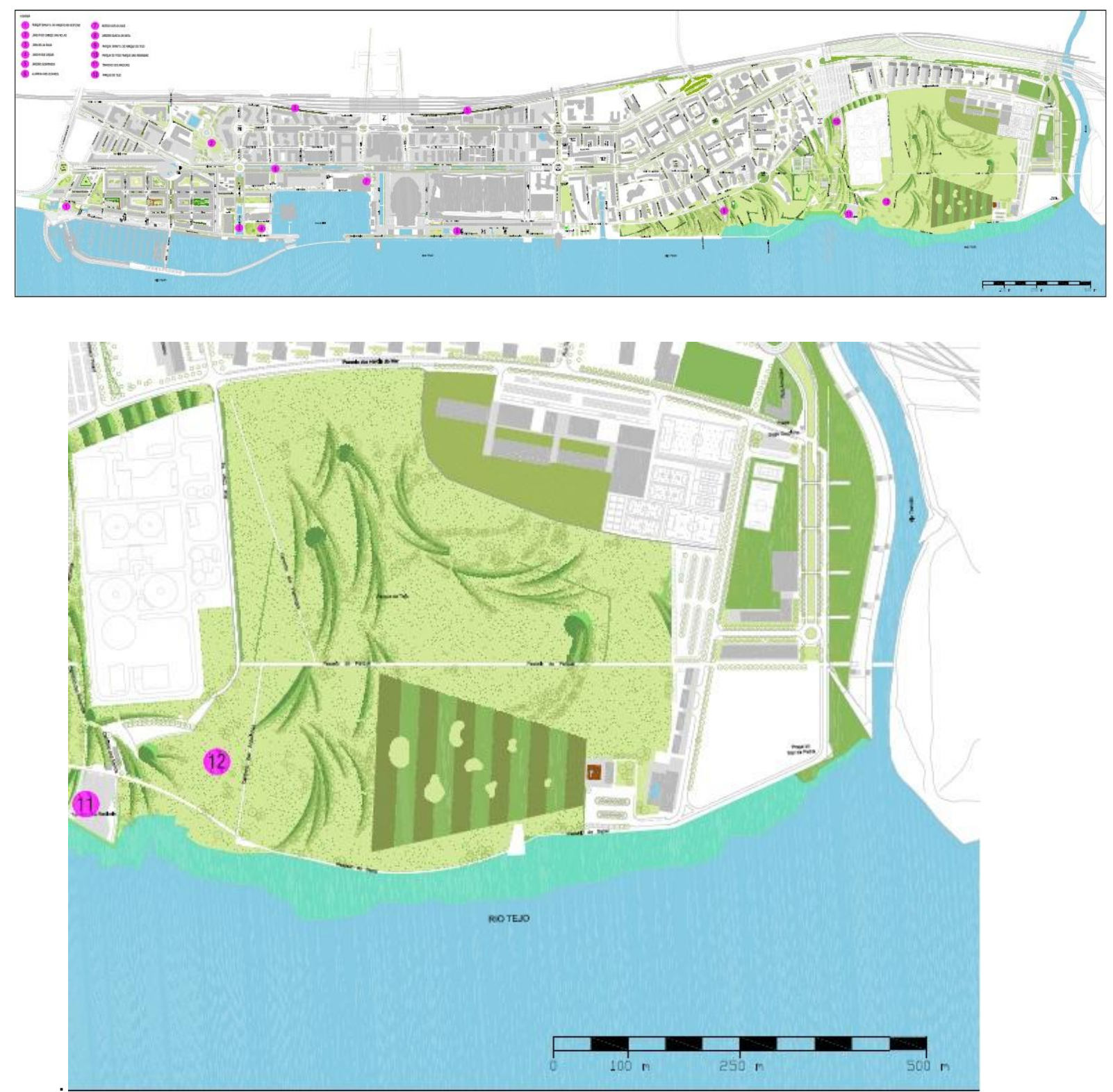

Figura 7.7 - Projeto do Parque das Nações em Lisboa, Portugal, no trecho superior e, o detalhe do Projeto do Parque do Tejo, situado no extremo norte do Parque, abaixo.

Fonte: <http://www.portaldasnacoes.pt>. Acesso em: 15 dez. 2010.

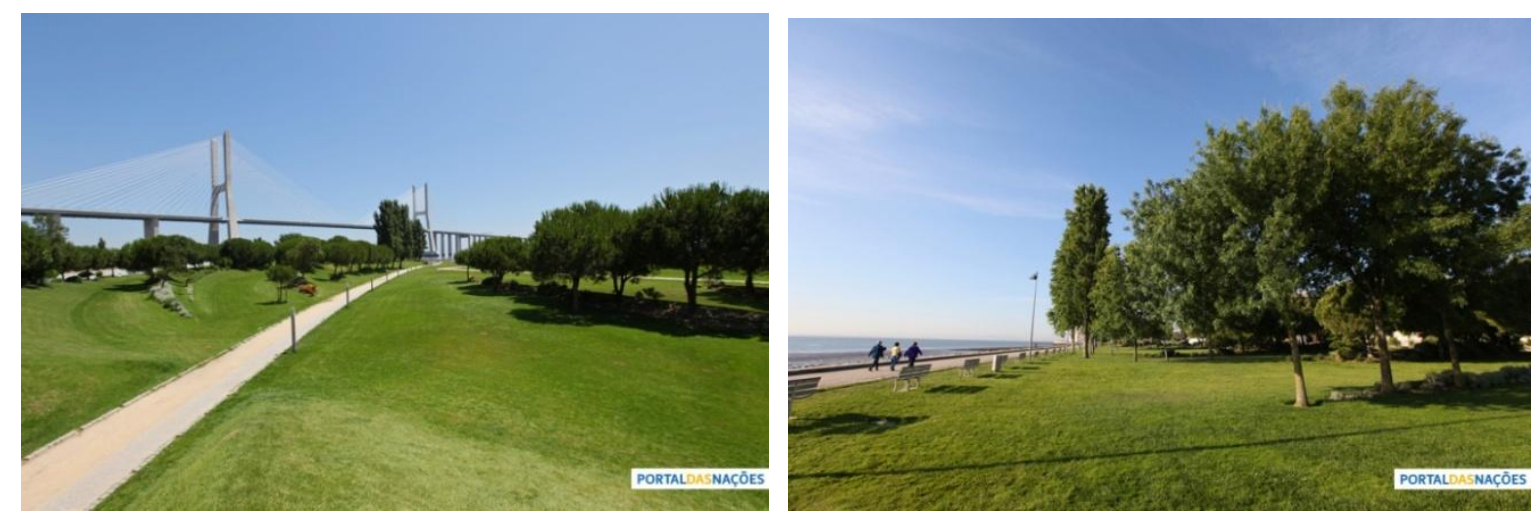

Figura 7.8 - Vistas do Parque do Tejo, na primavera.

Fonte: <http://www.portaldasnacoes.pt>. Acesso em: 15 dez. 2010. 


\subsubsection{Ilha Pulau Semakau - Singapura}

A ilha situada ao sul de Singapura, uma antiga vila de pescadores, foi desapropriada para implantação do lixão da cidade, após a incineração dos resíduos. A conversão da área em natureza preservada (Figura 7.9) se deu no início da década com a instalação de barreira impermeável no entorno da ilha, onde as cinzas foram estocadas. Existe um recife de coral ao longo da costa com abundante vida marinha e, no seu interior, pássaros e mangroves. A visita à ilha é permitida apenas com acompanhamento de guia. (WebEcoist, 2009).

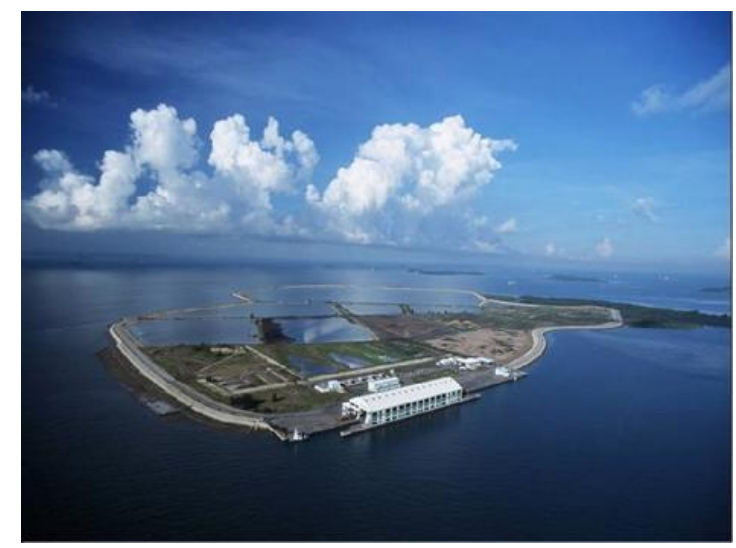

Figura 7.9 - Ilha Pulau Semakau, em Singapura.

Fonte: WebEcoist (2009).

\subsubsection{PARQUES-ATERROS NOS ESTADOS UNIDOS}

Conforme Harnik e Taylor (2006a) relatam, a conversão de aterros em parques nos Estados Unidos remonta a pelo menos o ano de 1916, quando, em Seattle, foi criado o campo para jogos Rainier sobre antigo lixão. $O$ famoso Parque Arborentum, em Washington, se originou da transformação, em 1935, de 25 hectares do lixão da Rua Miller. No ano seguinte, em Nova lorque, o lixão Coroña, conhecido como Vale das Cinzas, no filme 'O Grande Gatsby', de F. Scott Fitzgerald, foi fechado, iniciando-se a preparação do terreno para a construção da Feira Mundial de 1939. Uma investigação superficial nas grandes cidades americanas, realizada pelo Center for City Park Excellence (CCPE), revelou mais de 1.800 hectares de aterros convertidos em parques, com sucesso.

Os autores (2006b) verificaram, também, que o total de parques ou áreas públicas de recreação implantadas sobre antigos aterros ainda não foi calculado, 
nos Estados Unidos. Englobam áreas famosas, tal como o Flushing Meadow, em Nova York, onde já foram realizadas duas feiras internacionais até áreas obscuras, intra-urbanas, tal como quadras de tênis e basquete, campos de golfe e de futebol. Numa das áreas convertidas, em Berkeley, na Califórnia, acontece o festival internacional de pipa; em outra, em Albuquerque, no Novo México, o campeonato de balão. Apontam ainda que alguns dos melhores parques urbanos, americanos, foram implantados sobre aterros, ou igualmente, que o recobrimento automático de aterros produz péssimos parques. Adicionam que em época de escassez de espaços urbanos e de recursos, os aterros desativados passam a oferecer uma excelente oportunidade para criação de parques, por três motivos: o tamanho, a localização e o custo.

\subsection{PARQUe MILleNIUM}

O parque do Millenium, em Boston, Massachusetts, segundo Harnik e Taylor (2006a), inaugurado em dezembro de 2000, funcionou até 1994 (WebEcoist, 2009) como o conhecido lixão da rua Gardner. Atualmente são 40 hectares constituídos de campos de futebol, playgrounds, salas para conferência e anfiteatro, dez quilômetros de trilhas e ciclovias, com acesso ao rio (Figura 7.10). A criação do parque foi uma das primeiras iniciativas do movimento para transformar Boston em uma das cidades com mais áreas verdes nos Estados Unidos (WebEcoist, 2009).

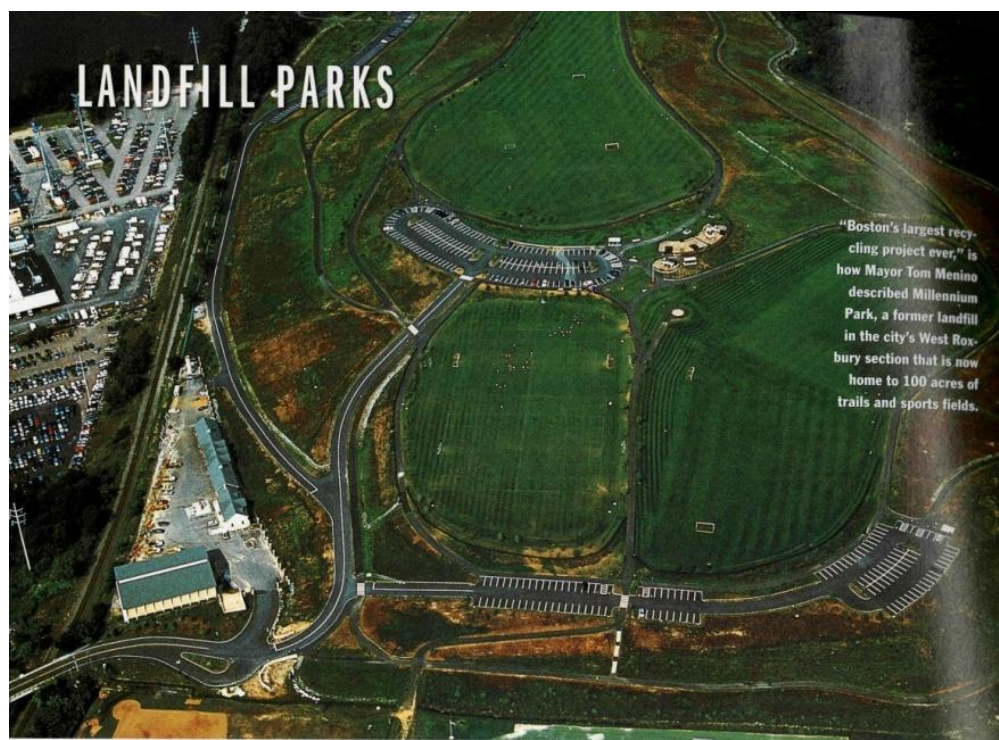

Figura 7.10 - Parque do Milennium, em Boston, com trilhas e campos de esportes.

Fonte: Harnik e Taylor (2006b, p.50). 


\subsection{PARQUE TRASHMORE}

O parque localiza-se na praia de Virgínia. Atualmente se estende por 1,65 hectares correspondendo a uma montanha de resíduo com 18 metros de altura e de 245 metros de comprimento, em boas condições de estabilidade, recoberta por solo e vegetação (Figura 7.11). Esse aterro necessitou de múltiplos tratamentos por décadas. O capeamento original dos resíduos foi executado em 1974, recapeado em 1986 e, por último, em 2003 (Harnik e Taylor, 2006a). O parque inclui quadras de basquete, pista de skate e áreas para picnic (Figura 7.12) e é atração turística da região (WebEcoist, 2009).

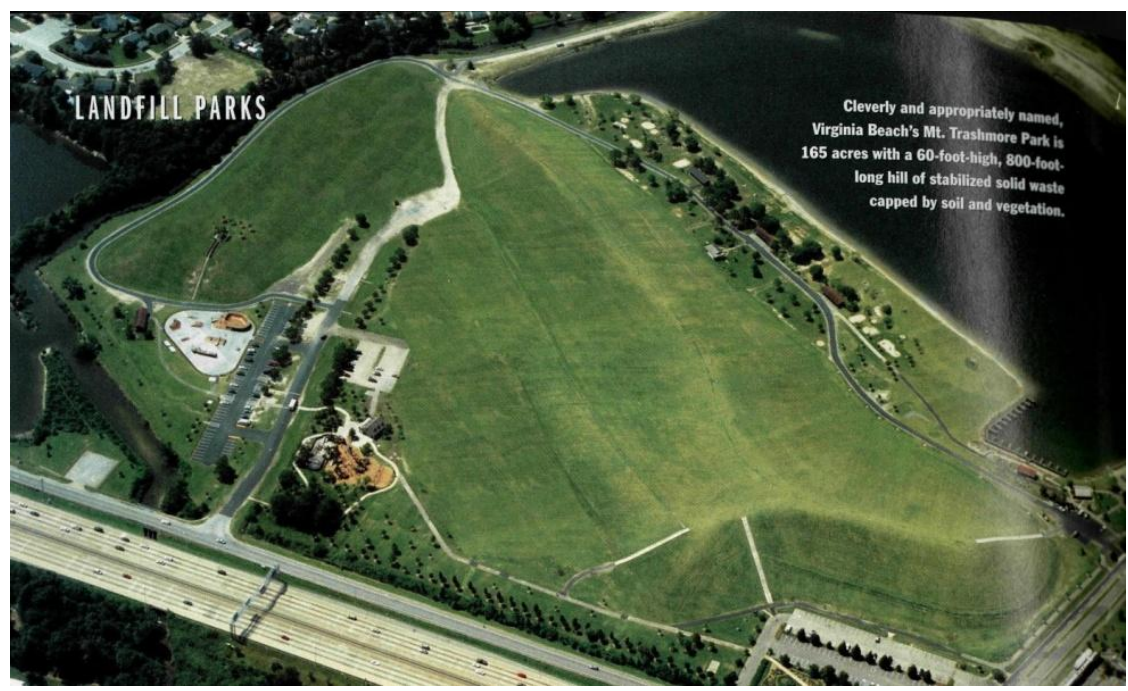

Figura 7.11 - O Parque Trashmore na praia de Virgínia. Fonte: Harnik e Taylor (2006b, p.52).
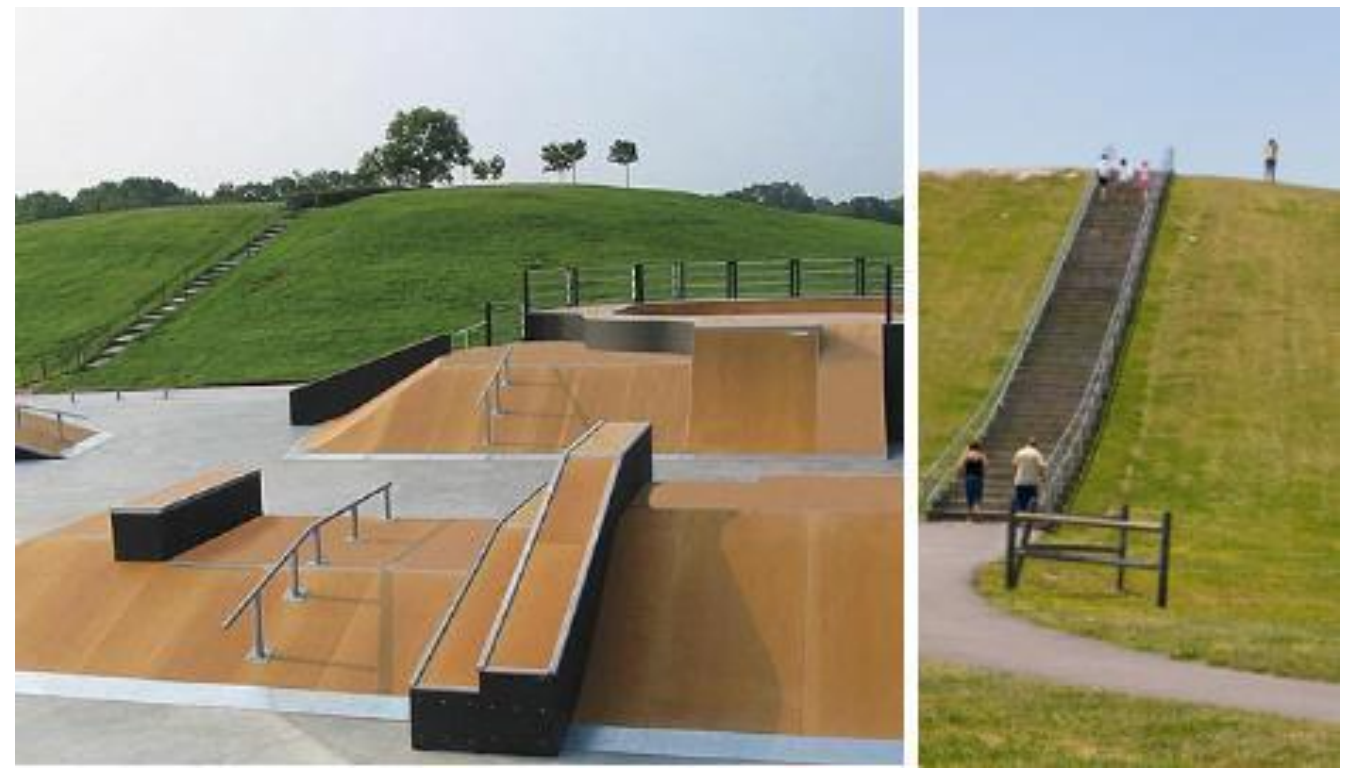

Figura 7.12 - Detalhe dos equipamentos instalados no Parque Trashmore Fonte: Ecoist, 2009. 


\subsection{PARQUe Natural SMIth-BybeE}

Essa área natural, localizada em Portland, no Oregon, conforme relato de Harnik e Taylor (2006a) é caracterizada por uma planície com 809 hectares que abriga no seu interior um lixão com 97 hectares (Figura 7.13). O lixão St. John funcionou por 50 anos, sendo encerrado em 1991, quando se iniciou um longo período de recuperação. A produção de gás metano é bombeada para abastecer uma companhia de cimento. A arrecadação obtida, US\$110.000/ano, é utilizada para custear as operações de fechamento do aterro.

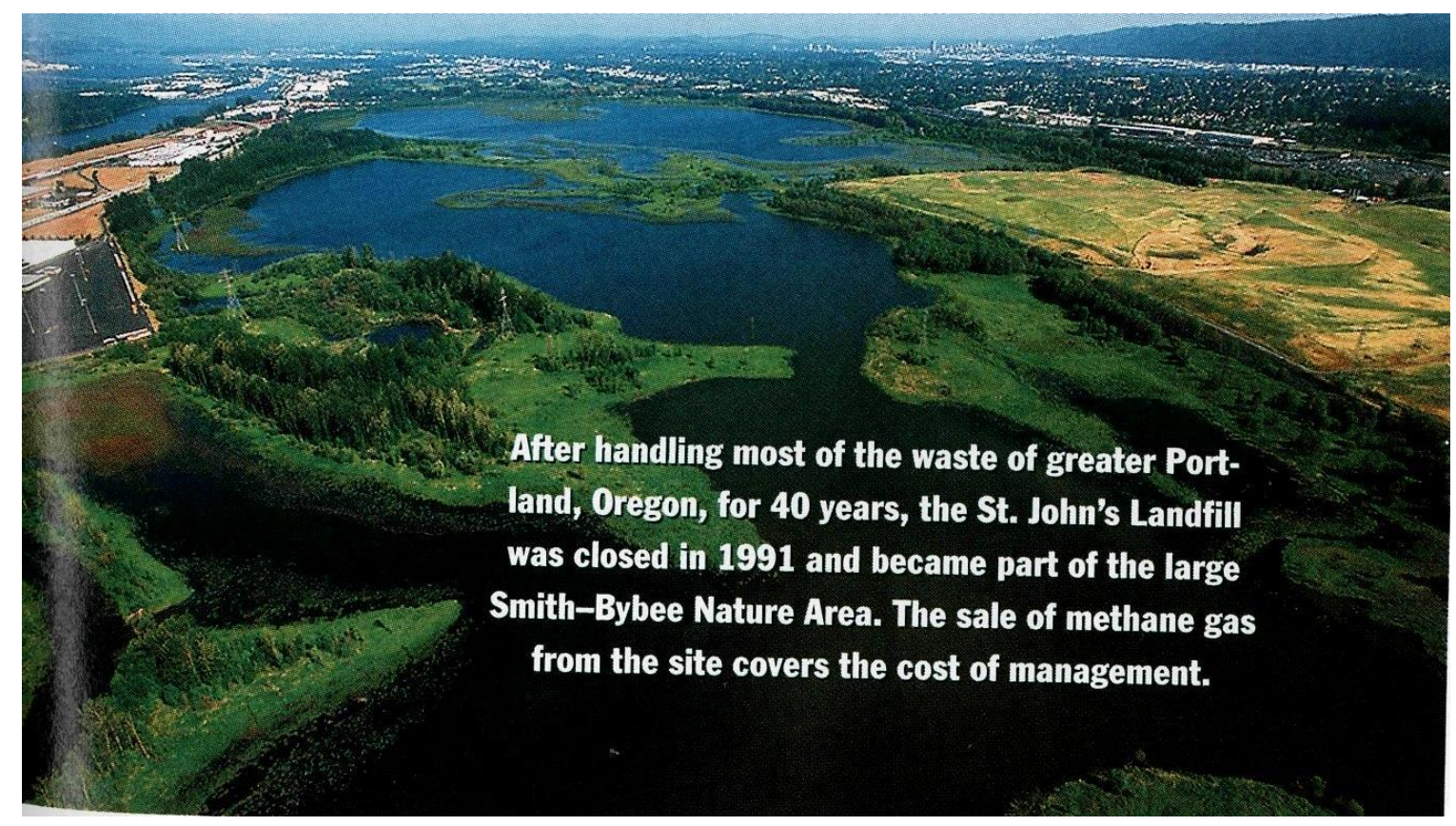

Figura 7.13 - Antigo aterro St. John incorporado á área natural de Smith-Bybee, em Portland, Oregon. Fonte: Harnik e Taylor (2006b, p.53).

\subsection{PARQUE MABEL DAVIS}

O caso do Parque Mabel Davis (Figura 7.14), com 0,50 hectares, mostra algumas dificuldades com as quais os planejadores de parques se deparam na conversão de aterros, de acordo com relato de Harnik e Taylor (2006a). Localizado a 6,5 Km ao sul de Austin, Texas, metade do parque está sobre um aterro fechado na década de 1950. A área foi inicialmente convertida em parque em 1979, antes das normas regulatórias específicas existirem, e pouco tempo depois da cobertura do aterro, se instalou a erosão e a poluição pelo chorume. Níveis elevados de chumbo 
Requalificação dos Aterros Desativados (BrownfieldS) no MunicípIo de SÃo PaUlo: Parques (GreenfieldS) Raposo TAVARES E Jardim PrimaVera

LUZIA HELENA dos SANTOS BaRRos

e pesticidas foram detectados no solo, muito provavelmente, derivados de fertilizantes ilegais e baterias, ali depositados.

Depois de anos de problemas, a cidade foi forçada a fechar o parque em 2000 e iniciar um programa de remediação, com custo de US\$ 8,5 milhões. De acordo com Christina Calvery, gerente de projeto do parque e do Departamento de Recreação, isso significou um redesenho do parque para alcançar os padrões exigidos pela EPA.

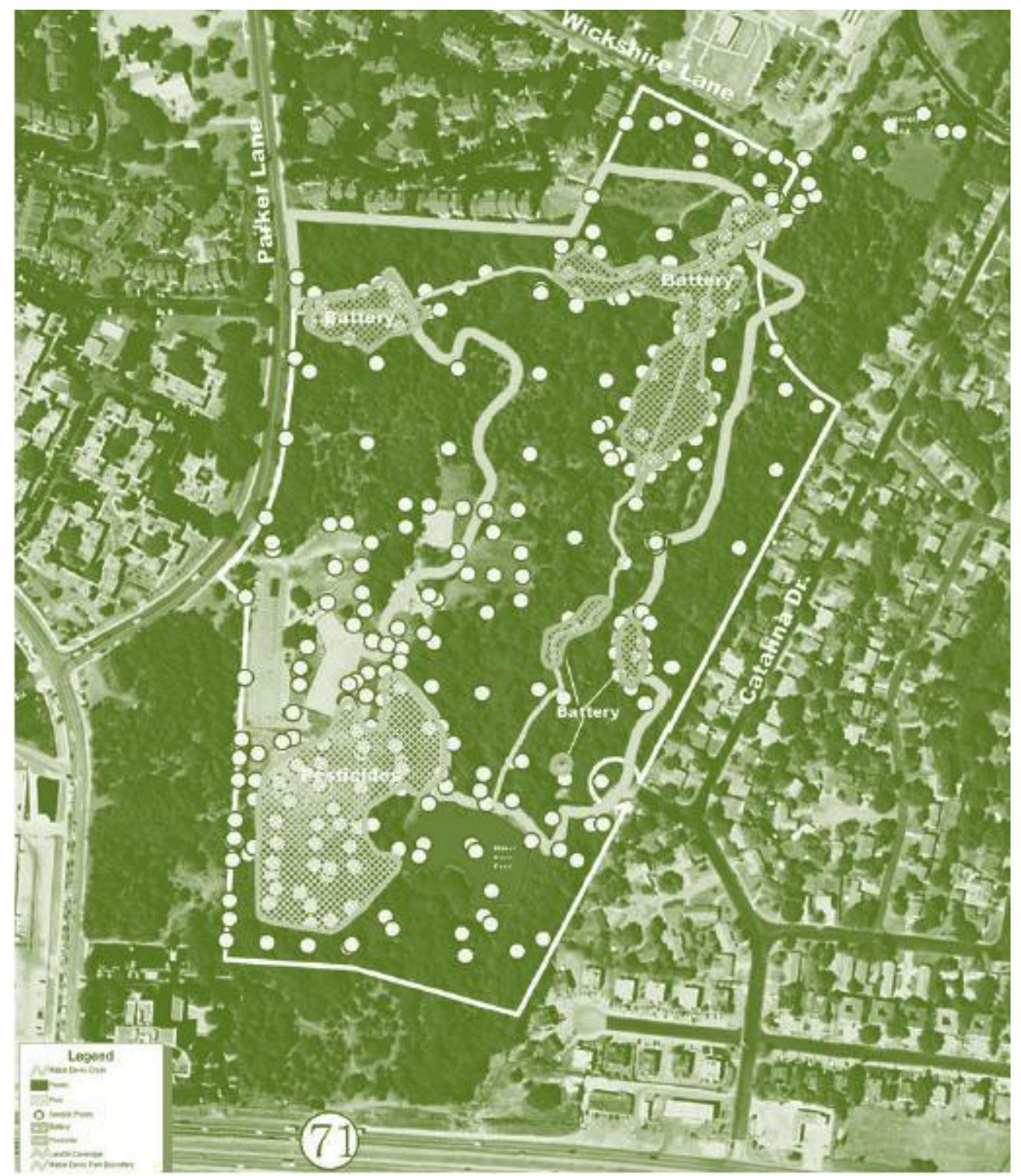

Figura 7.14 - Imagem do Parque Mabel Davis, em Austin, Texas.

Fonte: Harnik e Taylor (2006a, p.84). 


\subsection{IlHa SPETACLE}

Segundo Hazelrigg (2006) a ilha, com um hectare de extensão, foi aberta ao público em junho de 2006 e hoje é o caminho de entrada para as outras 34 ilhas que constituem o Parque Nacional do Porto de Boston. Contém o ponto mais alto do porto com uma vista panorâmica de $360^{\circ}$ (Figura 7.15). Os visitantes têm utilizado a ilha para soltar pipa, assistir sessões de jazz, explorar as trilhas apreciando a vegetação abundante e os animais. As crianças aproveitam para nadar na área de praia, rotineiramente (Figura 7.16).

O local, entretanto, por 47 anos, serviu como lixão para a cidade de Boston, encerrando suas atividades em 1959. Permaneceu abandonado por cerca de 20 anos como um depósito de substâncias tóxicas exposto, com combustão de gases e, funcionando como fonte de contaminação das águas de um dos portos mais poluídos da América. Somente no final dos anos 80 o interesse pela área foi retomado. Iniciou-se um programa de despoluição do porto com construção de uma moderna estação de tratamento de esgoto. Paralelamente, havia o projeto de construção do Túnel da Artéria Central de Boston (CA/T), conhecido como Big Dig, que precisava encontrar um lugar para dispor cerca de 4,3 milhões de toneladas de material de escavação. Com a autorização das agências municipal e estadual, foram depositadas 945.000 toneladas de material na llha, no período de 1993 a 1997. Para tanto a $\mathrm{CA} / \mathrm{T}$ se comprometeu a recobrir o aterro e a construir vias, uma marina e um centro de visitantes.

Para o recobrimento do aterro foi colocada uma camada de 0,50 metros de espessura, constituída de argilas glaciais, extraídas dos depósitos ao sul e próximos à Ilha Deer. Acima dessa camada foi colocada uma camada com dreno de areia, sobre esta uma de marga e, por último, uma cobertura de solo. A espessura total do recobrimento varia de 0,60 a 1,65 metros. A altura total do maciço da ilha (Figura 7.17) foi limitada considerando a proximidade do aeroporto de Logan, situado $6,5 \mathrm{Km}$ a noroeste.

O solo utilizado para a cobertura foi um solo manufaturado, que é composto de uma mistura de depósitos de argilas glaciais da ilha, areia grossa importada e o mais importante, composto de esgoto tratado (biosólido). O plantio de vegetação ocorreu no período de 1997 a 2000. A principal preocupação da projetista era a proteção do talude com inclinação de 3:1, com diferentes camadas de vegetação: 
grama, arbustos e árvores. O projeto previa a utilização de poucas espécies nativas, pois precisavam de espécies de crescimento rápido e capazes de conter os ventos imediatamente. Tinha como meta, também, a baixa ou inexistência de manutenção.

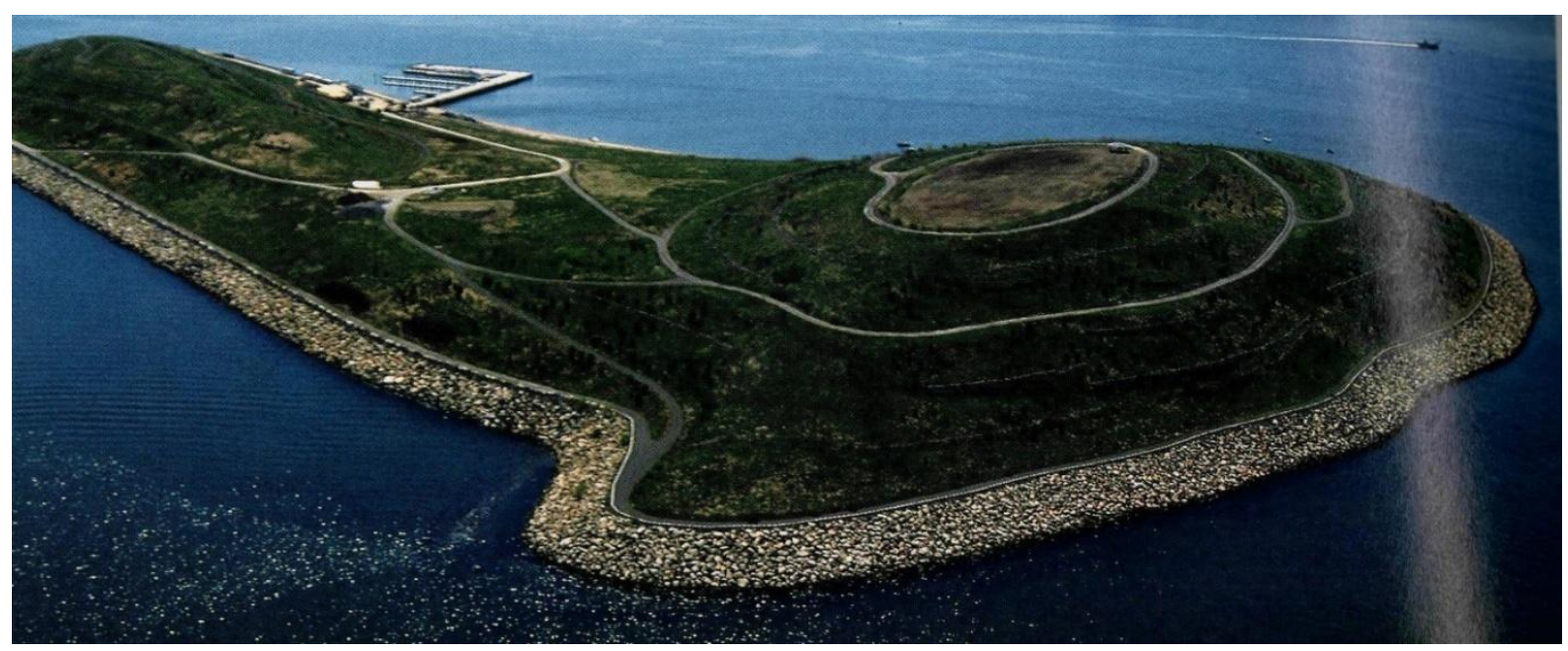

Figura 7.15 - Vista geral da llha Spetacle. Fonte: Hazelrigg (2006, p.56).

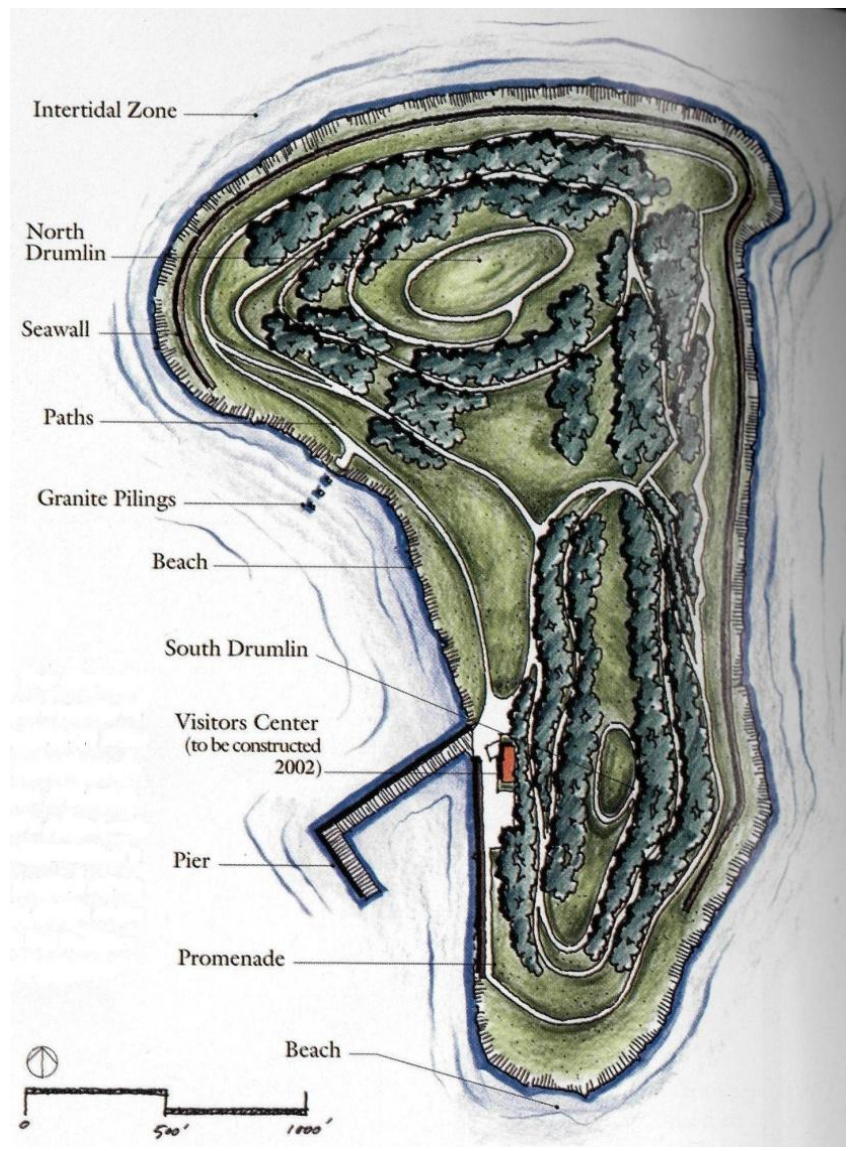

Figura 7.16 - Projeto do parque implantado sobre a llha Spetacle. Fonte: Hazelrigg (2006, p.58). 


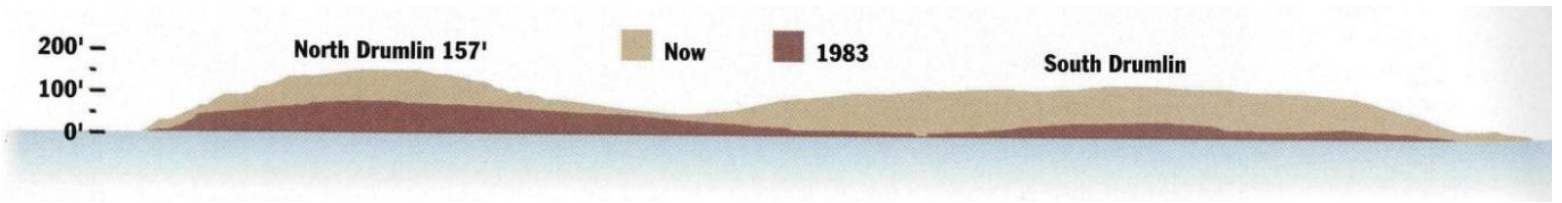

Figura 7.17 - Representação do perfil norte-sul da llha Spetacle.

Fonte: Hazelrigg (2006, p.58).

Drumlin - feição geomorfológica típica de atividade glacila, constituída de colinas ovóides ou elípticas, mais rombudas para montante das geleiras (glaciers) e mais alongadas para jusante. Elas ocorrem agrupadas, mais freqüentemente em áreas de tills basais ricos em argila. Podem aparecer centenas a milhares de drumlins indicando a direção e o sentido de fluxo das geleiras que as depositaram. Litologicamente, predomina till argiloso, às vezes arenosos, nada ou pouco estratificado. Pode ocorrer no seu interior um núcleo de rocha dura. (Suguio, 1998).

Till - sedimento clástico depositado diretamente pela geleira, composto por partículas de minerais e rochas de dimensões muito variadas, desde argila a matacão e sem estratificação. (Suguio, 1998).

Os projetistas sempre souberam que a lista de plantas utilizada era experimental e que algumas delas floresceriam e outras não. No entanto, verificaram a eficiência do critério de introduzir amplas fileiras de espécies, pois as plantas começam a constituir uma floresta dando forma à ilha (Figura 7.18).

Quanto aos problemas clássicos, que os projetos de reúso de aterros apresentam: recalque, emanação de metano e presença de chorume, somente este último, precisou de providências específicas; sendo bombeado para estação de tratamento, na ilha Deer, conforme exigência da agência ambiental.

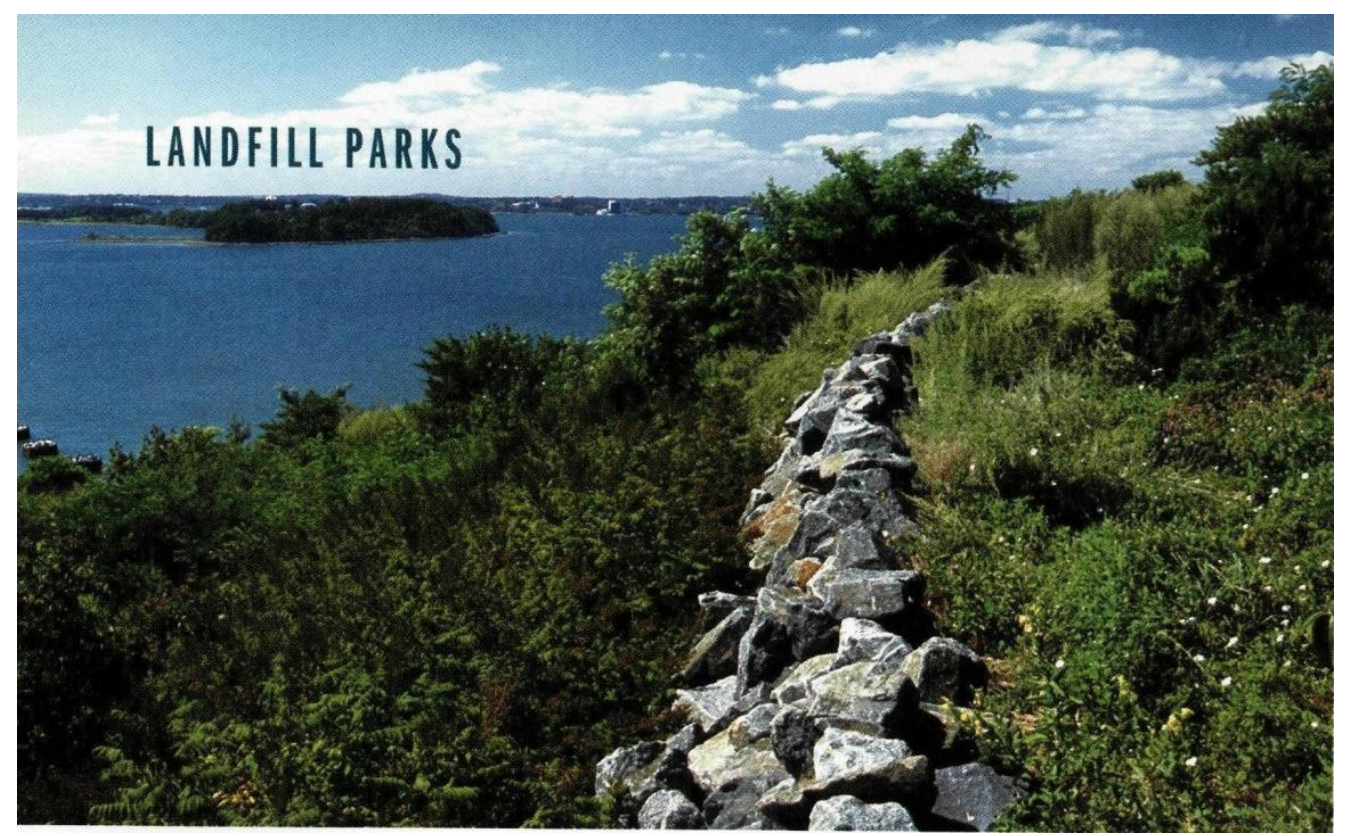

Figura 7.18 - Vegetação implantada no talude para proteção quanto à erosão e ação dos ventos. Fonte: Hazelrigg (2006, p.60). 
O parque possui $1 \mathrm{Km}^{2}$ e está localizado a cerca de $1,5 \mathrm{Km}$ da cidade de Buffalo. É um santuário para pássaros, cervos, peixes e outros animais. A pesca é permitida, mas a maioria dos visitantes utiliza o parque para observação de aves, fotografia ou apenas para passeio (WebEcoist, 2009).

\subsection{Parque Richard W. DeKorte}

O projeto do parque experimental sobre aterro foi o primeiro desenvolvido em New Jersey e um dos primeiros do país. O parque, situado em rota migratória do Atlântico, possui $0,4 \mathrm{Km}^{2}$ e caracteriza-se por uma wetland aberta com áreas para recreação e educação (Figura 7.19). Contém o campus da New Jersey Meadowlands Commission (NJMC) incluindo o prédio da Administração, o Centro Meadowlands para Educação Científica e Ambiental, o Observatório William D. McDowell e o Centro Ambiental Meadowlands. O projeto foi realizado por arquitetos paisagistas do NJMC's (LYNDHURST) em conjunto com especialistas ambientais, em wetland e em resíduos sólidos. Seis diferentes setores foram instituídos ao longo dos 20 anos com plantação de vegetação nativa, utilização de materiais reciclados e técnicas sustentáveis de acordo com exigências da agência ambiental (NJMC, s/d).

Originalmente um aterro ilegal, com cerca de $14.160 \mathrm{~m}^{2}$, foi implantado sobre uma ilha de sedimentos estuarinos, no início da década de 1950. A recuperação da área, pela NJMC, se iniciou, em 1989, com a construção de um dique ao redor do seu perímetro e, posteriormente, o recobrimento com solo formando os vales e montanhas. 


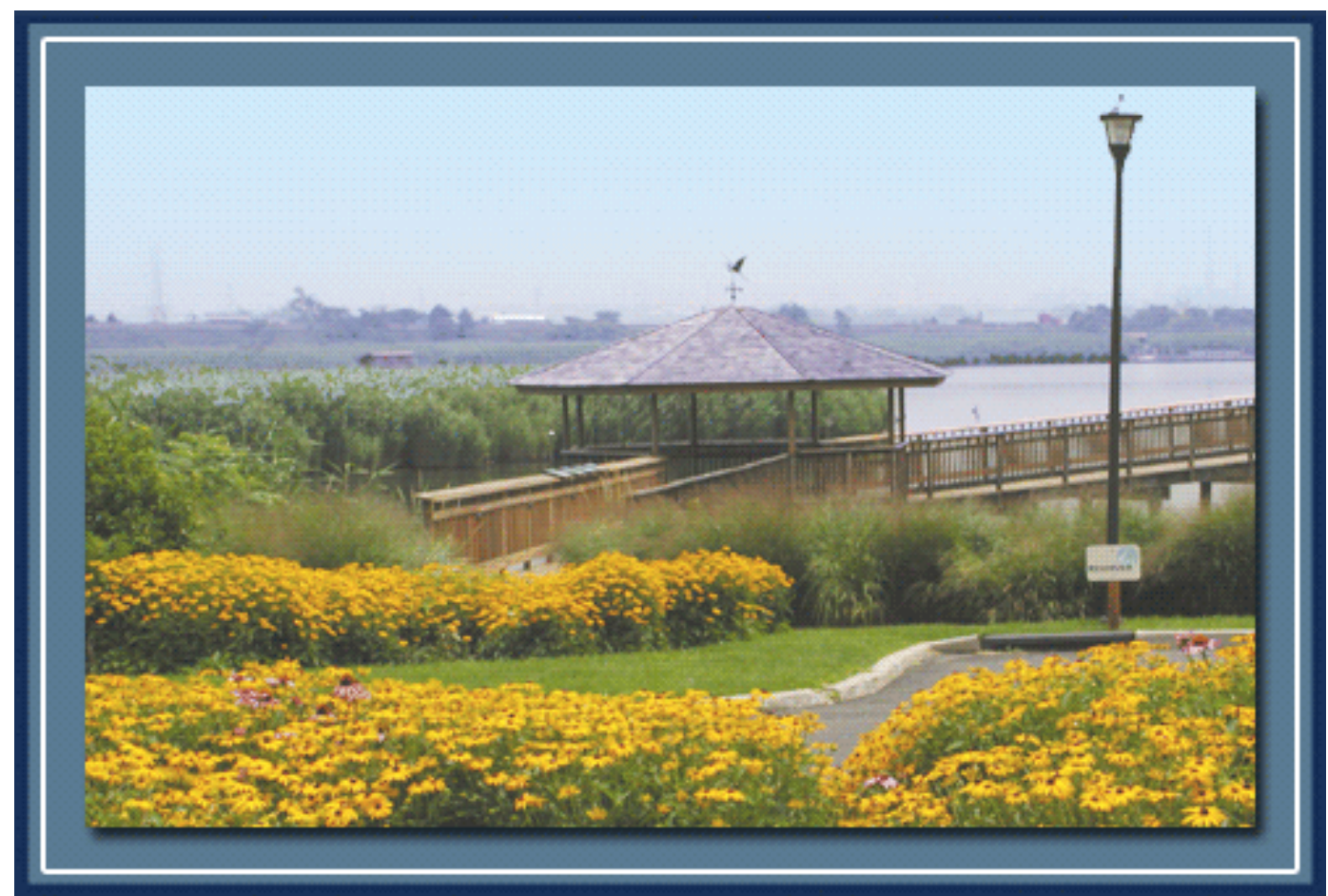

Figura 7.19 - Vista parcial do Parque Richard W. DeKorte Fonte: NJMC (s/d).

O parque situado em Nova lorque compreende uma área total de 2.200 hectares, correspondendo ao triplo da área do Central Park. O planejamento para a conversão do antigo aterro (Figura 7.20) em parque foi estabelecido no Plano Diretor, em 2001, sendo responsável pela sua execução o Departamento de Parques e Recreação, desde 2006. Os antigos aterros existentes correspondem a $45 \%$ da área e o restante é caracterizado por várzeas com zonas úmidas e córregos (NYC, 2009).

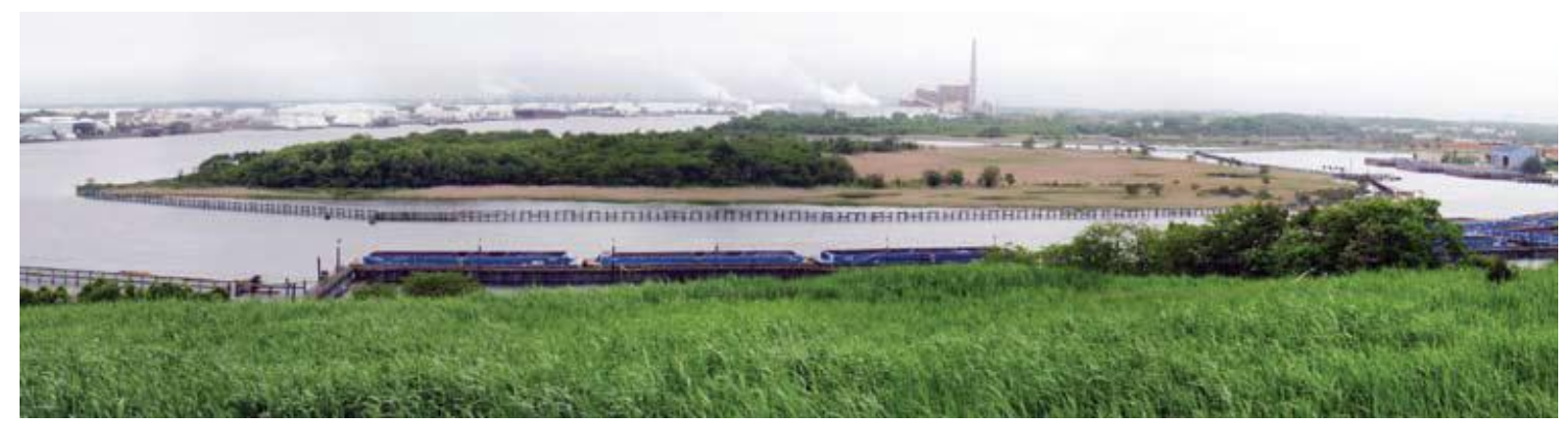

Figura 7.20 - Vista do antigo aterro Freshkills.

Fonte: NYC, 2009. 
Assim como o processo de construção do Central Park, que se iniciou em 1844 e se completou em 1873, o processo de implantação do parque Freshkills também requer um longo período, com previsão de término para 2036 (Figura 7.21). A sua primeira etapa está prevista para ser inaugurada em 2011, correspondendo ao campo de futebol (soccer) Owl Hollow e ao parque Schumul. A concepção do projeto prevê a sua implantação em etapas, a fim de permitir o testemunho da sua transformação pelo público e o seu envolvimento nesse processo (NYC, 2009).

Em épocas passadas projetos de grandes parques eram sustentados por especialistas de renome, ícones da arquitetura e engenharia como Olmsted e Moses. Atualmente, a criação de grandes parques depende de cooperação e dedicação de uma série de organizações, onde é preciso uma convergência de diversos interesses, agendas e ambições. No entanto, a extensão da área permite que todos eles sejam acomodados (NYC, 2009).

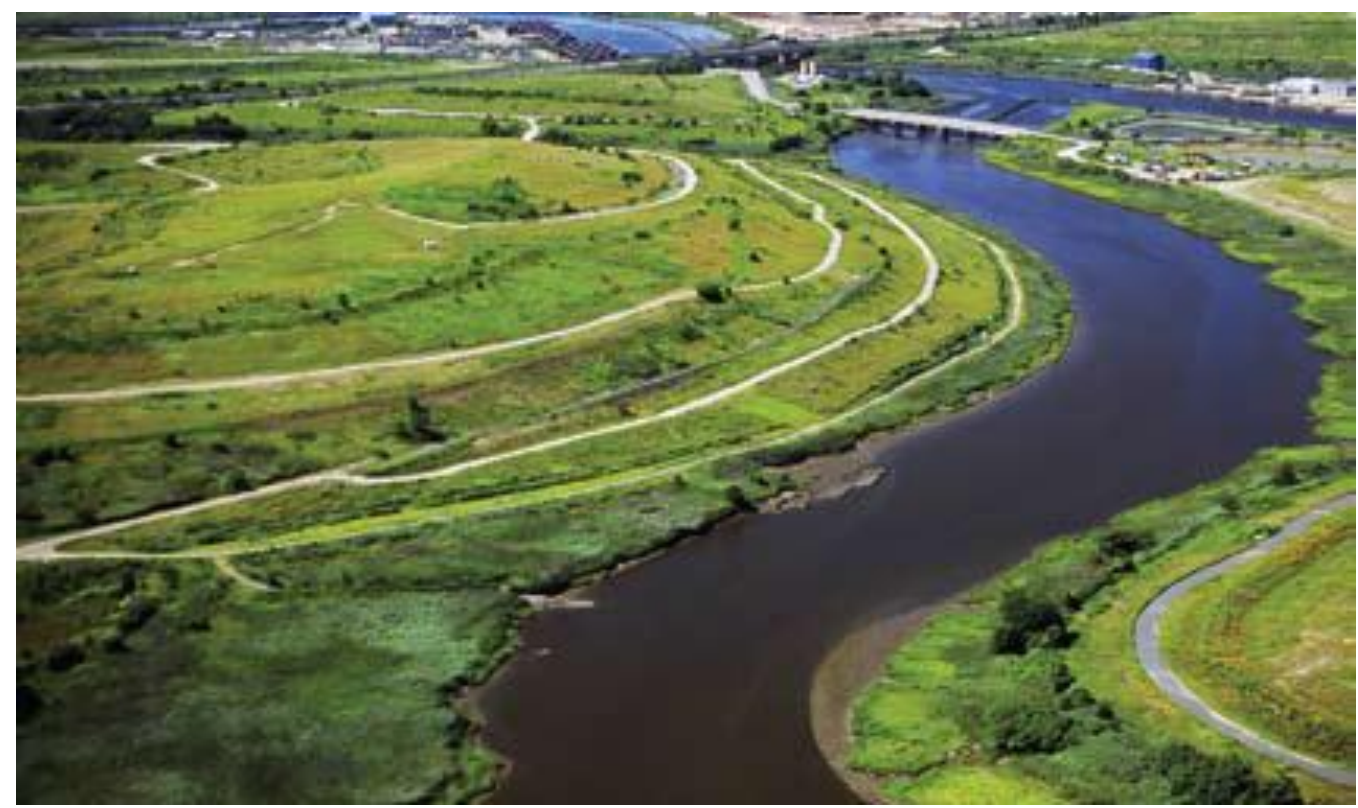

Figura 7.21 - Projeto de implantação final do parque Freshkills, em 2036.

Fonte: NYC, 2009.

\subsection{PARQue McMilLen e COMPLEXo EsPoRTIVOTIM OSMOND}

$\mathrm{Na}$ área (49 ha), pouco desenvolvida, onde foi proposto a implantação do parque, localizada na vila de Antioch, em Illinois, a cerca de $100 \mathrm{Km}$ de Chicago, encontrava-se o antigo aterro H.D.O. (Figura 7.22). A disposição de resíduos (municipal, comercial e industrial) ocorreu entre 1963 e 1984, abrangendo 20 
hectares. Em 1989, por exigência da agência ambiental de Illinois, o aterro foi recoberto com uma camada de argila, devido à constatação de contaminação da água subterrânea por cloreto de vinila, manganês e arsênio. Adicionalmente, foi observada a surgência de percolado, existência de tocas de animais e a emissão de gás. Em 1990, o aterro foi inscrito na National Priorities List do Superfund, permanecendo desocupado por mais de uma década (USEPA, 2010).

Em 1998, a EPA estabeleceu as especificações para o plano de remediação da área, executado pela empresa de gerenciamento de resíduos e finalizado em junho de 2001. Em seguida, a comunidade foi contatada para apresentação dos resultados da sua remediação e as alternativas para o seu reúso. Contudo, a comunidade solicitou que a EPA comprovasse as condições de segurança do local, exigindo: 1) uma declaração de que o aterro estava liberado para o uso recreacional (Ready for Reuse Determination ${ }^{40}$ ) e 2 ) a retirada da cerca para demonstrar que não havia restrição de uso da área pelos usuários. Para tanto, nova avaliação de risco para o uso recreativo foi realizada, comprovando os níveis mínimos de risco, abaixo dos valores estipulados pela EPA. Em seguida, a cerca foi removida e, emitido, em 12 de novembro de 2003, a declaração para reuso seguro da área como recreação (USEPA, 2010).

O reuso seguro comprovado da área impulsionou a requalificação dos seus arredores por meio da participação de vários interessados, instituindo-se o Land Use Commitee (LUC) com os seguintes componentes: organizações locais e da vizinhança, bem como os representantes do distrito escolar, da Vila e da municipalidade. A ampliação da área requalificada acarretou a elaboração de um plano de reuso articulado para toda a região e a viabilidade econômica para a sua implantação. A construção do complexo se iniciou em novembro de 2004, pela sua porção oeste. Em abril de 2008, foi inaugurado o Complexo Esportivo Tim Osmond (Figura 7.23) com 32 hectares e um custo de US\$1.1 milhão, incluindo campos de futebol, baseball, softball, soccer, pistas de corrida, playground e área para picnic. Em maio do mesmo ano, foi aberto o Parque McMillen, com custo de US\$3.2 milhões, contendo doze quadras de tênis, três novos campos de softball (Figura 7.24), cinco campos para soccer ou hockey e espaços para relaxar (USEPA, 2010).

\footnotetext{
${ }^{40}$ Esse documento, emitido pela EPA, assegura o uso produtivo de uma área e a proteção da saúde pública e do meio ambiente. Às vezes, essa declaração é necessária para garantir a cooperação das comunidades locais, dos incorporadores ou dos proprietários com a revitalização da área (USEPA, 2010, p.8)
} 


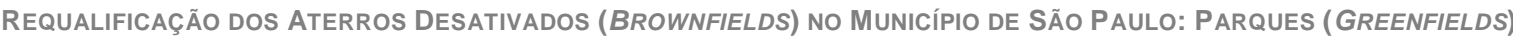
RAPOSO TAVARES E JARDIM PRIMAVERA

LUZIA HELENA DOS SANTOS BARROS

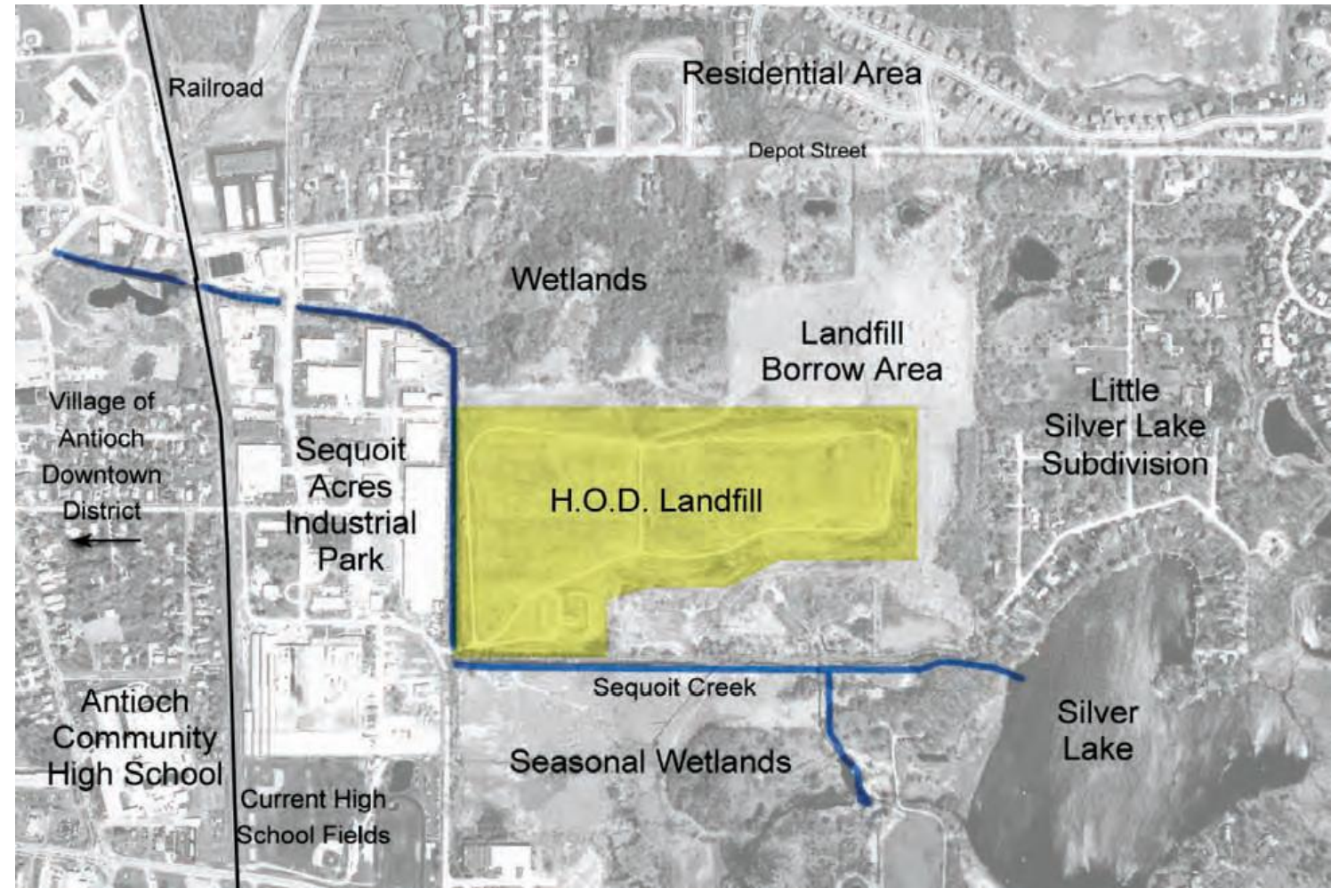

Figura 7.22 - Fotografia aérea da região do aterro H.D.O. com os usos do solo do entorno. Fonte: USEPA ( 2010, p.3).

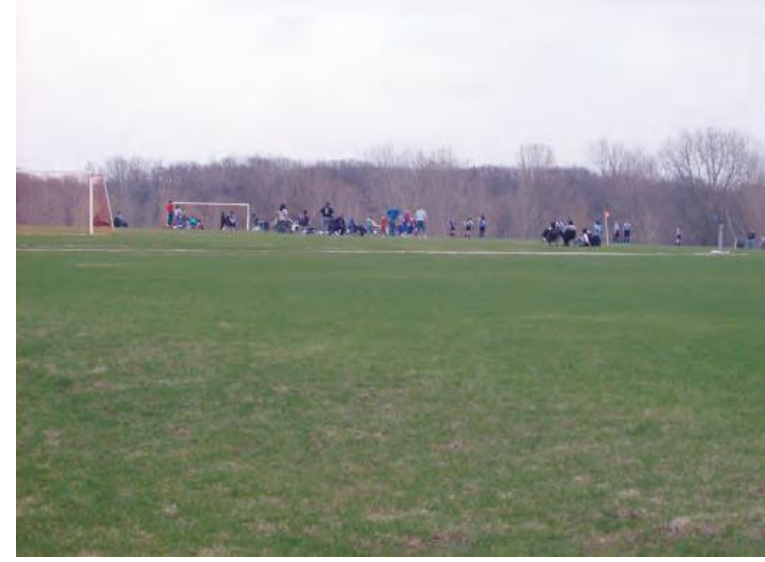

Figura 7.23 - Jogo de soccer no complexo Esportivo Osmond.

Fonte: USEPA (2010, p. 8)
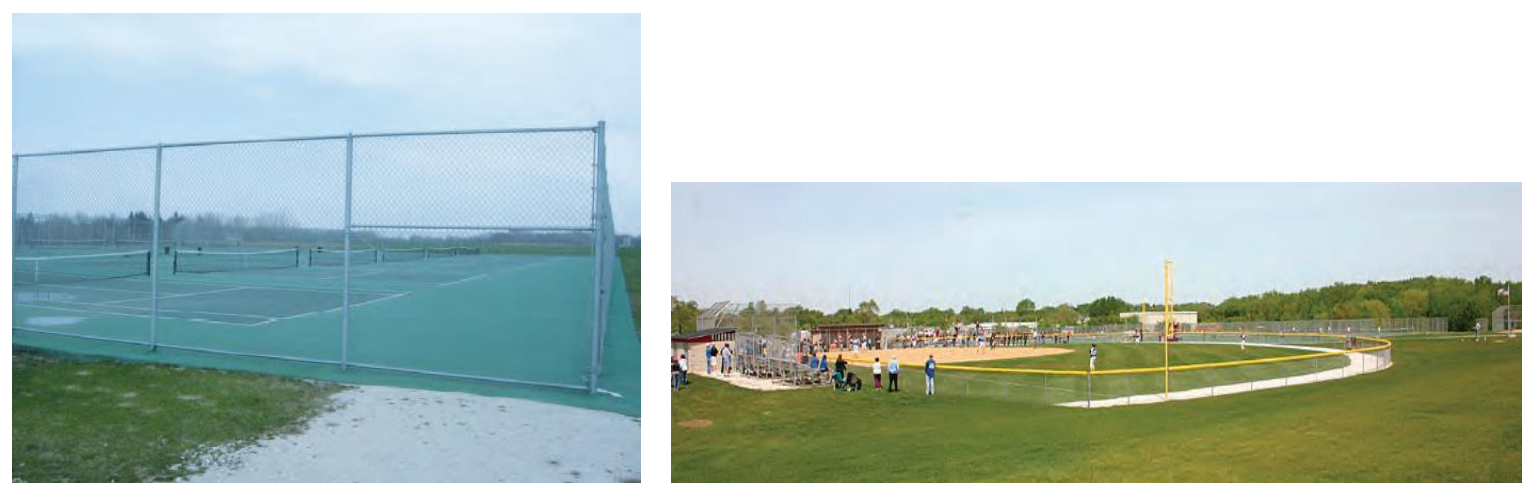

Figura 7.24 - Quadras de tênis e campo de softball no Parque McMillen. Fonte: USEPA (2010, p. 8 e 11). 


\subsection{PARQUE BOWERS}

O parque Bowers, antigo lixão Bowers, localiza-se no distrito de Pickaway, ao norte de Circleville, estado de Ohio, próximo ao rio Scioto. O reúso da área criou atividades de recreação para a população, com pesca e canoagem e a valorização das suas propriedades. O lixão, que possuía uma área de 4,8 hectares,foi instalado em cava de pedreira, no início da década de 1960, recebendo, a partir de 1963, também, resíduos químicos e industriais e encerrado em 1968, sendo, em seguida, abandonado. Em 1971, concentrações elevadas de substâncias químicas foram detectadas junto ao rio. Em setembro de 1983, a área foi incluída na Lista de Prioridades Nacionais (NPL) para remediação, apontando como potenciais responsáveis a Companhia E.I.DuPont de Nemours e as Indústrias PPG. As investigações realizadas diagnosticaram a presença de vários contaminantes nas águas subterrâneas: metais, compostos orgânicos voláteis e semi- voláteis, PCB's e pesticidas. O processo de remediação se iniciou em 1989 estabelecendo-se uma série de medidas para impedir a exposição à contaminação além da exigência do monitoramento do biogás e das águas subterrâneas por 30 anos após a cobertura do aterro (Morinaga, 2007).

Segundo o autor, a EPA decidiu executar intervenções para proteger a nova cobertura do aterro contra as inundações periódicas do rio Scioto. Promoveu-se a construção de uma zona de alagados (wetlands) de 2,8 hectares entre o rio e 0 antigo aterro (Figura 7.25).

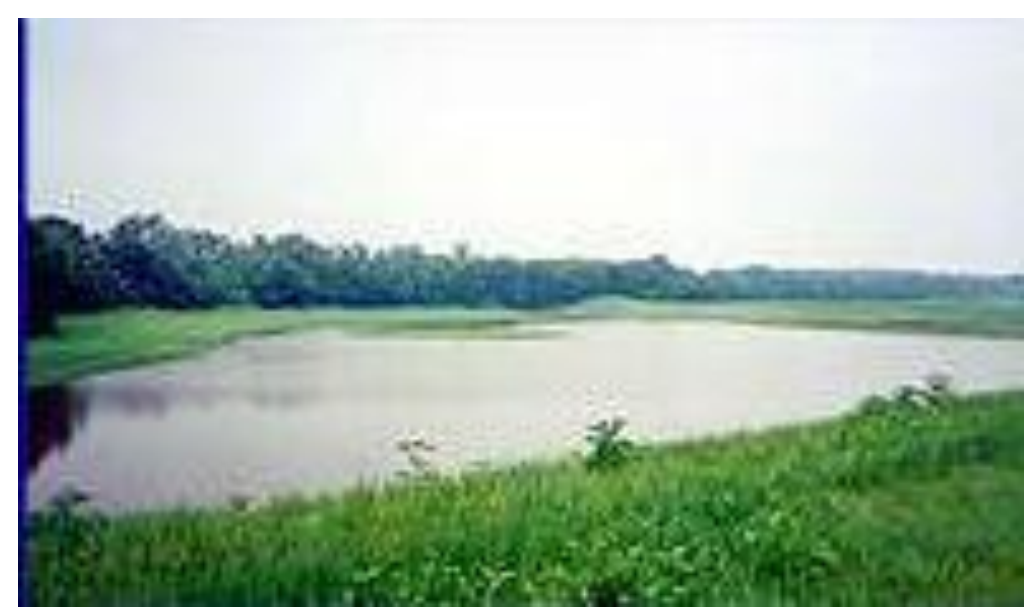

Figura 7.25 - Vista da wetland construída no Parque Bowers.

Fonte: USEPA apud Morinaga (2007, p. 107). 


\subsubsection{PARQUES-ATERROS NO CENÁRIO NACIONAL}

Nas últimas décadas, no Brasil, a implantação de parques, também, tem sido indicada como forma de recuperação de áreas degradadas, incluindo as áreas contaminadas, suspeitas ou com potencial de contaminação, por resíduos (Silva, 2001; SVMA, 2001, 2004b, 2005; Ramires et al, 2005; Lima et al, 2005; Rafael, 2006; Morinaga, 2007; Motta et al, 2007; Volpe-Filik et al, 2007).

\subsubsection{MUNICÍPIO de SANTO ANDRÉ}

No município de Santo André - SP, os antigos aterros, em geral, foram transformados em praças, no período de 1980-1986. As praças simplesmente são extensos gramados com alguns bancos e árvores (Figura 7.26), sendo que $61 \%$ dessas áreas apresentam grandes dimensões (maiores que 1 hectare), mais indicadas para utilização como parques. A conversão dos aterros em praças ocorreu sem a adoção de medidas de controle, monitoramento e descontaminação, explicada em parte pelo conhecimento incipiente sobre o assunto, àquela época (Rafael, 2006).

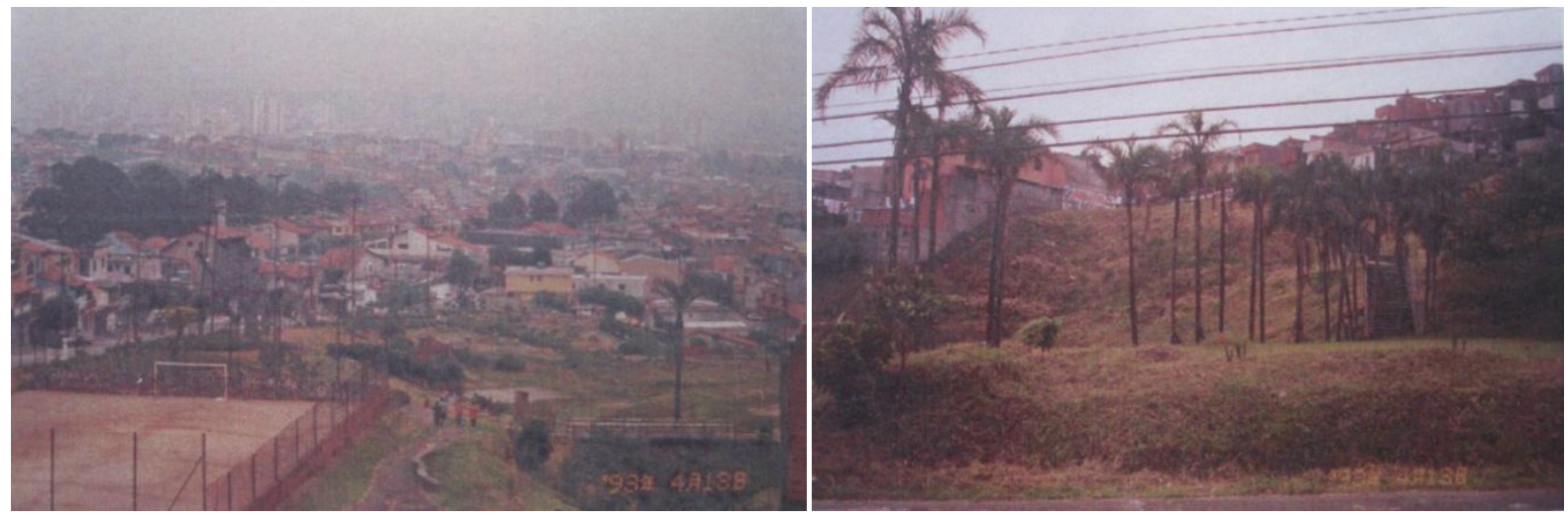

Figura 7.26 - Praça Pres. Eurico Gaspar Dutra, antigo aterro Dutra, em Santo André - SP. Fonte: Rafael (2006, p.215). 


\subsubsection{MUNICÍPIO dE SÃo VICENTE}

O Parque Ambiental de Sambaiatuba, inaugurado em 2002, foi implantado sobre o antigo lixão municipal de São Vicente. O lixão, instalado sobre manguezais em 1969, funcionou por mais de trinta anos, ocupando uma área de $47.000 \mathrm{~m}^{2} \mathrm{e}$ altura de $17 \mathrm{~m}$. A sua porção nordeste faz divisa com o município de Santos, demarcada pelo rio Bugre. A desativação do lixão foi objeto de um Termo de Ajustamento de Conduta, firmado em 1999 e complementado em 2000, entre a CETESB, a Secretaria de Estado do Meio Ambiente e a Prefeitura do Município de São Vicente (Morinaga, 2007).

Segundo o autor algumas intervenções foram necessárias para garantir a estabilidade do maciço de resíduos e o seu recobrimento. A escassez de solo argiloso na região levou à utilização de materiais da escavação de obras na cidade e da praia de Itararé para a camada de cobertura do lixão. Esses materiais possuem alta permeabilidade favorecendo a penetração das águas pluviais e a emissão de gases para a atmosfera, sendo inadequados a esse tipo de uso. Um sistema de monitoramento foi instalado para observação da qualidade das águas, da estabilidade do maciço e das edificações, bem como da emissão de gases.

O parque (Figura 7.27), sob administração da Companhia de Desenvolvimento de São Vicente (CODESAVI), possui espaços para lazer e esportes, com playground e quadras poliesportivas, além de um centro de educação ambiental, viveiro de mudas e uma composteira.
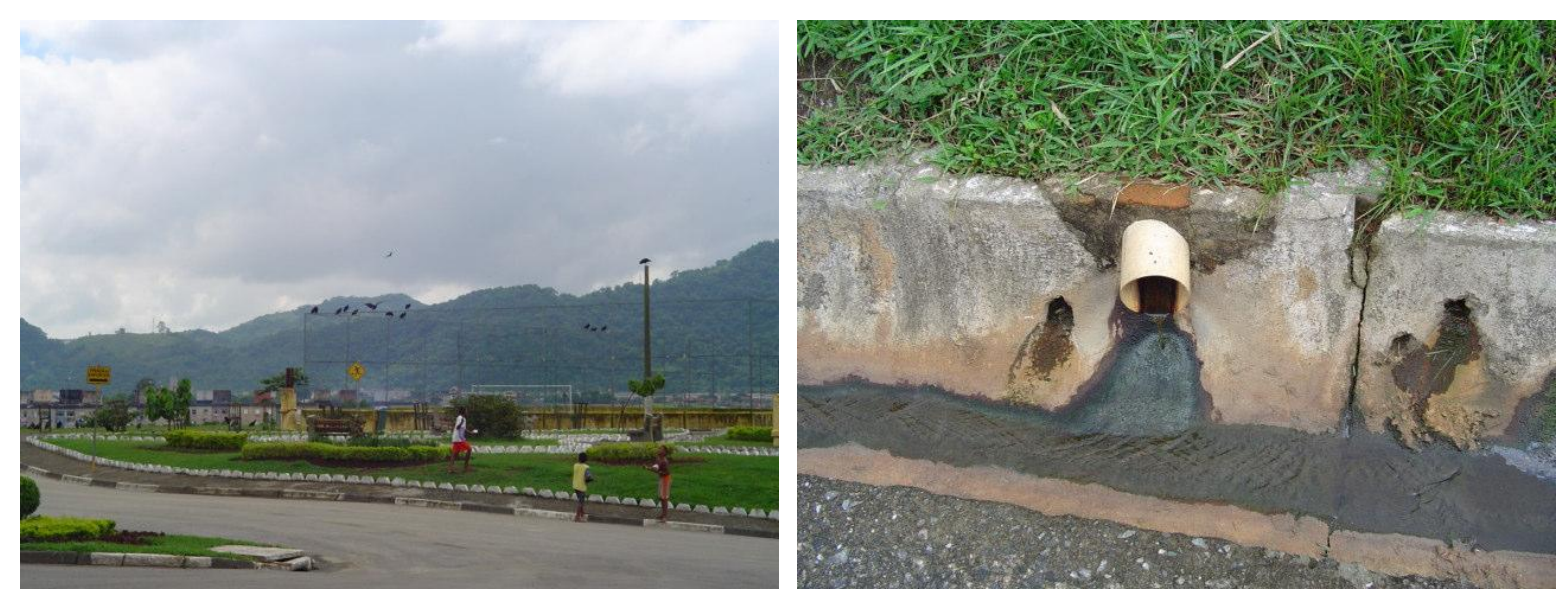

Figura 7.27 - À esquerda, porção central do parque e, à direita, detalhe da saída do dreno das águas pluviais com contribuição do percolado.

Fonte: Morinaga (2007, p. 78). 


\subsubsection{MunicíPIO de SÃo PaULO}

\subsection{PARQUe VILLA-Lobos}

O Parque Villa-Lobos, inaugurado em 1994, localiza-se na região oeste do município de São Paulo, no bairro de Alto de Pinheiros, às margens do Rio Pinheiros, quadrante sudoeste, com área de 73,2 ha e configura-se como um platô com cerca de 9 metros, acima da Marginal Pinheiros (Figura 7.28). Possui ciclovia, quadras, campos de futebol, playground, concha acústica, aparelhos para ginástica, pista de corrida e anfiteatro. É atravessado pelo córrego Boaçava, apresentando vegetação tipo bosque, com espécies da Mata Atlântica, gramados e canteiros (SMA, 2009).

A área do parque, situada em antiga planície de inundação do Rio Pinheiros, foi utilizada como depósito da Companhia de Entrepostos e Armazéns do Estado de São Paulo (Ceagesp), de material dragado do rio Pinheiros e de entulho. A sua implantação se iniciou em 1989 pelo Departamento de Águas e Energia Elétrica (DAEE) (SMA, 2009). Burjato (2004) informa que no início da sua implantação foram removidas famílias, houve canalização do córrego, remoção de $500 \mathrm{mil} \mathrm{m}^{3}$ de entulho e movimentação de outros 2 milhões $\mathrm{m}^{3}$ de entulho e terra para conformação do local.

O projeto original foi elaborado pelo arquiteto Décio Tozzi, que previa a implantação da Cidade da Música, com auditórios, teatro de ópera, centro de convivência musical, escolas de balé e música. De acordo com Sabbag $\left(1988^{41}\right.$, p.33 apud Burjato, 2004) foi acrescentado ao projeto, por demanda da população, um setor esportivo, pistas de corrida e skate, ciclovias e playground.

Cavalheiro (2004, p. 454) faz menção ao projeto do parque, no contexto dos paisagistas, ao se restringirem às atividades de ajardinamento, buscando, de acordo com Carita e Cardoso (1987) ${ }^{42}$, "[...] A imagem de um paraíso perdido ou prometido - necessidade de uma ordem outra de natureza - o jardim revela-se como um universo protegido das contingências naturais dos diferentes climas e geografias [...]". Alerta para a localização peculiar do parque, em área de inundação, na qual foi

\footnotetext{
${ }^{41}$ SABBAG, H.Y. Para um povo musical. Revista Arquitetura e Urbanismo, Ano 4, n. 19, ago/set 88. São Paulo: Pini, 1988. p. 32-39.

${ }^{42}$ CARITA, H.; CARDOSO, H. Tratado da grandeza dos Jardins em Portugal ou da originalidade e desaires desta arte. Lisboa: Edição dos autores, 1987. 15p.
} 
construído um dique de $2 \mathrm{~m}$ de altura, para evitar o alagamento que, no entanto, impossibilitou a visão do parque pelos transeuntes, a menos que eles se dirijam ao seu interior, ou o contemplem do alto dos edifícios ou de aeronaves.

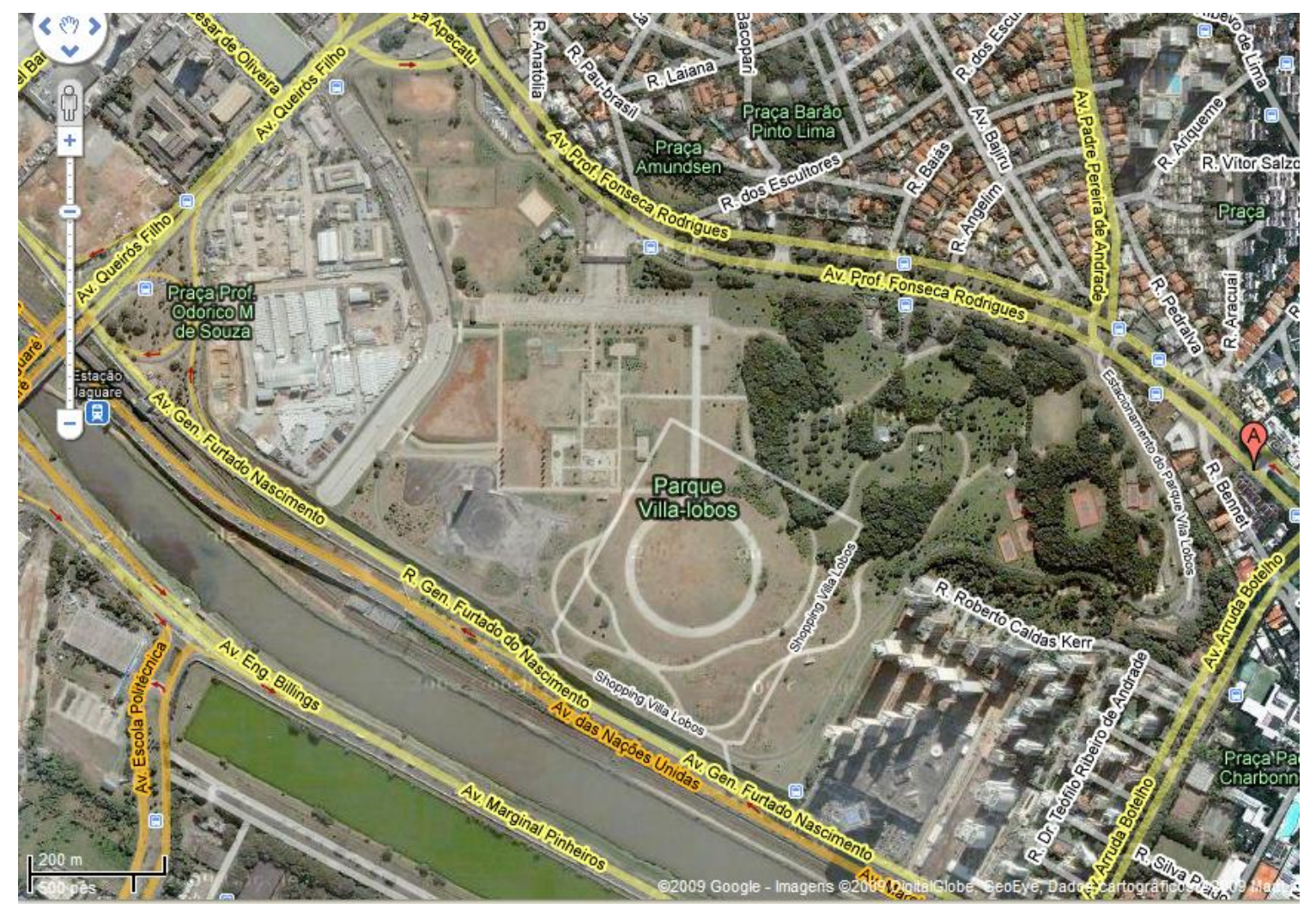

Figura 7.28 - Imagem de satélite mostrando o Parque Villa-Lobos, situado junto à Av. Marginal Pinheiros.

Fonte:<http://googlemaps>. Acesso em 27/05/2009.

Burjato (2004) relata que o projeto do parque sofreu várias alterações. Em 2004, a sua administração foi transferida para a Secretaria de Meio Ambiente do Estado (SMA) que elaborou um Plano de Revitalização, priorizando a adequação à acessibilidade e ao uso racional dos recursos naturais. Há previsão de investimentos de $R \$ 7$ milhões e $R \$ 1$ milhão em infraestrutura e paisagismo, respectivamente. Estão planejados espaços para a coleta de recicláveis e óleo de cozinha, para relaxamento ao som de músicas do compositor que dá nome ao parque, orquidário e novas sedes da Polícia Militar e Administração, bem como a criação de um Centro de Referência em Educação Ambiental, espaço com $3.150 \mathrm{~m}^{2}$, com biblioteca e anfiteatro. Será, também, incorporada ao parque área contígua com $126 \mathrm{mil} \mathrm{m}^{2}$, hoje utilizada como canteiro de obras do metrô (Souza, A., 2009). 


\subsection{PARQUE DA JUVENTUDE}

O Parque da Juventude (Figura 7.29) está situado na zona norte, no bairro do Carandiru, com área de 24 hectares, atravessada pelo córrego Carajás. O governo previu um investimento de cerca de $R \$ 22$ milhões. Anteriormente, no terreno situava-se o complexo Prisional do Carandiru, com três dos seus pavilhões implodidos (Segel, 2009).

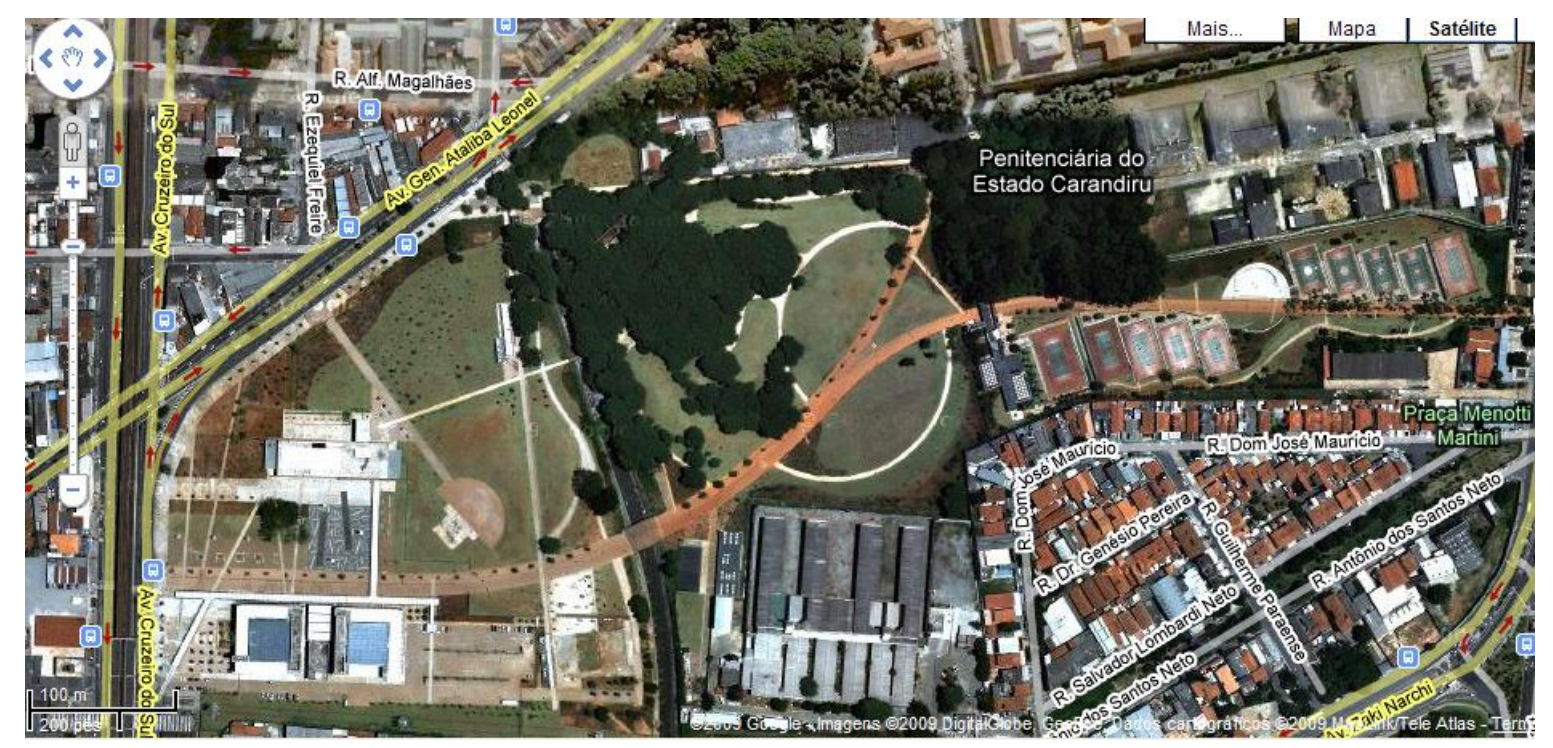

Figura 7.29 - Parque da Juventude, situado junto à Av. Gen. Ataliba Leonel. Fonte: <http://googlemaps>. Acesso em 27/05/2009.

O projeto do escritório Rosa Grena Kliass Arquitetura Paisagística Planejamento e Projetos Ltda., foi vencedor do Concurso Nacional de Plano Diretor da área, realizado em 1999. O projeto previu a reutilização de alguns pavilhões de presos para atividades de ensino, cultura, saúde e inclusão digital e a área externa como parque, estabelecendo três setores de acordo com as três fases de implantação da obra: Parque Esportivo, Parque Central e Parque Institucional (Kliass e Brenna, 2005). A sua execução ficou a cargo do escritório Aflalo e Gasparini Arquitetos. O primeiro setor, inaugurado em setembro de 2003, possui os seguintes equipamentos: quadras poliesportivas, pista de skate, de patins e de corrida. No setor central, inaugurado em outubro de 2004, estão os jardins, bosques, árvores ornamentais e frutíferas e 1,6 ha de Mata Atlântica, que podem ser percorridos pelas trilhas existentes. Para o setor cultural está prevista a implantação de teatro, escolas técnicas profissionalizantes e inclusão digital. Edifícios tombados permanecerão, 
dentre eles, um projetado por Ramos de Azevedo, será utilizado para a administração (GESP, 2005).

A área do parque situa-se parcialmente sobre antigo aterro (Carandiru), localizado no interior do presídio feminino (Silva, 2001), utilizado para conformação do pátio do presídio, sobre o qual estão implantadas as quadras poliesportivas (Figura 7.30) (SVMA, 2005; Ramires et al, 2005).

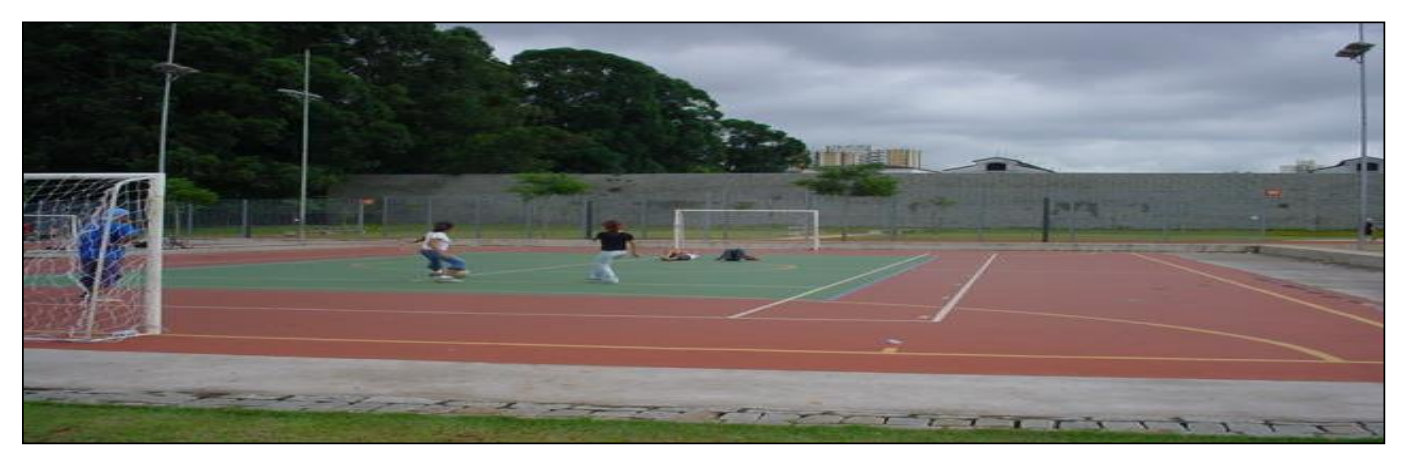

Figura 7.30 - Detalhe da quadra poliesportiva, em 24/03/05, implantada sobre o antigo aterro Carandiru.

Fonte: Ramires et al. (2005).

\subsection{PraÇa Vitor Civita}

A praça, inaugurada em 2008, possui $13.645 \mathrm{~m}^{2}$ e está situada na Rua do Sumidouro, em região de alta renda e de alto valor imobiliário, no quadrante sudoeste. Foi implantada a partir de uma parceria público-privado, em 2007, entre a Prefeitura do Município de São Paulo e a Editora Abril. No seu entorno encontramse a Subprefeitura de Pinheiros, a Secretaria de Meio Ambiente do Estado, a sede da Cetesb, a Sabesp, a Companhia de Engenharia de Tráfego (CET) e a sede da Editora Abril.

O projeto arquitetônico é do escritório Levisky Arquitetos e o projeto paisagístico de Benedito Abbud Paisagismo, Planejamento e Projetos (Figura 7.31), que atenderam ao Termo de Referência para Recuperação de Áreas Degradadas, desenvolvido pela SVMA (Praça Victor Civita, 2009).

Às margens do Rio Pinheiros, em terrenos contíguos, encontrava-se o "lixão" da Rua Sumidouro e o incinerador de Pinheiros (Ogata, 1978). O incinerador, mais conhecido como Sumidouro, funcionou de 1949 a 1989, no qual eram incinerados 
resíduos domiciliares, recebendo resíduos de serviços de saúde, somente nos últimos anos de operação. Ainda existiam, até a implantação do parque, sistema de bomba e filtro desativados e tanque de óleo diesel enterrado, que serviram ao funcionamento do incinerador (Morinaga, 2007).

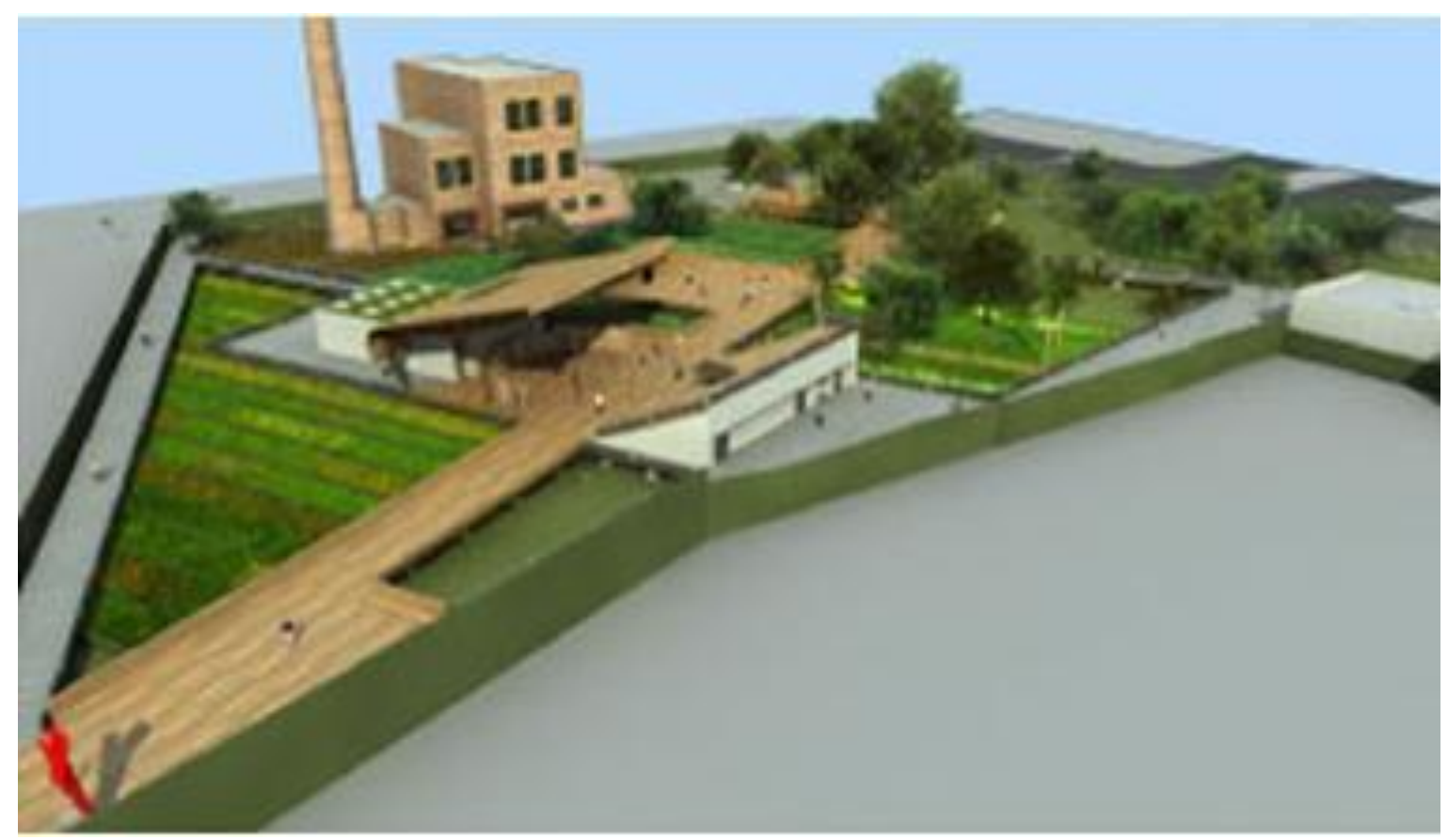

Figura 7.31 - Vista geral da Praça Victor Civita.

Fonte: <http://www.pracavictorcivita.org.br>. Acesso em 25/07/09.

A SVMA propôs a implantação de parque público no local como solução para a requalificação da área. Para tanto, a partir de 2002, foram realizadas investigações para avaliar o seu potencial de contaminação. As investigações foram realizadas no solo, incluindo os resíduos e cinzas distribuídos pelo terreno, na água, na chaminé do incinerador e na vegetação existente, arbustos e árvores (figueiras, eucaliptos e frutíferas) (Morinaga, 2007); além da vegetação rasteira comestível (aipim, batata, etc).

Segundo Morinaga (2007) as amostras apresentaram valores de intervenção acima dos estabelecidos pela Cetesb, no solo, para os metais chumbo, arsênio, níquel, cobre, zinco, cádmio e bário; na água para arsênio e selênio. As análises da vegetação não revelaram a presença de metais acima dos níveis aceitáveis pela Organização Mundial de Saúde (OMS). Considerando a inexistência de legislação específica sobre o tema, foi indicada a retirada e incineração de todas as espécies comestíveis. Análise específica para dioxinas e furanos, substâncias cancerígenas, 
foram realizadas no solo e no prédio do incinerador, apresentando, somente este último, padrões superiores ao de intervenção.

$\mathrm{Na}$ descrição da área e na previsão para implantação do futuro parque, com caráter cultural e ambiental, o autor relata que sob a área pavimentada, externa à edificação, existem depósitos de cinzas, recomendando a não remoção do piso, para evitar a exposição de trabalhadores e futuros usuários aos possíveis contaminantes. Sugere conjugar medidas de controle de engenharia e controle institucional com métodos de contenção dos contaminantes e monitoramento.

Quanto ao plantio de vegetação indica a construção de canteiros elevados, sobre camada de solo colocada sobre o piso impermeabilizado e drenagem eficiente. $\mathrm{Na}$ área permeável, com presença de vegetação, recomenda a introdução de camada de solo limpo, com o cuidado de não aterrar as espécies já existentes, e posterior plantio de espécies com raízes pouco profundas. Destaca que nesse trecho a vegetação teria função apenas contemplativa, devendo-se impedir o acesso ao seu interior. Sugere, também, a remediação da instalação predial mediante a remoção dos revestimentos internos e a raspagem do forro e dos pilares de concreto com implantação de novo revestimento.

A partir de 2005, a Empresa Municipal de Urbanização (Emurb), atual São Paulo Urbanismo (SP- Urbanismo), passa a coordenar o projeto de requalificação da área. Motta et al. (2007) esclarecem que estavam previstas duas fases para o projeto, uma com intervenção no lote do incinerador e a outra com intervenção nos lotes públicos lindeiros. A concepção do projeto considerava o edifício do incinerador como referência e indicava a ampliação da massa arbórea existente, bem como o seu adequado tratamento na implementação do plano de remediação.

Atendendo às diretrizes do Termo de Referência para requalificação da área, o projeto utilizou estratégias alternativas para proteção da vegetação pré-existente e introdução de novas espécies (Figura 7.32). Além disso, foi feita a impermeabilização do solo e tratamento das paredes internas do edifício do antigo incinerador (Figura 7.33). Os equipamentos instalados pelo projeto destoam da maioria dos mobiliários tipo-parque utilizados por SVMA. O fato pode ser visto como inovador, pois conseguiu se adaptar as restrições da área. Por outro lado, no futuro, há previsão da transferência da sua administração para o município. Até lá, esperase que a Prefeitura se organize para arcar com os custos diferenciados da praça. 
Requalificação dos Aterros Desativados (BrownfieldS) no MunicípIo de São Paulo: Parques (GreenfieldS) RAPOSO TAVARES E JARDIM PRIMAVERA

LUZIA HELENA dos SANTOS BaRRos
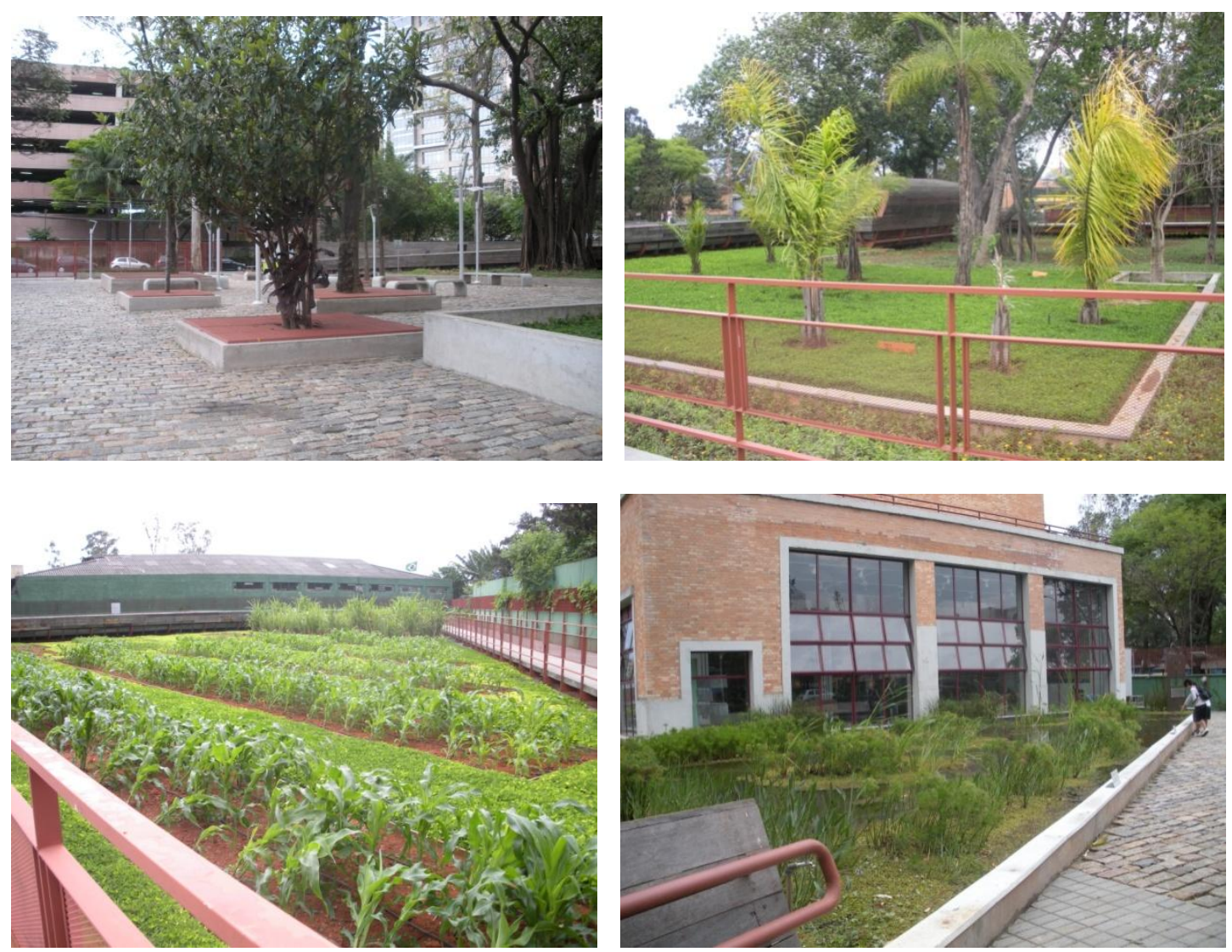

Figura 7.32 - Vista de detalhe das áreas externas da praça, em13/09/10. No alto à esquerda, são mostradas as estruturas de proteção à vegetação pré-existente, implantadas pelo projeto. Outras diferentes espécies vegetadas foram introduzidas, compondo os ambientes.
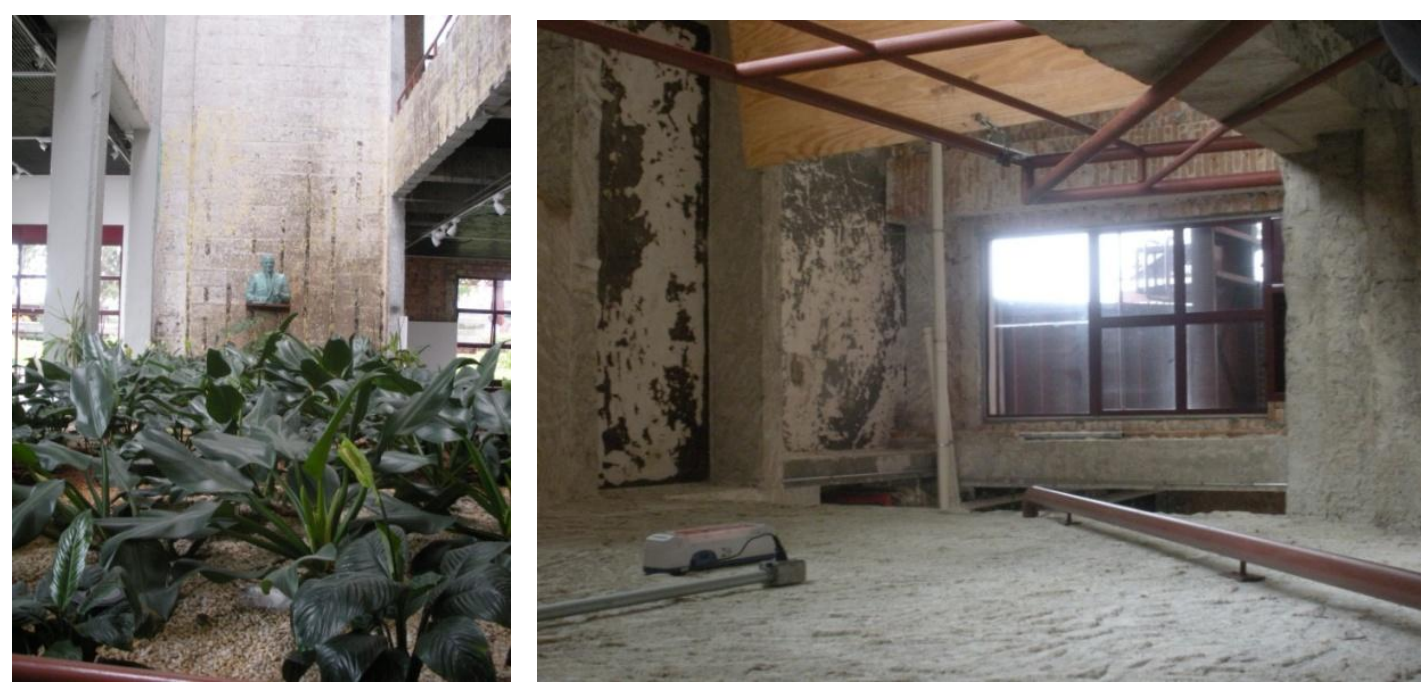

Figura 7.33 - Detalhe do interior do prédio do antigo incinerador, em 13/09/10, onde foi realizada a raspagem das paredes para retirada de elementos tóxicos (dioxina, etc.). Observa-se o busto do Sr. Civita, criador do Grupo Abril, em praça pública. 
7.2.3.2.4 PROJETOS PRELIMINARES

\subsection{FUtURO PARQUE SAPOPEMBa}

Sobre o antigo aterro Sapopemba (Figuras 7.34 e 7.35), em São Mateus, com contaminação confirmada e migração de gases para o entorno, conforme exposto no Capítulo 5, está prevista a implantação do Parque Central $1^{43}$, mais conhecido na região como Parque Olímpico, elemento que propiciará a conexão entre o Rio Aricanduva e a região de Mauá, mediante a implantação de parque linear. No limite nordeste do aterro está sendo implantada a extensão da Av. Nova Trabalhadores.

De acordo com os resultados obtidos das avaliações ambientais realizadas estabeleceu-se que não há risco de exposição dos futuros usuários, por contaminação do solo. Entretanto, por precaução, o GTAC/SVMA recomendou o recobrimento de todo o maciço de resíduos com pelo menos $0,50 \mathrm{~m}$ de camada de solo, exceto os drenos e chaminés para eliminação de gases existentes. Além disso, a restrição de captação e uso da água subterrânea para qualquer fim. Investigação complementar também foi sugerida para algumas porções com resíduos, para avaliação detalhada da produção de metano, conforme já exposto no Capítulo 5.

De posse de todos esses dados, em junho de 2010, o Depave/SVMA elaborou o projeto do parque ${ }^{44}$ (Figura 7.36). Ressalta-se que esse projeto é a última versão desenvolvida, pois, anteriormente, foi elaborado um projeto pela Secretaria de Coordenação das Subprefeituras - Coordenadoria das Áreas Verdes, que não atendeu as especificações técnicas exigidas. A fim de visualizar a situação do projeto na área do aterro foi realizada a sua sobreposição à ortofoto de 2004 (Figura 7.37).

\footnotetext{
${ }^{43}$ A recuperação do aterro assim como a implantação da CTR Leste, no Sítio Floresta, contíguo ao antigo aterro São João, estão sob a responsabilidade da concessionária ECOURBIS.

${ }^{44} \mathrm{O}$ histórico de avaliação da área do antigo aterro Sapopemba e a implantação do parque estão sendo tratados nos Processos Administrativos 2009-0.050.520-2, 2010-0.228.936-6 e 2010-0.218.603-6.
} 
Requalificação dos Aterros Desativados (BrownfieldS) no MunicípIo de São Paulo: Parques (GreenfieldS) RAPOSO TAVARES E JARDIM PRIMAVERA

LUZIA HELENA DOS SANTOS BARROS

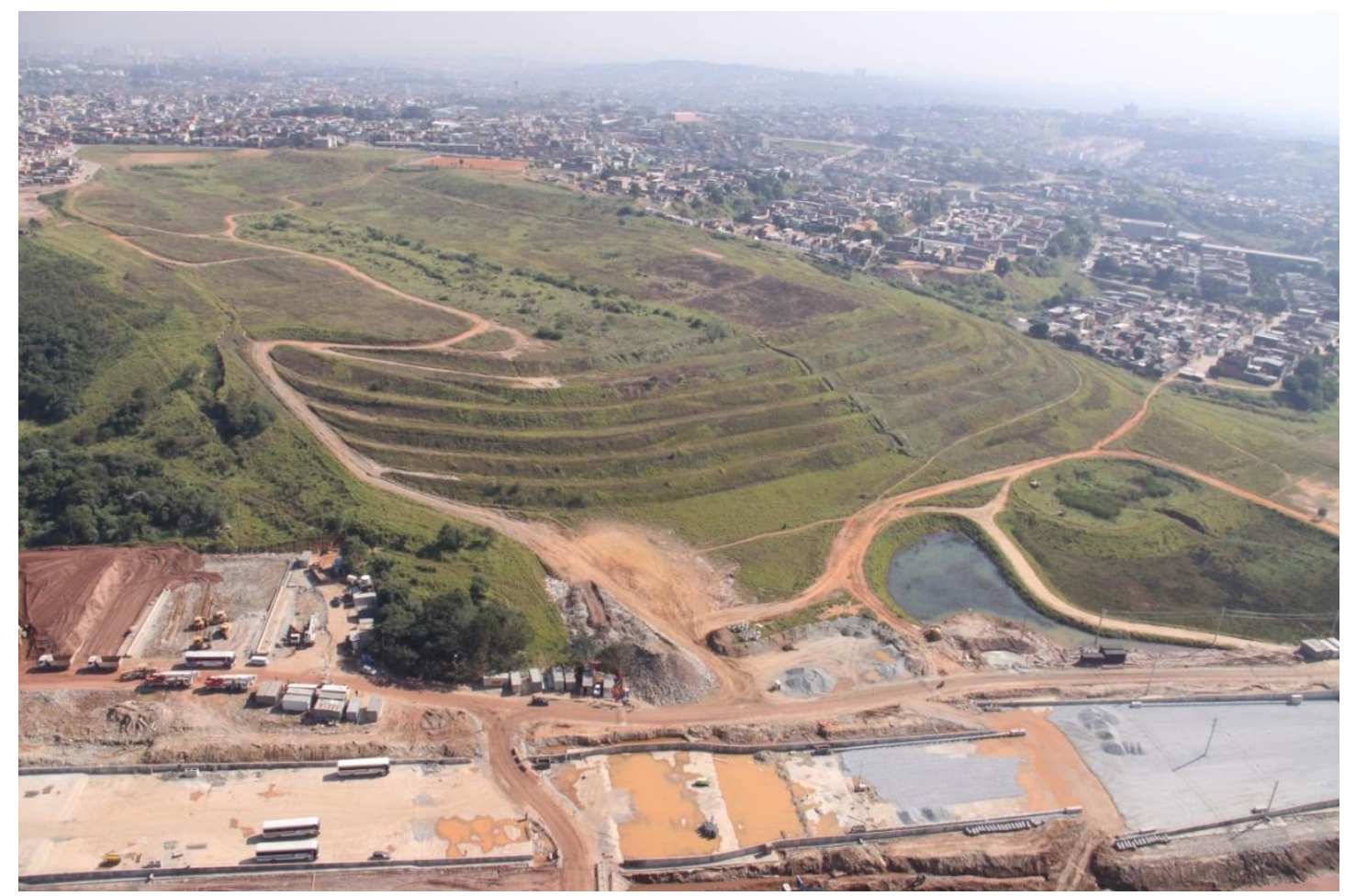

Figura 7.34 - Sobrevôo de helicóptero, realizado em 18/11/2010, sobre o antigo aterro Sapopemba, com visada para noroeste, mostrando a sua conformação topográfica, remanescente da antiga lagoa de chorume/percolado, à direita e, na parte inferior a implantação da continuação da Av. Nova Trabalhadores.

Fonte: SVMA/Decont

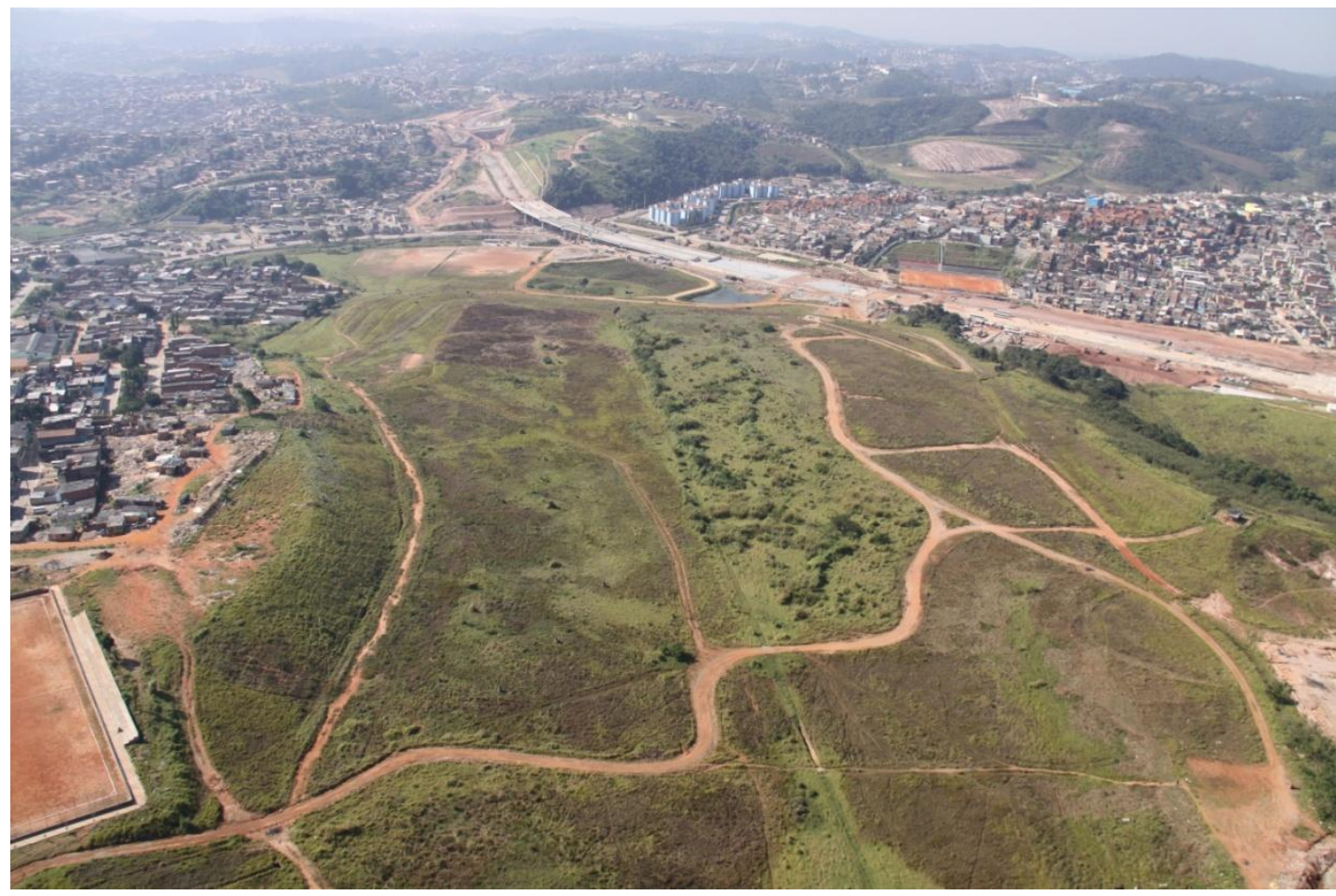

Figura 7.35 - Sobrevôo de helicóptero, realizado em 18/11/2010, sobre o antigo aterro Sapopemba, com visada para norte, mostrando a sua conformação topográfica, as circunvizinhanças e a implantação da continuação da Av. Nova Trabalhadores.

Fonte: SVMA/Decont. 


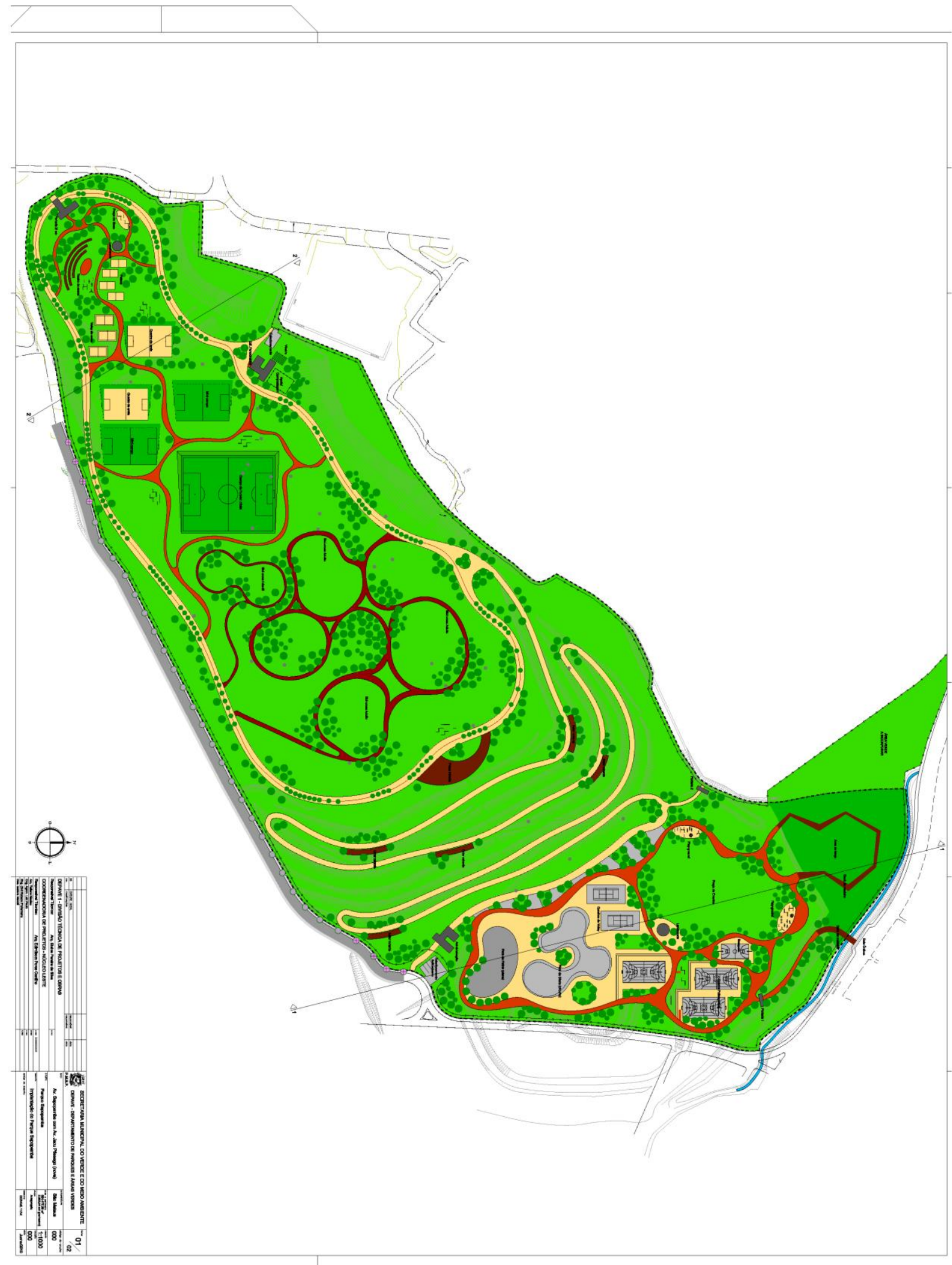

Figura 7.36 - Projeto do parque sobre o antigo aterro Sapopemba, elaborado por Depave/SVMA, em junho de 2010.

Fonte: SVMA/Depave 


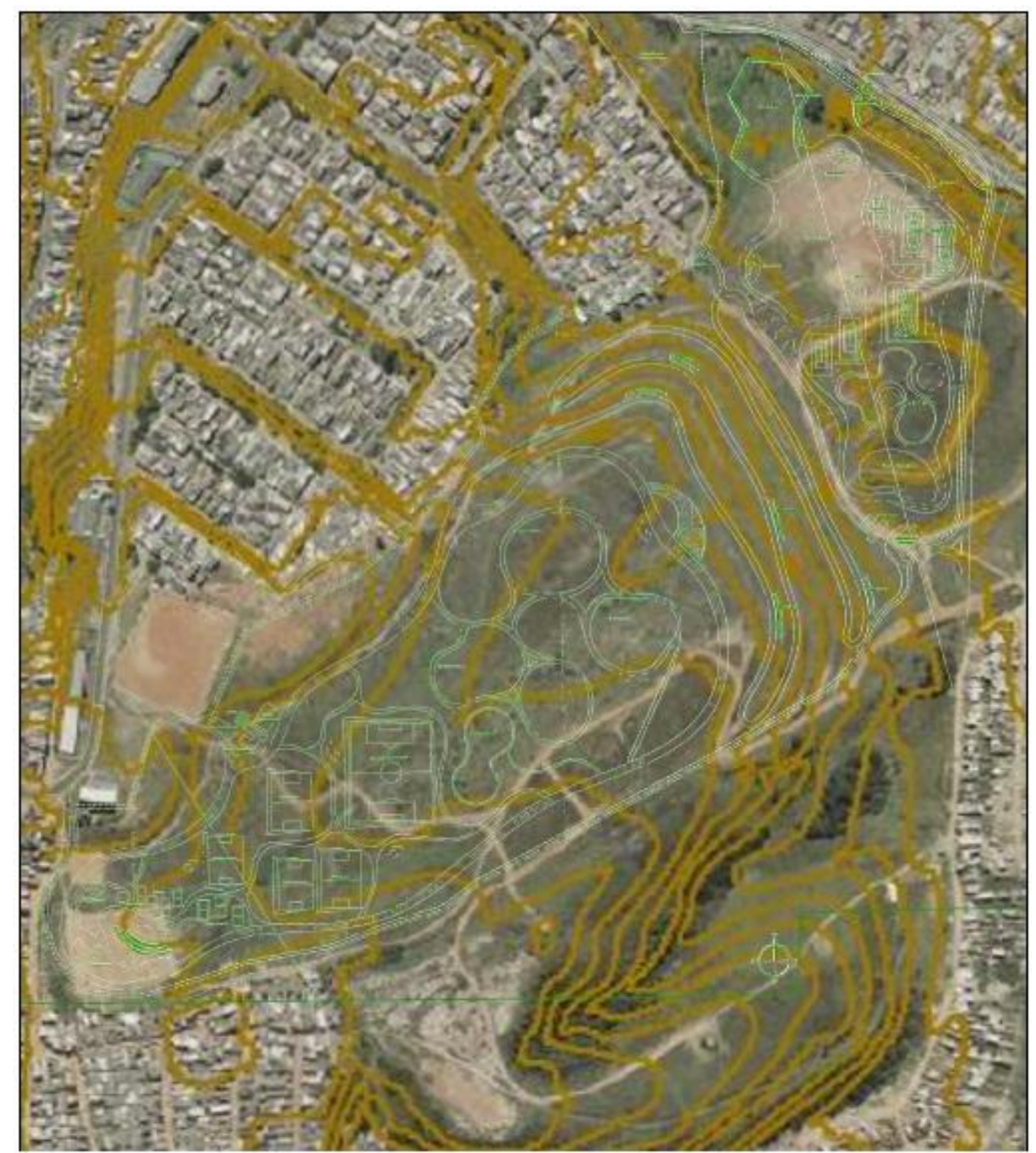

Organização: Luzia Helena dos S. Barros (2011).

Figura 7.37 - Sobreposição do projeto do parque à ortofoto de 2004.

Em 27 de agosto de 2010, o Depave informa ao Deapla sobre o início das obras para implantação do parque (Figura 7.38). O solo utilizado na terraplanagem vem sendo retirado da área de implantação da unidade CTR Leste. Deapla reitera todos os aspectos indicados anteriormente sobre a investigação ambiental realizada alertando, principalmente, quanto à avaliação inadequada da geração de gases e do sistema de drenagem existente, realizada por empresa contratada pela concessionária. Salienta, também, que o texto do projeto deixa claro que haverá eliminação de alguns elementos da história local (parte das antigas canaletas de drenagem e chaminés) devido ao necessário recobrimento com terra sem, no 
entanto, mencionar qualquer previsão para a implantação de sistema de drenagem de gases. Em setembro, foi realizada uma reunião entre as equipes técnicas dos três Departamentos envolvidos com o assunto (Depave, Decont e Deapla), decidindo-se pela inclusão, por Decont/GTAC, das providências necessárias à proteção da emissão de metano e com o acompanhando dos trabalhos de implantação do sistema de drenagem de gases recomendado (Figura 7.39).

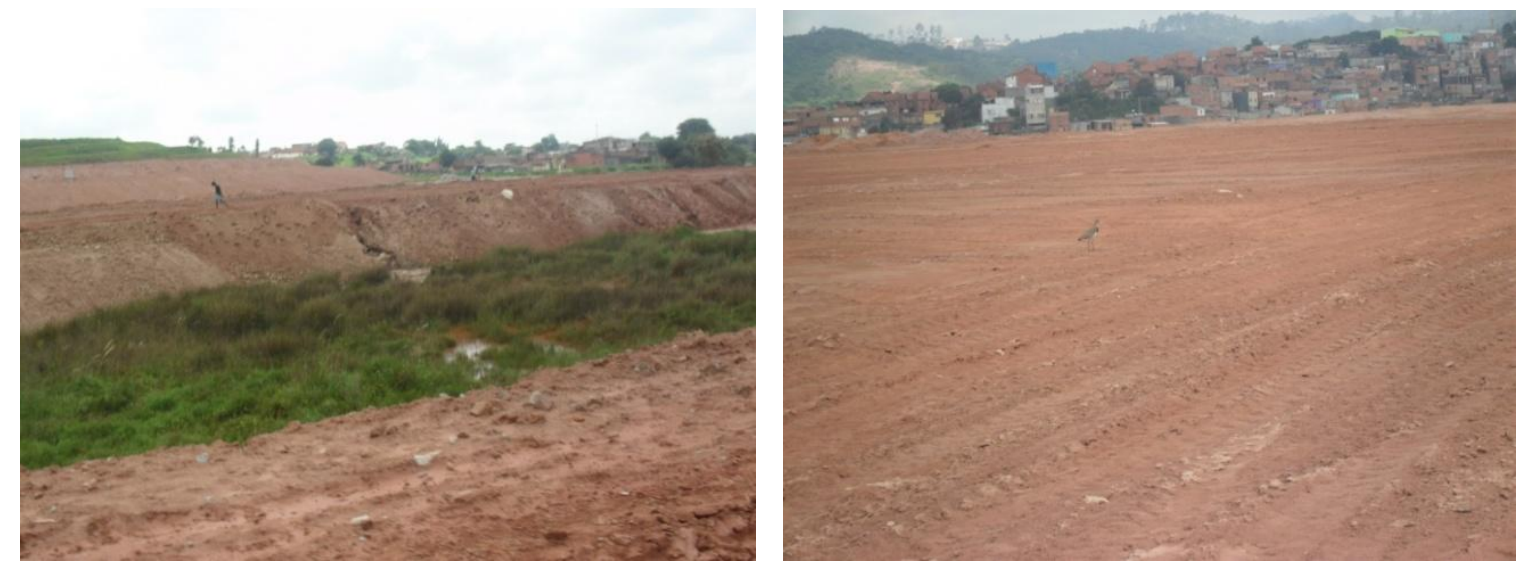

Figura 7.38 - Início das obras de implantação do parque sobre o antigo aterro Sapopemba, através da execução da terraplanagem. À direita, exemplar da fauna local, o quero-quero.

Fonte: SVMA/Decont. Data: 09/12/2010.
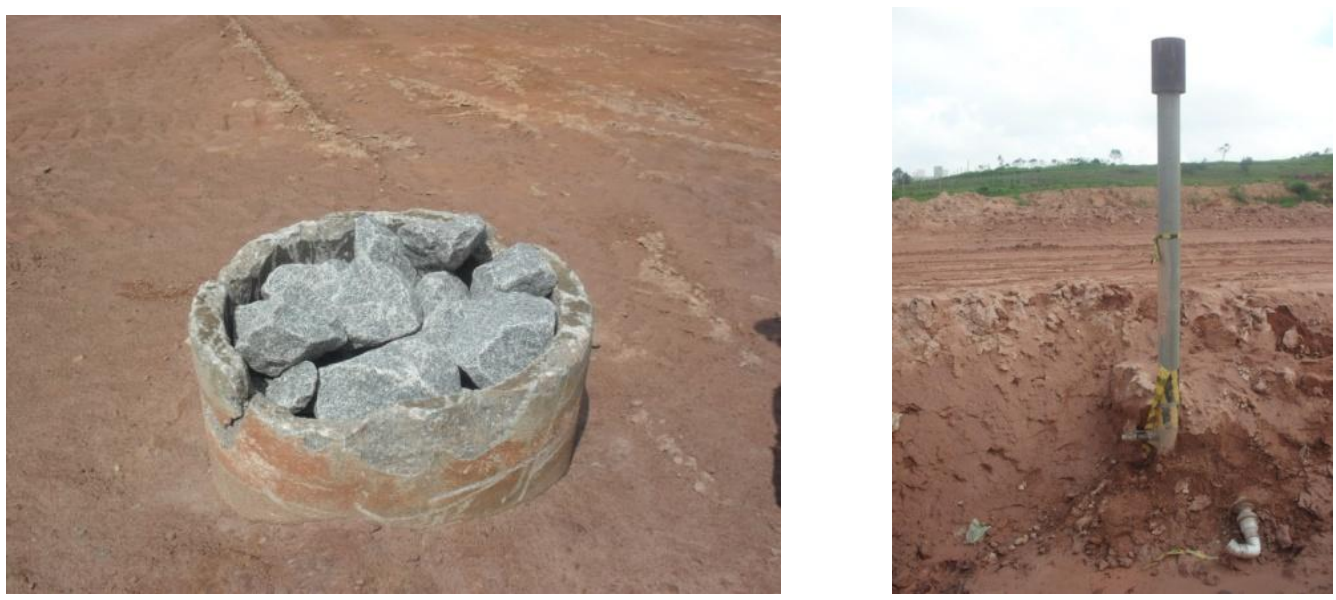

Figura 7.39 - Antigo aterro Sapopemba. À esquerda, eliminação de antigo dreno de drenagem de gases. À direita, instalação de medidor de emissão de gases.

Fonte: SVMA/Decont. Data: 09/12/2010. 


\subsection{Futuro Parque São Mateus}

No processo para recuperação do aterro desativado de São Mateus, em Itaquera, foi inicialmente realizado o projeto de restauração ecológica, pela USP/ESALQ (2006). O zoneamento ambiental da área do aterro foi utilizado para a escolha dos sistemas de restauração diferenciados previstos: implantação, adensamento, enriquecimento e condução da regeneração natural. As primeiras análises laboratoriais realizadas mostraram que em quase todos os pontos de amostragem foi detectado altos teores de manganês e grande heterogeneidade dos resultados para cromo, chumbo e níquel, nas amostras coletadas de $20-40 \mathrm{~cm}$ e de $40-60 \mathrm{~cm}$ de profundidade no solo, com alguns pontos apresentando valores superiores aos limites recomendados pela Cetesb. Entretanto, considerou-se que esses resultados não eram impeditivos ao plantio das espécies florestais nativas com fins à restauração ecológica do aterro. Recomendou-se, também, a não utilização de espécies frutíferas e análises periódicas dos metais pesados nos tecidos vegetais dos exemplares introduzidos. Contudo, a decisão sobre a necessidade de ações prévias para a redução dos níveis de metais encontrados estava a cargo das discussões entre a Ecourbis Ambiental e a Cetesb.

As diversas espécies ocorrentes na sua área e arredores foram catalogadas, priorizando-se as espécies arbustivo-arbóreas ${ }^{45}$, por meio de caminhadas mensais entre setembro e dezembro de 2005. De um total de 222 espécies amostradas, foram identificadas 212 espécies nativas regionais e 10 exóticas, muitas dessas últimas, relacionadas à contaminação biológica (Pinus e Pittosporum undulatum ou pau-incenso), que desfavorece a conservação da biodiversidade. Outras contribuem para o desequilíbrio local, o jambo (Syzygium jambos) e a jaca (Artocarpus heterophyllus). Foram encontradas, ainda, espécies constantes da lista vermelha de espécies ameaçadas de extinção da IUCN ${ }^{46}$ : Pouteria psammophila e Machaerium villosum.

O projeto incluiu, também, o levantamento da avifauna e de alguns mamíferos (mastofauna), realizado em 8 visitas à área, no período entre 17 de setembro e 21 de dezembro de 2005. O cadastro de 109 espécies da avifauna, de

\footnotetext{
${ }^{45}$ A priorização deu-se devido à importância do componente arbustivo-arbóreo na definição da fisionomia e estrutura da vegetação e da sua utilização no plantio de restauração.

${ }^{46}$ IUCN. IUCN 2004 Red List of Threatened species. Disponível em <http:www.iucredlist.org/>
} 
ocorrência rara ou ocasional $(72 \%)^{47}$, subestimado pelo curto tempo de estudo, indica uma riqueza específica bastante baixa, consoante a paisagem local empobrecida, representada por uma matriz predominantemente urbana com bolsões de vegetação densos e extensos. O pequeno fragmento de mata abriga a maior riqueza de espécies, seguido do eucaliptal, área aberta, vegetação ciliar e lago. As aves cadastradas são de ampla distribuição geográfica, típicas de áreas abertas ou de vegetação secundária, e com alta resiliência (capacidade para suportar perturbações ambientais), sendo identificadas 10 espécies de aves migratórias, as visitantes de verão (andorinhão-do-temporal, bentevi-rajado, tesourinha, juruviara) e as que migraram no inverno. Quatro espécies estão incluídas na lista de fauna ameaçada do Estado de São Paulo: Pyroderus scutatus (Pavó), Procnias nudicollis (Araponga), Amazona aestiva (Papagaio-verdaderi) e Macropsalis forcipata (Bacurau-tesoura-gigante).

Algumas espécies da mastofauna comprovadas na área: Dasypus novemcinctus (taut-galinha), Bradypus sp. (Preguiça), Cerdocyon thous (cachrro-domato) e Myocastor coypus (ratão-do-banhado) são adaptadas a ambientes com diferentes graus de antropização; outras foram apontadas pelos vigilantes do aterro: gambá, esquilo, ouriço-cacheiro e jaguatirica.

O estudo da ESALQ recomenda um enriquecimento, com plantio (Figura 7.40) e regeneração natural das bordas dos fragmentos de mata, para ampliar a sua área, estendo-se para as áreas abertas. Alerta para a necessidade de eliminar a caça furtiva no remanescente de mata e de melhorar a conservação das Áreas de Preservação Permanente, pois aves paludículas ${ }^{48}$ e alguns mamíferos estão estreitamente associados a estes ambientes.

Em abril de 2010, o Departamento de Limpeza Pública (Limpurb) ${ }^{49}$ informa à SVMA que inexiste exposição de resíduos na área do antigo aterro e nem tão pouco captação e consumo de água subterrânea ou do córrego, contíguo ao local. Esclarece que o líquido encontrado no aterro é decorrente de decomposição vegetal e não da massa de resíduos, tendo em vista que o mesmo está desativado desde 1985. Consulta, então, a SVMA/GTAC sobre a necessidade da realização dos monitoramentos recomendados (descritos no Capítulo 5), visto que a área em

\footnotetext{
47 São "espécies residentes e vagantes que transitam ou têm um padrão de ocorrência irregular", característico de mancha de vegetação inserida num mosaico de matriz urbana. Cerca de $90 \%$ delas são residentes ou vagantes na região geográfica do aterro (ESLAQ, 2006, p.52).

${ }^{48}$ São aves que vivem a beira d'água.

49 Ofício 31/Limpurb-4/10, de 07 de abril de 2010 (Processo Administrativo 2010-0.010.240-4, p. 293-294)
} 
questão não será destinada ao uso de parque, praça de esportes, etc. e sim, ao reflorestamento que já foi concluído conforme o TCRA 123/2007 - Restauração da Vegetação Nativa do Aterro Sanitário São Mateus. Por oportuno, considera-se que o termo restauração não deve ser utilizado na revegetação dos parques-aterros.
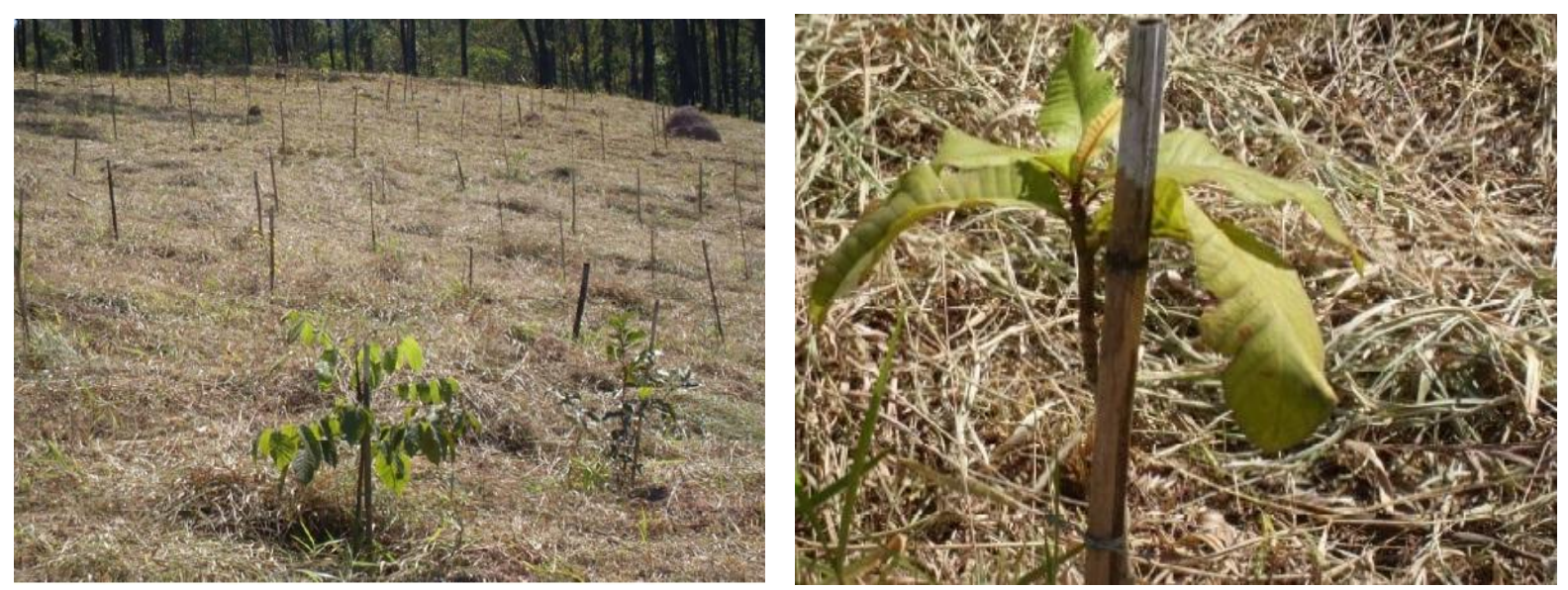

Figura 7.40 - Plantio de vegetação observado em 2009.

Fonte: SES (2009, p.11-12)

O GTAC/SVMA ${ }^{50}$ reitera a importância de realizar, no mínimo, mais uma campanha de monitoramento de metano a fim de se certificar da não ocorrência de migração de gás para o entorno e para avaliar o comportamento dos contaminantes na água subterrânea. Recomenda ainda que Limpurb oficialize a Secretaria de Negócios Jurídicos, Departamento de Defesa do Meio Ambiente e Patrimônio (DEMAP) sobre as restrições do terreno e que qualquer mudança de uso seja informada à SVMA.

\footnotetext{
${ }^{50}$ Informação Técnica 068/GTAC/2010 de 06 de maio de 2010 (Processo Administrativo 2010-0.010.240-4, p. 296-297)
} 

Descarte de resíduos na Praça Bragança, limite sudoeste do Parque Raposo Tavares, zona oeste do município de São Paulo.

Foto da autora em junho de 2009.

Implantação dos quiosques no futuro parque Jardim Primavera, zona leste do município de São Paulo.

Foto da autora em junho de 2011. 


\section{CONTEXTO URBANO E SOCIOAMBIENTAL DOS PARQUES- aterros Raposo Tavares e Jardim Primavera e o SEU POTENCIAL DE CONEXÃO NA PAISAGEM PAULISTANA}

Os estudos de caso tratados na Tese situam-se nos extremos de contraste entre os perfis ambientais e sócio-econômicos do eixo oeste-leste do Município e representam uma situação diferenciada para reúso dessas áreas. Quanto à segregação urbana, na visão de Villaça (2001), correspondem aos extremos de segregação urbana dos mais ricos, no quadrante sudoeste e, mais pobres, no nordeste (Capítulo 5). A partir de levantamento bibliográfico, da análise de dados secundários (SVMA, Cetesb - Agências Pinheiros e Tatuapé, Arquivo Municipal, Subprefeituras, Sempla, Seade, etc), do uso do solo, de entrevistas e de visitas às áreas, foram levantados os seguintes aspectos:

- Evolução do uso e ocupação do solo da região onde estão inseridos os parques, bem como os processos que originaram a sua criação;

- Aspectos biofísicos locais atuais;

- Perfil sócio-econômico e ambiental;

- Impactos e avaliação do potencial de contaminação dos parques-aterros na região; 
- Critérios técnicos adotados nos projetos paisagísticos dos parques-aterros;

- Participação da população.

As informações obtidas forneceram um panorama sobre as condições urbanas e sócio-ambientais das áreas de estudo e das suas vizinhanças. A partir desse diagnóstico, foi possível identificar os métodos técnico-científicos aplicados ao processo de requalificação desses aterros em parques e analisar em quais condições políticas, administrativas e socioambientais eles estão inseridos.

A investigação social adotou o método qualitativo, que segundo Martins (2004, p.289) "[...] privilegia a análise de microprocessos, através do estudo das ações sociais individuais e grupais [...]". Esses métodos são "[...] modelos diferenciados de abordagem empírica, especificamente voltados para os chamados "fenômenos humanos", ou seja, como métodos que fogem da tradicional conexão com os aspectos empíricos tais como medição e controle [...]" (Holanda, 2006, p. 363). Para tanto, utilizou-se a técnica de Entrevista aberta a fim de obter o panorama sobre o histórico de implantação, gestão e uso dos parques-aterros. A Entrevista aberta é a técnica de investigação mediante a conversação entre o investigador e o entrevistado, gravada, com duração entre 30 minutos e uma hora, que tem como máxima utilidade obter informações pragmáticas não só do que se pensa, mas também como se atua. Ou seja, como o indivíduo interioriza e recria as representações sociais ${ }^{1}$. Neste tipo de entrevista, previamente organizada por um roteiro, se pergunta sobre os comportamentos passados, presentes ou futuros. $O$ discurso deve abranger as realizações concretas da vida do entrevistado e deve ser transcrito (Bartolomé, 1997).

O roteiro é o marco da entrevista, que deve ser construído previamente, organizado por unidades temáticas que interessem ao investigador. Não deve estar estruturado seqüencialmente nem tampouco ser um questionário com perguntas. $O$ roteiro deve estar na cabeça do investigador, não deve ser apresentado ao entrevistado. A entrevista não pode se tornar um interrogatório.

Para os objetivos pretendidos, inicialmente foram previstas a realização de apenas as entrevistas com os administradores dos parques-aterros objeto dos

\footnotetext{
${ }^{1}$ Segundo Jodelet apud Spink (1993) "[...] são modalidades de conhecimento prático, orientadas para a comunicação e para a compreensão do contexto social, material e ideativo em que vivemos" (Souza e Zioni, 2003. P.77).
} 
estudos de caso. Posteriormente, incluiu-se também uma entrevista com um morador do entorno do parque-aterro Jardim Primavera, editor de um jornal e funcionário comissionado na atual gestão administrativa da Subprefeitura de são Miguel Paulista. Essa decisão se deu devido à participação ativa desse morador no processo de transformação do aterro em parque. Ressalta-se que o parque Jardim Primavera ainda não está implantado fisicamente, inexistindo administrador oficial, apesar da presença de eventuais usuários.

Uma análise mais aprofundada das questões sociais envolvidas no processo de criação dos parques-aterros exigiria a utilização, também, da técnica dos Grupos de Discussão (GD), definido por Bartolomé (1997) como um grupo de pessoas (6 a 8), simulado e moderado pelo investigador, para a discussão do discurso grupal, gravado, transcrito, que não é o somatório dos discursos individuais, mas sim proposto pelo investigador que intervém em todo o processo. $\mathrm{O}$ investigador precisa criar, a partir da transcrição, o sentido dos fragmentos de discurso que permite avaliar o discurso social (Bartolomé, informação verbal) ${ }^{2}$. No entanto, esse tema já sugeriria uma outra Tese.

Um roteiro para as referidas entrevistas ${ }^{3}$ foi elaborado com o objetivo de obter informações sobre os usuários do parque, a população do entorno, os principais problemas ambientais e os conflitos entre os diferentes atores e suas interfaces com o parque e a cidade. As seguintes unidades temáticas foram incluídas no roteiro:

a) Aspectos biográficos: formação, função atual e anterior; tempo no cargo, local de trabalho; local de moradia; participação em associações profissional ou comunitárias;

b) Diagnóstico do parque: problemas identificados no parque e no entorno; mudanças observadas; satisfação com o parque; expectativas para a área e seu entorno, conhecimento sobre outros parques, UC;

c) Atividades realizadas: função do Administrador, satisfação com a função, valorização; trabalhos de rotina, funcionários envolvidos, infraestrutura disponível; plano de manejo e projetos existentes, atores envolvidos;

\footnotetext{
${ }^{2}$ Informação fornecida por Bartolomé no IB/USP, em 2007.

3 As entrevistas foram consentidas, com autorização (declaração) para divulgação do seu conteúdo, acordando-se a oficialização da pesquisa junto a SVMA. Neste sentido, o processo administrativo no $2009-0.270 .353-2$ foi autuado, em setembro de 2009, sendo a autorização da pesquisa publicada no Diário Oficial da Cidade, em 01Jun2010, p. 24.
} 
d) Quadro institucional: estrutura administrativa associada, direta e indiretamente; existência de outras instituições atuando no parque ou no entorno próximo; integração com demais instituições públicas ou privadas, fonte de auxílio; regulamentos, composição e funcionamento do Conselho Gestor do Parque;

e) Usuários do parque: origem e perfil dos usuários com suas características sócio-demográficas (classe etária, horários de maior fluxo); formas de acesso; acessibilidade; usos praticados formais ou espontâneos; qual a percepção que acha que os usuários têm sobre o parque; levantamento do número de visitantes por mês ou outro período, boas e más práticas ambientais, etc..

A geomática foi adotada, por meio da integração do sensoriamento remoto e do Sistema de Informações Geográficas - SIG, para realizar a análise do potencial de conectividade dos parques-aterros e de suas possíveis zonas de amortecimento. O desenvolvimento de um modelo de tomada de decisão a partir de multivariáveis possibilitou apresentar dois cenários, um mais otimista e outro mais conservador.

\subsection{Contexto URBANO-AMBIENTAL dOS PARQUES-ATERROS RAPOSO TAVARES E Jardim Primavera}

Os parques-aterros Raposo Tavares e Jardim Primavera situam-se no extremo oeste e leste do Município, respectivamente, nas Subprefeituras do Butantã (SP-BT) e São Miguel Paulista (SP-MP), Distritos de Raposo Tavares (DT-RT) e Vila Jacuí (DT-VJ) (Figura 8.1).

A área da SP-BT com 384.069 habitantes (Barros, M. 2008a) compreende $56,3 \mathrm{Km}^{2}$, que correspondem a $3,75 \%$ da área total do município e com densidade demográfica de 6.822 habitantes $/ \mathrm{Km}^{2}$. A região é cortada por importantes eixos rodoviários (Rodovias Régis Bitencourt e Raposo Tavares) que fazem a ligação norte-sul do país e entre o município e o interior sul e oeste do estado de São Paulo. Morato et al. (2005), no estudo sobre as condições ambientais na Subprefeitura, afirmam que a vegetação mostra-se distribuída com maior desigualdade entre a população e é o "[...] indicador mais importante na qualidade ambiental urbana". 


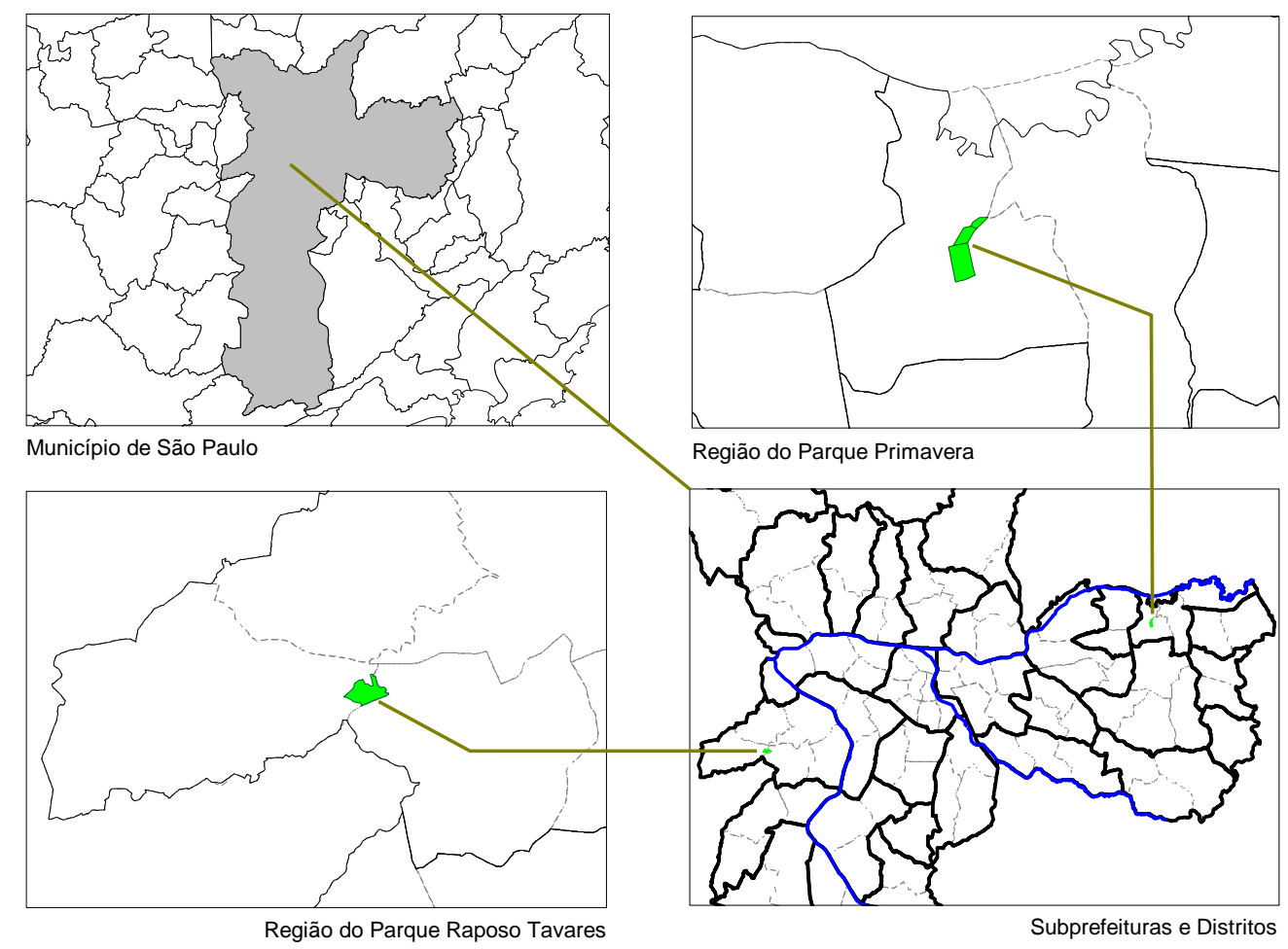

Elaboração: Arq. Flavio Fatigatti

Figura 8.1- Localização dos parques-aterros Raposo Tavares e Jardim Primavera no município de São Paulo.

O distrito Raposo Tavares (12,3 $\mathrm{Km}^{2}$ ), com 96.580 habitantes (Barros. M., 2010b), possui a densidade demográfica de 7.878 habitantes $/ \mathrm{Km}^{2}$. Apresenta a população mais jovem da zona oeste, com média de idade de 35,6 anos, conforme revelou a série DNA Paulistano (Barros, 2008b), pesquisa realizada pelo Datafolha. Quanto a renda familiar, 29\% ganham até 2 salários mínimos e $9 \%$ de 10 a 20 salários. Apenas $13 \%$ da população possuem nível superior. Quanto à classe econômica, 50\% pertencem à classe C, 34\% a B e 10\% a classe D. O Índice de Desenvolvimento Humano (IDH) ${ }^{4}$ é de 0,82. Segundo o indicador ambiental sintético, definido pela SVMA (2008), foi classificado como distrito do Tipo 2 (ver Capítulo 5, item 5.2). Segundo Morato et al. (2005), dentre todos os distritos da SP-BT, este possui, junto com o distrito Rio Pequeno, maior desigualdade ambiental.

A SP-MP compreende $24,6 \mathrm{Km}^{2}$ com população de 410.514 habitantes ${ }^{5}$, correspondendo a 1,64\% da área do município e densidade demográfica de 16.688 habitantes $/ \mathrm{Km}^{2}$. Ao norte, situam-se a Rodovia Ayrton Sena, a ferrovia da CPTM e o

\footnotetext{
${ }^{4}$ Atlas do Trabalho e Desenvolvimento de São Paulo, 2000 
Parque Ecológico do Tietê. De norte a sul é atravessada pela Av. Jacu-pêssego. O Plano Regional Estratégico ${ }^{6}$ instituiu a Operação Urbana Consorsiada Rio Verde/Jacu, elegendo a ocupação efetiva do eixo da avenida, com atividades geradoras de empregos, como pólo de desenvolvimento econômico para a região. Também, apontou a sub-bacia do rio Jacu como elemento determinante da paisagem na Rede Estrutural Hídrica-ambiental.

O distrito Vila Jacuí (7,8 Km²), com 164.253 habitantes (Barros, M. 2010a), possui densidade demográfica de 20.951 habitantes $/ \mathrm{Km}^{2}$. A média de idade da população (35,3 anos) é equivalente ao distrito Raposo Tavares, conforme a pesquisa acima citada, com apenas $6 \%$ possuindo nível de escolaridade superior. A renda familiar de $28 \%$ da população corresponde a até 2 salários mínimos e $3 \%$ entre 10 e 20 salários. Na sua população predomina a classe econômica C (64\%), seguida da B (26\%) e da D (8\%). O Índice de Desenvolvimento Humano (IDH) ${ }^{7}$ é de 0,78 . Foi classificado, também, segundo a SVMA (2008c) como distrito do Tipo 2 (ver Capítulo 5, item 5.2).

O recorte do mapa de uso e ocupação do solo (Capítulo 5) permitiu qualificar (Figuras 8.2, 8.3, 8.4) e quantificar (Tabela 8.1) as classes nos limites das Subprefeituras, Distritos e sub-bacias, que abrangem os estudos de caso.

A quantificação das classes definidas no mapa de uso e ocupação do solo ${ }^{8}$ para as Subprefeituras, Distritos e sub-bacias mostra que predomina a classe da urbanização. Proporcionalmente ela apresenta valores próximos no DT-RT $(50 \%)$ e na SP-BT (54\%); no DT-VJ (81\%) e na SP-MP (77\%); além das sub-bacias BPj (60\%) e BJc (65\%). A área da sub-bacia do Rio Jaguaré é a mais urbanizada (81\%). O solo exposto possui baixa ocorrência, apresentando maior valor no DT-RT $(5 \%)$.

Quanto à vegetação, predomina o maciço herbáceo. A proporção é equivalente na SP-BT (35\%) e DT-RT (34\%), assim como na SP-MP (17\%) e DT-VJ (15\%); além das sub-bacias BPj (28\%) e BJc (25\%). Na sub-bacia BJa corresponde a apenas $15 \%$. A classe maciço arbóreo tem ocorrência bastante restrita não sendo reconhecida no DT-VJ e na BJa; despontando no DT-RT com 9\%. Essa classe apresenta maior proporção na SP-BT (5\%) do que na SP-MP (1,5\%).

\footnotetext{
${ }_{7}^{6}$ Lei $13.885 / 2004$, Anexo XXIII - Livro XXIII

${ }^{7}$ Idem ao item 7.

${ }^{8}$ Tal como realizado no Capítulo 5, agrupou-se como maciço arbóreo, os tipos muito denso, denso e pouco denso. Como maciço herbáceo, incluiu-se a vegetação tipo parque. A classe urbanização é composta pelas classes: sistema viário asfaltado e edificação.
} 
Requalificação dos Aterros Desativados (Brownfields) no Município de São Paulo: Parques (GreenfieldS) RAPOSO TAVARES E JARDIM PRIMAVERA

LUZIA HELENA DOS SANTOS BARROS
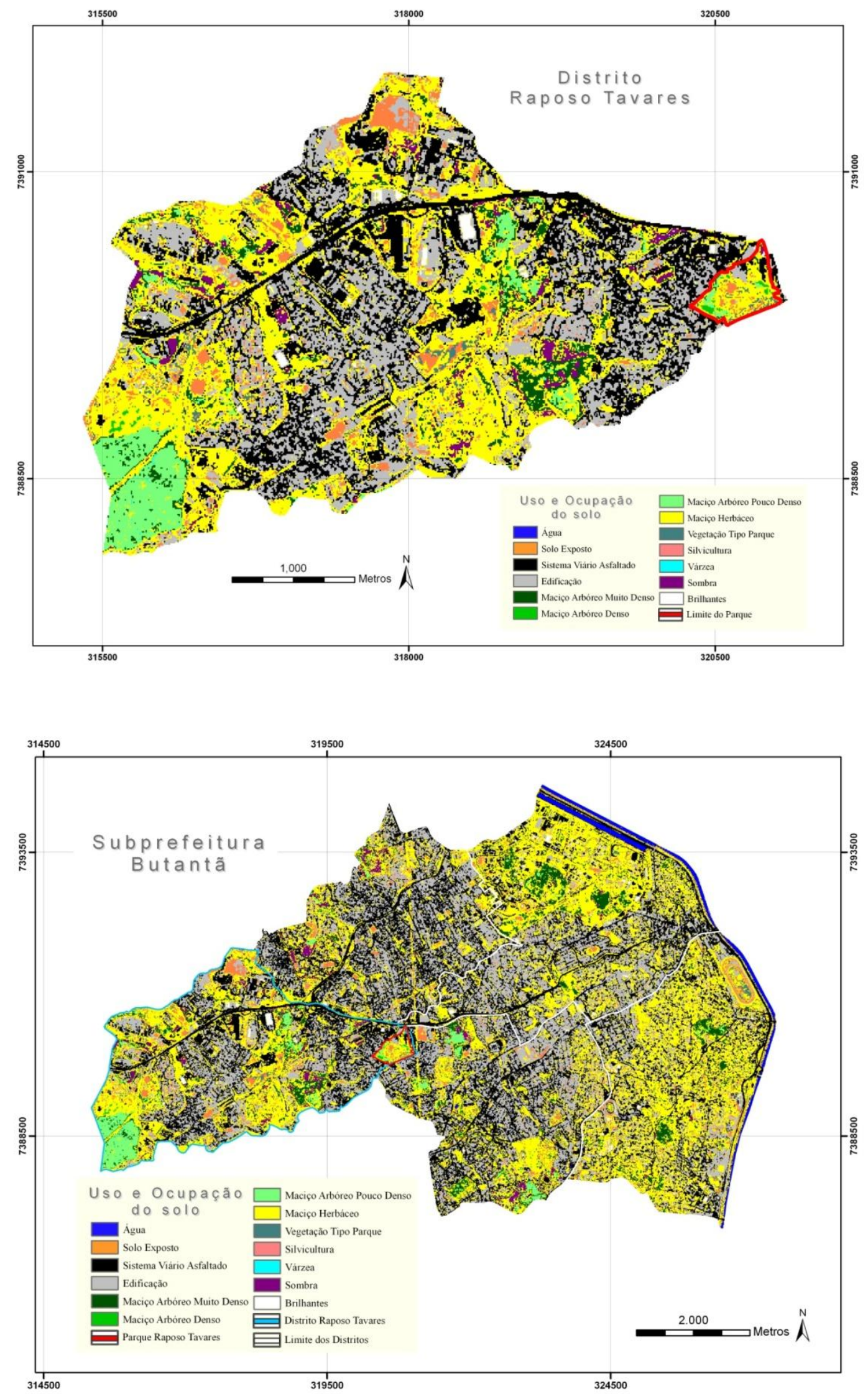

Elaboração: Luzia Helena Barros (2011)

Figura 8.2 - Mapa de uso e ocupação do solo do Distrito e Subprefeitura onde se situa o parqueaterro Raposo Tavares. 

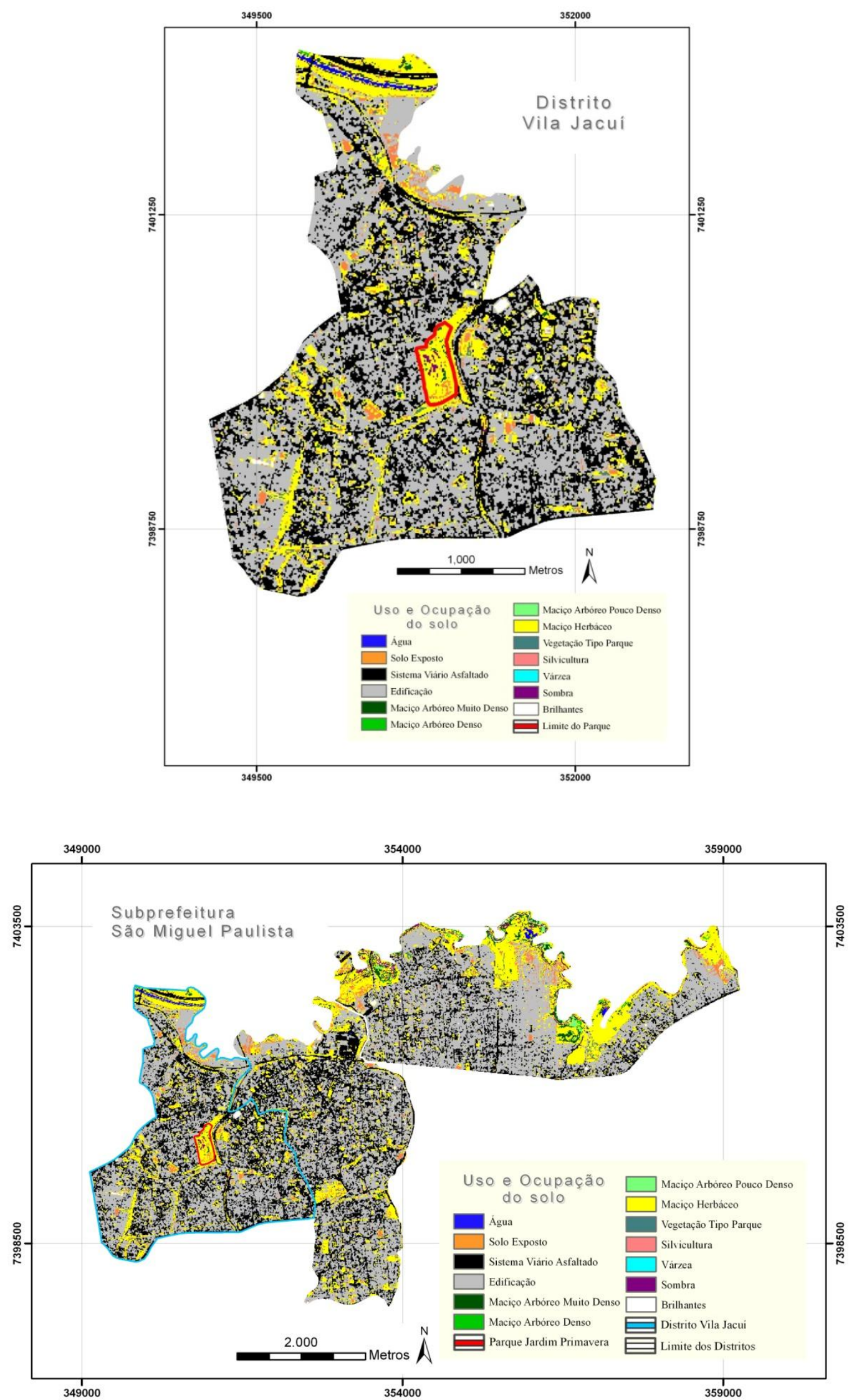

Elaboração: Luzia Helena Barros (2011)

Figura 8.3 - Mapa de uso e ocupação do solo do Distrito e Subprefeitura nos quais está inserido o parque-aterro Jardim

Primavera. 

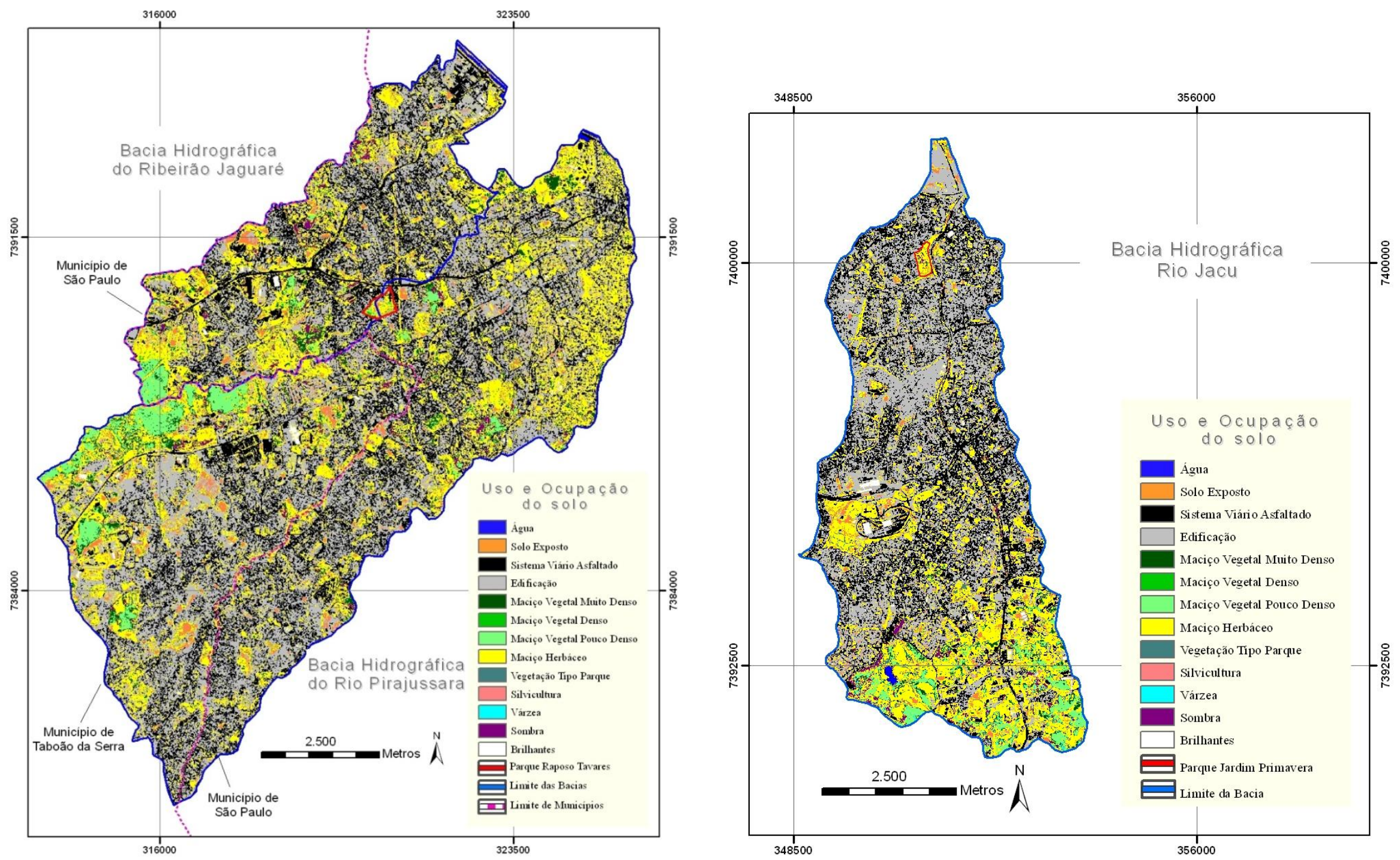

Elaboração: Luzia Helena dos S. Barros (2011)

Figura 8.4 - Mapa de uso e ocupação do solo das sub-bacias dos parques-aterros Raposo Tavares, à esquerda, e Jardim Primavera, à direita. 
Tabela 8.1 Quantificação (\%) das classes de uso e ocupação do solo nas áreas das respectivas Subprefeituras, Distritos e nas sub-bacias hidrográficas que abrangem os parques-aterros Raposo Tavares e Jardim Primavera.

\begin{tabular}{|c|c|c|c|c|c|c|c|c|c|c|c|c|c|c|}
\hline $\begin{array}{c}\text { Parques- } \\
\text { aterros }\end{array}$ & \multicolumn{8}{|c|}{ Raposo Tavares } & \multicolumn{6}{|c|}{ Jardim Primavera } \\
\hline Classes & (ha) & $\%$ & (ha) & $\%$ & (ha) & $\%$ & (ha) & $\%$ & (ha) & $\%$ & (ha) & $\%$ & (ha) & $\%$ \\
\hline Solo Exposto & 61,33 & 5,0 & 217,26 & 3,9 & 19,19 & 2,4 & 66,56 & 4,2 & 19,19 & 2,4 & 66,56 & 2,7 & 113,09 & 3,2 \\
\hline $\begin{array}{l}\text { Sist. Viário } \\
\text { Asfaltado }\end{array}$ & 304,82 & 24,8 & 1497,78 & 26,6 & 254,06 & 32,0 & 658,60 & 29,9 & 254,06 & 32,0 & 658,60 & 26,4 & 1001,74 & 28,5 \\
\hline Edificação & 293,21 & 23,9 & 1521,32 & 27,0 & 389,40 & 49,1 & 1268,63 & 30,6 & 389,40 & 49,1 & 1268,63 & 50,8 & 1292,42 & 36,8 \\
\hline $\begin{array}{l}\text { M. A. Muito } \\
\text { Denso }\end{array}$ & 50,11 & 4,1 & 182,27 & 3,2 & 2,96 & 0,4 & 27,90 & 2,4 & 2,96 & 0,4 & 27,90 & 1,1 & 72,03 & 2,1 \\
\hline $\begin{array}{l}\text { M. A. Pouco } \\
\text { Denso }\end{array}$ & 60,04 & 4,9 & 86,39 & 1,5 & 0,03 & 0,0 & 6,35 & 2,3 & 0,03 & 0,0 & 6,35 & 0,3 & 80,06 & 2,3 \\
\hline $\begin{array}{l}\text { Maciço } \\
\text { Herbáceo }\end{array}$ & 406,35 & 33,1 & 1897,66 & 33,7 & 114,85 & 14,5 & 417,61 & 27,1 & 114,85 & 14,5 & 417,61 & 16,7 & 841,69 & 24,0 \\
\hline V. Tipo Parque & 16,09 & 1,3 & 54,30 & 1,0 & 4,70 & 0,6 & 17,79 & 0,9 & 4,70 & 0,6 & 17,79 & 0,7 & 28,72 & 0,8 \\
\hline Silvicultura & 0,00 & 0,0 & 0,00 & 0,0 & 0,00 & 0,0 & 0,00 & 0,0 & 0,00 & 0,0 & 0,00 & 0,0 & 0,04 & 0,0 \\
\hline Várzea & 0,69 & 0,1 & 1,39 & 0,0 & 0,00 & 0,0 & 0,13 & 0,0 & 0,00 & 0,0 & 0,13 & 0,0 & 13,79 & 0,4 \\
\hline Sombra & 25,87 & 2,1 & 68,95 & 1,2 & 2,24 & 0,3 & 16,48 & 1,7 & 2,24 & 0,3 & 16,48 & 0,7 & 40,10 & 1,1 \\
\hline Brilhantes & 7,50 & 0,6 & 36,04 & 0,6 & 3,37 & 0,4 & 11,50 & 0,6 & 3,37 & 0,4 & 11,50 & 0,5 & 22,63 & 0,6 \\
\hline Total & 1229,04 & 100 & 5634,21 & 100 & 793,30 & 100 & 2498,23 & 100 & 793,30 & 100 & 2498,23 & 100 & 3512,62 & 100 \\
\hline
\end{tabular}


Comparando-se o uso e ocupação do solo das porções oeste e leste estudadas, verifica-se uma alta taxa de urbanização na porção leste e escassez de vegetação arbórea. Ressalta-se, entretanto, que na sub-bacia do Rio Jaguaré, porção oeste, a presença de vegetação arbórea é muito pouco significativa. Essas características respondem pelas temperaturas de superfície mais elevadas na porção leste do que na oeste, com diferenças de até $3^{\circ} \mathrm{C}$, apontadas no Atlas Ambiental do Município (SVMA, 2004a) e por Fatigatti (2009).

Resumidamente, a região do extremo oeste do município, onde está inserido o parque-aterro Raposo Tavares, apresenta indicadores de qualidade de vida um pouco melhores do que o extremo leste, na qual se situa o parque Jardim Primavera. Esse contraste reflete a diversidade socioambiental entre o eixo oesteleste do município de São Paulo, destacando-se o quadrante sudoeste como o vetor de expansão da classe alta de São Paulo, como já referido anteriormente.

As intervenções realizadas ao longo do tempo nos estudos de caso foram sintetizadas (Tabela 8.2), fornecendo o panorama geral da sua situação. 
Tabela 8.2 - A evolução das ações desenvolvidas nos estudos de caso

\begin{tabular}{|c|c|c|}
\hline Parque-aterro & Ano & Situação \\
\hline \multirow{13}{*}{$\begin{array}{l}\text { Raposo } \\
\text { Tavares }\end{array}$} & 1954 & Seleção, arrendamento do terreno e início do lixão \\
\hline & 1965 & Desapropriação da área \\
\hline & 1967 & Início do lixão (mat. orgânica, plástico, metal, vidro, etc.) \\
\hline & 1975 & Transformação em 'aterro controlado' \\
\hline & 1976 & Implantação do projeto de aproveitamento do biogás \\
\hline & 1978 & Pré-operação da estação de exploração do biogás \\
\hline & 1979 & Encerramento do aterro \\
\hline & 1980 & Elaboração e implantação do projeto paisagístico \\
\hline & 1981 & Inauguração do parque \\
\hline & 1987 & Encerramento do aproveitamento do biogás \\
\hline & $2003-2007$ & Implantação de sistema de drenagem do percolado \\
\hline & 2008 & Decreto 50.259 - oficializa o parque \\
\hline & $2008-2009$ & Implantação de pavimentação, iluminação, equipamentos \\
\hline \multirow{18}{*}{$\begin{array}{c}\text { Jardim } \\
\text { Primavera }\end{array}$} & Até 1950 & Área livre \\
\hline & 1968 & Início da mineração de areia \\
\hline & 1979 & Encerramento da mineração de areia \\
\hline & 1979 & Início do lixão (mat. orgânica, plástico, metal, vidro, etc.) \\
\hline & 1982 & Desapropriação da área \\
\hline & 1983 & Transformação em 'aterro controlado' \\
\hline & 1988 & Encerramento do aterro \\
\hline & $1988-1995$ & Migração de gás para residências próximas \\
\hline & $1991-1992$ & Projeto-piloto para recomposição vegetal \\
\hline & $\sim 1995$ & Plantio de eucaliptal \\
\hline & 2001 & Constatação de geração de gás \\
\hline & 2002 & Lei 13.308 - cria o Parque Jardim Primavera \\
\hline & 2005 & Avaliação preliminar da contaminação \\
\hline & 2007 & Elaboração do projeto paisagístico - Fase 1 \\
\hline & 2008 & $\begin{array}{l}\text { Fim da avaliação ambiental e de risco à saúde humana } \\
\text { Implantação da Fase } 1 \text { e sua interrupção }\end{array}$ \\
\hline & $2009-2010$ & Nova licitação para implantação da Fase 1 \\
\hline & Nov 2010 & Retomada da implantação da Fase 1 \\
\hline & Jun 2011 & Elaboração do Termo de Referência da Fase 2 \\
\hline
\end{tabular}




\subsubsection{Parque-ATERro Raposo Tavares}

O parque-aterro localiza-se à Rua Telmo Coelho Filho 200, altura do Km 14,5 da Rodovia Raposo Tavares, no bairro Água Podre, no extremo leste do distrito Raposo Tavares. Possui 19,5 hectares de área e faz limite com os distritos de Rio Pequeno, Butantã e Vila Sônia, integrantes da Subprefeitura do Butantã (Figura 8.5).

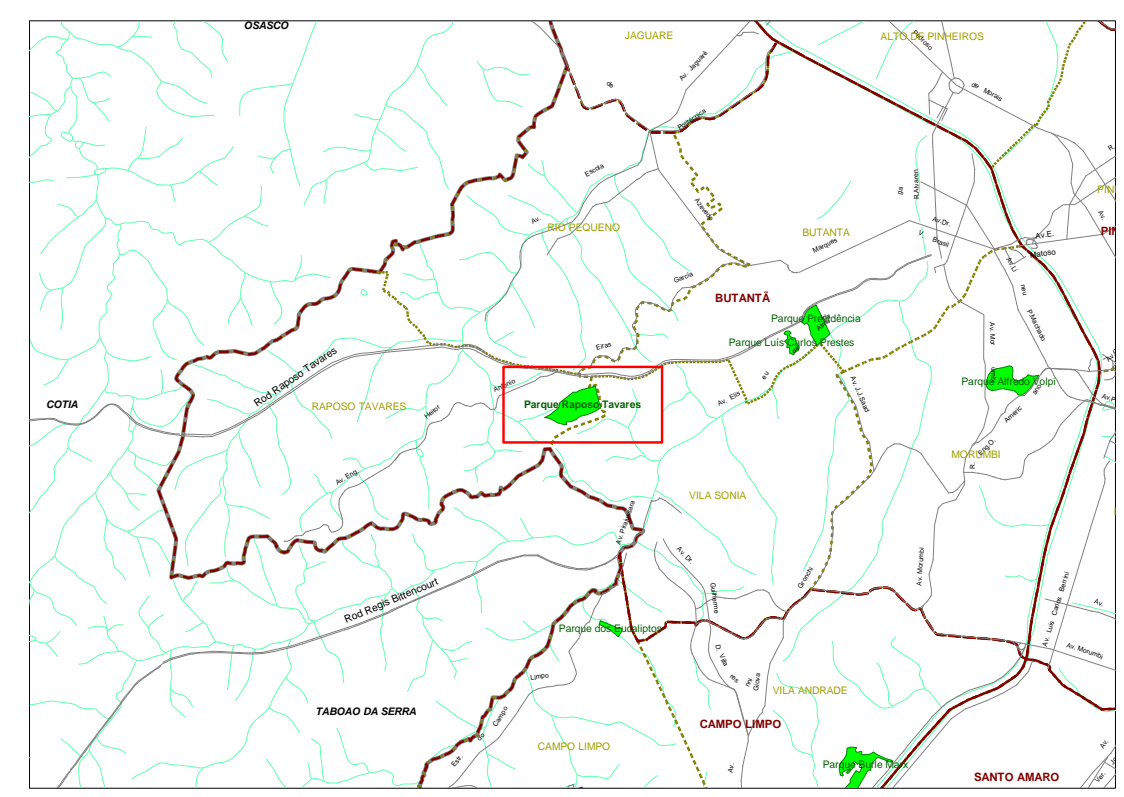

Elaboração: Arq. Flávio Fatigatti

Figura 8.5 - Localização do Parque Raposo Tavares Fonte: SVMA (2004).

Muitas informações para o desenvolvimento desse capítulo foram obtidas por meio de entrevista realizada em 27 de outubro de 2008, com o então administrador do parque, biólogo Fabio Santos Pellaes (Apêndice E), contratado por currículo em abril de 2007, substituído, em março de 2010, pela tecnóloga em saneamento ambiental Maíra Lucia Julião dos Santos, atual administradora. Anteriormente, ele atuava como professor em cursinho e em dois escritórios de consultoria ambiental. Morador da Vila Carrão, zona leste, atravessava a cidade diariamente, mas considerava a experiência proveitosa, apesar das dificuldades iniciais e dos vários desafios. Ponderou, no entanto, que 0 trato com as questões administrativas (fiscalização de contrato, gerência de pessoal e da empresa) consumiam a maior parte do tempo, restante pouco espaço para atuar na sua formação específica. Quando criança, freqüentava o Parque do Carmo e do Piqueri, posteriormente o Ibirapuera e, na faculdade, tratou de um estudo de caso, o próprio Raposo Tavares. 


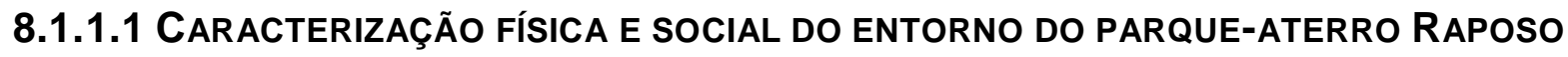

TAVARES

O levantamento topográfico de 1930 (SARA Brasil) deixa claro que o aterro foi executado sobre um divisor de águas onde estavam localizados os afluentes de dois tributários da margem esquerda do Rio Pinheiros, os Rios Jaguaré e Pirajussara. Conforme a Carta Geotécnica (Sempla, 1992), situa-se sobre maciço de solo e rocha gnáissica, com ocorrência de planície aluvial no seu extremo leste, acompanhando pequena drenagem.

O parque, segundo o Plano Regional Estratégico, está rodeado pela zona mista de proteção ambiental, sendo que a noroeste, junto à Rodovia Raposo Tavares, foi prevista a Zona Predominantemente Industrial e, ao sul Zonas Especiais de Interesse Social. No seu entorno próximo não há previsão de caminhos verdes ou parques lineares ou urbanos.

O mapa de temperatura da superfície aparente do entorno do parque-aterro mostra que ela varia entre 21 e $24 \stackrel{\circ}{ } \mathrm{C}$. Quando se observa a variação no período entre 1991 e 2006, verifica-se que no seu interior houve um aumento de $1^{\circ} \mathrm{C}$, chegando a até $2^{\circ} \mathrm{C}$, localmente. No entorno próximo, existem tanto manchas que mostram diminuição (até $3^{\circ} \mathrm{C}$ ) quanto aumento de até $5^{\circ} \mathrm{C}$ (Figura 8.6).
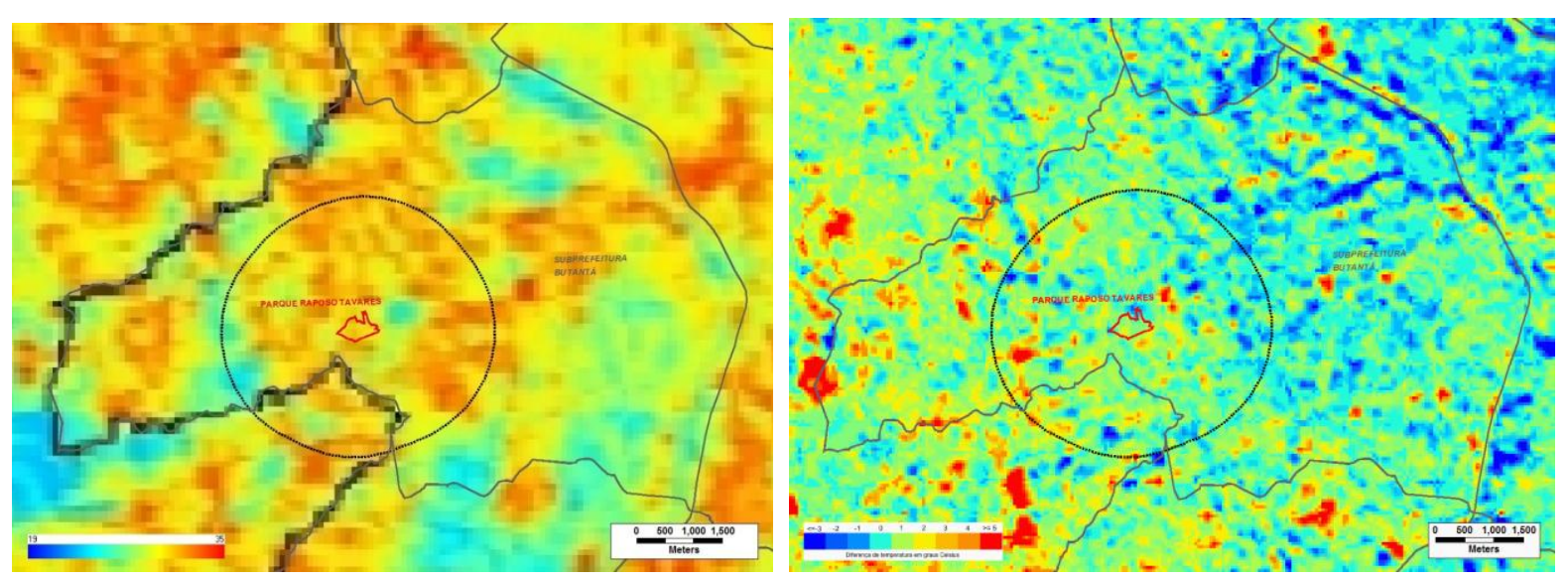

Elaboração: Arq. Flavio Fatigatti

Figura 8.6 - À esquerda, temperatura de superfície no entorno do parque-aterro Raposo Tavares, em 2006. À direita, a diferença da temperatura no período 2006-1991. Os mapas foram obtidos do processamento das imagens Landsat/1991, 2006.

Fonte - Fatigatti (2009) recorte do mapa produzido para o município de São Paulo. 


\subsubsection{USO E OCUPAÇÃO DO SOLO NO PARQUE-ATERRO RAPOSO TAVARES}

Utilizando-se do mapa de uso e ocupação do solo, apresentado no item 8.2, destacou-se o limite do parque-aterro Raposo Tavares, a fim de visualizar com mais detalhes as classes no seu interior (Figura 8.7 e Tabela 8.3).

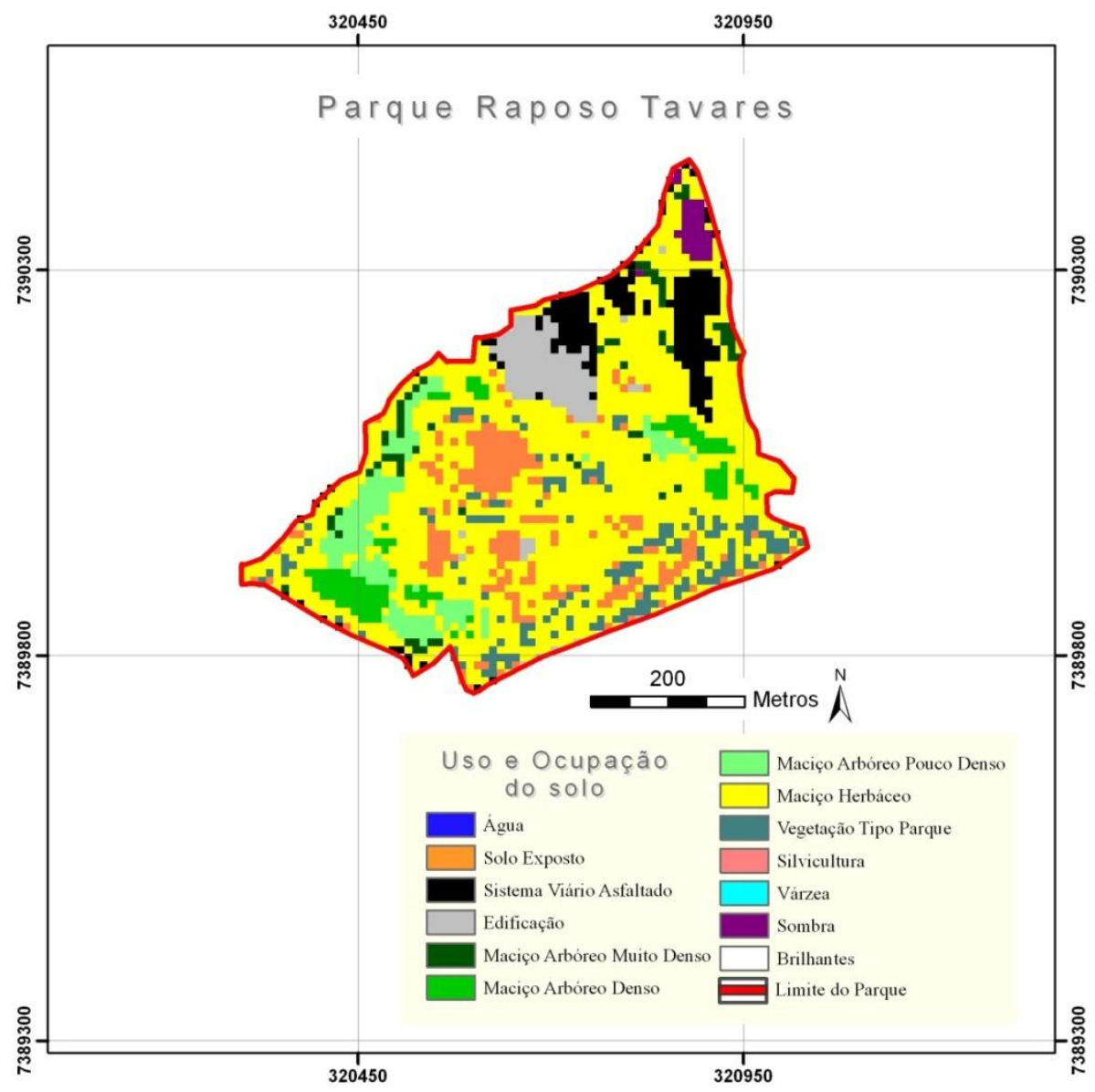

Elaboração: Luzia Helena dos s. Barros (2011)

Figura 8.7 - Mapa de uso e ocupação do solo do parque-aterro Raposo Tavares.

Tabela 8.3 - Quantificação das classes de uso e ocupação do solo no interior do parque-aterro Raposo Tavares (\%).

\begin{tabular}{lc}
\hline \multicolumn{1}{c}{ Classes } & Parque-aterro \\
Raposo Tavares
\end{tabular}


O mapa mostra que no interior do parque-aterro Raposo Tavares, com vegetação implantada desde o início da década de 1990, predomina a vegetação herbácea (70\%), com apenas $16 \%$ de vegetação arbórea na área total do parque. A classe urbanização (edificações e vias asfaltadas) ocorre com a proporção de $13 \%$, equivalente aos maciços arbóreos. Ressalta-se que a classe sistema viário asfaltado, incluiu, no interior do parque, quadras poliesportivas pavimentadas.

\subsubsection{Histórico de OCUPAÇÃo do aterRo Raposo TAVARES}

Segundo Ogata (1983), a origem do aterro Cotia, denominado de aterro do Km 14,5 da Via Raposo Tavares, a partir de 1974, está relacionada à urbanização do bairro de Pinheiros, que levou ao fechamento do lixão da R. Sumidouro, atual Praça Victor Civita (vide Capítulo 7). A área foi selecionada, em 1954, após a expulsão, neste mesmo ano, de outros três lixões das redondezas: Rodovia Raposo Tavares Km 15; lagoa Jaguaré e Jardim Universidade, na várzea do Rio Pinheiros.

A situação de emergência para a instalação do lixão, à época, de acordo com a autora, fez com que o terreno fosse arrendado e, não já desapropriado, como seria o mais apropriado. Esse fato levou o dono do terreno a receber os resíduos e a explorar o serviço de catação, atraindo grande contingente populacional com o surgimento de favelas na vizinhança. Como conseqüência, a redondeza que, até então, se apresentava como um hiato na malha urbana foi rapidamente loteada, a baixos preços.

A área destinada para 0 aterro foi declarada de utilidade pública para desapropriação, somente, em 1965 (Decreto № 6.112), posteriormente ampliada em 1973 (Decreto no 9.976) e 1977, com a incorporação de área pública do loteamento Jardim Santa Marta, Água Podre; totalizando uma área de $205.841 \mathrm{~m}^{2}$ (SVMA, 2005). O local estrategicamente estava próximo às regionais da Lapa, Pinheiros e Butantã e, da zona industrial.

A disposição de resíduos 'oficial' ${ }^{9}$ se iniciou em 1967 sem nenhum controle técnico, ou seja, os diversos tipos de material, inclusive industrial, eram dispostos diretamente sobre o terreno, sem nenhuma preocupação com impermeabilização

\footnotetext{
${ }^{9}$ Esta autora introduziu o termo no sentido de enfatizar que a partir desse momento o lixão passou a ser de propriedade municipal.
} 
para proteção do subsolo e águas subterrâneas. Também não se utilizava nenhum tratamento, pois àquela época inexistiam normas técnicas para disposição do material (Silva, 2001). Na fotoaérea de 1973, visualiza-se o aterro ainda em atividade (Figura 8.8).

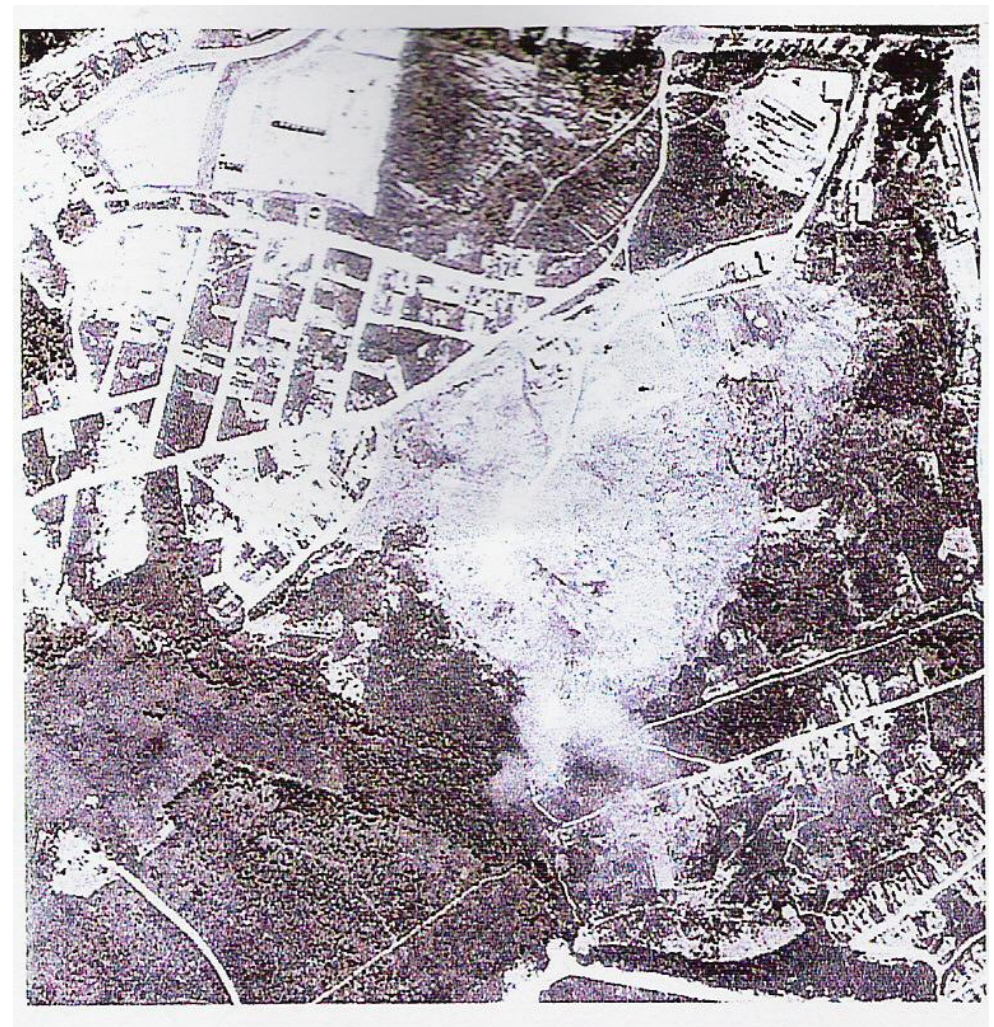

Figura 8.8 - Fotoaérea (1973), Esc. original: 1:8.000, do lixão Raposo Tavares (mancha clara). Fonte: Silva (2001, p.79).

O lixão passou a provocar diversos problemas. A fumaça originada da emanação de gases ocasionava má visibilidade na Rodovia, havia perigo de explosão e desabamento do lixo, presença de animais nocivos, etc. Uma explosão soterrou barracos próximos (Ogata, 1983). Protestos da população (exceto a da favela) e dos motoristas fizeram com que o Limpurb promovesse a alteração da operação do lixão para aterro controlado (Ogata, 1983; Silva, 2001), em 1975, conforme demonstra o projeto esquemático (Figura 8.9), perdurando a disposição até 1979. Os registros da operação do aterro controlado indicavam que foram dispostas cerca de dois milhões de toneladas de resíduos, mas muito provavelmente a quantidade real de resíduos deve ser maior que o dobro (Silva, 2001).

Neste aterro se deu a primeira experiência de aproveitamento do gás, mediante um convênio entre a Comgás e a Limpurb/PMSP, em 1976. A estação experimental e de armazenamento permitiu a distribuição do gás, inicialmente, em 
26 residências situadas a cerca de 700 metros do aterro. Posteriormente, o gás foi utilizado numa fábrica de cerâmica do entorno, pois os moradores não tinham condições de arcar com os custos das instalações. Essa estação e outra para aproveitamento do gás, em veículos, no aterro Santo Amaro, foram abandonadas por fatores econômicos (Silva, 2001).

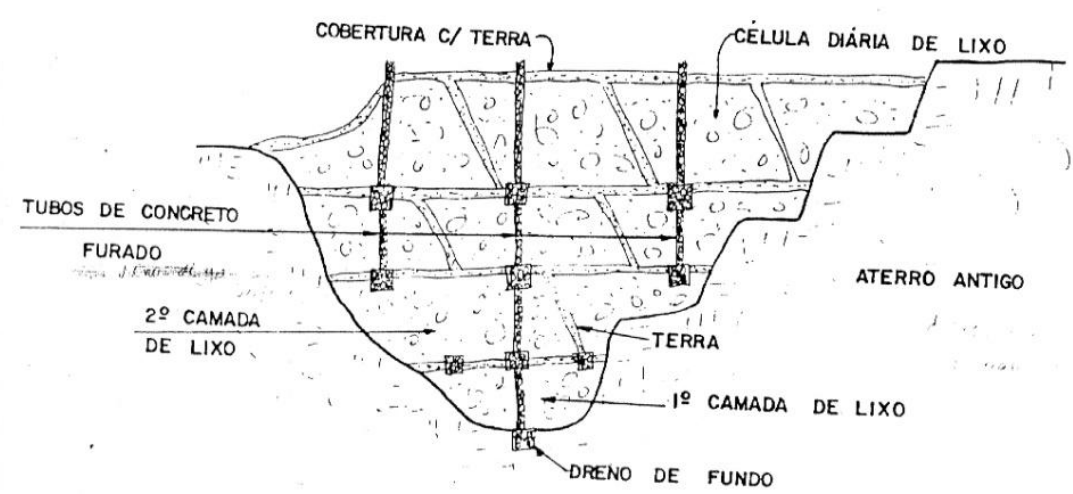

Figura 8.9 -: Corte esquemático do projeto do aterro controlado Raposo Tavares Fonte: Silva (2001, p.81).

A partir do projeto de parque elaborado, na década de 70 , pela equipe do Departamento de Parques e Áreas Verdes - Depave/SVMA, em 1981, foi inaugurado o parque municipal Raposo Tavares. É o primeiro parque implantado sobre antigo lixão/aterro, sobre parte do qual também se localiza a SP-BT.

\subsubsection{Antigo aterro Jacuí, futuro parque-aterro Jardim PrimaVera}

O futuro parque-aterro Jardim Primavera (antigo aterro Jacuí) está localizado na confluência das Av. Antonio Louzada Antunes, Mimo de Vênus e Rua Arareua, junto ao sistema viário Jacu-pêssego, zona leste do Município, no distrito de Vila Jacuí, com área total de 12,2 hectares (Figura 8.10).

A administração do futuro parque está a cargo do geógrafo, Sérgio Nunes, bacharel em direito e mestrando na geografia, atual administrador do parque Vila Sílvia $^{10}$, entrevistado em 11 de maio de 2010 (Apêndice F).O administrador Sérgio exerce a função há mais de dois anos e até então atuava como professor de cursos

\footnotetext{
${ }^{10}$ Ele presta serviços também no parque Primavera de uma forma oficiosa, pois o parque ainda não existe fisicamente, mas espera ser nomeado para o cargo assim que inaugurado o parque.
} 
pré-vestibular e de gestão ambiental e, também, como administrador do parque linear Tiquatira. Segundo ele, mesmo com a experiência positiva adquirida no Vila Sílvia, pode-se considerar a administração de um parque, remanescente de aterro, como uma experiência nova. É morador da zona leste e foi por quinze anos vizinho do antigo aterro Jacuí; fato que o motiva para a gestão do Jardim Primavera.

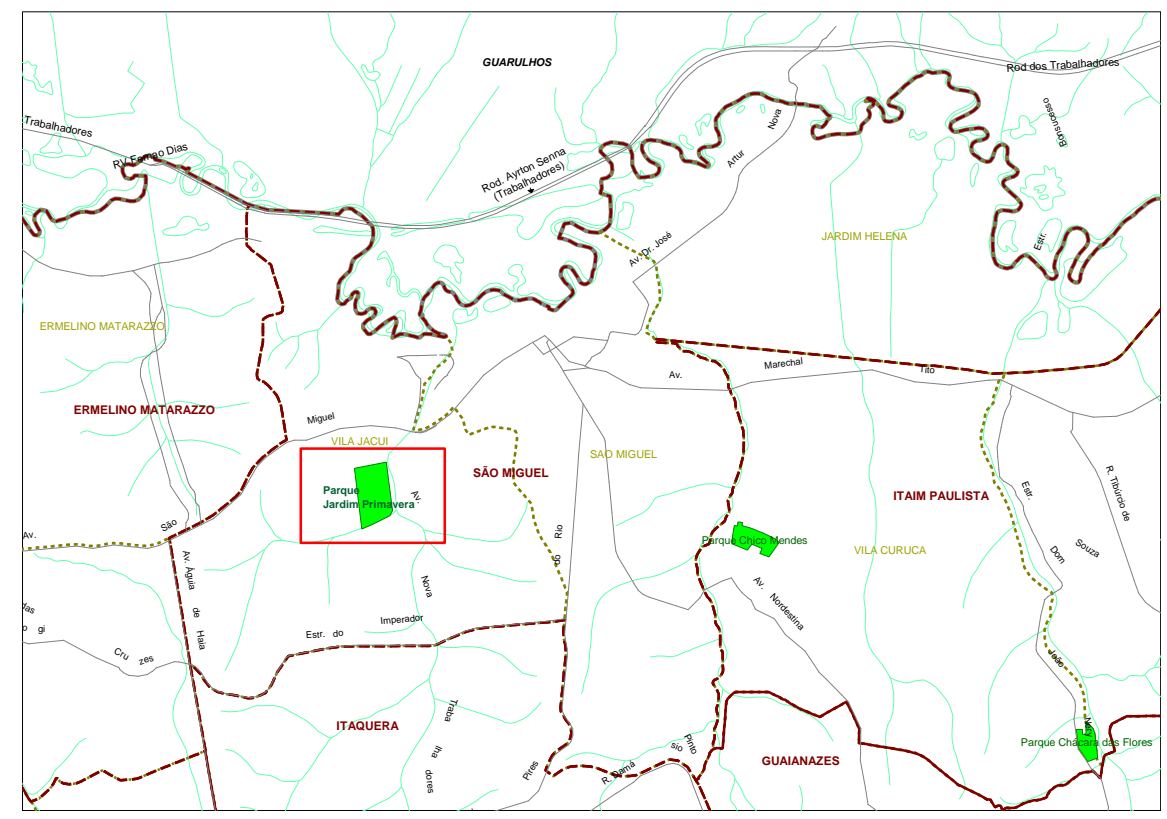

Elaboração: Arq. Flávio Fatigatti

Figura 8.10 - Localização do Parque Jardim Primavera Fonte: SVMA (2004).

A população do entorno, segundo Sérgio, é de classe média e média-baixa, sem favelas. Uma periferia consolidada, com infraestrutura de água, esgoto e energia elétrica. Os bairros que apresentam as melhores condições sociais são o Jardim Pedro José Nunes, o Vila Jacuí e o Parque Cruzeiro do Sul; o Jardim das Camélias, talvez um pouco menos. Os bairros União de Vila Nova e Vila Nair, conhecido também como Pantanal (não o do Jardim Romano), possuem população pobre onde, atualmente, ocorre uma forte urbanização com asfalto, água e esgoto.

\subsubsection{CARACTERIZAÇÃo FísICA do ENTORNO do ANTIGO ATERRO JACUÍ}

O aterro desativado está inserido na sub-bacia do Rio Jacu, no seu trecho inferior, ao longo das margens esquerdas do Rio Jacu e do córrego Limoeiro; sob 
terrenos originalmente inundáveis, já apontados por levantamento topográfico antigo (SARA Brasil, 1930). Como relata o IPT (1983) o local constitui-se de uma colina com amplitudes de até 20 metros, entalhada, a sul, pelo córrego Limoeiro e a norte por pequeno curso d'água parcialmente canalizado. Segundo a Carta Geotécnica (Sempla, 1992) ocorre sob os sedimentos terciários da Bacia de São Paulo em contato com a planície aluvial do Rio Jacu. Está indicado como Zona Especial de Proteção Ambiental - ZEPAM, no Plano Regional Estratégico, que mostra parques e áreas municipais ao longo da Av. Jacu-pêssego.

A temperatura de superfície do entorno do antigo aterro observada, em 2006, variou entre 23 e $25^{\circ} \mathrm{C}$. A comparação das temperaturas no período entre 1991 e 2006 mostrou que no seu interior houve uma diminuição da ordem de $3^{\circ} \mathrm{C}$, ao contrário do seu entorno imediato, que mostrou um aumento de cerca de até $2^{\circ} \mathrm{C}$ (Figura 8.11).
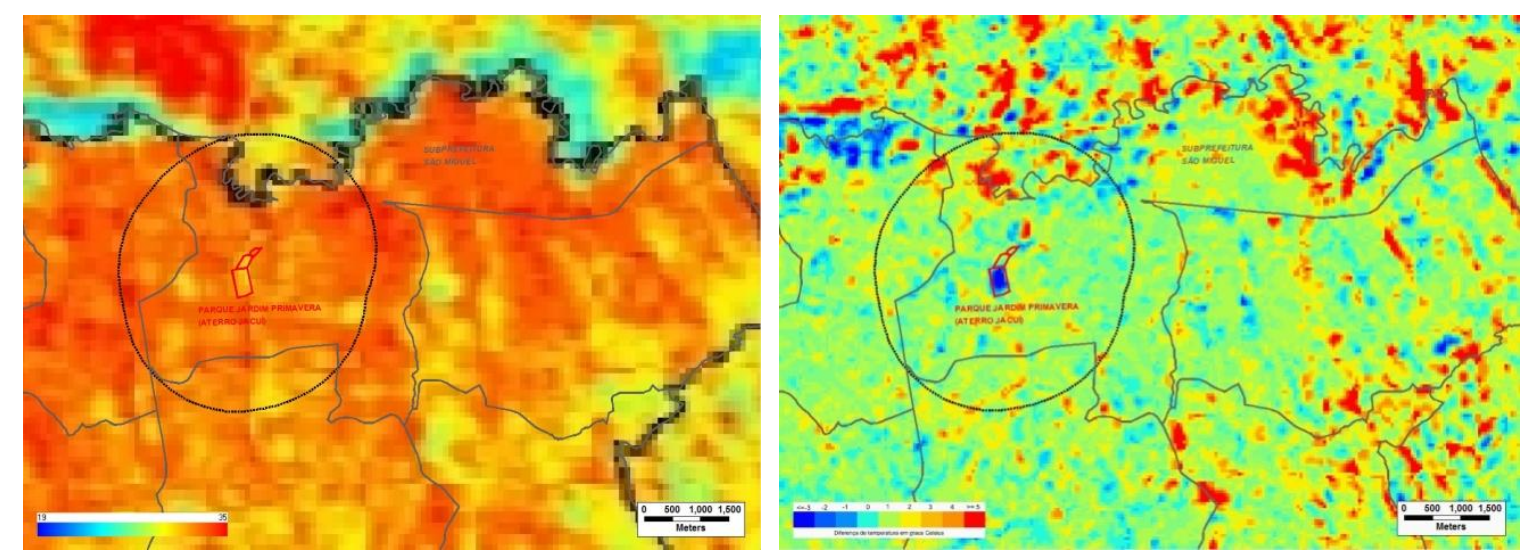

Elaboração: Arq. Flavio Fatigatti

Figura 8.11 - À esquerda, temperatura de superfície no entorno do parque-aterro Jardim Primavera, em 2006. À direita, a diferença da temperatura no período 2006-1991. Os mapas foram obtidos do processamento das imagens Landsat/1991, 2006.

Fonte - Fatigatti (2009), recorte do mapa produzido para o município de São Paulo.

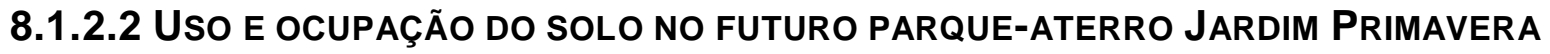

Utilizando-se, também, do mapa de uso e ocupação do solo, apresentado no item 8.2, destacou-se o limite do parque-aterro Jardim Primavera, a fim de visualizar com mais detalhes as classes no seu interior (Figura 8.12 e Tabela 8.4). 


$$
\text { O mapa de uso e ocupação do solo do parque-aterro Jardim Primavera }
$$
mostra que no seu interior a vegetação herbácea $(78 \%)$ predomina em toda a sua extensão, com os exemplares arbóreos representando apenas $6 \%$ da sua área total.

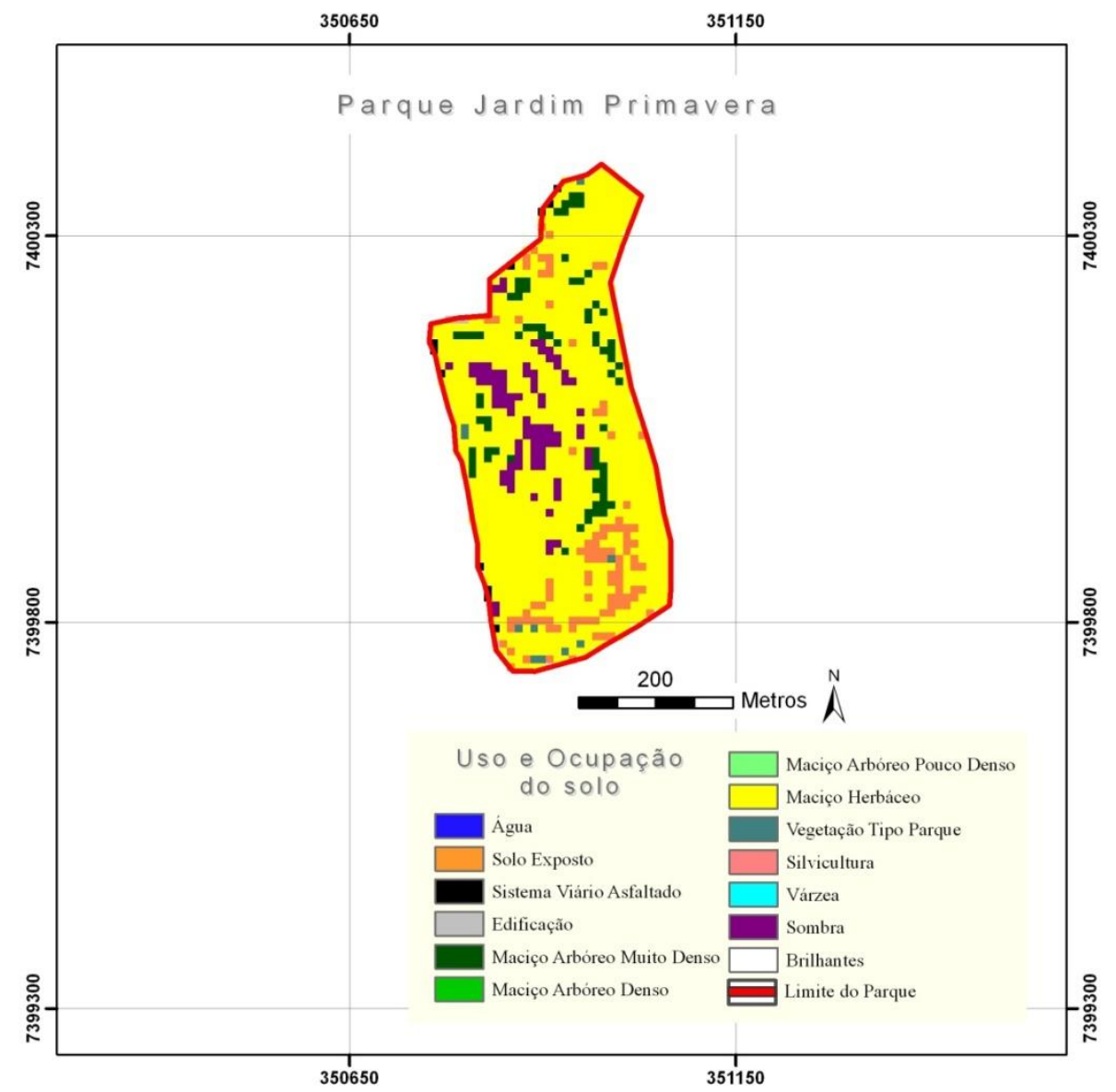

Elaboração: Luzia Helena dos S. Barros

Figura 8.12 - Mapa de uso e ocupação do solo do parque-aterro Jardim Primavera.

Tabela 8.4 - Quantificação das classes de uso e ocupação do solo no interior do parque-aterro Jardim Primavera (\%).

\begin{tabular}{lc}
\hline \multicolumn{1}{c}{ Classes } & $\begin{array}{c}\text { Parque-aterro } \\
\text { Jardim Primavera }\end{array}$ \\
Urbanização & 1 \\
M. A. m. Denso & 6 \\
M. A. Denso & - \\
M. A. p. Denso & - \\
M. Herbáceo & 78 \\
Água & - \\
Solo exposto & 8 \\
\hline
\end{tabular}




\subsubsection{HISTÓRICO DE OCUPAÇÃo dO ATERRO JACUÍ}

O Sr. Sylvio A. Sena, editor do jornal Pedro Nunes e morador à Rua da Polka, vizinho do antigo aterro, devido ao seu envolvimento em toda a história do aterro e na luta por sua transformação em parque ${ }^{11}$, foi entrevistado no dia 06 de maio de 2010 (Apêndice G). Forneceu informações valiosas sobre todos os processos de uso e ocupação do solo nas redondezas.

A região do aterro, até o começo da década de 50, se apresentava livre com pequena movimentação de terra (Figura 8.13). A exploração de areia se iniciou por volta de 1968, em sedimentos terciários da planície aluvionar do córrego Jacú, dando origem a duas grandes cavas (Figura 8.14), que interceptaram o lençol freático formando as lagoas. A mineração encerrou suas atividades em 1979.

As lagoas abandonadas ofereciam riscos de afogamentos, com registros de mortes, tal como lembrou o morador Sylvio; o que levou a população a pressionar o poder público para o seu aterramento. A disposição de resíduos então se iniciou de forma aleatória, diretamente sobre as duas antigas cavas mineração (Figura 8.14) e, em seguida, o lixão foi paralisado por exigência da população. A cava de mineração, segundo o IPT (1983), tinha a profundidade média de 25 metros, em relação ao nível natural do terreno, atingindo até 40 metros. Neste momento, houve um acordo com a população e o lixão foi transformado em aterro controlado (1981), com cerca de 2,5 milhões de resíduos depositados, com sua operação sendo finalizada em 1988 (Figura 8.15). Nesta época, inspeções técnicas da Cetesb detectaram migração de gás para residências próximas que se sucederam até 1994. Em decorrência do fato, a Cetesb determinou o fechamento de todos os poços de abastecimento de água na região, permanecendo apenas um, situado na R. Grinalda de Noiva para monitoramento. Em 1995, também foi constatada emissão de gás durante a construção do sistema viário Jacu-Pêssego, distante cerca de 500 metros do aterro (SVMA, 2001; Ramires e Vitor, 2010).

A abertura da Av. Jacu-Pêssego e, mais recentemente, o seu prolongamento na direção sul, passando ao longo do futuro parque-aterro Sapopemba, em São Mateus, vem acarretando transformações intra-urbanas na região. De acordo com Villaça $(2001$, p. 80$)$ "[...] o primeiro efeito de uma via nos terrenos adjacentes é a melhoria de sua acessibilidade e, daí, sua valorização [...]".

\footnotetext{
${ }^{11} \mathrm{O}$ seu nome foi indicado por colegas do GTAC/Decont e pelo próprio Sérgio, que sabiam da sua vivência no tema.
} 


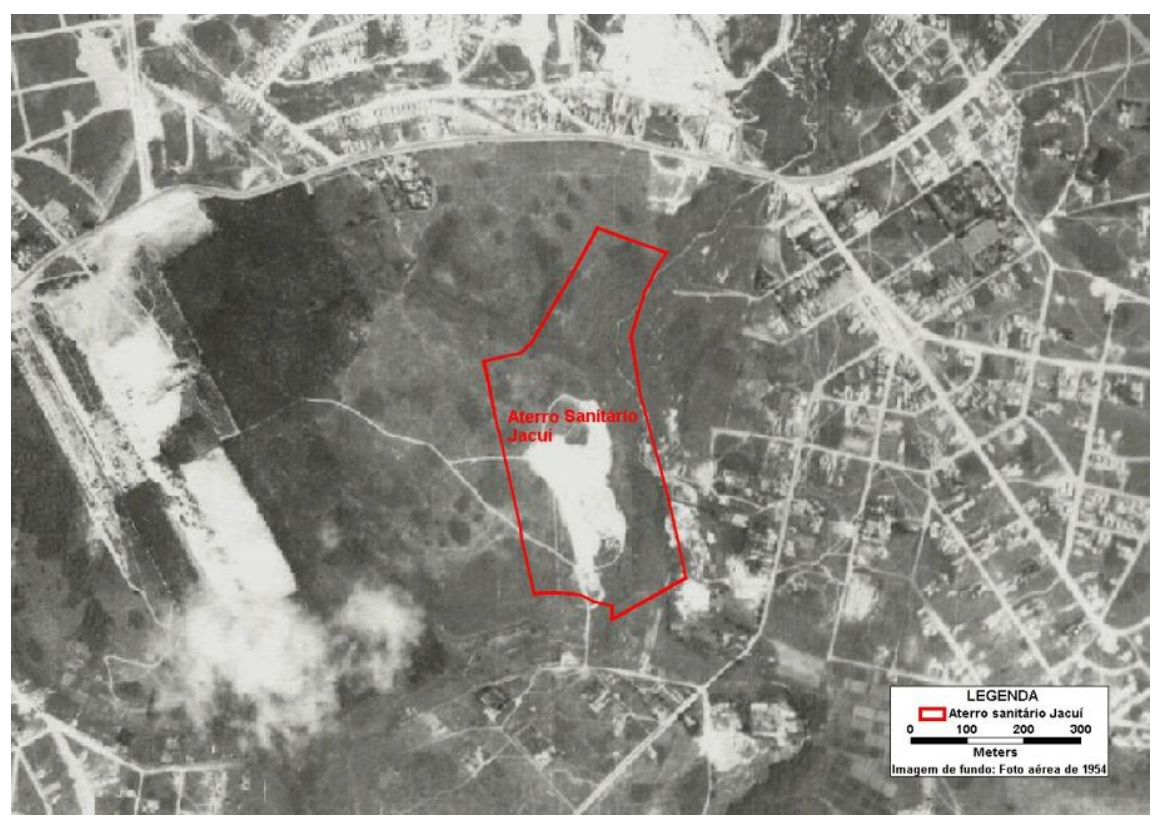

Elaboração: Arq. Flávio Fatigatti

Figura 8.13 - Fotoaérea de 1954 (Esc. Original 1:25.000), modificada, com o entorno do aterro Jacuí pouco ocupado.
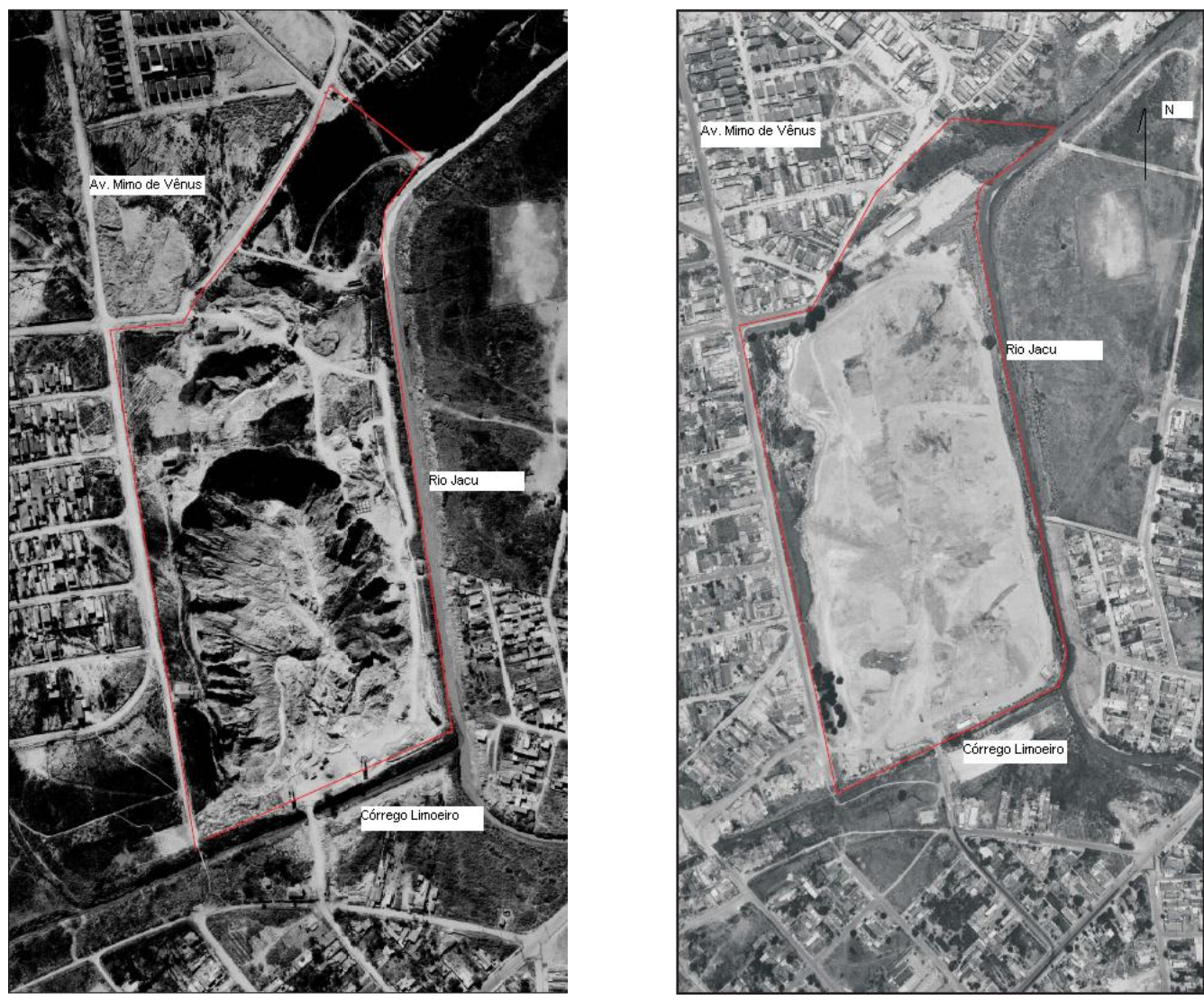

Figura 8.14 - À esquerda, fotoaérea modificada (1977), mostrando a mineração em atividade. À direita, fotoaérea modificada (1986), onde se observa que toda a área está aterrada.

Fonte: SVMA (2007) 


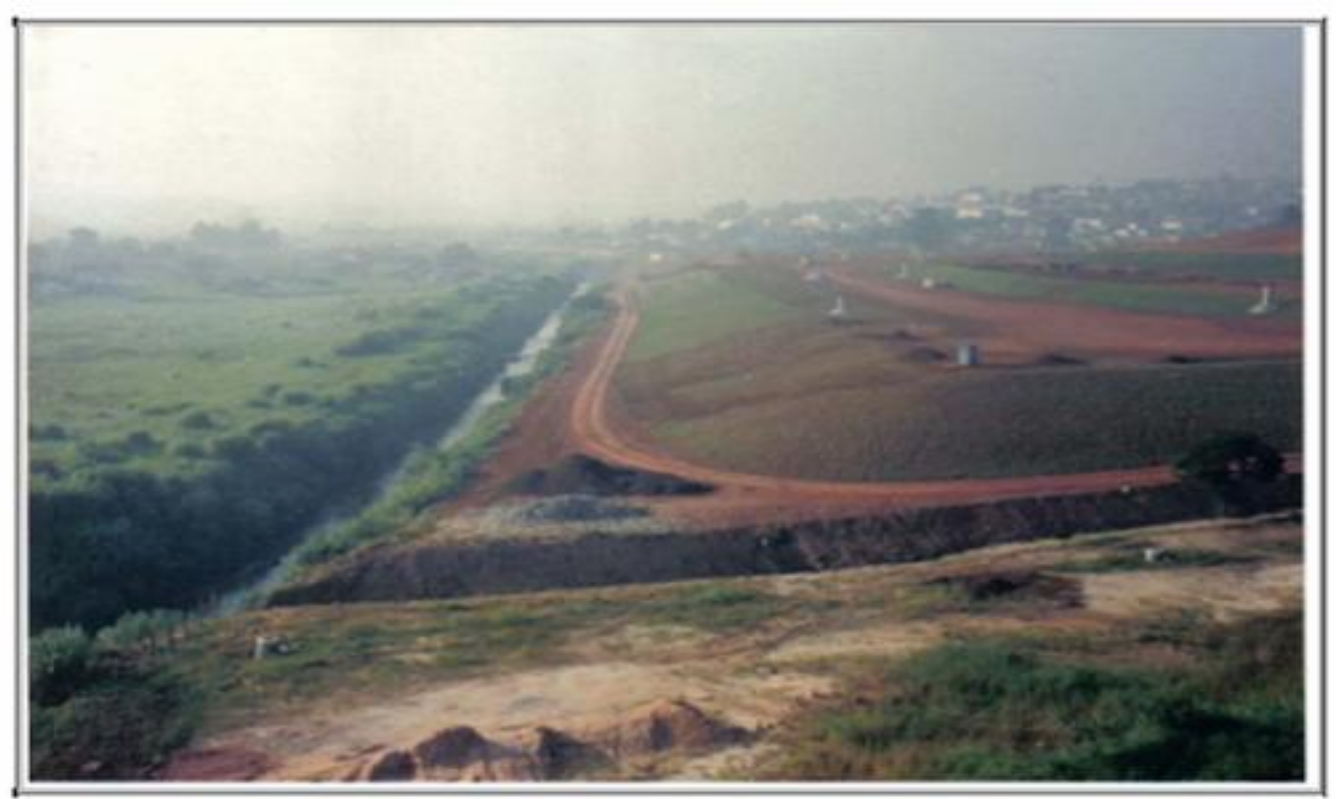

Figura 815 - Aterro, em 1986, com revegetação de grama nos taludes e os drenos de gás instalados. Fonte: Foto cedida pelo Sr. Silvio Sena, morador do bairro.

O loteamento da região, denominado Jardim Pedro Nunes, aparentemente, se inicia no final da década de 1970, após o encerramento da mineração, quando foi regularizado (AU 2464), tendo origem no arruamento (ARR 1967), aprovado em $1963^{12}$. O morador Sylvio confirma que adquiriu o seu lote regularizado, em setembro de 1979, sem notar o abismo da grande lagoa ao lado. Foi num domingo que ele percebeu 'em que buraco a gente se meteu'.

O encerramento do aterro, de acordo com o Sylvio, foi realizado em meio a conflitos entre bairros vizinhos, o bairro Pedro Nunes, mais diretamente afetado pelos problemas gerados pelo aterro (explosões) e o bairro Camélias, que não sofria o problema, pois o córrego Limoeiro impedia a migração do gás naquela direção. 0 bairro das Camélias recebia subsídio da empresa operadora do aterro, mediante os auxílios fornecidos à igreja da região e, por isso pleiteava a continuação da atividade. Mas com as palavras do morador: [...] a força das explosões e dos acontecimentos era maior. O Pedro Nunes já estava se transformando em uma bomba. [...].

Segundo o administrador Sérgio e o morador Sylvio, após encerrada a operação do aterro, seguiram-se anos de queima do gás através dos drenos. O mau

\footnotetext{
${ }^{12} \mathrm{Na}$ década de 1970 a Prefeitura iniciou a regularização de vários arruamentos (ARR,) aprovados anteriormente, mas com implantação, de fato, não coincidente com as antigas plantas. Entretanto, em muitos casos, a planta do loteamento regularizado (AU) foi simplesmente copiada do arruamento anterior. O Croquis no 100153 é o documento cadastrado na Prefeitura, que traz os dados sobre os arruamentos/loteamentos. Ele mostra a previsão de lotear, inclusive a área do futuro porto de areia. O ARR 1967 foi regularizado pelo AU 2464, no PA 10-184.912-79*11.
} 
cheiro e o fogo eram sentidos e vistos de longe e, por esse motivo, o aterro servia de ponto de referência em toda a região. Havia relatos de moradores sobre explosão. $O$ gás se propagava pelas fossas sépticas e chegava até as residências.

A área foi efetivamente desapropriada somente em 1982. A instalação da rede de esgoto e da adutora de $1.500 \mathrm{~mm}$ de aço carbono, pela Sabesp na região, ocorreu, respectivamente, em 1986 e 2003 (SVMA, 2007a).

Por meio de estudo da SVMA em cooperação com a Companhia de Gás de São Paulo - Comgás, em 2001, foi constatada uma significativa geração de gás no aterro e o funcionamento inadequado da maioria dos drenos (SVMA, 2001). Posteriormente, em 2004, a SVMA contratou o Centro de Estudos Integrados sobre o Meio Ambiente e Mudanças Climáticas ${ }^{13}$ para realizar estudos preliminares com o intuito de reduzir a emissão de gases contribuintes ao efeito estufa nos aterros ativos e desativados. Os valores encontrados para o gás bioquímico - GBQ no aterro Jacuí, mostraram que a geração de gás ainda presente era insuficiente ao aproveitamento para fins energéticos e comercialização dos créditos de carbono.

A área do antigo aterro apresenta-se recoberta por vegetação de espécies herbáceas e arbustivas e por uma grande extensão de eucaliptos pouco desenvolvidos, onde desponta os drenos de gás (Figura 8.16). O chorume

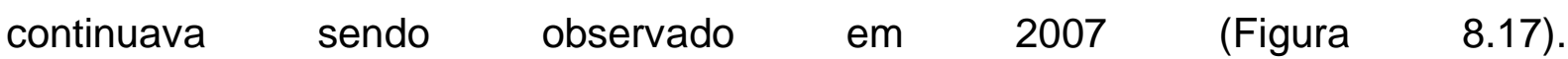
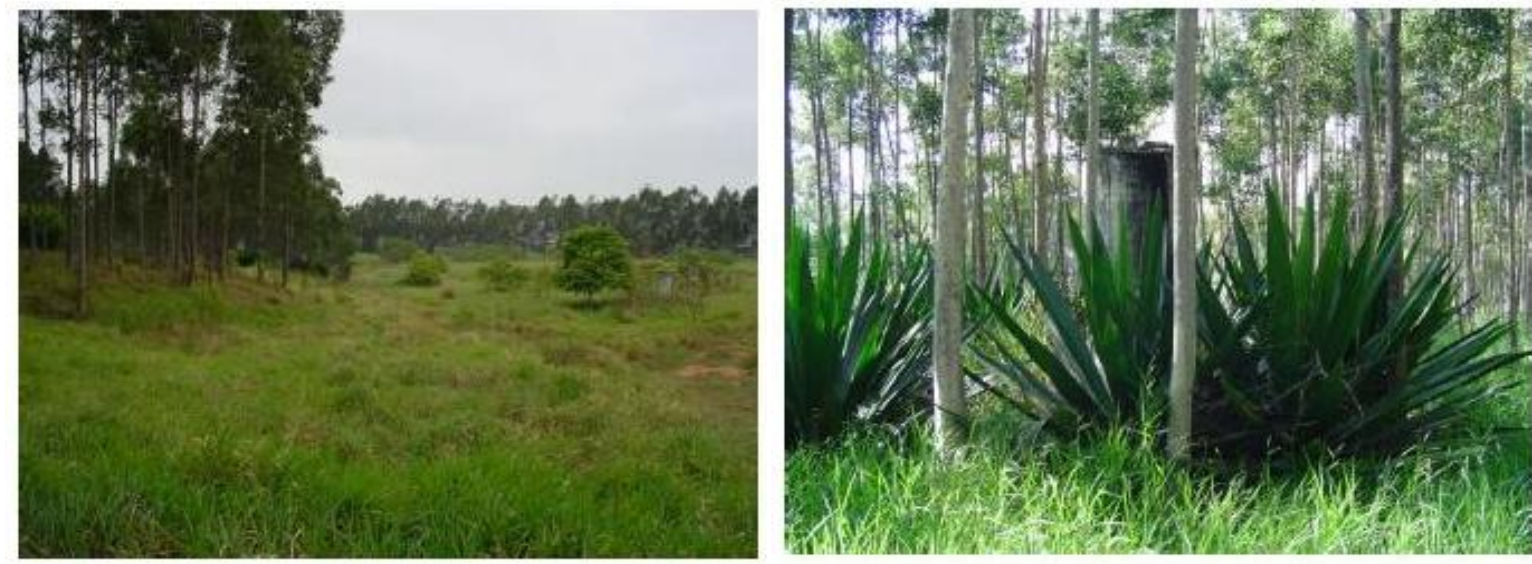

Figura 8.16 - Platô do antigo aterro mostrando a vegetação e detalhe de dreno de gás. Fonte: Morinaga (2007, p.131)

\footnotetext{
${ }^{13}$ Coordenação dos Programas de Pós-graduação em Engenharia - COPPE Universidade Federal do Rio de Janeiro - UFRJ (Contrato SVMA no 014//svma/2004 de 18 de maio de 2004.
} 


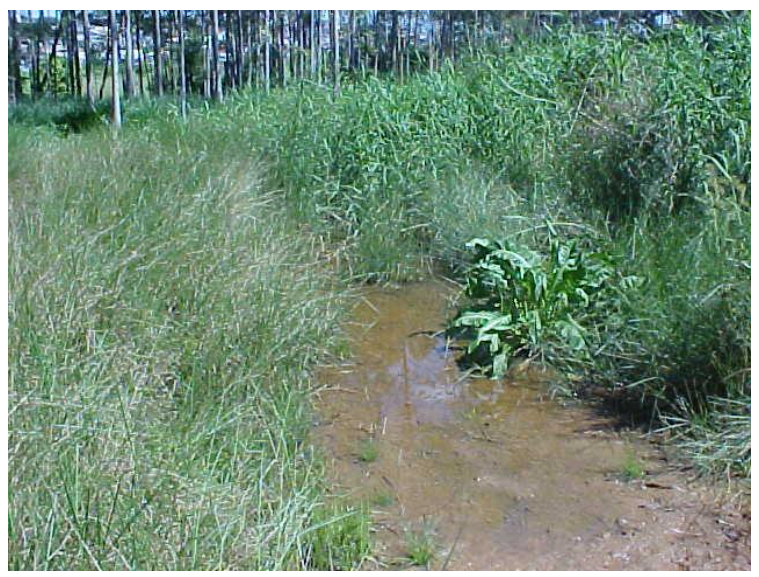

Figura 8.17 - Detalhe de ocorrência de chorume no aterro Jacuí, em 30/03/2007 . Fonte: SVMA/Decont/GTAC

O aterro está localizado na porção norte da Operação Urbana Rio Verde-Jacu (Figura 8.18). A Operação objetiva criar pólos voltados à atração de atividades econômicas para a geração de empregos e de renda para a região. Inclui a implantação de novos parques urbanos e lineares (PMSP, 2011). ${ }^{14}$
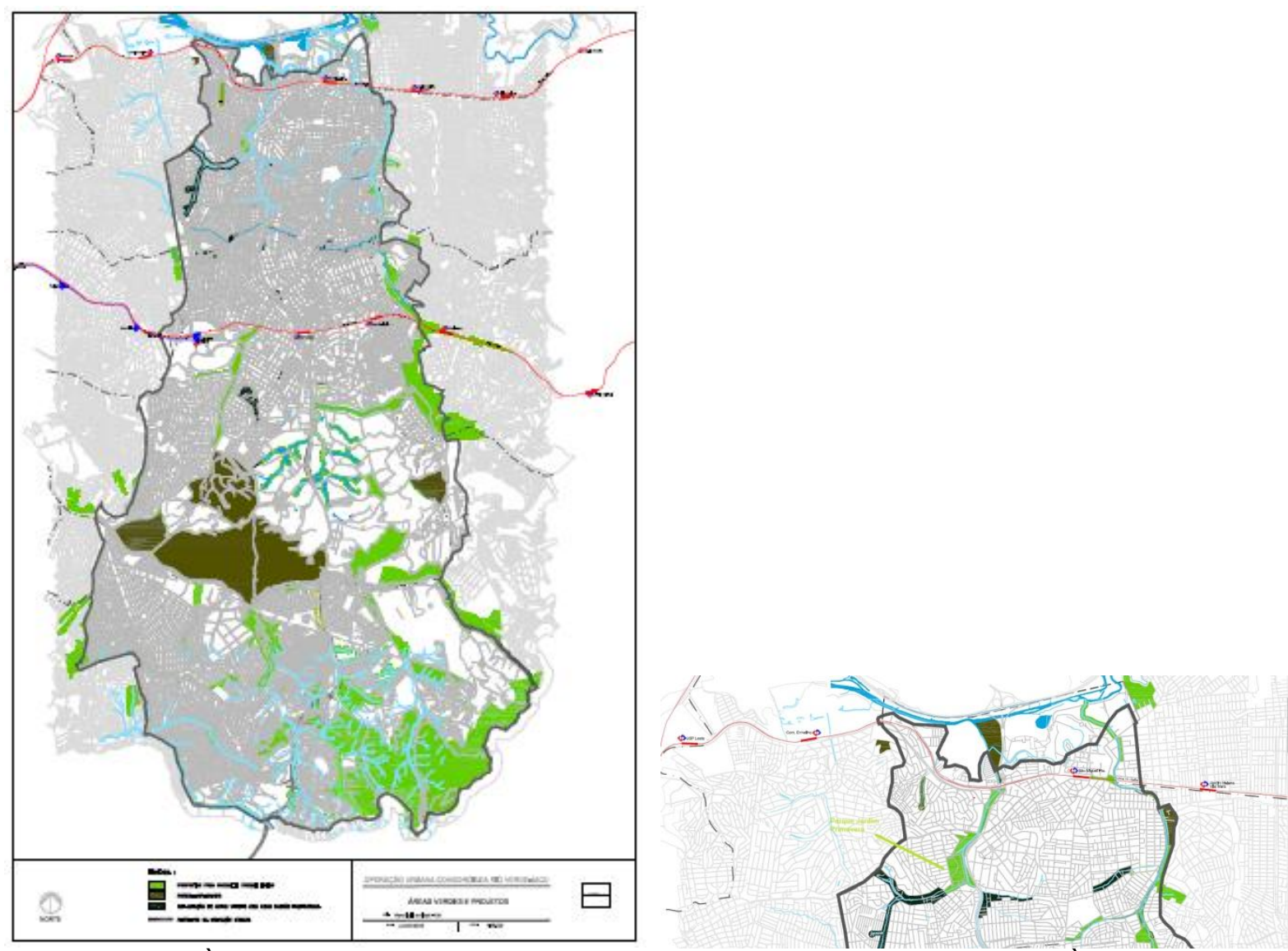

Figura 8.18 - À esquerda, delimitação da Operação Urbana Rio Verde-Jacu. À direita, detalhe mostrando o Parque Jardim Primavera como proposta de implantação. 


\subsubsection{AVALIAÇÃo dA CONTAMINAÇÃo do ATERRo JACUÍ}

A gestão das áreas contaminadas iniciada pelo município, em 2002 (Ver Capítulo 3), incluiu dentre os temas abordados, o estudo dos aterros municipais desativados, classificados a priori como áreas suspeitas de contaminação. Neste sentido, foram realizadas vistorias, pelo Decont/GTAC, em 12 aterros para priorizar, as ações para a remediação ou revitalização dessas áreas, como parques, levandose em conta o risco à saúde pública e ao ambiente. No aterro Jacuí constatou-se que o local apresentava boas condições de estabilidade, sem evidências de processos erosivos significativos, as instalações para drenagem e tratamento do chorume estavam desativadas e os drenos de gás conservados, ainda com odor característico. Não se observou surgência de resíduos ou percolado e, o córrego Limoeiro, que margeia o local aparentava estar poluído. A área possuía cerca muito precária, mas havia vigilância. As características do aterro e os critérios socioambientais adotados pelo estudo (Anexos $\mathrm{Hel}$ ) indicaram-no como prioridade 3 , dentre os seis aterros municipais vistoriados, atrás do Vila S. Francisco (ocupado por moradias) e do Raposo Tavares (parque) (SVMA, 2005; Ramires et al., 2005).

Dando continuidade aos estudos ambientais, no período de 2007 a 2008, a SVMA, mediante a contratação da empresa Weber Ambiental Ltda, executou as investigações quanto à provável contaminação da área, visando à implantação do Parque Jardim Primavera. A avaliação, realizada em duas etapas, tratou de verificar a estabilidade geotécnica do maciço de resíduos, identificar e quantificar os possíveis gases presentes; além das etapas de investigação confirmatória, detalhada e avaliação de risco à saúde humana.

As inspeções realizadas não constataram indícios de instabilidade, erosão ou vazamento de percolados superficiais provenientes do aterro. Apenas algumas fissuras ocorrem que deverão ser seladas durante a cobertura do aterro. As análises efetuadas no solo encontraram concentrações superiores aos valores de intervenção, recomendado pela Lista Americana EPA, para vanádio, ferro e alumínio. Na água subterrânea foram obtidas concentrações superiores aos valores de intervenção para alumínio, bário total, boro total, cádmio, chumbo, cobalto, cromo total, ferro total, manganês total, níquel, coliformes fecais e coliformes totais. O gás metano foi detectado em apenas dois poços com concentração na ordem de 2000 ppm; à exceção do poço cacimba aterrado, situado à Rua Grinalda de Noiva, ㄲo 253, 
com concentração superior a 10.000 ppm de VOC, onde foi registrado um índice de 100\% de explosividade (Figura 8.19). Possivelmente, os vapores são resquício de gases resultantes da decomposição e volatilização de compostos provenientes do aterro, que encontraram um caminho preferencial (fraturas no solo), já que não foi observada a presença de voláteis no poço de investigação próximo à cacimba aterrada (SVMA , 2008c; Ramires e Vitor, 2010).

Atendendo às etapas da metodologia para avaliação das áreas contaminadas, seguiu-se com a elaboração da avaliação de risco à saúde humana. Como modelo conceitual foi considerado de forma conservadora, a existência de um único aqüífero e que as águas subterrâneas estão impactadas, especialmente à jusante do aterro no sentido do Rio Jacu, pelo chorume, migrando verticalmente no solo e horizontal e verticalmente na água subterrânea. A avaliação de risco efetuada levou em consideração três diferentes cenários (atual, futuro e hipotético), as suas vias de exposição e os seus receptores (Tabela 8.5)

Os resultados da análise de risco indicaram que existem riscos diferenciados para todos os cenários previstos (Tabela 8.6). Quanto aos gases orgânicos, os estudos concluíram que há risco iminente de explosão, causado pela presença de gases no aterro, destacando-se a pluma mapeada no sentido da Rua Grinalda de Noiva (Figura 8.19). Para tanto, deverão ser executadas ações mitigadoras para evitar incidentes de explosão no local.

Os estudos empreendidos no antigo aterro relacionaram uma série de medidas para a gestão do futuro parque-aterro Jardim Primavera, conforme colocam SVMA (2008c) e Ramires e Vitor (2010): cobertura do solo exposto por uma camada de $0,5 \mathrm{~m}$ de solo predominantemente argiloso e plantio de gramíneas (ou opcionalmente asfaltamento/concretagem) nas áreas onde foram observados valores de concentrações de COVs acima de 250 ppm, sobre o depósito de resíduos sólidos e onde se pretende remover árvores para acesso de futuros usuários do parque; utilização de equipamento de proteção individual (uniformes, luvas, botas, máscaras) pelos trabalhadores de obras; restrição do uso da água subterrânea e instalação de um sistema de extração e tratamento dos gases provenientes do antigo aterro. 
Requalificação dos Aterros Desativados (BrownfIELDS) No MunicíPIO de SÃo PAULO: PARQUES (GREENFIELDS) RAPOSO TAVARES E JARDIM PRIMAVERA

LUZIA HELENA DOS SANTOS BARROS

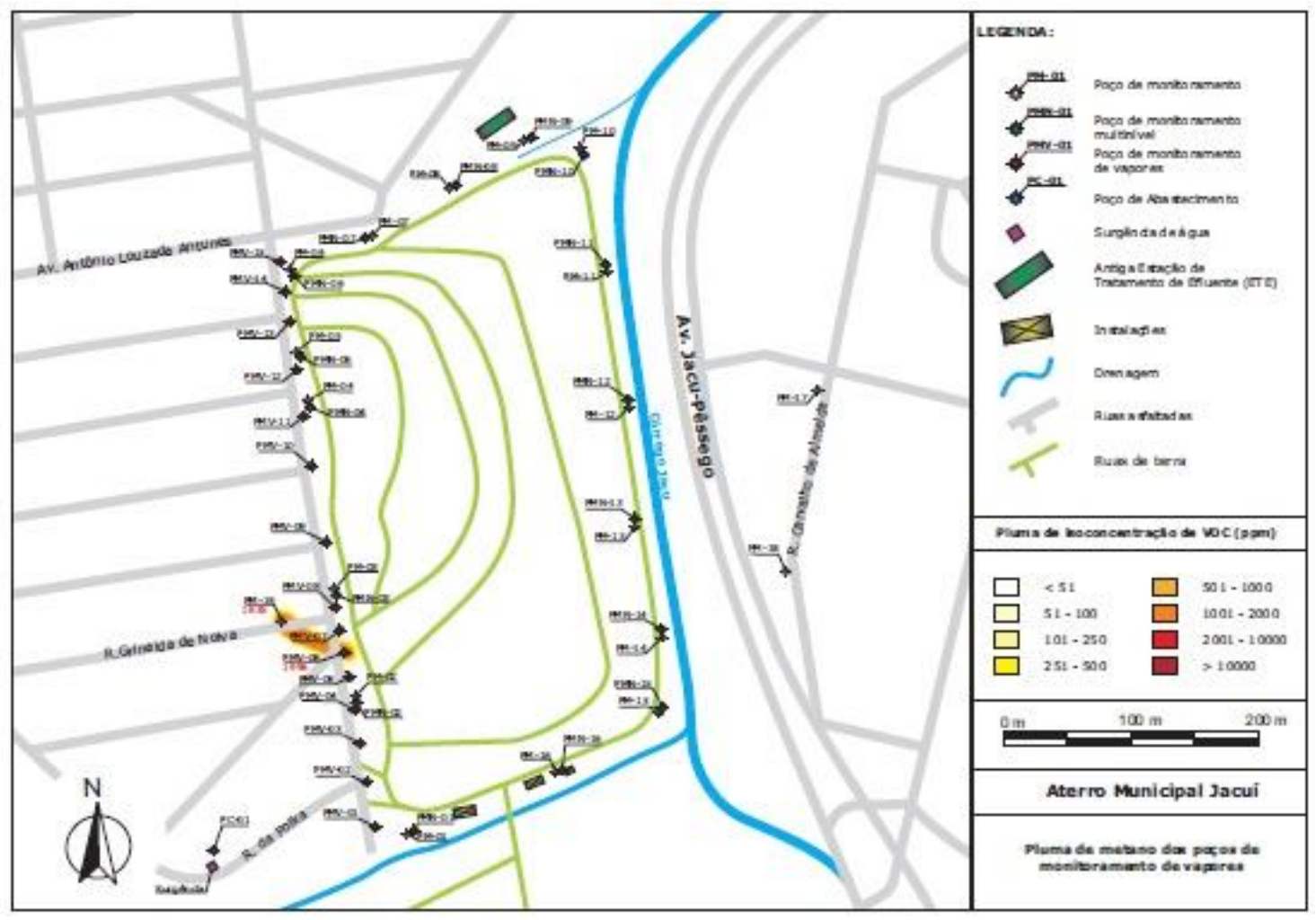

Figura 8.19 - Pluma de concentração do metano no parque-aterro Jardim Primavera. Fonte: SVMA (2008c, p. 75).

Tabela 8. 5 - Vias de exposição e receptores definidos para os diferentes cenários avaliados quanto ao risco à saúde humana no aterro desativado Jacuí.

\begin{tabular}{|c|c|l|}
\hline Cenários & \multicolumn{1}{|c|}{ Receptores } & \multicolumn{1}{c|}{ Vias de Exposição } \\
\hline $\begin{array}{c}\text { Atual } \\
\text { (Aterro) }\end{array}$ & $\begin{array}{c}\text { Trabalhadores comerciais, } \\
\text { seguranças e eventuais } \\
\text { trabalhadores de obras }\end{array}$ & $\begin{array}{l}\text { Ingestão acidental e contato dérmico com o solo, } \\
\text { contato dérmico com a água subterrânea e, } \\
\text { inalação de vapores oriundos do solo e da água } \\
\text { subterrânea em ambientes aberto e fechado }\end{array}$ \\
\hline $\begin{array}{c}\text { Futuro } \\
\text { (Parque) }\end{array}$ & $\begin{array}{l}\text { Crianças (0-6 anos), jovens } \\
\text { (6-16 anos), adultos e idosos }\end{array}$ & $\begin{array}{l}\text { Ingestão acidental e contato dérmico com o solo, } \\
\text { inalação de vapores provenientes do solo e água } \\
\text { subterrânea em ambientes aberto e fechado }\end{array}$ \\
\hline $\begin{array}{c}\text { Hipotético } \\
\text { (Parque) }\end{array}$ & $\begin{array}{l}\text { Crianças (0-6 anos), jovens } \\
(6-16 \text { anos), adultos e idosos }\end{array}$ & $\begin{array}{l}\text { Ingestão e contato dérmico com a água } \\
\text { subterrânea }\end{array}$ \\
\hline
\end{tabular}

Organização: Ramires e Vitor (2010).

Fonte: SVMA (2008c), Ramires e Vitor (2010).

Tabela 8.6 - Resultado da avaliação de risco à saúde humana no aterro desativado Jacuí

\begin{tabular}{|c|c|c|c|}
\hline Cenários & Receptores & Vias de Exposição & Risco Toxicológico \\
\hline $\begin{array}{c}\text { Atual } \\
\text { (Aterro) }\end{array}$ & $\begin{array}{c}\text { Trabalhadores de } \\
\text { obras }\end{array}$ & Ingestão acidental do solo & $\begin{array}{c}\text { Alta concentração de } \\
\text { alumínio }\end{array}$ \\
\hline $\begin{array}{c}\text { Futuro } \\
\text { (Parque) }\end{array}$ & Crianças (0-6 anos) & Ingestão acidental do solo & $1,3 \mathrm{E}+00^{15}$ (cumulativo) \\
\hline $\begin{array}{c}\text { Hipotético } \\
\text { (Parque) }\end{array}$ & $\begin{array}{c}\text { Crianças (0-6 anos), } \\
\text { jovens (6-16 anos), } \\
\text { adultos e idosos }\end{array}$ & $\begin{array}{c}\text { Ingestão e contato dérmico } \\
\text { com a água subterrânea }\end{array}$ & $\begin{array}{c}\text { Concentrações de alumínio, } \\
\text { ferro e manganês } \\
\text { (cumulativo) }\end{array}$ \\
\hline
\end{tabular}

Organização: a autora

Fonte: SVMA (2008c), Ramires e Vitor (2010).

${ }^{15} \mathrm{O}$ limite de toxicidade adotado é de $1,00 \mathrm{E}+00$. 
Além disso, recomendou-se o monitoramento semestral da qualidade da água subterrânea, a execução de investigação complementar com o objetivo de avaliar e quantificar a influência do aterro na qualidade da água do entorno; bem como a execução de amostragens e análises da água superficial dos córregos Jacú e Limoeiro para avaliar uma possível influência do aterro.

A fim de apontar a ordem de grandeza das alternativas propostas para a remediação do aterro, serão apresentados os custos estimados (abril/2008c), pela empresa contratada, Weber Ambiental Ltda. (Tabela 8.7).

Tabela 8.7 - Custo estimado para a remediação do aterro (Abril/2008).

\begin{tabular}{|c|c|c|c|}
\hline & & Ações & Custo $(\mathbf{R} \$)$ \\
\hline \multirow{2}{*}{ 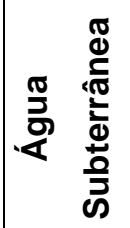 } & \multicolumn{2}{|c|}{ Monitoramento de poços e água superficial do córrego } & $25.000,00$ \\
\hline & \multicolumn{2}{|c|}{ Instalação de poços multiníveis } & $50.000,00$ \\
\hline \multirow{4}{*}{$\begin{array}{l}\frac{0}{0} \\
\text { क } \\
\circ \\
\frac{0}{2} \\
\frac{0}{\pi} \\
\frac{0}{3}\end{array}$} & \multirow{3}{*}{$\begin{array}{c}\text { Sistema }\left(\mathrm{SVE}^{16}\right) \\
\text { emergencial } \\
\text { (6 meses de operação) }\end{array}$} & Instalação dos equipamentos & $136.000,00$ \\
\hline & & $\begin{array}{c}\text { Tratamento com oxidador catalítico } \\
\text { elétrico }\end{array}$ & $178.102,00$ \\
\hline & & Tratamento com carvão ativado & $12.000,00$ \\
\hline & \multicolumn{2}{|c|}{ Sistema (SVE) para o aterro - Projeto piloto } & $50.000,00$ \\
\hline
\end{tabular}

Organização: Luzia Helena dos S. Barros (2011).

Fonte: SVMA (2008c).

\subsection{Potencial de Conectividade dos Parques-aterros Raposo tavares e JARDIM PRIMAVERA}

O capítulo 7, ítem 7.2.3, tratou da relação entre os princípios da ecologia de paisagem e os parques urbanos, apontando que os parques podem funcionar como "trampolins ecológicos", favorecendo a conectividade da paisagem urbana numa rede ecológica. Essa relação, também, é corroborada por Forsyth e Musacchio (2005) que adicionam a função de conexão entre pessoas e delas com a natureza. Os autores colocam que a combinação entre conexões ecológicas e sociais não é sempre fácil. Citam como exemplo as bordas de uma unidade de paisagem que, por

\footnotetext{
${ }^{16}$ Sistema de Extração de Vapores - SVE
} 
um lado, podem indicar um problema para os processos ecológicos, enquanto que por outro, podem prover importantes benefícios para as pessoas como lugares de conexões sociais. A forma de fragmentação da paisagem urbana resulta em porções com potencial mais ou menos favorável à conexão entre manchas de habitat. $A$ análise espacial desse potencial de conectividade é importante para identificar ações de manejo específicas a cada local.

A análise espacial, mediante a geoinformação, destacando-se, especialmente, o Sistema de Informações Geográficas (SIG) permite a manipulação e a integração de dados pré-existentes com o objetivo de gerar novas informações. No ambiente SIG alguns modelos estão disponíveis, dentre eles os que utilizam vários critérios, com diferentes pesos, para a tomada de decisão. Esses procedimentos de avaliação por multicritérios (Multi Criteria Evaluation - MCE) favorecem a tomada de decisões conjuntas de forma transparente e coletiva (Lang e Blaschke, 2009, p. 63). Os modelos, de acordo com esses mesmos autores (2009, p. 327), "( ) ressaltam e visualizam relações que, em parte, são tão complexas que só raramente são registradas em sua totalidade pelos tomadores de decisão e pelas pessoas envolvidas. ( )".

Neste item apresenta-se uma proposta metodológica que analise espacialmente o potencial de conexão entre os parques-aterros urbanos e as suas possíveis zonas de amortecimento ${ }^{17}$, em dois diferentes cenários.

O método foi aplicado aos estudos de casos discutidos na Tese, Raposo Tavares e Jardim Primavera, com 0 intuito de avaliar a potencialidade desses parques-aterros funcionarem como trampolins ecológicos, mediante a presença de outras manchas de vegetação significativa no seu entorno, que possam se interligar a manchas de vegetação remanescente, formando os corredores ecológicos; para promover a evolução, conservação e manutenção da vegetação dos diversos fragmentos vegetais.

A análise geográfica computadorizada, base da proposta, permitiu construir Mapas do Potencial de Conectividade dos Parques-aterros, considerando uma situação mais otimista e outra mais conservadora, para a apresentação de duas alternativas de cenários ao manejo específico de cada um deles. Para tanto, foram

\footnotetext{
${ }^{17}$ A zona de amortecimento foi definida pelo SNUC (Lei 9.895/2000, Art. 2으 - Inciso XVIII) como o entorno das Unidades de Conservação onde as atividades humanas estão sujeitas a normas e restrições de uso, com o propósito de minimizar os impactos negativos sobre a unidade.
} 
selecionados critérios bióticos e abióticos influentes no grau de conectividade; elaborando-se novos mapas temáticos a partir de alguns desses critérios; padronizando-os e atribuindo-se pesos aos mesmos e, por último, agregando-os para obter o mapa temático final. O mapa final mostra os diferentes graus do potencial de conectividade nos parques urbanos e seus arredores.

\subsubsection{MATERIAIS E MÉtOdOS}

A análise espacial desenvolvida utilizou o programa de processamento de imagens Idrisi TM Andes (Clark Labs, 1987 - 2006). Os critérios selecionados foram obtidos do Mapa de Uso e Ocupação do Solo, apresentado no Capítulo 5, item 5.2.1.1 e do Mapa de Verticalização, desenvolvido por Campos et al. (2009), com cessão das áreas de estudo pelo Prof. Dr. Silvio Macedo (FAU/USP). Para cada um dos critérios foi feito um mapa de distância em relação ao fator impactante (estrada/vegetação/rodovia/verticalização), em uma etapa posterior a de identificação desses fatores na imagem. O mapa de distância de rua foi feito a partir do mapa de vias, que também foi identificado no mapa de classificação junto com os maciços herbáceos e arbóreos. O mapa de distância de rodovias foi gerado a partir da vetorização e, consecutivamente, rasterização do seu vetor, a partir da rodovia em questão, visto que o trecho é pequeno e bastante visível.

A presente análise fez uso de dois critérios bióticos e cinco abióticos, conforme mostra o fluxograma (Figura 8.21). Os critérios bióticos, extraídos do Mapa de Uso e Ocupação do Solo foram os maciços vegetais, representados pelas classes, maciço arbóreo e herbáceo. O maciço arbóreo foi definido pelo agrupamento dos seus diferentes níveis de densidade (muito denso, denso e pouco denso). O Mapa de Verticalização ${ }^{18}$ forneceu os três critérios abióticos: verticalização de até $10 \%$, de 10 a $50 \%$ e de 50 a $100 \%$, na quadra. Os outros critérios abióticos escolhidos são as distâncias de rodovias e de vias asfaltadas.

\footnotetext{
${ }^{18}$ Foi considerado como edificação verticalizada aquela com mais de quatro pavimentos.
} 
* Ver Capitulo 5, item 5.2.1.1

** Maciço arbóreo muito denso + denso + pouco denso

${ }^{* *}$ Os pesos foram atribuídos pela autora

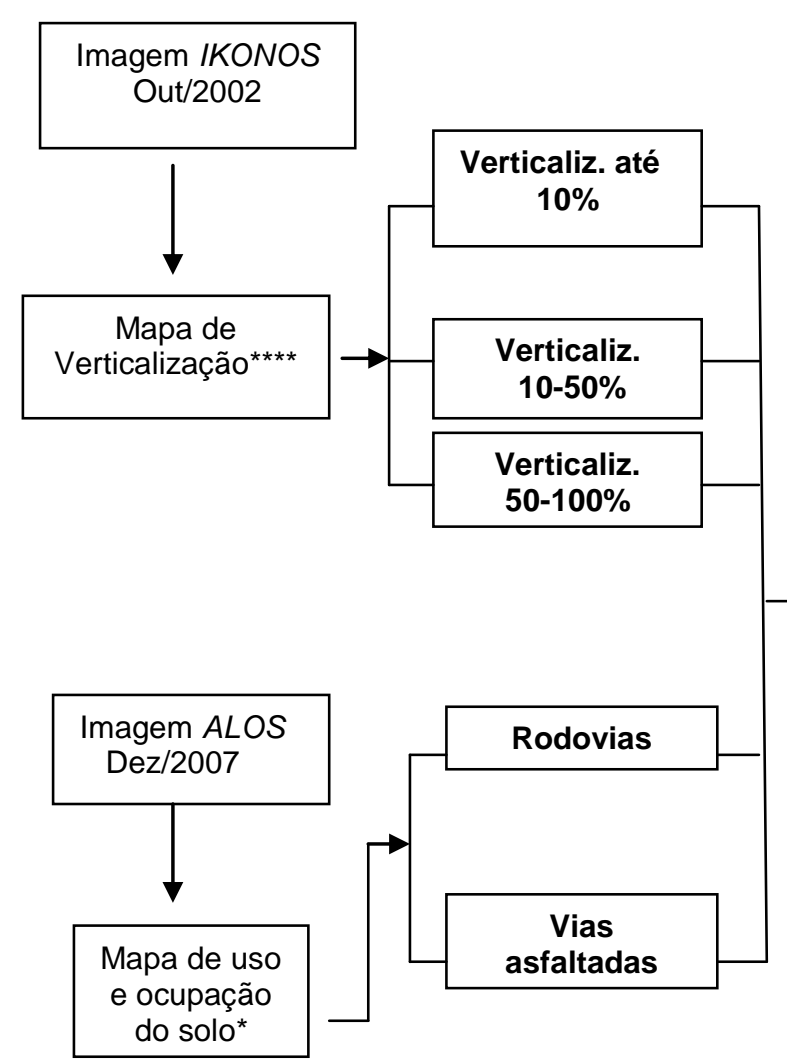

**** O mapa foi obtido conforme método desenvolvido por Campos et al. (2009), sendo o recorte das áreas de estudo cedido pelo Prof. Dr. Silvio Macedo (FAU/USP).

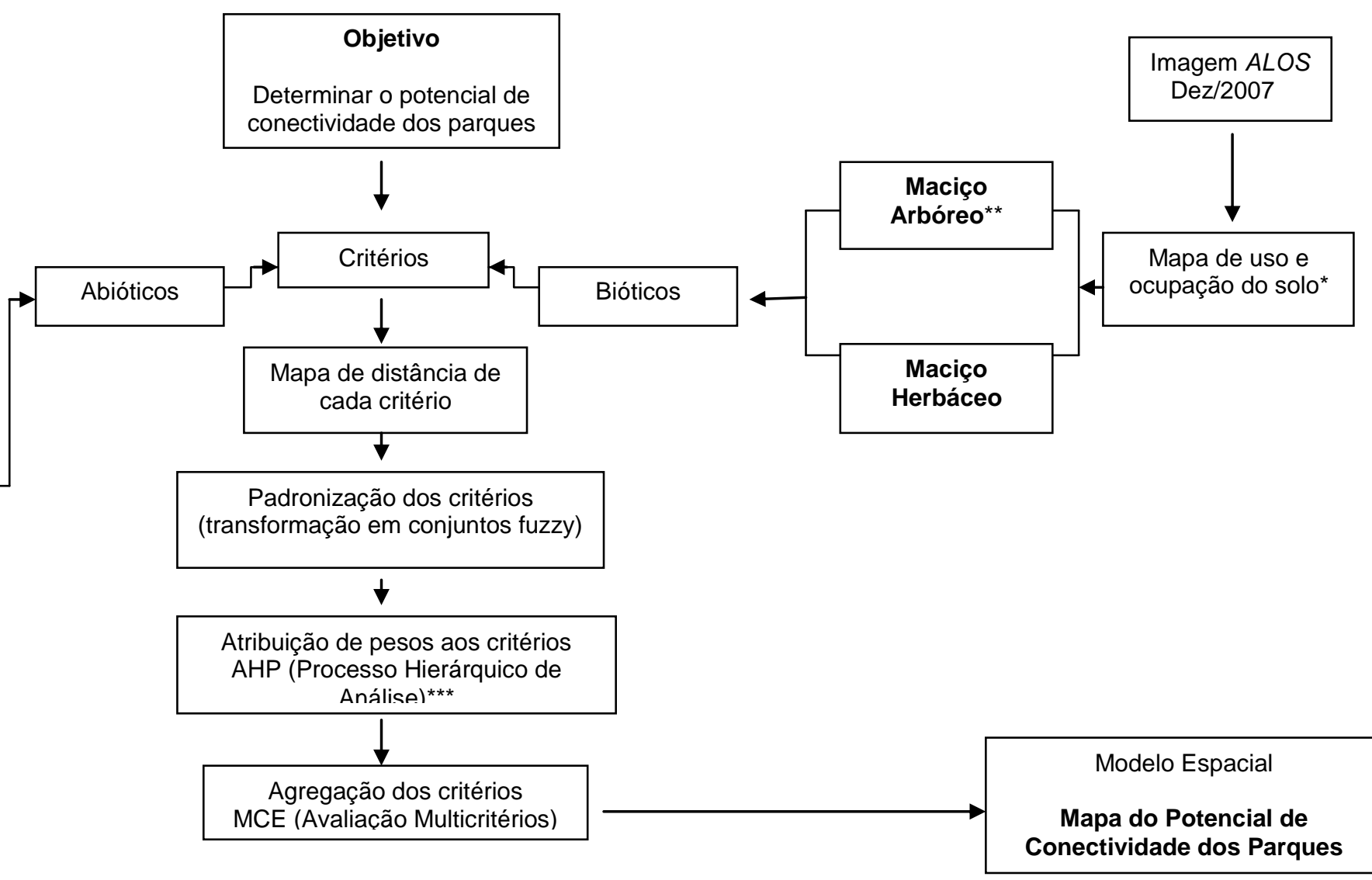

Figura 8.- Fluxograma apresentando as etapas da análise em ambiente SIG (Sistema de Informação Geográfica) para a obtenção do Mapa de do Potencial de Conectividade dos Parques

Fonte: Martins et al. (2009, p.4047); adaptado. 
As distâncias de influência dos critérios selecionados foram estabelecidas arbitrariamente. Para os diferentes graus de verticalização estabeleceu-se a distância de $20 \mathrm{~m}$, para as vias asfaltadas $150 \mathrm{~m}$ e para as rodovias $300 \mathrm{~m}$ (Tabela 8.8). As distâncias estipuladas para os maciços vegetais, de $500 \mathrm{~m}$ e $100 \mathrm{~m}$, relacionam-se a dois diferentes cenários, respectivamente: mais otimista (Modelo $A$ ) e mais conservador (Modelo B). Foi estabelecido também que o potencial de conectividade no entorno dos parques-aterros aumenta, quanto mais afastados do sistema viário e das edificações verticalizadas. Ao contrário, quanto mais próximos de manchas de vegetação melhor a conexão (Figura 8.22). Os critérios utilizados na análise possuem classes de intervalos quantitativos (distância do fator impactante), que foram padronizados, pois estavam em escalas diferentes, mediante a transformação em conjuntos fuzzy (escala de intervalos de 1 a 255, representada em variações de cores).

Tabela 8.8 - Dados de entrada utilizados nos modelos de MCE.

\begin{tabular}{|c|c|c|c|c|c|}
\hline Fator: & $\begin{array}{c}\text { Distância de } \\
\text { influência }\end{array}$ & $\begin{array}{c}\text { Tipo de } \\
\text { Curva }\end{array}$ & Ponto $\mathrm{A}$ & Ponto $\mathrm{B}$ & $\begin{array}{c}\text { Efeito do } \\
\text { fator }\end{array}$ \\
\hline Vias asfaltadas & 150 & linear & $\mathrm{A}=0$ & $\mathrm{~B}=150$ & Negativo \\
\hline Maciço Arbóreo & $500^{*} / 100^{* *}$ & linear & $\mathrm{A}=0$ & $\mathrm{~B}=100 / 500$ & Positivo \\
\hline Maciço Herbáceo & $500^{*} / 100^{* *}$ & linear & $\mathrm{A}=0$ & $\mathrm{~B}=100 / 500$ & Positivo \\
\hline Rodovias & 300 & linear & $\mathrm{A}=0$ & $\mathrm{~B}=300$ & Negativo \\
\hline Verticalização até $10 \%$ & 20 & linear & $\mathrm{A}=0$ & $\mathrm{~B}=20$ & Negativo \\
\hline Verticalização $10-50 \%$ & 20 & linear & $\mathrm{A}=0$ & $\mathrm{~B}=20$ & Negativo \\
\hline Verticalização $50-100 \%$ & 20 & linear & $\mathrm{A}=0$ & $\mathrm{~B}=20$ & Negativo \\
\hline
\end{tabular}

${ }^{\star}$ Modelo $\mathrm{A} ;{ }^{* \star}$ Modelo $\mathrm{B}$

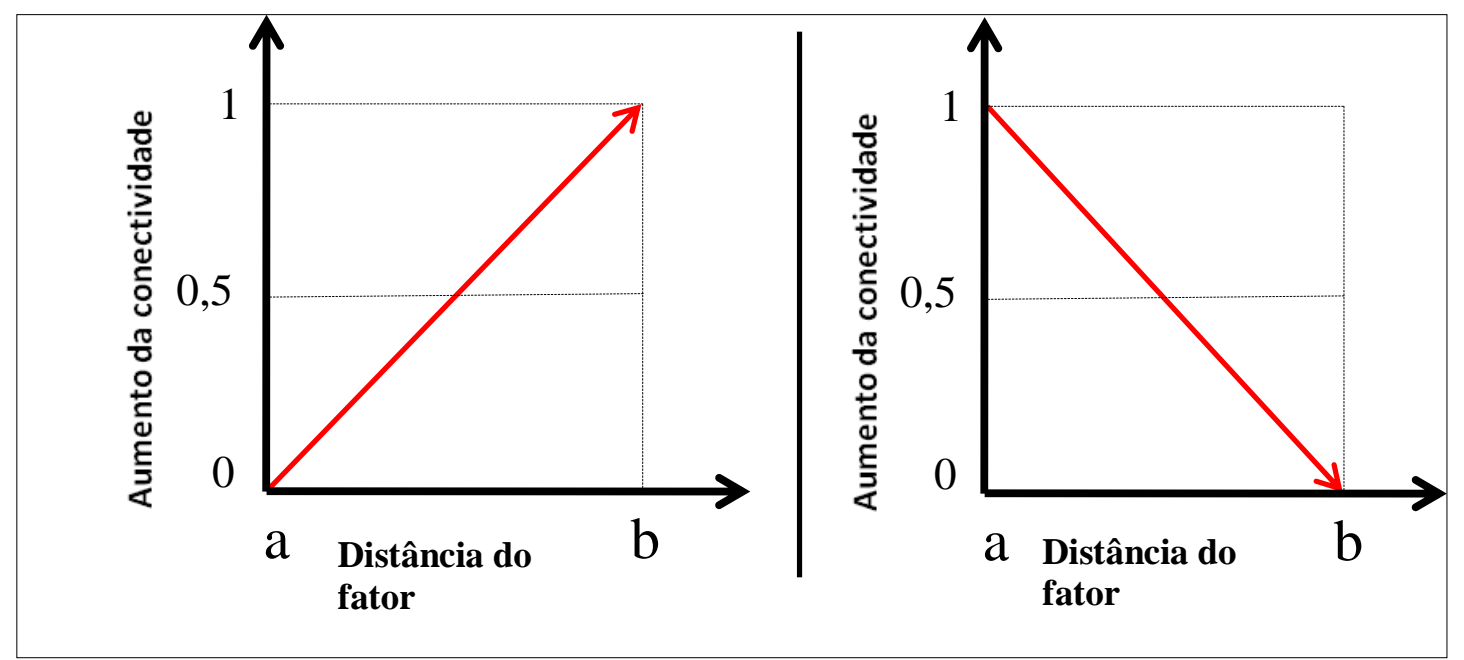

Figura 8.22 - Gráfico da relação do potencial de conexão com os fatores de entrada utilizados nos modelos A e B. 
$\mathrm{Na}$ etapa seguinte utilizou-se o Processo Hierárquico Analítico (AHP), desenvolvido por Saaty (1997) e corroborado por Eastman et al. (1995) e Eastman (1997), que compara os critérios dois a dois através de uma matriz quadrada. processo determina a hierarquização dos critérios numa escala de 1/9 (menos importância) até 9 (mais importante).

A etapa final constou da geração do Mapa de Potencial de Conectividade dos Parques-aterros, por meio da inserção dos critérios selecionados (mapas temáticos) e seus respectivos pesos, no programa IDRISI Andes, e a realização da avaliação multicritérios (MCE). Para a análise do potencial de conectividade foram propostas três diferentes alternativas para as possíveis zonas de amortecimento urbanas ${ }^{19}$ a serem criadas: de 500, 1.000 e 2.000 m. De acordo com Costa et al. (2009, p. 3):

[...] A zona de amortecimento é a possibilitadora de proteção a uma unidade de conservação. Não existem normas prévias que estabeleçam quais os tipos de avaliações devam ser feitas e que critérios (e/ou parâmetros) devem ser levados em conta. Entretanto, parte-se do princípio de que a investigação, nas áreas urbanas, deve ser feita com maior acuidade, diante da multiplicidade de uso e da complexidade da gestão dessas áreas, principalmente por parte do poder público.

A qualidade de vida das cidades pode ser medida, dentre várias formas, pelo uso de indicadores ou índices, números que representam uma relação entre vários aspectos ou um aspecto específico da realidade, segundo Oliveira $\left(1996^{20}\right.$ apud Rosset, 2005). Destacam-se entre esses indicadores os Índices de Área Verde - IAV e o de Cobertura Vegetal - ICV, que representam a relação entre as áreas verdes (praças, parques, etc) ou cobertura vegetal (vegetação em geral) e a população de uma dada área $\left(\mathrm{m}^{2} / \mathrm{hab}\right.$.).

\subsubsection{RESULtAdOS}

Os critérios abióticos e bióticos selecionados foram comparados dois a dois através de uma escala contínua (Tabela 8.9) numa matriz quadrada. O peso de cada critério foi calculado através da matriz quadrada, preenchida conforme a experiência da autora (Tabela 8.10) e, posteriormente, ajustados pelo programa, obtendo-se os pesos relativos de cada critério (Tabela 8.11).

\footnotetext{
${ }^{19} \mathrm{O}$ termo está sendo sugerido, como correlato à zona de amortecimento das Unidades de Conservação, definida pelo SNUC, sendo utilizado de agora em diante apenas o termo zona de amortecimento.

${ }_{20}$ OLIVEIRA, C.H. Planejamento ambiental na cidade de São Carlos com ênfase nas áreas públicas e áreas verdes: diagnóstico e propostas. Dissertação (Mestrado em ecologia e Recusrsos Naturais). Centro de Ciências Biológicas e Saúde. Universidade Federal de São Carlos - UFSCAR. São Carlos, SP. 1996. 181 p.
} 
Tabela 8.9 - Escala contínua de comparação entre duas variáveis. Os valores são inseridos na matriz de comparação par a par no Processo Hierárquico Analítico (AHP)

\begin{tabular}{|c|c|c|c|c|c|c|}
\hline \multicolumn{7}{|c|}{ Escala de comparação entre variáveis } \\
\hline $1 / 9$ & $1 / 6$ & $1 / 3$ & 1 & 3 & 6 & 9 \\
\hline Muito & Consideravelmente & Pouco & \multirow{2}{*}{ Equivalentes } & Pouco & Consideravelmente & Muito \\
\cline { 5 - 7 } & Menos importante & & Mais importante \\
\hline
\end{tabular}

Tabela 8.10 - Matriz quadrada obtida por meio dos pesos atribuídos aos critérios abióticos e bióticos

\begin{tabular}{|c|c|c|c|c|c|c|c|c|}
\hline \multicolumn{2}{|c|}{ Critérios } & \multicolumn{3}{|c|}{ Verticalização (\%) } & \multicolumn{2}{|c|}{ Vegetação } & \multicolumn{2}{|c|}{ Sistema viário } \\
\hline & & $\begin{array}{c}\text { Até } \\
10\end{array}$ & $\begin{array}{c}10 a \\
50\end{array}$ & $\begin{array}{l}50 a \\
100\end{array}$ & $\begin{array}{l}\text { Maciço } \\
\text { arbóreo }\end{array}$ & $\begin{array}{c}\text { Maciço } \\
\text { herbáceo }\end{array}$ & $\begin{array}{c}\text { Vias } \\
\text { asfaltadas }\end{array}$ & Rodovias \\
\hline జ్ల & Até 10 & 1 & & & & & & \\
\hline ర్ & 10 a 50 & 3 & 1 & & & & & \\
\hline$\stackrel{1}{>}$ & 50 a 100 & 6 & 3 & 1 & & & & \\
\hline 욤 & $\begin{array}{l}\text { Maciço } \\
\text { arbóreo }\end{array}$ & 9 & 6 & 3 & 1 & & & \\
\hline 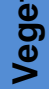 & $\begin{array}{c}\text { Maciço } \\
\text { herbáceo }\end{array}$ & 6 & 3 & 1 & $1 / 3$ & 1 & & \\
\hline 은 & $\begin{array}{c}\text { Vias } \\
\text { asfaltadas }\end{array}$ & 1 & $1 / 3$ & $1 / 6$ & $1 / 9$ & $1 / 6$ & 1 & \\
\hline மं & Rodovias & 6 & 3 & 1 & $1 / 6$ & $1 / 3$ & 6 & 1 \\
\hline
\end{tabular}

Tabela 8.11 - Pesos relativos atribuídos a cada um dos critérios

\begin{tabular}{|c|c|}
\hline Critérios & Peso relativo (\%) \\
\hline \hline Verticalização até $10 \%$ & 2.7 \\
\hline Verticalização $10-50 \%$ & 6.2 \\
\hline Verticalização $50-100 \%$ & 15.3 \\
\hline Maciço arbóreo & 41.8 \\
\hline Maciço herbáceo & 18.7 \\
\hline Vias asfaltadas & 2.7 \\
\hline Rodovias & 12.6 \\
\hline
\end{tabular}

Esses critérios e seus respectivos pesos foram transformados em imagens, inseridas no Modelo de Avaliação Multicritério (MCE) do IDRISI, produzindo os Mapas de Potencial de Conectividade dos Parques-aterros, considerando a relação das manchas de vegetação e a matriz nas suas zonas de amortecimento (Figura 8.21). Os mapas estão escalonados num gradiente de potencial de conectividade, separado em cinco classes (Tabela 8.12), representadas pela escala booleana, colorida, para facilitar a análise. De acordo com o método adotado foram desenvolvidos mapas de potencial de conectividade, em dois diferentes cenários, 
Requalificação dos Aterros Desativados (BrownfieldS) no MunicípIo de SÃo PaUlo: PARques (GreenfieldS) RAPOSO TAVARES E JARDIM PRIMAVERA

LUZIA HELENA dos SANTOS BARROS

mais otimista - Modelo A e mais conservador - Modelo B, para os casos de estudo:

Parque-aterro Raposo Tavares (Figuras 8.22) e Jardim Primavera (Figuras 8.23).

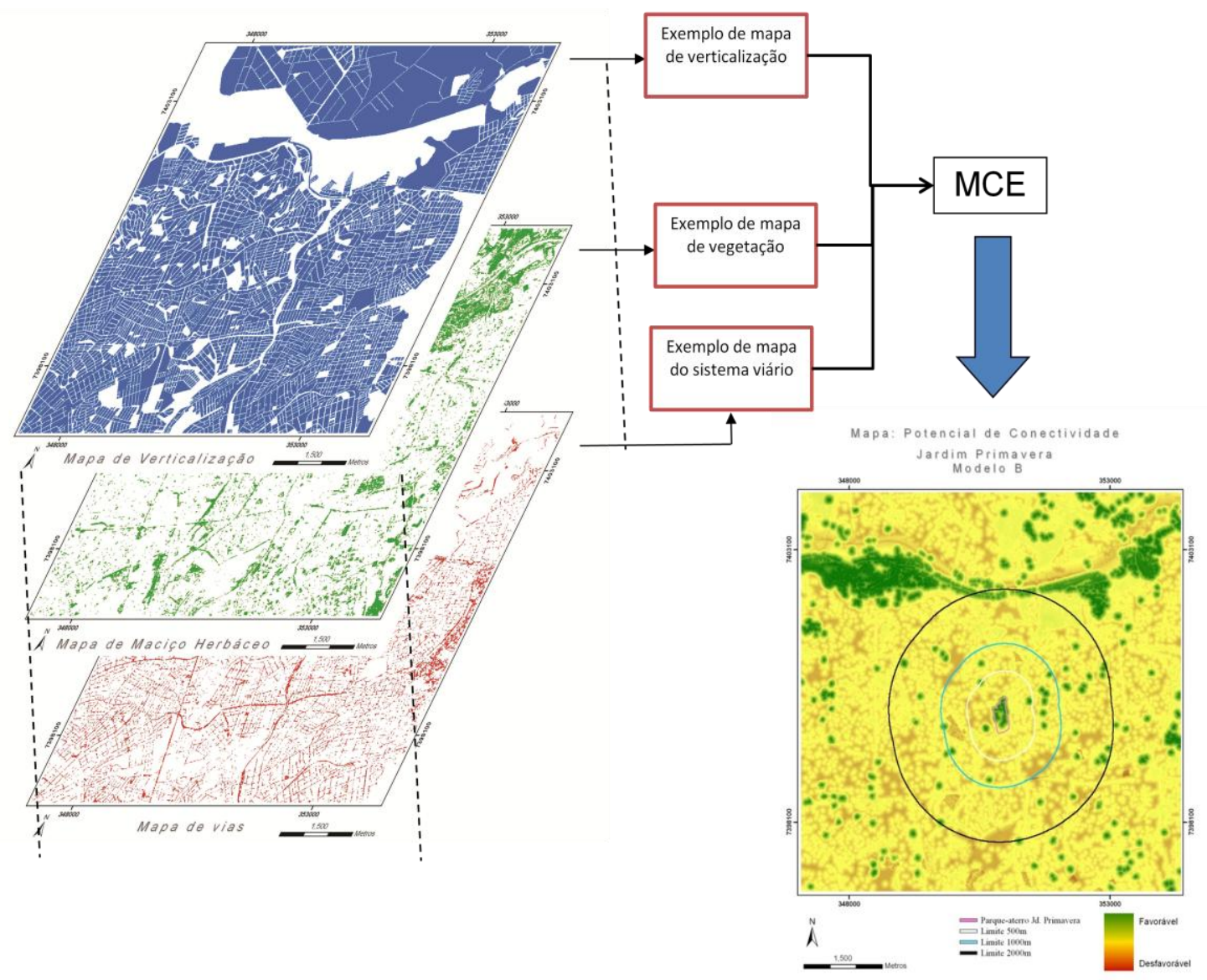

Figura 8.21 - Esquema de entrada dos dados no Modelo da Avaliação Multicritérios - MCE para a obtenção do Mapa de Potencial de Conectividade dos parques-aterros

Tabela 8.12 - Quantificação das classes de potencial de conectividade, para os dois cenários (Modelos A e B), segundo as possíveis zonas de amortecimento (500, 1.000 e 2.000m) nos Parquesaterros Raposo Tavares (RT) e Jardim Primavera (JP).

\begin{tabular}{|c|c|c|c|c|c|c|c|c|c|}
\hline RT Mod. A & Parque & $\begin{array}{l}500 \\
(\%)\end{array}$ & $\begin{array}{l}1000 \\
(\%)\end{array}$ & $\begin{array}{l}2000 \\
(\%)\end{array}$ & JP Mod. A & Parque & $\begin{array}{l}500 \\
(\%)\end{array}$ & $\begin{array}{l}1000 \\
(\%)\end{array}$ & $\begin{array}{l}2000 \\
(\%)\end{array}$ \\
\hline muito desfavorável & 0.0 & 0.0 & 0.0 & 0.1 & muito desfavorável & 0.0 & 0.0 & 0.0 & 0.0 \\
\hline desfavorável & 0.0 & 0.0 & 0.0 & 2.5 & desfavorável & 0.0 & 4.0 & 11.5 & 10.3 \\
\hline regular & 0.0 & 1.3 & 4.5 & 8.6 & regular & 0.0 & 28.7 & 33.6 & 37.9 \\
\hline favorável & 1.9 & 54.4 & 49.2 & 40.8 & favorável & 0.5 & 44.9 & 37.2 & 37.8 \\
\hline Muito favorável & 98.1 & 44.3 & 46.3 & 48.0 & Muito favorável & 99.5 & 22.5 & 17.7 & 14.0 \\
\hline RT Mod. B & Parque & $\begin{array}{l}500 \\
(\%) \\
\end{array}$ & $\begin{array}{c}1000 \\
(\%)\end{array}$ & $\begin{array}{c}2000 \\
(\%)\end{array}$ & JP Mod. B & Parque & $\begin{array}{l}500 \\
(\%) \\
\end{array}$ & $\begin{array}{c}1000 \\
(\%) \\
\end{array}$ & $\begin{array}{c}2000 \\
(\%)\end{array}$ \\
\hline muito desfavorável & 0.0 & 2.9 & 2.3 & 2.1 & muito desfavorável & 0.0 & 2.0 & 3.2 & 3.4 \\
\hline desfavorável & 1.0 & 54.5 & 50.5 & 50.2 & desfavorável & 3.3 & 71.1 & 75.5 & 76.2 \\
\hline regular & 20.5 & 19.9 & 21.2 & 20.8 & regular & 18.3 & 17.3 & 15.2 & 15.8 \\
\hline favorável & 31.2 & 13.1 & 14.4 & 14.5 & favorável & 34.6 & 5.4 & 3.8 & 3.2 \\
\hline Muito favorável & 47.3 & 9.6 & 11.6 & 12.3 & Muito favorável & 43.8 & 4.2 & 2.2 & 1.3 \\
\hline
\end{tabular}

Elaboração: Luzia Helena dos S. Barros (2011) 
Mapa: Potencial de Conectividade Raposo Tavares

318000 Modelo A 323000

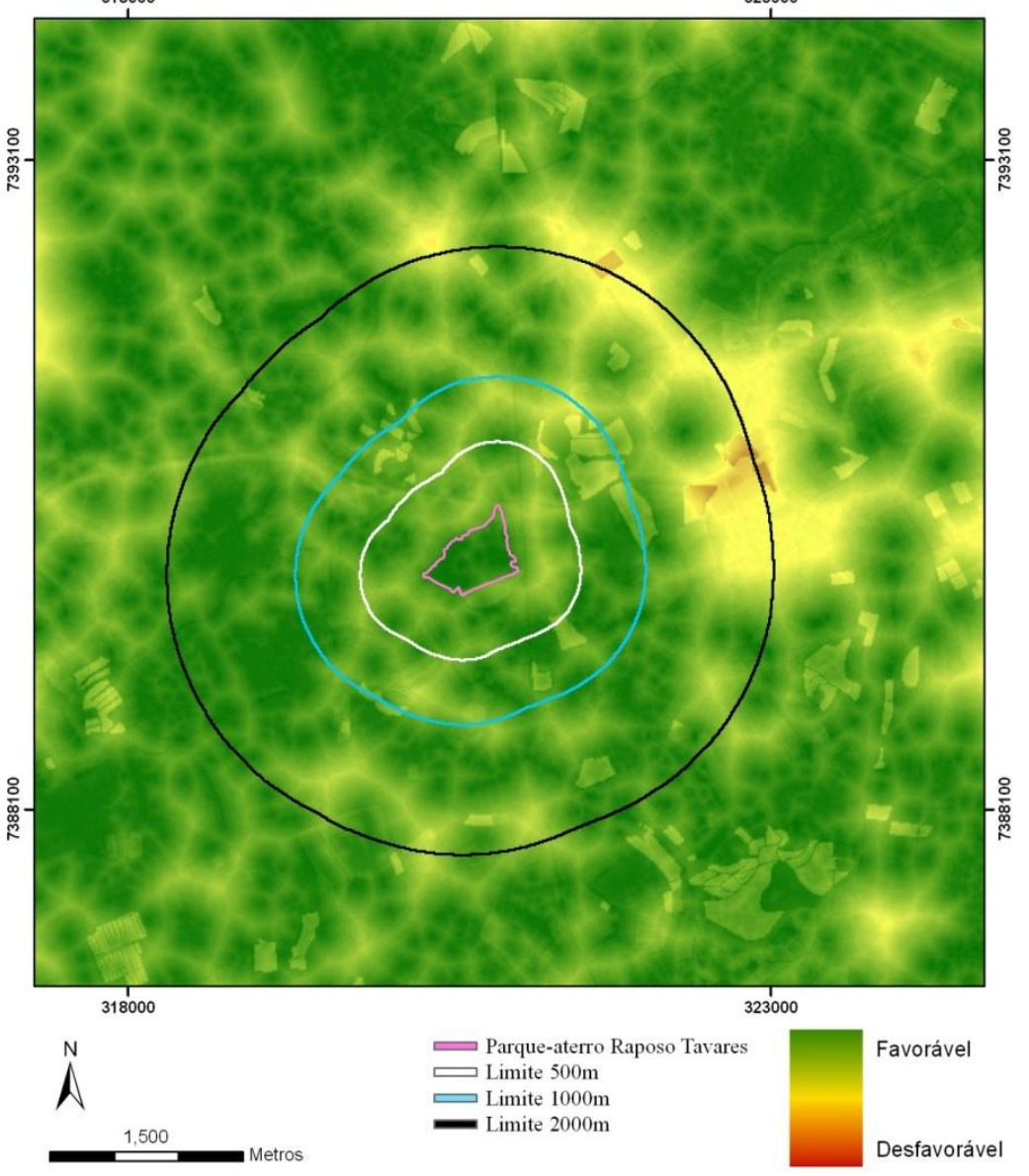

Mapa: Potencial de Conectividade Raposo Tavares Modelo B

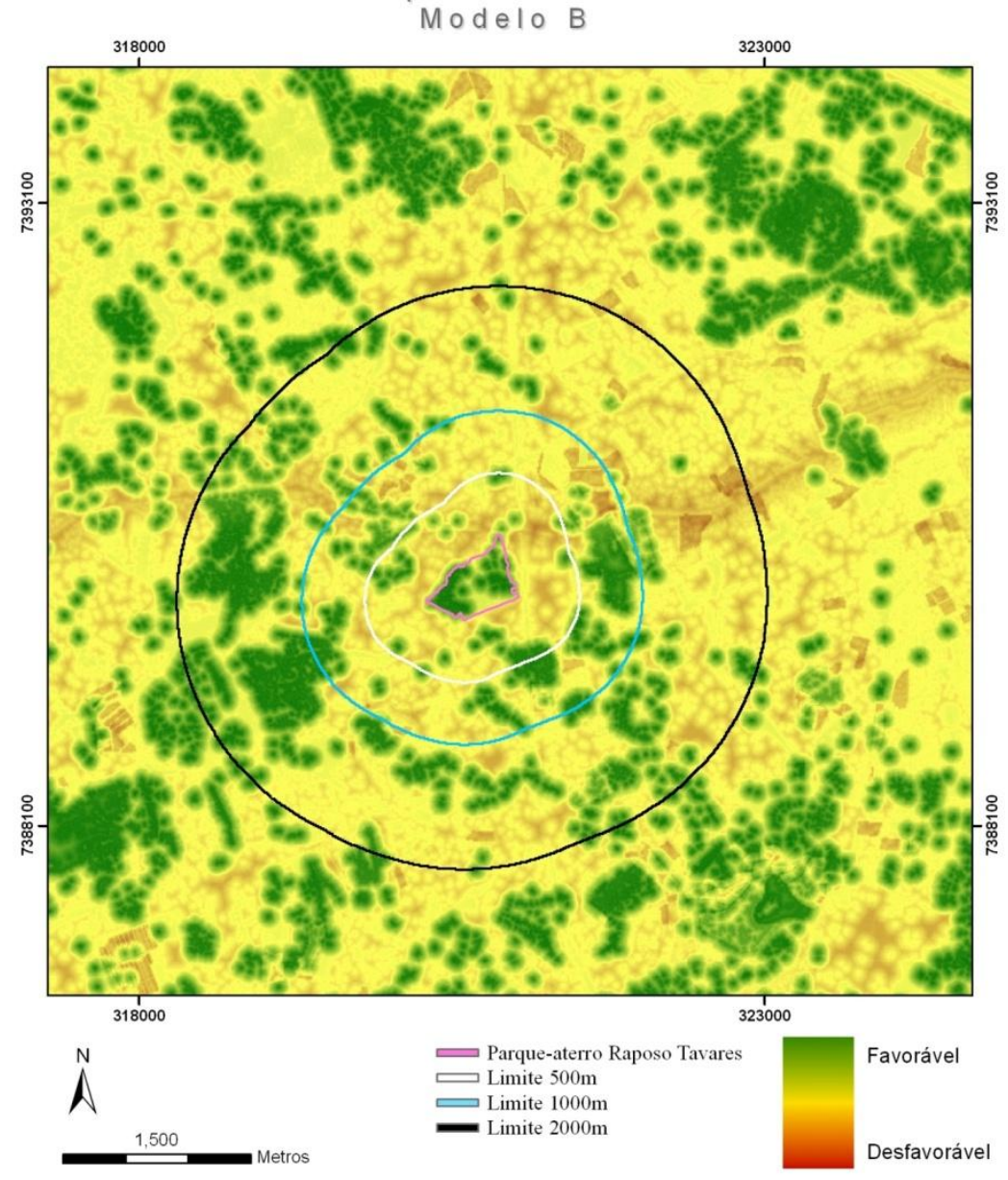

Elaboração: Luzia Helena dos S. Barros (2011)

Figura 8. - Mapa de Potencial de Conectividade do Parque-aterro Raposo Tavares, em dois cenários (Modelos A e B). 

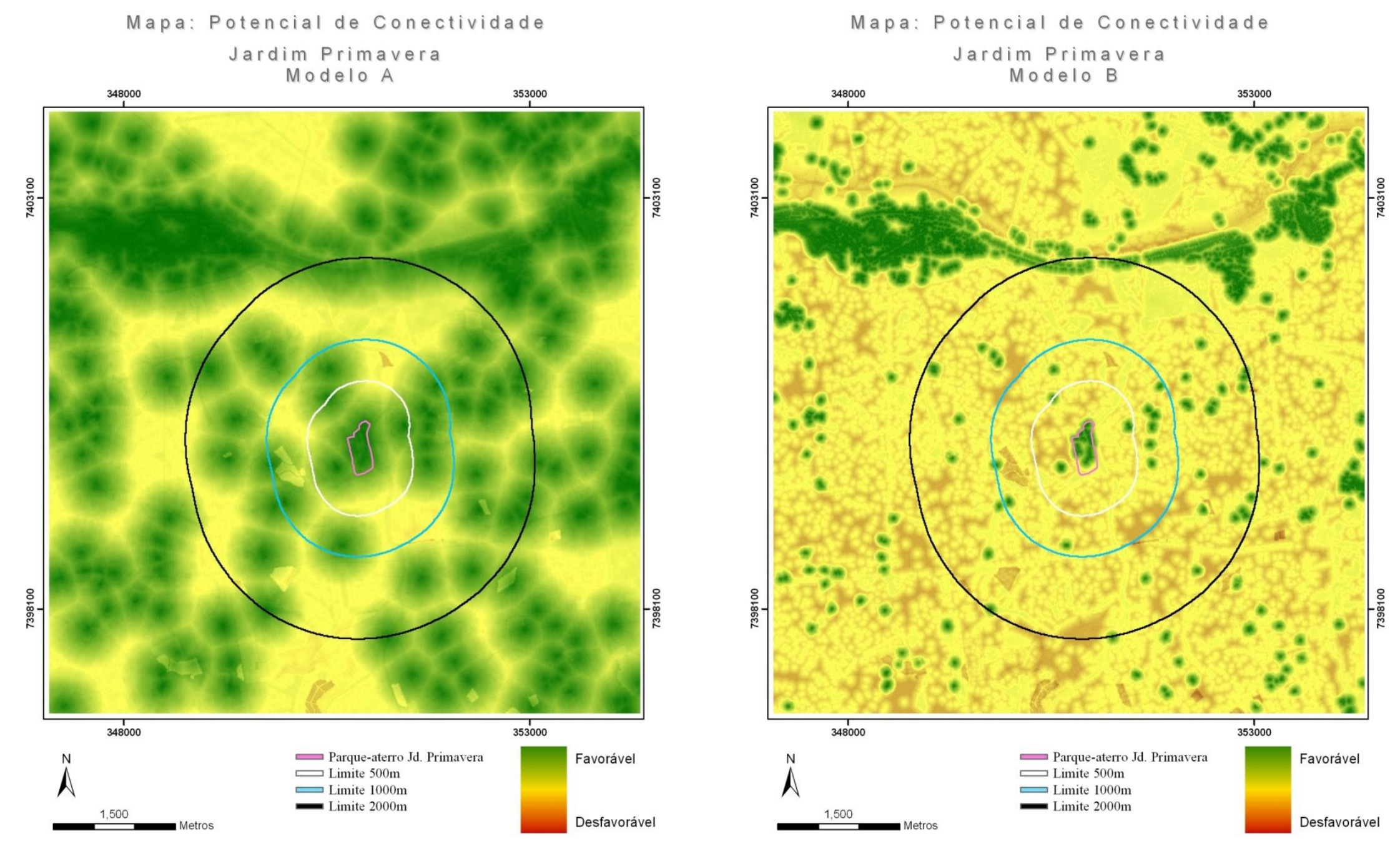

Elaboração: Luzia Helena dos S. Barros (2011)

Figura 8. - Mapa de Potencial de Conectividade do Parque-aterro Jardim Primavera, em dois cenários (Modelos A e B). 


\subsubsection{DISCUSSÃo}

O modelo de tomada de decisão desenvolvido, com base num processo dedutivo-indutivo, onde a vegetação é o elemento de conexão da paisagem, permitiu construir dois cenários, um mais otimista e outro mais conservador, para avaliar o potencial de conectividade entre os parques-aterros, Raposo Tavares e Jardim Primavera e, as suas zonas de amortecimento. Dentre as muitas variáveis ambientais disponíveis ao estudo, foram selecionadas aquelas consideradas mais acessíveis (gratuitas e previamente tratadas) e de importância direta no grau de conexão da paisagem. A simplicidade da utilização do AHP nessas variáveis também garantiu a consistência do modelo desenvolvido.

O Mapa de Potencial de Conectividade do Parque-aterro Raposo Tavares, no Modelo A, mais otimista (Figura 8.23), mostra que a zona de amortecimento de 500 $\mathrm{m}$, com potencial de $54 \%$, já é suficiente para promover a conexão entre as manchas de vegetação (habitats). No geral, até além da zona de amortecimento de $2.000 \mathrm{~m}$, o potencial de conexão da paisagem é favorável ou muito favorável. Mesmo a presença da Rodovia Raposo Tavares, imediatamente a norte do parque, neste cenário, não se apresenta como uma barreira intransponível. Exceção se faz à região situada a nordeste, onde inexiste a formação de corredores ecológicos que permitam a conexão com os parques Previdência e Luiz Carlos Prestes (ver localização na Figura 8.5), parques urbanos municipais mais próximos do Raposo Tavares. O Modelo B, mais conservador (Figura 8.23), permite verificar que a conexão, ao contrário, se torna muito mais desfavorável, em todas as zonas de amortecimento previstas, devido as barreiras existentes, que impedem a formação de corredores ecológicos. O potencial de conexão é desfavorável até no interior do próprio parque.

O Mapa de Potencial de Conectividade do Parque-aterro Jardim Primavera, no Modelo A, mais otimista (Figura 8.24), mostra que a conexão é mais favorável na zona de amortecimento de $500 \mathrm{~m}(45 \%)$, podendo ocorrer a despeito da presença das Av. S. Miguel e Jacu-pêssego, situadas, respectivamente, a noroeste e leste. Entretanto, a Av. do Imperador, que corta essa zona ao sul, funciona como forte barreira à criação de corredores. No geral, a matriz bastante urbanizada ao norte e ao sul do parque-aterro é um fator desfavorável à conexão. O mapa também permite visualizar as dificuldades para promover a conexão da paisagem com o Parque 
Ecológico do Tietê, situado ao norte. Essa possibilidade ocorre apenas na direção nordeste do parque-aterro. $\mathrm{O}$ modelo $\mathrm{B}$, mais conservador, do parque-aterro Jardim Primavera, como esperado, se apresenta totalmente desfavorável à conexão em todas as zonas de amortecimento previstas (71, 75 e 76\%). Esse fato pode ser explicado pela consolidação da urbanização nessa região, que cria barreiras à formação de trampolins e corredores ecológicos. Neste cenário, apenas o interior do parque-aterro mostra algum potencial favorável à conectividade.

No interior dos parques o cenário mais otimista, com mais de $95 \%$ de ocorrência da classe muito favorável, também, confirma a sua denominação, pois se mostra muito mais favorável à conexão do que o cenário conservador, onde essa classe se apresenta com valores médios da ordem de $45 \%$.

\subsection{CONTRASTES URBANO-AMBIENTAIS NOS ARREDORES DOS PARQUES- ATERROS ESTUDO DE CASO}

As características demográficas das Subprefeituras e Distritos que abrangem os parques-aterros estudados revelam um contraste acentuado, com a SP-BT (zona oeste) mostrando taxa da ordem de 2,5 vezes menor que a SP-MP (zona leste). A comparação entre a escolaridade, nível superior, nos distritos apresenta valor superior (cerca de 2 vezes) no DT-RT em relação ao DT-JP. Apesar disso, considerando o índice de desequilíbrio ambiental, obtido por Morato (2005), para o DT-RP e a classificação dos dois distritos como Tipo 2 (indicador sintético ambiental), é possível perceber que esses distritos possuem algumas características semelhantes e outros aspectos bastante distintos.

O estudo de uso e ocupação do solo mostrou alta taxa de urbanização nas duas regiões estudadas, com maior proporção na zona leste. Na zona sudoeste a sub-bacia do Rio Jaguaré é a mais urbanizada. Secundariamente, ocorre a vegetação herbácea e, de forma mais restrita, a vegetação arbórea, inexistente no distrito da Vila Jacuí e na sub-bacia do Rio Jaguaré. Os resultados obtidos confirmam as desigualdades ambientais regionais e locais. No interior dos parques- 
aterros estudados predomina a vegetação herbácea (>60\%) e, secundariamente, a vegetação arbórea.

A variação na temperatura está diretamente relacionada à ação antrópica (supressão e estado da vegetação, adensamento, verticalização, etc.) sobre o meio ambiente. O seu aquecimento, no período entre 1991 e 2006, correlaciona-se com os processos de supressão da vegetação e conseqüente exposição do solo ou de superfícies com materiais que possuem maior capacidade de absorção da energia solar. No caso do resfriamento não existe uma correlação clara, mas parecem se relacionar com o estado da vegetação como: recomposição, estágio e crescimento (Fatigatti, 2009).

O aumento de temperatura observada no parque-aterro Raposo Tavares parece confirmar essa correlação, pois nesse período foram realizadas algumas intervenções no local. Especialmente, a partir de 2003 várias obras foram executadas para instalação de drenagem do percolado, em toda a área do parque, com exposição do solo ou mesmo a utilização de concreto nas canaletas e nas escadas hidráulicas. Outra possibilidade é a abertura de mais quadras ou o seu recobrimento com asfalto ou outro material impermeável, assim como nos caminhos internos.

No caso do parque-aterro Jardim Primavera onde se observou um resfriamento pode-se associar à mudança de estado da vegetação. $O$ aterro, após ser encerrado, foi recoberto com grama e, posteriormente, foram introduzidas algumas espécies vegetais, durante a revegetação experimental (1991) e os eucaliptos (1995), em grande parte da sua superfície. Apesar das restrições para o desenvolvimento da vegetação neste tipo de substrato muitas delas conseguiram sobreviver. Ressalte-se, entretanto, que, no geral, de acordo com o mapa de uso do solo, não conseguiram atingir o estágio de maciço arbóreo.

Ogata (1983), no estudo do aterro Raposo Tavares, concluiu que ele é um exemplo de relevo postiço, construído ao longo de 24 anos e que teve um papel central na ocupação de uma periferia ainda com características semi-rurais. Nos primórdios do lixão existiam amplas áreas de cultivo, vegetação densa e somente o loteamento da Vila Albano. Ao longo da operação do lixão/aterro a situação se modificou bastante, ficando o mesmo cercado por loteamentos, favelas e indústrias.

Do mesmo modo, o aterro Jacuí, executado em 9 anos, também exerceu a função de pólo de atração da ocupação, para o seu entorno e, apresentou os vários 
problemas geotécnicos e de contaminação característicos desse tipo de atividade e os protestos da população para o seu encerramento. Todavia, para o efetivo reúso do Jacuí, se aguardou um período para estabilização do maciço de resíduos (> 20 anos), muito mais adequado, relativamente, do que no Raposo Tavares (apenas 2 anos). Além disso, no Jacuí, foram aplicadas todas as etapas de investigação da contaminação, recomendadas pelo sistema de gerenciamento das áreas contaminadas. As análises indicaram risco iminente, localizado, de explosão devido aos gases constatados e riscos toxicológicos nos cenários: atual (para trabalhadores de obras) e futuro (para todos os receptores considerados). No caso do Raposo, é importante alertar, que foi proposto, pelo GTAC, priorizar a avaliação do seu grau de contaminação, mas até hoje ela não foi realizada. Providenciou-se apenas a drenagem e disposição adequada do chorume.

A despeito dos resultados obtidos na avaliação da contaminação do Jacuí (início de 2008) recomendarem o uso de EPl's especiais pelos trabalhadores de obras, de instalação do sistema de extração de gases, de isolamento e comunicação sobre o risco nos antigos drenos, de monitoramento semestral do Rio Jacu e de investigação complementar para avaliar a qualidade da água do entorno, nenhuma dessas ações tinha sido implantada até agosto de 2011.

A comparação entre os modelos de tomada decisão desenvolvidos para os dois parques-aterros comprovou que os cenários mais otimistas (distância de influência da vegetação de 500 m) são os que apresentam o potencial de conectividade mais favorável. Além disso, que a conexão da paisagem está mais favorecida no entorno do parque-aterro Raposo Tavares, com urbanização menos consolidada. O cenário mais conservador (distância de influência da vegetação de $100 \mathrm{~m}$ ), nos dois casos, mostra que a conexão, quando acontece, se restringe aos limites do interior dos parques-aterros.

A metodologia proposta também permitiu observar que as zonas de amortecimento a serem estabelecidas para cada parque-aterro, dependem das condições ambientais dos seus arredores e da distância de influência de cada critério selecionado. Ou seja, a princípio, não se recomenda estabelecer um valor padrão para as zonas de amortecimento de parques urbanos. A utilização do modelo favorece a escolha de parâmetros ambientais para a definição dessas zonas, de acordo com as suas especificidades. Ainda foi possível notar a importância da presença de manchas de vegetação particulares e da arborização urbana na 
promoção da conectividade, pois mesmo a presença de parques públicos, próximos, não é garantia da ocorrência de conexão na paisagem.

O modelo outrossim, apresenta algumas restrições. Foi desenvolvido para os sete critérios selecionados, que derivaram dos Mapas de Verticalização e de Uso e Ocupação do Solo, obtidos dos processamentos das imagens Ikonos/2002 e ALOS/2007, respectivamente. E, neste caso, a situação específica de verticalização das áreas, em 2007, não é conhecida. 


\section{ANÁLISE DOS PARQUES-ATERROS RAPOSO TAVARES E JARDIM PRIMAVERA}

O município de São Paulo estabeleceu para os aterros desativados o uso futuro como parque urbano, promovendo a criação de espaços de lazer e revegetados, requalificados e remodelados pelos projetos paisagísticos. Esse fato, a exemplo do projeto para o Parque Estadual das Fontes do Ipiranga - PEFI (USP, s/d, p. 6), pode se traduzir na conversão de um "problema" em um modelo para criação de espaços requalificados, "[...] que podem possibilitar a ampliação da nossa percepção, fundamentando a ação política que conduza à cidadania ambiental". Entretanto, de modo geral, tais intervenções não se traduzem efetivamente como ações articuladas na paisagem da cidade para promoção da qualidade ambiental. Sakata (2004, p.17) identifica os vários tipos de projetos paisagísticos

[...] Há aqueles que melhoram a condição de vida da comunidade; aqueles que mudam a maneira como os lugares são percebidos e podem levar a outras transformações e há aqueles com fins unicamente eleitoreiros que não se sustentam a longo prazo.

A requalificação dos antigos aterros desativados em parques-aterros além de incluir a elaboração e a execução de projetos paisagísticos deverá prever a sua manutenção especial por décadas. Namiki (s/d) ${ }^{1}$ apud Sakata (2004) ressalta que

\footnotetext{
${ }^{1}$ NAMIKI,F. Manutenção de praças públicas. Dissertação (mestrado). Instituo de Pesquisas Tenológicas do Estado de São Paulo. (texto preliminar).
} 
essa etapa para os espaços públicos é tão importante quanto as outras, mas que geralmente os arquitetos consideram a sua tarefa concluída ao término da execução e inauguração do projeto; diferentemente dos usuários para os quais a manutenção tem o mesmo valor que a própria implantação do equipamento. Para Sakata (2011, p. 262)

[...] A apropriação da população é diretamente ligada à manutenção do espaço público e de seus mobiliários. Os espaços que tendem a ter manutenção são aqueles que têm significado por conta do seu uso pela comunidade. [...] Os projetistas devem buscar esta qualidade, em oposição ao efêmero e ao descartável. $O$ arquiteto deve propor soluções novas e criativas, mas que busquem ser permanentes.

Sakata (2004, p. 25) também ressalta que o projeto paisagístico tem relação direta com a manutenção

[...] A manutenção não deve ter um custo alto demais para o poder público, que freqüentemente atravessa crises financeiras. Para tal é necessário que a execução seja precisa, os materiais utilizados nos revestimentos sejam seguros e duráveis, a vegetação o mais rústica possível e, principalmente, que o espaço sirva à sociedade, como palco da vida cotidiana.

Os aterros de resíduos apresentam várias restrições à implantação de edificações, equipamentos urbanos, vegetação, etc; aspectos abordados nos Capítulos 4 e 6 . A requalificação de aterros desativados, considerados, inicialmente, como áreas suspeitas de contaminação do solo e das águas superficiais e subterrâneas, deverá então obedecer inicialmente às exigências legais quanto à avaliação do seu grau de contaminação. Primeiramente, realizar-se-á a Investigação Confirmatória, que trata da amostragem de solo e águas subterrâneas. Confirmada a contaminação será necessário proceder à Avaliação de Risco para quantificar os riscos gerados à saúde da população e aos ecossistemas, edificações, instalações de infra-estrutura urbana, produção agrícola, e outros, baseada em parâmetros físicos, químicos e biológicos. Os resultados desta avaliação são utilizados na definição das medidas de remediação, a serem incorporadas nas diretrizes dos projetos de requalificação destas áreas, de forma a garantir a segurança do seu reúso.

Morinaga (2007, p.71) relaciona algumas recomendações para a elaboração e implantação de projetos paisagísticos em áreas de aterros de resíduos domiciliares:

[...] execução de sistema de contenção; implantação de sistema de tratamento das águas subterrâneas, quando a contaminação estiver acima do nível de risco aceitável; implantação ou reforma de sistema de extração de gases passivo ou ativo, conforme os resultados das investigações; 
implantação de sistema de monitoramento; seleção de espécies adequadas às condições do aterro, especialmente do sistema de cobertura, determinados pela drenagem e características do solo.

Para Sakata (2004, p.25) o projeto de espaço livre público adequado deve se mostrar acessível à população

[...] deve possibilitar usos distintos para o maior número de pessoas, deve, enfim, convidar à convivência com o outro. Os espaços públicos, como [...] parques e praças, são dos últimos redutos, no início do século XXI, onde é possível pessoas de diferentes estratos sociais coexistirem.

Uma tendência recente é o desenvolvimento de projetos ecológicos de parques. Eles têm a finalidade de aumentar a qualidade do habitat e restaurar paisagens degradadas que tenham sido esgotadas ou abandonadas, por meio da reabilitação ou restauração da estrutura e função da paisagem do parque (Forsyth e Musacchio, 2005, tradução nossa).

Este capítulo trata da análise da implantação de dois projetos de parques urbanos, como requalificação de áreas contaminadas por resíduos, sobre aterros desativados situados no eixo oeste-leste do município de São Paulo: o Raposo Tavares (antigo aterro Raposo Tavares), na zona oeste, e o Jardim Primavera (antigo aterro Jacuí), na zona leste. No primeiro caso, a implantação do parqueaterro desconsiderou o seu passivo ambiental. Ao contrário, no segundo, esse fator foi pré-requisito para a previsão das intervenções necessárias a serem incorporadas no projeto paisagístico.

\subsection{PARQUe-ATERro Raposo TAVARES}

As obras para a implantação do parque-aterro, Raposo Tavares, primeiro na América Latina, foram iniciadas, em outubro de 1979, com custo de $R \$ 1,62$ milhão ${ }^{2}$ (Neder et al., 2005) e finalizadas em agosto de 1980. Aparentemente, foram executadas enquanto se terminava a elaboração do seu projeto, concluído em abril de 1980 (Figura 9.1) ${ }^{3}$. Não foram levados em consideração todos os cuidados especiais necessários ao tipo de substrato existente no aterro e aos possíveis problemas de contaminação. Todavia, o aterro foi recoberto por uma camada de

\footnotetext{
${ }^{2}$ Valor obtido com a aplicação do índice IGPI-DI, da Fundação Getúlio Vargas, em 2005.

${ }^{3} \mathrm{Na}$ prática municipal, geralmente por interesses políticos ou mesmo pela inexistência de articulação das ações, é comum iniciar-se uma obra sem a finalização de várias etapas necessárias ao bom desempenho da fase de execução e, posteriormente, à manutenção.
} 
argila, para evitar a emanação de gases e, outra de terra adubada para o plantio da vegetação.

O projeto determinou a instalação das edificações (administração, almoxarifado, sanitários e depósito) junto à entrada principal do parque e das quadras poliesportivas, campo de futebol e parque infantil no topo central do antigo aterro. A vegetação foi toda introduzida nas áreas livres adjacentes aos espaços edificados, conforme o roteiro botânico (Figura 9.2) de Hashimoto (1985/884 apud Neder et al., 2005), que recomendou a seleção de espécies com raízes curtas e resistentes às temperaturas mais elevadas. Neder et al. (2005) comentam, no entanto, que são poucas as plantas sobreviventes do projeto original, denotando as dificuldades para o seu desenvolvimento neste tipo de terreno. As faces dos taludes do aterro não foram contempladas com revetação no projeto inicial. Os mesmos autores citados relataram, também, segundo informações do Eng. Agr. Jefferson Steinberg (Depave/SVMA) que, desde 1998, foi iniciado um reflorestamento do parque com várias espécies pioneiras. As espécies que apresentaram melhor desenvolvimento foram: Tipuana tipo (tipuana), Schinus molle (aroiera-salsa), Chorisia speciosa (paineira), Tibouchina granulosa (quaresmeira), Caesalpinia ferrea (pau-ferro), Tabebuia heptaphylla (ipê-rosa) e Salix babilonica (chorão).

A vegetação atual do parque (Figura 9.3) contém indivíduos inadequados, tais como a bananeira (Figura 9.4), abacateiro, limoeiro, etc.. A introdução de plantas comestíveis (raízes, folhas, frutos, etc.) nessas áreas não é recomendado devido à possibilidade de fitotransporte de poluentes e conseqüente risco à saúde humana, assunto abordado nos capítulos 4 e 6 . Constatou-se, ainda, a presença de líquens ${ }^{5}$, em exemplares de vegetação do tipo bosque implantados sobre a massa de resíduos, expostos em superfície (Figura 9.5). Quanto à vegetação, o administrador do parque percebeu que em algumas espécies a raiz ao se aprofundar, encontra algum tipo de resíduo mais resistente e não conseguindo atravessá-lo, começa a crescer lateralmente, às vezes, levando à queda da árvore, muito comum com o ingá e o pinheiro e outras vezes não (Figura 9.6). Tal como Neder et al. relataram, não há estudo sobre a vegetação introduzida no parque, impedindo a existência de dados de observação precisos que auxiliem a revegetação de outras áreas similares.

\footnotetext{
${ }^{4}$ HASHIMOTO, G. Conheça o verde. Centro de Pesquisa e História Natural (CPHN). São Paulo, 1985/88.

${ }^{5}$ São associações simbióticas entre algas e fungos de diversos tipos, que podem funcionar, por meio da quantidade e diversidade, como indicadores da qualidade do ar. Ao se comparar áreas com a mesma insolação, a maior quantidade e riqueza de líquens indica melhor qualidade do ar. Comunicação verbal do biólogo Ricardo José F. Garcia, em 04/08/11.
} 
Requalificação dos Aterros Desativados (BrownfieldS) no MunicípIo de São Paulo: Parques (GreenfieldS) RAPOSO TAVARES E JARDIM PRIMAVERA LUZIA HELENA dos SANTOS BARROS

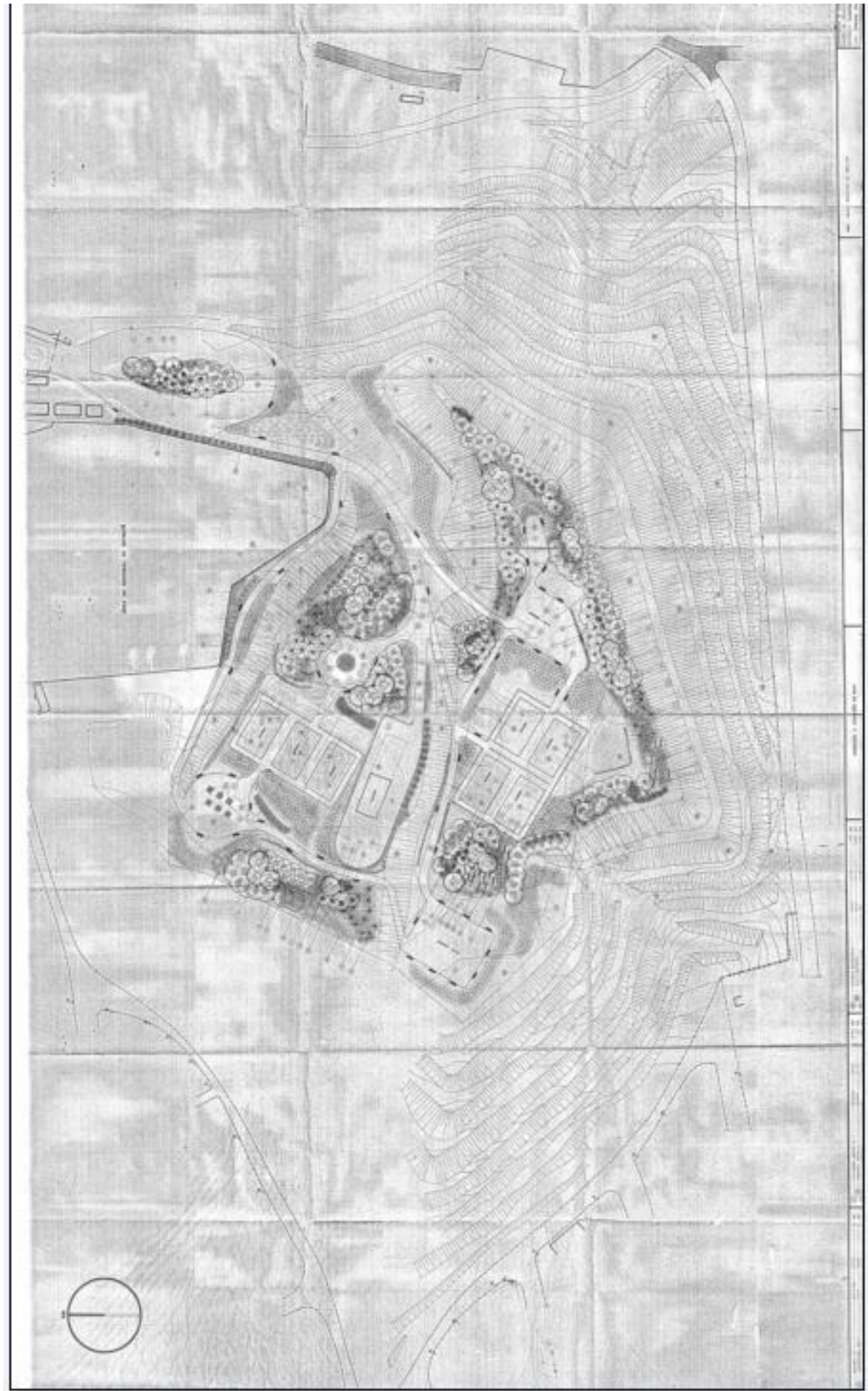

Figura 9.1 - Projeto do parque-aterro Raposo Tavares, elaborado em 1979/1980. Esc. Original: 


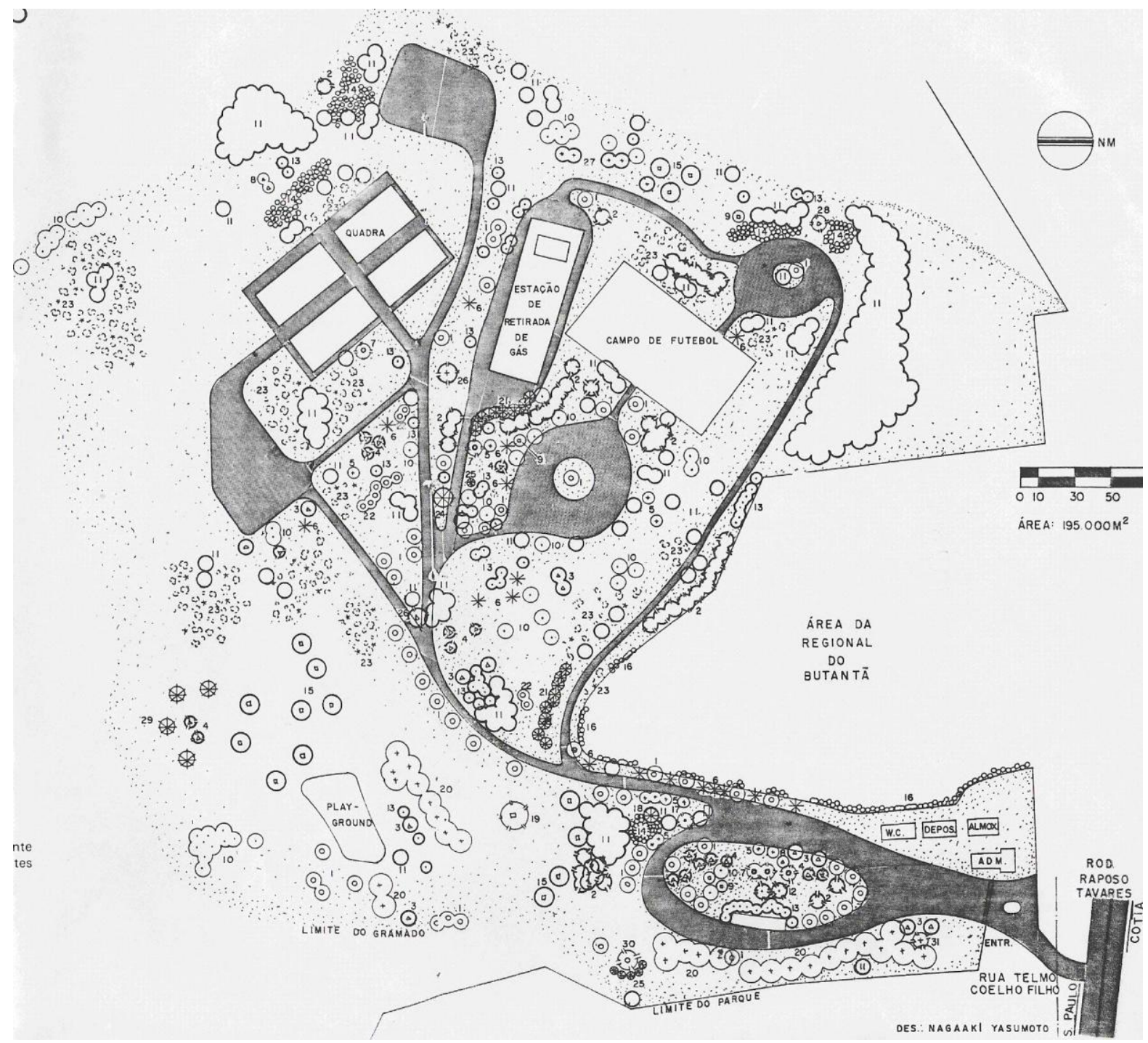

Figura 9.2 - Roteiro botânico elaborado por Hashimoto no período de1985-88.

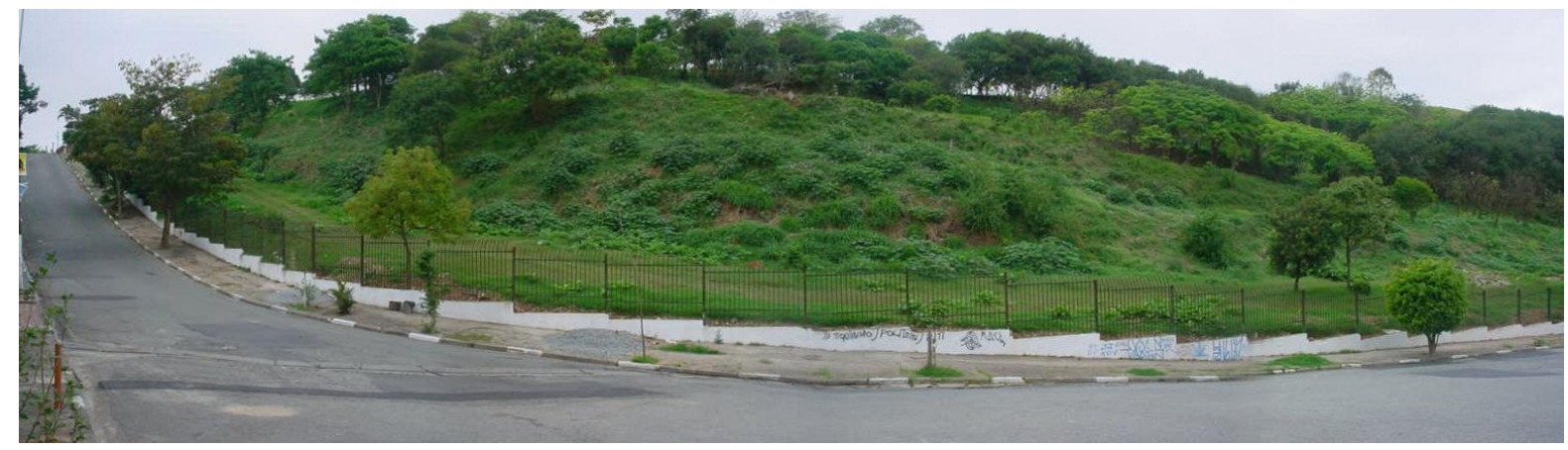

Figura 9.3 - Vista do limite do parque-aterro Raposo Tavares, em maio/2008, no cruzamento das ruas Alberto Astori e Domingos Nogueira. 


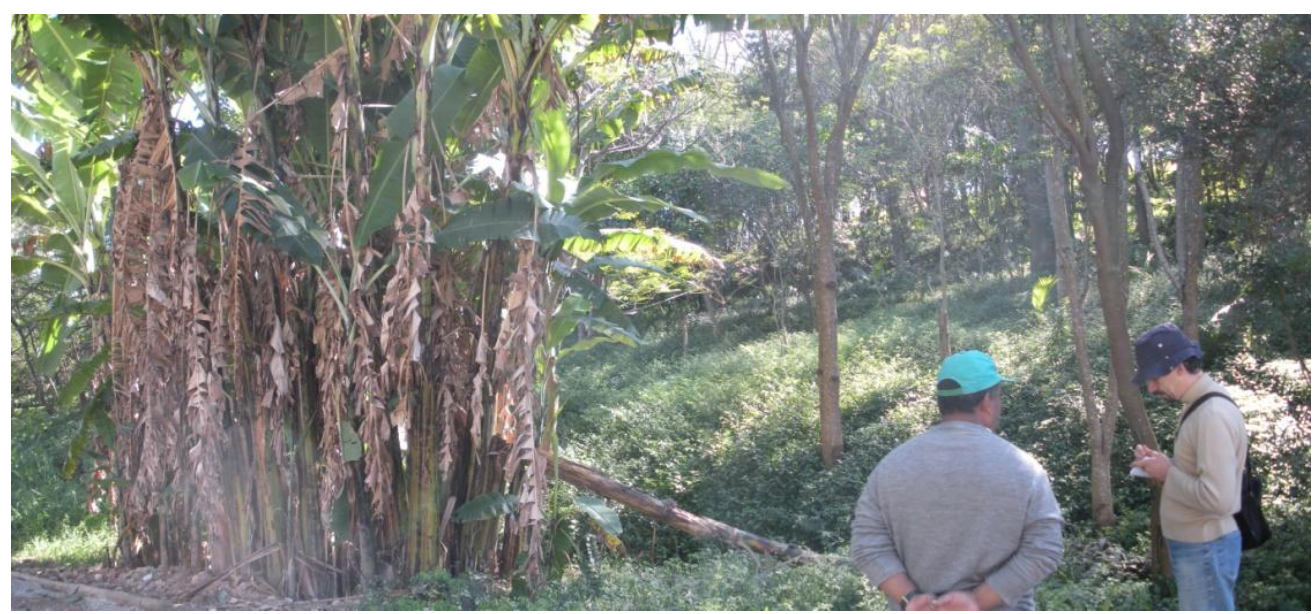

Figura 9.4 - Bosque com uva-japonesa, casuarina, paineira, citrus, araribá; que há cerca de um ano não tem sido roçado, onde há plantação irregular de bananeira. Data 03/06/09.
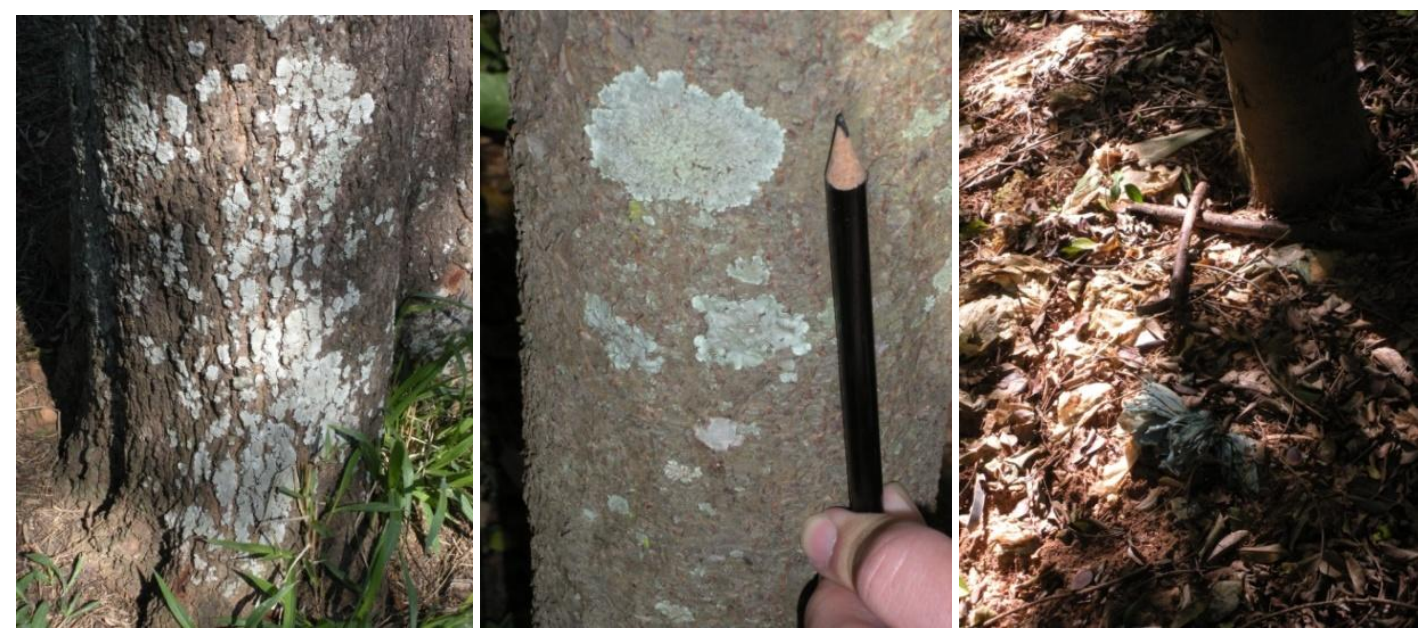

Figura 9.5 - Vegetação tipo bosque, em blocos quase homogêneos, com altura de cerca de 8 a 10 metros, onde se encontram: paineira, aroeira e leguminosas com líquens. Observar, exposição do resíduo no terreno, onde estão plantadas as árvores, à direita. Data 03/06/09.

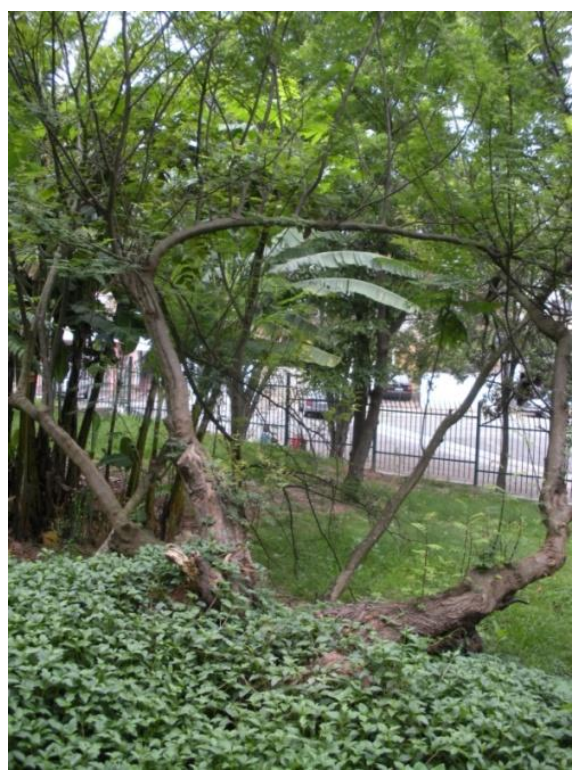

Figura 9.6 - Exemplar arbóreo que adaptou o seu desenvolvimento às condições impróprias do subsolo. Data: Out. 2008. 
O desenvolvimento da vegetação também é função da espessura da camada de solo limpo que recobre o parque, tal como apontou o administrador. Ele informa que atualmente o plantio, mediante o Termo de Compensação Ambiental TCA ou da equipe da própria Prefeitura (Figura 9.7), dá preferência às espécies do ecossistema nativo, atrativas da fauna, vegetação da mata atlântica e, no caso do Parque Raposo Tavares, espécies do cerrado. Considera que o plantio realizado pela Prefeitura mostra melhor aproveitamento, pois existe um acompanhamento contínuo das mudas e, apesar de apresentar mais dificuldades, adotou o plantio em talude, local com pouco potencial para outro uso e acesso difícil, impedindo o trânsito de pessoas e a prática de vandalismo.

Em 2002, por pressão do Ministério Público, a Cetesb autuou a Prefeitura devido ao afloramento de chorume, que era carreado para as áreas mais baixas; emitindo inclusive multa, posteriormente. A Cetesb alertava que essa situação ocorria desde a época da sua desativação e exigiu a elaboração e implantação de um plano de recuperação e adequação para o lançamento do chorume. O plano foi aprovado pela companhia em 2003, e o cronograma para a sua implantação, entregue pelo Depave/SVMA, previa a sua execução no mesmo ano. Ressalta-se que o plano foi elaborado sem o acompanhamento do GTAC/Decont, já naquela época setor competente, na Prefeitura, para tratar da gestão das áreas contaminadas. Entretanto, devido a sucessivos problemas orçamentários, a execução da drenagem de percolados e águas pluviais ${ }^{6}$ foi postergada para 0 exercício de 2006. A abertura da licitação foi prevista para setembro de 2006, com orçamento de $R \$ 574.000,00$ e prazo de execução em 180 dias. Todavia, ao longo desse período, algumas intervenções foram realizadas, mediante a contratação de serviços parciais e a utilização de Termos de Compromisso Ambiental - $\mathrm{TCA}^{7}$ (Figura 9.8).

Somente, em 2007, o Depave solicitou o apoio do GTAC, quanto à sugestão para destinação do percolado, pois não poderia ser jogado na rede de esgoto e muito menos nas galerias pluviais. O GTAC, então, sugeriu a retenção do percolado em caixas impermeabilizadas e a sua retirada periódica por caminhões para descarga diretamente na Estação de Tratamento de Esgoto da Sabesp. Essa

\footnotetext{
${ }^{6} \mathrm{O}$ assunto foi tratado no processo administrativo 2005-0.310.457-0.

7 Segundo Neder et al., TCA 26/2003 do Clube Paineiras do Morumbi, no valor de R\$108.990,97; TCA 44/2002 (PA $2002-$ 0.134.417-0); TCA 148/2004 (Pa 2004-0.227.193-5, no valor de $\mathrm{R} \$ 26.709,00$.
} 
Requalificação dos Aterros Desativados (BrownfieldS) no MunicípIo de São Paulo: Parques (GreenfieldS) Raposo TAVARES E Jardim PrimaVera

LUZIA HELENA DOS SANTOS BARROS

solução tem sido empregada em muitos países (vide Capítulo 7) devido ao alto grau de contaminação do chorume que dificulta o seu reúso.

Os fatos mostram que nem sempre é possível a realização de um trabalho integrado, mesmo entre departamentos de um único órgão público, o que só reforça a necessidade urgente de se compreender o caráter interdisciplinar no tratamento das questões ambientais, especialmente no caso das áreas contaminadas. Todavia esta possibilidade é cada vez mais difícil no poder público municipal, na medida em que a constituição de equipes de profissionais efetivos está se tornando inviável ${ }^{8}$.

O parque-aterro foi oficializado pelo Decreto 50.259, de 26 de novembro de 2008, com a área de $195.000 \mathrm{~m}^{2}$, mas prevendo a incorporação futura do terreno vizinho, ocupado pela Subprefeitura do Butantã (Figuras 9.9 e 9.10). O Decreto estabelece a responsabilidade da sua gestão à SVMA/Depave e determina a elaboração do Plano de Manejo, incluindo o diagnóstico ambiental. O parque mantém cinco portarias, sendo a principal na R. Telmo Coelho Filho, junto à Administração (Figura 9.11). Em 2007/2008, iniciou-se a execução de várias obras de melhorias no parque, dentre elas o recapeamento das vias internas, instalação de guaritas, escadas de acesso (Figura 9.12), quadras poliesportivas, quiosques e pista de Cooper. Entretanto, a necessidade de avaliação ambiental prévia, orientada pelo GTAC, não foi realizada, com a construção de edificações justamente sobre a massa de resíduos, apesar de evidentes a decomposição do lixo e a sua exposição.

O parque é bastante acidentado com variação de nível de cerca de 50 metros. Está cercado por ocupação de médio a baixo padrão e favelas. No seu trecho mais plano estão localizadas a entrada principal e a sede administrativa. A partir da entrada em direção a parte central estão as churrasqueiras e foram construídos, mais recentemente, outros sanitários (Figuras 9.13 a 9.18). No centro do platô, onde se situava a antiga estação de tratamento de gás, com vegetação tipo parque e gramado, localizam-se os equipamentos de lazer, o playground, as quadras de futebol (um campo com dimensões oficiais) e poliesportivas e os novos quiosques.

\footnotetext{
${ }^{8}$ Nas últimas administrações da Prefeitura de São Paulo, os técnicos mais experientes vêm sendo alijados das principais equipes elaboradoras de políticas públicas e tomadoras de decisão, em temas considerados complexos e com visibilidade política. Particularmente, na SVMA, apesar da entrada de novos profissionais concursados, no cargo de especialista ambiental, as necessidades do GTAC não foram supridas. Esses profissionais ainda não tinham a formação específica exigida no tratamento do tema e os antigos profissionais foram realocados em outros setores sem um período de transição para repasse de todo o conhecimento adquirido. No caso do Depave, a renovação da equipe de profissionais da Divisão de Projetos se deu, na sua grande maioria, por profissionais comissionados. Esse fato também pode ser observado na Siurb, responsável atualmente por executar as obras de implantação dos parques municipais. Alerta-se para os interesses políticos no aumento do quadro de profissionais comissionados, muitas vezes, mais compromissados com esses interesses do que propriamente com o interesse público. Ou então, muito mais sujeitos as pressões políticas dos vários poderes privados constituídos.
} 

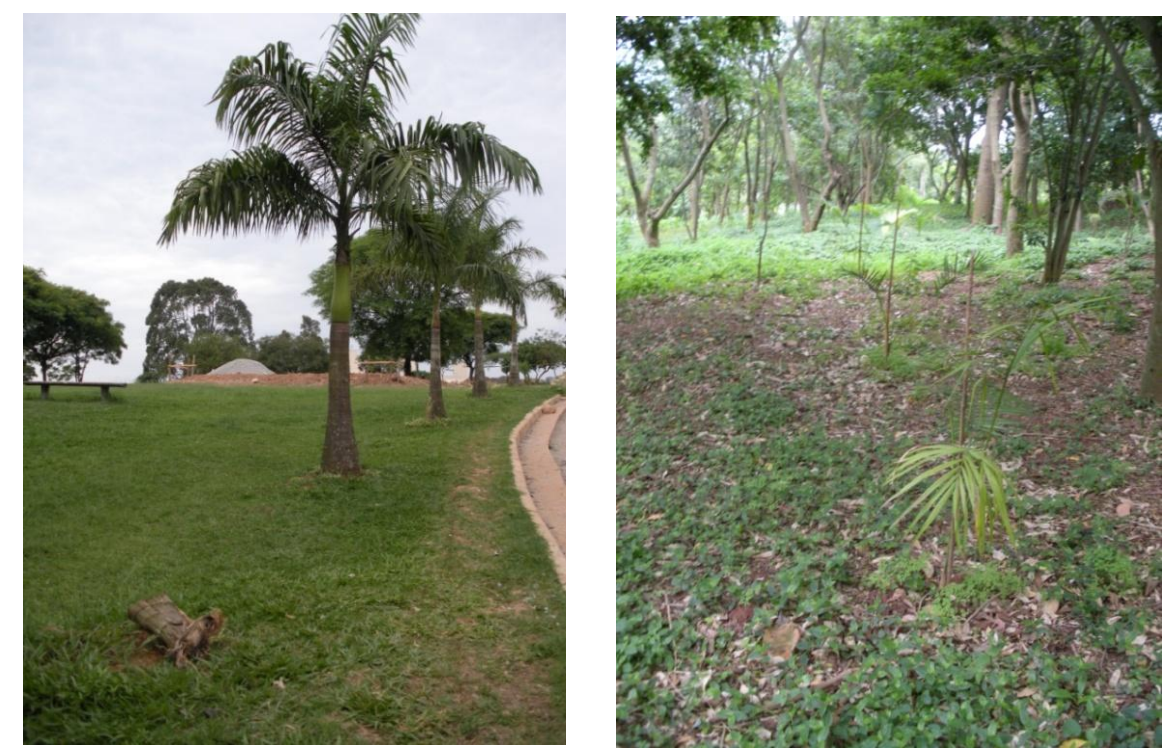

Figura 9.7 - Vegetação de palmeiras plantadas por meio de TAC ou da Prefeitura. Data: Out. 2008.
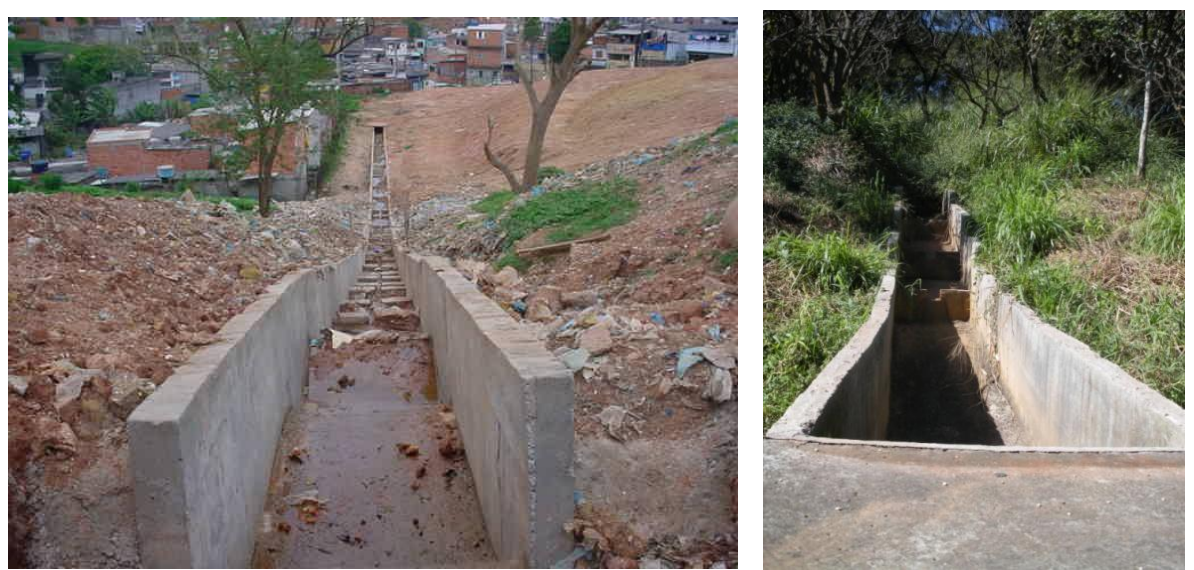

Figura 9.8 - Sistemas de drenagem em implantação, em 2006 e já instalados, em 2009.

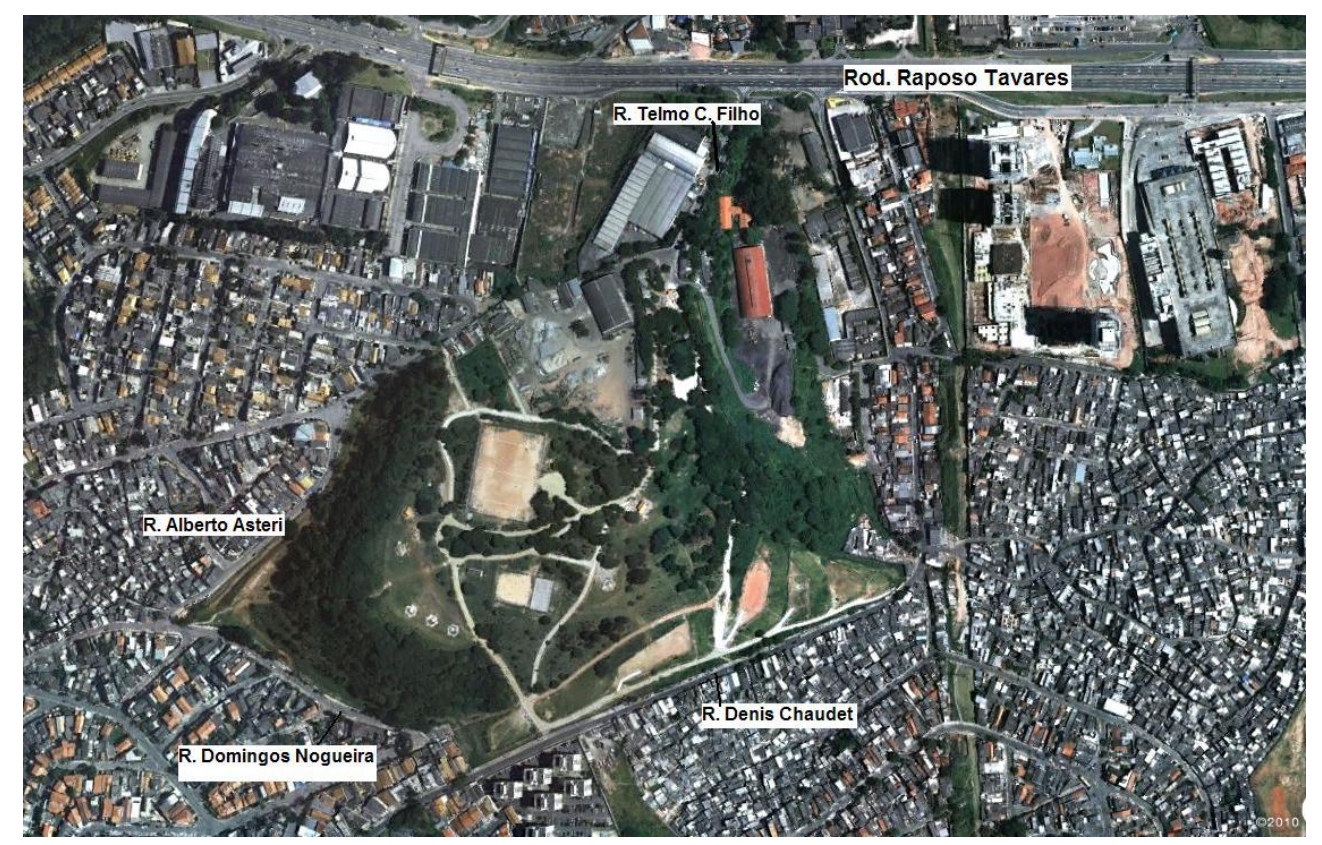

Figura 9.9 - Vista aérea do parque-aterro Raposo Tavares em 14/12/2010.

Fonte: Google Earth 2011. Acesso em: 03Ago2011. 
Requalificação dos Aterros Desativados (BrownfieldS) no MunicíPIO de SÃo PaUlo: PARQUES (GREENFIELDS) RAPOSO TAVARES E JARDIM PRIMAVERA

LUZIA HELENA DOS SANTOS BARROS
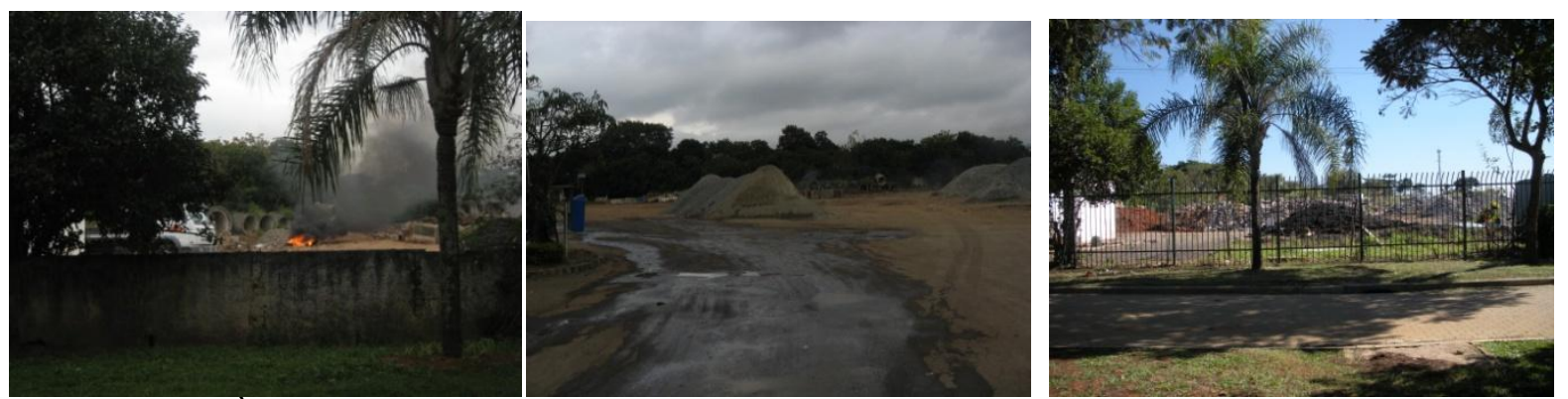

Figura 9.10 - À esquerda, terreno contíguo ao parque, ocupado pela SP-BT, em maio/2008, a ser incorporado à sua área, onde se observa a queima de material. À direita, visão de dentro do parque, em junho/2009, de outra área utilizada pela SP-BT, observada em 2008, no centro.
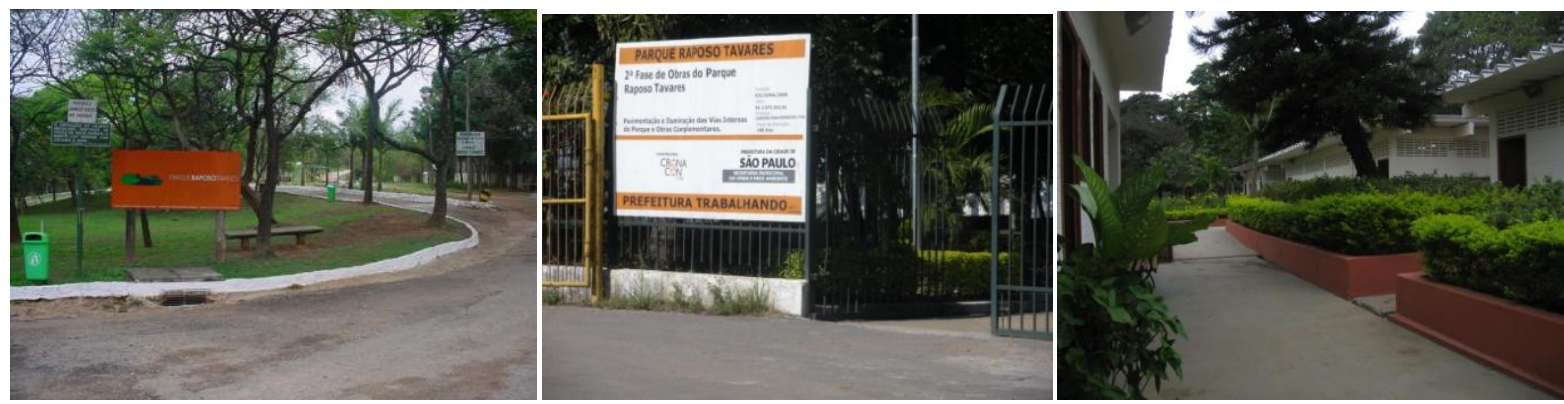

Figura 9.11 - Entrada principal do parque-aterro Raposo Tavares, na R. Telmo Coelho Filho, onde está situada a Administração. Data: 03/06/09 e 30/07/10.

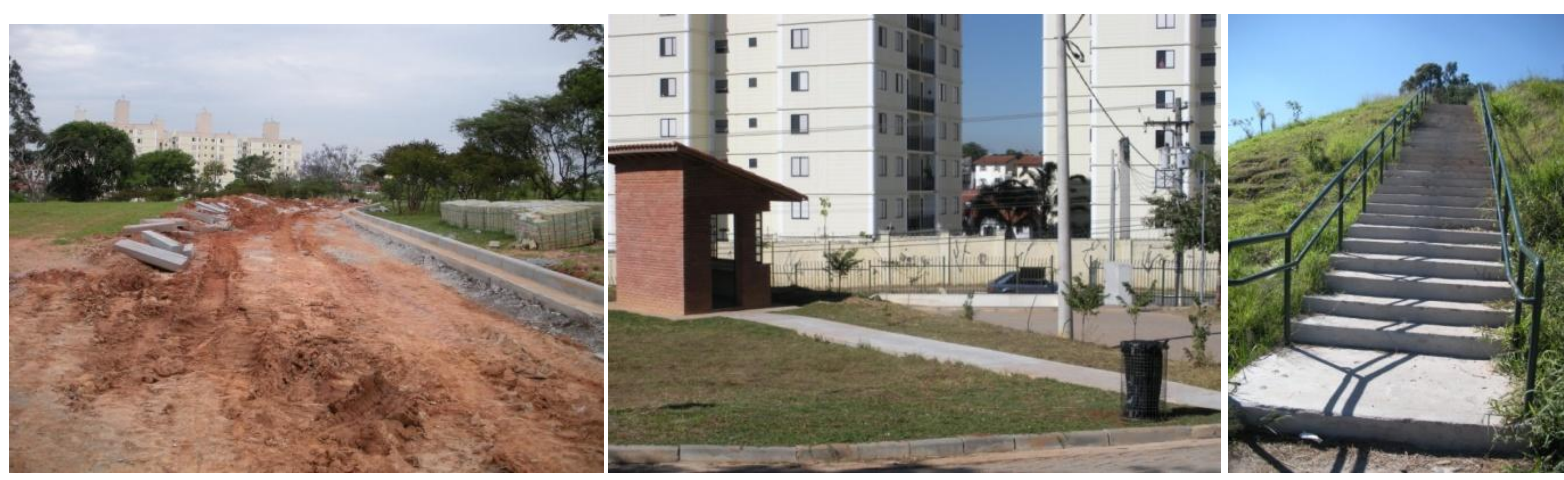

Figura 9.12 - À esquerda, recapeamento de via interna no parque-aterro Raposo Tavares, em 2008. No centro, portaria junto ao portão da R. Alberto Pastori, onde se observa, ao fundo, condomínio de prédios residenciais. À direita, escada, à montante, que serve de acesso ao campo de futebol. Data 03/06/09.

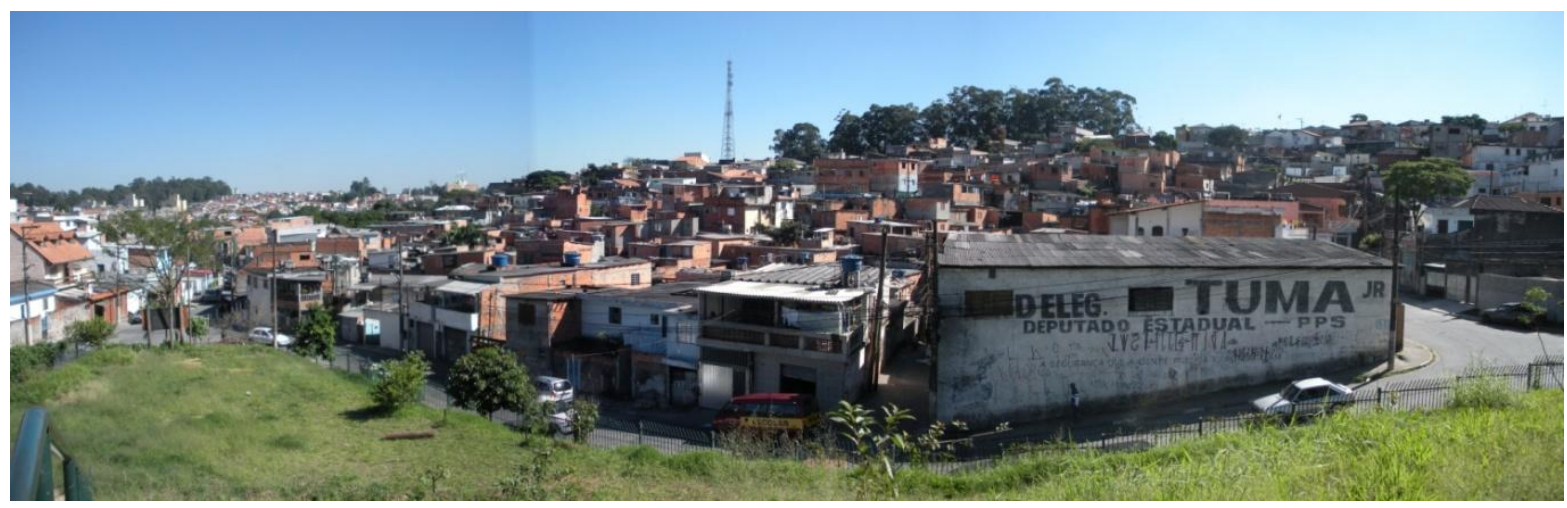

Figura 9.13 - Vista da favela Mandioquinha, junto à Rua Alberto Pastori. Data 03/06/09. 


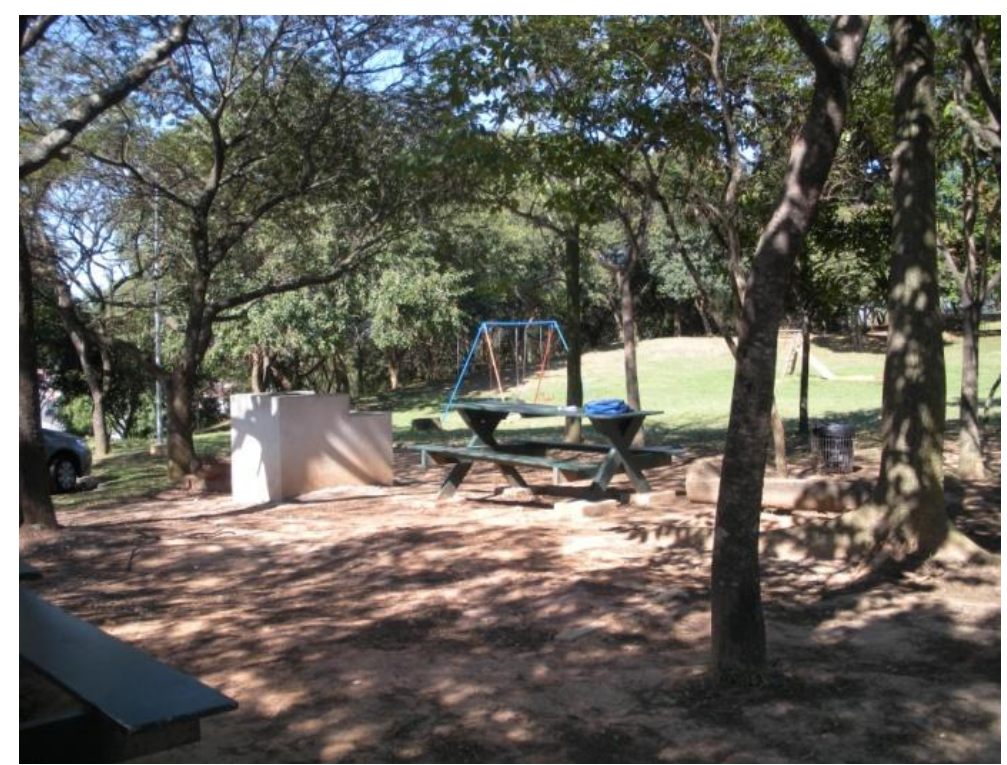

Figura 9.14 - Churrasqueiras ao lado do estacionamento sob vegetação tipo bosque com faveiro, leucena, ipês e pata-de-vaca apresentando altura entre 6 e 8 metros. Data 03/06/09.

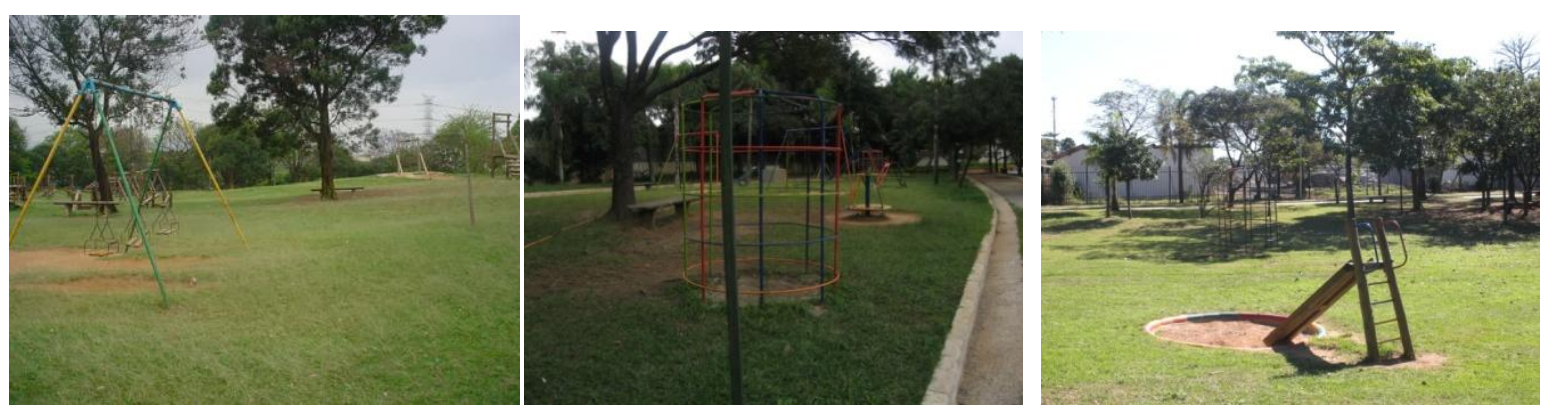

Figura 9.15 - Playground próximo à área das churrasqueiras, em três momentos distintos. Da esquerda para a direita em 2007, maio/2008 e junho/2009.

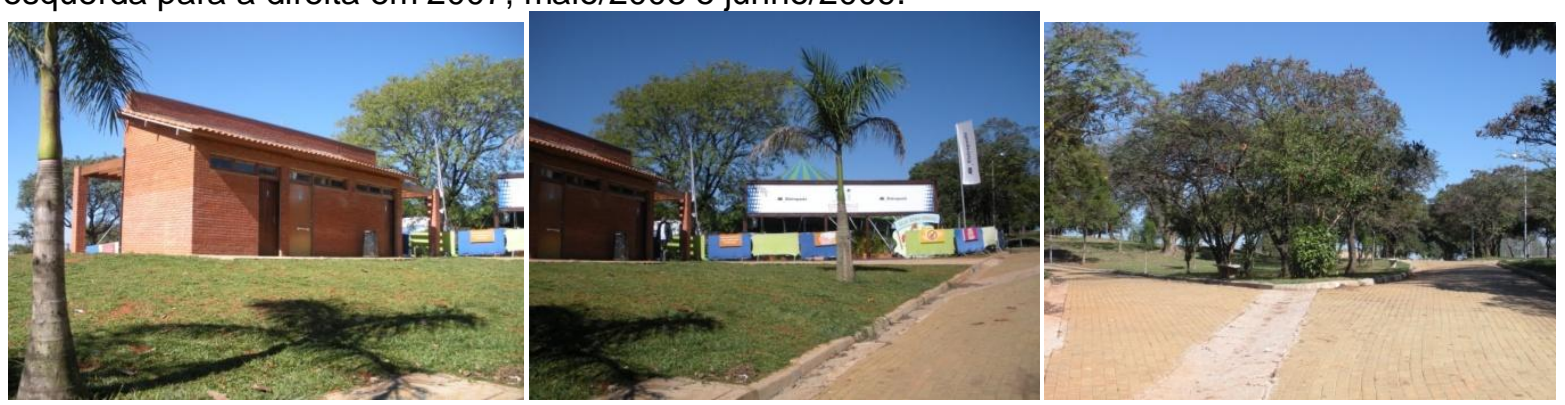

Figura 9.16 - Sanitários sobre gramado no topo do parque, junto ao caminho que sai da entrada principal. A Eletropaulo, sob contrato de parceria, usava a área temporariamente (3 meses) em atividades educativas. À direita, exemplares da vegetação arbórea Peltophorum dubiu e arbustiva Malvaviscus arboreus. Data 03/06/09.
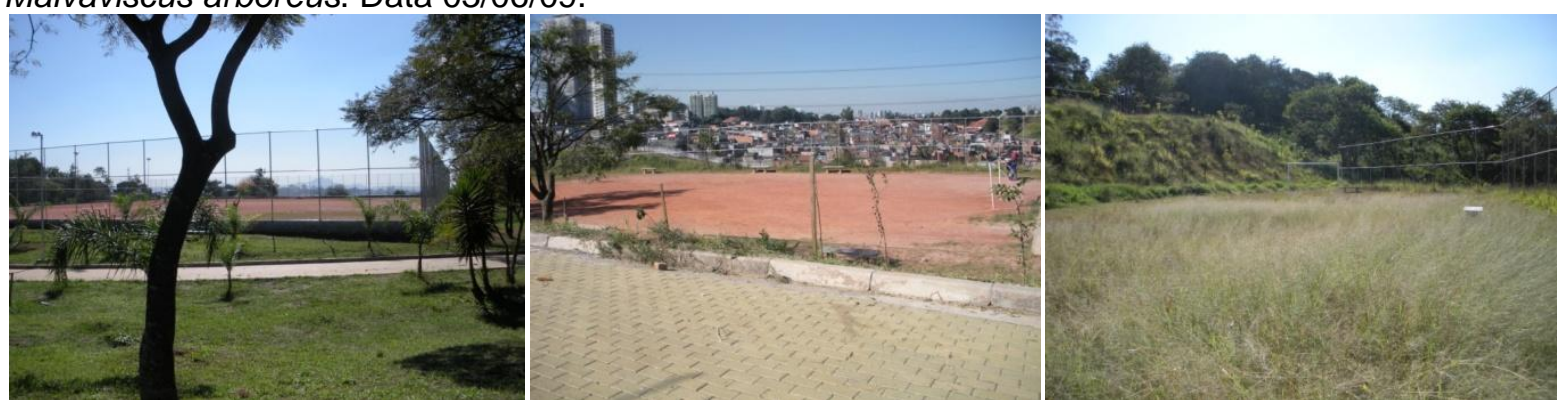

Figura 9.17 - Campos de futebol e quadras. Á direita, campo recoberto por capim Adonis, muito resistente, que virou praga no Rio Grande do Sul. Data 03/06/09. 


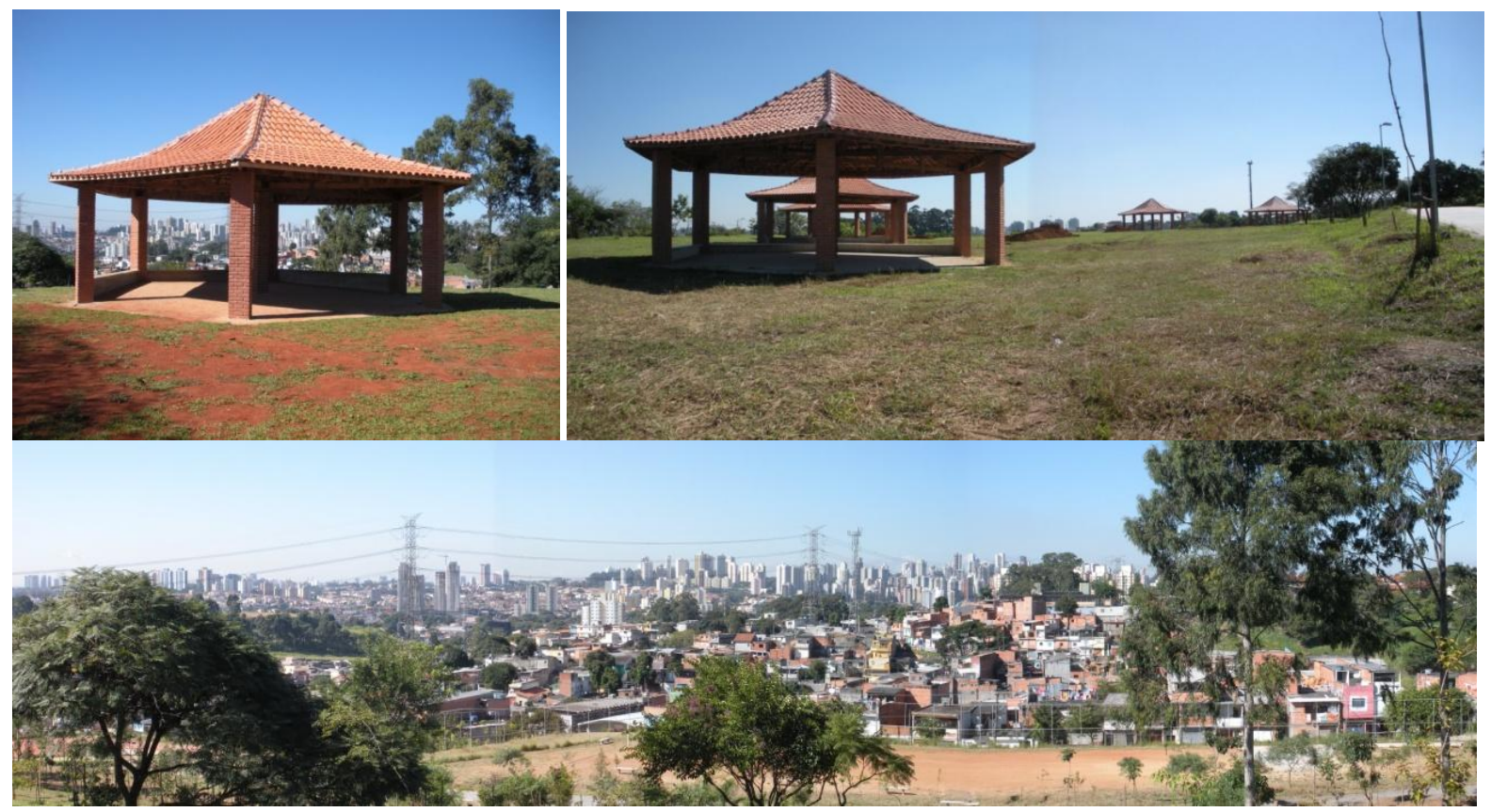

Figura 9.18 - Área gramada com solo exposto onde foram instalados quiosques. Ao sul avista-se o conjunto residencial denominado Jardim Jaqueline, ao longo da R. Denis Chaudet. Data 03/06/09.

Em fevereiro de 2009, iniciaram a operação de uma pequena composteira (Figura 9.19), em área isolada (cercada). O composto é utilizado dentro do parque. Há proposta para implantar, também, viveiro de mudas e minhocário. Um largo foi implantado no talude à jusante de um dos campos de futebol, voltado para a R. Alberto Astori (Figura 9.20). A vegetação do parque atrai avifauna, inventariada em 2010 pela $\operatorname{SVMA}^{9}$, e a prática da coleta de plantas por usuários (Figura 9.21) para utilização em chá, etc.

O mercado imobiliário aquecido em São Paulo, nos últimos tempos, mostra a tendência para lançamentos de empreendimentos a sudoeste do município, que conforme Vilaça (2001), tal como apresentado no capítulo 5, é o quadrante no qual se concentra a população de renda mais alta. $O$ mercado, além disso, se aproveitando do interesse da sociedade nas questões ambientais, vem explorando os espaços verdes públicos nas suas campanhas de propaganda, em várias cidades. O parque-aterro Raposo Tavares, mesmo com todos os problemas apresentados, tem funcionado como chamariz para lançamentos imobiliários, como é o caso do Clube Raposo - Espaço Residência, na Rodovia Raposo Tavares Km 14, ao lado do Raposo Shopping (Figura 9.22).

\footnotetext{
${ }^{9}$ A SVMA publicou no Diário Oficial da Cidade (DOC), de 21 de maio de 2010, no caderno suplemento o Inventário da Fauna do Município de São Paulo, disponível no sítio eletrônico da Secretaria ( Anexo J).
} 

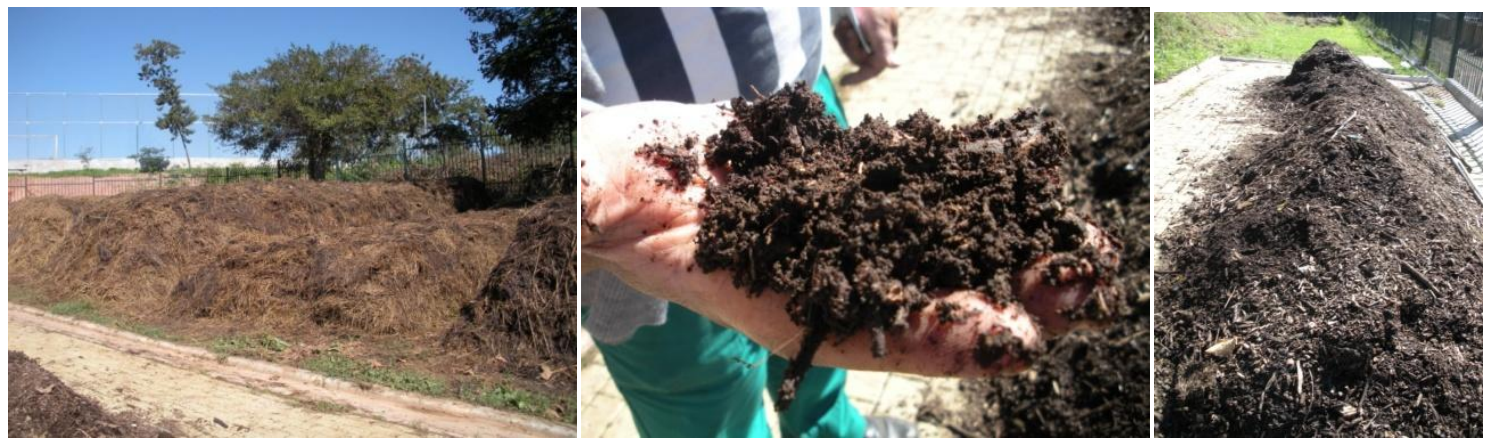

Figura 9.19 - Composteira implantada no parque em 2009. Data 03/06/09.

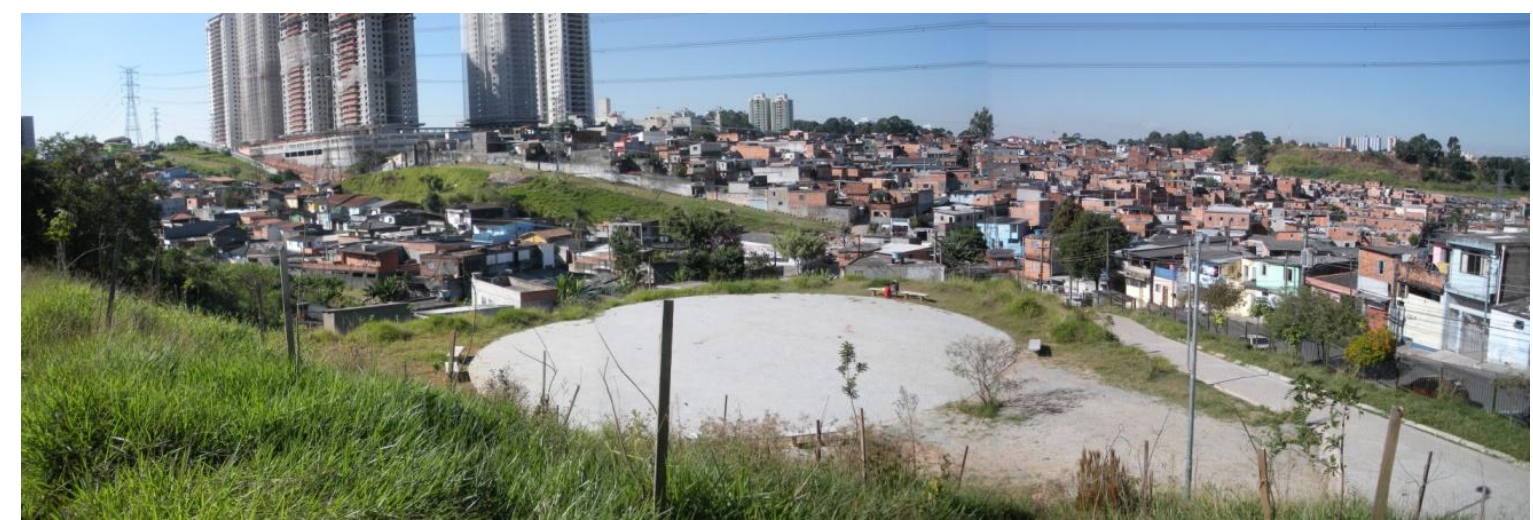

Figura 9.20 - Largo à jusante do talude de um dos campos de futebol, voltado para a R. Alberto Astori. Ao fundo notar o condomínio de prédios junto à Rod. Raposo Tavares. À esquerda, avista-se a Vila Albano e à direita o Jardim Jaqueline. Data 03/06/09.
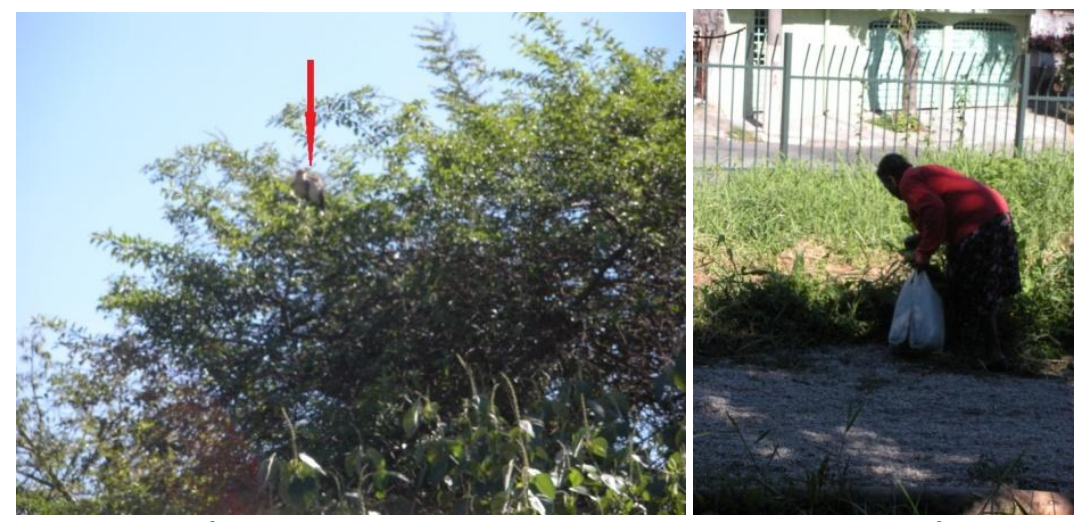

Figura 9.21 - No topo da árvore casal de passarinhos e no caminho, usuária colhendo planta.

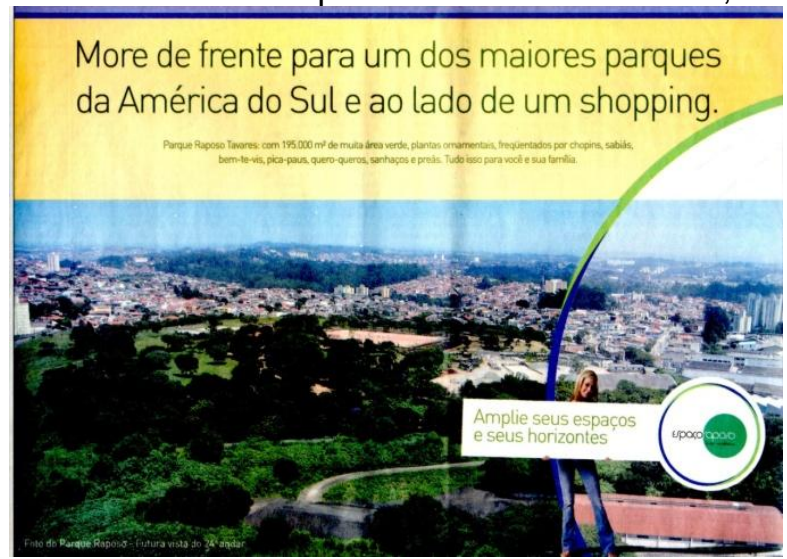

Figura 9.22 - Empreendimento Clube Raposo - Espaço Residência , Rod. Raposo Tavares Km 14, mostrando a vista do parque do $24^{\circ}$ andar.

Fonte: Folha de São Paulo, Caderno Brasil. Domingo, 11Mar2011. p. A9. 


\subsubsection{Plano de Gestão Preliminar do parque-aterro Raposo Tavares}

No período de 2009-2010, a SVMA iniciou as discussões para a elaboração dos planos de gestão dos parques municipais. Segundo o ex-administrador do parque, Fábio Pellaes, as propostas seriam elaboradas e, posteriormente, discutidas em conjunto para que em seguida os planos de cada parque fossem oficializados. Alguns parques tiveram seus planos desenvolvidos, mas 0 trabalho não teve continuidade e, segundo a atual administradora Maíra Lucia J. dos Santos, o instrumento permanece sem regulamentação até o momento.

O ex-administrador Fábio elaborou uma proposta de Plano de Gestão do Raposo Tavares que incluía o seu zoneamento (Figura 9.23, Anexo K), reproduzido a seguir:

- Área Administrativa/Manutenção: destinada às instalações da Administração, sanitários públicos, vestiários de funcionários, sala e depósito de manutenção e vigilância;

- Centro de Referência em Segurança Alimentar e Nutricional do Butantã (CRSAN): área com horta comunitária, Telecentro (em implantação), salas multi-uso, salão para plenárias e reuniões. Existe a possibilidade de este espaço abrigar a Sala Verde Raposo Tavares.

- Subprefeitura do Butantã - Unidade de Tráfego Intenso (UTI): área no interior dos limites do parque, utilizada pela Subprefeitura como depósito de fresa, galpão e oficina para reparo de veículos e posto de combustível. Desde final de 2009 em processo de desativação para incorporação ao Parque.

- Área de uso Intenso: área composta por quadras, quiosques, churrasqueiras, pistas, áreas de estar e gramados.

- Área de uso Restrito: destinada à compostagem, minhocário e viveiro.

- Área de Mata em Formação: devido a sua declividade, estas áreas apresentam baixo trânsito de freqüentadores e mostram os melhores resultados quanto à recomposição vegetal - o que as tornam áreas interessantes para plantios de enriquecimento.

O CRSANS atende a comunidade e tem a missão de apresentar soluções e métodos para a melhoria da qualidade de vida através da segurança alimentar, produção participativa, economia solidária e cultura de paz. Este centro é uma iniciativa pioneira, originada de um Termo de Cooperação, em que a SVMA (poder público), Instituto Pólis (OnG's) e a comunidade (moradores da região, associações e suas lideranças) acordaram que, apenas por meio da intersetorialidade é possível atender às necessidades e aos anseios da população. 


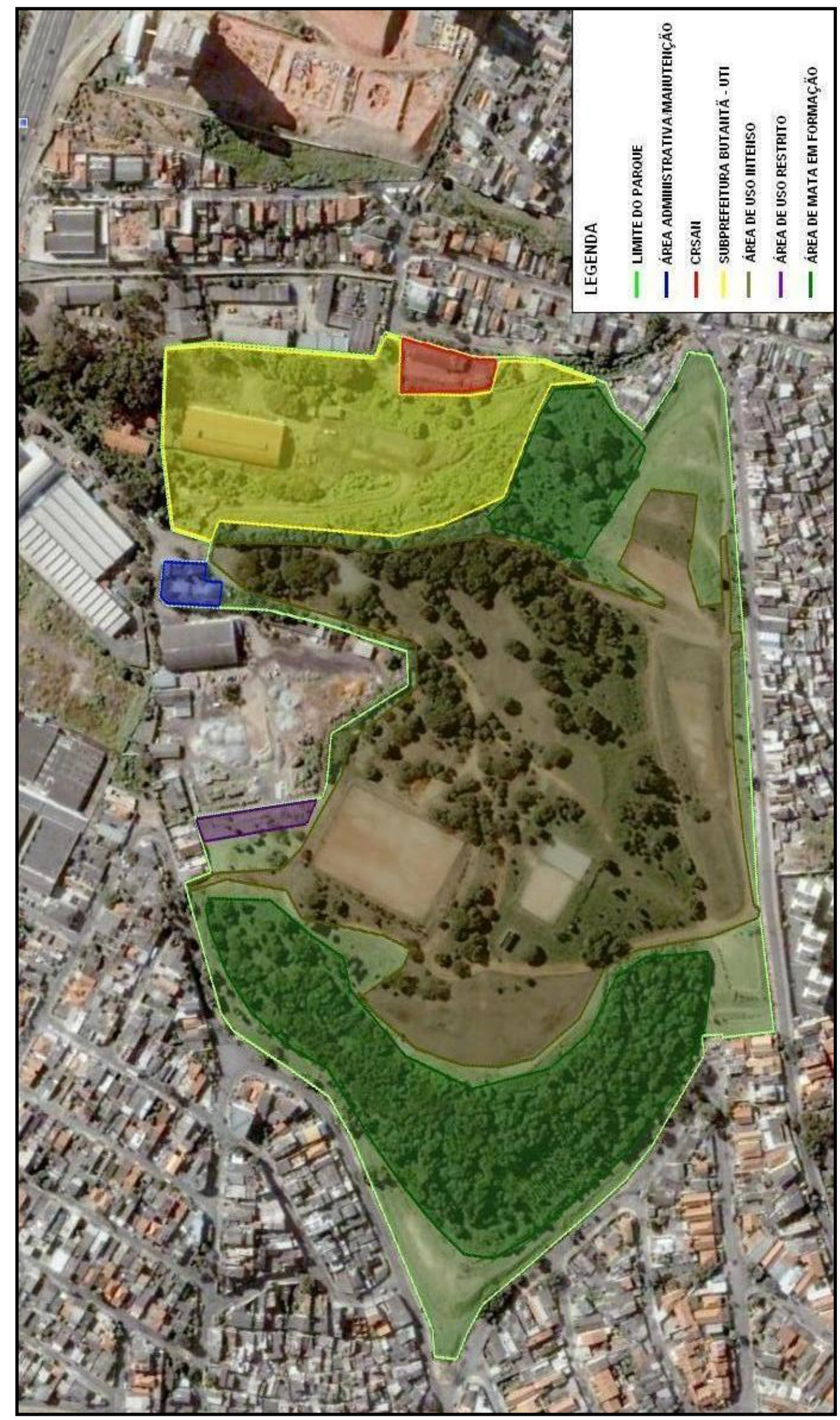

Figura 9.23 - Proposta preliminar do Plano de Gestão do parque-aterro Raposo Tavares, elaborada pelo ex-administrador, Fábio Pellaes, em 2010.

Fonte: Cedido pela administradora Maíra Lucia J. dos Santos. 


\subsubsection{Problemas decorrentes do antigo aterro Raposo TaVares}

São inúmeras as ocorrências de erosão, escorregamento, percolação de chorume e emanação de gases, dentre outras, relatadas desde a implantação do parque-aterro. Persistem o afloramento de resíduos, em subsuperfície (Figura 9.24), e a percolação de chorume (Figura 9.25); além de possíveis emanações de gases nos drenos instalados na época da operação do antigo aterro.

O substrato característico do local e os subprodutos gerados prejudicam diretamente o desenvolvimento da vegetação. Silva (2001) relata que funcionários observaram que os eucaliptos pulavam para fora do terreno e mostra o escoramento de alguns exemplares para ajudar a sua fixação (Figura 9.26). Segundo consulta aos engenheiros agrônomos, realizada pelo autor, a raiz profunda do eucalipto (pivotante) não consegue se desenvolver na massa de resíduos, enquanto que o seu caule continua a crescer com os poucos nutrientes fornecidos pelo solo pouco espesso. O aumento do peso do caule associado à baixa capacidade de suporte da raiz provoca a sua queda. Desta forma, árvores com raízes superficiais e de menor porte conseguem melhor adaptação às condições restritivas desse ambiente.

Neder et al. (2005), em questionários aplicados aos usuários do parque, apontaram que a sua maioria não entendia o significado de um aterro e nem sabia avaliar os riscos associados à sua transformação em parque. Esse fato explicava a despreocupação dos freqüentadores com o afloramento do chorume e a indicação da segurança (85\%) como o principal problema do parque. Os autores notaram que é comum ocorrer, no parque e nos seus arredores, depredação à vegetação ocasionando sucessivos re-plantios e a preferência por mudas com maior DAP Diâmetro na Altura do Peito, que exigem uma cova mais profunda. Isso provoca o desenterramento do lixo em subsuperfície e a nutrição inadequada do seu sistema radicular; além dos custos dos serviços se elevarem.

A pouca espessura de cobertura com solo limpo utilizada na implantação do parque, expõe os resíduos muito freqüentemente. Isso pode ser observado junto às drenagens executadas, na instalação de equipamentos, no talude das quadras ou campos de futebol, etc. (Figura 9.27). 


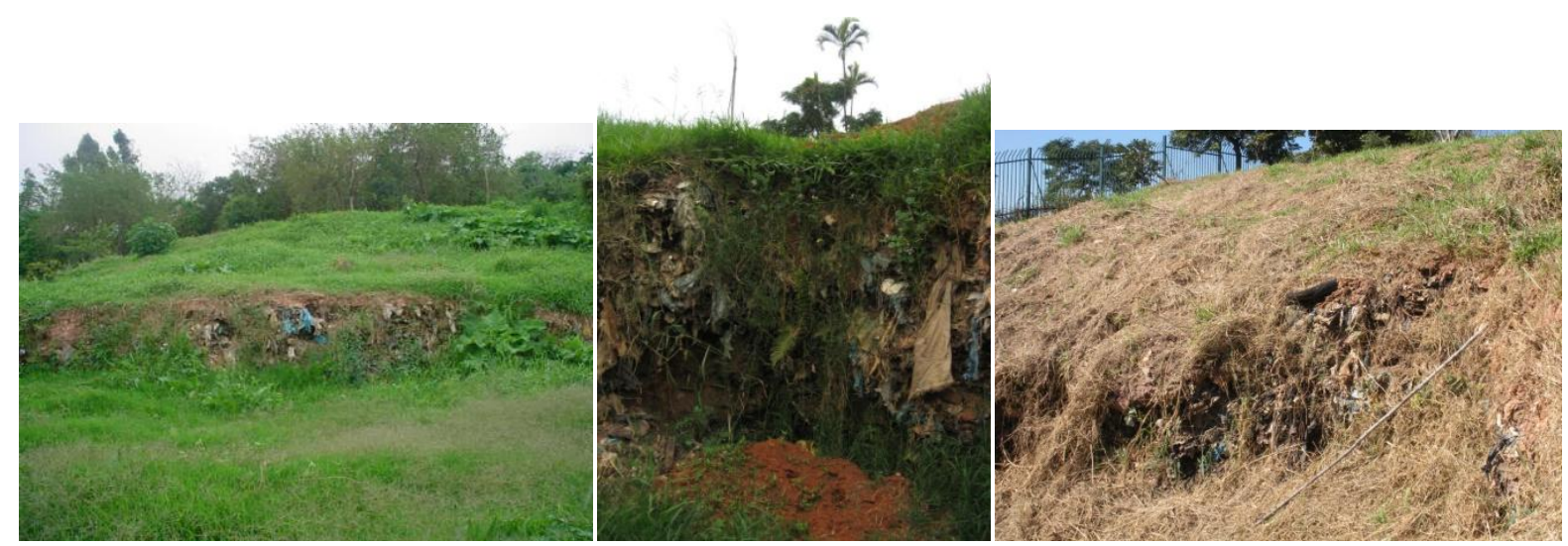

Figura 9.24 - Detalhe do afloramento dos resíduos, observados, da esquerda para direita, em 2005, 2008 e 2009, respectivamente.
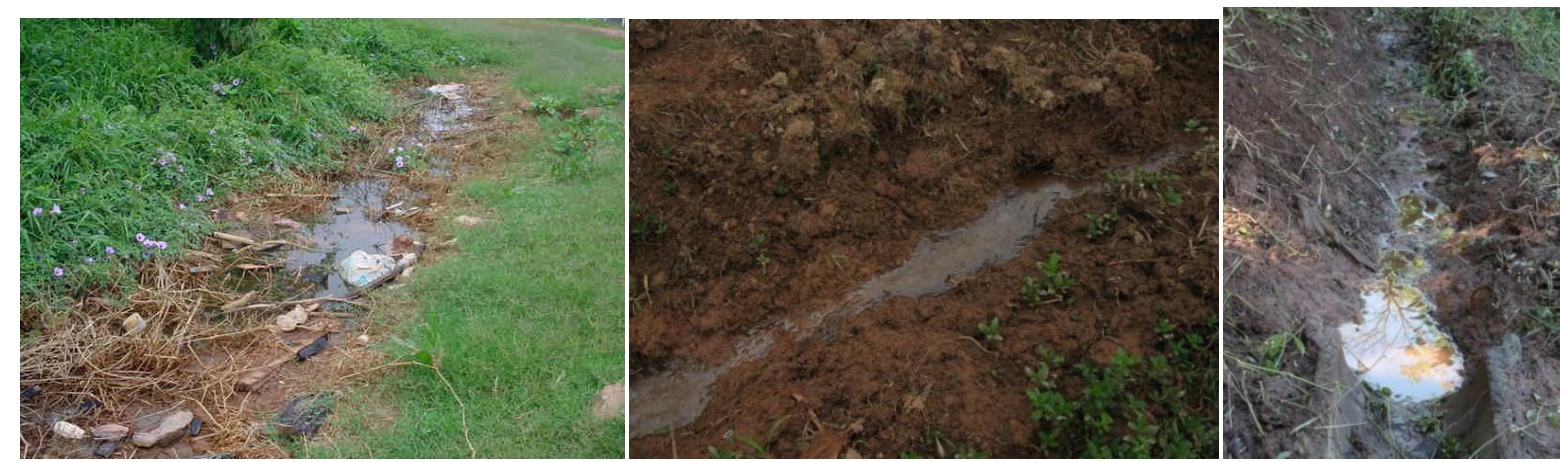

Figura 9.25 - Detalhe da percolação de chorume ainda recentemente observada, da esquerda para direita, em 2005, 2008 e 2009, respectivamente
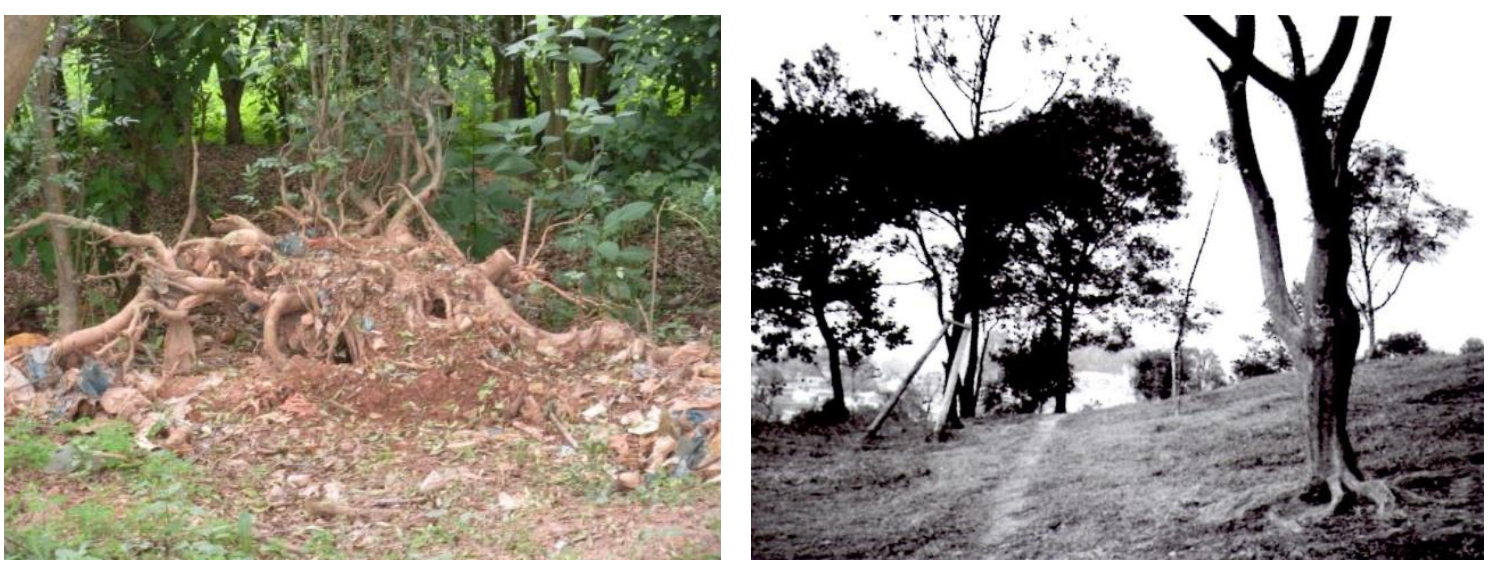

Figura 9.26 - À esquerda, detalhe mostrando o afloramento dos resíduos em área onde foi implantada vegetação de maior porte, que muitas vezes não sobrevive (03/06/09). À direita, dois exemplares de árvores distintas mostrando, em primeiro plano, melhores condições de adaptabilidade (raízes superficiais) e ao fundo escoramento do eucalipto (Silva, 2001, p.83). 

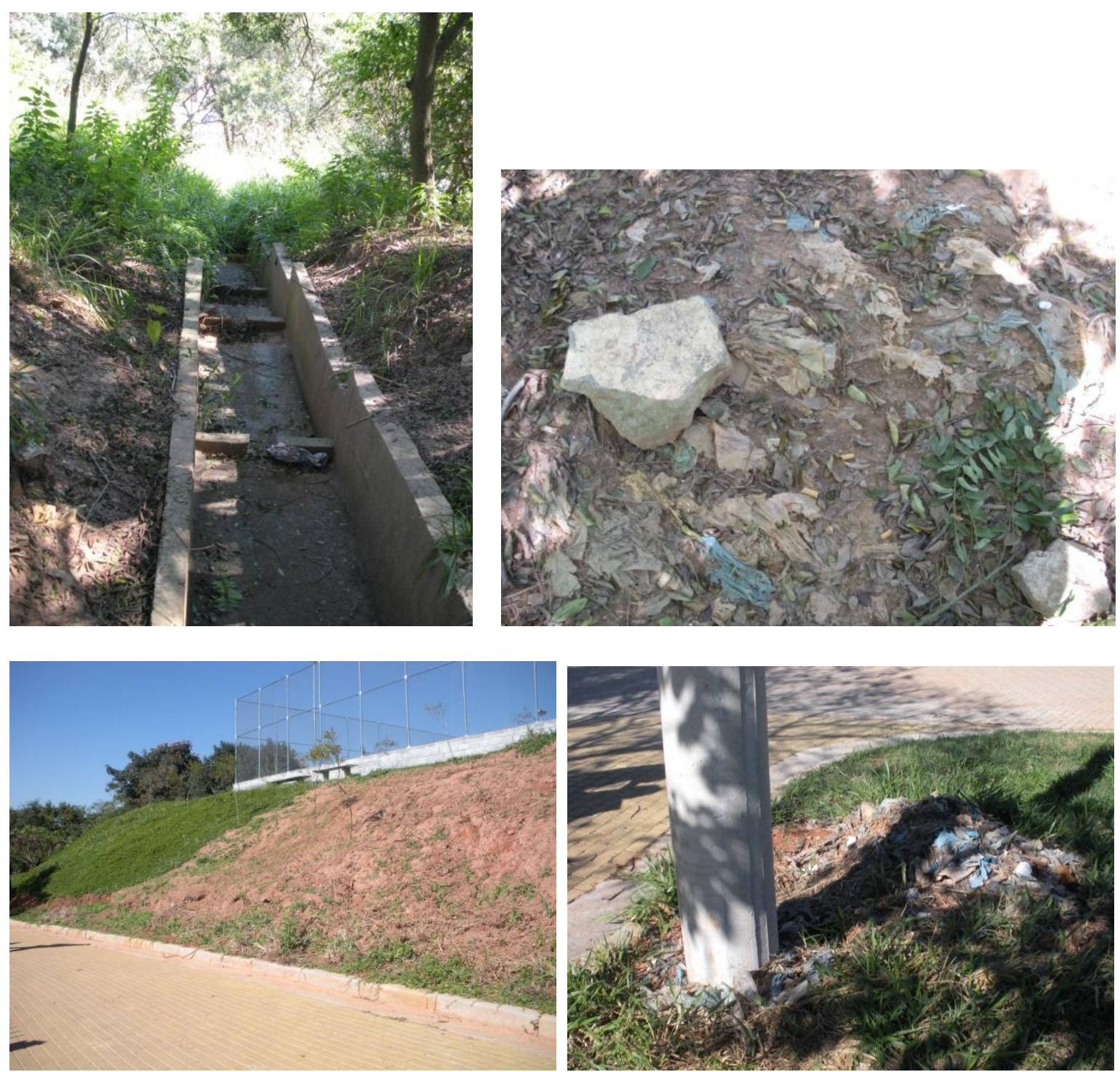

Figura 9.27 - Na parte superior, exposição dos resíduos nas proximidades da escada hidráulica.Abaixo, à esquerda, talude do campo de futebol onde aflora o resíduo, que está sendo recoberto pelo amendoim forrageiro. À direita, poste implantado provisoriamente, com a exposição do resíduo. Data 03/06/09.

\subsubsection{OUTROS PROBLEMAS EXISTENTES NO PARQUE-ATERRO RAPOSO TAVARES}

Neder et al. (2005) relatam que já na inauguração do parque, desprovido de cerca, os traficantes locais utilizavam o seu terreno como pasto para seus animais. Essa situação perdurou até por volta do ano de 2007, conforme informação do exadministrador.

A descaracterização da região como área de descarte de resíduos (ponto viciado) aparentemente não ocorreu até hoje, pois mesmo depois de muitos anos de encerrada aquela atividade e de sua transformação em parque a concentração de lixo, nas vizinhanças ainda ocorre. No interior do parque-aterro e no seu entorno, 
observam-se vários pontos utilizados para o descarte de lixo, com destaque para o cruzamento entre as ruas Alberto Astori e Domingos Nogueira, conhecida por Praça Bragança, em área que antes pertencia ao parque (Figura 9.28). Essa questão se revela no relato do ex-administrador do parque, que considera que o "aterro permaneceu vivo no inconsciente das pessoas". Informa que o local até hoje é chamado de lixão e, que muitas pessoas nem sabem onde fica o parque. Ao se perguntar para as crianças: - Onde vocês vão brincar? A resposta é invariavelmente: "- A gente está indo brincar no lixão".

Em algumas áreas, também se observa vestígios da prática de atividades religiosas, a exemplo de materiais utilizados em oferendas (Figura 9.29). Na divisa leste, no encontro das ruas Valentin Seitz e Denis Chaudet, as moradias provavelmente invadiram os limites do parque e os moradores abriram uma passagem na grade para acesso ao parque; que é utilizado como extensão de suas moradias (área de serviço) (Figura 9.30).

No período de 2007/2008, o Depave/SVMA iniciou um programa de identificação dos exemplares arbóreos, significativos, existentes nos parques municipais, com colocação de placas para denominá-los. Todavia, essa ação não obteve bons resultados, pois os usuários da maioria dos parques danificaram ou as retiraram. Pode-se aventar, segundo o Fábio, que o material (plástico) utilizado na sua confecção, de pouca resistência, tenha contribuído para a sua vida útil muito curta. As placas confeccionadas para o parque Ibirapuera utilizaram material diferenciado. No Raposo Tavares, de todas as árvores identificadas, apenas duas situadas na entrada do parque, ainda permaneciam com as suas placas de identificação, mas uma delas danificada; o restante das placas havia sido retirado (Figura 9.31).

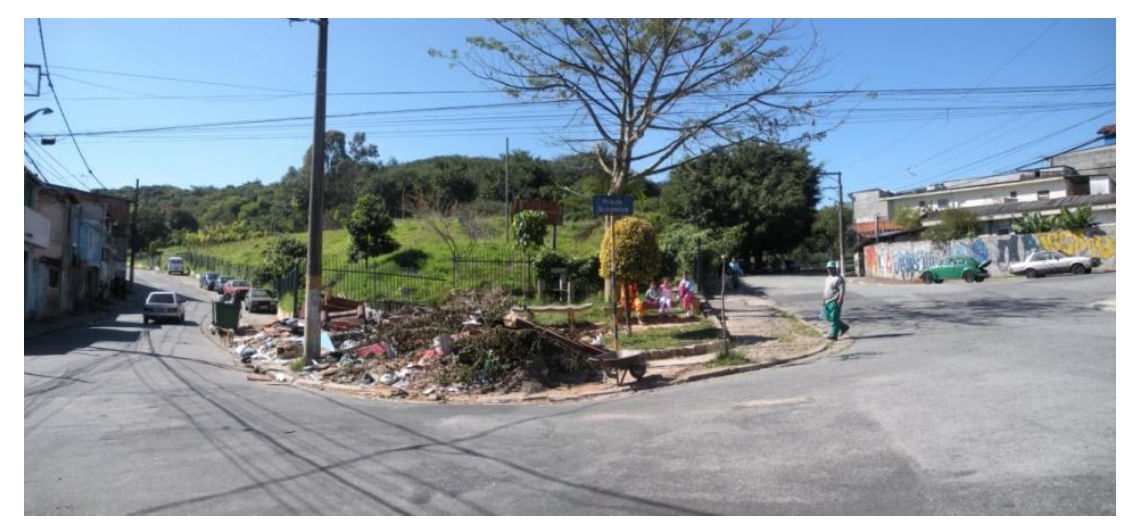

Figura 9.28 - Descarte de resíduos na Praça Bragança, limite sudoeste do parque. Data 03/06/09. 
Requalificação dos Aterros Desativados (BrownfieldS) no MunicíPIo de SÃo PaUlo: Parques (GreenfieldS) RAPOSO TAVARES E JARDIM PRIMAVERA

LUZIA HELENA DOS SANTOS BARROS
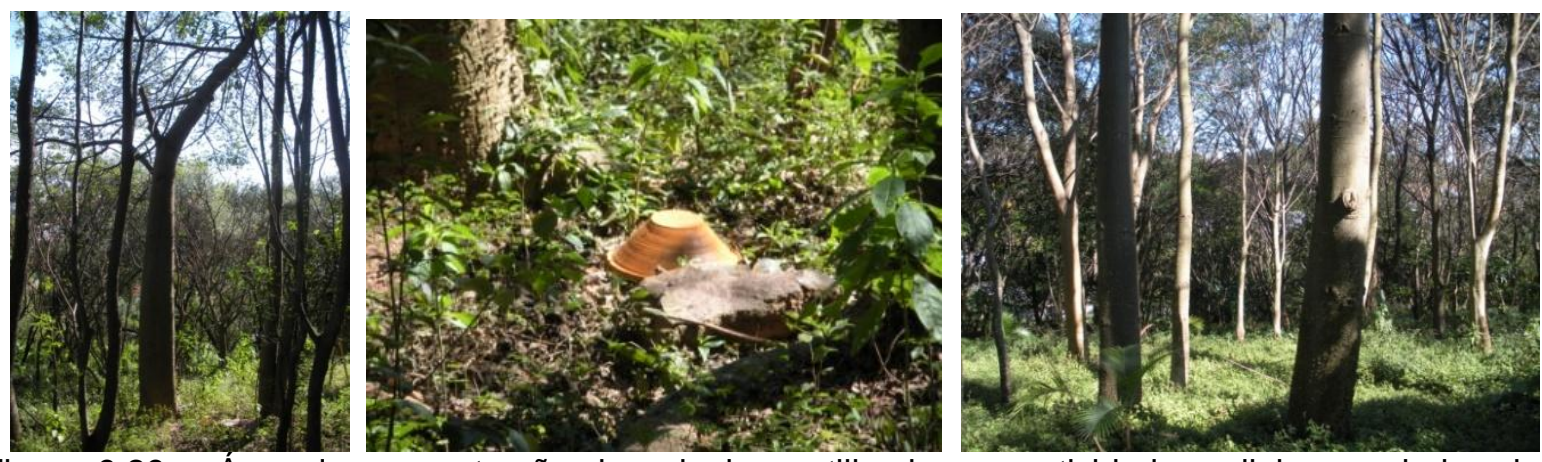

Figura 9.29 - Area de concentração de paineiras, utilizada para atividades religiosas, abaixo dos quiosques. Data 03/06/09.
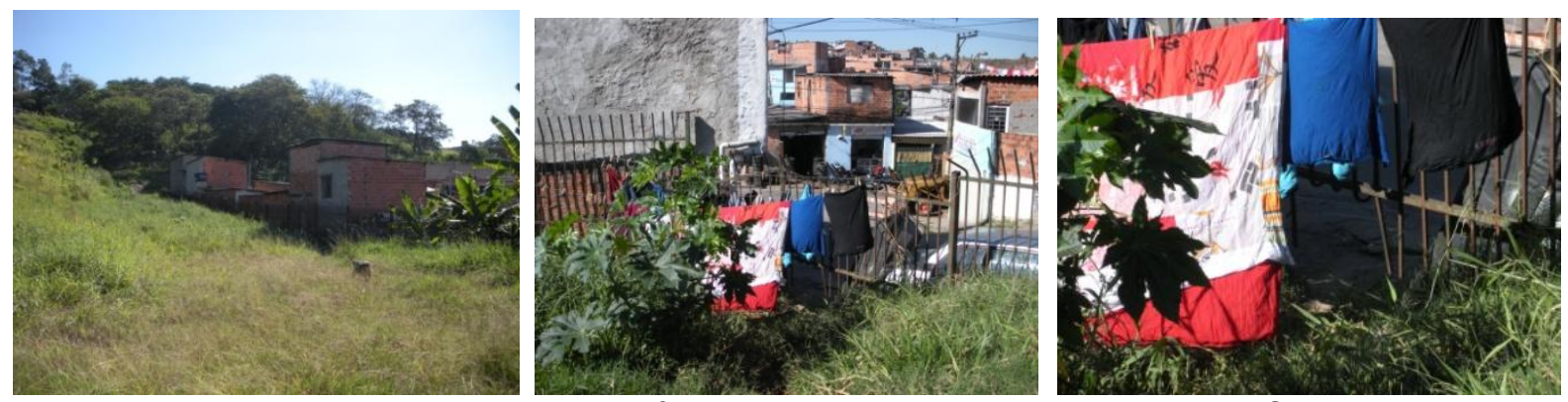

Figura 9.30 - Divisa leste do parque, próximo ao cruzamento das ruas Denis Chaudet e Valentin Seitz, onde, provavelmente, as moradias invadiram os limites do parque, com abertura de passagem através da grade. Data 03/06/09.
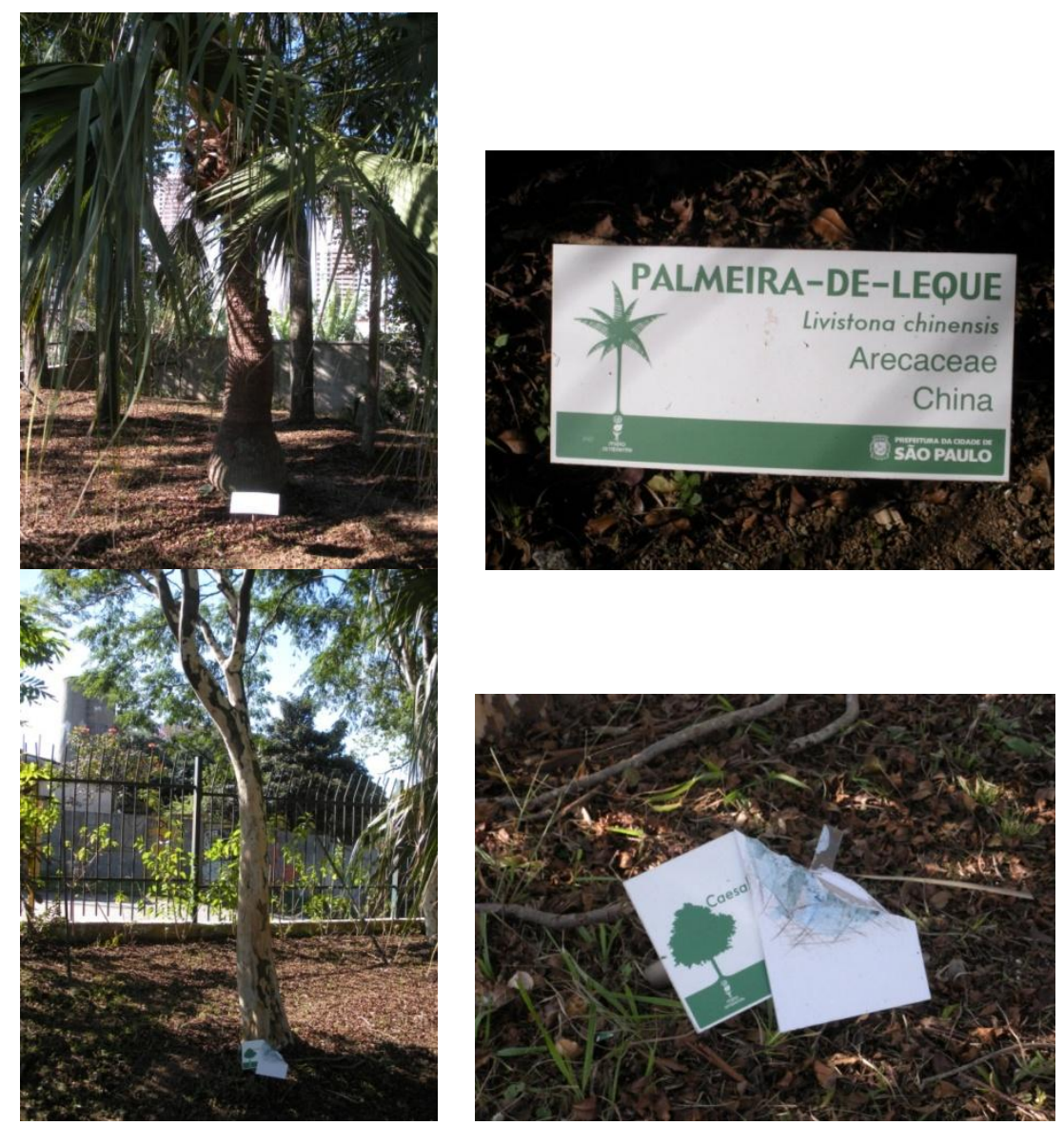

Figura 9.31 - Exemplares arbóreos que ainda permanecem identificados no parque-aterro Raposo Tavares. Notar que uma das placas está danificada. Data 03/06/09. 
O trato com os equipamentos instalados e as mudas plantadas no parque vem há muito tempo sendo motivo de preocupação do Depave. Desde a inauguração do parque existem relatos de vandalismo (destruição dos banheiros, brinquedos, etc.) praticados pelos usuários. Esse fato persiste até hoje, pois o exadministrador comenta que um dos seus maiores problemas é a perda de mudas, devido a essas ações. Ele percebe, também, uma série de "sintominhas" reveladores do não reconhecimento da área como parque. Algumas ações de parte dos usuários fazem diferença. "[...] Eles têm uma idéia muito distorcida do espaço público. [...] Se ele é nosso, na verdade ele é meu, posso fazer o que quiser". Cita como exemplo, as hortas implantadas para consumo próprio no parque.

Segundo a pesquisa de perfil de usuários realizada há pouco tempo, de acordo com o administrador Fábio, a maior parte dos freqüentadores mora na região e vem a pé, à exceção dos times de futebol. Relata que existe uma rivalidade entre as comunidades. Segundo ele, a administração do parque elege como público alvo a comunidade dos usuários do parque como um todo, mas a realidade é outra. Os moradores se identificam como Comunidade Jaqueline, Comunidade Mandioquinha, Vale da Esperança, etc. e disputam a localização para a implantação de cada equipamento ou exigem a instalação do mesmo equipamento próximo a cada comunidade. Outra questão, apontada pelo Fábio, é a utilização do parque para defender interesses pessoais como se fossem coletivos, utilizando-se da participação no Conselho Gestor. A maioria dos conselheiros está interessada na "visibilidade junto à comunidade". Cita o exemplo da solicitação de um segundo campo de futebol que, segundo ele não seria prioridade naquele momento. Afirma que os piores episódios de violência ocorridos no parque estavam relacionados ao campo de futebol.

Apesar de todos os problemas ainda existentes no parque-aterro, a sua situação mudou bastante nesses últimos dez anos, pois o quadro era de completo abandono (Figura 9.32). 


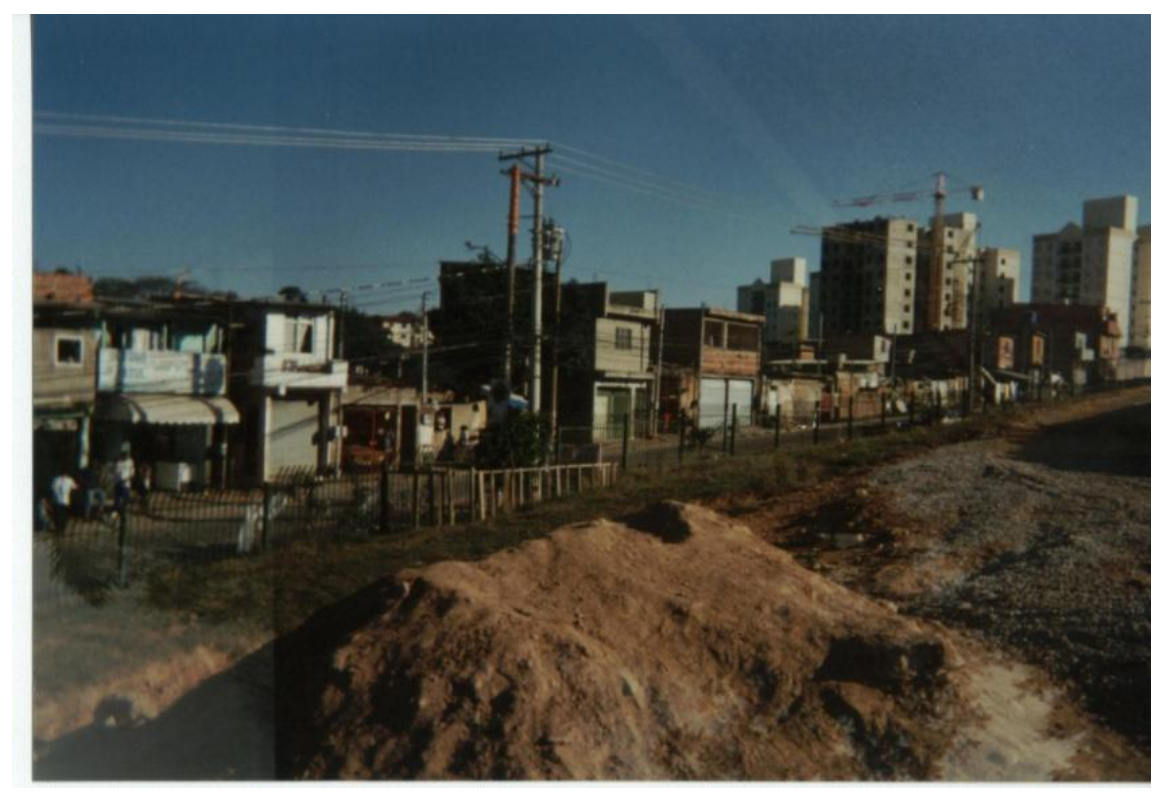

Figura 9.32 - Panorama do parque-aterro Raposo Tavares em 2001.

Fonte: Foto cedida pelo administrador Fábio Pellaes.

\subsection{PARque-ATERro Jardim PrimaVera}

No início da década de 1990 foi elaborado o primeiro projeto para a implantação do parque, denominado Primavera. $O$ projeto $^{10}$ foi desenvolvido pela equipe técnica da Divisão de Projetos do Departamento de Parque e Áreas Verdes (Depave), ligado, à época, a Secretaria Municipal de Serviços e Obras (SSO), que promoveu reuniões com a comunidade e o Departamento de Limpeza Urbana (Limpurb), da mesma SSO. Apesar de não ter existido nenhuma avaliação prévia, quanto à contaminação provocada pelos resíduos, a sua concepção aparentemente levou em conta o substrato do aterro, visto que a equipe questionou a implantação do parque em aterro, ainda não estabilizado. Poucas edificações foram previstas, a serem construídas fora do maciço de resíduos; além de quadras esportivas gramadas, sobre os platôs do aterro, evitando-se pisos rígidos, provavelmente, para minimizar os problemas com os possíveis recalques e de confinamento de gases, bem como o cuidado de recomendar a seleção de espécies da vegetação com raízes superficiais.

Entretanto, ao se iniciarem as obras do parque muitos problemas, desconhecidos até então, foram constatados, destacando-se: o forte cheiro de gás nas antigas instalações da Limpurb, borbulhas provocadas pelas suas emanações,

\footnotetext{
${ }^{10}$ A implantação do parque foi tratada no processo administrativo $02.002 .812 .90 * 06$, arquivado desde 1994
} 
nas poças d'água, inclusive externas ao maciço do aterro e, dificuldade para a implantação dos gramados. Esses problemas determinaram a paralisação das obras, em 1991, com a sugestão de que se aguardasse a estabilização do terreno e a eliminação dos gases para posterior implantação do parque.

Em dezembro de 1991, a Seção Técnica de Levantamento dos Recursos Naturais, do Depave, ainda na SSO, iniciou um projeto piloto para a recomposição da vegetação no aterro (Fukushima-Hein et al., 1992). Foram delimitadas três áreastestes com diferentes tipos de vegetação: bosque de essências nativas e exóticas, gramíneas e leguminosas e regeneração espontânea. Foi previsto o prazo de cinco anos para o acompanhamento da adaptabilidade das espécies ao substrato.

Em 1995, foram plantados 5.000 eucaliptos sobre o antigo aterro, de acordo com o morador Sylvio, ação que integrava o Projeto Um Milhão de Árvores. Segundo o administrador Sérgio, os eucaliptos plantados, principalmente sobre o núcleo da massa de resíduos, muito próxima à superfície, pouco se desenvolveram ${ }^{1}$, possuem pequeno Diâmetro na Altura do Peito - DAP $(0,10 \mathrm{~m})$ e tendência de queda freqüente. Quanto às espécies frutíferas, cita a presença de bananeiras, que se reproduzem absurdamente $\mathrm{e}$, as amoreiras, introduzidas pelo projeto de revegetação iniciado em 1991; vistosas, grandes e com farta produção de frutas (Figura 9.33), consumidas pelos vigilantes e pelas crianças.

Em 2002, a Lei Municipal 13.308, criava oficialmente o Parque Jardim Primavera (Figura 9.34), garantindo a execução dos estudos da avaliação ambiental, determinando prazo para a sua regulamentação (60 dias) e início da sua construção (180 dias). A Lei relacionava os equipamentos a serem implantados (padrão parque) e incluía: viveiro de plantas, para fornecer mudas à população, vegetação arbórea, de grande porte em $40 \%$ da área do parque e a criação do Conselho Gestor.

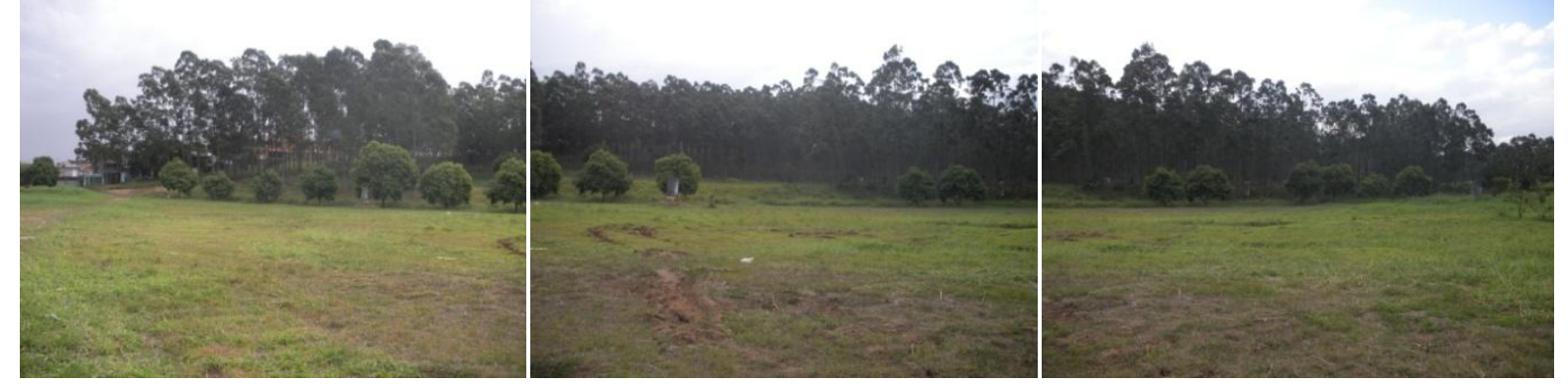

Figura 9.33 - Vista geral do antigo aterro Jacuí (07/06/2011), mostrando os eucaliptos plantados por volta de 1995, ao fundo e, as amoreiras, em primeiro plano, introduzidas em 1991.

${ }^{1}$ O Eng. Agr. José Francisco de Almeida Neto (Depave/SVMA) observou, em 2008, que os eucaliptos com cerca de dez anos de idade apresentavam porte de cinco anos. 


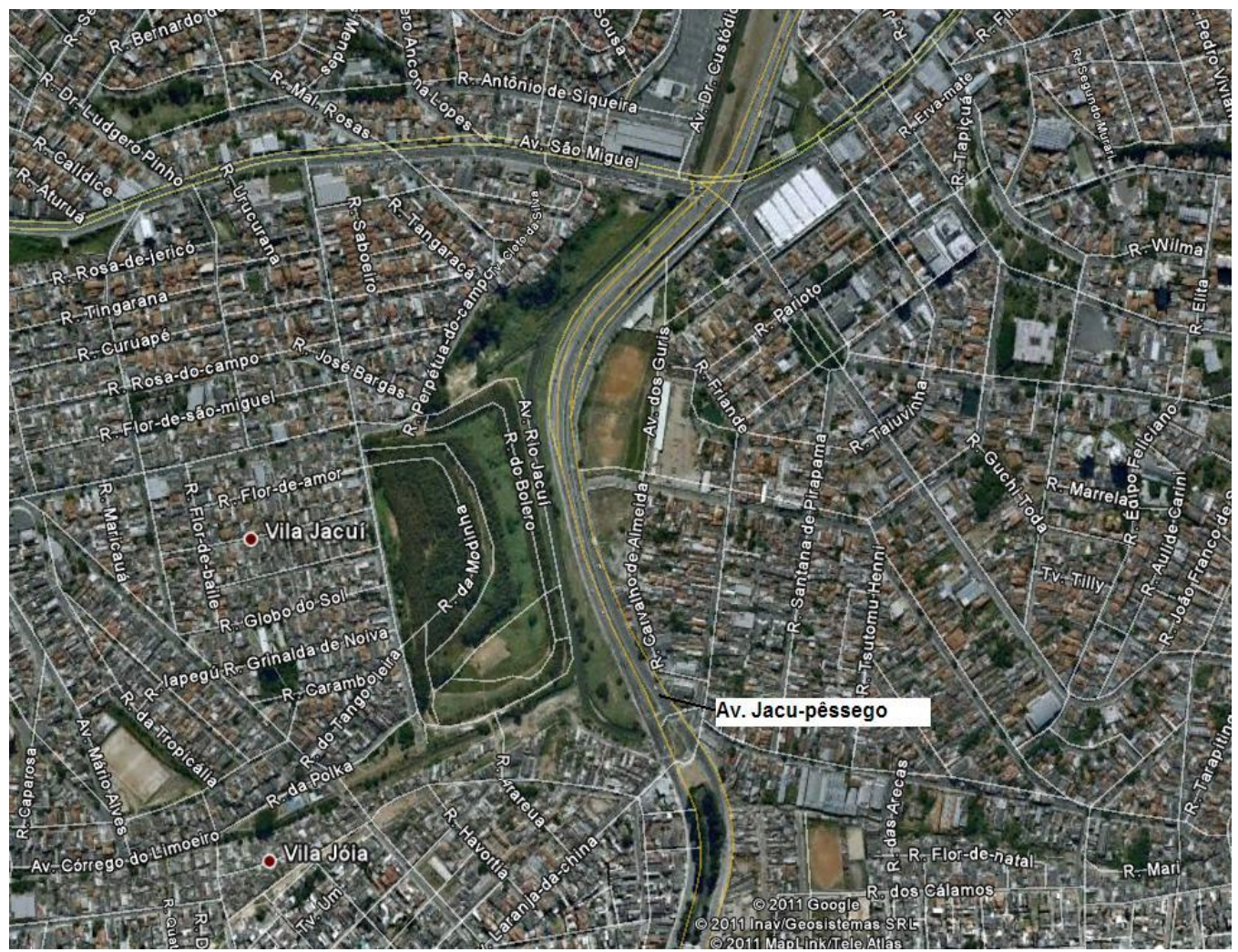

Figura 9.34 - Imagem aérea do aterro desativado Jacuí (14/12/2008), sobre o qual está sendo implantado o Parque Jardim Primavera.

Fonte: Google Earth. Acesso em 27Jul2011.

A reivindicação insistente dos moradores dos arredores do antigo aterro, o acompanhamento e exigências do Ministério Público, aliada aos estudos de avaliação da contaminação realizados, fez com que a Prefeitura retomasse o projeto para transformação do aterro em parque público. O Diário Oficial da Cidade, em 2006, estampava na sua primeira página: "São Miguel Paulista vai ganhar o Parque Primavera com 122 mil m"12, que beneficiaria também moradores de Ermelino Matarazzo, Itaquera e de Guarulhos.

Tendo em vista a confirmação de contaminação do solo e águas subterrâneas em alguns trechos e de gases na massa de resíduos, foi definido que o projeto e a sua implantação seriam desenvolvidos em duas etapas. Para o desenvolvimento do projeto foi selecionada, como primeira etapa (Fase 1, Figura 9.35), a parte do terreno onde não houve deposição de resíduos, com maior probabilidade de não apresentar riscos à saúde humana.

\footnotetext{
${ }^{12}$ Informava sobre reunião entre lideranças da região (OnG's, representantes do legislativo e empresafiais e entidades locais) para discutir a elaboração do projeto do parque, a ser realizada naquela data $(06 / 12 / 06)$.
} 


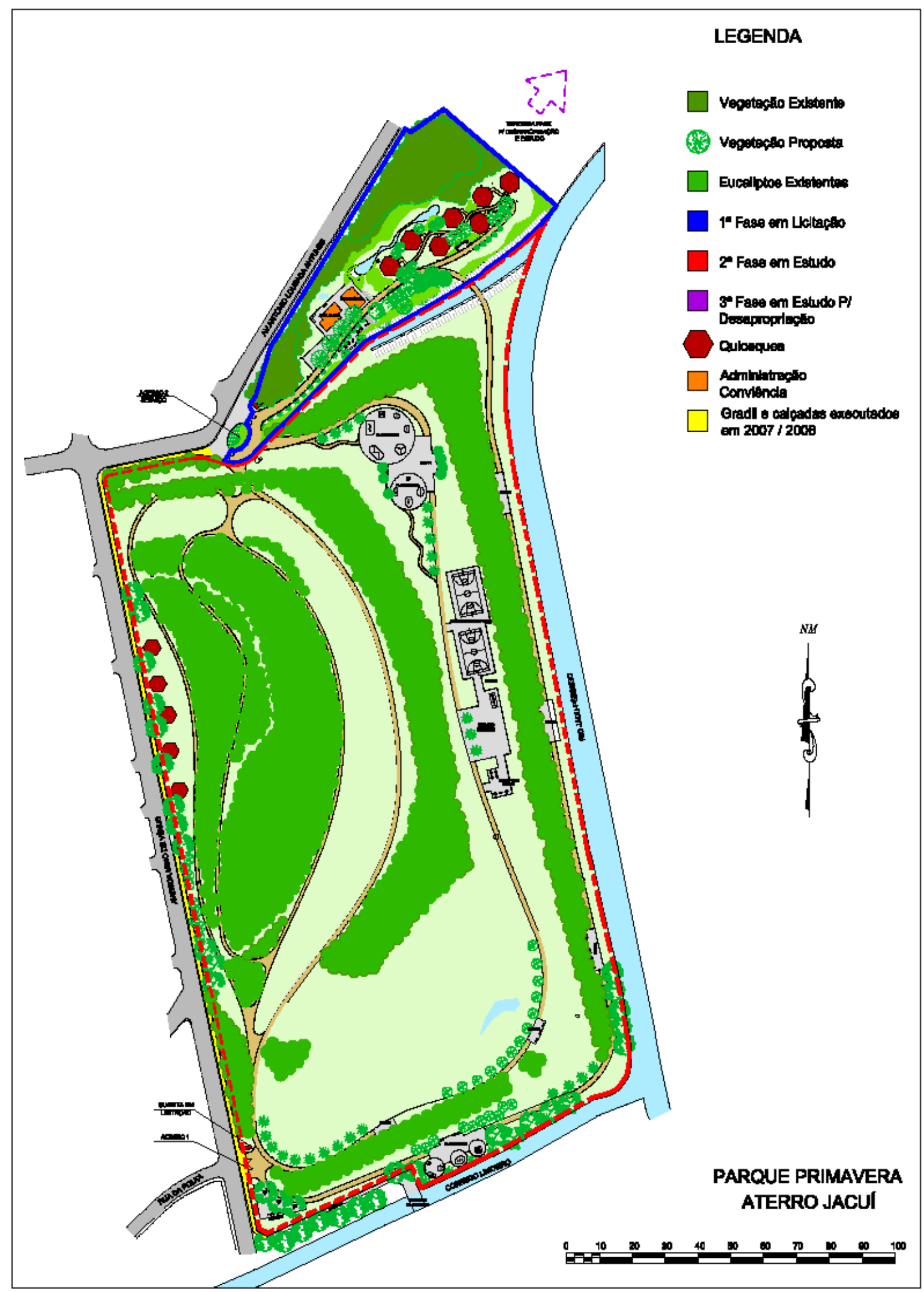

Figura 9.35 - Projeto do parque-aterro Jardim Primavera, elaborado em 2007 pelo Depave. Fonte: Depave/SVMA. 
O projeto do parque-aterro (Fase 1), elaborado em 2007-2008, por equipe da Divisão de Projetos ${ }^{13}$, do Depave, com subsídios técnicos do GTAC/Decont, foi concebido de forma a atender as exigências e recomendações efetuadas na avaliação ambiental anteriormente realizada, sem deixar de considerar, quando possível, as reivindicações da comunidade quanto aos equipamentos a serem instalados. Atende às exigências para pessoas com necessidades especiais, inclusive nas edificações, tendo sido aprovado pela Comissão Permanente de Acessibilidade (CPA). Foi apresentado à população esclarecendo-se as restrições da área e, no entendimento do morador Sylvio atendeu as suas expectativas. No entanto, conforme o futuro administrador relata, a população deseja uma ampla infra-estrutura de lazer, com todo o tipo de equipamentos existentes em outros parques. Não entendem as especificidades da massa de resíduos. Para a população é como se o lixo não existisse mais, a "terra comeu". Ressalta que as informações são fornecidas à sociedade organizada "[...] mas a grande massa não tem o domínio das informações".

A Fase 1 do projeto compreende o trecho da área municipal situada junto à Rua Perpétua do Campo (Figura 9.36), com cerca de $14.400 \mathrm{~m}^{2}$, onde existe declividades mais acentuadas do que no restante do terreno, com relevo mais suave, no qual está prevista a implantação de edificações e equipamentos: administração com sanitários, centro de convivência e quiosques. Os maciços de vegetação arbórea de grande porte, existentes nesse trecho, deverão ser preservados e, demolida a antiga estação de tratamento do chorume. Todas as áreas que permanecerão permeáveis deverão ser recobertas com solo, de boa qualidade na espessura de 0,30 metros, para eliminar a via de exposição por contaminação de metais identificada no solo. $\mathrm{Na}$ entrada do parque está projetada a utilização de piso intertravado, piso drenante em concreto no caminho principal e nas áreas externas das edificações e piso de terra e areia no caminho dos quiosques. A cerca tipo parque, projetada para todo o seu perímetro, foi implantada, em 2008, desconsiderando as aberturas das entradas do parque previstas no projeto. Ao longo de quase todo o seu perímetro foi implantada a calçada verde, em 2007 (Figura 9.37). Nesse trecho foi criado um pequeno lago aproveitando um represamento já existente.

\footnotetext{
${ }^{13}$ Arquiteto Carlos Minoru Morinaga, que fez parte da equipe do GTAC, no período entre 2002 e 2005 e, o Eng. Agrônomo José Francisco de Almeida Neto.
} 

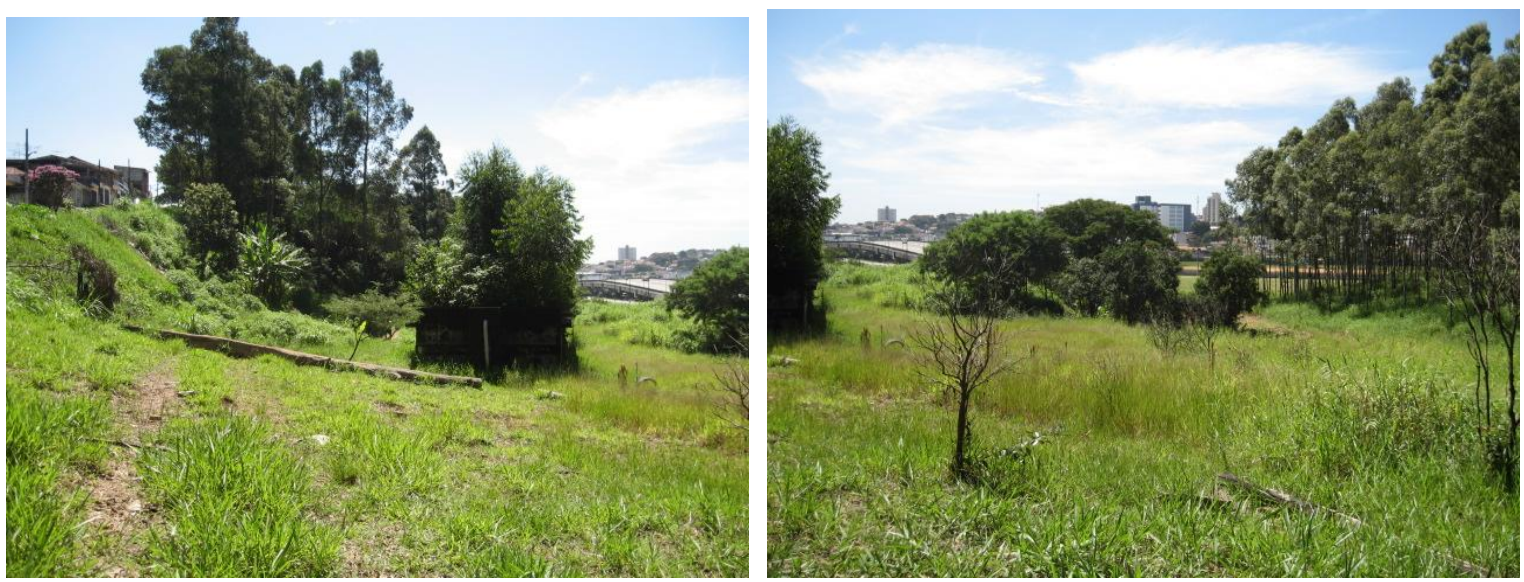

Figura 9.36 - Área destinada à implantação da Fase 1 do Parque-aterro Jardim Primavera. Situação em 2007.
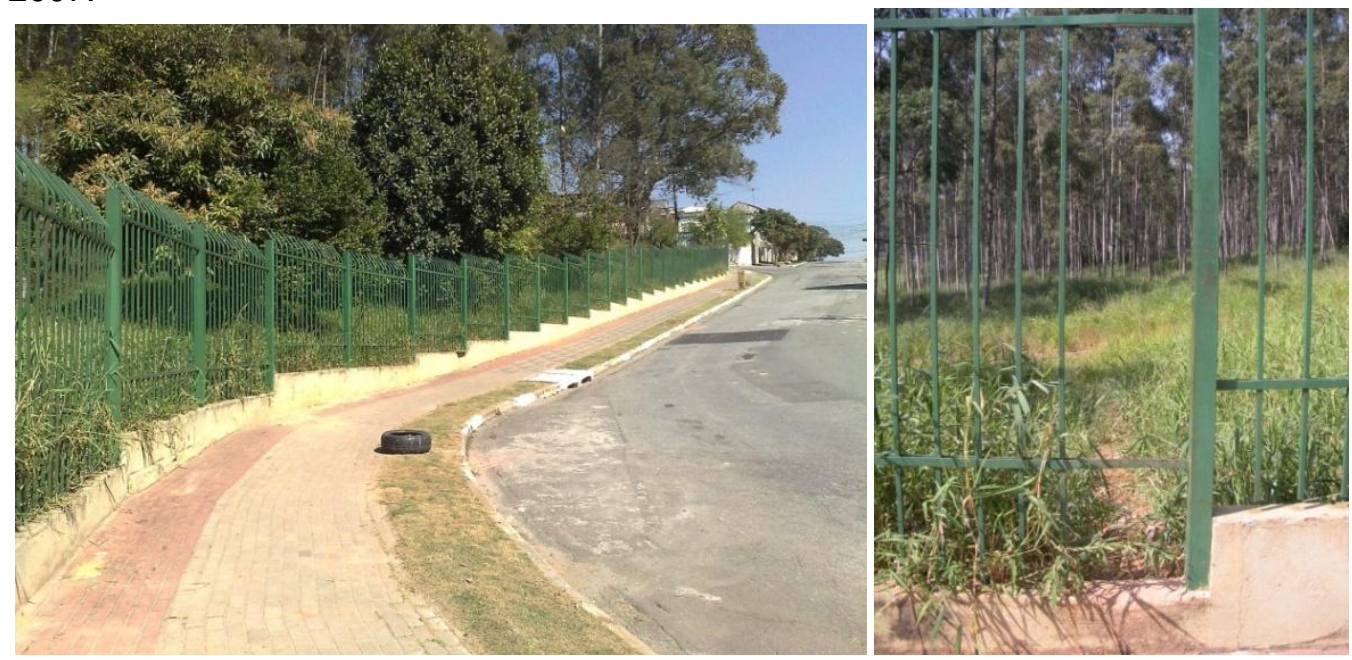

Figura 9.37 - Cerca tipo parque e calçadas verdes implantadas, em 2008, no parque-aterro Jardim Primavera. À direita, junto ao acesso projetado para a Fase 1, notar a passagem aberta na cerca, pelos moradores do entorno.

Para a vegetação foi previsto o reflorestamento do trecho entre as duas grandes massas preservadas, de modo a formar um maciço contínuo. As outras áreas devem receber tratamento paisagístico com espécies arbóreas nativas, gramados, arbustos e forrações. Recomendou-se, também, que a arborização das calçadas verdes complementasse o paisagismo do seu interior.

A implantação das obras do parque-aterro iniciou-se em setembro de 2008 (Figura 9.38). Durante a demolição da antiga caixa de contenção e tratamento do chorume (Figura 9.39) foi descoberto um resíduo de lodo (a 0,80 m de profundidade), que para ser retirado precisava de cuidados especiais, não previstos no contrato. Esse fato gerou a interrupção dos trabalhos e o cancelamento do contrato, no mesmo ano. As obras foram retomadas apenas em novembro de 2010 (Figuras 9.40 a 9.43), com custo previsto de $R \$ 1,74$ milhão e prazo de 300 dias 
para a sua execução ${ }^{14}$. O projeto foi readequado, eliminando-se três quiosques, situados mais a nordeste, dos sete previstos, a serem realocados na Fase 2. A alteração foi realizada em virtude dos três quiosques estarem interferindo na margem do Rio Jacú, Área de Preservação Permanente - APP (Figura 9.44). O parque-aterro possui cerca de $37.000 \mathrm{~m}^{2}$ de $\mathrm{APP}^{15}$.
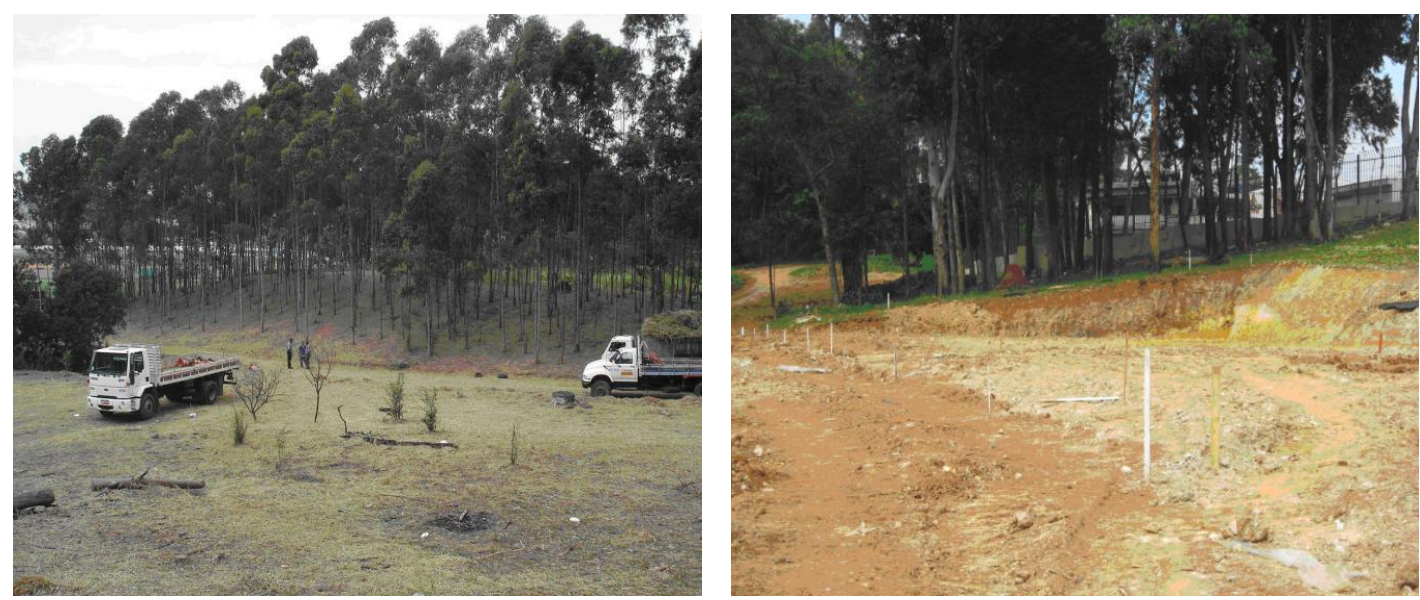

Figura 9.38 - Preparação do terreno destinado à implantação da Fase 1 do parque-aterro Jardim Primavera, à direita. À esquerda o início das obras, em 2008, em seguida interrompidas.

Fonte: Ramires e Vitor (2010)
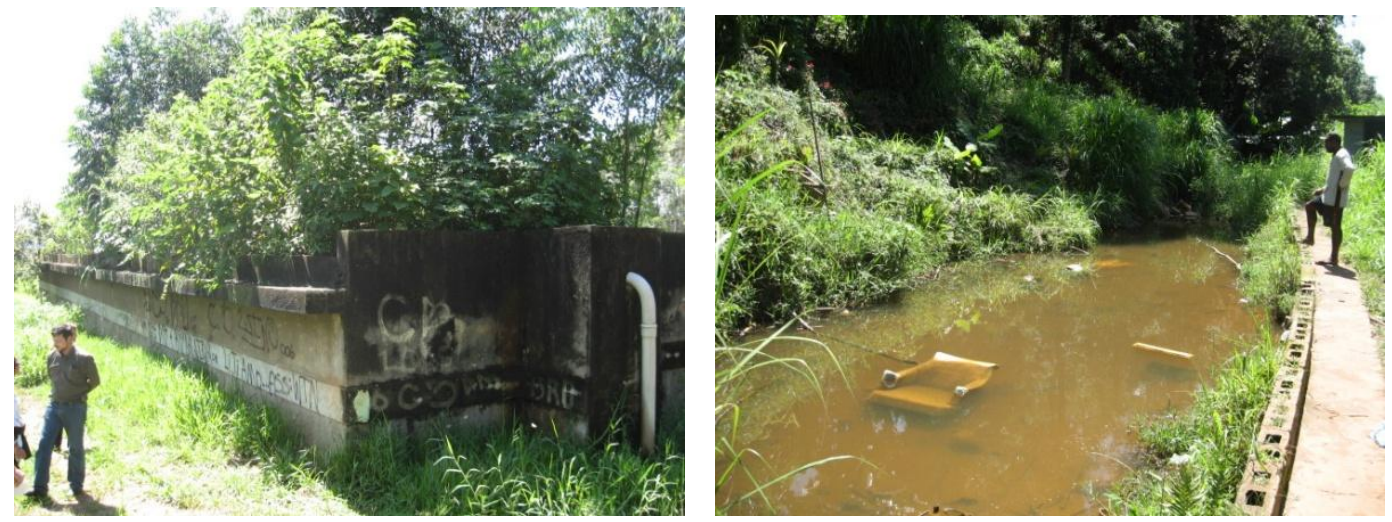

Figura 9.39 - Caixa de contenção e tratamento de chorume desativada, à esquerda. À direita, lagoa poluída existente ao lado da antiga caixa. Situação em 2007.

\footnotetext{
${ }^{14}$ Inicialmente os serviços para a implantação do parque (Fase 1) foram contratados pela SVMA no valor de R\$1,2 milhão (PA 2008-0.119.524-8 ). O GTAC/Decont/SVMA recomendou a retirada e o envio do chorume para a ETE da Sabesp. Acordo entre - Decont e a Limpurb/SS indicou a sua destinação para o CDR de Guarulhos. A nova contratação, devido a mudanças administrativas, foi efetuada pela Siurb (2009-0.350.483-5), com transferência da dotação orçamentária da SVMA. A fiscalização da obra, em andamento, é responsabilidade da Divisão de Edificações/Siurb, possuindo um acompanhamento do Depave/SVMA.

${ }^{15}$ Informações obtidas do administrador do parque, Sérgio Nunes, Depave, em 07/06/2011, do Arq. Edimilsom Peres Castilho (Depave), em 09/06/2011 e, de matéria realizada por Fabio Pagotto, 'São Miguel aguarda estréia de parque na zona leste', no jornal Diário de São Paulo, de 01/07/2011, p. 18-19.
} 

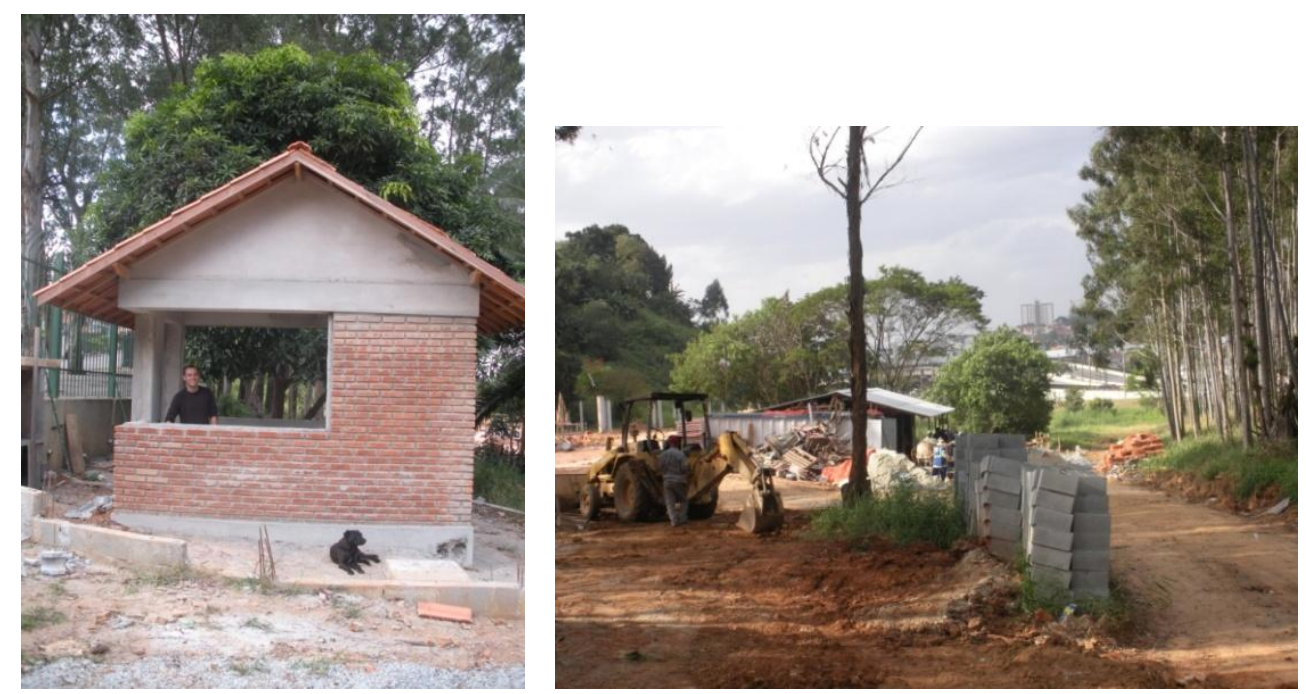

Figura 9.40 - Obras no parque-aterro Jardim Primavera. No canto superior esquerdo, a implantação da Guarita, no portão de acesso e, à direita, área de circulação junto à futura Administração. Data: 07/06/2011
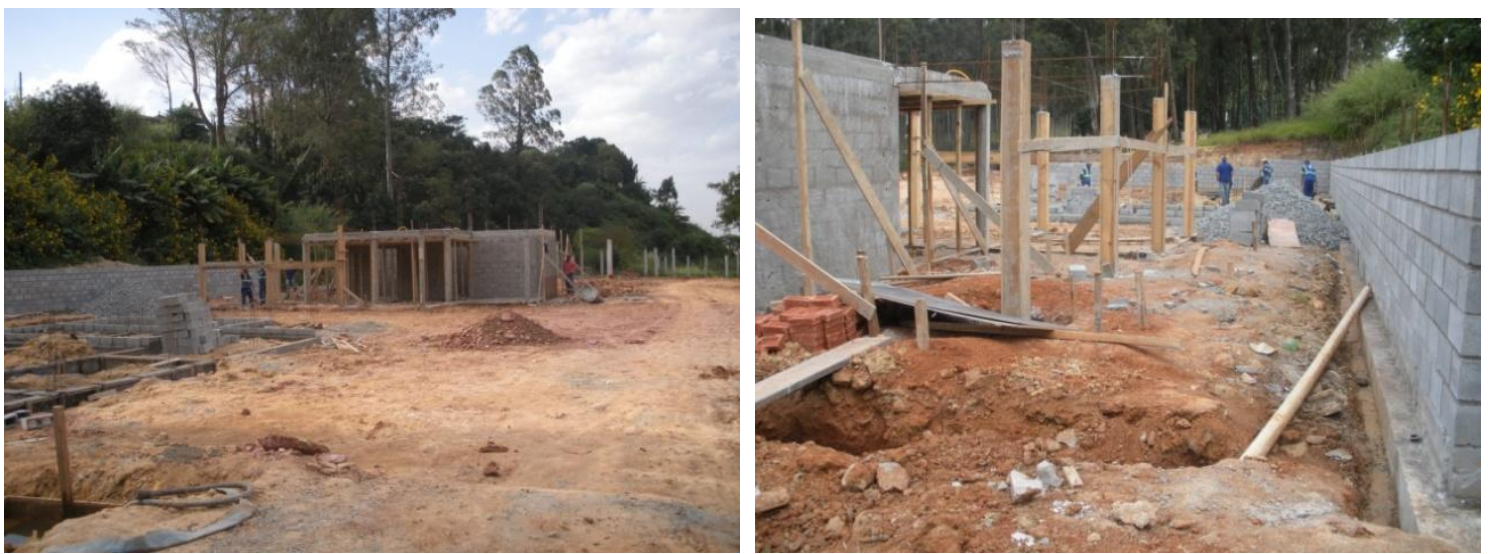

Figura 9.41 - Obras no parque-aterro Jardim Primavera. Implantação das edificações da Administração e Convivência. . Data: 07/06/2011
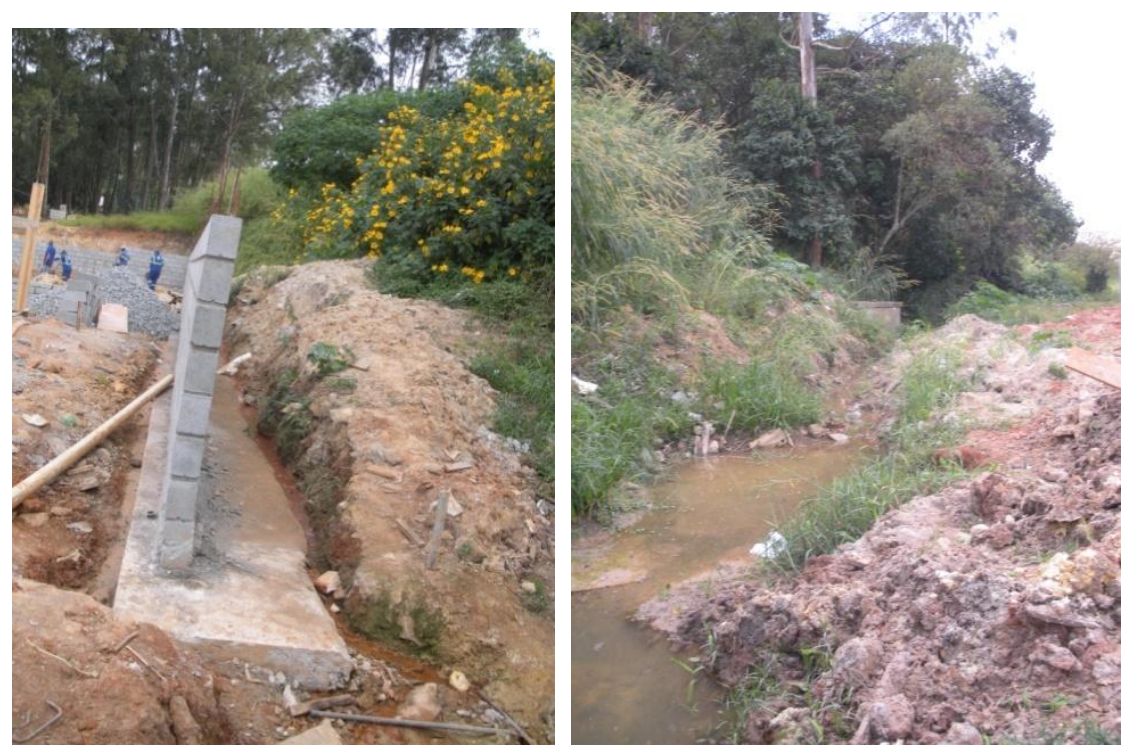

Figura 9.42 - Situação da drenagem existente no limite nordeste do parque-aterro Jardim Primavera, onde está previsto um espelho d'água, em 07/06/2011. 

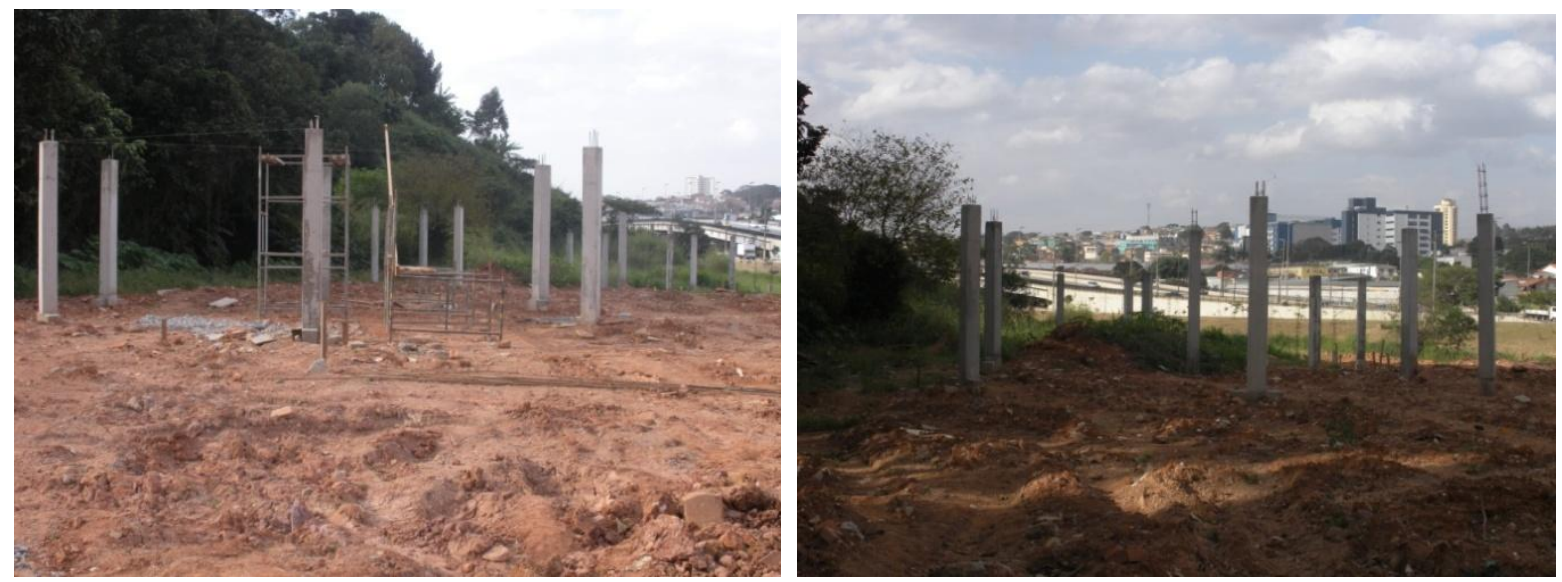

Figura 9.43 - Implantação dos quiosques no parque-aterro Jardim Primavera, em 07/06/2011. À direita, pilares de dois dos três quiosques realocados que serão demolidos.

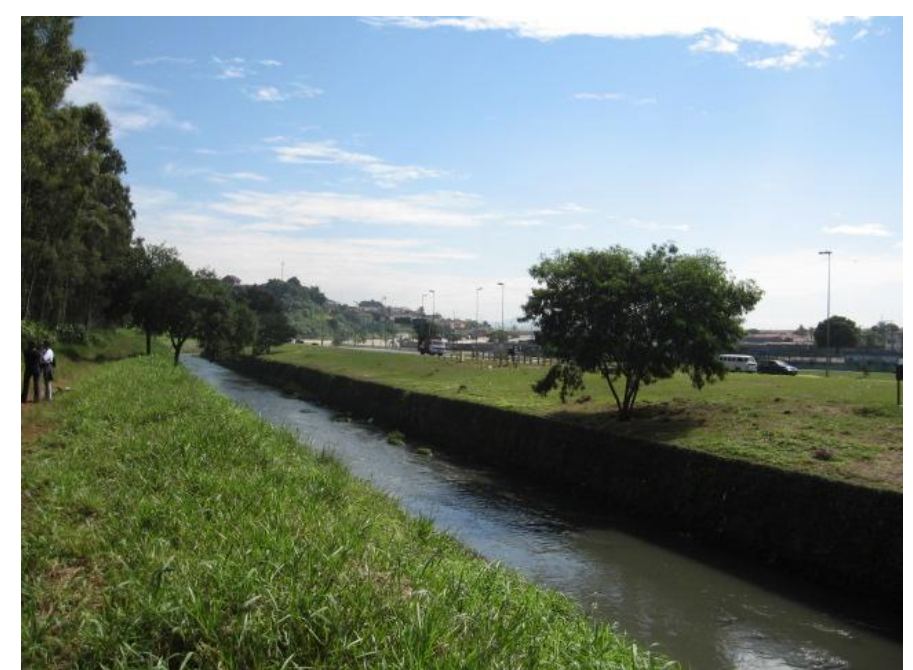

Figura 9.44 - Visada de sul para norte das margens do Rio Jacu, retificado, ao longo da Av. Jacupêssego, limite leste do parque-aterro, em 2007.

A avaliação de risco à saúde humana na área do antigo aterro, finalizada no início de 2008, apontou riscos toxicológicos à saúde para os trabalhadores de obras e as crianças (0-6 anos), por ingestão acidental do solo, respectivamente, no cenário atual e futuro de parque, devido à concentração de alumínio detectada nas imediações da antiga estação de tratamento de chorume. Essa questão ensejou uma comunicação do GTAC/Decont ao Depave quanto às medidas mitigadoras necessárias: utilização de equipamentos de proteção individuais (EPl's), especiais, pelos trabalhadores das obras e, a cobertura de solo orgânico $(0,50 \mathrm{~m})$ e plantio de grama nas áreas abertas (playground, áreas de descanso, etc.). Na visita ao local, realizada em junho de 2011, com a obra de implantação da Fase 1 em andamento não se observou a utilização de EPI's especiais pelos trabalhadores. 
Afora toda a problemática técnica, administrativa e política para a implantação do parque-aterro Jardim Primavera, a sua inauguração é importante para a região. Além de significar uma conquista da população, será o segundo parque implantado na Subprefeitura de São Miguel Paulista, que até 2010 não dispunha de nenhum parque público, disponibilizando área verde e de lazer para a população.

O morador Sylvio justifica a demanda por um parque no local:

[...] porque o solo não permite, então, a única possibilidade da gente usufruir dessa área é com um parque. E ainda tem outra coisa: a lei da compensação. Como a prefeitura usufruiu nove anos trazendo todo o lixo da cidade de São Paulo para cá, agora a comunidade quer uma compensação do sofrimento que teve durante todo esse tempo. Então, que tipo de compensação? A implantação de um parque. Porque em outros países, eu não sei exatamente qual, já houve essa experiência, já implantaram um parque em cima de um aterro sanitário. Agora, obviamente que é um parque específico. Específico em que sentido? Como a própria terra tem contaminação, mas como já foi avaliado, [...] O que acontece? A contaminação que tem no solo é de cobre, zinco. Enfim, vários metais. Não causa, assim, um dano para a saúde. E, também, como foi já colocado no projeto, eles estariam impermeabilizando praticamente toda a área do parque. Então, iriam ser feitas quadras poliesportivas cimentadas, gramados, quiosques. Eles iriam fazer uma impermeabilização quase que completa. Pistas de ciclismo, pista de caminhada: tudo pavimentado. Que, ao mesmo tempo, estaria impermeabilizando o solo, para até as crianças não terem contato com a terra. Esse é o projeto.

Por intermédio do Projeto 100 Parques (SVMA, 2008) de acordo com o administrador Sérgio, foi inaugurado, na Vila Nair (Jardim Pantanal), o Parque Vila Jacuí, área degradada, desocupada, junto à Av. Jacu-Pêssego, nas proximidades do parque Primavera. Esse, sim, tem toda a infra-estrutura (várias quadras, campos de futebol, pistas de skate, bancos de areia, playgrounds), característica de um parque mais urbano, desejada pela população, mas ainda sem vegetação. Ele avalia também que, no futuro, serão dois parques vizinhos de naturezas distintas, complementares, que têm a função de minimizar o déficit de áreas verdes da região. Além disso, terão o raio de influência ampliado, pela facilidade de acesso oferecido pela Av. Jacu-pêssego, que alcança a região de São Mateus. Ao longo da avenida situam-se três parques, de sul para norte: Raul Seixas, Primavera e o Vila Jacuí; podendo estes dois últimos desafogarem a demanda alta do pequeno parque Raul Seixas, encravado no conjunto habitacional José Bonifácio, em Itaquera.

O Termo de Referência da Fase 2 do projeto do parque-aterro está em elaboração, pelo Depave, com previsão para a abertura de licitação ainda este 
$a^{16}{ }^{16}$. Esta etapa se refere à implantação do projeto sobre o maciço de resíduos, onde serão construídas ciclovias, pistas para caminhadas, uma quadra poliesportiva e um espaço com usos múltiplos para eventos. A execução desta segunda fase exige, além da adoção das medidas mitigadoras como cobertura com solo limpo (0.50 m) e plantio de gramíneas nos locais de uso direto, a implantação do sistema de extração e tratamento dos gases. Não é recomendado o plantio de vegetação arbórea de grande porte e de espécies frutíferas.

O processo licitatório para contratação dos serviços de extração e tratamento dos gases foi iniciado em $2008^{17}$, com orçamento estimado na ordem de $\mathrm{R} \$$ 230.000,00, em 01/12/2009, mas, em 22/05/2010, foi declarado prejudicado, devido à inexistência de interessados no certame. Este fato fez com que o GTAC/Decont acionasse o Depave para o fechamento da área com concentração de emanações gasosas (Figura 9.45); até a definição da melhor técnica para extração do metano, de forma a reduzir as concentrações e eliminar a condição de explosividade. Recomendou, além disso, a instalação de três drenos de gases.

Durante a fase de estudos para a elaboração do projeto do parque, observouse, a nordeste da área, um maciço vegetal que se estendia da margem esquerda do Rio Jacu até o talude de divisa com um loteamento. Esse fato levou a SVMA a providenciar a incorporação desse terreno ao futuro parque. Neste sentido, foi obtida a Declaração de Utilidade Pública - DUP no 49.947, de 25 de agosto de $2009^{18}$.

Ao se comentar sobre o acesso ao parque-aterro, citando a Av. Jacupêssego, o morador Sylvio se sentiu à vontade para colocar a sua sugestão, apesar de anteriormente ter afirmado que o projeto estava de acordo com os desejos dos moradores, apresentando como justificativa a mudança das coisas.

[...] O projeto é de uma passarela. Entre a Jacu-pêssego e o parque, tem um grande gramado. Então, o que eles fariam?[...] nesse espaço do gramado, poderia ser construído um estacionamento bem grande. Porque assim que o parque for implantado, vai ter que ter um estacionamento, porque vai ter carro que vai vir de tudo quanto é lugar. Não vão ser só esses 80.000. Os 80.000 que eu estou falando são os beneficiados diretos. Agora, tem os beneficiados indiretos. [...] vai ter um grupo, por exemplo, o Sensação, vai vir tocar aí. Então, vai vir gente de tudo quanto é lado. Então, teria que ter esse grande estacionamento. [...]. E aqui seria, futuramente, na frente da minha casa, um terminal de ônibus. Porque teria que ter uns pontos finais bem próximos do parque, também. Eu tenho um monte de sonhos e planos. E sei lá se eu vou conseguir. Porque há 31 anos, quando tudo começou, eu tinha 27 anos. Eu já estou com 58. Já, já, estou com 60, morro e não vejo esse parque sair.

\footnotetext{
${ }^{16}$ Informação fornecida pelo Arq. Edimilsom Peres Castilho (Depave/SVMA), em 09/06/2011

${ }_{17}$ Processo Administrativo 2008-0.167.084-1.

${ }^{18}$ Processo Administrativo 2008-0.083.351-8.
} 


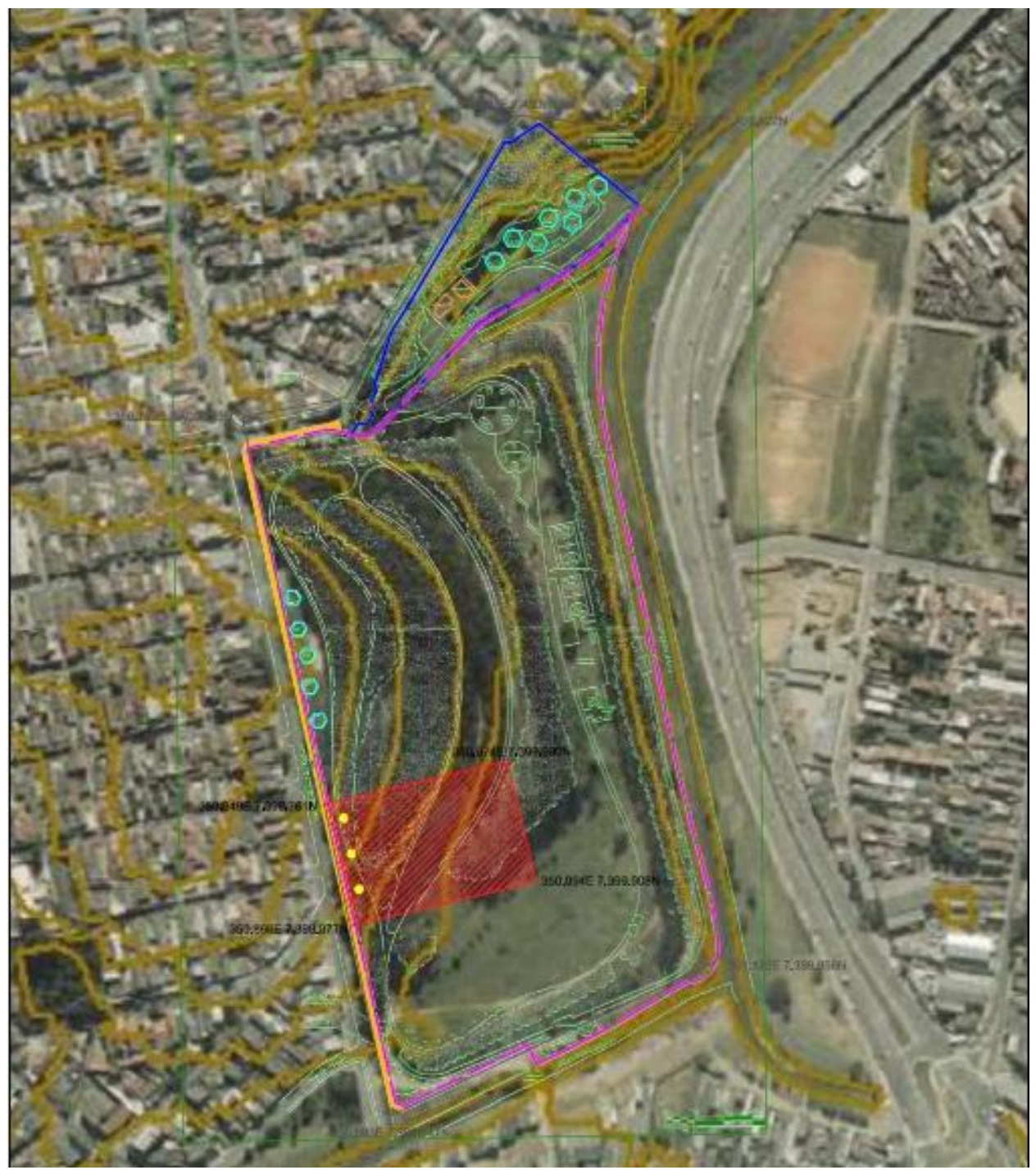

\section{Legenda}

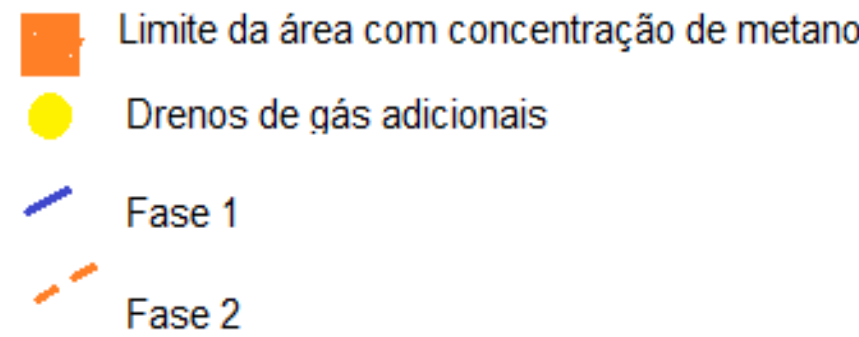

Organização: Luzia Helena dos S. Barros (2011)

Figura 9.45 - Sobreposição do projeto paisagístico do parque-aterro Jardim Primavera e dos limites da área de concentração de emanações gasosas, a ser isolada, e dos drenos de gás adicionais, indicados pelo GTAC/Decont, sobre ortofoto 2004.

Fonte: GTAC/Decont/SVMA; Depave/SVMA; Mapa Digital da Cidade. 


\subsubsection{ALGUNS EXEMPLOS DE USOS DA ÁREA DO FUTURO PARQUE-ATERRO JARDIM}

Apesar das condições impróprias para o uso da área como parque, antes da adoção das medidas mitigadoras e de sua efetiva implantação, sempre houve presença de eventuais usuários. Segundo o futuro administrador, o campo de futebol de terra é um exemplo de uso consolidado, muito antes da implantação do parque. Até a pesca era praticada na lagoa poluída, próximo a antiga caixa de tratamento do chorume. Outras práticas ocorrem como caminhadas, atividades de recreação, utilização como passagem e até campeonatos de pipa são promovidos no local (Figuras 9.46 e 9.47 ).

A situação de risco de explosão por escapamento de gás, localmente, persiste até hoje, podendo afetar diretamente os seus usuários. Uma medida simples, já indicada na avaliação de risco (SVMA, 2008c) como o isolamento dos drenos, já alertaria a população e evitaria a ocupação das suas proximidades.

A partir de 2009, com a chegada do administrador e a contratação de vigilância, promoveu-se o fechamento paulatino da área do aterro, para evitar incidentes até a inauguração da Fase 1. Mas essa condição, segundo o Sérgio, precisa ser negociada rotineiramente com os usuários, pois várias e constantes são as solicitações para o seu uso.

Outra condição característica da área é a plantação de árvores frutíferas ou espécies medicinais, por moradores da vizinhança, disponibilizando alimentos, sem avaliar a sua condição de contaminação. Persiste também, segundo o Sérgio, o "ponto viciado" de despejo de entulho, junto ao córrego Limoeiro, em área limítrofe ao parque. No local, a disposição é freqüente, durante o dia e a noite, concentrando maior quantidade do que no eco-ponto, recentemente implantado ao lado. A área está sob três diferentes estâncias de poder: Sabesp (Projeto Córrego Limpo), Transpetro (duto da Petrobrás) e Subprefeitura (ruas municipais). E por isso a sua gestão se torna bastante difícil e confusa. Na visita ao local, em junho de 2011, a Subprefeitura de São Miguel Paulista estava trabalhando na rua ao lado do córrego, devido ao desbarrancamento das suas margens (Figura 9.48).

Para o administrador Sérgio, a sua experiência profissional juntamente com as discussões entre os outros administradores de parques permitiu concluir que as características dos arredores estão diretamente relacionadas ao uso do parque e, 
que por isso os projetos de parque precisam incorporar essa questão. Mencionou, além disso, que a previsão de criação desse parque por todos esses anos levou à eleição de muitos políticos. Por oportuno, aponta-se que o atual secretário do Verde e Meio Ambiente, Eduardo Jorge, pelo Partido Verde, ex-secretário municipal da saúde, ex-deputado estadual, pelo Partido dos Trabalhadores, morador hoje da Vila Clementino, quadrante sudoeste e, provável candidato a prefeito, já participara, do movimento contra o lixão do Parque do Carmo, conforme informa (Costa, 2000), quando em 1977 era médico-sanitarista do distrito de Itaquera e morador do bairro.
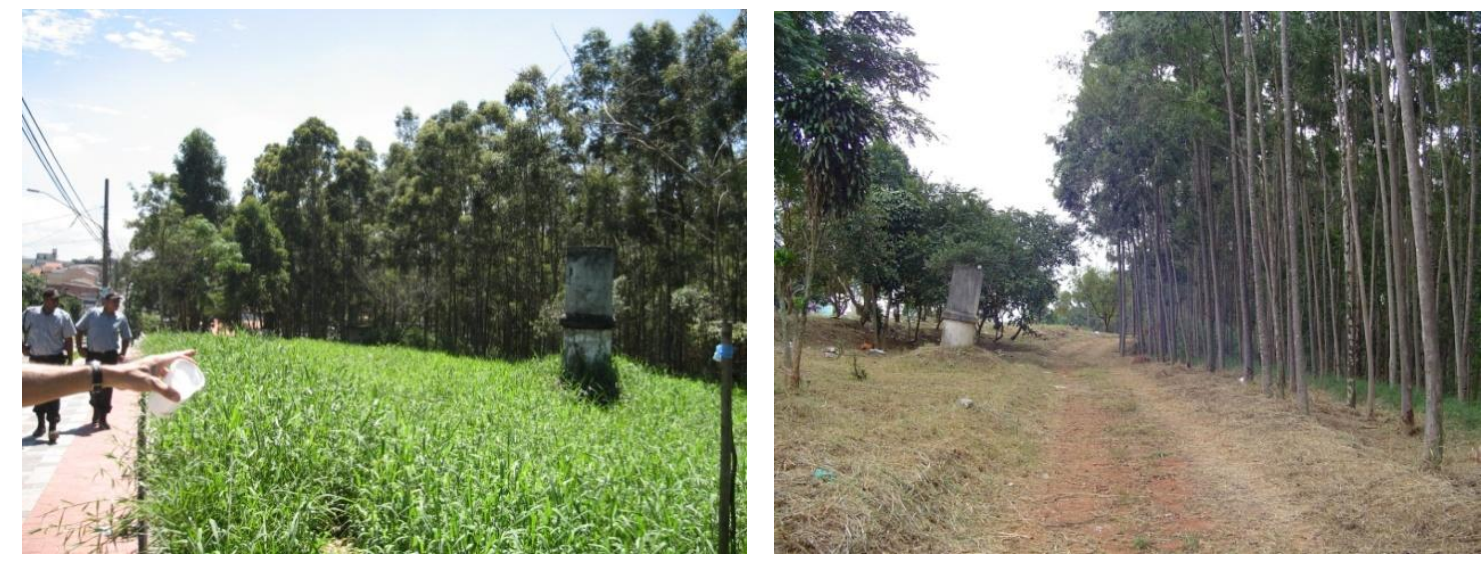

Figura 9.46 - Antigos drenos de gases do aterro Jacuí, próximos a locais de circulação da população, sem qualquer sistema de isolamento ou comunicação de risco de escapamento de gás.
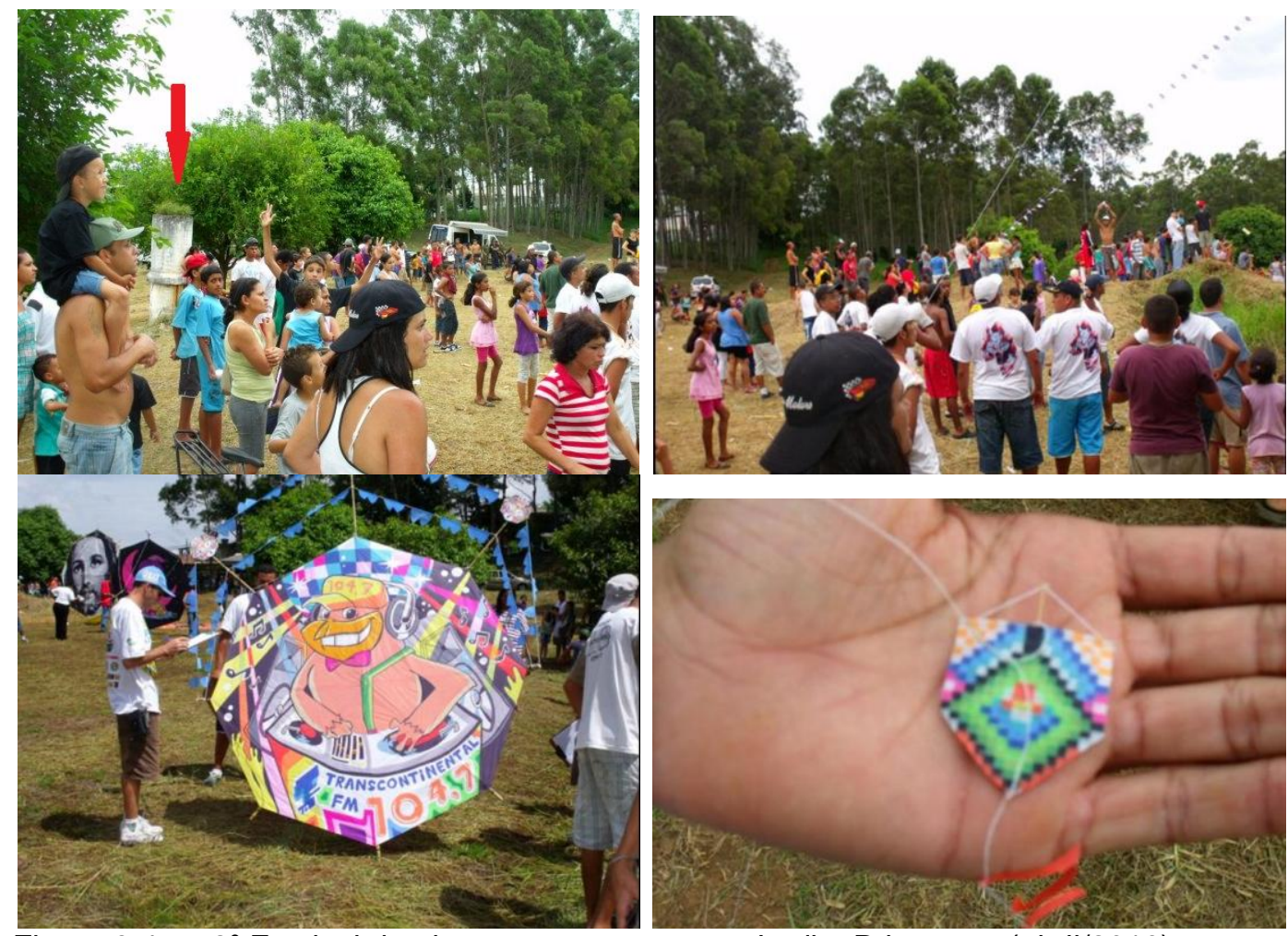

Figura $9.47-2^{\circ}$ Festival de pipas no parque-aterro Jardim Primavera (abril/2010), na entrada junto ao cruzamento da R. da Polka e a Av. Mimo de Vênus. Observar antigo dreno de gás, à esquerda, muito próximo do local de reunião dos participantes.

Fonte: Fotos cedidas pelo morador Sylvio Sena. 


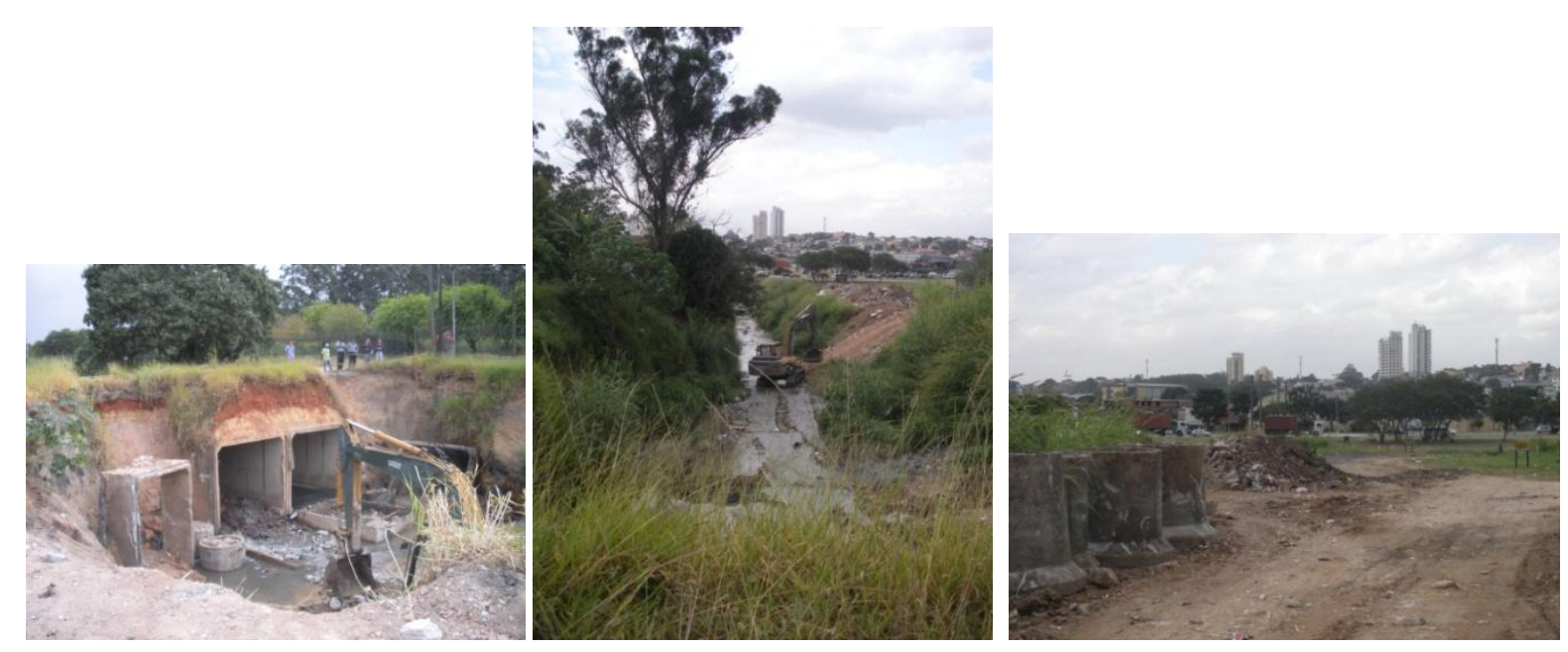

Figura 9.48 - Obras em execução, pela SP-MP, para recuperação da canalização do córrego Limoeiro, limítrofe ao parque-aterro. Nota-se, também, que persiste o descarte irregular nas suas margens, um dos "pontos viciados" dessa região. Data: 07/06/2011

\subsection{AdEQUAÇÃO TÉCNICA, AMBIENTAL E PAISAGÍSTICA dOS PROJETOS IMPLANTADOS E PROPOSTOS NOS PARQUES-ATERROS RAPOSO TAVARES E JARDim PrimaVera}

\subsubsection{Projeto do Parque-aterro Raposo Tavares}

O parque-aterro Raposo Tavares foi uma primeira experiência de reúso de um aterro desativado para a implantação de um parque urbano público na América Latina. No entanto, foi concebido para uma região periférica, com população de baixa renda e dependente, em muitos casos, da operação do próprio aterro para sobreviver e, ainda, numa época em que não se tratava a questão da contaminação e os seus efeitos ao ambiente e à saúde humana com a devida atenção. Esses fatos contribuíram para o desenvolvimento de um projeto de parque em descompasso com os desejos das comunidades vizinhas e, além disso, sem atentar para a especificidade do seu substrato.

O projeto original (Figura 9.1) contemplou a implantação das quadras e playgrounds sobre o corpo central da massa de resíduos, com piso em terra batida, que favorecia à exposição aos possíveis contaminantes do subsolo. Algumas quadras foram colocadas ao lado da usina piloto de exploração do gás, em 
funcionamento àquela época, sem considerar os riscos aos quais os usuários estariam imediatamente expostos. Os sanitários, depósito e a administração foram locados, imediatamente junto à entrada principal do parque-aterro, fora da massa principal de resíduos, evitando que a infra-estrutura necessária à instalação dessas edificações interferisse no corpo principal dos resíduos. São mantidos como tal até hoje. Ressalta-se que foram localizadas, no arquivo do Depave/SVMA, apenas algumas plantas do projeto, não sendo encontrado o seu respectivo memorial descritivo.

Quanto à vegetação indicada, também, para implantação sobre o corpo central do antigo aterro, não previa, a princípio, a formação de maciços vegetais contínuos, importantes para promover a conexão entre habitats. Para a vegetação foi definida uma diversidade de espécies, dentre elas: quaresmeiras, paineiras, grevílea, unha-de-vaca, Julieta, suinã, esponjinha, piracanta, iúca, alcalifa, sálvia, lírio, grama batatais, etc.; sem recomendação para o acompanhamento sistemático do seu desenvolvimento com vistas a subsidiar re-plantios ou mesmo, modelos para replicar em outras áreas com as mesmas restrições.

O parque hoje apresenta uma área com bosque denso, implantado sobre 0 talude situado a oeste, não indicado pelo projeto e, sobre uma porção menor, à leste. No plano de gestão estas porções estão definidas como área de mata em formação, sendo sugerido o seu enriquecimento. Ao se relacionar essas manchas ao mapa de potencial de conectividade do parque-aterro (Capítulo 8) pode-se inferir que o enriquecimento previsto, no caso do modelo A - mais otimista, contribuirá para a conexão, funcionando o parque como ponto de ligação entre outras manchas do seu entorno. Ao se observar o modelo B - mais conservador deduz-se que mesmo com o adensamento daqueles maciços vegetais a conexão entre manchas estará prejudicada nas suas zonas de amortecimento, devido a existência de barreiras que impedem a criação de corredores ecológicos. Essa situação se repete inclusive no interior do parque onde a área definida para uso intenso funciona como barreira interna à conectividade.

As intervenções recentemente executadas parecem não ter levado em consideração alguns cuidados básicos, pois, no topo central, instalaram: sanitários e vários quiosques. No caso dos sanitários há que se considerar a interferência direta das suas instalações no subsolo. Esses equipamentos favorecem, também, a circulação de usuários no centro do antigo aterro, definida como área de uso 
intensivo no plano de gestão, sem ao menos colocar uma cobertura de solo limpo suficiente para impedir a exposição daqueles resíduos, ainda hoje constatada. Os caminhos recuperados e implantados e seus sistemas de drenagem evitam a ocorrência de erosão com conseqüente exposição de resíduos e o surgimento de chorume, no entanto, não consideraram os riscos ambientais e à saúde humana por ora das escavações necessárias à sua construção. Essas intervenções pontuais e desarticuladas parecem responder a demandas locais e imediatas, ou mesmo, a interesses políticos não verbalizados. Um projeto paisagístico específico certamente acolheria todas essas demandas de uma forma eficiente, estética, técnica e ambientalmente adequada.

Apesar deste parque-aterro situar-se no quadrante sudoeste, setor de concentração da população de renda mais alta e privilegiado quanto às infraestruturas urbanas e de forte ação do mercado imobiliário (Villaça, 2001), localmente, está inserido no distrito que apresenta um dos índices mais baixos de desigualdade ambiental da SP-BT (Morato et al., 2005) e que possui baixo controle urbano-ambiental da SVMA (SVMA, 2008a).

A história desse parque-aterro nos remete ao parque Mabel Davis, descrito no Capítulo 7, item 7.3.2.4.4. Após mais de 20 anos apresentando problemas, precisou ser fechado ao público para a instalação de um programa de remediação, com o conseqüente redesenho do parque. Talvez essa providência seja a melhor alternativa para o Raposo Tavares.

\subsubsection{Projeto do parque-ATERro Jardim Primavera}

O parque-aterro Jardim Primavera é o primeiro parque na América Latina que vem sendo implantado de acordo com os procedimentos estabelecidos no gerenciamento de áreas contaminadas (Capítulo 3). Mas mesmo assim, quando se decidiu pela execução em duas etapas, a fim de atender aos anseios políticos e da população, não aguardando o encerramento de todas as etapas dos estudos ambientais (Capítulo 8), internalizando assim alguns riscos possíveis, desencadeou contratempos nas obras e no cronograma de implantação.

A Fase 1 (Figura 9.35), em implantação, fora do corpo principal do aterro, concentrou as edificações de maior peso (Administração e Convivência) e o maior 
número de quiosques. Entretanto, o remanescente de chorume encontrado e o atendimento aos limites da APP provocaram a realocação das edificações e o remanejamento de três quiosques.

A manutenção da vegetação existente e o seu enriquecimento, proposto por meio do reflorestamento, a fim de interligar dois maciços existentes, e do tratamento paisagístico com espécies arbóreas nativas, arbustos, etc., de acordo com os diferentes espaços a serem implantados e, ainda aventando-se a necessidade de utilizar a arborização do passeio, que circunda o parque-aterro, como complemento ao seu paisagismo mostra a preocupação de favorecer a heterogeneidade, diversidade e conectividade entre a vegetação do interior e da borda do parqueaterro.

A Fase 2 (Figura 9.35), em estudo, sobre a massa de resíduos, possui maiores restrições à implantação de projeto paisagístico. Os equipamentos previstos situam-se nas bordas do parque-aterro onde é provável encontrar-se as menores espessuras de resíduos. Propõe-se a manutenção dos eucaliptos existentes e o enriquecimento da vegetação, com tratamento paisagístico restrito, também, às bordas do maciço de resíduos, com seu adensamento junto ao córrego Limoeiro, em APP. Mas o mesmo tratamento não foi dado à margem do Rio Jacu. $\mathrm{Na}$ área demarcada, onde há concentração de metano (Figura 9.45) não foi previsto a implantação de nenhuma edificação, sendo proposta apenas a introdução de vegetação, que terá que ser postergada.

Esse modelo projetual mostra a tendência de fornecer uma visão ecológica para as paisagens metropolitanas, tal como coloca Flores et al. $\left(1998^{19}\right.$ apud Forsyth e Musacchio, 2005). Os autores afirmam que a chave do planejamento de sistemas de espaços abertos no meio urbano é manter ecossistemas saudáveis, e para isso é preciso que possuam flexibilidade, conectividade e diversidade, com espécies que apresentem capacidade genética, biológica e bioquímica para adaptarse e responder às mudanças ambientais. Para eles a heterogeneidade, diversidade e conectividade no interior e entre os espaços verdes contribuem fortemente com os aspectos e processos pelos quais as pessoas e as instituições os valorizam.

Neste sentido, o mapa de potencial da conectividade elaborado para o parque-aterro é fundamental para a definição de ações precisas com vistas à criação

\footnotetext{
${ }^{19}$ FLORES, A..;PICKETT, S.T.A.; W.C.; ZIPPERER, .; POUYAT, R.; PIRANI, R. Adopting a modern view of the metropolitan landscape: The case a greenspace system for the New York city region. Landscape and Urban Planning, ํㅡ 39. 1998. P. 295308.
} 
de corredores ecológicos. Os mapas dos cenários previstos mostram, no geral, baixa potencialidade para a conectividade, especialmente a sul e ao norte, onde se localizam, respectivamente, a APA do Carmo e o Parque Ecológico do Tietê. No cenário conservador o parque-aterro se mostra como uma pequena mancha imersa numa matriz intensamente urbanizada.

Apesar das restrições impostas pelas origens da área avalia-se que poderá ser retomado um projeto-piloto, a exemplo do iniciado em 1991, para avaliar o desempenho da vegetação existente e das novas espécies a serem introduzidas. $\mathrm{E}$, neste caso, tentar a implantação, com os devidos cuidados, de espécies no centro do maciço de resíduos, a fim de possibilitar o aumento da conectividade do ambiente ou, mesmo um projeto para fitorremediação do substrato.

A fim de favorecer a conectividade da paisagem na região, sugere-se que o projeto paisagístico do parque avance para além dos seus limites de forma a promover a articulação da sua composição vegetal com a vegetação dos parques vizinhos e com a arborização de ruas. Outra possibilidade a ser considerada seria a construção de zonas alagadas já que o parque é cercado pelo Rio Jacu e seus afluentes, todos eles contribuintes do Rio Tietê.

Essas ações podem ser incluídas nas propostas ora em desenvolvimento para a Operação Rio Verde-Jacu, pois talvez estejamos vivenciando uma mudança de direção para leste, a exemplo do que sugere o título de um seminário promovido pela Associação Comercial de São Paulo (ACSP) em parceria com a PMSP, ocorrido neste mês de setembro: "Zona Leste, o futuro de SP passa por aqui". O prefeito Kassab (DOC, 2011) anunciou incentivos fiscais da ordem de $R \$ 50$ milhões no orçamento de 2012 e redução de 50 a 60\% no Imposto Territorial Urbano (IPTU) aos investidores e de $60 \%$ no Imposto Sobre Serviços (ISS). Além disso, serão emitidos Certificados de Incentivos ao Desenvolvimento (CID's) a investimentos no comércio, na indústria e na prestação de serviço. O secretário de Desenvolvimento Urbano apresentando o projeto da Operação Urbana destacando as melhorias na infra-estrutura viária e a instalação do Pólo Institucional de Itaquera. Nenhuma menção foi feita à implantação de parques ou áreas verdes. Será isso apenas retórica? 


\subsection{Proposta de diretrizes para o Plano de Gestão dos Parques-}

ATERROS

Desde a década de 1980 o termo "gestão ambiental" vem sendo empregado nos vários documentos e artigos técnicos, bem como em procedimentos de gerenciamento desenvolvidos nas várias instituições e em diferentes níveis de decisão. A definição da palavra gestão, pelos dicionários, significa ato de gerir, de administrar, de gerência, de direção, de administração. Nesse sentido tem dimensão ampla, referindo-se às atividades de formulação ou execução de políticas. O setor empresarial tem utilizado largamente o conceito como gestão empresarial e o setor público como administração pública e, mais recentemente, como gestão pública.

Segundo Souza (2002), gestão significa "administrar uma situação dentro dos marcos dos recursos presentemente disponíveis e tendo em vista as necessidades imediatas". Martins (2004) alerta que um dos recursos mais frágeis no poder público é justamente a capacidade de gestão.

Oliveira (2004, p.30) observa que

[...] A incorporação da gestão ambiental às organizações exige um grande estímulo e reforço às atividades que realizam a interconexão entre as diferentes unidades administrativas. [...] a abordagem integrada, interdisciplinar, incorpora novas questões. Ela exige a coleta e a constante reunião de diversas fontes diferenciadas visando a preparação de bases para o diálogo com os vários setores envolvidos (SLOCOMBE, 1993) e, além disso, o desenvolvimento da capacidade de trabalhar em grupo. [...].

Para o IBAMA o termo gestão se confunde com manejo quando se trata de Unidades de Conservação. Entende como gestão ou manejo (IBAMA, 1996, p. 12)

[...] o conjunto de ações e atividades necessárias ao alcance dos objetivos de conservação das áreas protegidas, incluindo as atividades afins, tais como proteção, recreação, educação, pesquisa e manejo de recursos, bem como as atividades de administração ou gerenciamento.

Para o Sistema Nacional de Unidades de Conservação (SNUC, Lei 9.985/2000) manejo é "[...] todo e qualquer procedimento que vise assegurar a conservação da diversidade biológica e dos ecossistemas (Art. $2^{\circ}$, Inciso VIII). E para que o manejo seja realizado é necessária a elaboração do plano de manejo, conceituado pelo SNUC (Art. $2^{\circ}$, Inciso XVII) como:

[...] Documento técnico mediante o qual, com fundamento nos objetivos gerais de uma Unidade de Conservação, se estabelece o seu zoneamento e 
as normas que devem presidir o uso da área e o manejo dos recursos naturais, inclusive a implantação das estruturas físicas necessárias à gestão da Unidade.

Segundo a mesma Lei (Art. 27, 1) "o plano de manejo deve abranger sua zona de amortecimento ${ }^{20}$ e os corredores ecológicos, incluindo medidas com o fim de promover sua integração à vida econômica e social das comunidades vizinhas".

Os planos de manejos para unidades de conservação são definidos, também, por Santos (2004, p.38):

[...] são instrumentos voltados à preservação e conservação dos recursos naturais, bem como ao uso desses recursos para pesquisa científica e para visitação pública na forma de ecoturismo e educação ambiental, dentro de espaços pré-estabelecidos por documento legal.

Os conceitos estabelecidos pelo SNUC não abrangem de forma adequada as especificidades de todos os parques urbanos paulistanos. Essa condição tem desencadeado discussões nos municípios para a criação de um sistema municipal específico. Neste sentido o município de São Paulo elaborou uma proposta de classificação das suas áreas verdes (Capítulo 7) com o objetivo de estabelecer o seu Sistema Municipal de Unidades de Conservação - SMUC, ainda não definido. Segundo a SVMA (2004) os parques municipais são áreas correlatas às UC's, do SNUC, com outras modalidades especiais de proteção e uso.

Apesar do SNUC não abranger os parques municipais urbanos, os seus conceitos, desde que adaptados, podem servir de base científica aos termos urbanos correlatos. Sendo assim, é interessante mencionar os aspectos adotados, por Vilhena $\left(2002^{21}\right.$ apud Silva, 2005, p.93), como pré-requisitos à definição e manejo das zonas de amortecimento:

- compromisso político por parte das autoridades locais, líderes comunitários e representantes dos órgãos do governo;

- legislação favorável ao estabelecimento das zonas de amortecimento;

- fortalecimento político, humano e institucional dos órgãos governamentais responsáveis pelo manejo de áreas protegidas;

- regularização fundiária;

- existência de iniciativas regionais para o desenvolvimento;

- participação das comunidades locais na definição de parâmetros para delimitação e manejo das zonas de amortecimento, tendo em vista o conhecimento que os moradores possuem da região e

- definição da zona de amortecimento elaborada sob critérios técnicos e científicos e coerentes com a sua função.

\footnotetext{
${ }^{20}$ Neste estudo, denominou-se zona de amortecimento urbana (Capítulo 8).

${ }^{21}$ VILHENA, F. Parâmetros para La delimitacións y manejo adaptativo de zonas de amortiguamiento em parques nacionales Del cerrado, Brasil. Magister Scientiae (Programa de Educacion para El Desarollo y La conservación). Centro Agronômico tropical de Investigación y Eneseñanza, Escuela de Posgrado. Turrialba, costa Rica. 2002. 202 p.
} 
Ainda, segundo Oliva (2003 22 apud Silva, 2005, p.93), a sua implementação efetiva necessita do estabelecimento de parcerias e de gestão compartilhada.

As características dos parques urbanos acarretam formas diferenciadas para o seu gerenciamento e, no caso dos parques-aterros, precisam levar em consideração o substrato original do terreno e suas restrições. Esta particularidade exige a elaboração de Planos de Gestão ${ }^{23}$ específicos.

Desta forma, considerando o estudo realizado até o momento sobre os processos de transformação de aterros desativados em parques urbanos faz-se oportuno apresentar, a seguir, algumas diretrizes para contribuir na elaboração dos planos de gestão dos parques-aterros. Para Santos (2004, p.24) "[...] As diretrizes referem-se a um conjunto de instruções ou indicações de caráter geral necessárias para o estabelecimento de planos e normas."

- Incorporar as exigências da avaliação ambiental realizada com todas as suas recomendações quanto à remediação, se necessária, avaliação de risco à saúde humana e outros controles e monitoramentos;

- Desenvolver métodos de comunicação de risco aos usuários e funcionários;

- Adotar métodos para incorporar a participação efetiva da população;

- Selecionar espécies vegetais com base em estudos anteriores em áreas semelhantes, tal como o estudo realizado no antigo aterro Santo Amaro;

- Prever a utilização de espécies vegetais resistentes ou que necessitem de pouca manutenção;

- Considerar o uso da fitorremediação, quando cabível;

- Prever o acompanhamento do desenvolvimento e desempenho das espécies de vegetação introduzidas, para criar banco de dados e subsidiar técnica e cientificamente outros projetos de implantação de parques-aterros;

- Abranger a zona de amortecimento urbana do parque-aterro;

- Desenvolver modelo de tomada de decisão para melhor definir a sua zona de amortecimento urbana;

- Especificar as restrições de uso da zona de amortecimento urbana.

\footnotetext{
${ }^{22}$ OLIVA, A. Programa de manejo de fronteiras para o Parque Estadual Xixová-Japuí, SP. Dissertação (Mestrado em Recursos Florestais com opção em Conservação de Ecossistemas Florestais . escola superior de Agricultura "Luiz de Queiroz" - ESALC, Universidade de São Paulo - USP. Piracicaba, SP. 2003. 239 p.

${ }^{23}$ Plano de Gestão vem sendo utilizado para os parques urbanos no lugar de manejo, pois eles são áreas correlatas às UC's, mas não abrangidos pelo SNUC.
} 


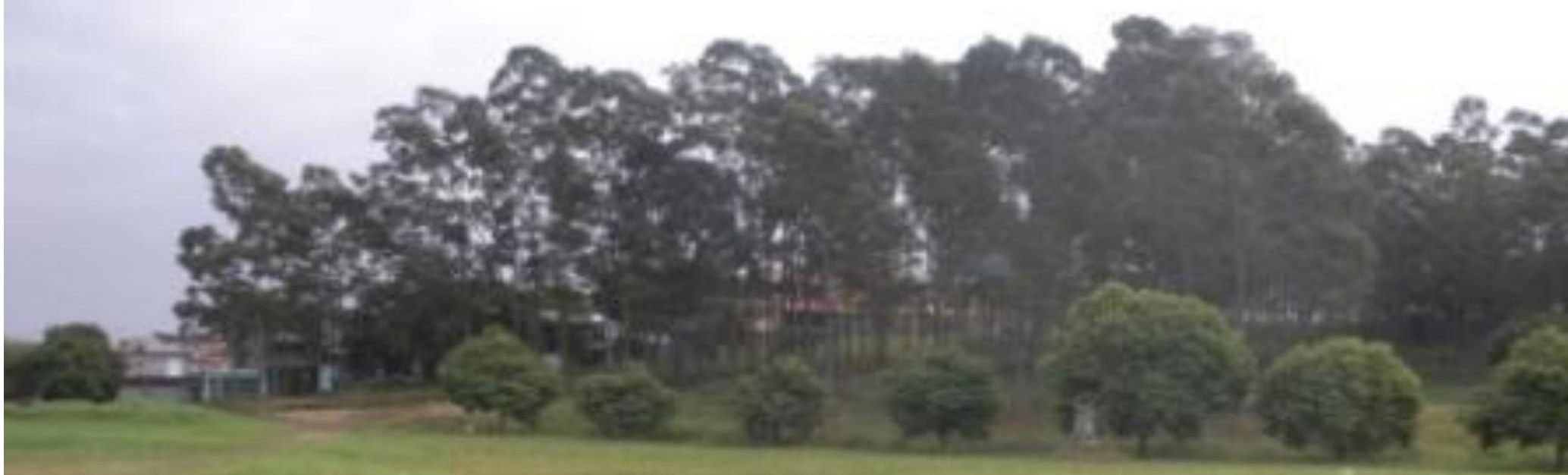

Mudam-se os tempos, mudam-se as vontades, Muda-se o ser, muda-se a confiança; Todo o mundo é composto de mudanças, Tomando sempre novas qualidades.

Luís V. de Camões

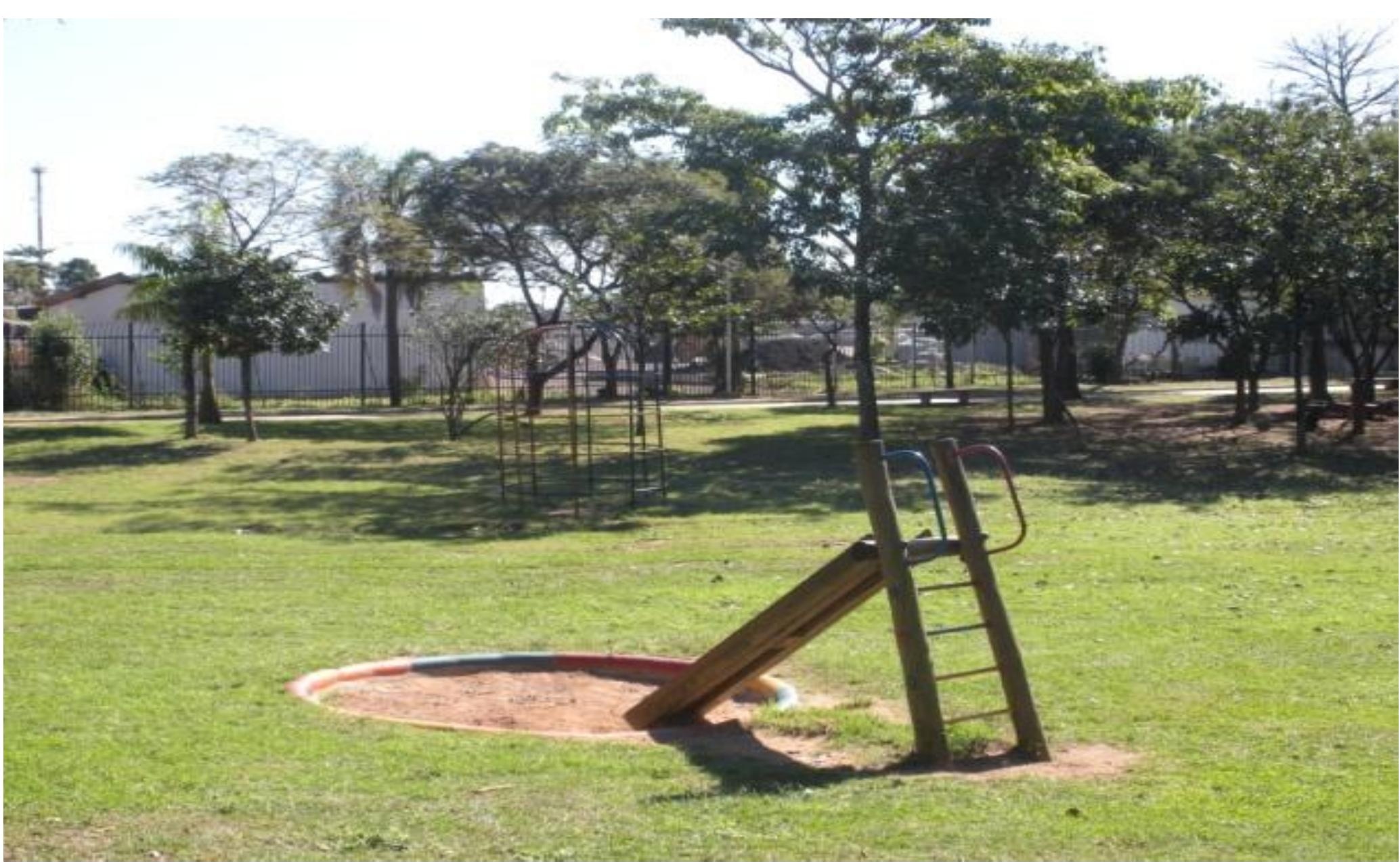


Futuro Parque Jardim Primavera, São Paulo Foto da autora em junho de 2011

Parque Raposo Tavares, São Paulo. Foto da autora em junho de 2009. 


\section{Conclusão}

Os mais recentes problemas de ocupação de antigos lixões, em São Paulo, SP, evidenciam que a utilização e a incorporação dos brownfields ou das áreas contaminadas, situados tanto em zonas centrais como periféricas da cidade, à matriz urbana, sem a avaliação de risco e as devidas medidas de remediação ou de controle, pode acarretar vários riscos à saúde da população e ao meio ambiente. Da mesma forma, estas áreas podem representar problemas de gestão urbana como desvalorização do entorno, cortes no tecido urbano, ocupação clandestina, entre outros.

O gerenciamento das áreas contaminadas, preferencialmente, com integração município-estado, permite conhecer a sua localização, quantificar e qualificar os riscos associados e, principalmente, elaborar mecanismos e estratégias para a sua prevenção, controle, remediação para uso futuro específico e requalificação urbana e paisagística. As políticas públicas que tratam da gestão das áreas contaminadas em São Paulo, tal como afirmam Morinaga (2007) e Ramires (2008) deixaram de lado a postura negligente, característica da década de 1980, para hoje situarem-se na fase corretiva, na qual o poder público reconhece essa problemática e promove estratégias de planejamento para lidar com o assunto.

Outro aspecto essencial ao bom desempenho das ações de gerenciamento é a estruturação administrativa, técnica e política dos setores públicos responsáveis diretos pela sua aplicação. Neste sentido, será necessário prover, especialmente, a SVMA, de recursos humanos e financeiros compatíveis com a abrangência do tema 
e com a crescente demanda constatada. Além disso, dispor o SIGAC de informações georreferenciadas a serem disponibilizadas na Internet, incluindo as áreas públicas e situadas na zona rural do município.

Ressalta-se, corroborando Morinaga (2007) e Ramires (2008), que cabe aos órgãos governamentais, em particular, ao município de São Paulo, a responsabilidade de incluir a questão das áreas contaminadas na gestão e no planejamento urbano-ambiental, mediante a criação de instrumentos legais e de ações concretas para a prevenção e o controle do uso e ocupação desses espaços. Desta forma o gerenciamento dessas áreas favorecerá a requalificação de espaços urbanos degradados, desde que realizada de forma adequada, o que necessariamente implica uma avaliação prévia do problema e a internalização do tema nos procedimentos internos dos órgãos municipais, assim como a mudança de visão dos empreendedores privados no tratamento de terrenos com passivos ambientais.

As diretrizes hoje existentes no município para a requalificação da maioria dos antigos aterros municipais como parques, as possibilidades paisagísticas oferecidas por este equipamento e pelas técnicas de remediação (fitorremediação e zonas alagadas construídas), aliadas ao baixo custo e às possibilidades de associação com outros métodos, são oportunidades para o desenvolvimento de projetos paisagísticos criativos. Entretanto, a implantação desses projetos em áreas contaminadas deve ser encarada com cautela, em razão dos possíveis riscos à saúde dos trabalhadores da obra como dos seus futuros usuários. No caso específico dos aterros de resíduos, os aspectos mais preocupantes dizem respeito à presença de gases, formados a partir da decomposição do lixo, à estabilidade do maciço e à eventual ocorrência de chorume com a conseqüente contaminação do solo e das águas subterrâneas. Os dois estudos de caso apresentados representam duas épocas distintas do nível de conhecimento e da forma de abordar a questão da requalificação dos aterros em parques.

O parque-aterro Raposo Tavares foi concebido num momento em que os lixões ainda eram a única forma de disposição de resíduos. Como conseqüência, seria mesmo de se esperar que o projeto do parque não tivesse contemplado alguns aspectos importantes, que poderiam ter evitado problemas, como o afloramento de lixo, que persiste até o presente. Por outro lado, o projeto elaborado para o parqueaterro Jardim Primavera, sobre o antigo aterro Jacuí, procurou atender a todos os 
quesitos técnicos e ambientais, num trabalho conjunto entre o Depave e o GTAC, com a participação efetiva da comunidade moradora do entorno. A elaboração do projeto em duas fases possibilitou iniciar a implantação do parque em parte da área externa ao aterro, onde não se esperava constatar contaminação, enquanto se aguardava a complementação da avaliação ambiental prevista. Todavia ao término da avaliação de risco foi constatado risco toxicológico e remanescente de chorume, neste trecho, que levou à alteração do projeto e do cronograma das obras. Portanto, considera-se que as etapas de avaliação preconizadas no sistema de gerenciamento de áreas contaminadas devem ser executadas, previamente, à elaboração final do projeto paisagístico, para evitar contratempos no momento da sua execução ou alterações de projeto. Embora a execução do Parque Jardim Primavera tenha, no geral, atendido aos preceitos técnicos, isso não é suficiente para preconizar procedimentos semelhantes em outras áreas, a exemplo do Parque Raposo Tavares.

Quanto à participação da população observa-se que é importante adotar métodos que permitam a sua efetiva contribuição, pois como afirmam Forsyth e Musacchio (2005) ela fornece importantes informações sobre os valores locais e suas necessidades; além de, quando envolvida no projeto, possibilitar o aumento do seu compromisso com o parque, incluindo o interesse na sua manutenção. Tal como sugere Albuquerque (2006) os parques urbanos “(...) nunca estarão configurados iguais, pois são peculiaridades das ações que os definem, ou seja, a cultura, não sendo apenas modelos arquitetônicos" e paisagísticos. O que corrobora com a observação do administrador do parque-aterro Jardim Primavera, Sérgio Nunes, para a necessidade de incorporação das características do entorno aos projetos dos parques.

No município existem implantados, atualmente, cinco parques-aterros. Entretanto, os projetos arquitetônicos, paisagísticos e o planejamento das intervenções neste tipo de terreno, ainda efetivamente, não se traduzem como ações articuladas na paisagem da cidade para promoção da qualidade ambiental. Tais intervenções precisam de melhor entendimento tanto por parte dos profissionais envolvidos diretamente com esta problemática, quanto por parte da população, dos políticos e das autoridades. Os exemplos de parques-aterros apresentados mostram a importância do envolvimento da população nas discussões iniciais sobre as dificuldades de intervenção nessas áreas e sobre as alternativas para sua 
requalificação, a fim de viabilizar a junção de esforços no intuito de efetivar as ações de longo prazo, necessárias à implantação e manutenção de um parque-aterro.

As vantagens para a qualidade ambiental, atribuídas à vegetação arbórea $\mathrm{e}$ arbustiva, apontam para a necessidade de priorizar o plantio dessas espécies na revegetação dos aterros, quando viável. A vegetação foi selecionada, no modelo de tomada de decisão desenvolvido, como elemento de conexão da paisagem, nos arredores dos parques-aterros, porque ela é, em geral, prevista nos projetos de implantação desses parques e pela sua importância na promoção da qualidade de vida. Em contraposição, o sistema viário e, especialmente, a verticalização foram os critérios utilizados como barreiras à conexão. $O$ modelo revelou que o Parque Raposo Tavares apresenta melhor potencial de conectividade do que o Parque Jardim Primavera e pode ser utilizado pelos projetistas como um elemento orientador no projeto de revegetação e de outros elementos. No entanto, não foi objeto do estudo diferenciar o tipo de vegetação e as suas respectivas funções e exigências. Outros atributos da paisagem também são importantes para a sua conexão. Como exemplo, pode-se citar a drenagem. A drenagem, entretanto, deverá ser analisada com todas as suas características: se canalizada, se provida de vegetação, com fluxo lento ou turbulento, etc. Essas informações, geralmente, não estão disponíveis e tornam a sua análise muito mais complexa.

O modelo ademais se apresenta como uma ferramenta muito mais versátil na análise da paisagem do que os Índices de Área Verde (IVA) ou de Cobertura Vegetal (ICV). Tais índices levam em conta a relação do somatório das áreas verdes (praças, parques, etc.) ou da cobertura vegetal com a população de um distrito, município ou cidade. Desconsideram os vários outros fatores que favorecem ou desfavorecem o potencial de conectividade numa dada paisagem, bem como a relação entre eles.

Considerando a importância para a Administração Pública do aparato legal para a criação dos parques-aterros, recomenda-se a inclusão da exigência de estudos de avaliação ambiental da contaminação, a exemplo da lei de criação do Jardim Primavera. Sugere-se, também, estabelecer um trabalho integrado entre as equipes responsáveis pela elaboração dos estudos ambientais, do projeto paisagístico e a população. Quanto à especificação dos equipamentos, da vegetação e de outros tipos de atividades, deverá ser deixado por conta do trabalho integrado das equipes da avaliação ambiental, dos projetistas e da população. Pode- 
se recomendar prazo para início dos estudos ambientais, mas não o das obras de implantação do parque, pois este dependerá sempre dos resultados finais e das recomendações dos estudos empreendidos. Deve-se estabelecer a necessidade de estudos ambientais para a definição da zona de amortecimento urbana no Plano de Gestão ou, mesmo, na fase de estudo do projeto paisagístico. Mas independente das especificidades dos parques-aterros e, como afirma Bartalini (1999) da "crise de identidade" dos parques urbanos devido à sobreposição de atribuições com os parques infantis e centros esportivos, para os usuários "(...) estar num parque é, antes de tudo, uma experiência singular, diversa da que se pode ter num centro esportivo ou num parque de diversões".

A incorporação dos antigos lixões e aterros municipais, ao tecido urbano, como parque-aterro, se faz necessária, visto a localização (intra-urbana), o tamanho e os custos envolvidos na sua requalificação, se comparável a outros tipos de uso e, além disso, a criação de áreas verdes e de lazer em lugares tão carentes de qualidade de vida. A requalificação das áreas pode, por outro lado, compensar os moradores por tantos anos de impactos diretos sofridos, ainda mais, se considerarmos que são poucas as áreas disponíveis no espaço urbano. Para tanto, considerando a complexidade e particularidade dos processos envolvidos na remediação, revegetação, manutenção e monitoramento dos parques-aterros projetados ou implantados recomenda-se o estudo dessas áreas, preferencialmente, com o estabelecimento de convênios com instituições de pesquisa.

A criação de uma classe especial, parque-aterro, no Sistema de Áreas Verdes do município é fundamental para garantir a implantação de projetos ajustados às especificidades do terreno e o seu tratamento diferenciado por parte do poder público, da população e dos profissionais envolvidos no assunto. A inclusão do termo aterro, no nome da classe, reforça o registro de todo o diferencial de tratamento da área e a declaração do seu uso restritivo. A classe parque-aterro teria função semelhante ao registro de contaminação ou de uso declarado na matrícula de um imóvel. É uma forma de proceder à requalificação ambiental da cidade, mas assumindo os processos históricos de transformação da sua paisagem, resguardando as suas marcas e especificidades. Os projetos paisagísticos dos parques-aterros não podem ser utilizados, simplesmente, como instrumentos para maquiar uma realidade incômoda, nem tão pouco, apenas como propulsores do 
incremento da valorização imobiliária dos seus arredores ou, ainda, como plataforma política nos períodos pré-eleitorais. 


\section{REFERÊNCIAS BIBLIOGRÁFICAS}

AB'SABER, A.N. Geomorfologia do sítio urbano de São Paulo. Cotia, SP: Ateliê Editorial, 2007. $349 \mathrm{p}$.

AB'SABER, A.N. Súmula geomorfológica do Planalto Paulistano. In: Aspectos geológicos e geotécnicos da bacia sedimentar de São Paulo. (Mesa Redonda). Publicação Especial. São Paulo: ABGE/SBG - NSP. 1980. p. 33-36.

ABRAHÃO, R.A., VELLOSO, D.A. Fundações. In: OLIVEIRA, A.M. dos S.; Brito, S.N.A. de (Eds.) Geologia de Engenharia. Associação Brasileira de Geologia de Engenharia - ABGE. São Paulo, 1998. p. $381-396$.

ALBUQUERQUE, M.Z.A. Espaços livres públicos inseridos na paisagem urbana: Memórias, rugosidades e metamorfoses. Studo dos parques urbanos 13 de Maio, Recife-Brasil e do Tiergarten, Berlim-Alemanha. Dissertação. (Geografia). Centro de filosofia eCiências Humanas. Universidade de Pernambuco. Recife. 2006. 229 p.

AMARAL, C.P.; CERRI, L.E.S. Riscos Geológicos. 1998. p. 300-310. In: Oliveira, A.M.S. e Brito, S.N.A. (Eds.) Geologia de Engenharia. São Paulo: Associação Brasileira de Geologia de Engenharia (ABGE). 1998. $586 \mathrm{p}$.

ANDRADE, J.C.M. Fitotransporte de Metais em Espécies Arbóreas e Arbustivas em Aterro de Resíduos Sólidos Urbanos. 2005. 263 p. Tese (Doutorado em Engenharia Civil). Universidade Federal do Rio de Janeiro (UFRJ) - COPPE. Rio de Janeiro, 2005

ANDRADE, J.C. da M. Vegetação em Aterros Sanitários de Resíduos Sólidos Urbanos: Estudo de Caso do Aterro Santo Amaro, São Paulo. Dissertação (Mestrado em Engenharia Civil). Universidade Federal do Rio de Janeiro - UFRJ, Coordenação do Programa de Pós-graduação em Engenharia - COPPE. Rio de Janeiro, 2000. 186 p.

ARAGAKI, S. Florística e estrutura de trecho remanescente de floresta no Planalto Paulistano (SP). Universidade de São Paulo, São Paulo. Dissertação. (Mestrado em Biociências). 1997. 108 p.

ARAUJO, G.H.S.; ALMEIDA, J.R.; GUERRA, A.J.T.. Gestão Ambiental de Áreas Degradadas. Rio de Janeiro: Bertrand Brasil. 2005. 320p.

ASOCIACIÓN INTERAMERICANA DE INGENIERIA SANITARIA Y AMBIENTAL - AIDIS; Centro Internacional de Investigaciones para el Desarrollo - IDRC. Directrices para la Gestion Integrada y Sostenible de Residuos Solidos Urbanos en America Latina y el Caribe. Wanda Maria Risso Gúnther, W.M.R.; Grimberg, E. (Coord.). São Paulo: AIDIS/IDRC, 2006. 118 p.

ASSOCIAÇÃO BRASILEIRA DE LIMPEZA PÚBLICA E RESÍDUOS ESPECIAIS - ABRELPE. Panorama dos Resíduos Sólidos no Brasil 2009. São Paulo. 2009. 207 p. Disponível em:< http://www.abrelpe.org.br> Acesso em: 10/06/2010. 
ASSOCIAÇÃO BRASILEIRA DE LIMPEZA PÚBLICA E RESÍDUOS ESPECIAIS - ABRELPE. Panorama dos Resíduos Sólidos no Brasil 2010. São Paulo. 2010. 199 p. Disponível em:< http://www.abrelpe.org.br> Acesso em: 12/09/2011.

ASSOCIAÇÃO BRASILEIRA DE NORMAS TÉCNICAS (ABNT). NBR 113.896. Aterros de Resíduos Não Perigosos. Critérios para Projeto, Implantação e Operação. 1997.

NBR 10.004. Resíduos Sólidos - Classificação.

AZEVEDO, A.A.; ALBUQUERQUE FILHO,, J.L. Águas Subterrâneas. 1998. p. 111-130.In: Oliveira, A.M.S. e Brito, S.N.A. (Eds.) Geologia de Engenharia. São Paulo: Associação Brasileira de Geologia de Engenharia (ABGE). 1998. 586 p.

BARROS, L.H.S., JARDINEIRO, K.S., BITENCOURT, M.D. Classificação da imagem ALOS para identificação do potencial de revegetação dos aterros desativados no Município de São Paulo. Anais... XV Simpósio Brasileiro de Sensoriamento Remoto. Curituba. 2011. p. 909-916. Disponível em: www.dsr.inpe.br/sbsr2011/files/indexaut.htm. Acesso em: maio 2011.

BARROS, M. DNA Paulistano. Extremo Leste. FOLHA DE S.PAULO. Datafolha 4. Especial 1. Domingo, 24 de agosto de 2008. 2008a. 10p.

BARROS, M. DNA Paulistano. Extremo Oeste. FOLHA DE S.PAULO. Datafolha 5. Especial 1. Domingo, 31 de agosto de 2008. 2008b.10p.

BARROSO, D.A. O verde como estratégia de valorização imobiliária: a formação de um projeto urbanístico em São Paulo. 2007. P. 157-172. In: Metrópole: acumulação urbana. Cadernos Metrópole, n. 18. 2007.

BARTALINI, V. Parques públicos municipais de São Paulo. Ação da municipalidade no provimento de áreas verdes. Universidade de São Paulo. Tese (Doutorado em Arquitetura e Urbanismo). São Paulo. 1999. 220 p.

BARTHOLOMEI, C. L. B. Influência da Vegetação no Conforto Térmico Urbano e no Ambiente Construído. Universidade Estadual de Campinas (UNICAMP). Tese (Doutorado em Engenharia Civil). Campinas. 2003. 189 p.

BARTOLOMÉ, M.M. Técnicas de investigación. La indagación cualitativa y sus usos más comunes em la investigación social. In: ESCUELA DE ANIMACION Y EDUCACION JUVENIL. Planificación, organización y evaluación de proyetos sociales. Consejaria de Educación y Cultura. Direción General de Juventud. Madrid, Espanha. 1997. p. 44-70.

BECK, U. La sociedad del riesgo: hacia una nueva modernidad. España (Barcelona): Ed. Paidós Ibérica. 2002. 304 p.

BENVENUTO, C. Tratamento do chorume é um desafio. Revista Limpeza Pública. Associação Brasileira de Resíduos Sólidos e Limpeza Pública - ABLP. № 73. São Paulo, SP. 2010. p. 27-28. 
Requalificação dos Aterros Desativados (Brownfields) no Município de São Paulo: Parques (GreenfieldS) Raposo TAVARES E Jardim Primavera

LUZIA HELENA dos SANTOS BARROS

BERTRAND, G. Paisagem e geografia física global: esboço metodológico. Tradução de Olga Cruz. São Paulo: IGEO-USP, 1971. p. 1- 27 (Série Caderno de Ciências da Terra, 13).

BEZERRA, M. C. e RIBAS, O. A construção da sustentabilidade das cidades brasileiras. VI Curso de Política Ambiental, Brasília. Instituto de Educação do Brasil - IEB. 2005. (CD ROM disponibilizado).

BITAR, O.Y. Instrumentos de Gestão ambiental (IGA's) Aplicáveis ao Planejamento, Instalação, Operação e Desativação de Empreendimentos. In: Simpósio de Gestão Ambiental. Anais... 2001. CD Rom.

BITENCOURT, M.D. Modelagem espaço espectro temporal da qualidade a água, utilizando análise geográfica computadorizada. 2009, p. Universidade de São Paulo (USP)/ Instituto de Biociências(IB), Parceria SABESP. (Processo FAPESP no 2006/51869-3).

BORELLA, M.F.P. Reintegração de aterros sanitários à paisagem urbana. In: Seminário sobre Resíduos Sólidos (RESID 2004), 2; 2004. ABGE, São Paulo. Anais... (CD ROM).

BOSCOV, M.E.G. Geoctenia Ambiental. São Paulo: Oficina de Textos. 2008. 248 p.

BOX, T.W. Reclamation of drastically disturbed land. In: Symposium Ohio, 1, 1978, Wooster. Proceedings... Wiscosin. American Society of Agronomy, 1978. p. 3-5.

BRASIL. MINISTÉRIO DA SAÚDE (MS). FUNDAÇÃO NACIONAL DA SAÚDE (FNS). Manual de Saneamento. 3를 - Brasília. 1999. 374 p:Il

MINISTÉRIO DAS CIDADES (MC). Secretaria Nacional de Saneamento Ambiental (SNSA). Sistema Nacional de Informações sobre Saneamento (SNIS). Diagnóstico do Manejo de Resíduos Sólidos Urbanos - 2007. Parte 1 - Texto: Visão Geral da Prestação de Serviços. Brasília. 2009. $262 \mathrm{p}$.

BRASIL , S. Lição Esquecida. Moradores voltam a ocupar barracos condenados pela Defesa Civil e se recusam a deixar o Morro do bumba. VEJA RIO. Ano 20, oㅜ 15. 13Abr.2011. Rio de Janeiro. p. 25-26.

BRITO FILHO, L.F. Estudos de Gases em Aterros de Resíduos Sólidos Urbanos. Dissertação (Mestrado em Engenharia Civil). Universidade Federal do Rio de Janeiro UFRJ, Coordenação do Programa de Pós-graduação em Engenharia - COPPE. Rio de Janeiro, 2005. $222 \mathrm{p}$.

BURGOS, R. Parques Públicos Urbanos na Metrópole Paulistana: Concepção e Uso na Produção do Espaço Urbano. Universidade de São Paulo. Dissertação (Mestrado em Geografia Humana). São Paulo. 2003. 195 p.

BURJATO, A.L.P. de F. Parques Acessíveis - Um Direito de Cidadania. Aplicação de procedimentos para avaliação de projeto implantado: o caso do Parque Villa-Lobos. Universidade de São Paulo. Tese (Doutorado em Arquitetura e Urbanismo). São Paulo. 2004. 248 p. 
CÂMARA MUNIPAL DE SÃO PAULO - CMSP. Comissão Parlamentar de Inquérito - CPI. Contaminação e Passivo Ambiental. 2002/2003. Disponível em: <www.camara.sp.gov.br>. Acesso em $15 / 11 / 09$

Poluição. 2006. Disponível em: <www.camara.sp.gov.br>. Acesso em 15/11/09.

Danos Ambientais e seus respectivos passivos, decorrentes de exercício de atividades e práticas industriais e econômicas inadequadas, irregulares ou ilegais. Relatório Final. Diário Oficial do Município de São Paulo, São Paulo, p. 83-103, 16 de dezembro de 2009.

CAMPBELL, C.S.; OGDEN, M.H. Construted Wetlands in the Sustainable Landscape. Ed. John Wiley \& Sons, Inc. New York, USA. 1999. 270p.

CAMPOS, A.C.A.; COSSIA, D.; MACEDO, S.S.; PRETO, M.H.; ROBBA, F. Análise do Sistema de Espaços Livres da Cidade Brasileira - Uma Metodologia em Construção: Estudo de Caso para o Município de São Paulo. Paisagem Ambiente: ensaios, no 26. São Paulo. 2009. P. 197-210.

CAVALHEIRO, F. Intervenções na paisagem: Planejamento de Espaços Livres. 2004. p. 451-455. In: SANTOS, J.E. dos (Org.) Faces da Polissemia da Paisagem: Ecologia, Planejamento e Percepção. São Carlos: RIMA. 2004.

CAVALHEIRO, F. Urbanização e alterações ambientais. 1991. p. 88-99. In: TAUK, S. M. Análise ambiental: uma visão multidisciplinar. Edunesp, São Paulo. 1991.

CHRISTOFOLETTI, A. Geografia física. Boletim de Geografia Teorética. Rio Claro, v. 11, n. 21-22, 1981. p. 5-18.

COMPANHIA AMBIENTAL DO ESTADO SÃO PAULO - Cetesb. Área Contaminada Crítica Jurubatuba. Disponível em: http://www.cetesb.sp.gov.br/Solo/areas_contaminadas/areas_criticas/jurubatuba/jurubatuba.pdf. Acesso em: 19 nov. 2010.

Decisão de Diretoria no 103/2007/C/E, de 22 de junho de 2007. Dispõe sobre o procedimento para gerenciamento de áreas contaminadas. São Paulo: 2007. Disponível em: <http://www.cetesb.sp.gov.br/Solo/areas_contaminadas/proced_gerenciamento_ac.pdf>. Acesso em: $14 / 07 / 09$.

Guia para avaliação do potencial de contaminação em imóveis. São Paulo, 2003. 80 p.

Inventário Estadual de Resíduos Sólidos domiciliares 2009. SAVASTANO NETO, A. (Coord.). São Paulo, 2010. 177 p. Disponível em:<http://www.cetesb.sp.gov.br/Solo/publicacoes.asp>. Acesso em: 21/05/2010.

Inventário Estadual de Resíduos Sólidos domiciliares 2010. SAVASTANO NETO, A. (Coord.). São Paulo, 2011. 186 p. Disponível em:<http://www.cetesb.sp.gov.br/Solo/publicacoes.asp>. Acesso em: 10/09/2010. 
Requalificação dos Aterros Desativados (Brownfields) no Município de São Paulo: Parques (GreenfieldS) Raposo Tavares e Jardim Primavera

LUZIA HELENA dOS SANTOS BARROS

Manual de Gerenciamento de Áreas Contaminadas. São Paulo, 2001-2007. Projeto Cetesb/GTZ, Cooperação Técnica Brasil - Alemanha. 389 p.

Relação de Áreas Contaminadas. Áreas Contaminadas - Solo, São Paulo, 2009. Disponível em:< http://www.cetesb.sp.gov.br/Solo/areas_contaminadas/relacao_areas.asp >. Acesso em: 20/07l/2010.

Relatório de Estabelecimento de Valores Orientadores para Solos e Águas Subterrâneas no Estado de São Paulo. São Paulo. 2002.

CORREIA, B.S.; SILVA, M. C.; MAGNABOSCO, M. Ocupação do Espaço Urbano e natureza: Os Parques nas Cidades. Universidade de São Paulo (USP). Faculdade de Arquitetura e Urbanismo (FAU). Paisagens em Debate. N 05, 2007. p. 1-18.

COSTA, H.S.M. e BRAGA, T.M. Entre a Conciliação e o Conflito: Dilemas para o Planejamento e a Gestão Urbana e Ambiental. X Seminário sobre a Economia Mineira. Disponível em: http://www.cedeplar.ufmg.br.>. Acesso em: Maio/2006.

COSTA, N.M.C. da; COSTA, V.C. da; SANTOS, J.P.C.S. Definição e caracterização de áreas de fragilidade ambiental, com base em análise multicritérios, em zona de amortecimento de Unidade de Conservação. 2009. $17 \quad$ p. $\quad$ Disponível $\quad$ em: $<$ http://egal2009.easyplanners.info/area04/4036_Costa_Nadja_Maria_Castilho_da.pdf>Acesso em: 21Jul2010.

COSTA, R.E.A.B. ITAQUERA VIROU CIDADE: a luta dos moradores de ltaquera e de São Mateus contra o lixão e o movimento para a criação da APA do Parque e Fazenda do Carmo (São Paulo, 1984-1992). 2000. 177 p. Dissertação (Mestrado em História). Universidade Católica de São Paulo (PUC-SP) - São Paulo, 2000.

CROMPTON, J.L. The Impact of Parks and Open Space on Property Values and Property Tax Base. 2001. 124 p. Disponível em: <http://www.rtps.tamu.edu/Faculty/PUBS/roperty\%20Value.PDF>. Acesso em 03 dez. 2010.

CROSTA, A.P. Processamento Digital de Imagens de Sensoriamento Remoto. Ed. rev. Campinas, SP. IG/UNICAMP. 1993, 1992. 170 p.

DINARDI, A.L.; FORMAGI, V.M.; Cassiana M. R.; Coneglian, C.M.R.; BRITO, N.N. de; DRAGONI SOBRINHO, G.; TONSO, S.; PELEGRINI, R. Fitorremediação. In: Forum de Estudos Contábeis, III. Faculdades Integradas Claretianas, Rio Claro, São Paulo. 2003. 15 p. Disponível em: http://www.universoambiental.com.br/Agua_Imagens_Arq/fito.pdf. Acesso em 07set.2010.

DRAMSTAD, W.E.; OLSON, J.D.; FROMAN, R.T.T. Landscape Ecology Principles in Landscape Architecture and Land-Use Planning. Island Press, Washington,DC.1996. 80p.

DUARTE, D.; GONÇALVES, J. Environment and Urbanization: Microclimatic Variations in a Brownfiled Site in São Paulo, Brazil. In: Conference on Passive and Low Energy Architecture, 23. PLEA2006. Proceedings... Geneva, Switzerland. September, 2006. p. 6-8. Disponível em:<http://www.unige.ch/cuepe/html/plea2006/Vol2/Plea2006_PAPER839.pdf>. Acesso em: 30 nov. 2010. 
EASTMAN J.R. Idrisi Andes: Users Guide, Clark Labs for Cartographic Technology and Geographic Analysis, Clark University, Worcester, Mass. 2006.

EASTMAN, J.R. Idrisi for Windows user's guide. Clark University Laboratory, Clark University, Worcester, Pennsylvania. USA. 1997.

EASTMAN, J.R.; JIN, W.; KYEM, P.A.K.; TOLEDO, J. Raster procedure for multi-criteria/multiobjectives decisions. Photogrammetric Engineering \& Remote Sensing, 1995. 61: 539-547.

FATIGATTI, F.L. Estudo da variação da temperatura da superfície do município de São PAULO no período 1991 - 2006 com a utilização de imagens termais do satélite LANDSAT -5 TM. Anais... XIV Simpósio Brasileiro de Sensoriamento Remoto. Natal. 2009. p. 665-662.

FERREIRA, A.B.de H. Novo Dicionário da Língua Portuguesa. Ed. Nova Fronteira. Rio de Janeiro. RJ. 1975.1517 p.

FIGUEIRA, R.M. Evolução dos Sistemas Tecnogênicos no Município de São Paulo. 2007. 126 p. Dissertação (Mestrado em Geologia). Universidade de São Paulo (USP). São Paulo. 2007.

FONTES, N.; SHIMBO, I. Análise de Indicadores para gestão e Planejamento dos espaços livres Públicos de Lazer: Município de Jaboticabal. In: Encontro Nacional da ANPUR, 10. 2003. Belo Horizonte. Anais... Belo Horizonte. 2003. 1 CD-ROM.

FORMAN, R.T.T. Land Mosaics: The Ecology of Landscapes and Regions. Cambridge: University Press, 1999. 632 p.

FORMAN, R.T.T.; GODRON, M. Landscape Ecology. New York: Jonh Wiley \& Sons, 1986.

FORSYTH, A.; MUSACCHIO, L.R. Designing Small Parks - A Manual for Adressing Social and Ecological Concerns. John Wiley \& Sons. New Jersey, 2005. 205 p.

FUKUSHIMA-HEIN, Y.K.; GARCIA, R.J.F.; PANTEN, E.; TAKAHASHI, C.Y.; SANFILIPO, L.H. Recomposição da Vegetação em Área Degradada. In: congresso Nacional sobre Essência Nativas, $2^{\circ}$. Revista do Instituo Florestal. São Paulo, Vol. 4. Parte 4. 1992. P. 1050-1053.

GARCIA, R.J.F. Composição florística dos estratos arbóreo e arbustivo da mata do Parque Santo Dias (São Paulo - SP, Brasil). Universidade de São Paulo. Dissertação (Mestrado em Biociências). São Paulo. 1995. 211p.

GLOEDEN, E. Gerenciamento de áreas contaminadas na bacia hidrográfica do reservatório Guarapiranga. Instituto de Geociências - IG. Universidade de São Paulo - USP. Tese (Doutorado em geociências). 1999. 225 p.

GOMES, C.S.; MORETTO, E.M. Indicadores para formulação e avaliação de políticas para o sistema de áreas verdes urbanas do município de São Paulo. São Paulo, 2009. p. 262-273. In: SÃO PAULO (MUNICÍPIO). SECRETARIA DO VERDE E MEIO AMBIENTE (SVMA). Seminário de Áreas Verdes, 2. Contribuições à Qualidade Ambiental da Cidade. Anais... São Paulo, 2009. 519 p. 
Requalificação dos Aterros Desativados (Brownfields) no MunicípIo de São Paulo: Parques (GreenfieldS) Raposo TAVARES E Jardim Primavera

LUZIA HELENA dOS SANTOS BARROS

GONÇALVES, F.M. Discussões sobre o papel dos espaços livres públicos nos bairros de elite contemporâneos. Paisagem e Ambiente - ensaios. São Paulo, n 15. 2002. p. 9-34.

GOUVEIA, N.; PRADO, R.R. Riscos à saúde em áreas próximas a aterros de resíduos sólidos urbanos. Revista de Saúde Pública. 2010. 8 p.

GRELLET, F.; LOBATO, E.. Chuva e Morte no Rio. FOLHA DE SÃO PAULO. Cotidiano. São Paulo, 09 abr2010. p. C1-C7.

GRIMBERG, E. (Coord.). Diagnóstico Rápido, Lixo e Resíduos na Cidade. In: Dimensões de Gênero no Manejo de Resíduos Domésticos em Áreas Urbanas e Peri Urbanas. Fase 1. Instituto Polis. 2009. 28 p. Disponível em:<http://www.polis.org.br/noticias_interna.asp?codigo=935>. Acesso em: 10/04/2010.

GRIMSKI, D. Revitalização de áreas degradadas e contaminadas na Alemanha e Europa. 2004. p. 3-15. In: Remediação e Revitalização de Áreas Contaminadas. Aspectos técnicos, Legais e Financeiros: Experiências nacionais e internacionais. São Paulo. 2004.

GUZZO, P.; CARNEIRO, R.M.A.; OLIVEIRA JUNIOR, H. Cadastro Municipal de Espaços Livres Urbanos de Ribeirão Preto (SP): Acesso Público, índices e Bases para novos Instrumentos e Mecanismos de Gestão. Revista Brasileira de Arborização Urbana (REVSBAU), V. 1, N. 1. Sociedade Brasileira de Arborização Urbana Piracicaba, SP. 2006. p.19-30. Disponível em: <http://www.revsbau.usp.br/artigos_cientificos/artigo03.pdf>. Acesso em: 28 out. 2010.

HARNIK, P.; TAYLOR, M.; Welle, B. From Dumps to Destinations: The Convertion of Landfilss to Parks. The Trust for Public Land. 2006a. p. 83-88. Disponível em: <http//: tpl.org/content_documents/ccpe_places_article_8_06.pdf. Acesso em 22 mai. 2009.

HARNIK, P.; TAYLOR, M.; Welle, B. From Dumps to Destinations: The convertion of landfills to parks has great potencial for cities. American Society of Landscape Architects (ASLA). Vol. $96 \mathrm{n}^{-0}$ 12. Dezembro. 2006b. p. 50-55.

HAZELRIGG, G. The Ultimate Spectacle. What did it take to convert a decaying pile of trash into what boston's mayor calls the harbor's newest jewel? American Society of Landscape Architects (ASLA). V. 96 n. 12. Dezembro, 2006. p. 56-63.

HENKE-OLIVEIRA, C. Análise de padrões e processos no uso do solo, vegetação, crescimento e adensamento urbano. Estudo de caso: Município de Luiz Antonio (SP). Universidade Federal de São Carlos (UFSCAR). Tese (Doutorado em Ecologia e Recursos Naturais). São Carlos. 2001. 101 p.

IAOCHITE, J.C. Apropriação e Revalorização do Espaço Urbano: análise da Ocorrência de Brownfields no Município de Americana -SP. Dissertação (Mestrado em Geografia). Instituto de Geociências e Ciências Exatas. Universidade Estadual Paulista. Rio Claro. 2005. 123 p.

INSTITUTO BRASILEIRO DE GEOGRAFIA E ESTATÍSTICA - IBGE. Pesquisa nacional de saneamento básico 2000. Rio de Janeiro. 2002. 397 p. Disponível em: <http://www.ibge.gov.brhomeestatistica-populacao-condicoesdevida-pnsb-pnsv.pdf.> Acesso em: 19/09/09. 
INSTITUTO BRASILEIRO DO MEIO AMBIENTE E RECURSOS NATURAIS RENOVÁVEIS - IBAMA. Manual de Recuperação de áreas degradadas pela mineração: técnicas de revegetação. Brasília: IBAMA, 1990. 96 p.

INSTITUTO DE PESQUISAS TECNOLÓGIAS DO ESTADO DE SÃO PAULO - IPT. Diretrizes para consolidação dos taludes adjacentes ao aterro sanitário do Jacuí, localizado em São Miguel Paulista, Município de São Paulo. Relatório № 18.893. 1983. 17 p.

A abordagem geotecnogênica: a geologia de engenharia no quinário. In: Curso de Geologia Aplicada ao Meio ambiente. DIGEO - IPT, São Paulo, ABGE. 1995. p. 231-241.

/COMPROMISSO EMPRESARIAL PARA RECICLAGEM (CEMPRE). Lixo Municipal: Manual de Gerenciamento Integrado. São Paulo: $2^{\mathrm{a}}$ d., 2000.

ISENBERG,R.H.; PETERSON, E.R.; STERNBERG, D. From landfill to leisure. Waste Management World. September-October, 2004. p. 45-53. Disponível em: <http://www.scs-securecom/Papers/lsenberg-Peterson_From_Landfill_to_Leisure.pdf>. Acesso em: 09 nov. 2009.

ISERNHAGEN, I.; BOURLEGAT, J.M.G. Le; CARBONI, M. Trazendo a Riqueza Arbórea Regional para dentro das Cidades: possibilidades, limitações e benefícios. Revista Brasileira de Arborização Urbana (REVSBAU), V. 4, N. 2. Sociedade Brasileira de Arborização Urbana Piracicaba, SP. 2009. P. 117-138. Disponível em: <http://www.revsbau.usp.br/ artigos_cientificos/artigo73-versaopublicacao.pdf >. Acesso em: 28 out. 2010.

JORGE, F.N.; BAPTISTI, E.; GONÇALVES, A. Monitoramento em Aterros Sanitários nas Fases de Encerramento e de Recuperação: Desempenhos Mecânico e Ambiental. In: Seminário sobre Resíduos Sólidos (RESID 2004), 2; 2004. ABGE, São Paulo. Anais... (CD ROM).

KLIASS, R.G. A Evolução dos Parques Urbanos na Cidade de São Paulo. Universidade de São Paulo. Dissertação (Mestrado em Arquitetura e Urbanismo). São Paulo. Vol. 1. 1989. 250 p.

KLIASS, R.G.; BRENNA, J.L. Parque da Juventude - Carandiru - São Paulo. Associação Brasileira de Arquitetos Paisagistas - ABAP. Informativo Paisagem Escrita. Ano I, n. 02. São Paulo, Setembro 2005. p. 3-5. Disponível em: <http://www.abap.org.br/pe/pe02.pdf>. Acesso em: 29 jun. 2010.

LANG, S.; BLASCHKE, T. Análise da Paisagem com SIG; tradução Kux, H. São Paulo: Oficina de Textos, 2009. 424p.

LAZZARO, V.H.P. Implantação de Corredor Ecológico e sua importância para Avifauna nos Parques Urbanos, através da Educação Ambiental. SECRETARIA DO VERDE E MEIO AMBIENTE (SVMA). Seminário de Áreas Verdes, 1. Anais... 2008. 23p.

LEE, G.F.; JONES-LEE, A. Impact of Municipal and Industrial Non-hazardsous Waste Landfills on Public Health and the Environment: An Overview. Prepared for California EPA comparative Risk Project, Sacramento, CA. 1994. 
Requalificação dos Aterros Desativados (Brownfields) no Município de São Paulo: Parques (GreenfieldS) Raposo TAVARES E Jardim PrimaVera

LUZIA HELENA dOS SANTOS BARROS

em Geografia). Instituto de Geociências e Ciências Exatas. Universidade Estadual Paulista. UNESP, Rio Claro. 2005. 144 p.

LEO, O.C.D. O lugar lixo na cidade de São Paulo, a gestão territorial e a contribuição geográfica. Dissertação. (Mestrado em Geografia) Faculdade de Filosofia, Letras e Ciências Humanas. Universidade de São Paulo, São Paulo. 2006. 209 p.

LEUENBERGER, M.; BRANDSCH, N. Redução in situ do risco associado às emissões de gases de aterro pr'ximas a residências. In: MOERI, E.N.; RODRIGUES, D.; NIETERS, A. (Eds.) Áreas Contaminadas: Remediação e Revitalização. Estudos de Casos Nacionais e Internacioanais, Vol. 4. V Seminário Internacional sobre Remidiação e Revitalização de Áreas Contaminadas. 2008. p. 191-199.

LIMA, J.D.; NOBREGA, C.C; FLORES NETO, J.P. Monitoramento e controle ambiental do Parque do Roger. In: Congresso Brasileiro de Engenharia Sanitária e Ambiental, 23. ABES, São Paulo. Anais... 2005. Disponível em: <http://www.bvsde.paho.org/bvsacd/abes23>. Acesso em 17 out. 2008.

LIMA, J.S. Avaliação da Contaminação do Lençol Freático do Lixão do Município de São Pedro da Aldeia - RJ. Dissertação (Mestrado em Engenharia Ambiental).Faculdade de Engenharia. Universidade do Estado Rio de Janeiro - UERJ. Rio de Janeiro. 2003. 77 p.

LIMA,S.B. de. Pós-tratamento de chorume com wetlands construídos utilizando macrófitas aquáticas emergentes da região de Campo Mourão-PR. Tese (Doutorado em Química). Universidade Estadual de Maringá - UEM. Maringá, 2008. 86 p.

LOPES, R.M. Nos Rastros dos Restos: As Trajetórias do Lixo na Cidade de São Paulo. 1998. 225 p. Dissertação (Mestrado em História). Departamento de História. Universidade Pontifícia Católica de São Paulo - PUC-SP. São Paulo. 1998.

MACEDO, S.S.; SAKATA,F.G. Parques Urbanos no Brasil. São Paulo: Imprensa Oficial do Estado. 2003.

MAGALHÃES, J.S.B. Avaliação da Gestão de Sítios Contaminados por Resíduos Perigosos nos EUA, Canadá, Países europeus e Brasil, e Exemplo de um Manual Simplificado de Avaliação de Saúde Ambiental destes Sítios para o Brasil. Dissertação. (Mestrado em Saúde Pública).Escola de Saúde Pública. Fundação Oswaldo Cruz - Fiocruz. Ministério da Saúde. Rio de Janeiro, 2000. 95 p.

MARCELINO, E.V. Desastres Naturais e Geotecnologias: Conceitos Básicos. Ministério da Ciência e Tecnologia. Instituto Nacional de Pesquisas Espaciais (INPE). Centro Rio Grande do Sul. Caderno didático no 1. Santa Maria, RS. Fevereiro, 2008. 38 p. Disponível em: <http://www.inpe.br>. Acesso em: 16mai2010

MARKER, A. A Revitalização de áreas urbanas degradadas. Políticas, Instrumentos e incentivos no cenário nacional. Projeto de Gestão Ambiental Urbana - ProGAU. Projeto Demonstrativo no 4. PMSP/SVMA. São Paulo. 2003. 44 p. Relatório de Consultoria.

MARKER, A. Avaliação ambiental de terrenos com potencial de contaminação: gerenciamento de riscos em empreendimentos imobiliários. (Guia Caixa: Sustentabilidade Ambiental; Caderno 2). Brasília. Caixa. 2008. 164p. 
MARTINS, H.H.T.S. Metodologia qualitativa de pesquisa. Educação e Pesquisa, São Paulo. v. 30, n. 2. Maio/Abo 2004, p. 289-300.

MARTINS, I. A.; BITENCOURT, M.D.; PEREZ, C.F.; JARDINEIRO, K.S. Proposta metodológica para análise espacial de qualidade de habitat para mamíferos grande porte em fragmento de cerrado. Anais... XIV Simpósio Brasileiro de Sensoriamento Remoto. INPE. Natal, 2009. p. 40434047.

MATTOS, T.P. Avaliação da Contaminação hídrica no entorno do antigo Lixão da Marambaia RJ. Dissertação (Mestrado em Engenharia Ambiental). Faculdade de Engenharia. Universidade do Estado Rio de Janeiro - UERJ. Rio de Janeiro. 2005. 102 p.

MELAZO, G.C.; COLESANTI, M.T.M. Parques Urbanos: Importantes "Espaços Verdes" na Dinâmica Ambiental das Cidades. In: Simp. Reg. Geografia, II. Anais... UFB. 2003. Disponível em <http://www.ig.ufu.br/2srg/5/5-11.pdf>. Acesso em 25 mai. 2009.

MELO, M.A.S. de. O Meio Ambiente e o Registro de Imóveis. Ver. Direito Imobiliário, Ano 27, N. 57, julho-dezembro, 2004. p. 111-154.

METZGER, J.P. O que é ecologia de paisagens? Biota Neotropica, vol.1, no 1/2, Campinas/SP. 2001. p. 1-9. Disponível em <http://www.biotaneotropica.org.br>. Acesso em 20/08/07.

MEYER, R.M.P.; GROSTEIN, M.D. A Leste do centro: territórios do urbanismo. São Paulo: Imprensa Oficial do Estado de São Paulo, 2010. 324 p.

MEYER, R.M.P.; GROSTEIN, M.D.; BIDERMAN, C. São Paulo Metrópole. São Paulo: Editora da Universidade de São Paulo; Imprensa Oficial do Estado de São Paulo. 2004. 290p.

MOERI, E.; COELHO, R. Tecnologias e Experiências (Cases Studies) em Diagnóstico, Remediação e Revitalização de Áreas Contaminadas. In: Revitalização de Brownfields: Riscos e Oportunidades.CSD - Geoklock Geologia e Engenharia Ambiental. 2005. (apresentação em slides).

MOLITERNO, M. Áreas Contaminadas e o Setor Imobiliário: Análise da Aplicação do Guia de Avaliação do Potencial de contaminação em Imóveis. Instituto de Dissertação (Mestrado profissional). Pesquisas Tecnológicas do Estado de São Paulo - IPT. São Paulo. 2006. 102 p.

MORATO, R.G.; KAWAKUBO, F.S.; LUCHIARI, A. Geoprocessamento para a análise da desigualdade ambiental na Subprefeitura do Butantã. In: Simpósio Brasileiro de Geografia Física Aplicada (SBGFA), 11. 2005, São Paulo. Anais... Artigos, p. 2331-2338. CD-ROM.

MORI, R.T. Oscilações dos níveis freáticos e as repercussões na ocupação urbana. In: Problemas Geológicos e Geotécnicos na Região Metropolitana de São Paulo, São Paulo. ABAS/ABGE/SBG-SP. 1992. p. 227-240.

MORINAGA, C.M. Recuperação de Áreas Contaminadas: Um novo desafio para projetos paisagísticos. 2007. 152 p. Dissertação (Mestrado em Arquitetura e Urbnismo). Faculdade de Arquitetura e Urbanismo, Universidade de São Paulo - USP. São Paulo. 2007. 
Requalificação dos Aterros Desativados (Brownfields) no MunicípIo de São Paulo: Parques (GreenfieldS) Raposo Tavares e Jardim Primavera

LUZIA HELENA dOS SANTOS BARROS

MORINAGA, C.M.; Pereira, H.M.S.B; Galvanese, H.C.; Ueta, I.H.; Sepe, P.M. As Potencialidades e limitações da aplicação de instrumentos urbanísticos de incentivo para a revitalização de áreas contaminadas na cidade de São Paulo. In: Áreas Contaminadas: Remediação e Revitalização Estudos de casos nacionais e internacionais. V. 4, p. 67-84. V Seminário Internacional sobre Remediação e Revitalização de Áreas Contaminadas (2007). São Paulo.

MOTTA, M.; SILVA, F.A.N. da; LOBATO, R.; RAMIRES, J.Z.S.; VITOR, J.D.S.; MONTEIRO, R.; TAKIYA,H.; MANETTI,C.; BRETTAS, L.E.; GLOEDEN, E.; NETO, V. de A.; MARKER, A. Proposta de revitalização de brownfield na área do antigo Incinerador Pinheiros. 2007. p. 189-204. In: MOERi, E.; RODRIGUES, D.; NIETERS, A. (Eds.). Áreas contaminadas: remediação e revitalização. São Paulo: Signus Editora. 2007. 204 p.

MUNEROLI, C.C. Arborização Urbana: Espécies Arbóreas Nativas e a Captura do Carbono Atmosférico. Dissertação (Mestrado em Engenharia). Universidade de Passo Fundo. Passo Fundo, RS. 2009. 137 p.

NDUBISI, F. Ecological Planning: A Historical and comparative Synthesis. Baltimore: The Johns Hopkins University Press, 2002.

NEDER, A.A.; MOURÃO, C.T.O.; SOUZA, J.A.V.; HUANG, Y.T. Parque sobre Aterro Desativado Estudo de Caso do Parque Raposo Tavares. Monografia. SENAC. São Paulo, 2005. 96 p.

NETO, V.A. Área Contaminada Crítica do Jurubatuba. In: Workshop Internacional de Meios Fraturados: Contaminação e Gestão. São Paulo: CEPS/USP. 2010. (Palestra).

NEW YORK CITY (NYC). Park \& Recreation. Fresh Perspectives. FreshkillsPark Newsletter Fall/Winter 2009. New York, 2009. 8 p. Disponível em: <http://www.nycgovparks.org/sub_your_park/fresh_kills_park/html/fresh_kills_park.html> Acesso em: 02 dez. 2010.

NOVACK, T; KUX, H. J. R. Classificação da cobertura do solo urbano inserindo arvores de decisão a rede hierárquica. In: XIV Simpósio Brasileiro de Sensoriamento Remoto - SBSR. Natal. Anais... 2009.

NUCCI, J.C. Qualidade ambiental e adensamento urbano: um estudo de ecologia e planejamento da paisagem aplicado ao distrito de Santa Cecília (MSP). São Paulo: Humanitas/FFLCH, 2001. 236 p.

OGATA, M.G. Os Resíduos Sólidos na Organização do Espaço e na Qualidade do Ambiente Urbano: Uma contribuição Geográfica ao Estudo do Problema na Cidade de São Paulo. 1978. 173 p. Dissertação (Mestrado em Geografia). Faculdade de Filosofia, Letras e Ciências Humanas. Universidade de São Paulo - USP. São Paulo. 1978.

OGATA, M.G. Os Resíduos Sólidos na Organização do Espaço e na Qualidade do Ambiente Urbano: Uma Contribuição Geográfica ao Estudo do Problema na Cidade de São Paulo. Rio de Janeiro: IBGE, 1983. 188 p. 
OLIVEIRA, A.M.S. Depósitos tecnogênicos associados à erosão atual. In: Congresso Brasileiro de Geologia de Engenharia, 6, Salvador. Atas.... Salvador. ABGE, v. 1, 1990. p. 411-415.

OLIVEIRA, C. Gestão Ambiental e Arranjos Institucionais: Os Parques Ecológicos Paulistas. Tese de (Doutorado em Saneamento). Universidade de Campinas - UNICAMP. Campinas, SP. 2004. $266 \mathrm{p}$.

OLIVEIRA, C.N. de. Recuperação ambiental de aterros sanitários na região metropolitana de Campinas: revegetação e uso futuro. Dissertação (Mestrado em Engenharia e Saneamento). Faculdade de Engenharia Civil, Arquitetura e Urbanismo. Universidade Estadual de Campinas Unicamp. Campinas, SP. 2005. 88 p.

OLIVEIRA, N. O Papel dos Parques para a Sensibilização Ambiental e Conservação da Biodiversidade em Meio Urbano. 2006. p.146-156. In: CÂMARA MUNICIPAL DO PORTO. Congresso Internacional de Parques Urbanos e Metropolitanos. Parques Urbanos e Metropolitanos: Manual de Boas Práticas. Porto, Portugal. 2006. 223 p.

OLIVEIRA, P.S.G. de Estudo das várzeas visando o controle de cheias urbanas e a restauração ecológica: o caso do parque linear do ribeirão das Pedras, em Campinas, SP. Campinas, SP. Faculdade de Engenharia Agrícola. Universidade Estadual de Campinas. Tese (Doutorado em Engenharia Agrícola). 2004. 159 p.

OLIVEIRA, S. Determinação de alguns parâmetros indicadores de poluição por efluente líquido de um aterro sanitário. Tese (Doutorado em Agronomia). Faculdade de Ciências Agronômicas. Universidade Estadual Paulista - UNESP. Campos de Botucatu, SP. 2001. 84 p.

PÁDUA, J.A. Um Sopro de Destruição: pensamento político e crítica ambiental no Brasil escravagista, 1786-1888. Rio de Janeiro: Jorge Zahar Ed., $2^{3}$ ed. 2004. 318p.

PELLEGRINO, P.R.M. Paisagens Temáticas: Ambiente Virtual. Tese (Doutorado em Arquitetura e Urbanismo). Universidade de São Paulo, São Paulo. 1995. 135 p.

PELLOGIA, A. O homem e o ambiente geológico: geologia, sociedade e ocupação urbana no Município de São Paulo. São Paulo, Ed. Xamã,1998. 271 p.

PELLOGIA, A.U.G. As coberturas remobilizadas: depósitos tecnogênicos de encostas urbanas no Município de São Paulo. Solos e Rochas, 17 (2). 1994. p.125-129.

PENA, A.; CABRAL, J. Região de Lisboa e Vale do Tejo. Roteiros da Natureza. Temas e Debates Actividades Editoriais LDA. 1996. 142 p.

PORTO, M.F.S. Uma Ecologia Política dos Riscos: princípios para integrarmos o local e o global na promoção da saúde e da justiça ambiental. Rio de Janeiro: Ed. FIOCRUZ, 2007. 248 p.

POSSAMAI, F.P.; COSTA, M.M.DE; VIANA, E. Lixões Inativos na Região Sul do Estado de Santa Catarina: Cenário e aspectos Jurídicos. 2006. 12 p. Disponível em: <http://www.fmd.pucminas.br/Virtuajus/2_2006/Docentes/pdf/Fernando.pdf>. Acesso em: 22jul2009. 
Requalificação dos Aterros Desativados (Brownfields) no Município de São Paulo: Parques (GreenfieldS) Raposo TAVARES E Jardim Primavera

LUZIA HELENA dOS SANTOS BARROS

PRAÇA VICTOR CIVITA Espaço aberto da Sustentabilidade - Revitalização. 2009. Disponível em: $<$ http://pracavictorcivita.org.br>. Acesso em 25 jul. 2009.

PRODAM - EMPRESA DE TECNOLOGIA DE INFORMAÇÃO E COMUNICAÇÃO DO MUNICÍPIO DE SÃO PAULO. Sistema Integrado de Informações Urbanas. 2006. (Apresentação de slides).

RAFAEL, L.F.A. Resíduos Sólidos e Evolução Urbana em Santo André - SP. - Ed. revisada - São Paulo, 2006. 216 p. Dissertação (Mestrado em Engenharia Civil). Escola Politécnica. Universidade de São Paulo - USP. 2006

RAMIRES, J.Z. Áreas contaminadas e os Riscos Socioambientais em São Paulo. Dissertação (Mestrado em Geografia Humana). Faculdade de Filosofia, Letras e Ciências Humanas. Universidade de São Paulo - USP. São Paulo, 2008. 175 p.

RAMIRES, J.Z., REZENDE, J.V.; BARROS, L.H.S.; BRUNI, H.S.; ANIAS, A.A. Ações para revitalização de aterros desativados no município de São Paulo. In: $11^{\circ}$ Congresso. Brasileiro de Geologia de Engenharia e Ambiental, Anais... (CD ROM). 2005.

RAMIRES, J.Z.S.; VITOR, J.D.A. O Impacto Ambiental Oriundo do descarte irregular de resíduos: A Contaminação do Solo e das Águas Subterrâneas no Município de São Paulo. Anais... XVI Congresso Brasileiro de Águas Subterrâneas/XVII Encontro Nacional de Perfuradores de Poços. São Luis, Maranhão. 2010.

RAMIRES, J.Z; VITOR, J.D.S.; MOTTA, M.T. A atuação do município de São Paulo na identificação e controle do uso de áreas contaminadas. In: Áreas Contaminadas. Remediação e Revitalização Estudos de casos nacionais e internacionais. V. 4, p. 3-14. 2008. V Seminário Internacional sobre Remediação e Revitalização de Áreas Contaminadas (2007). São Paulo.

REAL, J.L.G. Riscos Ambientais em Aterros de Resíduos Sólidos com Ênfase na Emissão de Gases. Dissertação (Mestrado em engenharia). Coordenação de Programas de Pós-graduação em Engenharia - COPPE. Universidade Federal do Rio de Janeiro - UFRJ. 2005. 173 p.

REIS, J.M. O Município e o Meio Ambiente. Apontamentos sobre ação ambiental na órbita dos Municípios. Rev. Direito Ambiental, Ano 9, no35, julho-setembro Notas. 2004. p:357-369.

ROCHA, Y.T. Vegetação Urbana: Caracterização e Planejamento. 2007. p.113-121. In: TÂNGARI, V.R et al. (Org.). Águas Urbanas: uma contribuição para a regeneração ambiental como campo disciplinar integrado. $1^{\mathrm{a}} \mathrm{Ed}$. Universidade Federal do Rio de Janeiro, Faculdade de Arquitetura e Urbanismo, Programa de Pos-graduação em Arquitetura. (Coleção PROARQ). 2007. 368 p.

RODRIGUES, R.R.; GANDOLFI, S. Conceitos, Tendências e Aç̃es para a Recuperação de Florestas Ciliares. Cap. 15.1, 2004. p: 235-247. In: RODRIGUES, R.R.; LEITÂO FILHO, H.F. Matas Ciliares Conservação e Recuperação. São Paulo, EDUSP/FAPESP. 2004. 320 p.

RODRIGUEZ, F.A. A aplicação de resultados de pesquisa em recursos hídricos para o desenvolvimento social. Workshop ciência e Sociedade. Rio de Janeiro. 2007. Disponível em: $<$ http://www.redevale.ita.br/apresentacao/workshop/Oficina/C\&S/Interaguas/Fernando_Rodtiguez.pdf >. Acesso em 26nov2007. 
RODRIGUEZ, S.K. Geologia Urbana da Região Metropolitana de São Paulo. 1998. 171 p. Tese (Doutorado em Geociências) Instituto de Geociências. Universidade de São Paulo - USP. São Paulo. 1998.

ROSSET, F. Procedimentos metodológicos para estimativa do Índice de Áreas Verdes Públicas. Estudo de Caso: Erechim, RS. Dissertação (Mestrado). Ecologia e Recursos Naturais. Universidade Federal de São Carlos. São Carlos, SP. 2005.

ROSSETI, A.I.N.; PELLEGRINO, P.R.M.; TAVARES, A.R. As Árvores e suas Interfaces no Ambiente Urbano. Revista Brasileira de Arborização Urbana (REVSBAU), v. 5, n. 1. Sociedade Brasileira de Arborização Urbana Piracicaba, SP. 2006. p. 1-24. Disponível em: <http://www.revsbau.usp.br/artigos_cientificos/artigo59-publcacao.pdf>. Acesso em: 05 nov. 2010.

RUBERG, C. A destinação dos resíduos sólidos domiciliares em megacidades: o caso de São Paulo. 2005. 309 p. Tese (Doutorado em Arquitetura e Urbanismo). Faculdade de Arquitetura e Urbanismo. Universidade de São Paulo - USP. São Paulo. 2005.

SAATY,T. A scaling method for priorities in hierarchical structures. J. March. Psychol, 15. p. 234281.

SALES, C. A. Propriedade imobiliária e obrigações propter rem pela recuperação ambiental do solo degradado. Rev. Direito Ambiental, Ano 9, no 34, abril-junho, 2004. p. 8-9.

SÁNCHEZ, L.E. Avaliação de impacto ambiental: conceitos e métodos. São Paulo. Oficina de Textos, 2006. 495 p.

SÁNCHEZ, L.E. Desengenharia: O Passivo Ambiental na Desativação de Empreendimentos Industriais. Edusp/FAPESP. São Paulo. 2001. 256 p

SÁNCHEZ, L.E. Revitalização de áreas contaminadas. In: MOERI, E.; COELHO, R.; MARKER, A (Eds.) Remediação e revitalização de áreas contaminadas. São Paulo: Instituto EKOS Brasil, Ed. Signus. 2004. p. $79-90$.

SANTOS, R.F. O retrato da complexidade dos parques da região metropolitana de São Paulo. In: PARQUE DE CIÊNCIA E TECNOLOGIA (PRCEU/USP); SECRETARIA DO MEIO AMBIENTE ESTADO DE SÃO PAULO (SMA). Mesa Redonda: Parques nas cidades: complexidade de estrutura e funções. Seminário 2006. Parques Urbanos: Preservação e Lazer nas Áreas Públicas. Resumo. 19 out. 2006.

SANTOS, R.F. Planejamento ambiental: teoria e prática. São Paulo: Oficina de Textos, 2004. 184 p.

SÃO PAULO (ESTADO). EMPRESA PAULISTA METROPOLITANA (Emplasa). Por dentro da Região Metropolitana de São Paulo. São Paulo. Junho 2011. 77 p.

SECRETARIA DO ESTADO MEIO AMBIENTE (SMA). SECRETARIA DO ESTADO DE SANEAMENTO E ENERGIA (SSE). Projeto Jurubatuba: restrição e controle do uso de águas 
Requalificação dos Aterros Desativados (Brownfields) no Município de SÃo PaUlo: PaRQues (GREENFIELDS) RAPOSO TAVARES E JARDIM PRIMAVERA

LUZIA HELENA dOS SANTOS BARROS

subterrâneas. Departamento de Águas e Energia Elétrica, Instituto Geológico, Secretaria do Estado Meio Ambiente. Secretaria do Estado de Saneamento e Energia. São Paulo: DAEE/IG, 2009. 109 p. Disponível em <http:// www.igeologico.sp.gov.br/downloads/livros/Jurubatuba.pdf>. Acesso em 19nov.10.

Site Oficial do Governo do Estado de São Paulo. Secretaria do Governo de Esporte e Lazer -
$\begin{aligned} & \text { Segel. } \\ & \text { Parque da Juventude. }\end{aligned} \quad 2005 . \quad$ Disponível em
www.saopaulo.sp.gov.br/hotsite/parquejuventude/>. Acesso em 10/03/05.

SECRETARIA DO MEIO AMBIENTE (SMA). Parque Vila Lobos. São Paulo. 2009. Disponível

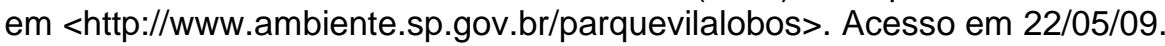

SECRETARIA MUNICIPAL DO PLANEJAMENTO (SEMPLA). Vegetação Significativa do Município de São Paulo. São Paulo, SP. 1988.

SÃO PAULO (MUNICÍPIO). EMPRESA MUNICIPAL DE URBANIZAÇÃO - EMURB. Centro Administrativo /Municipal. Estudos Geotécnicos e de Engenharia Ambiental. Diagnóstico dos problemas geotécnicos e ecológico-sanitários surgidos pelo depósito de lixo na área da Coroa. 1974. 55 p. (Relatório Interno).

PREFEITURA DO MUNICÍPIO DE SÃO PAULO. Prefeitura apresenta Projeto Nova Luz e abre primeira fase de consulta pública. Diário Oficial da Cidade. Ano 55. Número 213. 18 de novembro de 2010.2 P. $\quad$ I. $\quad$ Disponível em: <http://diariooficial.imprensaoficial.com.br/nav_v4/index.asp?c=1>. Acesso em: 19nov.10.

SECRETARIA MUNICIPAL DA HABITAÇÃO (Sehab). Superintendência de Habitação (HABI). Relatório de Avaliação Ambiental Confirmatória das Áreas no entorno do Aterro Sanitário Sapopemba. São Paulo: Consórcio Bureau-Sistema PRI, 2006. 51p. (RE004-06_SFrancisco).

SECRETARIA MUNICIPAL DA SAÚDE (SMS). Centro de controle de Zoonoses. Animais sinantrópicos: como prevenir. Manual do Educador. São Paulo, s/d. 25 p. Disponível em: <http://www.prefeitura.sp.gpv.br/.../Sinantropicos_1253737170.pdf.> Acesso em:06out2010.

Coordenação de epidemiologia e Informação (CEInfo). 2009. Disponível em: <http://ww2.prefeitura.sp.gov.br/cgi/tabcgi.exe?secretarias/saude/TABNET/POP/pop.def>. Acesso em 29 mai. 2010.

SECRETARIA MUNICIPAL DO PLANEJAMENTO (SEMPLA). Cadastramento dos Espaços Arbóreos Significativos do Município de São Paulo. São Paulo, SP. 1985.

Relatório Final do Grupo Técnico de detalhamento da Carta Geotécnica do Município de São Paulo. São Paulo. (Relatório Interno). 1994.

SECRETARIA MUNICIPAL DE SERVIÇOS - SES. Departamento de Limpeza Pública Limpurb, Caracterização dos Resíduos Sólidos Domiciliares do Município de São Paulo - 2004. São Paulo. 2004. 110 p. (Relatório Interno).

Sistema de Limpeza Pública do Município de São Paulo. 2010. Apresentação disponibilizada pelo Limpurb. 
Investigação Confirmatória do Aterro São Mateus, São Paulo/SP. São Paulo: Weber Ambiental, 2009a. 273 p. (Projeto Weber no 01.440.08; Processo Administrativo 2006-0.301.066-7). <http://www.atsdr.cdc.gov/HAC/landfill/html/ch2.html>. Acesso: 18 Jul. 2005. 389 p.

SECRETARIA MUNICIPAL DO VERDE E MEIO AMBIENTE (SVMA). Ações Locais para a Biodiversidade na Cidade de São Paulo. Relatório Interno. São Paulo: SVMA, 2008B. 40 p.

Análise, Caracterização e Proposta de Ação para Revitalização dos Aterros Desativados no Município de São Paulo. São Paulo, 2005. Relatório Interno. 57p.

Atlas ambiental do Município de São Paulo - O verde, o território, o ser humano: diagnóstico e bases para a definição de políticas públicas para as áreas verdes no Município de São Paulo. São Paulo: SVMA, 2004a. 266 p.

Avaliação Preliminar da Viabilidade Ambiental da Implantação de Parques Municipais em Aterros Sanitários Desativados. São Paulo, 2001. Relatório Interno. 62 p.

Complementação da Investigação Confirmatória, com avaliação de risco à saúde humana na área do antigo Aterro de Vila Albertina, São Paulo/SP. São Paulo: Weber Ambiental, 2009c. V. 1, 278 p.; V. 2, 40 p. (Projeto Weber no 01.480.09; Processo Administrativo 2007-0.220.258$0)$.

1993.

Diagnóstico Cartográfico Ambiental do Município de São Paulo. São Paulo, SP.

Execução de Serviços Técnicos de Avaliação de Passivo Ambie tal na área do Antigo Aterro Municipal Jacui, visando à implantação do Parque Municipal Jardim Primavera. Processo 2006-0.120.602-5. Edital 004/SVMA/2006. Contrato: 07/SVMA/2007. Projeto Weber no 01.257.07. Weber Ambiental. Maio 2007a. 140 p.

Fauna silvestre: Quem são e onde vivem os animais na metrópole paulistana.

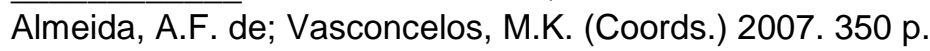

Geo Cidade de São Paulo: panorama do meio ambiente urbano. São Paulo: SVMA/IPT/PNUMA, 2004b. 204 p.

Guia dos Parques Municipais. São Paulo, 2007a. 109 p.il.

Informação Técnica no 129/GTAC/2008, de 08/12/08. Análise do Relatório de Investigação Detalhada na área do antigo Aterro Sapopemba e utilização da área. São Paulo: SVMA, 2008a. 2 p. (TID no 3379658).

Investigação Confirmatória do Aterro Municipal Vila São Francisco, São Paulo/SP. São Paulo: REGEA Geologia e Estudos Ambientais, 2010. 36 p. (Relatório Final).

Investigação Confirmatória para a área do antigo Aterro Jardim Damaceno, São Paulo/SP. São Paulo: Weber Ambiental, 2009b. 265 p. (Projeto Weber no 01.438.08; Processo Administrativo 2006-0.301.556-1). 
Requalificação dos Aterros Desativados (Brownfields) no Município de São Paulo: Parques (GreenfieldS) Raposo Tavares e Jardim Primavera

LUZIA HELENA dOS SANTOS BARROS

Relatório de Avaliação Ambiental e Análise de Risco Tier 2 - Fase 2. Antigo Aterro Municipal Jacui. Processo 2006-0.120.602-5. Edital 004/SVMA/2006. Contrato: 07/SVMA/2007. Projeto Weber no 01.257.07. Weber Ambiental. Abril 2008. 108 p.

Parecer Técnico no 014/GTAC/2010, de 12/02/10. Acompanhamento dos estudos de Avaliação Ambiental na área do antigo Aterro Municipal Vila Albertina. São Paulo: SVMA, 2010a. 7 p. (Processo Administrativo 2010-0.013.544-2, p.281-291).

Parecer Técnico ํo 024/GTAC/2010, de 19/03/10. Acompanhamento dos Estudos de Avaliação Ambiental na Área do Antigo Aterro Municipal São Mateus. São Paulo: SVMA, 2010b. p. . (Processo Administrativo 2010-0.010.240-4, p.280-285).

Parecer Técnico no 135/GTAC/2009, 05/11/09. Projeto Preliminar do Parque Urbano Sapopemba. São Paulo: SVMA, 2009a. 6 p.

Parecer Técnico oㅜ 144/GTAC/2008, de 21/10/08. Termo de Referência para Contratação de Serviços de Complementação de Investigação Confirmatória, com Avaliação de risco à Saúde Humana, na área do antigo Aterro Municipal Vila Albertina. São Paulo: SVMA, 2008b. 7 p. (Processo Administrativo 2010-0.013.544-2, p. 324-330)

Parecer Técnico no 146/GTAC/2008, de 21/10/09 2009b

Projeto 100 Parques. São Paulo, 2009. Disponível em <http://www9.prefeitura.sp.gov.br/sitesvma/100_parques/parques_sp/>. Acesso em 18/05/09.

/Centro de Estudos da Metrópole (CEM). Indicadores Ambientais e Gestão Urbana. Desafios para a Construção da Sustentabilidade na Cidade de São Paulo. SEPE, P.M.; GOMES, S. (Coord.). 2008. 150 p. + CD ROM.

/Fundação de Pesquisa em Meio Ambiente (FUPAM). Sistematização Bibliográfica sobre Planejamento Urbano-Ambiental e Zoneamento Ambiental. Produto 5 - Relatório II. Projeto "Pesquisa e análise de aplicação de Instrumentos em Planejamento Urbano Ambiental no Município de São Paulo". 2006b. 49 p. (Relatório Interno).

SAKATA, F. G. O Projeto Paisagístico como instrumento de requalificação urbana. Dissertação (Mestrado em Arquitetura e Urbanismo). Faculdade de Arquitetura e Urbanismo, Universidade de São Paulo. São Paulo. 2004. 282 p.

SAKATA, F. G. Paisagismo Urbano: Requalificação e Criação de Imagens. São Paulo: Edotora da Universidade de São Paulo, 2011. 272 p.

SCHÄFFER, W.B.; PROCHNOW, M. (Orgs.) A Mata Atlântica e Você. Como preservar, recuperar e se beneficiar da mais ameaçada floresta brasileira. APREMAVI. Brasília. 2002. 155 p.

SCORSIN, R.O.A.; PIRES, A.L.; JUCHEM, P.A. Análise da Avaliação do Passivo Ambiental de Postos de Combustíveis no Desenvolvimento de um Seguro Ambiental. 2006. 
SEPE, P.M.; SILVA, F.A.N. Revitalização de Áreas Contaminadas no município de São Paulo. In: MOERI, E.; COELHO, R.; MARKER, A. (Eds.) Remediação e revitalização de áreas contaminadas. São Paulo: Instituto EKOS Brasil, Ed. Signus. 2004. p. 43 - 52.

SHERER, P.M. The Benefits of Parks: Why America Needs More City Parks and Open Spaces. The Trust for Public Land. 2006. 32 p. Disponível em: <http://www.tpl.org-content_documentsccpe_places_article_8_06.pdf>. Acesso em: 22 mai. 09.

SHINZATO, P. Impacto da Vegetação nos Microclimas Urbanos. Universidade de São Paulo. Dissertação (Mestrado em Arquitetura Urbanismo). São Paulo, 2009. 173 p.

SILVA FILHO, C. A. Proteção e Fomento da Vegetação no Município de São Paulo: potencialidades, alcance e conflitos. Universidade de São Paulo. Tese (Doutorado em Arquitetura e Urbanismo). São Paulo. 2005. 227 p.

SILVA, D.A. Zoneamento Ambiental de um Setor do Parque Estadual da Cantareira e Entorno Seccionado pela Rodovia Fernão Dias (BR 381). Tese (Doutorado em Geografia). Faculdade de Filosofia, Letras e Ciências Humanas -FFLCH, Universidade de São Paulo. 2005. 232 p.

SILVA, F.A.N. Avaliação Ambiental Preliminar de Antigas Áreas de Disposição de Resíduos Sólidos Urbanos do Município de São Paulo. 2001. 104p. Dissertação (Mestrado em Geociências). Instituto de Geociências. Universidade de São Paulo - USP. São Paulo, 2001.

SILVA, F.A.N.; SEPE, P.M. A Implantação de parques urbanos em áreas especiais: uma análise para a reutilização de antigas áreas contaminadas. In: SÃO PAULO (MUNICÍPIO). SECRETARIA MUNICIPAL DO VERDE E MEIO AMBIENTE - SVMA. Seminário de Áreas Verdes, 2. Contribuições à Qualidade Ambiental da Cidade. São Paulo. p. 493-503.

SILVA, R.C.; DONAIRE, D. A Gestão de Resíduos Sólidos Urbanos: Um Estudo de Caso na Prefeitura de São Paulo. Revista Administração e Diálogo, v.9, n.1, 2007, p: 121-143. Pontifícia Universidade Católica de São Paulo. Disponível em: http://revistas.pucsp.br/index.php/rad/article/view/1514/1017. Acesso em 06/12/09.

SIMI, R; JUNIOR, R. S.; NETO, R. S. Corredor Ecológico e Zoneamento Ambiental para criação de Unidade Territorial auxiliado por um SIG. 2007. In: Simpósio Brasileiro de Sensoriamento Remoto (SBSR), 13, 2007, Florianópolis. Anais... São José dos Campos: INPE, 2007. Artigos, p. 5517-5524. CD-ROM, On-line. ISBN 978-85-17-00031-7. Disponível em: <http:// marte.dpi.inpe/col/dpi.inpe.br/sbsr@80/2006/11.16.00.05/doc/1063-1070.pdf>. Acesso em 25/10/08.

SINDICATO NACIONAL DAS EMPRESAS DE ARQUITETURA E ENGENHARIA CONSULTIVA (Sinaenco). Estudos dos Parques Paulistanos. 2008. Disponível em: <http://www.sinaenco.com.br/downloads/Estudo_Parques_relatorio.pdf>. Acesso em 25/05/09.

SOUZA, A. FOLHA DE S. PAULO. Secretaria quer recuperar vocação ambiental do parque VillaLobos. Caderno Cotidiano. Domingo, 26/07/09. 2009. p. C9. 
Requalificação dos Aterros Desativados (Brownfields) no Município de São Paulo: Parques (GreenfieldS) Raposo TAVAREs e Jardim Primavera

LUZIA HELENA dOS SANTOS BARROS

SOUZA, D.V.; ZIONI, F. Novas perspectivas de análise em investigações sobre meio ambiente: a teoria das representações sociais e a técnica da triangulação de dados. Saúde e Sociedade. V.12, n. 2. Jul/Dez. 2003. p. 76-85.

SOUZA, L.A. de. Potencial fitorremediador de leguminosas herbáceas associadas a fungos micorrízicos arbusculares em solo contaminado com chumbo. Dissertação (Mestrado em Biologia Vegetal). Universidade Estadual de Campinas (Unicamp). Instituto de Biologia (IB). Campinas, SP, 2010a. 94p.

SOUZA, M. L. Mudar a Cidade: uma introdução critica ao planejamento e a gestão urbana. Rio de Janeiro, Bertrand Brasil. 2002. 556 p.

SOUZA, M.L. O desafio metropolitano: um estudo sobre a problemática sócio-espacial nas metrópoles brasileiras. Rio de Janeiro: Ed. Bertand, 2000. 368 p.

SOUZA, S.C.R.de Tolerância aos metais pesados chumbo e zinco e potencial fitorremediador de mudas de espécies arbóreas. Universidade Estadual de Campinas (Unicamp). Instituto de Biologia (IB). Dissertação (Mestrado em Biologia Vegetal) Campinas, SP, 2010b. 85p.

SPANGENBERG, J.; SHINZATO, P.; JOHANSSON, E.; DUARTE, D. Simulation of the Influence of Vegetation on Microclimate and Thermal Comfort in the City of São Paulo. Revista Brasileira de Arborização Urbana (REVSBAU), V. 3, N. 2. Sociedade Brasileira de Arborização Urbana

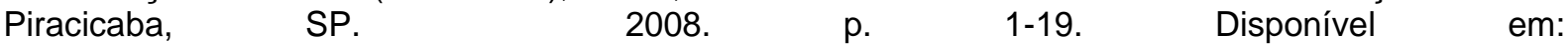
<http://www.rvsbau.esalq.usp.br/artigos_cientificos/artigo36.pdf>. Acesso em: 28 Out. 2010.

SUGUIO, K. Dicionário de Geologia Sedimentar e Áreas Afins. Rio de Janeiro: Bertrand Brasil, 1998. $1222 \mathrm{p}$.

TAYLOR, P.D.; FAHRIG, L.; HENEIN, K.; MERRIAM, G. Connectivity is a vital element of landscape structure. OIKOS - Forum, V. 68, № 3, 1993. pp. 571-573. Disponível em: $<$ http://www.landscape.acadiau.ca/Phil_Taylor/PDF/TaylorFarigMerrianOikos.pdf>. Acesso em 05 nov. 2008.

TEIXEIRA, W.; TOLEDO, M.C.M.de.; FAIRCHILD, T.R.; TAIOLI, F. (Orgs.) Decifrando a Terra. São Paulo: Oficina de Textos, 2000; $2^{\mathrm{a}}$ Reimpressão, 2003. 568 p.

TIVERON, V.P.M. Gestão de Resíduos sólidos no Município de São Paulo - Atores em Processo e Conflito. 2001. 175 p. Dissertação (Mestrado em Ciência Ambiental). Programa de Ciência Ambiental. Universidade de São Paulo - USP. São Paulo. 2001.

TRESSOLDI, M.; CONSONI, A.J. Disposição de Resíduos. In: OLIVEIRA, A.M. dos S.; Brito, S.N.A. de. (Eds.) Geologia de Engenharia. Associação Brasileira de Geologia de Engenharia - ABGE. São Paulo, 1998. p. $343-360$. 
TSUHAKO, E.M. Wetlands naturais e construídas. Escola de Engenharia de São Carlos. Universidade de São Paulo. (Apresentação de slides). s/d.

UNITED STATES ENVIRONMENTAL PROTECTION AGENCY - USEPA. Technical Approaches to Characterizing and Redeveloping Brownfields Sites: Municipal Landfills and Ilegal Dumps. Office of Research and Development. . Cincinnati, Ohio. 2002. 70 p. EPA/625/R-02/2002. Disponível em: <http://www.epa.gov/nrml/pubs/625r02002/625r02002.pdf>. Acesso em: 10 out. 2009.

Superfund Redevelopment Initiative. Energizing a New Future. Alternative Energy and Recreational Reuse at The H.D.O. Landfill Superfund Site in Northern Illinois. 2010. 15 p. Disponível em: <http://www.epa.gov/superfund/programs/recycle/pdf/hodcase.pdf>. Acesso em: 07 dez. 2010.

UNIVERSIDADE DE SÂO PAULO (USP). ESCOLA SUPERIOR DE AGRICULTURA LUIZ DE QUEIROZ (ESALQ). Projeto de Restauração Ecológica do Aterro Sanitário Desativado São Mateus, São Paulo-SP. Piracicaba: ESALQ, 2006. 111 p.

Parque da Ciência e Tecnologia da Pró-Reitoria d Cultura. Faculdade Arquitetura e Urbanismo. Projeto de Sustentabilidade sócio-ambiental urbana: PEFI - Parque Estadual das Fontes do Ipiranga. $45 \mathrm{p}$.

VALENTIM, L.S.O. Requalificação urbana, contaminação do solo e Riscos à Saúde: Um Caso na Cidade de São Paulo. Ed. Annablume. São Paulo, SP. 2007. 159 p.

VALENTIM, L.S.O. Sobre a Produção de Bens e Males nas Cidades: Estrutura urbana e cenários de risco à saúde em áreas contaminadas da Região Metropolitana de São Paulo. Faculdade de Arquitetura e Urbanismo - FAU. Universidade de São Paulo - USP. São Paulo. 2010. 266 p. Tese (Doutorado em Planejamento Urbano).

VASCONCELOS, M.K.; GARCIA, R.J.F. Estudo espacializado dos padrões de vegetação e uso do solo. 2007, p. 54-55. In: SÃO PAULO (Município). Secretaria Municipal do Verde e Meio AmbienteSVMA.. ALMEIDA, A.F. de; VASCONCELOS, M.K. (Coords.) Fauna silvestre: Quem são e onde vivem os animais na metrópole paulistana. 2007. $350 \mathrm{p}$.

VASQUES, A.R Considerações sobre Estudos de Caso de Brownfields: Exemplos no Brasil e no Mundo. Rev. Bibliográfica de Geografia y Ciências Sociales (Serie documental de Geo Crítica). Universidade de Barcelona. 2006. 12p. Disponível em: www.ub.es/geocrit/b3w-648.htm . Acesso em: 28/10/09.

VASQUES, A.R. Geotecnologias nos Estudos sobre Brownfields: Identificação de Brownfields em Imagens de Alta Resolução Espacial e Análise da dinâmica da Refuncionalização de Antigas Áreas Fabris em São Paulo. Tese (Doutorado em Geografia Física). Faculdade de Filosofia, Letras e Ciências Humanas - FFLCH, Universidade de São Paulo - USP. 2009. 242 p.

VASQUES, A.R. Refuncionalização de Brownfields: Estudo de Caso na Zona Leste de São Paulo - SP. Dissertação. (Mestrado em Geografia). Instituto de Geociências e Ciências Exatas. Universidade Estadual Paulista. Rio Claro. 2005. 160 p.

VELOSO, H. P.; RANGEL FILHO, A.L.R.; LIMA, J.C. Classificação da vegetação brasileira adaptada a um sistema universal. IBGE. Rio de Janeiro. 1991. 124 p. 
Requalificação dos Aterros Desativados (Brownfields) no Município de São Paulo: Parques (GreenfieldS) Raposo TAVAREs e JardiM Primavera

LUZIA HELENA dOS SANTOS BARROS

VEYRET, Y (Org.). Os riscos: o homem como agressor e vítima do meio ambiente. [tradutor

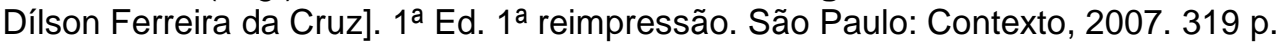

VILHALVA, D.A.A. Efeitos Morfo-anatômicos do Cádmio em Campuloclinium chlorolepis Baker (Asteraceae) e Galianthe grandifolia E. L. Cabral (Rubiaceae). 2008. p. 6-55. In: VILHALVA,

D.A.A. Estudo Morfofisiológico do Desenvolvimento das Espécies Galianthe grandifolia E. L. Cabral (Rubiaceae) e Campuloclinium chlorolepis Baker (Asteraceae) Submetidas a diferentes Concentrações de Cádmio. Universidade Estadual de Campinas (UNICAMP). Tese (Doutorado em Biologia). Campinas, SP. 2008. 135 p.

VILLAÇA, F. Espaço intra-urbano no Brasil. São Paulo. Ed. Studio Nobel/FAPESP/LILP. 2001. $373 p$.

VILLAÇA, F. Uma contribuição para a história do planejamento urbano no Brasil. 2004. p. 169-244. In: DEÁK, C. SCHIFFER, S.R. (Orgs.) 0 processo de urbanização no Brasil. $1^{\underline{a}}$ ed. $1^{\underline{a}}$ reimpr. Universidade de São Paulo - USP. São Paulo. 2004. 346 p.

VIMIEIRO, G.V.; SILVA, F.V.B. Fitorremediação para Tratamento de Áreas Contaminadas. In: Congresso Brasileiro de Engenharia Sanitária e Ambiental, 24. ABES Saneamento ambiental: compromisso ou discussão? Belo Horizonte - MG. 2007. III-026. Anais... CD ROM.

VOLPE-FILIK, A.; AGUIRRE JR., J.H., LIMA, A.M.L.P.; FERREIRA, F.B.J.; SALIM, M.; FARIA, O.A.; ALVAREZ, I.A. Criação de Parques Urbanos em Aterros Sanitários Desativados, Estudo do Aterro Sapopemba, São Paulo,SP. Revista da Sociedade Brasileira de Arborização Urbana, v. 2, n. 3, p.80-87, 2007. Disponível em: <http://www.revsbau.esalq.usp.br/notas-tecnicas/nota05.pdf >. Acesso em: 17 mai. 2010.

WALKER,C. The Public Value of Urban Parks. In: Beyond Recreation: A Broader View of Urban Parks. The Wallace Foundation. 2004. p. 1-7. Disponível em: http://www.urban.org/UploadedPDF/3110011_urban_parks.pdf. Acesso em: 29 mai2009.

WEBECOIST. Garbage to Green: 10 Landfills Turned into Nature Preserves. In: Animals \& Habitats, Geography \& Travel, Nature \& Ecosystems. Disponível em: <http://webecoist.com/2009/05/10/garbage-to-green-10-landfills-turned-into-nature-preserves/>.

Acesso em: 02 dez. 2010.

WEBER, J. Critérios de Planejamento Urbano e Ambiental na Implantação de um Cadastro de Áreas Contaminadas e Suspeitas de Contaminação. Projeto de Recuperação do Solo e das Águas Subterrâneas em Áreas de Disposição de Resíduos Industriais. Cooperação Técnica BrasilAlemanha. Dr. Krätzig Ingenieurgesellschaft mbH. Relatório de Consultoria. 1996. 47p.

ZANIRATO, S.H.; RAMIRES, J.Z.S.; AMICCI, A.G.N.,;RIBEIRO, Z.M.; RIBEIRO, W.C. Sentidos do Risco: Interpretações Teóricas. Rev. Bibliográfica de Geografia y Ciências Sociales (Serie documental de Geo Crítica). Universidade de Barcelona. Vol. XIII, no 785, 25 de mayo de 2008. 


\section{APÊNDICES E ANEXOS}

CD ROM 
Requalificação dos Aterros Desativados (Brownfields) no Município de São Paulo: Parques (Greenfields) Raposo Tavares e Jardim Primavera

Luzia Helena dos Santos Barros

\section{APÊNDICES}

APÊNDICE A - Quantificação (\%) das classes de uso e ocupação do solo nas áreas de entorno $(500,1.000$ e $2.000 \mathrm{~m})$ dos aterros do Grupo 1

\begin{tabular}{|c|c|c|c|c|c|c|c|c|c|c|c|c|c|c|c|c|c|c|}
\hline & \multicolumn{6}{|c|}{ Aterro Pedreira Cit } & \multicolumn{6}{|c|}{ Aterro Lauzanne Paulista } & \multicolumn{6}{|c|}{ Aterro Itatinga } \\
\hline & \multirow{2}{*}{\multicolumn{2}{|c|}{$\frac{500 m}{4}$}} & \multicolumn{2}{|c|}{$1000 \mathrm{~m}$} & \multicolumn{2}{|c|}{$2000 \mathrm{~m}$} & \multicolumn{2}{|c|}{$500 \mathrm{~m}$} & \multirow{2}{*}{\multicolumn{2}{|c|}{\begin{tabular}{l|l}
$\frac{1000 m}{20}$ & $\%$ \\
a)
\end{tabular}}} & \multicolumn{2}{|c|}{$2000 \mathrm{~m}$} & \multicolumn{2}{|c|}{$500 \mathrm{~m}$} & \multicolumn{2}{|c|}{$1000 \mathrm{~m}$} & \multicolumn{2}{|c|}{$2000 \mathrm{~m}$} \\
\hline & & & (ha) & $\%$ & ha) & $\%$ & (ha) & $\%$ & & & (ha) & $\%$ & ha) & $\%$ & (ha) & $\%$ & & \begin{tabular}{|l|l|}
$\%$ \\
$177 \%$ \\
\end{tabular} \\
\hline Água & 0.22 & $0.20 \%$ & 0.28 & $0.07 \%$ & 31 & $0.02 \%$ & 0.01 & $0.01 \%$ & .02 & \begin{tabular}{|l|l|}
$0.01 \%$ \\
.030 \\
\end{tabular} & 0.07 & $0.01 \%$ & 0.00 & $0.00 \%$ & $\frac{3.02}{3.10}$ & $0.00 \%$ & $\frac{28.07}{3707}$ & $\frac{1.77 \%}{2.309}$ \\
\hline olo Exposto & 4.74 & $4.28 \%$ & & & 1.06 & $2.76 \%$ & 2.20 & & 71 & $1.60 \%$ & & $1.37 \%$ & 4.51 & $99 \%$ & 1.10 & $58 \%$ & 7.22 & \\
\hline & 27.53 & $24.86 \%$ & 117.36 & $1.20 \%$ & 476.22 & $34.56 \%$ & 41.86 & $41.54 \%$ & 143.83 & $40.22 \%$ & 487.75 & $36.35 \%$ & 56.00 & $32.23 \%$ & 199.65 & 40.88\% & 601.16 & 37.85 \\
\hline ficacăo & 32.68 & $29.51 \%$ & 16.58 & $30.99 \%$ & 505.74 & $36.70 \%$ & 46.60 & $46.24 \%$ & 149.27 & $41.75 \%$ & 524.18 & 39.068 & 83.48 & $48.04 \%$ & 198.34 & $40.61 \%$ & 494.75 & 31.15 \\
\hline $\begin{array}{l}\text { M. A. Muito } \\
\text { Denso }\end{array}$ & 4.66 & $4.21 \%$ & 11.75 & $3.12 \%$ & 27.08 & $1.97 \%$ & 0.57 & $0.57 \%$ & 5.84 & $1.63 \%$ & 29.54 & $2.20 \%$ & 0.39 & $0.22 \%$ & 2.25 & $0.46 \%$ & 32.82 & 2.079 \\
\hline M.A. Denso & 0.22 & $0.20 \%$ & 0.66 & $0.18 \%$ & 1.56 & $0.11 \%$ & 0.00 & $0.00 \%$ & 0.01 & $0.00 \%$ & 0.58 & $0.04 \%$ & 0.00 & $0.00 \%$ & 0.64 & $0.13 \%$ & 7.09 & 0.459 \\
\hline $\begin{array}{l}\text { M. A. Pouco } \\
\text { Denso }\end{array}$ & 3.93 & $3.54 \%$ & 9.71 & $2.58 \%$ & 13.48 & $0.98 \%$ & 0.00 & $0.00 \%$ & 4.02 & $1.12 \%$ & 44.08 & $3.28 \%$ & 0.01 & $0.01 \%$ & 0.20 & $0.04 \%$ & 23.88 & 1.50 \\
\hline $\begin{array}{l}\text { Maciço } \\
\text { Herbáceo }\end{array}$ & 34.01 & $30.71 \%$ & 95.63 & $25.42 \%$ & 288.99 & $20.97 \%$ & 9.01 & $8.94 \%$ & 44.74 & $12.51 \%$ & 206.18 & $15.36 \%$ & 26.91 & $15.49 \%$ & 67.44 & 13.8170 & 329.81 & 20.7 \\
\hline & & & & & & & & & & & & & & & & & & \\
\hline & 0.0 & & & & & & & & & & & & & & & & & \\
\hline & 0.1 & $\underline{0}$ & & & & & 0.00 & 0.0 & & & & 0.1 & & & & & & 0.12 \\
\hline & & & & & & & & & & & & & & & & & & \\
\hline & & & 0. & & & & & & $\frac{1.93}{57.57}$ & & & & 178 & & & & & 100 \\
\hline & & $100 \%$ & 76.18 & $100 \%$ & 377.90 & & 100.77 & $100 \%$ & 357.57 & $100 \%$ & & & 3.76 & $100 \%$ & 88.3 & $100 \%$ & 888.19 & 1008 \\
\hline
\end{tabular}

\begin{tabular}{|c|c|c|c|c|c|c|c|c|c|c|c|c|c|c|c|c|c|c|}
\hline & \multicolumn{6}{|c|}{ Aterro Jardim Damaceno } & \multicolumn{6}{|c|}{ Aterro Vila São Francisco } & \multicolumn{6}{|c|}{ Aterro Pedreira Itapuí } \\
\hline Classes: & & $\mathrm{om}$ & & $30 \mathrm{~m}$ & & & & $0 \mathrm{~m}$ & 100 & $0 \mathrm{~m}$ & 200 & & & & & $\mathrm{om}$ & 200 & \\
\hline & & $\%$ & a) & $\%$ & 1a) & $\%$ & a) & $\%$ & 1a) & $\%$ & ha) & $\%$ & ha) & $\%$ & ha) & $\%$ & ha) & $\%$ \\
\hline Agua & 0.00 & $0.00 \%$ & & $00 \%$ & & $0.21 \%$ & 0.00 & $0.00 \%$ & & $0.00 \%$ & & $0.00 \%$ & 0.00 & $0.00 \%$ & 0.00 & $.00 \%$ & $\frac{72}{752}$ & $0.27 \%$ \\
\hline osto & 4.04 & $2.92 \%$ & 93 & $3.49 \%$ & & & 1.78 & $2.01 \%$ & 8.60 & $2.58 \%$ & 01 & $1.85 \%$ & 3.58 & $3.21 \%$ & 12.61 & $34 \%$ & 2.63 & $3.45 \%$ \\
\hline & 38.80 & $28.04 \%$ & 91.00 & $21.25 \%$ & 299.06 & $20.23 \%$ & 33.43 & 37.79\% & 112.42 & $33.67 \%$ & 476.09 & $36.75 \%$ & 31.15 & $27.99 \%$ & 116.17 & 30.81\% & 126.03 & $30.88 \%$ \\
\hline Edificaçăo & 52.63 & $38.03 \%$ & 152.41 & -35.58\% & 3.93 & $32.05 \%$ & 45.79 & $51.76 \%$ & \begin{tabular}{|l|l|l|l}
771 \\
\end{tabular} & $51.39 \%$ & 55.64 & $50.61 \%$ & 49.54 & $44.52 \%$ & 171.90 & $45.58 \%$ & 505.46 & $36.64 \%$ \\
\hline $\begin{array}{l}\text { M. A. Muito } \\
\text { Denso }\end{array}$ & 4.60 & $3.32 \%$ & 16.32 & $3.81 \%$ & 47.39 & $3.21 \%$ & 0.00 & $0.00 \%$ & 0.17 & $0.05 \%$ & 1.11 & $0.09 \%$ & 0.18 & $0.16 \%$ & 0.82 & $0.22 \%$ & 21.16 & $1.53 \%$ \\
\hline M.A. Denso & 0.74 & $0.53 \%$ & 2.17 & $0.51 \%$ & & $0.55 \%$ & 0.00 & $0.00 \%$ & 0.00 & $0.00 \%$ & 0.00 & $0.00 \%$ & 0.00 & $0.00 \% 6$ & 0.00 & $0.00 \%$ & 0.09 & $0.01 \%$ \\
\hline $\begin{array}{l}\text { M. A. Pouco } \\
\text { Denso }\end{array}$ & 4.41 & $3.18 \%$ & 31.30 & $7.31 \%$ & 37.13 & $16.04 \%$ & 0.00 & $0.00 \%$ & 0.00 & $0.00 \%$ & 0.00 & $0.00 \%$ & 0.00 & $0.00 \%$ & 0.00 & $0.00 \%$ & 11.93 & $0.86 \%$ \\
\hline $\begin{array}{l}\text { Maciço } \\
\text { Herbáceo }\end{array}$ & 30.68 & $22.17 \%$ & 110.10 & $25.71 \%$ & 329.53 & 22.2996 & $6.8 B$ & $7.78 \%$ & 37.36 & $11.19 \%$ & 128.50 & $9.92 \%$ & 25.87 & $23.25 \%$ & 70.66 & $18.74 \%$ & 313.22 & $22.70 \%$ \\
\hline & & & & & & & & & & & & & & & & & & \\
\hline & & & & & & & & & & & & & & & & & & \\
\hline & & & & & & & & & & & & & & & & & & \\
\hline & 0.81 & & & & & & & & & & & & & & & & & \\
\hline & & & & & & & & & & & & & & & & & & \\
\hline & & & & & & & & & & & 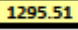 & & 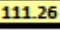 & & & & 1379.60 & \\
\hline
\end{tabular}

APÊNDICE B - Quantificação (\%) das classes de uso e ocupação do solo nas áreas de entorno $(500,1.000$ e 2.000 m) dos aterros do Grupo 2

\begin{tabular}{|c|c|c|c|c|c|c|c|c|c|c|c|c|c|c|c|c|}
\hline \multirow{3}{*}{ Clasies: } & \multicolumn{8}{|c|}{ Aterro Engenheiro Goulart } & \multicolumn{8}{|c|}{ Aserro Carandiru } \\
\hline & \multicolumn{2}{|c|}{ Aterro } & \multicolumn{2}{|c|}{$500 \mathrm{~m}$} & \multicolumn{2}{|c|}{$1000 \mathrm{~m}$} & \multicolumn{2}{|c|}{$2000 \mathrm{~m}$} & \multicolumn{2}{|c|}{ Aberro } & \multicolumn{2}{|c|}{$500 \mathrm{~m}$} & \multicolumn{2}{|c|}{$1000 \mathrm{~m}$} & \multicolumn{2}{|c|}{$2000 \mathrm{~m}$} \\
\hline & (tha) & 5 & the & 5 & (ha) & 5 & (n) & 5 & (a) & 8 & (ब) & 8 & (k) & 8 & (tha) & $x^{2}$ \\
\hline bona & 0.15 & asm & 10.45 & $496 \%$ & \begin{tabular}{|l|l|}
11.48 \\
\end{tabular} & $2.00 \%$ & 17.35 & 1.025 & 000 & $0.00 \%$ & 4.69 & $0.09 \%$ & 1033 & 0.875 & 20.26 & 0,235 \\
\hline Solo Expong & 0.14 & $0.55 \%$ & 5.00 & $2.3 \%$ & 17.52 & $3.12 \%$ & 25.17 & 2.7245 & 122 & $1.41 \%$ & 925 & $1.56 \%$ & 152 & $1.34 \%$ & 3822 & $135 \mathrm{~s}$ \\
\hline $\begin{array}{l}\text { Sist Visrio } \\
\text { Astaltado }\end{array}$ & 1.38 & $5.39 \%$ & 2337 & $11.38 \%$ & 81.71 & $14.88 \%$ & 431.68 & $25.43 \mathrm{~m}$ & 34.27 & $39.54 \times 6$ & 234.32 & $39.46 \%$ & 507.62 & $42.50 \%$ & 1254.67 & $44.74 \%$ \\
\hline Edrikacto & 0.03 & $0.12 \%$ & 4.33 & 2065 & 50.11 & $1077 \%$ & 41751 & $24.5 \mathrm{gm}$ & SE, S & 44.278 & 250.52 & $42.19 \%$ & 472.45 & $40.14 \mathrm{~s}$ & 1005.12 & 57.255 \\
\hline $\begin{array}{l}\text { M. A. Muito } \\
\text { Dense }\end{array}$ & 4.43 & $17.32 \%$ & 15.48 & $738 \%$ & 30.40 & 5.5416 & 38.67 & $2.28 \%$ & 0.02 & $0.02 \%$ & 157 & $0.26 \%$ & 4.65 & $0.39 \%$ & 10.04 & $0.36 \%$ \\
\hline M. A D*ano & 0.12 & $0.47 x$ & 15.11 & 7218 & 3151 & $5.76 x$ & 5900 & $2.30 x$ & 000 & 0.00 & 001 & $0.00 \pi$ & 001 & $0.00 x$ & 0.28 & 0.015 \\
\hline $\begin{array}{l}\text { M. A. Pouco } \\
\text { Denss }\end{array}$ & 6.08 & $23.81 \%$ & 18.19 & $8.67 \%$ & 23.69 & $5.23 \%$ & 30.96 & $1.82 \%$ & 000 & $0.00 \%$ & 0.05 & $0.01 \%$ & 0.08 & $0.013 \%$ & 1.53 & $0.05 \%$ \\
\hline $\begin{array}{c}\text { Mariso } \\
\text { Merthices }\end{array}$ & 9.26 & $36.24 \%$ & 10268 & $48.95 \%$ & 262.38 & $47>79 \%$ & 621.98 & $36.64 \%$ & 899 & $10.37 \%$ & 74.42 & 12.536 & 159.84 & $12.63 \%$ & 36990 & D.29. \\
\hline V. Tipo parque & 0.08 & 0.315 & 3.96 & $1.00 \%$ & 10.00 & 33\% & 21.74 & $1.25 \%$ & 0.08 & $0 . \pi \times s$ & 515 & $.57 \%$ & 0.47 & a.s5s & 11.77 & 2.425 \\
\hline Siviculturs & $0 \%$ & 0.000 & $0, \infty$ & $0.00 \%$ & $0, \infty$ & $000 \%$ & 000 & $0.00 x$ & 000 & 0,00 & 000 & $0 \omega \infty$ & 000 & $0,00 x$ & 000 & $000 x$ \\
\hline váries & 0.10 & $0.5 \%$ & 0.20 & $0.10 \%$ & 0.22 & $0.05 \%$ & 0.22 & $0.01 \%$ & 0.00 & $0.00 \%$ & 0.00 & $0.00 \mathrm{~m}$ & 0.00 & $0.00 \%$ & 0.00 & 0.005 \\
\hline sombra & 3.70 & $14.75 \%$ & 2.52 & $457 \%$ & 13.58 & $2.4 x$ & 18.5 & $1.00 \%$ & 0.02 & $0.07 \%$ & 0.24 & 0.015 & 1.07 & $0.02 \%$ & 2.22 & 0.055 \\
\hline Drihantes & 0.01 & $0.04 x$ & 0.89 & $0.42 \%$ & 2.34 & $0.43 \mathrm{~K}$ & 13.84 & $0.82 \%$ & 311 & $3.58 \%$ & 1362 & $229 \%$ & 1797 & $1.50 \%$ & 3031 & $100 \%$ \\
\hline Tool & 25.55 & $100 \mathrm{~h}$ & 20275 & 1006 & 548.97 & $100 \%$ & 1627.55 & $100 \%$ & 86.60 & 10000 & 503.24 & 10036 & 1124.55 & $100 \%$ & 2304.37 & 10056 \\
\hline
\end{tabular}


Requalificação dos Aterros Desativados (Brownfields) no Município de São Paulo: Parques (Greenfields) Raposo Tavares e Jardim Primavera

Luzia Helena dos Santos Barros

\section{APÊNDICE C - Quantificação (\%) das classes de uso e ocupação do solo nas áreas de entorno $(500,1.000$ e $2.000 \mathrm{~m})$ dos aterros do Grupo 3.}

\begin{tabular}{|c|c|c|c|c|c|c|c|c|c|c|c|c|c|c|c|c|}
\hline \multirow{3}{*}{ Classes: } & \multicolumn{8}{|c|}{ Aterro Vila Albertina } & \multicolumn{8}{|c|}{ Aterro Santo Amaro } \\
\hline & \multicolumn{2}{|c|}{ Aterro } & \multicolumn{2}{|c|}{$500 \mathrm{~m}$} & \multicolumn{2}{|c|}{$1000 \mathrm{~m}$} & \multicolumn{2}{|c|}{$2000 \mathrm{~m}$} & \multicolumn{2}{|c|}{ Aterro } & \multicolumn{2}{|c|}{$500 \mathrm{~m}$} & \multicolumn{2}{|c|}{$1000 \mathrm{~m}$} & \multicolumn{2}{|c|}{$2000 \mathrm{~m}$} \\
\hline & (ha) & $\%$ & (ha) & $\%$ & (ha) & $\%$ & (ha) & $\%$ & (ha) & $\%$ & (ha) & $\%$ & (ha) & $\%$ & (ha) & $\%$ \\
\hline Agua & 0.00 & $0.00 \%$ & 0.00 & $0.00 \%$ & 0.00 & $0.00 \%$ & 1.07 & $0.07 \%$ & 0.00 & $0.00 \%$ & 11.75 & $4.62 \%$ & 18.83 & $2.98 \%$ & 109.55 & $5.90 \%$ \\
\hline Solo Exposto & 0.82 & $5.09 \%$ & 4.82 & $2.74 \%$ & 10.56 & $2.15 \%$ & 28.78 & $1.81 \%$ & 4.97 & $14.16 \%$ & 15.73 & $6.19 \%$ & 32.82 & $5.20 \%$ & 62.98 & $3.39 \%$ \\
\hline $\begin{array}{l}\text { Sist Viário } \\
\text { Asfaltado }\end{array}$ & 0.04 & $0.25 \%$ & 12.26 & $6.96 \%$ & 40.65 & $8.27 \%$ & 204.14 & $12.82 \%$ & 1.10 & $3.13 \%$ & 47.87 & $18.82 \%$ & 169.23 & $26.80 \%$ & 578.89 & $31.19 \%$ \\
\hline Edificaçấo & 0.10 & $0.62 \%$ & 6.48 & $3.68 \%$ & 32.11 & $6.53 \%$ & 217.28 & $13.64 \%$ & 1.08 & $3.07 \%$ & 45.09 & $17.73 \%$ & 153.10 & $24.25 \%$ & 501.74 & $27.03 \%$ \\
\hline $\begin{array}{l}\text { M. A. Muito } \\
\text { Denso }\end{array}$ & 0.16 & $0.99 \%$ & 12.65 & $7.18 \%$ & 33.06 & $6.73 \%$ & 81.70 & $5.13 \%$ & 0.04 & $0.11 \%$ & 4.13 & $1.62 \%$ & 8.55 & $1.35 \%$ & 27.46 & $1.48 \%$ \\
\hline M.A. Denso & 0.01 & $0.06 \%$ & 2.62 & $1.49 \%$ & 7.24 & $1.47 \%$ & 11.94 & $0.75 \%$ & 0.00 & $0.00 \%$ & 0.62 & $0.24 \%$ & 1.40 & $0.22 \%$ & 2.78 & $0.15 \%$ \\
\hline $\begin{array}{c}\text { M. A. Pouco } \\
\text { Denso }\end{array}$ & 0.06 & $0.37 \%$ & 51.51 & $29.24 \%$ & 164.26 & $33.43 \%$ & 539.73 & $33.89 \%$ & 0.00 & $0.00 \%$ & 0.61 & $0.24 \%$ & 1.45 & $0.23 \%$ & 9.51 & $0.51 \%$ \\
\hline $\begin{array}{l}\text { Maciço } \\
\text { Herbáceo }\end{array}$ & 14.07 & $87.52 \%$ & 82.70 & 46.95\% & 192.87 & $39.25 \%$ & 476.82 & $29.94 \%$ & 22.17 & $63.11 \%$ & 114.32 & $44.94 \%$ & 221.48 & $35.08 \%$ & 514.33 & $27.71 \%$ \\
\hline V. Tipo Parque & 0.82 & $5.09 \%$ & 2.83 & $1.60 \%$ & 8.16 & $1.66 \%$ & 13.90 & $0.87 \%$ & 5.71 & $16.27 \%$ & 9.99 & $3.93 \%$ & 15.99 & $2.53 \%$ & 24.44 & $1.32 \%$ \\
\hline Silvicultura & 0.00 & $0.00 \%$ & 0.00 & $0.00 \%$ & 0.00 & $0.00 \%$ & 0.29 & $0.02 \%$ & 0.00 & $0.00 \%$ & 0.00 & $0.00 \%$ & 0.00 & $0.00 \%$ & 0.00 & $0.00 \%$ \\
\hline Várzea & 0.00 & $0.00 \%$ & 0.14 & $0.08 \%$ & 0.77 & $0.16 \%$ & 7.17 & $0.45 \%$ & 0.00 & $0.00 \%$ & 0.00 & $0.00 \%$ & 0.00 & $0.00 \%$ & 0.00 & $0.00 \%$ \\
\hline Sombra & 0.00 & $0.00 \%$ & 0.13 & $0.07 \%$ & 1.69 & $0.34 \%$ & 7.94 & $0.50 \%$ & 0.00 & $0.00 \%$ & 3.45 & $1.35 \%$ & 6.10 & $0.97 \%$ & 10.64 & $0.57 \%$ \\
\hline Brilhantes & 0.00 & $0.00 \%$ & 0.02 & $0.01 \%$ & 0.06 & $0.01 \%$ & 1.83 & $0.11 \%$ & 0.05 & $0.14 \%$ & 0.81 & $0.32 \%$ & 2.41 & $0.38 \%$ & 13.66 & $0.74 \%$ \\
\hline Total & 16.08 & $100 \%$ & 176.16 & $100 \%$ & 491.43 & $100 \%$ & 1592.58 & $100 \%$ & 35.12 & $100 \%$ & 254.36 & $100 \%$ & 631.36 & $100 \%$ & 1855.98 & $100 \%$ \\
\hline
\end{tabular}

\begin{tabular}{|c|c|c|c|c|c|c|c|c|c|c|c|c|c|c|c|c|}
\hline \multirow{3}{*}{ Classes: } & \multicolumn{8}{|c|}{ Aterro São Mateus } & \multicolumn{8}{|c|}{ Aterro Sapopemba } \\
\hline & \multicolumn{2}{|c|}{ Aterro } & \multicolumn{2}{|c|}{$500 \mathrm{~m}$} & \multicolumn{2}{|c|}{$1000 \mathrm{~m}$} & \multicolumn{2}{|c|}{$2000 \mathrm{~m}$} & \multicolumn{2}{|c|}{ Aterro } & \multicolumn{2}{|c|}{$500 \mathrm{~m}$} & \multicolumn{2}{|c|}{$1000 \mathrm{~m}$} & \multicolumn{2}{|c|}{$2000 \mathrm{~m}$} \\
\hline & (ha) & $\%$ & (ha) & $\%$ & (ha) & $\%$ & (ha) & $\%$ & (ha) & $\%$ & (ha) & $\%$ & (ha) & $\%$ & (ha) & $\%$ \\
\hline Água & 0.00 & $0.00 \%$ & 0.28 & $0.14 \%$ & 4.49 & $0.82 \%$ & 4.55 & $0.27 \%$ & 0.00 & $0.00 \%$ & 0.00 & $0.00 \%$ & 0.00 & $0.00 \%$ & 0.24 & $0.01 \%$ \\
\hline Solo Exposto & 0.57 & $3.20 \%$ & 3.98 & $1.93 \%$ & 13.32 & $2.44 \%$ & 45.61 & $2.69 \%$ & 4.81 & $15.64 \%$ & 22.53 & $9.33 \%$ & 39.87 & $6.56 \%$ & 101.79 & $5.62 \%$ \\
\hline $\begin{array}{l}\text { Sist Víário } \\
\text { Asfaltado }\end{array}$ & 0.35 & $1.97 \%$ & 21.33 & $10.35 \%$ & 76.36 & $13.97 \%$ & 388.30 & 22.8896 & 0.14 & $0.45 \%$ & 38.99 & $16.15 \%$ & 127.71 & $21.01 \%$ & 403.94 & $22.30 \%$ \\
\hline Edificaçáo & 0.22 & $1.24 \%$ & 16.98 & $8.24 \%$ & 72.48 & $13.26 \%$ & 375.91 & $22.15 \%$ & 0.37 & $1.20 \%$ & 86.27 & $35.73 \%$ & 222.23 & $36.55 \%$ & 553.52 & $30.56 \%$ \\
\hline $\begin{array}{l}\text { M. A. Muito } \\
\text { Denso }\end{array}$ & 0.87 & $4.89 \%$ & 10.57 & $5.13 \%$ & 34.14 & $6.25 \%$ & 70.02 & $4.13 \%$ & 0.00 & $0.00 \%$ & 3.80 & $1.57 \%$ & 8.87 & $1.46 \%$ & 52.93 & $2.92 \%$ \\
\hline M.A. Denso & 0.01 & $0.06 \%$ & 0.44 & $0.21 \%$ & 0.56 & $0.10 \%$ & 1.41 & $0.08 \%$ & 0.00 & $0.00 \%$ & 0.01 & $0.00 \%$ & 0.27 & $0.04 \%$ & 4.03 & $0.22 \%$ \\
\hline $\begin{array}{l}\text { M. A. Pouco } \\
\text { Denso }\end{array}$ & 0.64 & $3.60 \%$ & 47.85 & $23.22 \%$ & 104.22 & $19.07 \%$ & 239.91 & $14.13 \%$ & 0.00 & $0.00 \%$ & 0.68 & $0.28 \%$ & 5.76 & $0.95 \%$ & 63.25 & $3.49 \%$ \\
\hline $\begin{array}{c}\text { Maciço } \\
\text { Herbáceo }\end{array}$ & 14.35 & $80.73 \%$ & 67.45 & $32.72 \%$ & 171.18 & $31.32 \%$ & 461.87 & $27.21 \%$ & 24.26 & $78.84 \%$ & 82.84 & $34.31 \%$ & 189.01 & $31.09 \%$ & 578.22 & $31.92 \%$ \\
\hline V. Tipo Parque & 0.09 & $0.51 \%$ & 0.54 & $0.26 \%$ & 3.03 & $0.55 \%$ & 12.77 & $0.75 \%$ & 1.19 & $3.86 \%$ & 5.78 & $2.40 \%$ & 13.36 & $2.20 \%$ & 35.07 & $1.94 \%$ \\
\hline Silvicultura & 0.00 & $0.00 \%$ & 0.01 & $0.00 \%$ & 0.01 & $0.00 \%$ & 0.05 & $0.00 \%$ & 0.00 & $0.00 \%$ & 0.00 & $0.00 \%$ & 0.00 & $0.00 \%$ & 0.19 & $0.01 \%$ \\
\hline Várzea & 0.07 & $0.39 \%$ & 7.63 & $3.70 \%$ & 14.26 & $2.61 \%$ & 22.21 & $1.31 \%$ & 0.00 & $0.00 \%$ & 0.00 & $0.00 \%$ & 0.15 & $0.02 \%$ & 10.41 & $0.57 \%$ \\
\hline Sombra & 0.60 & $3.37 \%$ & 28.38 & $13.77 \%$ & 50.72 & $9.28 \%$ & 70.98 & $4.18 \%$ & 0.00 & $0.00 \%$ & 0.02 & $0.01 \%$ & 0.08 & $0.01 \%$ & 4.88 & $0.27 \%$ \\
\hline Brilhantes & 0.01 & $0.06 \%$ & 0.68 & $0.33 \%$ & 1.87 & $0.34 \%$ & 3.75 & $0.22 \%$ & 0.00 & $0.00 \%$ & 0.52 & $0.22 \%$ & 0.67 & $0.11 \%$ & 2.73 & $0.15 \%$ \\
\hline Total & 17.78 & $100 \%$ & 206.11 & $100 \%$ & 546.62 & $100 \%$ & 1697.34 & $100 \%$ & 30.78 & $100 \%$ & 241.43 & $100 \%$ & 607.98 & $100 \%$ & 1811.19 & $100 \%$ \\
\hline
\end{tabular}


APÊNDICE D - Quantificação (\%) das classes de uso e ocupação do solo nas áreas de entorno (500, 1.000 e 2.000 m) do parque-aterro Raposo Tavares e aterro Jacuí ou parque-aterro Jardim Primavera

\begin{tabular}{|c|c|c|c|c|c|c|c|c|c|c|c|c|c|c|c|c|}
\hline \multirow[t]{2}{*}{ Classes } & \multicolumn{2}{|c|}{$\begin{array}{l}\text { Parque } \\
\text { Raposo } \\
\text { Tavares }\end{array}$} & \multicolumn{2}{|c|}{$500 \mathrm{~m}$} & \multicolumn{2}{|c|}{$1000 \mathrm{~m}$} & \multicolumn{2}{|c|}{$2000 \mathrm{~m}$} & \multicolumn{2}{|c|}{$\begin{array}{c}\text { Parque } \\
\text { Jardim } \\
\text { Primavera }\end{array}$} & \multicolumn{2}{|c|}{$500 \mathrm{~m}$} & \multicolumn{2}{|c|}{$1000 \mathrm{~m}$} & \multicolumn{2}{|c|}{$2000 \mathrm{~m}$} \\
\hline & (ha) & $\%$ & (ha) & $\%$ & (ha) & $\%$ & (ha) & $\%$ & (ha) & $\%$ & (ha) & $\%$ & (ha) & $\%$ & (ha) & $\%$ \\
\hline Água & 0,0 & 0,0 & 0,0 & 0,0 & 0,0 & 0,0 & 0,3 & 0,0 & 0,0 & 0,0 & 0,0 & 0,0 & 0,0 & 0,0 & 1,8 & 0,0 \\
\hline $\begin{array}{c}\text { Solo } \\
\text { Exposto }\end{array}$ & 2,3 & 9,3 & 9,0 & 4,3 & 19,5 & 3,5 & 52,4 & 9,3 & 1,0 & 7,7 & 4,7 & 2,8 & 10,2 & 9,3 & 47,8 & 9,3 \\
\hline $\begin{array}{l}\text { Sist. Viário } \\
\text { Asfaltado }\end{array}$ & 1,9 & 7,6 & 77,7 & 37,0 & 187,6 & 34,0 & 569,4 & 7,6 & 0,1 & 0,9 & 56,2 & 33,0 & 169,7 & 7,6 & 510,7 & 7,6 \\
\hline Edificação & 1,3 & 5,3 & 72,5 & 34,5 & 185,8 & 33,7 & 566,7 & 5,3 & 0,0 & 0,3 & 75,4 & 44,3 & 232,5 & 5,3 & 796,7 & 5,3 \\
\hline $\begin{array}{l}\text { M. A. Muito } \\
\text { Denso }\end{array}$ & 0,7 & 2,7 & 2,1 & 1,0 & 12,3 & 2,2 & 47,8 & 2,7 & 0,7 & 5,7 & 0,9 & 0,6 & 1,4 & 2,7 & 2,9 & 2,7 \\
\hline M. A. Denso & 1,1 & 4,6 & 1,1 & 0,5 & 1,3 & 0,2 & 1,8 & 4,6 & 0,0 & 0,0 & 0,0 & 0,0 & 0,0 & 4,6 & 0,0 & 4,6 \\
\hline $\begin{array}{l}\text { M. A. Pouco } \\
\text { Denso }\end{array}$ & 1,6 & 6,5 & 2,0 & 1,0 & 11,0 & 2,0 & 21,3 & 6,5 & 0,0 & 0,0 & 0,0 & 0,0 & 0,0 & 6,5 & 0,0 & 6,5 \\
\hline $\begin{array}{l}\text { Maciço } \\
\text { Herbáceo }\end{array}$ & 13,7 & 55,9 & 40,9 & 19,5 & 120,0 & 21,7 & 402,1 & 55,9 & 10,0 & 77,7 & 29,9 & 17,6 & 65,2 & 55,9 & 205,5 & 55,9 \\
\hline $\begin{array}{l}\text { V. Tipo } \\
\text { Parque }\end{array}$ & 1,6 & 6,7 & 2,2 & 1,0 & 5,0 & 0,9 & 12,3 & 6,7 & 0,1 & 0,8 & 0,9 & 0,6 & 2,4 & 6,7 & 9,7 & 6,7 \\
\hline Silvicultura & 0,0 & 0,0 & 0,0 & 0,0 & 0,0 & 0,0 & 0,0 & 0,0 & 0,0 & 0,0 & 0,0 & 0,0 & 0,0 & 0,0 & 0,0 & 0,0 \\
\hline Várzea & 0,0 & 0,0 & 0,0 & 0,0 & 0,2 & 0,0 & 0,4 & 0,0 & 0,0 & 0,0 & 0,0 & 0,0 & 0,0 & 0,0 & 0,0 & 0,0 \\
\hline Sombra & 0,3 & 1,3 & 2,0 & 1,0 & 7,1 & 1,3 & 23,3 & 1,3 & 0,9 & 6,9 & 1,1 & 0,7 & 1,2 & 1,3 & 2,9 & 1,3 \\
\hline Brilhantes & 0,0 & 0,0 & 0,4 & 0,2 & 1,7 & 0,3 & 7,5 & 0,0 & 0,0 & 0,0 & 1,1 & 0,6 & 1,8 & 0,0 & 5,3 & 0,0 \\
\hline Total & 24,5 & 100 & 210,0 & 100 & 551,6 & 100 & 1705,2 & 100 & 12,9 & 100 & 170,3 & 100 & 484,4 & 100 & 1583,3 & 100 \\
\hline
\end{tabular}




\section{APÊNDICE E - Entrevista com fÁBIO SANTOS PELLAES, Administrador do Parque Raposo Tavares, 27 OUTUBRO 2008.}

Luzia: Fábio, como Ihe expliquei, essa entrevista faz parte da minha pesquisa de doutorado, que elencou como uma das áreas de estudo esse parque. E já que você está, nesse momento, tratando da implantação dessa nova pista no parque poderia começar por aí.

Pellaes: Essa pista que está sendo instalada é na verdade a complementação de uma obra anterior, que compreendia a instalação de sistema de captação de águas pluviais e líquidos percolados. Guia e sarjeta, na parte de águas pluviais, e a drenagem, na parte de líquidos percolados.

Luzia: Mas essa drenagem dos líquidos percolados também está passando por aqui?

Pellaes: Sim, é uma rede subterrânea. Como o parque foi instalado sobre um aterro e a decomposição do material não cessou completamente, havia produção de chorume, que acabava aflorando nos pontos mais baixos do parque.

Luzia: Isso eu cheguei a ver. Já tem algum tempo, não é?

Pellaes: Sim, há alguns anos. Quando assumi, em 2007, o parque passava por essa obra, iniciada no fim de 2006, aproximadamente, e concluída em meados de 2007.

Luzia: Você me disse que é biólogo. Como você veio trabalhar aqui como administrador de parque? Por quê? Qual a sua motivação?

Pellaes: Entrei no começo de 2007. Em abril, mais ou menos. Por volta de abril de 2006, entreguei um currículo para o administrador do Parque do Piqueri, que na época eu não conhecia. Após analisar, ele se comprometeu a encaminhá-lo para a Secretaria. E realmente o fez. Houve uma troca de administrador, e fui chamado para uma entrevista com o então Diretor do Depave 5, Marco Renier, e com o Engenheiro Agrônomo Eduardo Panten. Naquele momento, haviam três parques disponíveis: o Raposo Tavares, o Luís Carlos Prestes, o Vila dos Remédios ou Jardim Felicidade, não me recordo. Acabei vindo para cá.

Luzia: Foi você que escolheu o parque?

Pellaes: Durante a entrevista, apresentaram a realidade dos dois primeiros parques e por último apresentaram o Raposo Tavares. Falaram sobre as dimensões, a vizinhança e o antigo aterro. Perguntaram se me interessava e respondi que sim, que aceitava o desafio.

Luzia: Você teve alguma preocupação a mais devido o parque estar implantado sobre um antigo aterro? Isso te levou a algum questionamento?

Pellaes: Tive algumas surpresas. A princípio, quando entreguei o currículo para o Sidney, administrador do Piqueri, não sabia que havia a possibilidade de me tornar administrador de parque. Pensei que poderia exercer algum cargo na Secretaria. Quando me telefonaram oferecendo o cargo, 
Requalificação dos Aterros Desativados (Brownfields) no Município de São Paulo: Parques (Greenfields) Raposo

Tavares e Jardim Primavera

Luzia Helena dos Santos Barros

pensei que seria algo ligado mais à biologia. Também o é, mas tem toda a parte de fiscalização de contrato, gerência de pessoal, da empreiteira que presta serviços para a Prefeitura e, no meu caso, ainda teve essa surpresa. Na verdade, dizer que eu não sabia é uma mentira, pois quando estava na pós-graduação, na Oswaldo Cruz (sou especialista em gestão ambiental) fiz um trabalho justamente sobre este parque.

Luzia: Então você fez na Oswaldo Cruz? E estudou esta área aqui?

Pellaes: Na verdade, não foi o trabalho de conclusão de curso, e sim um dos trabalhos curtos feitos durante o semestre, uma revisão bibliográfica. Aí tomei contato com a questão do chorume que aflorava. Mas nunca tinha vivenciado a questão e passei a vivenciar quando entrei aqui. Porém, quando entrei, a primeira fase de obras já estava em andamento. Portanto, não foi uma situação que vivi com tanta intensidade, já estava começando a ser controlada. Hoje não temos mais esse problema.

Luzia: $E$ você chegou a ter algum contato com o antigo administrador, com quem estava antes no seu lugar?

Pellaes: Se não me engano, surgiu outra oportunidade de emprego para ele e ele aceitou. O parque ficou com uma "janela", um período sem administrador, até que eu fosse contratado e assumisse o cargo. Não conheci imediatamente o antigo administrador. Na verdade, o conheci recentemente, há cerca de três meses. Ele veio, pois tinha algum negócio com um ex-funcionário, veio conversar com esse funcionário e acabamos nos encontrando.

Luzia: O que você tem achado de sua experiência como administrador de parque? É uma novidade para sua formação, mas você está gostando desse contato direto com o funcionário, com o usuário do parque? Como é isso?

Pellaes: Eu estou gostando bastante, é bem desafiador. Quando entrei não imaginava a amplitude. Logo no início, ocorreu a fase crítica, devido as dificuldades que o parque tem, a relação com o entorno -que talvez seja o mais difícil aqui-, me chocaram muito.

Luzia: Mas por quê? Qual é essa relação tão preocupante?

Pellaes: O problema tem a ver com a história do parque. Aqui era um aterro, era uma área afastada do centro -como ninguém quer um aterro perto de casa, então jogaram para cá--, era uma área desocupada, só que em função do próprio uso, ela começou a atrair pessoas, que explorariam o lixão, para recolher materiais, recolher comida, vender coisas. E começa a gerar uma comunidade que vive do aterro. E ela começa a crescer, cresce desordenadamente, e vai constituindo as favelas que a gente tem em volta do parque. Quando o aterro foi desativado, passou por um período de mais ou menos dois anos fechado, antes da abertura do parque, pois houve uma porção de intervenções que foram necessárias para se tornar um parque. Apesar de o aterro ter sido encerrado, ele permaneceu vivo no inconsciente das pessoas. Na mentalidade ele continua. Tanto que, se você 
Requalificação dos Aterros Desativados (Brownfields) no Município de São Paulo: Parques (Greenfields) Raposo

Tavares e Jardim Primavera

Luzia Helena dos Santos Barros

andar por aí e conversar com as pessoas e perguntar sobre o Parque Raposo Tavares, quase ninguém sabe onde é.

Luzia: Eles não reconhecem essa área como parque? Até hoje?

Pellaes: Até hoje eles chamam de 'lixão'. Você conversa com as crianças:

- Onde vocês estão indo brincar?

- Ah... A gente está indo brincar lá no lixão.

E o problema maior é sintomático: se você chama de lixão, você vai tratar como um lixão. Aí você começa a perceber os problemas que a gente tem aqui.

Por exemplo, você estava me perguntando da viabilidade das árvores aqui. Um dos maiores problemas que temos não é a questão de solo, mas a questão do vandalismo. Perdemos muitas mudas por vandalismo, pessoas que passam e arrancam mesmo a troco de nada.

Luzia: Isso está relacionado, talvez, com essa questão de a área não estar identificada como parque.

Pellaes: E aí, você percebe que tem uma porção de fatos problemáticos. Um é as pessoas no geral não reconhecerem a área como um parque. Não é a totalidade e eu não diria nem que é a maioria, mas são muitas pessoas. E essas pessoas fazem diferença. Outro problema é quando se percebe que as pessoas têm uma idéia muito distorcida do espaço público. No entendimento das pessoas, se ele é 'nosso', na verdade ele é 'meu'; se é 'meu', posso fazer o que eu quiser. Então, até hoje eu tenho problema com pessoas que entram, fazem hortas para consumo próprio, e temos que remover. E nesse momento, a questão de ter sido um aterro, de poder haver alguma contaminação por qualquer substância que venha a se refletir na produção, não sensibiliza as pessoas.

Luzia: Nem você explicando?

Pellaes: Nem explicando. Não sensibiliza. Outro exemplo: sou muito abordado por pessoas solicitando playground, que plantem uma determinada planta, quadras - sempre próximo às casas dessas pessoas. Aqui, inclusive, existe uma certa rivalidade entre as comunidades freqüentadoras e como o parque é administrado por potencialidade de área. (áreas com características para a instalação de um playground, de uma quadra ou de um bosque) gera conflitos, pois as pessoas dizem que 'você colocou um playground na frente do Jaqueline, tem que colocar um na frente do Mandioquinha'. Eles não atravessam o parque para usar os equipamentos, tem que estar do lado deles. É uma situação insustentável. Se fosse assim, teria um bosque no meio do parque e o entorno todo ocupado com quadra e playground.

Outra questão é uma certa confusão entre secretarias. Por exemplo, um parque, embora seja uma área adequada para isso, não tem como prioridade a prática de esportes. Ele é uma área adequada para isso, você pode vir praticar esportes, mas não é o carro-chefe do parque encher ele de equipamentos esportivos. $E$ as pessoas não entendem isso. Elas querem que você tenha quadras. Uma porção de quadras, quanto mais campos você tiver, melhor. Inclusive, uma vez eu passei por uma situação um pouco desagradável. Uma senhora, que faz parte do Conselho Gestor do parque e 
Requalificação dos Aterros Desativados (Brownfields) no Município de São Paulo: Parques (Greenfields) Raposo

Tavares e Jardim Primavera

Luzia Helena dos Santos Barros

tem influência, tem contato com deputados e tal, comentou que havia um deputado interessado em investir no parque. Uma reunião foi marcada e fui conversar com o cidadão. Me perguntou como o parque estava indo - estava na primeira fase de obras, próximo da conclusão - relatei o que estava sendo feito. Logo em seguida, ele cortou a conversa e falou: '- Tenho uma verba para destinar ao parque e quero saber da possibilidade de instalar um segundo campo de futebol'. O parque já tem um campo de tamanho oficial e, aliás, campos de futebol de tamanho oficial dentro de parques são uma experiência um pouco negativa, ainda mais em parques da periferia.

Luzia: Mas porque isso?

Pellaes: Respondi a ele que não era interessante, elenquei todas as razões para isso e elenquei outras ações que seriam prioritárias para o Parque, ao que ele respondeu "- E se eu falar diretamente com o seu chefe? Será que eu consigo colocar um campo de futebol?" Respondi que ele poderia tentar, mas que eu havia sido escolhido pela Secretaria do Verde como representante de sua linha de ação e que dificilmente a resposta da Secretaria seria divergente da minha.

Luzia: E ele falou porque exatamente ele queria implantar um segundo campo?

Pellaes: Na verdade, o discurso dele era que, segundo essa senhora que o acompanhava, era o interesse da comunidade. Só que aí é um outro problema muito grande, pois interesses pessoais acabam sendo mostrados como interesses coletivos, o que nem sempre procede.

Luzia: É. O porquê não é interessante ter campo de futebol?

Pellaes: Por exemplo, os piores episódios de violência que eu tenho dentro do parque são relacionados ao campo. Por mais próximo que eu seja dos representantes de esportes da subprefeitura, e eu tenho um relacionamento muito bom com a subprefeitura -aqui é a sub do Butantã--, eu não consigo ter uma pessoa acompanhando o uso do campo. Então, é mais uma tarefa a meu encargo.

Luzia: O uso do campo de futebol também não tem nenhuma relação com a Secretaria de Esportes? Pellaes: Oficialmente, não. Poderia ter. Eu já tive alguns problemas aqui justamente por essa separação. O que aconteceu? Essa mesma pessoa, essa senhora, enviou uma carta à Secretaria de Esportes solicitando a instalação de um segundo campo aqui. Na ocasião ela se identificou como presidente do Conselho Gestor.

Luzia: Mas ela não é?

Pellaes: Não, até porque a figura Conselho Gestor não tem um presidência. É um colegiado. Mas (ela) se identificou como presidente do Conselho Gestor, enviou a carta à Secretaria de Esportes, deu o endereço do parque. A Secretaria de Esportes fez o que era da competência dela. Enviou um técnico para reconhecer a área e ver se tinha possibilidade, ou não, de instalar o campo. Ele veio até 
Requalificação dos Aterros Desativados (Brownfields) no Município de São Paulo: Parques (Greenfields) Raposo

Tavares e Jardim Primavera

Luzia Helena dos Santos Barros

aqui, conversou comigo e ficou surpreso, porque não sabia que a área que tinham indicado para ele era dentro de um parque. Eu falei para ele: “- É um parque. Pertence à Secretaria do Verde e não do Esporte, e qualquer instalação de qualquer equipamento aqui passa pelo crivo do Verde". Ele concordou comigo e falou: "- Eu preciso só atestar que a área existe, que cabe o campo, porém, não compete à Secretaria de Esporte decidir". E foi isso que ele fez. Depois esse relatório chegou até mim e foi arquivado. Mas é o interesse pessoal tomando a frente.

Luzia: Como é o funcionamento desse Conselho Gestor? Quem faz parte? Ele é ativo? Quais os interesses que são discutidos no conselho?

Pellaes: Cada mandato de um Conselho Gestor tem a duração de dois anos. Quando entrei aqui estávamos no final de um mandato e, até por causa dessa janela, desse período que ficou sem administrador, acredito que o conselho se desarticulando um pouco. Quando entrei e soube que o parque tinha um Conselho Gestor, convoquei uma reunião extraordinária para me apresentar, dizer qual seria a minha proposta, o que pretendia fazer e ouvi-los e conhecê-los. Naquele momento foi muito positivo e, inclusive, alguns dos conselheiros comentam até hoje que nunca tinham presenciado uma atitude desse tipo, que eu imagino que, na verdade, é o mínimo que eu podia fazer. Só que, depois disso, o pessoal acabou perdendo o interesse. Ao final daquela reunião extraordinária, a gente marcou uma ordinária e nenhum conselheiro compareceu.

Luzia: Nossa! Mas quanto tempo depois?

Pellaes: Acho que um mês. A ideia é que as reuniões ordinárias ocorram mensalmente e acabou não acontecendo. Como estava prestes a encerrar o mandato e ter uma nova eleição, achei melhor não ficar desgastar tentando reordenar um conselho deteriorado. Era melhor esperar o próximo e andar com eles.

Luzia: Mas como está a atuação do atual Conselho?

Pellaes: O Conselho Gestor funciona da seguinte forma: - tem que ter, no mínimo -isso por lei--, 18 pessoas. Nove são representantes da sociedade civil e nove são representantes do poder público. Os nove da sociedade civil se dividem em três vagas, três cadeiras para entidades, associações que sejam atuantes na região, ou que tenham interesse em desenvolver alguma atividade no parque, e seis representantes dos frequentadores do parque, que são eleitos em votação. Os outros nove do poder público são indicados pelas secretarias: o administrador do parque; é previsto um representante da Secretaria do Verde; e aí as combinações vão variando de acordo com a característica do parque. Por exemplo, pode ter um representante da Secretaria de Cultura, representante da Guarda Civil Metropolitana, da Secretaria de Esportes; depende da característica do parque. Representantes da subprefeitura local...

Luzia: Quais são os representantes da comunidade do entorno hoje nesse conselho?

Pellaes: Não tivemos três associações inscritas, foram apenas duas que automaticamente entraram no conselho. A cadeira vaga passou para os representantes dos freqüentadores, que passaram a ter, 
Requalificação dos Aterros Desativados (Brownfields) no Município de São Paulo: Parques (Greenfields) Raposo

Tavares e Jardim Primavera

Luzia Helena dos Santos Barros

ao invés de seis, sete. Porém, não houve equilíbrio com o poder público, pois as secretarias não indicaram seus representantes.

Luzia: O maior peso é da sociedade civil, não é?

Pellaes: É engraçado, pois a idéia muito defendida é que tem que ser igual. Tem que haver equilíbrio entre as forças. Mas se preocupam muito que não haja número menor de representantes dos freqüentadores. Só que nesse caso, temos um número menor do poder público. E a coisa anda. Mesmo assim tem que andar.

Luzia: Esses representantes dos freqüentadores são atuantes? O que os desperta? Qual o interesse maior deles para o parque?

Pellaes: Minha opinião pessoal não é muito positiva quanto a isso. Não todos, mas a maioria dos conselheiros, procura o Conselho Gestor como uma forma de ter visibilidade junto à comunidade. Junto a alguma figura política, até para buscar apoio e falar: "- Olha, eu sou representante do Conselho Gestor, é interessante você me ter do seu lado, porque eu represento a comunidade". Coisas assim... Alguns, sim, estão engajados em questões do parque. Inclusive, quando entrei, havia um documento gerado em uma das últimas reuniões do Conselho Gestor, com o administrador, antes de sua saída. Nele havia uma série de solicitações para o parque. Ao entrar, analisei e, dentro do possível, avaliei quais questões eram pertinentes, quais não eram. A maior parte das solicitações, ou já foram concluídas ou estão sendo concluídas junto com a segunda fase de obras, que está acontecendo agora. Claro que, muitas vezes, são solicitadas coisas que não têm um crivo técnico. Se é exeqüível ou não. Exemplo de coisas que já solicitaram para esse parque: garagem subterrânea, quadra coberta, piscina - o que foge totalmente da proposta atual de parque. Soube que outros parques passaram por isso. Por exemplo, no Parque Anhanguera - que fica lá em Perus e é o maior parque municipal de São Paulo, maior que o Ibirapuera -, foi solicitado um açougue dentro do parque.

Luzia: Falando nisso, você tem conhecimento de outros parques dentro da cidade, profissionalmente ou particularmente?

Pellaes: Sim. Quando entrei, minha experiência pessoal como freqüentador se somou à experiência profissional. Como todo paulistano, tinha muito conhecimento do Ibirapuera, além do Parque do Carmo e do Piqueri, que eram parques que visitava quando criança. Conheci este parque por estudo de caso, mas não pessoalmente. O visitei antes de tomar posse. É uma coisa interessante pois os administradores, todos eles, têm um perfil diferente do que havia anteriormente. São todos formados, com curso superior na área ambiental (agrônomos, engenheiros florestais, biólogos etc.) e experiência na área. Então, essa equipe que se formou quando houve a mudança de todos os administradores, começou a delinear um perfil que tem como uma das características mais marcantes a articulação entre os administradores, junto com a secretaria, mas principalmente entre eles mesmos. Temos os parques divididos em grupos de contrato. Por exemplo, a empresa que faz a manutenção aqui, a Servimarc, que cuida da limpeza e conservação de áreas verdes, faz parte de um contrato que contempla outros parques. Neste caso, o Parque Raposo Tavares faz parte do Grupo 
Cemucam, que tem ainda o Parque Cemucam, o Previdência, o Luís Carlos Prestes e o Alfredo Volpi. Os administradores exercem ainda a função de fiscal deste contrato, em todos os parques do grupo. Isso acontece em todos os outros grupos. $\mathrm{E}$ isso começa a formar uma unidade entre esses parques. Por exemplo, caso haja algum problema de lida diária, os administradores se comunicam. Às vezes algum tem à disposição alguma ferramenta que os demais não possuem e que pode ser disponibilizada para resolver a questão sem precisar mobilizar a Secretaria e depender de prazo para que aquilo seja executado. Às vezes transferências de materiais.

Luzia: Isso é interessante. Agiliza mais o trabalho. E você aqui também tem, além dessa empresa, funcionários efetivos na equipe?

Pellaes: Sim. A equipe é composta pelos funcionários da empreiteira, da empresa de vigilância particular patrimonial e os funcionários da prefeitura, funcionários de carreira e os apenados.

Luzia: O que é 'apenado'?

Pellaes: É a pessoa que cometeu alguma infração não muito grave e foi sentenciada ao cumprimento de serviços à comunidade; podem ser indicados a trabalhar em parques, na manutenção, serviços gerais. Tive algumas experiências ruins aqui e acabei suspendendo temporariamente mas penso em solicitar novamente a presença de apenados.

Luzia: Quantos funcionários da prefeitura existem aqui trabalhando hoje?

Pellaes: São nove. Um está para se aposentar.

Luzia: E eles cooperam com sua administração?

Pellaes: É uma relação difícil, há agravantes. Minha idade acaba atrapalhando, pois há funcionários que têm de casa o que tenho de vida. Então eles não o respeitam de imediato. Em contra partida, relatam um histórico de descaso da prefeitura em relação ao funcionário público, informam que não têm aumento há alguns anos, que a Secretaria do Verde, alguns anos atrás, era muito relapsa em relação aos funcionários, que eles ficavam largados nos parques. Já ouvi outros depoimentos, de outras pessoas, dizendo que os piores funcionários da secretaria e da prefeitura eram encaminhados aos parques. Funcionários com problemas de alcoolismo e uso de drogas. Então, você tem uma certa resistência ao trabalho. Houve episódios aqui que me levaram a não contar muito com o apoio dos funcionários, a não depender disso. Se houver, ótimo; mas não contar com isso, não depender.

Luzia: E os funcionários das empreiteiras? Você tem um relacionamento bom? Porque você também tem que gerenciar isso.

Pellaes: Sim. O relacionamento com eles é mais fácil.

Luzia: E o que você percebe da vegetação? Você acha que tem alguma diferença em estar implantada em área de antigo aterro, ou não? Você consegue verificar isso? 
Requalificação dos Aterros Desativados (Brownfields) no Município de São Paulo: Parques (Greenfields) Raposo Tavares e Jardim Primavera

Luzia Helena dos Santos Barros

Pellaes: $O$ que se observa aqui é que algumas espécies apresentam uma certa dificuldade em função do solo, a raiz vai se aprofundando e chega em alguma camada de lixo e não consegue ultrapassar. Aí ela começa a crescer lateralmente e, às vezes, não consegue sustentar a árvore, sustentar a copa, e acaba caindo. Um fenômeno que observo aqui e que é muito interessante, acontece muito com o ingá: - muitos ingás caem, têm a raiz exposta, só que parte da raiz permanece enraizada e a árvore segue o desenvolvimento dela. Ela tombou, tem uma parte que vai ficar paralela ao solo mesmo, mas ela se apruma e segue crescendo. Temos uma porção delas espalhadas. Mas têm algumas que não conseguem se sustentar mesmo. Tivemos um pinheiro aqui, não muito grande, que caiu. Isso também varia porque houve uma diferença na espessura da camada de solo que foi colocada no parque. Tem trechos que têm uma camada satisfatória e tem trechos que têm uma camada muito rasa. Então, dependendo do trecho onde a árvore foi plantada, ela tem maior ou menor dificuldade para se desenvolver.

Luzia: Dá para a gente saber mais ou menos quais as áreas que têm uma condição um pouco melhor do que outras? Dá para separar isso?

Pellaes: Percebemos por tentativa e erro e por observação.

Luzia: Mas você não tem isso em um registro?

Pellaes: Não. Porque, na verdade, tecnicamente isso não deveria ter acontecido. Todas as áreas deveriam ter uma camada satisfatória. Mas observando as duas fases de obras você vai detectando essas coisas. Por exemplo, a primeira fase de obras compreendeu a instalação de redes de drenagem. Para instalar a drenagem precisaram abrir valas. E na abertura dessas valas era possível visualmente detectar a espessura do lixo.

Luzia: Mas quando se fez isso foi registrada essa questão, de quanto se tinha de solo, ou não?

Pellaes: Não. Só a observação.

Luzia: A questão dos usuários. O que eles trazem? Você tem um relato da frequência? De qual o perfil de idade, são mais crianças ou mais adultos que freqüentam o parque? Qual o período de maior frequência? E, além de todos esses problemas você já relatou, quais as boas práticas ambientais dos usuários?

Pellaes: Estamos concluindo uma pesquisa de perfil de usuário, há coisas que já estão bem cristalizadas, dá para detectar. Temos certos públicos que são atingidos pelo parque. Você percebe que em final de semana, preferencialmente no domingo, o dia que é mais frequentado, muitas pessoas vêm para o parque usar o campo de futebol. Você consegue claramente distinguir os frequentadores do parque como um todo e frequentadores do campo, que vêm para jogar futebol e ir embora. Eles vêm, param o carro, e a estrutura que eles usam do parque é o estacionamento, o sanitário e o campo. Aos domingos também aumenta o número de famílias.

Luzia: Esse pessoal do campo é aqui da área do entorno ou vem de longe? 
Requalificação dos Aterros Desativados (Brownfields) no Município de São Paulo: Parques (Greenfields) Raposo

Tavares e Jardim Primavera

Luzia Helena dos Santos Barros

Pellaes: Algumas vezes vem de longe. Há campeonatos acontecendo. Vêm times de outros bairros, de outras regiões, se enfrentar. Aliás, se enfrentar, é um termo bem apropriado. Já ouve alguns episódios de pessoas mostrarem armas umas para as outras, para ameaçar juiz, coisas assim. Mas aos domingos também há mais famílias com filhos. Durante a semana há um perfil que está começando a se consolidar agora, em função da obra também -eu faço essa leitura. No período da manhã, das $6 \mathrm{~h}$ até as $9 \mathrm{~h} 30$, mais ou menos, todos os dias, durante a semana, corredores e, às vezes, pessoas de idade, que vêm andar ou correr. Como estão instalando a pista, está aumentando a frequência, estão melhorando as condições para esse público. Então ele passa a responder. Próximo ao meio-dia eu tenho algumas escolas e creches do entorno que trazem as crianças para cá.

Luzia: Mas próximo ao meio-dia por quê?

Pellaes: Em função do horário deles, de entrada e saída das turmas.

Luzia: Você tem aqui dentro do parque algum programa específico para trabalhar com escola ou com outra instituição que tenha ao redor?

Pellaes: Existe uma iniciativa da Secretaria de Esportes, através de uma contratada, que desenvolvia um projeto que se chamava 'Mais Esporte', que passou por uma mudança de formatação, que usa o campo de futebol para dar aulas de futebol para crianças carentes, vinculado ao fornecimento de uma refeição. As crianças vêm, têm aula e, acaba a aula, ganham um lanche, umas bolachinhas e um achocolatado. $\mathrm{O}$ que exigem em contrapartida é que a criança esteja regularmente matriculada e freqüentando a escola. Aí ela pode participar.

Luzia: Mas a escola é pública ou tanto faz?

Pellaes: Acho que tanto faz, mas a maior parte do público atendido é de escola pública. Mas acho que eles não vão impedir...

Luzia: Você sabe quantas escolas públicas existem aqui no entorno?

Pellaes: Não sei.

Luzia: E também nenhuma escola pública veio procurar você para tentar fazer algum trabalho conjunto?

Pellaes: Duas coisas aconteceram. Já fui procurado por escolas e já as procurei. Fui a algumas escolas conversar com a diretoria, avisar que o parque estava disponível para visitação, pois temos um programa de monitoria. Na verdade, a Secretaria do Verde passou a contratar estagiários e, em função da característica de cada parque, do potencial que ele tem, desenvolver algum trabalho. Aqui os estagiários estão desenvolvendo trilhas monitoradas. É uma prática comum nos outros parques, mas aqui não havia. Já fizemos algumas experiências com a 'Casa do Betinho', que é uma espécie de creche. Fizeram uma trilha com algumas atividades durante e após a trilha. Agora estão na fase 
Requalificação dos Aterros Desativados (Brownfields) no Município de São Paulo: Parques (Greenfields) Raposo

Tavares e Jardim Primavera

Luzia Helena dos Santos Barros

de avaliação - estão colhendo as experiências, analisando e vendo o que pode ser melhorado em função da experiência que tiveram.

Luzia: Quantos estagiários trabalham aqui?

Pellaes: Já foram três. Uma recentemente teve que concluir o estágio e não contratamos um terceiro estagiário para ocupar essa vaga em função da mudança da legislação de estágio. Agora precisa consolidar a lei, para que possamos contratar.

Luzia: Então esse trabalho faz pouco tempo, desde que você entrou.

Pellaes: Faz pouco tempo. Entrei e alguns meses depois ocorreu essa possibilidade de ter estagiários. São três vagas aqui, uma vaga nível técnico e duas nível universitário. Eu tinha uma técnica em Meio Ambiente e hoje tenho duas estudantes de biologia.

Luzia: O pessoal que frequenta o parque, a maioria, que eu entendi, que vêm para o campo, vem de carro. E os outros, vêm a pé?

Pellaes: Isso é outro dado que já temos definido pela pesquisa, que é a abrangência do parque. A maior parte dos frequentadores mora na região. Salvo essa questão de time -é que muitas vezes a pessoa acaba trazendo outras pessoas, acaba trazendo uniforme e, então, eles acabam vindo de carro- mas a maior parte das pessoas mora no entorno e vem a pé. A maior parte mora muito próximo.

Luzia: Você conhece alguma área próxima do parque que poderia estar servindo de conexão, de corredor ecológico aqui próximo?

Pellaes: Interessante você tocar nessa pois este parque tem três vagas para estagiários e os outros parques têm um número determinado de vagas. Em um dos parques da região, que faz parte deste grupo de contrato, que é o Parque da Previdência, um dos estagiários que trabalhou lá, Vítor Hugo, desenvolveu um trabalho sobre corredor ecológico. Inclusive o trabalho dele foi premiado com o terceiro lugar na prefeitura toda, entre os trabalhos desenvolvidos por estagiários. Ele tem o projeto de estabelecer um corredor ecológico entre o Raposo Tavares, o Luís Carlos Prestes e o Previdência. O Raposo Tavares está em uma área mais árida, para uma área mais arborizada, que é a do Previdência. Pensa-se em colocar o Volpi também. O interessante nos três parques, o Raposo, o Luís Carlos Prestes e o Previdência, é que eles já estão ligados por um eixo, que é a Raposo. O Volpi está um pouco deslocado, mas é possível também colocá-lo nessa questão. Entre o Previdência e o Luís Carlos Prestes é muito fácil porque eles estão muito próximos. A distância entre o Previdência e o Raposo já é maior, mas existe uma outra área verde no meio. Mas é uma área particular, um condomínio.

Luzia: Mas você acha que dá para fazer? Porque o que eu queria saber é se as espécies aqui introduzidas têm relação com a dos outros parques, ou não? 
Requalificação dos Aterros Desativados (Brownfields) no Município de São Paulo: Parques (Greenfields) Raposo Tavares e Jardim Primavera

Luzia Helena dos Santos Barros

Pellaes: Sim. É uma tendência nos parques quando vai ocorrer plantio, que se dá usualmente de duas formas. Uma por TCA (Termo de Compensação Ambiental). Por exemplo, o proprietário de algum terreno vai executar algum empreendimento, vai erguer um prédio e vai ter que remover a vegetação, Então é indicada essa vegetação que vai ser removida, essa documentação é apresentada à prefeitura e a prefeitura indica geralmente o fornecimento de mudas para o viveiro, transplante de alguns espécimes e um determinado número para ser plantado em uma outra área. Normalmente eles contemplam algum parque nessa situação. Normalmente a empreiteira, a firma que representa o empreendimento, não tem essa face de trabalho, eles não têm equipes de plantio. Então eles contratam uma outra empresa para fazer esse serviço. Essa empresa normalmente entra em contato com a administração para negociar quais são as espécies que vão ser plantadas. O que acontece é que a gente sempre orienta para que sejam plantadas espécies do ecossistema nativo. No caso, a gente pede as árvores da mata atlântica preferencialmente, algumas árvores de cerrado, principalmente aqui, que a vegetação foi toda implantada, para ir recuperando essa característica nessa área.

Luzia: Você tem o número de espécies que foram plantadas aqui via TCA?

E desde quando isso começou?

Pellaes: Tenho desde que entrei. Eu tenho registrado.

Luzia: Tem outra forma de plantação que você falou, não é?

Pellaes: Há plantios da própria prefeitura. Aqui, no caso, nós temos no Parque da Previdência o Núcleo de Gestão Descentralizada Centro-Oeste. Seria um braço da Secretaria do Verde, um pouco mais afastado do centro. A secretaria está lá na rua do Paraíso e tem os núcleos descentralizados mais próximos dos parques. Eles costumam, através do núcleo, enviar plantio para os parques. Isso é uma forma, de uns tempos para cá, que eu tenho considerado mais interessante do que o TCA. O que acontece? Embora a idéia de executar um TCA seja muito interessante, acaba esbarrando no problema do interesse da empresa. O interesse deles é fazer o plantio o mais rápido possível e ir embora. Eu não condeno o pensamento deles, mas é que não é adequado para a realidade do parque. Eles pensam do ponto de vista estritamente logístico. Querem entrar no parque, ter uma área bem próxima de onde eles entraram, de preferência plana, e plantar tudo ali naquela área. Só que a realidade do parque muitas vezes não permite isso. Então, você planta dez aqui, cem lá no meio do bosque, então terá que carregar a árvore lá para o meio do bosque... Isso acaba não sendo tão interessante para essas empresas. Já o pessoal que faz os plantios via prefeitura, como eles não têm essa questão dessa meta para atingir, eles são mais engajados na questão de que o plantio vá para frente. No caso deste parque, quem responde pelos plantios são dois engenheiros agrônomos, o Keller e o Miranda, que ficam lá no Parque da Previdência e que frequentemente visitam o parque para ver como está o desenvolvimento. 
Requalificação dos Aterros Desativados (Brownfields) no Município de São Paulo: Parques (Greenfields) Raposo

Tavares e Jardim Primavera

Luzia Helena dos Santos Barros

Luzia: então, existe acompanhamento das mudas plantadas.

Pellaes: Tem um acompanhamento. Inclusive, este parque recebe muitos elogios por parte do Keller e do Miranda porque é um lugar que eles tiveram uma experiência muito proveitosa. Embora a gente tenha algumas perdas, principalmente por vandalismo, não é nem por viabilidade das mudas --pois às vezes vem uma muda meio fraca e não pega--, a maior parte por vandalismo mesmo. Nós adotamos a técnica de plantar em talude, que na verdade é justamente o que as empresas que executam TCA não querem muito, porque é muito inclinado, é difícil. Mas o pessoal do plantio da prefeitura percebeu que nos taludes, além de você ocupar uma área que não tem muito potencial para outro uso, a perda é menor, até pela dificuldade de a pessoa transitar pelo talude. Então, ela acaba não indo lá quebrar e o aproveitamento é melhor.

Luzia: Nesse plantio vocês levam em consideração a questão do material de composição do solo, da problemática de contaminação?

Pellaes: Tem algumas coisas que a gente observa. Por exemplo, aqui temos um problema com a comunidade que, por se sentir 'dona' do parque -mas no sentido pejorativo de 'o parque é meu' e não 'o parque é nosso'--, as pessoas vem e querem plantar aqui o que é do gosto delas. O que acontece muito é plantarem abacateiros. Tem uma porção de abacateiros aí e eles crescem muito. Dependendo de onde a pessoa plantou não é adequado. Às vezes elas plantam perto do gradil, o abacateiro cresce e além de caírem os abacates, pode cair o galho, pode cair o próprio abacateiro. Acredito que devemos evitar plantas que estimulem o consumo. Embora seria maravilhoso que isso um dia fosse viável, para a situação presente eu penso que não é possível. Escolhe espécies que atraem fauna.

Luzia: Dependendo do tipo de vegetação pode haver problema de contaminação do próprio fruto. Isso é complicado. Já essa outra vegetação não apresentaria esse fator de preocupação.

Pellaes: Justamente. Essa é uma preocupação. Inclusive, nessa questão de plantios, as pessoas acabam plantando próximo do gradil coisas que a tradição consagrou como medicinais. Boldo é muito plantado. Mas não há justificativa para tê-lo aqui. Então, se a pessoa quer ter um pé de boldo, tenha em casa em um vaso. Eu já tive alguns problemas por mandar limpar a área e tirar os pés de boldo. As pessoas não entendem que não é um local apropriado. Ainda mais se você vai consumir.

Luzia: Em uma visita anterior, há um tempo atrás, o parque era usado como pasto para cavalos. Isso ainda existe?

Pellaes: Vivi esse problema. Estou aqui há mais ou menos um ano e meio e já tive duas ameaças de morte, uma em função dos cavalos. Sim, era constante. Eu testemunhei várias vezes cavalos correndo aqui dentro. Inclusive diziam que antes era pior ainda, que além de cavalo tinha bodes. E é engraçado pois não fiz nada quanto aos bodes, mas um dia antes de eu entrar já não tinha mais bodes. Não sei o que aconteceu. Acho que fizeram um churrasco aí e foram todos os bodes...rs. Eu não cheguei a ver, mas foi no dia anterior à minha chegada que alguém resolveu para mim o problema dos bodes. Sim, o pessoal soltava cavalos aqui. Um dos fatores associados a esse 
Requalificação dos Aterros Desativados (Brownfields) no Município de São Paulo: Parques (Greenfields) Raposo Tavares e Jardim Primavera

Luzia Helena dos Santos Barros

problema que eu detectei é que este parque ficava aberto 24 horas por dia. Administrativamente ele funcionava no horário normal, das $7 \mathrm{~h}$ às $18 \mathrm{~h}$, mas os portões ficavam abertos, pois a comunidade alega que este parque é área de travessia. Eles querem ir até a Raposo e precisavam atravessar o parque. Eu imagino que qualquer área grande é uma área de travessia, mas isso não significa que ela tenha que ficar aberta 24 horas por dia. Por exemplo, o Ibirapuera. Se você desce ali na avenida Ibirapuera e quer chegar na praça Quarto Centenário é muito mais rápido você ir por dentro do parque. Só que se você chegar lá $11 \mathrm{~h}$ da noite, você não vai atravessar o parque, você vai dar a volta. E nunca ninguém reclama por causa disso. Mas aqui as pessoas reclamam que têm que dar a volta. O que aconteceu é que eu não pude fechar o parque de cara, senão eu teria alguns problemas um pouco mais violentos, até ameaça à minha integridade. Então, o que fiz? Esperei passar um período para as pessoas saberem que estou aqui, o que estou fazendo, para me tornar conhecido e as pessoas saberem que não estou colocando o paletó na cadeira e indo embora, que estou aqui trabalhando. E comecei a consultar as pessoas. Consultei o conselho para saber que horário de fato o parque tinha um certo fluxo. Conversei com os funcionários também, pois temos vigilância $24 \mathrm{~h}$. Dessas conversas todas entendi que, a partir das $10 \mathrm{~h}$ da noite, cai tremendamente 0 ingresso de pessoas. $E$ as poucas pessoas que entram são aquelas que entram com as intenções não tão nobres. E o trânsito começa a aumentar a partir das $4 \mathrm{~h}$ da manhã, que é um horário em que muitas pessoas que trabalham longe estão indo pegar condução na Raposo. Então, entendi que eu deveria fechar o parque das $10 \mathrm{~h}$ da noite às $4 \mathrm{~h}$ da manhã. Pedi para que um funcionário, que trabalhava com pintura, fizesse umas placas para informar que o portão ficaria fechado. De cara, tinha pensado em colocar no aviso que 'este portão permanecerá fechado das $10 \mathrm{~h}$ da noite às $4 \mathrm{~h}$ da manhã'. Só que aí eu entendi que esse aviso ficaria um pouco agressivo. Então, inverti. Colocamos: 'este portão permanece aberto das $4 \mathrm{~h}$ da manhã às $10 \mathrm{~h}$ da noite'. A informação é a mesma, só se inverteu e ficou um pouco mais simpático.

Luzia: Não parece, mas isso faz uma diferença.

Pellaes: É. Você não está dizendo: 'você NÃO PODE entrar de tal a tal hora'. Você está dizendo: 'você PODE entrar de tal a tal hora'. Isso, no inconsciente, acaba dando uma diferença. Aí o que fizemos foi colocar as placas, mas não fechar os portões imediatamente. Colocamos as placas e encostamos os portões, para que a pessoa chegasse, desse de cara com o portão fechado e, óbvio, ela não ia gostar muito, ia ficar meio brava, ia balançar o portão e o portão ia abrir. Mas agora a informação já está entrando: 'o parque vai fechar'. Fizemos isso por três dias e, a partir do quarto dia passamos a trancar com cadeado. As duas primeiras semanas ainda tivemos alguns episódios de pessoas que reclamavam, que ameaçavam os vigilantes e tal, mas acostumaram. Acostumaram com o horário do parque e parou. Isso também acabou influenciando na história dos cavalos.Na verdade, quanto à questão dos cavalos, ao invés de chamar a zoonoses de cara, eu tentei aplicar a política da boa vizinhança. Fui descobrir de quem eram os cavalos e avisar que ela não poderia deixar os cavalos lá, só que acho que a pessoa acabou se acomodando e foi deixando. E ela sempre dizia: 'ah, os cavalos estão amarrados, alguém solta e no meio da noite eles vão para o parque'. Até que tive um episódio que alguém, que até hoje não sei exatamente quem foi, avisou a zoonoses que os 
Requalificação dos Aterros Desativados (Brownfields) no Município de São Paulo: Parques (Greenfields) Raposo

Tavares e Jardim Primavera

Luzia Helena dos Santos Barros

cavalos estavam aqui. E a zoonoses veio e cumpriu com o papel dela. Removeram os cavalos e foram embora. Só que quando eles tiraram do parque e eu estava aqui. Então a pessoa achou que tinha sido eu. Invadiram o parque, eu estava tendo uma reunião em uma sala, invadiram o parque e foram me ameaçar de morte lá dentro, por causa disso.

Luzia: E aí não teve mais retorno desde então. Isso faz quanto tempo?

Pellaes: Não. Os cavalos voltaram, não para dentro do parque. A pessoa conseguiu recuperar, pagou uma taxa e depois disso ainda tivemos alguns episódios de cavalos entrando durante o dia, quando os portões estão abertos, mas já faz pelo menos uns quatro meses que não é relatado. Não sei se mandaram para outro lugar ou se essas medidas resolveram, mas não tenho relato de cavalos entrando no parque.

Luzia: Você citou o Núcleo de Gestão Descentralizada. Eles também têm um trabalho de educação ambiental. Vocês trabalham em conjunto na educação ambiental?

Pellaes: Estamos em conversas, por exemplo, para gerar um folder sobre o parque. Isso até acabaria talvez amenizando essa questão de as pessoas não entenderem o parque como tal e entenderem como um lixão. Uma medida é essa e já estivemos conversando também sobre compor trilhas, aproximadamente da forma que existe no Parque da Previdência, uma trilha temática, com estações, com paradas para se refletir sobre alguma questão que é proposta ali para você, pela observação mesmo. Mas isso está no início.

Luzia: Fábio, antes de você vir trabalhar no parque você trabalhava onde?

Pellaes: Trabalhei em dois escritórios de consultoria ambiental. Servimar é um deles, e o outro se chamava Instituto Ambiental A.C.H.O., aqui em São Paulo. E, na verdade, desde quando estava no terceiro ano da faculdade eu lecionava. Fui professor de cursinho e foi uma atividade que eu interrompi em função do parque. Embora eu trabalhe de domingo à quinta-feira, e tenha a sexta-feira livre, acabei jogando minhas aulas para sexta-feira, mas não consegui dar conta. Exige muito. Pelo menos o parque neste pé em que está, neste momento, exige bastante dedicação e, então, não consegui manter as aulas.

Luzia: Por enquanto você atua só como administrador, também, porque você mora longe, não é?

Pellaes: Eu moro longe. É um outro agravante.

Luzia: Você teria mais algum outro comentário interessante ou já falamos quase tudo?

Pellaes: Acho que nós falamos quase tudo. Não consigo lembrar de mais nada.

Luzia: Bom, obrigada pela entrevista. 
Requalificação dos Aterros Desativados (Brownfields) no Município de São Paulo: Parques (Greenfields) Raposo Tavares e Jardim Primavera

Luzia Helena dos Santos Barros

\section{DECLARAÇÃO}

Eu, Fábio Santos Pellaes, R.G. n 32.273.616-X - SSP-SP, emitido em 14 de maio de 2009, administrador do Parque Municipal Raposo Tavares, no período de 16 de abril de 2007 a 28 de fevereiro de 2010, vinculado à Secretaria do Verde e Meio Ambiente - SVMA, da Prefeitura do Município de São Paulo, de acordo com autorização dada à pesquisadora Luzia Helena dos Santos Barros, da Faculdade de Arquitetura e Urbanismo da Universidade de São Paulo FAU-USP, publicada no Diário Oficial da Cidade de São Paulo, no dia 01 de junho de 2010, pg. 24, declaro que autorizo a utilização do conteúdo, revisado por mim, da entrevista, realizada em 27 de outubro de 2008, sobre o Parque Raposo Tavares, na sua pesquisa de doutorado sobre a "Requalificação de áreas degradadas por contaminação no Município de São Paulo".

São Paulo, de 12 de novembro de 2010

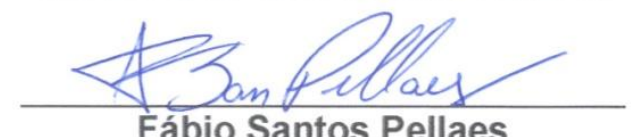




\section{APÊNDICE F - Entrevista com SÉRGIO NUNES, administrador (futuro) do Parque Jardim} Primavera, 11 MAIO 2010

Luzia: Sérgio, de acordo com nossa conversa anterior, gostaria que você explicasse a sua experiência na administração do futuro Parque Jardim Primavera. Inicialmente, explicar um pouco como chegou ao cargo de administrador do Parque Vila Sílvia e como ocorre a integração com a administração do futuro Parque Primavera.

Sérgio: Sou geógrafo e bacharel em direito. Atualmente faço mestrado em turismo e meio ambiente dentro da geografia: com o tema: "Turismo e Meio Ambiente em Bertioga". Antes de me tornar administrador, era professor de geografia para o ensino médio, para cursinhos pré-vestibulares e para cursos técnicos de gestão ambiental. Ministrava aulas tanto na rede pública quanto na particular. Fui avisado de uma seleção para administradores dos parques municipais. Participei da seleção pública. E foi uma grande surpresa quando eu fiquei sabendo que uma das áreas que iam me delegar era a área do futuro Parque Primavera. Eu fiquei, de início, muito empolgado, mas um pouco triste, pois haviam alguns problemas com a implantação do parque em função de atraso na licitação e da empresa que não continuou a obra. Me mandaram, então, provisoriamente, para o Parque Vila Sílvia que já estava pronto e sem administrador.

Portanto, hoje, eu administro o Parque Vila Sílvia, que também está em expansão. Situa-se na região da Subprefeitura da Penha. Eu fiscalizo e administro algumas situações da área do futuro Parque Primavera do qual, tenho a expectativa, de ser o administrador quando ele estiver pronto. A implantação desse parque, de acordo com previsões do Depave-1, está prevista para meados de agosto. Nós estamos em fase de licitação. Aliás, já está definida a empresa vencedora da licitação. Também já está autorizada uma construção de uma guarita. Ou seja, esse ano o parque começa. Eu tenho essa expectativa pelas notícias do Depave-1.

Enfim, eu administro essa situação lá e toda a problemática que advém de uma área degradada, de um antigo aterro que sabemos, é composto por todo tipo de lixo: hospitalar; de cemitério; lixo doméstico; entre outros conforme relato de moradores. Todo tipo de resíduo tem ali no subsolo.

Luzia: Desde quando você atua na SVMA exatamente?

Sérgio: Eu estou a mais ou menos um ano na Secretaria.

Luzia: No trabalho de administrar/fiscalizar o Jacuí/Jd.Primavera você conta com apoio de alguns funcionários?

Sérgio: Tenho apoio que todo administrador de parque tem. Lógico que é uma situação atípica, porque é um parque com origem em área degradada. O Parque Primavera, por enquanto, só tem o administrador, que sou eu e dois vigilantes. Na Secretaria, existem técnicos. Os arquitetos que cuidam de todos os parques; o Decont, que também está bastante envolvido com a questão do Primavera, por se tratar de uma área contaminada. Para o controle ambiental da área, está em fase licitação o serviço de extração de gás. Este serviço está há quase um ano em discussões quanto ao 
Requalificação dos Aterros Desativados (Brownfields) no Município de São Paulo: Parques (Greenfields) Raposo

Tavares e Jardim Primavera

Luzia Helena dos Santos Barros

aspecto jurídico, que eu não sei dizer bem qual é. Mas agora foi para a fase de licitação e será extraída uma bolha de gás que tem no interior do parque. O preço do serviço de extração está em $\mathrm{R} \$$ 280 mil ou algo próximo disso. Então, é uma coisa bem-grande.

E, assim, enquanto gestor, eu estou lá sozinho, por hora. Naturalmente que uma vez implantado o parque, espero que daqui a uns seis, sete meses, ou que seja até o final do ano. Aí, sim, com certeza estagiários, assistentes na parte de gestão virão. Agora, todo o apoio técnico de fiscalização, controle e obra, busco na Secretaria. Enfim, algumas especificações do projeto do parque. Além da avaliação de passivo ambiental que eu tive conhecimento. Tenho uma cópia, conheço as especificações técnicas e de contaminação da área. Quem está lá, somos nós do Depave-5. Agora, a Secretaria está por trás, dando todo apoio técnico.

Eu acho que isso não vai, sinceramente, ter problemas. Porque o Primavera, de acordo com - Decont, é o único parque na América Latina que teve essa avaliação de passivo antes da implantação de um parque. A gente sabe que o Raposo não teve. Outros que, também, têm algumas parcelas de aterro também não tiveram. E a notícia que se tem é que o Primavera é o pioneiro. Então, isso me deixa muito contente. Quer dizer, já é um passo a mais no Brasil e isso me deixa muito feliz.

Luzia: Qual a sua opinião sobre esse tipo de integração, onde, primeiro, se faz a avaliação do passivo para, depois, saber como implantar o parque?

Sérgio: A avaliação do passivo é importante porque, para mim, enquanto gestor no futuro, a avaliação dos graus de exposição das áreas permite que eu avalie onde posso ou não desenvolver tais e tais atividades, onde eu posso colocar um playground para as crianças brincarem, onde eu não posso. Não significa falar: “-Ah, mas então por que vai ter um parque ali?” Não, é possível ter um parque ali.

Luzia: De acordo com as expectativas do Decont, do Depave, é possível?

Sérgio: É, só que com todos os cuidados que devem ser tomados. Então, quer dizer, com um estudo em mãos, dessa natureza, eu posso dizer: "-Aqui eu posso desenvolver. Colocar um campo de futebol, onde as crianças podem jogar descalças, por exemplo, e em outro lugar não. Aqui, no máximo, eu posso fazer uma trilha e em outro lugar colocar uma quadra, enfim"

Luzia: Esse parque, apesar de todas essas restrições, vem sendo utilizado pelos usuários do entorno. Como é que isso tem acontecido?

Sérgio: Isso entra, quase que em uma questão político-administrativa. Eu, como já disse, estou fiscalizando a área. Então, quando eu cheguei lá, o cercamento estava incompleto. A primeira atitude foi terminar o cercamento do parque, dos fundos do parque, o que foi feito. Segundo o Depave-1, a verba tinha acabado justamente nos fundos e ficou a parte mais crítica. Inclusive, perigosa, por causa do tráfico de drogas que nós temos ali. Foi cercada só no final. E, aí, eu coloquei um portão e fechei. Só que essa área já era usada há anos, antes mesmo da sua transferência da Limpurb/SES para a 
Requalificação dos Aterros Desativados (Brownfields) no Município de São Paulo: Parques (Greenfields) Raposo Tavares e Jardim Primavera

Luzia Helena dos Santos Barros

Secretaria. Já existia um campo de futebol de terra. Aquelas situações em que o uso da área já está consolidado muito antes do parque.

Eu cheguei a tentar fechar. Mas, aí, vem uma questão política da comunidade, das associações de bairro. Que o uso é muito pequeno, mas tem gente que ainda quer andar com o seu cachorro na coleira lá dentro, quer sentar lá, etc. Não é aconselhável: é até proibido em parques. Mas, nesse caso, nós não temos um parque ainda. De mães: "-Ah, meu filho está na rua. Deixa empinar pipa em lugar aberto." Eles vão empinar pipa lá. Que, naturalmente, vai ser proibido quando se tornar parque. Enfim, outras pessoas gostam de caminhar lá dentro, apesar do mato alto. Enfim, mas isso é raríssimo: é raríssimo.

O uso, mesmo, que nós temos ali, é de um campinho de terra com traves de madeira que os jovens e adultos, no final de semana, gostam de jogar o seu futebol, vão lá. Por isso que eu não fechei. Mas eu consegui fechar em parte. Ele era aberto 24 horas. Com uma arborização de eucaliptos densa, perigosa: estava aberto 24 horas. Com o tráfico entrando e saindo. Consegui fechar. Aí, consegui fechar às 18 horas e abrir às 06 horas. Até um momento que eu tive um outro problema: uma mulher foi espancada dentro do parque pela madrugada. E, aí, eu resolvi abrir a área às 08 horas. Eu queria ir fechando aos poucos. Você fala: "-Puxa, mas caramba, o Sérgio está com uma posição contrária do que é..." Não, não é: eu estou tentando preservar a área, para quando a implantação do parque chegar, a área estar preservada. E aí, sim, quando houver estruturas de lazer próprias, segurança para a população, eu poder abrir.

Mas o fato de eu restringir o uso, ir fechando e diminuir os horários. De dois portões abertos passou para apenas um portão e hoje, eu tenho meio portão. Assim a freqüência foi diminuindo. Para quê? Para evitar riscos de acidentes e não provocar o descontentamento da população local. Para a população, também perceber as mudanças. Aqueles que ainda se arriscam a entrar. Eu já avisei e deixei claro para todos eles que era por conta e risco, aquela coisa toda. Tenho feito isso e estou reduzindo quase a zero o uso dessa área, que não é uma área própria para lazer, por enquanto. Enfim, agora, com a notícia da implantação... E, aí, em função das obras, não há desculpa; eu vou fechar a área do futuro parque, vou colocar um cadeado e colocar: "Em função das obras, estamos fechados. Reabriremos assim que for inaugurado, que for finalizada a implantação."

Lá, quando eu cheguei, nós tínhamos oito velhas guaritas, se eu não me engano, dois depósitos e uma casa abandonada lá dentro. Então, havia moradores de rua morando lá dentro. Nós tínhamos drogados que dormiam, gente que utilizava para transar, para atos libidinosos os mais diversos. Dos piores usos possíveis. Gente que ficava se escondendo para assaltar, para tentar estuprar. Enfim, a primeira coisa que eu fiz foi demolir essas guaritas que eram remanescentes do antigo aterro. A casa, também, que estava servindo de abrigo. Tinha gente realmente morando lá com família e tive que tirar. Era uma situação complicada. Porque, antes disso, era queimar colchão, era queimar isso, era chamar polícia e tal. Consegui autorização para demolição. A demolição foi feita. Eliminamos esse problema.

Outra situação era o resquício da antiga caixa de contenção de chorume que a empresa que começou a obra abandonou, deixou aberta, com o seu fundo, o seu piso expostos. Ainda existe um resíduo de chorume não líquido, mas como se fosse um lodo. Eu não podia, naturalmente, aterrar 
Requalificação dos Aterros Desativados (Brownfields) no Município de São Paulo: Parques (Greenfields) Raposo

Tavares e Jardim Primavera

Luzia Helena dos Santos Barros

aquilo, que seria jogar a sujeira para debaixo do tapete, além de ser ambientalmente incorreto. $E$ eu aguardo as posições do Decont. Mas eu não podia aguardar com aquilo aberto. Então, o que eu fiz? Cerquei com um alambrado, coloquei um aviso. Mas, infelizmente, essas semanas atrás foi roubada a tela que protegia. Porque, infelizmente, é o seguinte: não são crianças, são adultos que vão lá com a ideia que, ali, dá peixe.

Porque, às vezes, aparece um peixinho ou outro, que eu não sei como sobrevive. Eu não sei se por alguma alga, alguma coisa que permite a vida ali. Eu já encontrei até isopor lá, para o pessoal guardar os peixinhos. Mas é incrível: a gente vai lá, a gente vê que é cortado com alicate de corte. Não é criança que vai lá não: é adulto que insiste em ir. E a gente vai e fecha. Estou com uma nova solicitação para tampar de novo e assim vai. Até que um dia seja implantado o parque. Essa é uma questão meio complicada, mas, enfim.

Luzia: Apesar do contato com os usuários, existe uma parte dos moradores que não entende como lidar com essa situação, de parque sobre aterro?

Sérgio: Isso. Não, não entende. O duro de lidar com a população, é que cada um tem uma opinião, cada um tem uma posição. Desde opinião pessoal até opinião política. Por exemplo, estou com o gradil. Nós fizemos um gradil belíssimo, padrão Depave, gradil de parque, com calçada verde, tijolo inter-travado e tudo. Mas acho que, em uma audiência pública, quando a Secretaria mostrou o projeto para a população - que eu acho isso muito bacana - , mostrou-se aonde seria a entrada principal do parque. Aí, aconteceu todo o problema da empresa que abandonou. E essa abertura não foi feita ainda. Vai ser feita no local onde foi prometido, mas não foi feita ainda. O que aconteceu? A população abriu um pedaço do alambrado com um macaco hidráulico. Falou que se for colocada uma grade, ali, para fechar, eles vão lá e abrem em outro lugar, de novo. Para ter acesso, justamente, a essa área.

E falando da implantação do parque, a expectativa daquela população é muito grande. Já há mais dev30 anos se espera alguma coisa parecida com isso. Desde o começo, em que era banco de areia, lá na década de 1960. Em que o banco de areia começou a avançar em direção ao loteamento que tinha na época. A população conseguiu brecar o banco de areia, onde se tirava areia para a construção civil. Aí, como a legislação ambiental, na época, era inexistente, a situação era frágil, terrível. Não havia banco de areia, mas tinha uma cratera. Era uma cratera enorme em que se resolveu instalar um aterro descontrolado. Então, era camada de lixo, camada de terra. E assim foi até chegar ao nível da rua, digamos assim.

Aí, mais luta da população. Eu fui morador de lá durante 15 anos, não sou mais. Então, a gente convivia com isso. Os mais antigos podem relatar isso melhor. Os caminhões de lixo passando na porta de casa, pelas ruas de terra do loteamento, como a maioria das ruas dos loteamentos aqui na periferia. Eram todas de terra. Aí, o que acontece? Uma das ruas foi asfaltada exclusivamente para o aterro. Para dar acesso aos caminhões que depositavam lixo. Quer dizer, você tinha um bairro que não era asfaltado, mas no qual uma das ruas - não me lembro o nome agora, mas próxima da entrada lá - foi asfaltada. Não é a Antônio Louzada. A Antônio Louzada, hoje, é a avenida principal do bairro. Aí, você tem a Mimo de Vênus, aqui na lateral do parque. É a última, já próxima do córrego 
Requalificação dos Aterros Desativados (Brownfields) no Município de São Paulo: Parques (Greenfields) Raposo

Tavares e Jardim Primavera

Luzia Helena dos Santos Barros

do Limoeiro. Essa foi asfaltada com o objetivo de dar acesso aos caminhões de lixo que traziam todo tipo de lixo, como eu já disse: hospitalar, doméstico. Segundo moradores, até de cemitério.

Então, isso foi acontecendo. Até que, por pressão da população, protestos, todo tipo de manifestação, se conseguiu, junto ao poder público da época, o fim do aterro. Na verdade, não é o fim do aterro, é o fim das atividades do aterro. Porque, depois desse processo, seguiu-se mais sete anos de queima do gás do subsolo através dos tubos.

Luzia: Mesmo com o aterro encerrado o gás continuava sendo eliminado?

Sérgio: Encerrou só a deposição do lixo no aterro. Houve a última camada de terra. E, a partir daí, a queima. Houve a instalação dos tubos e fogo durante sete anos. Que serviu, inclusive, de referência em toda a região. É, porque você via o fogo de longe. A gente sentia o mau cheiro que também era muito grande. Eu ouvia, quando criança, relatos de pessoas: "-Ah, fulano de tal estava em casa, lá no corredor da casa dele, estava fumando um cigarro, jogou no ralo e explodiu." Houve uma pequena explosão. Por quê? Porque o gás do subsolo do aterro se propagava. E como a gente tinha, na época, um tempo atrás, muitas fossas sépticas, tinha muitas casas sem rede de esgoto e o gás se propagava pela aeração do solo e chegava até as residências. Aconteciam essas pequenas explosões. Isso tudo, depois, foi comprovado pela avaliação do passivo.

Então, tinha uma série de problemas: mosquitos, ratos que tomavam conta das casas. Isso diminuiu bastante; consideravelmente. Enfim, depois desses sete anos, onde houve queima, o aterro foi mesmo desativado. Eu só não sei precisar a data. Depois, a Limpurb passa essa área para a Secretaria do Verde com a promessa e a expectativa de tornar essa área um parque.

E com a demora de 30 anos, todos os problemas que houveram ao longo desse processo, há uma inquietação da população, um inconformismo. Se, hoje, você for a algum morador, mesmo eu, que luto pela causa fielmente, se for falar: "-Não, o parque vai acontecer." Nossa, eu sou recebido com a maior rispidez do mundo. E eu tenho que entender. Porque se eu também estivesse na situação deles, eu também faria a mesma coisa. Eles já estão desacreditados. A população não é obrigada a entender os imbróglios do processo da administração. As burocracias, os prazos legais que devem ser cumpridos. E, aí, na ocorrência de um problema, quais são os novos prazos, os novos processos. A única coisa que eu posso dizer é: “-Confiem na gente que vai acontecer." E eu acredito que vai acontecer. Porque o processo já está acontecendo. A licitação está em Siurb, então está rolando. O projeto do parque foi apresentado para a população e eles aguardam um parque com a maior infraestrutura de lazer: com n quadras, equipamentos, etc.. Eu já avisei para algumas associações, já conversei que não é bem assim. Nós não podemos instalar todo tipo de equipamento. Não é em todo local do parque, mas as pessoas dizem: "-Ah, não, não dá. Já acabou. O lixo aqui já acabou." Eles não entendem que, ali, ainda existe lixo. Eles acham que, assim, era tudo lixo orgânico. A impressão que dá é essa: que era tudo lixo orgânico e que aquilo ali já foi, que a terra comeu. Vulgarmente falando é isso: que a terra comeu. Não entendem que ali embaixo tem madeira, tem plástico, tem vidro, tem todo tipo de material que são centenas, às vezes, milhares de anos para se decompor. Que tem borracha, que tem uma série de coisas ali no subsolo. 
Requalificação dos Aterros Desativados (Brownfields) no Município de São Paulo: Parques (Greenfields) Raposo

Tavares e Jardim Primavera

Luzia Helena dos Santos Barros

Luzia: Apesar de muitos moradores terem acompanhado todo o processo de surgimento do lixão, eles acreditam que o problema acabou?

Sérgio: Acham que ali acabou. Então, ali eu já posso construir edificações, ali eu já posso colocar quadra. Então, eles estão esperando um Parque do Piqueri, do Carmo, como qualquer outro parque. E eu já avisei que, no início, não haverão quadras. A maior parte do parque, eu diria que mais de $80 \%$ da área, ainda está sob estudo do Decont. Ainda existe essa bolha de gás a ser retirada. Então, a gente só vai implantar um trechinho correspondendo à primeira fase do parque.

Luzia: Essa primeira fase a área é bem-pequena em relação ao total.

Sérgio: Exatamente, bem-pequena, só com sete quiosques, uma área de convivência e a administração.

Luzia: A população participou da elaboração do projeto do parque, de alguma forma, não foi? Mas mesmo participando ainda não consegue perceber as diferenças dessa área?

Sérgio:É porque quando a gente fala população, a gente fala da sociedade civil organizada, que são associações, entidades e tal, representantes, ali, do comércio, disso ou daquilo, de um setor ou outro. Mas a grande massa não tem o domínio das informações. Por mais que se tente divulgar. Assim, a Secretaria vai, realiza uma audiência pública, como tem feito. Vai em um auditório da Subprefeitura com 50 pessoas. Essas 50 pessoas, por mais que tentem multiplicar as informações, não dão conta da população, da massa. Por mais que tenha um jornal do bairro que, às vezes, até coloca as informações que a Secretaria tem realizado.

Luzia: Elas não conseguem assimilar, também?

Sérgio: Não. Tem gente que, até hoje, você fala assim: "-Aqui vai virar um parque.", "-Aonde? No lixão?." Eles não sabem, você entendeu? Eu acho que só quando o parque estiver lá na frente deles, pronto.

Eu vivo essa realidade aqui no parque Vila Sílvia. Tem tanta gente que passa por aqui que fala: “-Aqui é parque?" Quando vê alguma placa, vê alguma coisa. Lógico que é um parque novo, muito recente, que ainda estão sendo feitas placas de orientação de trânsito que designam o lugar do parque e tudo mais.

No caso do Primavera, em função, também, das promessas políticas anteriores, de 10, 20 anos atrás, há muito desgaste. Cada candidato a vereador, deputado, prefeito etc., que passava por lá, que fazia a sua campanha, falava: "-Aqui vai ser uma creche." O outro falava: "-Aqui vai ser um posto de saúde. Não, aqui vai ser um parque e vai ter isso." Aí, o outro falava: "-Não, vai ter isso." E foi se passando o tempo, cada um com uma promessa. Então, além disso, há uma confusão na população, em função de 20, 30 anos de promessas, sobre qual o uso final daquela área. E não é fazendo política para a gestão atual, mas a única coisa concreta que nós temos é uma lei, de 2002, que cria o Parque Primavera. Que cria legalmente. E, aí, sim, se dá um uso definitivo para a área. Antes disso, eram só especulações políticas. 
Requalificação dos Aterros Desativados (Brownfields) no Município de São Paulo: Parques (Greenfields) Raposo

Tavares e Jardim Primavera

Luzia Helena dos Santos Barros

Luzia: Então, o uso da área como parque também foi uma solicitação da população do entorno, ou não?

Sérgio: Sim. E atendida pela Secretaria do Verde. Cria-se uma área de lazer. Bom, você tinha um lixão. Então, fazer daquela área uma área de lazer, recreação, uma área "limpa" - é um sonho. É a mesma coisa que você tornar uma área de asfalto em uma floresta. As pessoas queriam o oposto do que se tinha. E viram essas expectativas, possivelmente atendidas, com o plano da Secretaria.

Luzia: Você tem idéia do número de população do entorno do parque?

Sérgio: Não, esse número eu ainda não tenho. Eu sei que, assim, nós temos ali a Subprefeitura de São Miguel. Os bairros limítrofes, mesmo, do parque são Vila Jacuí, Jardim das Camélias, Jardim Pedro Nunes e Parque Cruzeiro do Sul. Lógico que outros bairros, ainda, do entorno, como o Bairro do Limoeiro. Que mais? Como o Parque Guarani. São próximos, também, e, com certeza, as pessoas vão fazer uso. Mas limítrofes, mesmo, são esses quatro bairros que eu falei. Mas eu não tenho levantamento de população do entorno, não. Apesar de que, assim, volto a defender a gestão atual e etc.: pelo Projeto 100 Parques, um dos parques já foi terminado, inaugurado, o Parque Vila Jacuí, que fica na Vila Nair, também conhecida como Jardim Pantanal, não é uma área arborizada, por enquanto. É uma área degradada, que foi desocupada, junto à Jacu-Pêssego, muito próximo.É o parque vizinho do Parque Primavera. Esse, sim, tem toda a quantidade de quadras, suficiente para uso da população, campos de futebol, pistas de skate, bancos de areia à vontade, playgrounds. Que é uma característica de um parque, talvez, mais urbano.

E o Primavera, não, ele não vai ter essa característica. Vão ser dois parques colados com naturezas diferentes. Isso eu acho muito bom. Você tenta minimizar, nesse sentido, o déficit de áreas verdes. E, também, de áreas de lazer da região. Então, com o parque. E outra: eu acho que um parque vai complementar o outro nesse sentido. Apesar de ser uma área remanescente de aterro; uma área de contemplação, arborizada para caminhada e trilha, acho que o Parque Primavera vai ser a melhor opção. Quando você quer uso de quadras, de pista de skate e essas opções, você vai usar o Parque da Vila Jacuí, que são vizinhos. Então, eu acho que para essa população, terminados esses dois parques, abertos, em uso, vai ser amplamente suficiente para a população desses bairros que eu citei.

Luzia: Você acha que quando o Primavera for implantado, ele poderá atender uma região mais ampla, não só dos bairros do entorno?

Sérgio: Vejo que sim. Nós temos, ali a Jacu-Pêssego. Ela foi feita parcialmente e aguardou-se, agora, o complemento do Rodoanel e ela foi tomando vulto. No início, a Jacu-Pêssego quase não tinha movimento algum de carro, mas o movimento foi aumentando ao longo do tempo. E agora foi feito, recentemente, nos últimos anos, a interligação com a Rodovia Airton Senna. Então, você tem um acesso desde a Rodovia Airton Senna. Aí, você adentra, então, a região de São Miguel, Vila Jacuí. E vai em direção à Itaquera, até chegar em São Mateus, praticamente. Onde está sendo feita, agora, terminada, a interligação com o Rodoanel em Mauá, se não me engano. 
Requalificação dos Aterros Desativados (Brownfields) no Município de São Paulo: Parques (Greenfields) Raposo

Tavares e Jardim Primavera

Luzia Helena dos Santos Barros

Então, quer dizer, se houver a divulgação correta de onde fica o parque etc., pelo jornal, pelo site da Secretaria e pela mídia, enfim, eu tenho certeza que alguém que ache bonito e goste, tem fácil acesso pela Jacu-Pêssego desde a região de São Mateus. Até o Parque Primavera ou até o Parque Vila Jacuí, o vizinho. Então, o pessoal de Itaquera com certeza vai poder fazer uso também. $\mathrm{Na}$ sequência da Jacu-Pêssego nós temos, então, o Parque Raul Seixas, que é bem pequeninho e tem uma demanda bastante alta: é uma área de conjunto habitacional. Que a gente, talvez, quem sabe, até, consiga desafogar um pouco essa demanda do Raul Seixas para o Parque Primavera. Então, Raul Seixas em uma ponta, Primavera mais ou menos no meio e, na outra ponta, o Parque Vila Jacuí.

Luzia: Essa região, realmente, tem muito pouca área verde. A Zona Leste, não é?

Sérgio: Sim. Talvez nem tanto em Itaquera. Se a gente caminhar um pouco por Itaquera, a gente tem mais áreas verdes: o Parque do Carmo e, enfim, o seu entorno, não é tão deficitário assim. Eu já tive contato com estudos que, por exemplo, em comparação da temperatura do centro de São Paulo a essa extrema periferia, digamos assim, Itaquera, tem uma diferença de cinco a seis graus em dias de muito calor, no verão. Então, em função das ilhas de calor do centro. Então, eu julgo que Itaquera não. Mas você tem outras áreas: Cidade Tiradentes, a própria área de São Miguel Paulista e outras áreas, você tem, sim, um déficit grande de área verde. E esse é o entorno do Parque Primavera. Uma área deficitária mesmo.

Luzia: Qual o tipo de edificação que se encontra no entorno do parque?

Sérgio: Em termos de perfil da população do entorno eu diria que nós temos uma classe média e classe média-baixa. No entorno, que eu digo, áreas limítrofes: não há favelamento. Aquilo que a gente podia considerar favela, já foi, digamos assim, transformado. A gente tem uma parte periférica, uma periferia consolidada, com uma infraestrutura de água, esgoto e energia elétrica. Então, eu não posso considerar como favela. Já são todas construções de alvenaria, não há nada de madeira. Ainda que as favelas, atualmente, sejam constituídas de alvenaria. Mas não há favela. E, digamos, os bairros que mais apresentam as melhores condições sociais são o Jardim Pedro José Nunes e o bairro de Vila Jacuí. De maneira geral. Naturalmente que cabem, aí dentro dos bairros, as exceções. E o Jardim das Camélias, talvez um pouco menos. O Parque Cruzeiro também tem boas condições.

Agora, o bairro que fica atrás do Parque Cruzeiro, que já é o bairro que é limítrofe ao Parque Vila Jacuí, que também pode fazer uso do Primavera - está nessa região do entorno - esse tem uma população pobre. Pobre que, inclusive, atualmente, passa por um forte processo de reurbanização: asfaltamento, água e esgoto. É a Vila Nair. Eu não sei se é esse o nome do bairro, mas as pessoas vão para lá e falam que é esse: União de Vila Nova e Vila Nair. Que apelidam essa área de Pantanal. Nós temos o Pantanal, do Jardim Romanoa e temos esse Pantanal, atrás do Parque Cruzeiro do Sul. Essa área, sim, é extremamente pobre.

Luzia: Você sabe que o Raposo Tavares também é um parque que foi construído sobre um antigo aterro. Mas você já teve oportunidade de conhecer o Raposo Tavares? 
Requalificação dos Aterros Desativados (Brownfields) no Município de São Paulo: Parques (Greenfields) Raposo

Tavares e Jardim Primavera

Luzia Helena dos Santos Barros

Sérgio: Sim, eu o conheci. Conheci também o seu administrativo. Fiz, lá, uma visita, mas foi rápida. E tive contato com o antigo administrador: o Fábio. O novo administrador eu não sei nem que é. O Fábio me passou algumas experiências que ele teve dos usos no parque. Porque uma coisa é o parque implantado e vazio: outra coisa é o parque implantado e em uso. Então, eu acho que o que difere, além da formatação interna do parque, é a população do entorno. Eu acho que isso é fundamental. Eu vim de uma reunião, hoje, em que... A gente faz uma reunião, os administradores, aqui, da Leste. A gente fez uma reunião e a gente falando das diferenças dos lineares. $E$ um administrador levantou uma coisa bastante interessante. Ele falou: "-É diferente um linear em que você tinha uma área degradada que se tornou linear. Então, quer dizer, agora você tem uma conservação, uma limpeza do local. Então, a população meio que aprova aquilo. Agora, se você tem um linear que teve que desapropriar um monte de casa onde aquela população morava. Ela teve que ir para lugar mais afastado, teve que sair dali, às vezes até há um repúdio dessa população em função daquela instalação ali, daquele parque." Então, quer dizer, você vê? Dois parques lineares, mas que, em função da situação, não estou falando de entorno mais, não estou falando de projeto: eu estou falando da situação em que ele surgiu, que ele foi implantado, gera uma apatia ou empatia pelo ambiente.

Fora que, quando você tem... Não estou dizendo que a pobreza traz prejuízos ao meio ambiente: não é isso. Mas que influi, influi. Quando eu estou no Parque do Ibirapuera, Parque da Aclimação - não que esses parques não tenham problemas, não é isso - até mesmo o Parque Vila Prudente ou outros mais em que você fala de educação ambiental, preservação ambiental para a população, para os usuários, para os frequentadores do parque, é recebido de uma fora. Agora, como eu vou no linear Itaim, que eu tenho favelamento? Como é que eu vou no Santa Amélia, que é uma área periférica terrível? Que, algumas áreas, as pessoas não têm saneamento básico, não têm uma casa de alvenaria, não têm energia elétrica. Como é que eu vou chegar nessa pessoa e falar assim... Uma pessoa que despeja o esgoto dela no córrego. Como é que eu vou falar, assim, para ela não jogar... É difícil falar para ela não jogar papel no chão. Não é a pobreza, em si, que causa o problema ambiental. Mas é, digamos assim... Como é que eu posso dizer? A situação socieconômica que não permite que essas pessoas possam pensar adequadamente em meio ambiente. Pode até ser uma coisa muito, sei lá, radical da minha parte, mas é o que eu tenho assistido.

Então, de forma resumida: entorno difere o uso do parque. O projeto, ou seja, o objetivo daquele projeto de parque, para que eu quero aquele parque e a situação em que ele surgiu. Isso tem uma importância. Citando, só assim, o linear do Tiquatira, que eu administrei: ele é diferente dos outros lineares. A maioria dos lineares está em uma área de ocupação irregular, de grande deposição de esgoto. E já o Tiquatira, não, ele tem, em uma ponta, um núcleo de favelamento, mas o que caracteriza o Tiquatira são os bares. Olha que coisa curiosa, é a noite. O linear do Tiquatira é cercado nas duas laterais de barzinhos que são amplamente freqüentados, sexta, sábado e domingo. Então, à noite, há uma invasão, mesmo com todas as tentativas de impedimento que nós fazemos, de carros estacionando em cima do gramado. Então, olha o entorno mudando a característica do uso. 
Requalificação dos Aterros Desativados (Brownfields) no Município de São Paulo: Parques (Greenfields) Raposo

Tavares e Jardim Primavera

Luzia Helena dos Santos Barros

Luzia: No Jacuí foram plantados, há um tempo atrás, vários eucaliptos, pela própria prefeitura. Você tem observado ou tem conhecimento de como esses eucaliptos se desenvolveram?

Sérgio: Tenho. Bom, conhecimento superficial, na verdade. Mas a gente nota, porque os eucaliptos foram plantados em quase toda a extensão do parque. Alguns eucaliptos se desenvolveram e têm um dap, base mais avantajado, tem um caule mais avantajado. Aqueles que estão no núcleo de onde a gente sabe que teve grande deposição e que o lixo está quase raso, muito próximo da superfície, ele não desenvolve, praticamente: ele fica muito fininho. E a quebra de eucaliptos é frequente. Um vento, uma tempestade sempre tem quebra. Mesmo estando plantados há muito tempo, há eucaliptos com ainda DAP de 10 centímetros, o que é muito pouco. Assim, eles caem muito fácil, se desprendem do solo com muita facilidade.

Luzia: Então, pode-se comprovar que há dificuldade para implantação de árvores nessa área.

Sérgio: No caso de eucalipto, sim. Eu não sou agrônomo, mas, naturalmente, existem outras espécies que se adaptam melhor à situação de aterro.

\section{Luzia: E quanto às amoreiras que, também, foram plantadas há um tempo atrás, existe essa dificuldade?}

Sérgio: Não. A situação das amoreiras é a seguinte: eu não tenho notícia de quando ou quem plantou. Elas são bastante antigas no parque.

Luzia: Foram plantadas na década de 1990, também.

Sérgio: Então. A gente tem pé de banana, também, lá atrás. Muita gente vai lá e pega. Elas nascem absurdamente. Os pés de amora são vistosos, grandes e têm bastante amora. O que eu não sei é se há contaminação ou não. Eu não tenho nenhuma análise laboratorial - pelo menos nunca tive acesso - que diga que o pé de amora conduz algum contaminante. Agora, a criançada vai lá. Eu nunca tive notícia de nenhum problema. Eu não me arrisco, sinceramente. Os vigilantes colhem banana, lá, toda semana e comem. Até hoje nunca reclamaram de uma desinteria. Mas eu não sei: cada um tem um organismo diferente.

Luzia: No entorno do futuro parque existem muitas escolas. Alguma escola, em algum momento, usou o aterro para alguma atividade?

Sérgio: Não. Até então, não houve interesse de nenhuma escola. Existem muitas escolas no entorno: EMEI, EMEF, escolas estaduais, particulares. Não houve interesse de nenhuma escola ou faculdade. Nós temos faculdades muita próximas: Unicsul e a Unicastelo. Que, na verdade, são duas que são bem próximas ao parque. Nunca houve interesse dessas instituições. Mas também nunca houve interesse meu em trazê-los para a área, por hora. É como eu já te disse: a minha intenção é restringir o uso até o ponto de evitar riscos. Lógico que, quando implantado o parque, aí sim eu vou trazer essas escolas. Pelo menos pretendo trazer essas escolas para dentro do parque para gerar o bom uso da área. 
Eu fui professor; a gente sabe disso: a gente trata na geografia e na biologia, enfim, as questões do meio ambiente e dos impactos ambientais, mais precisamente, mais nos livros, nos vídeos. Enfim, o que é o impacto ambiental? O que é uma remediação? O que eu posso fazer? Ou até o Primavera, mesmo, quando implantado, quando tomadas as devidas medidas de precaução, pode ser um grande laboratório. Principalmente para alunos de ensino médio, alunos de ensino técnico em gestão ambiental. É um grande laboratório, para educação ambiental, para tudo. Até agora não houve nenhuma manifestação de interesse. A primeira pessoa que teve algum interesse em pesquisa foi você. Pelo menos desde quando eu assumi a área.

Luzia: Soube que está havendo a discussão, dentro da Secretaria, para a elaboração do plano de gestão dos parques. Como essa questão está sendo tratado no caso do Primavera?

Sérgio: A maioria dos parques está elaborando esse plano de gestão de acordo com algumas diretrizes do Depave-5, Departamento de Parques e Áreas Verdes, que cuida da gestão ambiental. E é obrigação legal de todo administrador ter um plano de gestão para os parques implantados. Então, essa é a grande característica fundamental: para parques implantados. O que nós chamamos de Parque Primavera ainda não é um parque, de fato. É uma área que aguarda implantação. Então, não há obrigação legal dessa área ter esse plano de gestão, por hora. Mas sabendo que já há uma previsão, eu já tenho elaborado algumas coisas, eu já tenho um plano, digamos assim, parcialmente feito, do Parque Primavera. Eu já iniciei. Eu só não posso continuar, porque eu não sei onde vão estar as coisas, eu não sei onde vai ser alocada a administração, onde eu posso ter um centro de educação ambiental. Eu não sei o que vai ser feito. Então, é parcial. Já está sendo escrito. Como eu tenho essa expectativa, de eu mesmo assumir o parque lá na frente - independente de não ser eu também, lógico - mas eu já estou me precavendo, fazendo. Uma questão de melhorar o meu trabalho.

Então, dentro desse plano, ele tem desde aspectos operacionais, de abertura, fechamento, postura, regimento, postura de vigilantes, postura do pessoal da limpeza e tal, aquela coisa toda; até ações de educação ambiental com o entorno, com a população, com as escolas que nós falamos. Então, esse plano contempla tudo que envolva a gestão.

Luzia: Existe algum trabalho/ação de integração, sobre a implantação do parque, com a Subprefeitura ou com alguma outra instituição da região?

Sérgio: Sim, há. Olha, atualmente a Subprefeitura de São Miguel Paulista tem sido bastante parceira. Porque eu faço parte de um departamento chamado Depave 5, Departamento de Parques. Depave 5 que é responsável pela gestão. E, legalmente, as atribuições legais desse departamento é a conservação de parques implantados; a gestão de contratos de parques implantados. Nós não temos contrato, ainda, de conservação lá, porque não existe parque. A lógica é essa. Então, tem mato crescendo, algumas situações, árvore que cai. O gramado mesmo, da calçada, que cresce. Então, isso tudo a gente tem contado com o socorro da subprefeitura que tem ido lá e cortado, tem tirado entulho do entorno. Que tem um acúmulo de entulho nos fundos do parque, que a população deposita. Então, a Subprefeitura é bastante parceira. Isso eu não posso reclamar, não. 
Requalificação dos Aterros Desativados (Brownfields) no Município de São Paulo: Parques (Greenfields) Raposo

Tavares e Jardim Primavera

Luzia Helena dos Santos Barros

Luzia: Mas é basicamente com a Subprefeitura? Não teria outra instituição, a Secretaria de Saúde ainda não está envolvida?

Sérgio: Então, nós já tivemos, lá, a vigilância da Suvis: Supervisão de Vigilância em Saúde. Para ver essa questão dos animais sinantrópicos: escorpiões e etc. Ver se tem foco de dengue, essas coisas. Nós já tivemos a visita, mas eu não posso dizer que seja um parceiro frequente. A Subprefeitura sim: trabalha muito.

Luzia: Como você trata os conflitos que existem junto ao córrego do Limoeiro?

Sérgio: Essa região que você está falando é a região dos fundos do parque, que não faz parte do parque, mas que, querendo ou não, nos influencia indiretamente. É uma área que tem uma forte deposição de entulho. Tem mais entulho do que o eco-ponto, com certeza. É só você ficar ali... Não precisa ficar uma hora, se você ficar 15 minutos, você vai ver um carroceiro depositando. É frequente: é o dia inteiro e a noite com deposição até de pequenos caminhões, de carros trazendo entulho. Assim, desde muitos anos ali se tornou o ponto oficial.

Luzia: Um ponto viciado.

Sérgio: É mais que viciado, é "oficial". É "oficial" por quê? Se tornou oficial, porque as pessoas sabem que colocam ali e a Subprefeitura manda um caminhão por semana para retirar. E porque?: "Ah, mas puxa, a Subprefeitura está errando?" Não. Ela não pode deixar uma área que está do lado de um córrego gerar montanhas de entulho e de lixo.

Mas, por outro lado, é de difícil gestão. Porque nós temos de um lado, o parque; para dentro do parque não há deposição. Mas, querendo ou não, por um lado o parque. O córrego, que é de gestão da Sabesp. Um trecho de rua nessa área que é de gestão da subprefeitura local. E mais um outro trecho que tem um duto por baixo que é da gestão da Transpetro. Quer dizer, então, ali, é uma gestão bastante difícil, digamos assim. Ela fica confusa, pelo menos. Um pequeno trecho, uma pequena área com metros de cada gestão. Então, é complicado. Há um projeto da Transpetro de reurbanizar aquilo ali, de tornar pelo menos uma área de lazer. Que nós já temos um ecoponto do lado, ainda não inaugurado: em vias de inauguração. Nós temos um ecoponto muito próximo do parque. A gente espera que isso diminua com os descartes. Eliminar acho difícil. Se você for lá fotografar, você vai ver que o negócio é feio. Mas que minimize.

E também tem o projeto do Córrego Limpo. Que, uma vez, conversando com engenheiros da Sabesp que visitaram a área, aquele córrego do Limoeiro vai ser contemplado com esse projeto Córrego Limpo. Então, a expectativa é que haja uma limpeza do córrego, deixar ele mais retilíneo, aberto. Com a eliminação do esgoto que é depositado, o desvio desse esgoto para uma estação de tratamento. Isso tudo venha a beneficiar. E, aí, querendo ou não, tem uma ligação muito forte com o parque: daí, melhora toda a situação.

Luzia: Foi apresentada, recentemente, pelo Prefeito, a operação urbana do rio Jacu. Que eu saiba inclui todo o trecho da Jacu-Pêssego. Você sabe se essa operação urbana está contemplando alguma intervenção, também, no parque,? 
Requalificação dos Aterros Desativados (Brownfields) no Município de São Paulo: Parques (Greenfields) Raposo

Tavares e Jardim Primavera

Luzia Helena dos Santos Barros

Sérgio: A gente tem a área cercada do parque e a área não cercada, que é a área limítrofe ao córrego Jacu-Pêssego. Ainda não chegou nada na área do Primavera. O que existiu: no ano passado, nós tivemos um plantio de muitas mudas lá; acho que quase 150 mudas à margem da JacuPêssego. Entre o córrego e a avenida. Mas só, por hora. Nenhuma outra intervenção tivemos ali. Pelo menos no último ano, não houve nenhuma intervenção.

Luzia: Considerando a possibilidade de você se tornar o administrador do Primavera, como você está vendo essa sua experiência de administrar o parque Vila Sílvia? Está gostando dessa experiência?

Sérgio: Eu estou gostando muito, na verdade. Eu estou gostando muito de lidar com a situação do parque. Desde quando eu era professor, eu gostava de lidar com as pessoas, com a população. Mas o Primavera não vai deixar de ser uma experiência nova. É lógico que a bagagem... Porque quando a gente entra na Secretaria, a gente conhece toda a parte burocrática, a quem recorrer quando surge determinado problema. De contaminação, o Decont; de obras, o Depave-1. Essa experiência vai ser levada para o Primavera. A experiência com o próprio frequentador do parque, com o conselho gestor. Tudo isso... Que bom que eu vim para o Vila Sílvia antes. Nesse ponto foi muito bom, porque aqui está sendo a minha escola. Eu já vou levar tudo isso meio que na minha cabeça, pronto para implantar lá. Naturalmente, adaptando à realidade local, que muda.

Agora, o fato de administrar um antigo aterro, um parque remanescente de aterro é, para mim, uma experiência nova. E, aí sim, eu vou ter que recorrer bastante à experiência do administrador do Raposo. E, também, pesquisar. Porque como isso não é uma situação típica, eu vou ter que pesquisar bastante, vou ter que buscar soluções de situações que, eu tenho certeza, só vão acontecer no Primavera.

Luzia: Outros parques estão previstos para serem implantados sobre antigos aterros. Você provavelmente vai se tornar uma referência na administração desse tipo de parque. O que você acha disso?

Sérgio: Espero poder ajudar e espero ser ajudado. Porque, eu acho que no futuro, se houver mais parques, como você mesma está dizendo, eu até gostaria muito de abrir um grupo de trabalho só de parques com origem em antigos aterros. Acho que um grupo de trabalho seria bem-bacana para a discussão dos problemas, busca de soluções. Eu acho que, uma vez implantado, eu teria o maior prazer do mundo de encabeçar esse grupo.

Luzia: Um tempo atrás participei de um grupo que começou a rediscutir o sistema de áreas verdes do município. A discussão incluía a questão da classificação dos parques e a proposição de sistema municipal, tal como o SNUC. Você sabe se isso está acontecendo e qual a situação atual?

Sérgio: Não. Eu não tenho acesso a nada relacionado a isso. Infelizmente não.

Luzia: Bem, a unidade que você tem mais contato é a Subprefeitura?

Sérgio: É, além dos parques vizinhos, o Ermelino Matarazzo, que é um dos mais próximos. Não tenho contato, ainda, com o Vila Jacuí. Não posso dizer que tenho, pois foi inaugurado há poucas 
Requalificação dos Aterros Desativados (Brownfields) no Município de São Paulo: Parques (Greenfields) Raposo

Tavares e Jardim Primavera

Luzia Helena dos Santos Barros

semanas e ainda não tem administrador. Possivelmente terei uma relação grande com esse parque. Eu tenho um contato direto com a administradora do Parque Linear do Tiquatira, que era da minha administração e, agora, está com outra administradora. E ela esta lotada aqui no Vila Sílvia.

Luzia: Os parques lineares não têm uma sede, não têm uma administração?

Sérgio: É, via de regra não. Nós temos o linear Guaratiba que tem. O Guaratiba, perto da estação de Guaianazes, inclusive, é cercado. É um parque linear cercado, que é uma coisa atípica. Mas os outros não têm. Mas o Tiquatira é um dos maiores lineares que temos no município e um dos mais problemáticos em função do grande uso. Então, nós temos uma administradora só para esse parque. Geralmente, um administrador administra um parque tradicional e um linear. No caso do Tiquatira, não dá, o administrador tem que se dedicar só ao Tiquatira, porque a demanda, ali, é grande. Ele é bem diferente. Mas lá não tem uma administração. Assim, como aqui é o parque mais próximo, a administradora fica, aqui, conosco. Ela tem uma saleta só dela e fica administrando daqui.

Os parques mais próximos são o Ermelino Matarazzo, o Vila Sílvia, que é esse que eu estou, o linear do Tiquatira, com a sua administradora, o linear do Itaim, que tem o mesmo administrador do Ermelino Matarazzo. Por proximidade, são esses. E do Raul Seixas.

Devido a reunião mensal de administradores em que se troca experiências, tenho contato também com o administrador do Santa Amélia, o Jorge. Além disso, com o administrador do Vila do Rodeio, na Cidade Tiradentes, com a Luciana do Parque Chácara das Flores, com o Parque Lajeado e o Parque Guaratiba, que estão com dois administradores novos. Em função de eu ter administrado esses dois parques antes deles chegarem, também. Então, esses são os maiores contatos que eu tenho. E a gente troca experiência. Então, quer dizer, além da Subprefeitura que nos dá apoio, também tem o apoio dos administradores que se ajudam. Isso é muito legal na Secretaria.

Luzia: Então, a administração dos parques é subdividida por regiões?

Sérgio: Sim. A Secretaria tem, em função desse plano de aumentar o número de parques, o Projeto 100 Parques. A Secretaria cresceu e, naturalmente, começou a ter uma dificuldade de gestão. E, aí, criou-se núcleos de gestão descentralizada. Os chamados NGD's. Na Região Norte, na Leste, na Oeste. Na Leste, nós temos três: Leste 1, Leste 2 e Leste 3. O Vila Sílvia faz parte da Leste 2 e o Primavera faz parte da Leste 1. E, agora, tem Leste 3, também. Que é para melhor gestão dessas áreas, principalmente em relação à educação ambiental.

Luzia: Como houve uma mudança recente na estrutura da SVMA, os parques e seus administradores estão ligados aos NGD's?

Sérgio: Nós somos ligados aos NGD's, sim. Determinadas coisas a gente busca nos NGD's. Como eu te disse: em relação à educação ambiental e discussão de problemas, o NGD é que faz essas reuniões que eu te falei, mensais. Então, os administradores da região do NGD Leste 2, que é o Vila Sílvia, por exemplo, se reúnem uma vez por mês em tal dia, para discutir os problemas, buscar as soluções. É um grupo de trabalho. 
Requalificação dos Aterros Desativados (Brownfields) no Município de São Paulo: Parques (Greenfields) Raposo

Tavares e Jardim Primavera

Luzia Helena dos Santos Barros

Luzia: Bem, achei que vocês estavam ligados apenas ao Depave-5. E os NGD's estão ligados a qual Departamento? Ao de Planejamento?

Sérgio: Não, ao Depave. E tem diretores. Cada NGD tem um Coordenador. Mas esses NGD's são muito novos, tem cerca de uns dois anos, no máximo. Estão passando por um processo de maturação, ainda. Tem NGD que acabou de ter uma sede, o NGD 2. Eu não sei se é o Leste 1.

Luzia: E onde que é a sede do NGD 1, você sabe?

Sérgio: O Leste 1 fica no casarão do parque do Carmo, ao qual estará ligado o parque Primavera. O Leste 2 está no CERET e o 3 eu não sei. Mas com o desenvolvimento desses núcleos, vai ajudar muito a nossa atuação. Porque, querendo ou não, você imagina o Parque da Cidade Tiradentes, o Parque Vila do Rodeio, a dificuldade da comunicação. Porque, às vezes, você tem a comunicação, comunicação é telefone, certo? Mas, às vezes, insumos, materiais, documentos, processos. É diferente, o administrador do Vila do Rodeio tem um contato diferente que a administradora da Aclimação tem, que fica ao lado da Secretaria. Então, tem parque muito próximo à Secretaria, tem parque que é infinitamente distante: o Parque das Águas, o Guarapiranga. É muito longe. Então, é necessário núcleos descentralizados mais próximos dos parques, com técnicos. Com agrônomos, com educadores ambientais, que possam dar essa assessoria técnica. Isso é extremamente importante. Mas tudo está sendo um processo de maturação. Demora um tempo, mas a idéia muito bacana.

Luzia: Você consegue fazer a interface da sua experiência de trabalho com o seu mestrado?

Sérgio: Consigo. O meu mestrado é voltado aos impactos do turismo em relação ao espaço litorâneo de Bertioga. Só que, dentro dessa pesquisa, eu estou investigando as políticas públicas de meio ambiente do município. Que lá tem suas peculiaridades, porque, por ser uma área litorânea, mas que, também, tem todos os seus problemas; invasão de áreas protegidas, legislação, plano diretor. Tudo isso eu encontro, também, aqui na Zona Leste, na periferia. Eu encontro alguém querendo ocupar uma área de parque, alguém construindo, por exemplo, perto do córrego do Limoeiro. Eu sei que no plano diretor você tem uma destinação do uso daquela área que, às vezes, não está sendo obedecida em função de uma invasão. Eu tenho as ações do poder público, também, incididas sobre essa ocupação. Coisas que eu encontro em Bertioga também. Então, quer dizer, a experiência acadêmica também é importante. Mas eu diria que a prática é fundamental. Então, para mim, uma coisa está casando com a outra, apesar de serem lugares totalmente diferentes.

As ações que eu pesquiso são as ações do turismo. Quer dizer, o turismo tem gerado um aumento de população, uma ocupação do município de Bertioga, muito grande. E, aí, você tem todo o problema ambiental derivado disso. No caso do Primavera, não, são ocupações residenciais, com fim residencial, mas que podem também trazer problemas.

Luzia: Tudo isso faz parte da política pública de meio ambiente. Tanto faz aqui quanto noutro município. 
Requalificação dos Aterros Desativados (Brownfields) no Município de São Paulo: Parques (Greenfields) Raposo

Tavares e Jardim Primavera

Luzia Helena dos Santos Barros

Sérgio: É, porque quando a gente fala de meio ambiente, eles falam assim: "-Ah, a política pública de meio ambiente o que é? É a lei ambiental?" Não. Então, naturalmente, é muito complexo. Assim como, também, as políticas de saúde são complexas. Mas a de meio ambiente é tão complexa, porque você envolve habitação; hoje, você envolve esportes e lazer, porque isso acontece dentro dos parques, que são áreas da Secretaria. Então, você tem saneamento básico envolvido. Você tem problema de segurança pública, porque as áreas que nós temos o meio ambiente. Então, as áreas florestadas, por exemplo, podem ser áreas escuras, com pouca segurança. Então, hoje, tratar de meio ambiente é tratar de uma questão não só ambiental mais socioambiental. E, aí, se torna amplamente complexo.

Luzia: O que se verifica é que existem ações que são muito parecidas, tanto num lugar como noutro, tal como você vem observando em São Paulo e em Bertioga.

Sérgio: Naturalmente que uma ocupação irregular vai ter deposição de esgoto, também, nos córregos, nos canais, que vão desaguar na praia. Aqui, vão desaguar no Jacu-Pêssego; lá na praia. Então, mudam algumas coisas, mas as origens, às vezes, são as mesmas.

Luzia: Bem, Sérgio, obrigado. Acho que consegui abordar todos os aspectos que pretendia na entrevista. 
Requalificação dos Aterros Desativados (Brownfields) no Município de São Paulo: Parques (Greenfields) Raposo Tavares e Jardim Primavera

Luzia Helena dos Santos Barros

\section{DECLARAÇÃO}

Eu, Sérgio Roberto Nunes, C.I. $n^{\circ} 29.449 .046-2$ - SSP-SP, administrador do Parque Municipal Vila Sílvia, vinculado à Secretaria do Verde e Meio Ambiente - SVMA, da Prefeitura do Município de São Paulo, de acordo com autorização dada à pesquisadora Luzia Helena dos Santos Barros, da Faculdade de Arquitetura e Urbanismo da Universidade de São Paulo - FAU-USP, publicada no Diário Oficial da Cidade de São Paulo, no dia 01 de junho de 2010, pg. 24, declaro que autorizo a utilização do conteúdo, revisado por mim, da entrevista, realizada em 11 de maio deste ano, sobre o futuro Parque Jardim Primavera na sua pesquisa de doutorado sobre a "Requalificação de áreas degradadas por contaminação no Município de São Paulo".

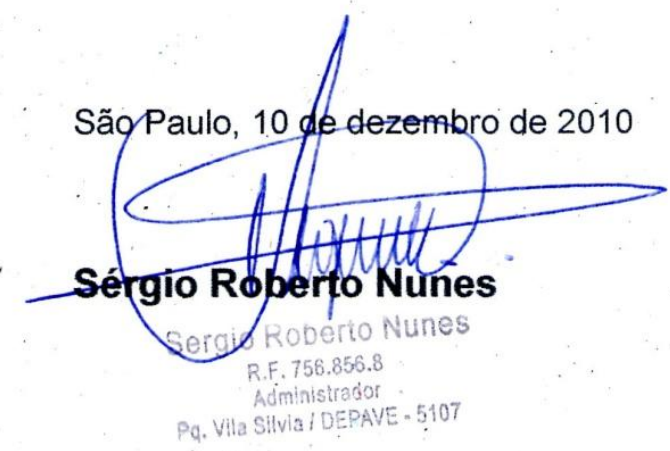




\section{APÊNDICE G - entrevista com SYLVIO SENA, morador do bairro Pedro Nunes, Parque} Jardim Primavera, 6 de maio de 2010

Luzia: Sylvio, considerando que você mora ao lado do antigo aterro Jacuí, futuro parque Primavera, e é editor do jornal do bairro, gostaria de ouvir um pouco dessa história.

Sylvio: Há 12 anos que eu faço esse jornal. Toda a história do Parque Primavera está nesse jornal. E na minha mente. Na minha vivência.

Luzia: Você mora aqui, nesse lugar, há quantos anos?

Sylvio: Desde 1979. Quando começou o lixo. Quando minha filha nasceu, ela engoliu, cheirou, sentiu, sofreu toda a história do aterro sanitário.

Luzia: No guia de ruas existem ruas traçadas na área do aterro. Naquela época, a área foi vendida como um loteamento, englobando o aterro? Você lembra disso?.

Sylvio: Não, não foi vendido. Porque, antes, aqui era um abismo. Era um abismo onde havia um porto de areia. Era um abismo tão profundo que você ficava com medo de chegar na beirada, assim, de tão fundo que era. Aí, em 1979 entrou o primeiro caminhão de lixo. Só que era lixão mesmo. Lixão propriamente dito: bruto. Era só jogando lixo. Foi quando as comunidades se juntaram e pediram o fechamento. Deitamos na rua e tudo, não deixamos os caminhões entrar. Foi um 'auê' danado. Uma mobilização muito grande, na época. Aí, se transformou em aterro. Até então não era aterro, era o lugar que a prefeitura jogava lixo. Aí, contrataram uma empresa, a Heleno \& Fonseca. Contrataram a empresa Heleno \& Fonseca e começaram a fazer os drenos, com aproximadamente um metro de diâmetro, cerca de 15 bocas. Eram 24 horas por dia com chama, aquele fogo, do gás do lixo: metano. A noite parecia dia, aqui, devido a todas aquelas bocas acesas. Parecia o próprio inferno, mesmo, ali. Volta e meia havia umas explosões de alguma bolha, a gente acordava na madrugada, todos assustados. Enfim, de 1979 a 1988. No dia 31 de agosto de 1988 entrou o último caminhão de lixo, pois fizemos a mobilização. Só que, antes, veio a Globo, o SBT, vieram todas as emissoras de televisão que a gente conseguiu mobilizar. Porque os gases começaram a explodir dentro das casas. Tinha infiltração por debaixo do solo. Inclusive, um senhor foi fumar um cigarro sentado na privada, acendeu o fósforo e jogou o palito no ralo. O ralo: 'pá', estourou para cima, porque o gás estava saindo no ralo do banheiro.

Luzia: E onde ele morava, em que rua, você se lembra?

Sylvio: Na Mimo de Vênus, divisa com o aterro. Praticamente só separado pelo asfalto. E, na Rua Grinalda de Noiva, tinha um poço. Tinha não, tem, que até hoje sai gás lá. Nós fomos lá, na época. Inclusive foi na campanha do PT, que a Erundina ganhou. E a Erundina foi nesse poço e o homem, o dono da casa, como estava escuro, acendeu um palito e o gás que subia do poço chamuscou o rosto dele. Aí, com essa grande mobilização e com essa explosão que estava acontecendo, a gente conseguiu mobilizar muita gente. Fomos até a Cetesb. Na época, era o Rogê Ferreira o presidente e 
Requalificação dos Aterros Desativados (Brownfields) no Município de São Paulo: Parques (Greenfields) Raposo

Tavares e Jardim Primavera

Luzia Helena dos Santos Barros

avisamos que uma hora ia voar tudo isso aqui pelos ares. Foi quando, no dia 31 de agosto de 1988, entrou o último caminhão de lixo. Conseguimos desativar o aterro.

Aí, veio o governo Maluf, plantou 5.000 mudas de eucalipto. De lá para cá a gente está tentando transformar isso em um parque com muita briga, com muita luta. Aí, fizeram a avaliação ambiental. Os técnicos fizeram a sondagem, de 2006 para cá. Quase $\mathrm{R} \$ 500$ mil esse trabalho que a prefeitura fez com o Eduardo Jorge. Fizeram a avaliação. Ainda tem uma bolha de gás, que está atrapalhando a própria implantação do parque. E a gente vem brigando, brigando. Quando foi agora, foi feita a licitação, vai sair a licitação dia 22. Acho que estourou agora: dia 22 de abril. A licitação da extração dessa bolha.

A licitação foi adiada porque eles têm um valor de $R \$ 200$ mil para a liberação da extração dessa bolha. Mas quando eles abriram o primeiro envelope, a primeira empresa pediu mais de $R \$ 1$ milhão para extrair a bolha. Aí, eles encerraram a licitação para poder fazer uma melhor avaliação. Como essa empresa fugiu, assim, totalmente do que estava previsto pela Secretaria, eles adiaram, cancelaram essa licitação, para fazer uma avaliação melhor para ver se, realmente, essa empresa não extrapolou totalmente a expectativa da própria Secretaria.

Então, agora, eles vão fazer uma nova avaliação para poder fazer outra licitação. Se essa empresa que pediu mais de $\mathrm{R} \$ 1$ milhão estiver correta na avaliação que eles fizeram para poder fazer essa extração... Porque deve ser um maquinário sofisticado ou coisa parecida. Bastante complexo. Então, agora estamos aguardando.

Luzia: Sylvio, entendo que a iniciativa para implantar um parque sobre esse antigo aterro foi da vizinhança. Por que, exatamente, vocês querem que seja implantado um parque? Bem, hoje, ele formalmente já existe, porque foi criado por lei.

Sylvio: Já existe em decreto. Foi criado por lei. Agora, por que a gente quer um parque? Como aí não pode sofrer nenhuma edificação porque o solo não permite, então, a única possibilidade da gente usufruir dessa área é com um parque. E ainda tem outra coisa: a lei da compensação. Como a prefeitura usufruiu nove anos trazendo todo o lixo da cidade de São Paulo para cá, agora a comunidade quer uma compensação do sofrimento que teve durante todo esse tempo. Então, que tipo de compensação? A implantação de um parque. Porque em outros países, eu não sei exatamente qual, já houve essa experiência, já implantaram um parque em cima de um aterro sanitário.

Agora, obviamente que é um parque específico. Específico em que sentido? Como a própria terra tem contaminação, mas como já foi avaliado, como eu já tinha dito antes, por Decont... Decont é Departamento de Controle Ambiental. Você trabalhou lá, talvez você saiba disso. O que acontece? A contaminação que tem no solo é de cobre, zinco. Enfim, vários metais. Não causa, assim, um dano para a saúde. E, também, como foi já colocado no projeto, eles estariam impermeabilizando praticamente toda a área do parque. Então, iriam ser feitas quadras poliesportivas cimentadas, gramados, quiosques. Eles iriam fazer uma impermeabilização quase que completa. Pistas de ciclismo, pista de caminhada: tudo pavimentado. Que, ao mesmo tempo, estaria impermeabilizando o solo, para até as crianças não terem contato com a terra. Esse é o projeto. 
Requalificação dos Aterros Desativados (Brownfields) no Município de São Paulo: Parques (Greenfields) Raposo

Tavares e Jardim Primavera

Luzia Helena dos Santos Barros

Esse projeto está muito na geladeira, sabe? Está muito esquecido. E quando a gente chama para uma conversa, eles vêm e prometem. Eles prometeram no dia 05 de dezembro. Nós tivemos uma reunião em novembro. Eles prometeram que até o dia cinco de novembro sairia uma nova licitação da implantação da primeira fase do Parque Primavera. Qual seria essa implantação do Parque Primavera? São $14.700 \mathrm{~m}^{2}$, que não sofreram aterro. É um solo limpo. Não tem contaminação nenhuma. Fizeram um projeto, ano retrasado. Fizeram um projeto, liberaram a verba de $R \$ 1,2$ milhão. A empresa ganhou: a Tetra. A empresa, não esqueço o nominho dela. Ela é Tetra: nunca vai ser penta, porque ela faliu. Começou a fazer o serviço de terraplenagem e faliu.

Luzia: Mas a área em que a empresa trabalhou é muito pequena, não?

Sylvio: Ela não chegou a fazer praticamente nada e aí, faliu. Eles não chamaram a segunda colocada, por motivos jurídicos. Nem a explicação correta a gente tem. Mesmo que eles dêem a explicação, a gente não está acreditando muito mais neles. Então, o que acontece? Esse dinheiro voltou para a Secretaria e tudo ficou paralisado mais de um ano. Já vai fazer dois anos que a obra está paralisada. Aí, quando foi em novembro, nós chamamos a Secretaria para uma conversa. Eles disseram que até o dia 05 de dezembro, estariam fazendo uma nova licitação. 05 de dezembro já passou, ontem foi dia cinco de maio. Então, são cinco meses além do dia que eles prometeram. Quer dizer, eles não cumpriram com a promessa de até 05 de dezembro. E já faz cinco meses que passou da promessa deles.

Luzia: E nesse intervalo vocês tiveram contato, de novo, com a Secretaria?

Sylvio: Nós não conversamos mais com a Secretaria, porque, para mim, fica difícil. São 31 anos que eu luto por isso, desde setembro de 1979. Agora, em setembro, vai fazer 31 anos que eu luto por isso. Minha filha vai fazer 31 anos também. E quando eu chamo a comunidade, que eu quero mobilizar a comunidade, a comunidade não acredita mais: já desacreditou dos políticos. Já desacreditou de tudo. Porque, há 31 anos lutando e há 31 anos eles prometendo... Quando eu falo: “Gente, dessa vez vai acontecer.", “-Ah, Sylvio, para com isso", "Você é um sonhador." O meu apelido aqui na comunidade, agora, é sonhador. Porque todos aqueles que estiveram no início da luta, em 1979, uns morreram, outros venderam a casa porque se desgostaram e outros desistiram da luta. O único que continua desde 1979 sou eu, que nunca desisti desse sonho.

Luzia: Você tem uma associação formal criada? Como se chama?

Sylvio: A associação é a Associação Camélias, porque o bairro é o Jardim Camélias. Depois do córrego já é o Jardim Camélias. E aqui é o Jardim Pedro José Nunes, onde eu moro. E a gente continua com a luta, aqui, na Associação Camélias.

Luzia: Existem outras associações envolvidas, também?

Sylvio: Tem outras associações aqui da Pedro Nunes, também. E eu tenho o jornal, que quando o Eduardo fez esse estudo, esse laudo, foi quase $\mathrm{R} \$ 500$ mil. Em seguida, ele fez o calçamento de todo parque. E, em seguida, colocou o gradeamento. De 1979 até 2008, nunca havia sido cercado. A área 
Requalificação dos Aterros Desativados (Brownfields) no Município de São Paulo: Parques (Greenfields) Raposo

Tavares e Jardim Primavera

Luzia Helena dos Santos Barros

era aberta, largada. Agora, hoje, graças a Deus, tem o gradeamento, tem um calçadão. É um quilômetro de calçada, um quilômetro de grades. Então, até aí, fizeram somente isso. E estamos aqui. Agora, eu vou, novamente, mobilizar pelo menos um pouco da comunidade - espero - e nós vamos voltar batendo, de novo, para ver se a gente consegue fazer com que eles implantem esse parque o mais rápido possível. Ou, ao menos, que eles façam essa fase um, da parte não contaminada, para a qual estava liberado o dinheiro. Eles não estão ligando muito, não. Eles não estão preocupados com a comunidade, não, sabe?

Luzia: Atualmente, ainda há escape de gás para alguma casa? Há registros recentes?

Sylvio: Não, escape de gás que ainda possa ter é no poço na rua Grinalda de Noiva. Ele continua aberto, entendeu? E esse gás que vem de lá, provavelmente, é dessa bolha que tem lá no centro do aterro.

Luzia: Você tem idéia de quantas pessoas moram aqui no bairro e seriam beneficiadas com o parque?

Sylvio: Só aqui na Pedro Nunes são 4.200 residências. Eu tenho esse número porque eu distribuo exatamente 4.200exemplares do jornal. Então, eu te dou o número exato de quantas casas tem: tem 4.200 casas só dentro do Pedro Nunes. Tem o Conjunto Garagem, que são 2.020 apartamentos, pertence ao Pedro Nunes também. Então, só aí são 6.250 residências, só na Pedro Nunes. Aí, tem o Jardim das Camélias, que deve ter em torno de 4.000 ou mais redidências. Já seriam 10.000. Tem a Vila Jacuí, depois da Av. Jacu-Pêssego, que deve ter, aproximadamente, também, esse percentual de moradia, então 14.000. Aí, tem o Parque Cruzeiro. Eu estou falando só do entorno, são 20.000 residências, que multiplicando por quatro, dá 80.000 pessoas diretamente beneficiadas.

Luzia: Você acha que de alguma forma a Av. Jacu-Pêssego dificulta o acesso ao parque? É uma via bastante larga e movimentada. Existe alguma passagem fácil para o pessoal?

Sylvio: O projeto é de uma passarela. Entre a Jacu-Pêssego e o parque, tem um grande gramado. Então, o que eles fariam? A minha sugestão, que eu já coloquei para eles, é que entre a JacuPêssego e o parque, nesse espaço do gramado, poderia ser construído um estacionamento bem grande. Porque assim que o parque for implantado, vai ter que ter um estacionamento, porque vai ter carro que vai vir de tudo quanto é lugar. Não vão ser só esses 80.000 . Os 80.000 que eu estou falando são os beneficiados diretos. Agora, tem os beneficiados indiretos. Que, por exemplo, aqui no parque vai ter um grupo, por exemplo o Sensação, vai vir tocar aí. Então, vai vir gente de tudo quanto é lado. Então, teria que ter esse grande estacionamento. A minha sugestão é essa aproveitar a faixa entre a Jacu-Pêssego e o parque.

E aqui seria, futuramente, na frente da minha casa, um terminal de ônibus. Porque teria que ter uns pontos finais bem-próximos do parque, também. Eu tenho um monte de sonhos e planos. $\mathrm{E}$ sei lá se eu vou conseguir. Porque há 31 anos, quando tudo começou, eu tinha 27 anos. Eu já estou com 58. Já, já, estou com 60 , morro e não vejo esse parque sair. 
Requalificação dos Aterros Desativados (Brownfields) no Município de São Paulo: Parques (Greenfields) Raposo

Tavares e Jardim Primavera

Luzia Helena dos Santos Barros

Luzia: Espero que você consiga ver o parque implantado.

Sylvio: Eu sonho. Tem hora que eu falo: “-Meu Deus, será que depois de tanta luta, 31 anos de luta, eu vou conseguir usufruir pelo menos um mês?

Luzia: Você anteriormente já havia trabalhado na Prefeitura? Ou agora é a sua primeira experiência? E agora qual a sua visão do outro lado, de dentro da administração?

Sylvio: Do outro lado. O que eu vejo dentro da administração, como funcionário, é a vontade política: falta muita vontade política. Porque, para eles implantarem esse parque, isso é café pequeno. Para quem faz um CEU no valor de $R \$ 21$ milhões, fazer um parque no valor de $R \$ 5$ milhões é muito barato. Falta vontade política para implantar esse parque: é só o que falta. Vontade política e vergonha na cara. Porque tem $30 \mathrm{CEUs.} \mathrm{Tudo} \mathrm{bem,} \mathrm{cada} \mathrm{um} \mathrm{tem} \mathrm{a} \mathrm{sua} \mathrm{utilidade,} \mathrm{obviamente.} \mathrm{O}$ CEU tem as suas funções diferentes, suas atividades diferentes. O CEU serve diretamente para educação: educação e cultura. Agora, veja bem: eu tenho que sair daqui para ir no Parque do Carmo para levar um filho, um neto para empinar uma pipa. Eu tenho que pegar o meu filho e levar aqui. Porque as crianças da periferia, o lazer deles são os fios, o risco de levar um choque e morrer eletrocutado. Não tem área de lazer. E, aqui, temos um espaço de $122.000 \mathrm{~m}^{2}$ ao léu, "abandonado". Cento e vinte e dois mil metros quadrados de mato, porque nem o mato eles cortam.

Eu falo, diretamente, da Subprefeitura onde eu trabalho. Na gestão do Subprefeito Décio Ventura, ele pediu para que limpasse o parque todinho. Passou uma máquina niveladora e fez umas pistas de caminhada. O povo daqui ficou eternamente grato a esse subprefeito. As pessoas da terceira idade, que eu costumo chamar da melhor idade, de manhã, 06 horas, estavam fazendo caminhada dentro do parque, respirando aquele cheiro de eucalipto. Porque tem 5.000 pés de eucalipto dentro desse parque, as pessoas podiam estar respirando esse pela manhã, fazendo caminhada. Como já foi feito.

Luzia: Havia usuários, então, mesmo sem o parque estar implantado?

Sylvio: Mesmo sem estar implantado o parque, existia essa atividade, você entendeu? Agora, o que acontece? Tem um matagal aí dentro: os nóias... Porque é o seguinte: o que a prefeitura está fazendo? A prefeitura está dando lazer e entretenimento para os nóias. Os nóias entram no meio do mato para fumar seu cigarrinho, para cheirar as suas drogas. $E$ as pessoas de bem não têm direito. $E$ as pessoas do mal, uma minoria - graças a Deus que é uma minoria muito minoria - ficam lá. Fazem sexo, usam droga. Estupro: teve estupro já, que está registrado o $\mathrm{BO}$. Na 63 tem o registro do estupro. Então, isso, para mim, é falta de vontade política e vergonha na cara.

Luzia: Com o cercamento do parque houve mudança na freqüência dos usuários?

Sylvio: Estou falando do parque cercado. Eu não estou falando de antes, não. Eu estou de agora, de hoje. Porque é o seguinte, eles forçaram a grade e abriram um vão onde todo mundo passa. $E$ mesmo pelo portão aberto, entra também. Porque os vigias não proíbem ninguém de entrar, certo? Nem pode. Então, o que acontece? Eles não sabem quem está entrando, entendeu? A pessoa entra normal, chega lá no meio, começa a usar a sua droga e tal. Ou a pessoa, curiosa, uma senhora, um 
Requalificação dos Aterros Desativados (Brownfields) no Município de São Paulo: Parques (Greenfields) Raposo

Tavares e Jardim Primavera

Luzia Helena dos Santos Barros

senhor que esteja com o filho, que queira passear mesmo com o mato, nem entra. Quem tem direito é quem usa para o mal.

Luzia: A área antigamente, como você disse, era usada mais pelo pessoal de melhor idade. A freqüência era maior?

Sylvio: Não, era usada por todos. De manhã havia umas 200 pessoas fazendo caminhada: entre idosos, adultos e jovens. De manhã, nossa! Você ia ali 07 horas, nossa, era gente que não acabava mais. A coisa mais linda do mundo.

Luzia: Existem muitas escolas aqui no entorno?

Sylvio: Só aqui dentro da Pedro Nunes tem três. São duas escolas municipais e uma estadual. Escola de primeiro e segundo grau. E creches são quatro. Tem três EMEls. Pré: três. Olha, graças a Deus, a única coisa que tem de bom nesse bairro é que quando foi feito o loteamento, a prefeitura pegou bastante espaço para fazer equipamento público. Não estou falando da recente, não: estou falando das antigas que deixaram pronto. Nós tínhamos, já, uma escola municipal, que é a Pedro Aleixo. E, em 1987, foi inaugurada a escola estadual. De lá para cá, só fizeram uma EMEl, agora, inaugurada na gestão do Kassab; um EMEI. De1987 para cá só foi feita essa EMEI. Quer dizer, o bairro ficou parado. Aí, veio a gestão Kassab, fez a praça aqui, fez a praça ali: tem duas praças. Enfim, cercou o parque, fez o calçamento do parque. Então, teve um avançozinho. Mas de 1987 até 2008, ficou 21 anos esse bairro sem uma obra, sem nada.

Luzia: As escolas utilizavam a área do aterro para alguma atividade?

Sylvio: Não. Eu estou querendo juntar a escola para a gente conseguir dar um abraço simbólico nesse parque e chamar a imprensa.

Outro fato que aconteceu foi que no início da década de 90 vieram jogar aí BHC de uma indústria. Eram cerca de dez caminhões todos enfileirados, aí, para entrar. E eles puseram aquele plástico, fizeram uma vala bem imensa. Aí, todo mundo: “-Para que essa vala, meu?” Aí, graças a Deus, uma pessoa da prefeitura me ligou dizendo o que estava acontecendo, você entendeu? Ninguém informou nada. lam, simplesmente, clandestinamente, sem falar com ninguém. Algum esperto, porque sempre tem gente que leva vantagem. Aí, uma pessoa da prefeitura me ligou e falou assim: "-Sylvio, aquela vala é para jogar os venenos de BHC." Aí, mobilizamos a comunidade inteira, invadimos esse parque aí e fizemos os caminhões recolherem o plástico do buraco, lá, e tudo. E os caminhões voltaram todos para trás. Aí, vieram as máquinas, fecharam os buracos e esse BHC não foi depositado aí.

Luzia: Mais recentemente, com a Secretaria mais envolvida com a implantação do projeto do parque, depois da lei que o criou houve participação direta da comunidade, na discussão do projeto? Houve essa interação da comunidade com os técnicos da Secretaria do Verde? 
Requalificação dos Aterros Desativados (Brownfields) no Município de São Paulo: Parques (Greenfields) Raposo Tavares e Jardim Primavera

Luzia Helena dos Santos Barros

Sylvio: Houve. Nós tivemos uma comissão paritária onde foi decidido que seria implantado, lá dentro, quiosques com churrasqueira, pista de ciclismo, pista de caminhada, quadras poliesportivas. Enfim, vários equipamentos de diversão e entretenimento. Aí, quando foi feito o projeto, publicado no Diário Oficial e tudo, veio constando todos esses equipamentos.

Luzia: Então, o projeto está adequado aos desejos da comunidade, vamos dizer assim? Conseguiu responder a solicitação de vocês?

Sylvio: Isso. Exatamente. Inclusive, até ultimamente, estava sendo discutido ainda, porque com o tempo as coisas mudam. Então, aí, nós tivemos outra discussão. Já, várias outras discussões do que a gente gostaria que tivesse e tal. Então, quanto a isso, não tem problema nenhum. Na teoria, está tudo bonito, está tudo lindo e maravilhoso. Eu já me vi até brincando lá dentro, na teoria. Eu sou um sonhador. Muito. Só falta colocar em prática.

Luzia: A Subprefeitura teve participação direta, também, na elaboração do projeto? Como é que é essa interação?

Sylvio: Não, a Subprefeitura apoia. Quem manda, quem determina, é a Secretaria do Verde. Então, o que acontece? Na última conversa que nós tivemos, em reunião com a Secretaria e a própria Subprefeitura também, ficou definido que a subprefeitura estaria fazendo a limpeza do parque: o desmatamento e tudo mais. Se você passar lá, agora, você pode dar uma olhada lá: está um matagal. $\mathrm{O}$ que acontece com esse matagal? Como o parque circunda dois córregos - um é o córrego do Limoeiro e o outro é o Jacuí - então, o que acontece? Ratazana, escorpião, aranha, você entendeu? Todos esses tipos de bichos estão invadindo as moradias próximas da divisa. A gente fala, a gente briga, a gente vai à luta e tudo mais. Eu, até, como funcionário, agora, da casa, o que eu faço? Eu instruo a comunidade. Eu oriento a comunidade qual o tipo de manifestação, qual o tipo de reivindicação que deve ser feito, você entendeu?

Luzia: Próximo daqui existe unidade de saúde?

Sylvio: Temos o posto de saúde colado ao parque, na R. Mimo de Vênus. O endereço oficial do posto de saúde é uma rua que não tem expressão nenhuma, mas ela faz esquina com a Mimo de Vênus.

Luzia: Bem, Sylvio, você se lembra de mais detalhes sobre a sua vivência com o aterro?

Sylvio: Eu vivo esse parque há 31 anos. Quando eu comprei aqui, esse lote, foi em setembro de 1979. O corretor deu um nó na minha cabeça e da minha cunhada, porque meu irmão comprou aqui ao lado vizinho de muro, mas ele vendeu, foi embora. Ele desistiu. É um dos que desistiu. Começou a luta, mas desistiu. Ele falou para mim que isso aí nunca ia sair. O corretor nos pegou lá em cima, veio por lá, quando chegou aqui, eu comprei. Ele não passou por ali, onde era o abismo. E eu não conhecia aqui. Eu morava aqui perto, mas eu não sabia que existia esse abismo. Porque naquele tempo não tinha esse acesso tão fácil. E aqui não tinha rua. Aqui era tudo um matagal. 
Requalificação dos Aterros Desativados (Brownfields) no Município de São Paulo: Parques (Greenfields) Raposo

Tavares e Jardim Primavera

Luzia Helena dos Santos Barros

Quando comprei o lote eles só tinham feito a terraplenagem recentemente. Minha cunhada comprou aqui, eu comprei aqui. Aí, nós subimos na perua do corretor e tal. Porque estava uma fila no dia do loteamento. Nós fomos o número duzentos e pouco da fila. Aí, fomos embora.Depois, meu irmão falou assim: "-Oh, hoje é domingo, vamos conhecer lá em volta do lote." Quando nós vimos esse abismo aí, meu irmão quase quis me matar. "-Você e minha mulher são dois burros, como é que vocês não viram isso?

O buraco era ao lado. Mas como tudo era terra por aqui, eu não vi o buraco, só vi a terra. Aí, foi que nós vimos em que buraco a gente se meteu.

Luzia: Esse loteamento foi aprovado pela Prefeitura?

Sylvio: É aprovado pela prefeitura, ele é normal. Já tem escritura definitiva e tudo, tudo bonitinho. Por isso que eu falei para você: quando a prefeitura liberou o loteamento disso daqui, graças a Deus a administração fez com que sobrasse esses vários espaços públicos, você entendeu?

Luzia: Mas quando o loteamento foi lançado ainda não existia o lixão não é?

Sylvio: Não, só existia o buraco. Um porto de areia, jJá desativado. Era uma lagoa, onde, inclusive, ocorreram mortes.

Luzia: Você lembra quando o porto de areia fechou?

Sylvio: Ah, não. Quando eu cheguei aqui já não tinha mais o porto de areia. Só tinha uma lagoa.

Luzia: E essa lagoa permaneceu por quanto tempo?

Sylvio: Essa lagoa ficou até o começo do lixão. Misturou o lixo com a água. Foram jogando lixo dentro da água e aterrando. E queriam continuar, ainda, jogando lixo. Porque eles queriam nivelar até o nível da rua, até a Jacu-Pêssego, no mesmo nível. E a Heleno \& Fonseca, como estava ganhando muito dinheiro naquela época, queria continuar. Aí, eles jogaram a turma, lá, do Camélias, contra a turma da Pedro Nunes. Porque a turma do Camélias queria a continuação do aterro. Eles queriam, porque as irmãs da Igreja Católica, Nossa Senhora Aparecida, foram muito ajudadas, pela Heleno \& Fonseca.

O que aconteceu? A Heleno \& Fonseca fez uma quadra, para eles, coberta, deu uma fábrica de blocos para as irmãs, lá na igreja. Fizeram o esgoto pela calçada, sem quebrar o asfalto, sabe? Então, eles tiveram tanto benefício ali, que até tem um político que brincava, que a igreja do Camélias mandava tanto dinheiro para Roma que eles não sabiam como uma igreja tão pobre daquela, podia mandar tanto dinheiro, lá, para Roma. Então, até esse boato surgiu. Aí, quando começou a explodir as coisas aqui, foi que começou aquele alvoroço, aquela mobilização. E o pessoal de lá, brigando para continuar.

Luzia: Para o pessoal do bairro Camélias interessava que a Heleno \& Fonseca continuasse o aterro? Sylvio: Isso. Porque eu acho que até a própria empreiteira chegou neles, lá, e falou: "-Olha, se vocês conseguirem fazer com que a gente continue aqui, vocês vão ganhar tanto." Mas eles não sofreram 
Requalificação dos Aterros Desativados (Brownfields) no Município de São Paulo: Parques (Greenfields) Raposo

Tavares e Jardim Primavera

Luzia Helena dos Santos Barros

nenhuma explosão, porque o córrego do Limoeiro, impedia que o gás passasse para o lado de lá. E nós, aqui, do lado de cá, sofrendo todas as amarguras da vida. Aí, foi a comissão de lá, contra a comissão daqui, falar com o Rogê Ferreira, da Cetesb, em 1988. Tinha uma comissão falando com o Rogê Ferreira e a outra esperando para entrar.

Eu vivi, eu vi. Eu falo porque eu estava lá. Eu falei para o Rogê Ferreira: "-Rogê, se fosse no Morumbi que tivesse um buraco daquele, vocês iriam pegar uma montanha, por em uma carreta e colocar ela de bico para baixo e ia tampar de uma vez só." Ainda fiz essa brincadeira com o Rogê Ferreira, naquela oportunidade. $\mathrm{E}$ as irmãs juntaram um povo lá que, Deus me perdoe,totalmente inconsequente, inexperiente e ignorante do que estava acontecendo; para fazer um 'auê', um movimento a favor da continuação do aterro. Olha que absurdo.

Luzia: Mas o que aconteceu para vocês conseguirem, realmente, paralisar o aterro?

Sylvio: Era uma força. E a força das explosões e dos acontecimentos era maior. A Pedro Nunes já estava se transformando em uma bomba. Já tinha o caso do homem que foi fumar um cigarro dentro do banheiro. Casos concretos. Fatos estarrecedores. Não se pode evitar, ignorar. Porque quando veio a Globo, naquela oportunidade, na rua Antônio Louzada, no final, ali, nós fizemos o seguinte com o câmera que estava focalizando. Tinha uma arvorezinha na calçada de uma casa, pegamos um jornal, acendemos e colocamos, ali, onde estava plantada aquela árvore, assim, de longe. Assim, no chão: 'pá'; queimou a árvore todinha. Então, isso eram fatos que não podiam ser ignorados.

A prefeitura, na época, se viu obrigada a fazer alguma coisa. A Cetesb estava envolvida diretamente e disse: "Não, não: para com isso, antes que ocorra uma tragédia maior." Havia outros problemas também de saúde, respiração. As crianças, a minha filha mesmo, nasceu em julho de 1979 e em setembro de 1979 foi quando começou o aterro. Então, o que acontecia? Volta e meia e eu estava dentro do hospital fazendo inalação da minha filha, você entendeu? O cheiro era muito forte. A minha casa, a janela, a porta, era tudo com aquela telinha fina, popios havia nuvens e nuvens de mosquito. Era um horror. Sabe o que é um horror?

Meus cachorros não tinham orelha mais, porque os mosquitos comiam as orelhas dos cachorros. Eu pegava óleo queimado de carro com um pincel e passava na orelha deles. Mas, daqui a pouco, um mosquito ia lá e achava um lugarzinho. Quando ia ver, aquela mutuca de mosquito, comendo a orelha dos cachorros. O que eu estou falando para você, aqui, não é exagero. Foi a pura realidade do que eu vivi aqui em função desse aterro. Os caminhões passavam na frente da minha casa, descarregados. Porque eles entravam carregados pela outra ponta, lá. Mas eles passavam com aquela água caindo. Aquele chorume. Passava na rua da minha casa. Aí, os mosquitosse acumulavam no chão, onde caia aquele caldo, o chorume. Eu só conheço essa palavra por causa desse aterro. Então, os mosquitos voavam naquela lama, porque era um chorume. Voavam ali. E, dali para a minha casa, era só uma batida de asa: já estava aqui dentro. Era loucura. Eu vivi dias, aqui, que você não acredita. 
Requalificação dos Aterros Desativados (Brownfields) no Município de São Paulo: Parques (Greenfields) Raposo

Tavares e Jardim Primavera

Luzia Helena dos Santos Barros

Luzia: Como você disse foram plantados 5.000 eucaliptos. Mas existem também árvores frutíferas. Você lembra quando foram plantadas?

Sylvio: Na mesma ocasião do eucalipto.

Luzia: Você sabe se as pessoas costumam comer as amoras?

Sylvio: Amora? Nossa. Quando dá amora o povão invade ali e come tudo. Nunca teve problema nenhum. Nunca ninguém morreu de comer amora, não.

Tem amora, eucalipto. Tem aves, pássaros. Está gostoso, só falta a gente usufruir. É, só falta o parque na realidade.

Eu torço, porque é o seguinte: 60 anos, meu Deus do céu. Vou morrer e não vou ver esse parque.

Luzia: Bem, Sylvio, obrigada pela entrevista. 
Requalificação dos Aterros Desativados (Brownfields) no Município de São Paulo: Parques (Greenfields) Raposo Tavares e Jardim Primavera

Luzia Helena dos Santos Barros

\section{DECLARAÇÄO}

Eu, Sylvio Alves Sena, Carteira de Identidade RG n० 5.861.011-X - SSPISP. emitida em 21/11/1986, morador á rua da Polka, 461, Jd. Pedro José Nunes, Vila Jacuí, São Paulo-S.P, vizinho do antigo aterro Sanitário Jacui, fưturo Parque Primavera e, editor do Jornal Pedro Nunes, de acordo com autorização dada a pesquisadora Luzia Helena dos Santos Barros: da Faculdade de Arquitetura e Urbanismo da Universidade de Săo Paulo - FAU-USP, publicada no Diárío Oficial da Cídade de Sảo Paulo, no dia 01 de junho de 2010. pg 24 declaro que autorizo a utilizaçăo do conteúdo, revisado por mim, da entrevista. realizada em of de maio de 2010, sobre o aterro e futuro Parque Primavera, na sua pesquisa de doutorado sobre a "Requalificaçăo de áreas degradadas por contaminaçăo no Município de São Paulo".

Săo Paulo, og de junho de 2011

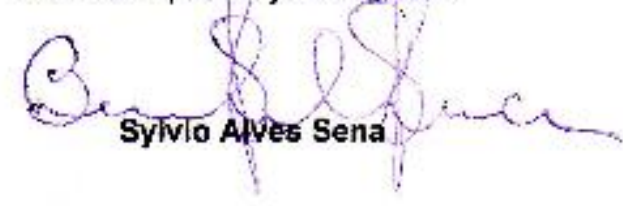


Requalificação dos Aterros Desativados (Brownfields) no Município de São Paulo: Parques (Greenfields) Raposo Tavares e Jardim Primavera

Luzia Helena dos Santos Barros

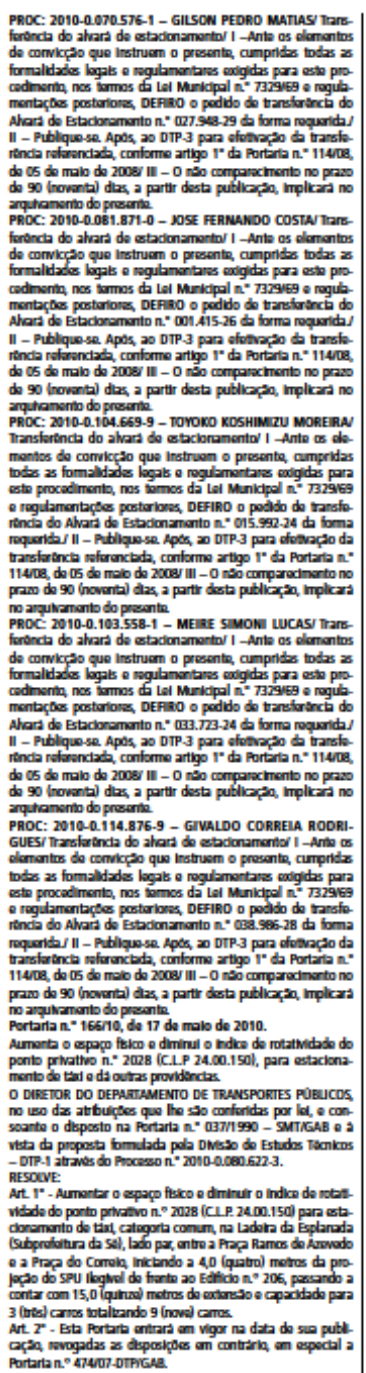

\section{VERDE E MEIO AMBIENTE}

ins Alves Sobrinho

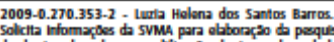

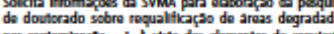

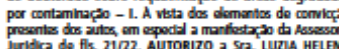

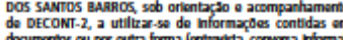

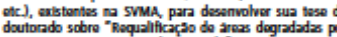

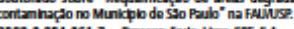

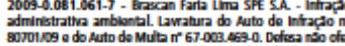

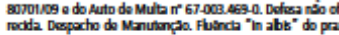
vita das dor

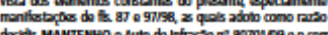

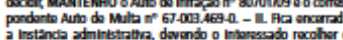

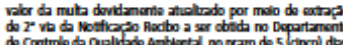

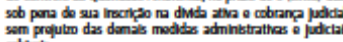

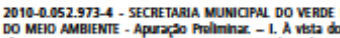

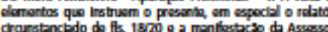

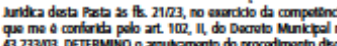

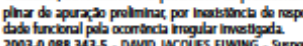

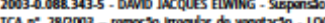

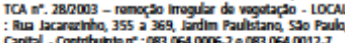

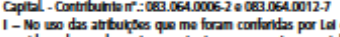

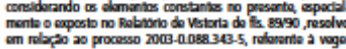

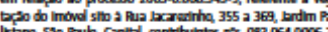

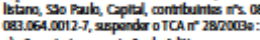

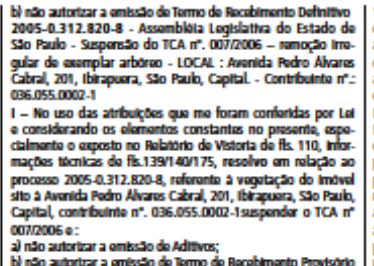

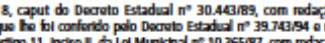

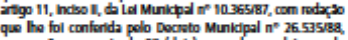

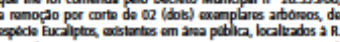

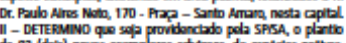

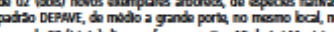

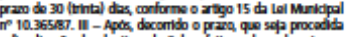

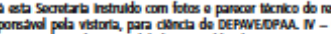

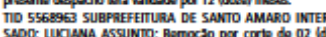

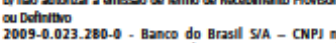

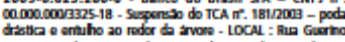

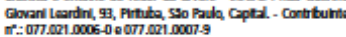

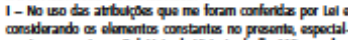

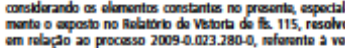

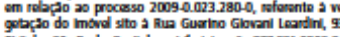

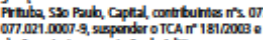

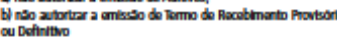
2009-0.143.444-9 - PORT ROCHELE EMPRERNOMEN

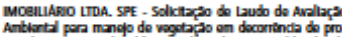

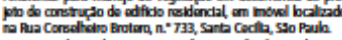

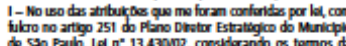

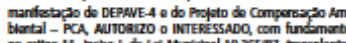

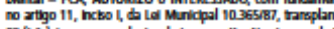

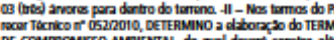

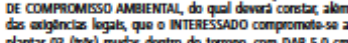

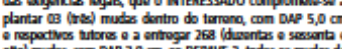

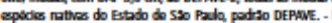

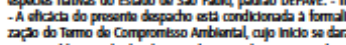

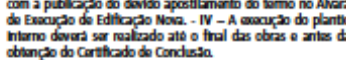

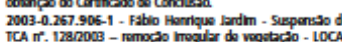

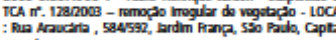

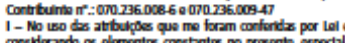

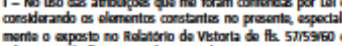

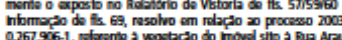

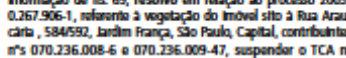

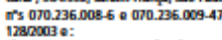

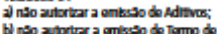

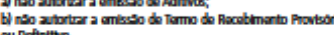
2010-0.136.973.0 - LNANA LUCA VERRA CENEVVA

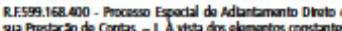

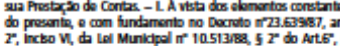

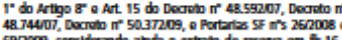

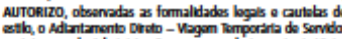

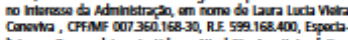

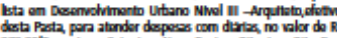

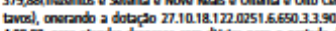

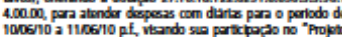

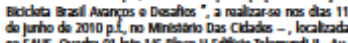

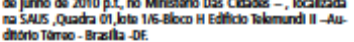

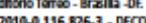

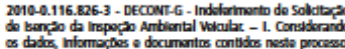

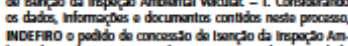

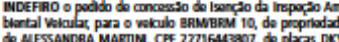

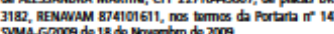

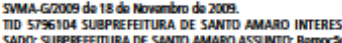

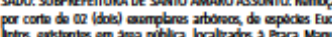

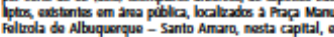

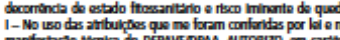

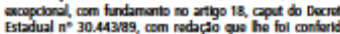

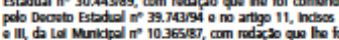

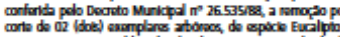
Wats

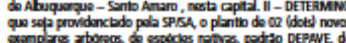

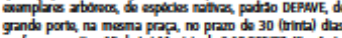

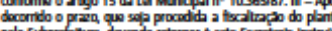

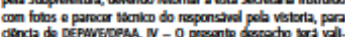

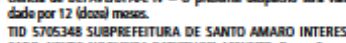

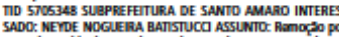

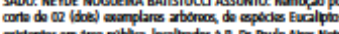

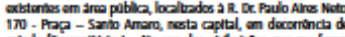

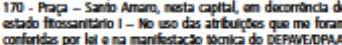

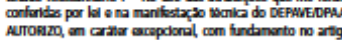

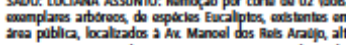

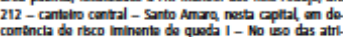

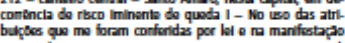

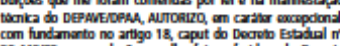

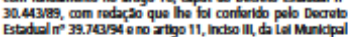

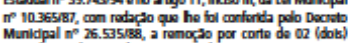

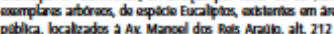

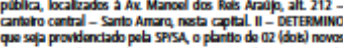

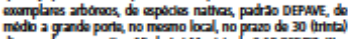

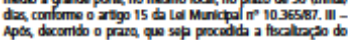

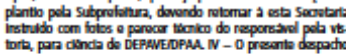

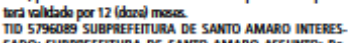

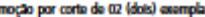

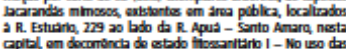

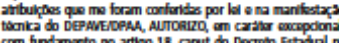

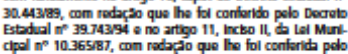

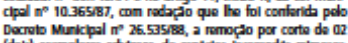

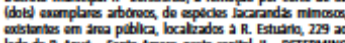

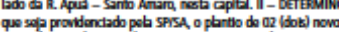

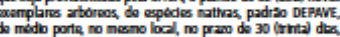

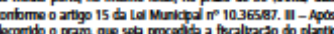

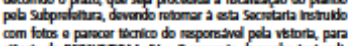

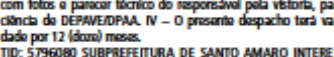

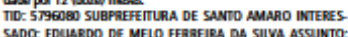

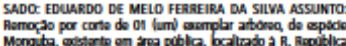

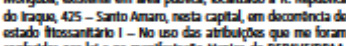

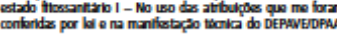

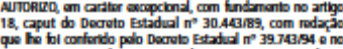
$\begin{array}{ll}2 & 1\end{array}$

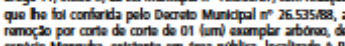

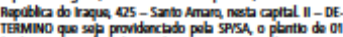

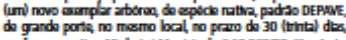

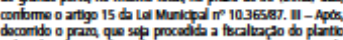

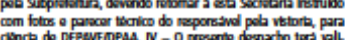

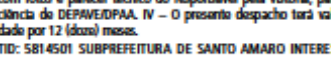

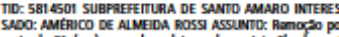

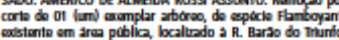

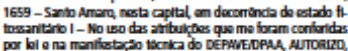

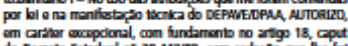

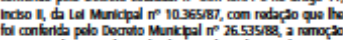

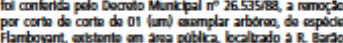

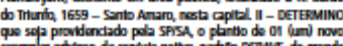

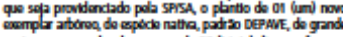

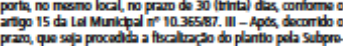

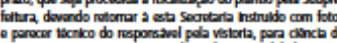

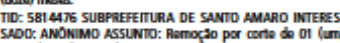

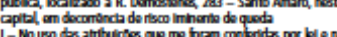

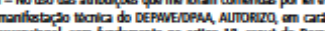

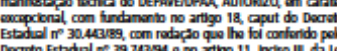

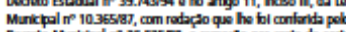

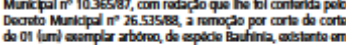

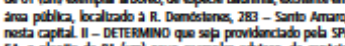

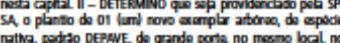

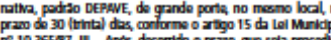

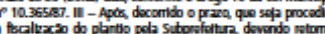

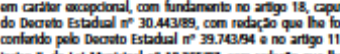

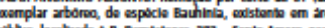

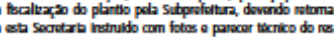

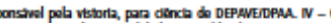

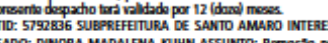

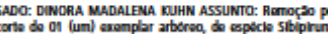

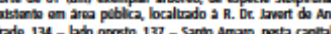

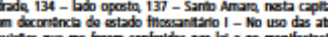

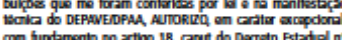

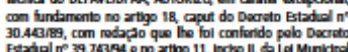

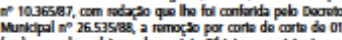

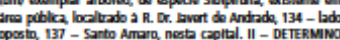

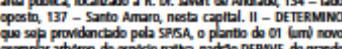

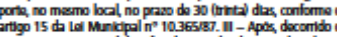

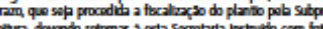

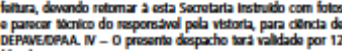

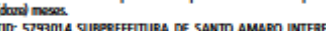

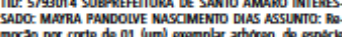

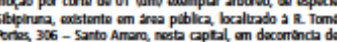

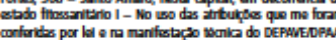

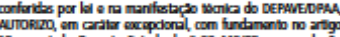

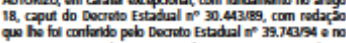

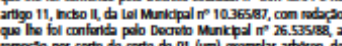

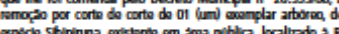

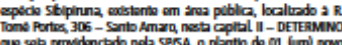

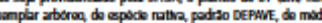

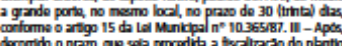

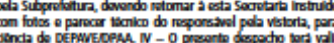

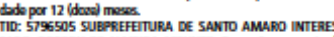
por conte do

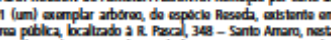

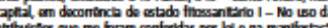

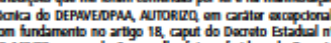

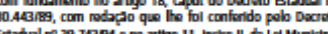

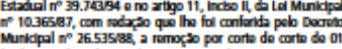

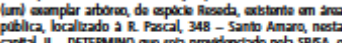

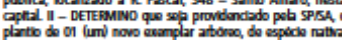

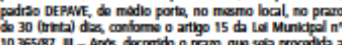

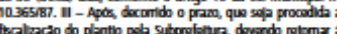

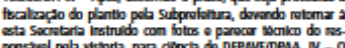

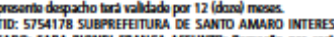

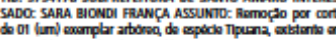

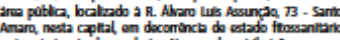
作

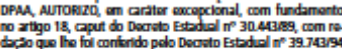

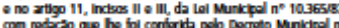

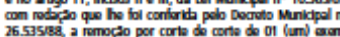

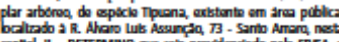

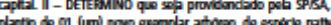

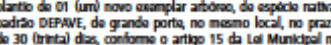

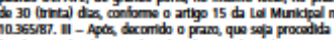

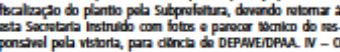

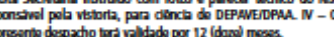

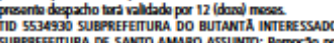

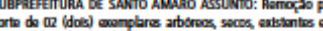

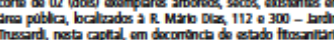

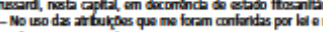

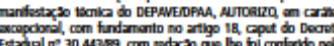

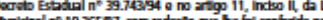

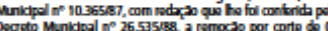

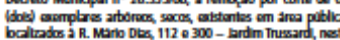

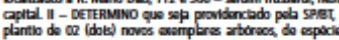

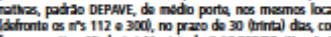

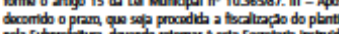

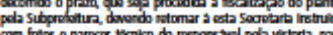

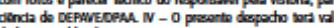

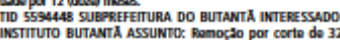

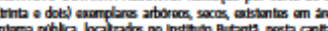

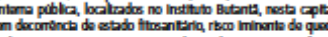

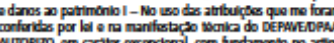

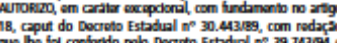

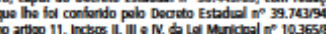

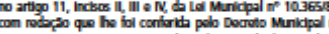


xlviii

Requalificação dos Aterros Desativados (Brownfields) no Município de São Paulo: Parques (Greenfields) Raposo Tavares e Jardim Primavera

Luzia Helena dos Santos Barros 


\section{ANEXOS}

ANEXO A - Localização das áreas de disposição de lixo do município, segundo o compartimento geomorfológico, no final da década de 70 .

\begin{tabular}{|c|c|c|c|c|}
\hline $\begin{array}{l}\text { Compartimento } \\
\text { geomorfológico }\end{array}$ & Aterro/Lixão & Incinerador & $\begin{array}{l}\text { Usina } \\
\text { tratamento } \\
\text { de lixo }\end{array}$ & $\begin{array}{l}\text { Estação } \\
\text { transbordo }\end{array}$ \\
\hline $\begin{array}{l}\text { Altas colinas e espigões } \\
\text { secundários }\end{array}$ & $\begin{array}{l}\text { S. João Clímaco (Via. } \\
\text { Anchieta) }\end{array}$ & & & \\
\hline \multicolumn{5}{|l|}{ Altas colinas periféricas } \\
\hline - Além-Tietê & $\begin{array}{c}\text { Tremembé, F. } \\
\text { Peciccaco, Lauzane } \\
\text { Paulista, Jardim } \\
\text { Damaceno, Vila } \\
\text { Albertina }\end{array}$ & & & \\
\hline - Além-Pinheiros & $\begin{array}{c}\text { Via Raposo Tavares } \\
\mathrm{Km} 13 ; 14,5 ; 15 \text { e } 16 .\end{array}$ & & & \\
\hline - $\quad$ AlémTamanduateí & Terceira Divisão & & & \\
\hline Várzea do Rio Tietê & $\begin{array}{c}\text { Vila Guilherme, R. } \\
\text { Manuel Menten, S. } \\
\text { Quirino, Coroa, Cidade } \\
\text { Náutica, João Veloso } \\
\text { Filho,Novo S.Quirino, } \\
\text { Av. Santa Marina, } \\
\text { Penha, Piqueri, Eng. } \\
\text { Goulart, Aymoré (Itaim } \\
\text { Paulista), Parque Novo } \\
\text { Mundo (funerária), } \\
\text { Jardim Andaraí, } \\
\text { Pitangui }\end{array}$ & $\begin{array}{l}\text { Ponte } \\
\text { Pequena }\end{array}$ & & $\begin{array}{l}\text { Ponte } \\
\text { Pequena }\end{array}$ \\
\hline Várzea do Rio Pinheiros & $\begin{array}{c}\text { R. Sumidouro, } \\
\text { Jurubatuba, Pedreira } \\
\text { (Rio Grande) }\end{array}$ & Sumidouro & $\begin{array}{c}\text { Vila } \\
\text { Leopoldina }\end{array}$ & \\
\hline Várzeas de outros rios & $\begin{array}{l}\text { R. Barão de Rezende, } \\
\text { R. Cirino de Abreu, S. } \\
\text { Mateus. }\end{array}$ & São Mateus & & \\
\hline
\end{tabular}

Organização: Luzia Helena dos S. Barros (20111)

Fonte: Ogata (1978, p.74) 
ANEXO B - Composição histórica dos resíduos sólidos no Município de São Paulo

\begin{tabular}{|c|c|c|c|c|c|c|c|c|c|c|c|c|c|c|}
\hline Material (\%) & 1927 & 1957 & 1969 & 1976 & 1991 & 1996 & 1998 & 2000 & 2003 & 2004 & 2006 & 2007 & 2008 & 2009 \\
\hline Matéria Orgânica & 82,5 & 76 & 52,2 & 62,7 & 60,6 & 55,7 & 49,5 & 48,2 & 57,9 & 60,5 & 55,5 & 57,0 & 61,3 & 63,6 \\
\hline $\begin{array}{c}\text { Papel, papelão e } \\
\text { jornal }\end{array}$ & 13,4 & 16,7 & 29,2 & 21,4 & 13,9 & 16,6 & 18,8 & 16,4 & 10,5 & 9,6 & 14,7 & 13,4 & 10,7 & 9,8 \\
\hline Emb. Longa Vida & & & & & & & & 0,9 & 1,3 & 1,1 & 1,1 & 1,2 & 1,1 & 1,0 \\
\hline Emb. PET & & & \multirow{4}{*}{1,9} & \multirow{4}{*}{5} & \multirow{4}{*}{11,5} & \multirow{4}{*}{14,3} & \multirow{4}{*}{22,9} & \multirow{4}{*}{16,8} & 0,7 & 0,5 & 0,4 & 0,5 & 0,6 & 0,6 \\
\hline Isopor & & & & & & & & & 0,3 & 0,2 & 0,2 & 0,3 & 0,2 & 0,3 \\
\hline Plástico Mole & & & & & & & & & 12,5 & 10,9 & 6,4 & 10,3 & 5,0 & 6,5 \\
\hline Plástico Duro & & & & & & & & & 3,6 & 3,4 & 8,2 & 5,0 & 6,8 & 6,7 \\
\hline Metais Ferrosos & 1,7 & 2,2 & 7,8 & 3,9 & 2,8 & 2,1 & 2 & 2,6 & 1,4 & 1,1 & 1,0 & 1,1 & 1,5 & 1,4 \\
\hline Pilhas e Baterias & & & & & & & & 0,1 & 0,1 & 0,1 & 0,1 & 0,1 & 0,0 & 0,0 \\
\hline Vidros & 0,9 & 1,4 & 2,6 & 1,7 & 1,7 & 2,3 & 1,5 & 1,3 & 1,6 & 1,2 & 1,1 & 1,4 & 1,6 & 1,6 \\
\hline Terra e Pedra & & & & 0,7 & 0,8 & & 0,2 & 1,6 & 0,8 & 1,5 & 3,7 & 2,1 & 1,8 & 1,8 \\
\hline Madeiras & & & 2,4 & 1,6 & 0,7 & & 1,3 & 2 & 1,6 & 0,8 & 0,5 & 0,5 & 1,5 & 1,0 \\
\hline Trapos e Panos & 1,5 & 2,7 & 3,8 & 2,9 & 4,4 & 5,7 & 3 & & 3,9 & 3,3 & 2,5 & 2,7 & 3,4 & 2,4 \\
\hline Diversos & & 0,1 & & & 1,7 & 2,6 & & 9,3 & 1,0 & 1,5 & 1,2 & 2,2 & 2,3 & 1,7 \\
\hline Alumínio & & & & 0,1 & 0,7 & 0,7 & 0,9 & 0,7 & 0,7 & 0,6 & 0,4 & 0,4 & 0,3 & 0,4 \\
\hline Borracha & & & & & & & & & 0,3 & 0,2 & 0,3 & 0,1 & 0,1 & 0,0 \\
\hline Espuma & & & & & & & & & & 0,1 & 0,0 & 0,0 & 0,0 & 0,0 \\
\hline Sub-total & & & & & & & & & 98,3 & 96,6 & 97,3 & 98,3 & 98,2 & 98,8 \\
\hline Perdas na triagem & & & & & & & & & 1,7 & 3,4 & 2,7 & 1,7 & 1,8 & 1,2 \\
\hline
\end{tabular}

Obs: Não foram localizados dados para os anos excluídos da série.

Organização: Luzia Helena dos S. Barros (2011)

Fonte: SES/Limpurb (2004; 2010); Grimberg (2009); Tiveron(2001, p.66) 
ANEXO C - Características que definem o que é e o que não é brownfield

\begin{tabular}{|c|c|}
\hline field & field \\
\hline 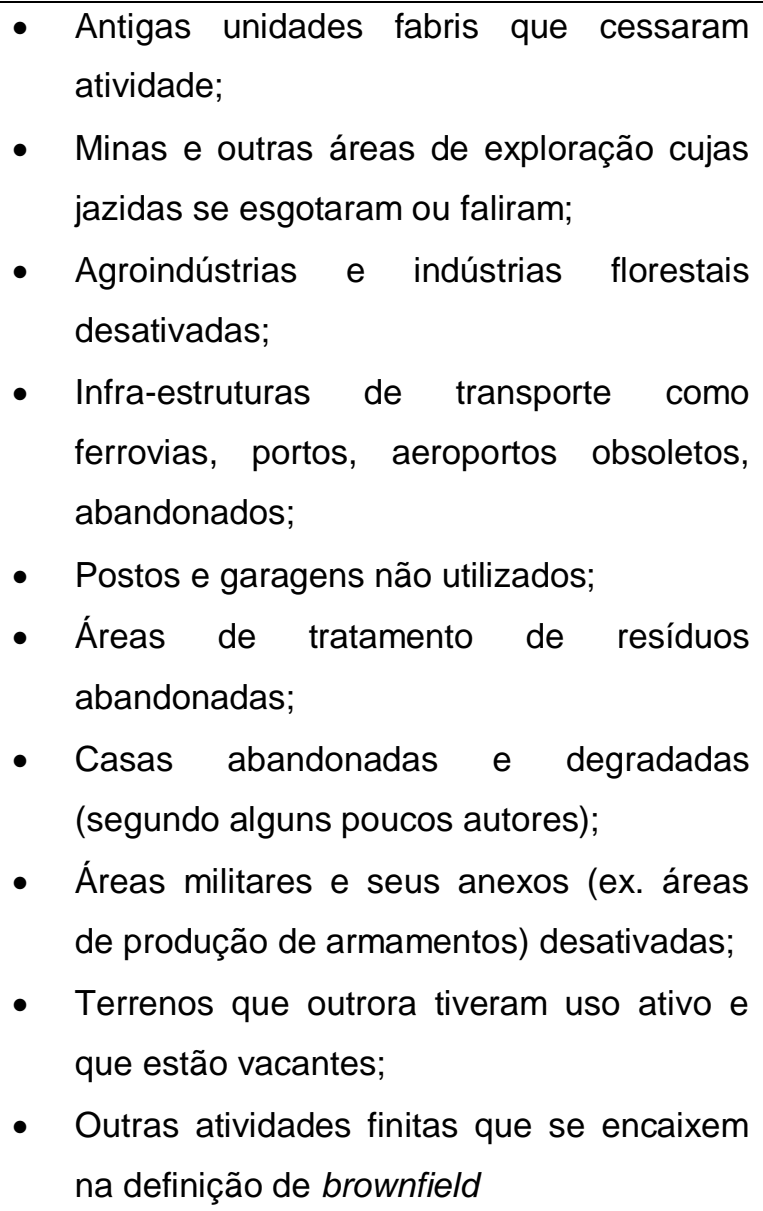 & $\begin{array}{l}\text { - } \text { - Cábricas ainda em operação; } \\
\text { - Locais em construção; } \\
\text { - Áreas militares em uso; } \\
\text { - Áreas cultivadas que não foram afetadas } \\
\text { por praguicidas e fertilizantes; } \\
\text { - } \text { Pilhas de estéril e rejeitos, montes de } \\
\text { - espólio de minas de carvão; } \\
\text { Anão que sofreram queimadas, mas que } \\
\text { - Locais degradadostais; } \\
\text { - Qualquer terreno ou edifício que tenha uso } \\
\text { industrial, comercial ou outro reconhecido } \\
\text { que estja em estágio avançado de } \\
\text { cessação de atividade, mas que ainda } \\
\text { funcione; } \\
\text { - Outros usos que não se encaixem na } \\
\text { definição de brownfield }\end{array}$ \\
\hline
\end{tabular}

Fonte: Vasques (2009, p. 40) 
ANEXO D - Tipologias para análise de brownfields

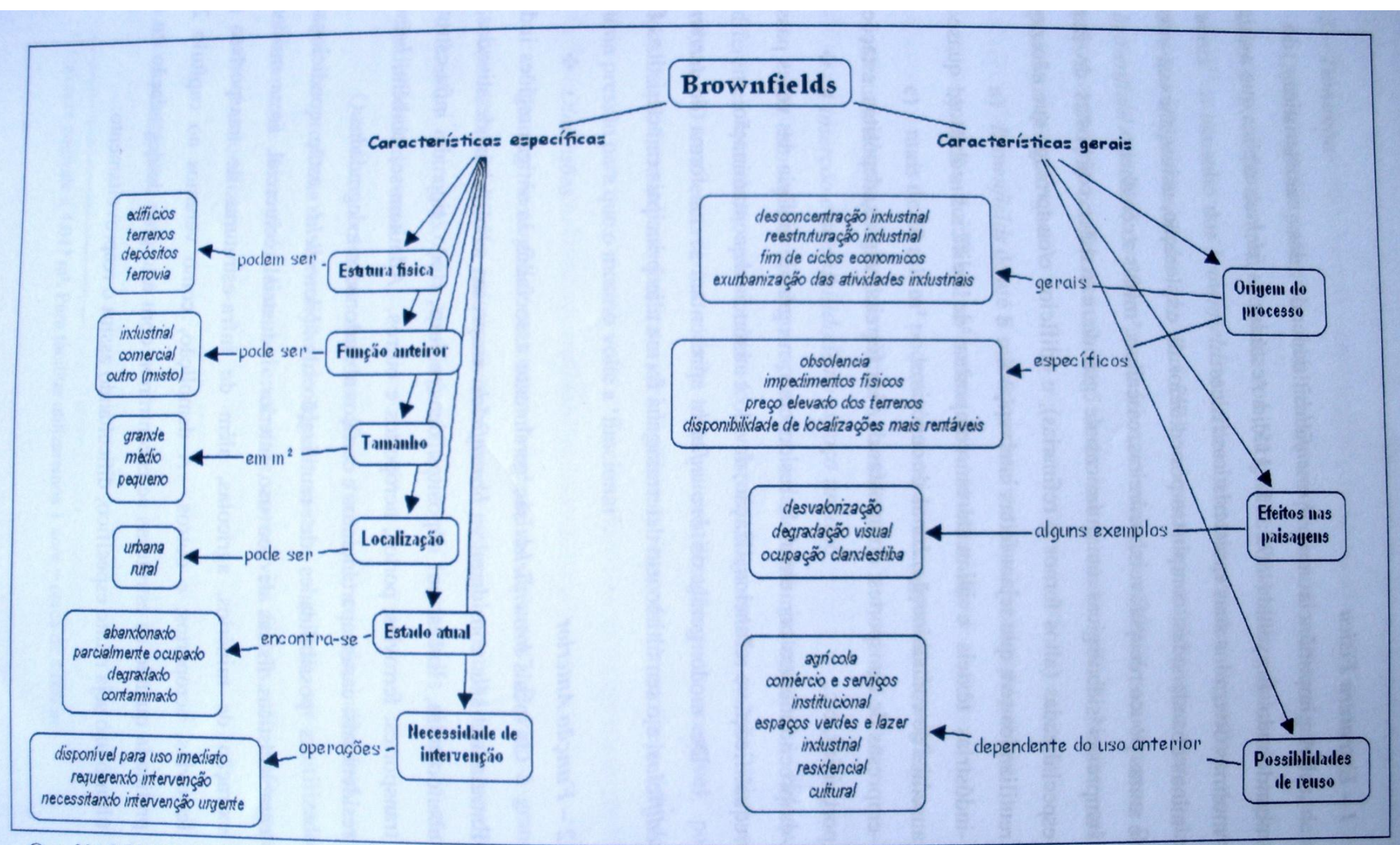

Org. VASQUES (2005)

Fonte: Vasques $(2005$, p.15) 
Anexo E - Valores (mg/l) indicativos da composição química de percolados de aterros sanitários no Brasi

\begin{tabular}{|l|c|c|}
\hline & \multicolumn{2}{|c|}{ Aterros do Brasil } \\
\hline Parâmetro & Recentes (1 ano) & Antigos (+20 anos) \\
\hline PH & 6,9 & 7,1 \\
\hline DBO & 4286 & 55 \\
\hline DQO & 6050 & 96 \\
\hline TOC & 2040 & 38 \\
\hline Nitrog. nitrato & 0,77 & 85 \\
\hline Nitrog. amoniacal & 224 & 34 \\
\hline Ortofosfatos & 0,16 & 0,3 \\
\hline Cloretos & 2777 & 520 \\
\hline Sulfatos & 218 & - \\
\hline Sódio & 1590 & 380 \\
\hline Magnésio & 215 & 35 \\
\hline Cálcio & 700 & 230 \\
\hline Cromo & 0,09 & 0,02 \\
\hline Ferro & 38 & 0,1 \\
\hline Níquel & 0,03 & 0,03 \\
\hline Cobre & 0,03 & 0,15 \\
\hline Zinco & 0,20 & 0,95 \\
\hline Cádmio & 0,01 & 0,005 \\
\hline Chumbo & 0,08 & 0,06 \\
\hline
\end{tabular}

Fonte: Cetesb (1992 apud Silva, 2001:24), onde não foi especificado o número de aterros analisados 
Requalificação dos Aterros Desativados (Brownfields) no Município de São Paulo: Parques (Greenfields) VI Raposo Tavares e Jardim Primavera

Luzia Helena dos Santos Barros

Anexo F - Delimitação dos setores habitacionais de interesse social situados nas imediações do antigo aterro Sapopemba.

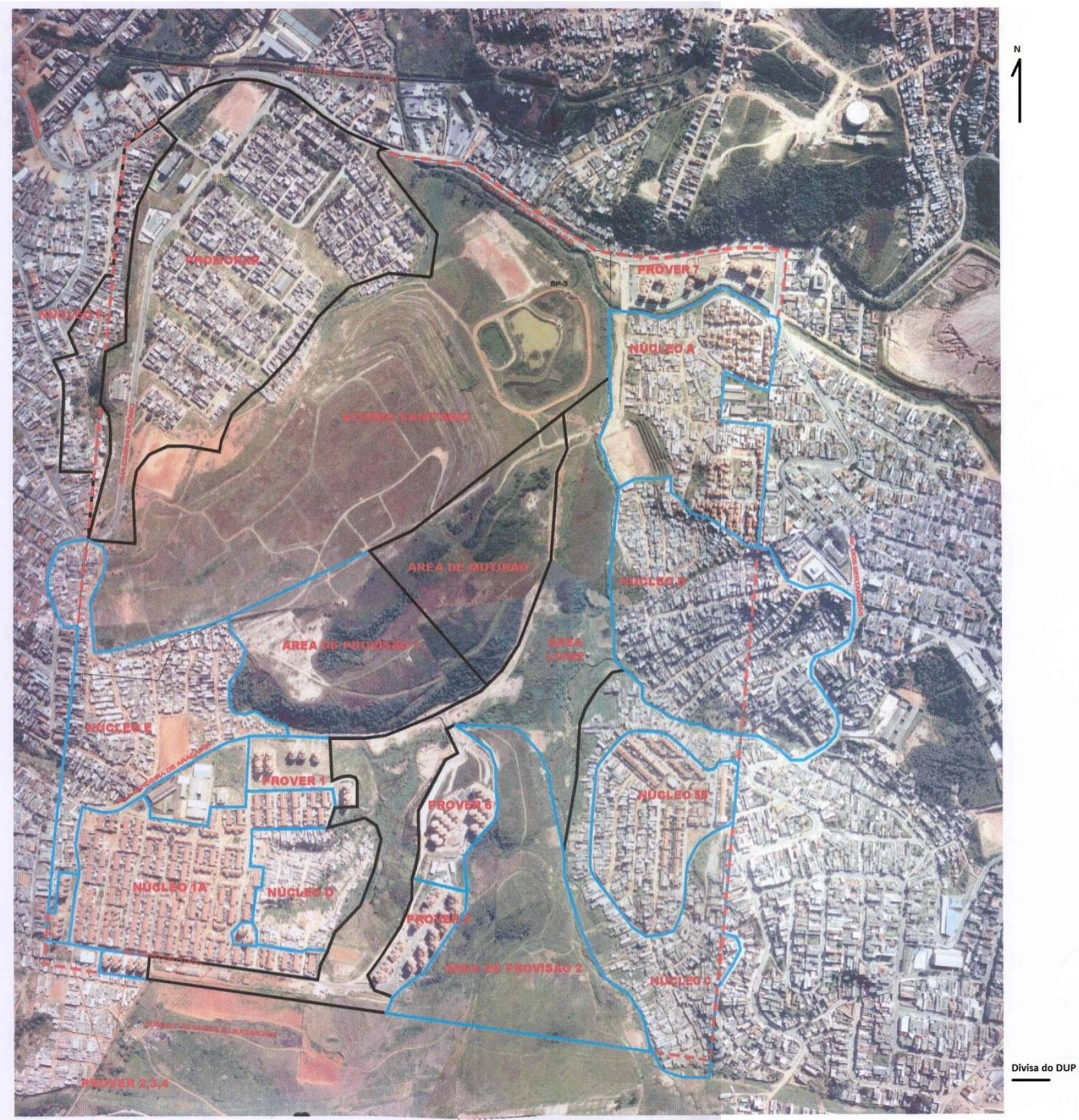

Fonte: Sehab/HABI (2006, Anexo II) 
Requalificação dos Aterros Desativados (Brownfields) no Município de São Paulo: Parques (Greenfields) VII Raposo Tavares e Jardim Primavera

Luzia Helena dos Santos Barros

Anexo G - Tipologias de Espaços Livres e Áreas Verdes (SVMA, 2006b, p.9 e 10).

\begin{tabular}{|c|c|c|}
\hline TIPOLOGIAS & SITUAÇĀO FUNDIÁRIA & GESTÄO \\
\hline 1 - UNIDADES DE CONSERVAÇÃO & Público / Particular & $\begin{array}{l}\text { federal, estadual, } \\
\text { municipal ou } \\
\text { particular }\end{array}$ \\
\hline \multicolumn{3}{|l|}{ Unidades de Proteção Integral } \\
\hline Estação Ecológica & Público & \\
\hline Reserva Biológica & Público & \\
\hline Parque Nacional & Público & \\
\hline Monumento Natural & Público/Particular & \\
\hline Refúgio da Vida Silvestre & Público/Particular & \\
\hline \multicolumn{3}{|l|}{ Unidades de Uso Sustentável } \\
\hline Área de Proteção Ambiental & Público/Particular & \\
\hline Área de Relevante Interesse Ecológico & Público/Particular & \\
\hline Floresta Nacional & Público & \\
\hline Reserva Extrativista & $\begin{array}{l}\text { Público/Concessão } \\
\text { Privada }\end{array}$ & \\
\hline Reserva de Fauna & Público & \\
\hline Reserva de Desenvolvimento Sustentável & \begin{tabular}{|l|l|} 
Público \\
\end{tabular} & \\
\hline Reserva Particular do Patrimônio Natural & Particular & \\
\hline \multicolumn{3}{|l|}{2 - PARQUES NUCLEARES INTRAURBANOS } \\
\hline Parques de Vizinhança & Público & subprefeitura \\
\hline Parques de Bairro & Público & SVMA \\
\hline Parques Regionais & Público & SVMA. / estad. \\
\hline Parques da Cidade & Público & SVMA. / estad. \\
\hline \multicolumn{3}{|l|}{3 - PARQUES LINEARES DA REDE HIDRICA } \\
\hline Tipo 1 - Alta integridade & Público / Particular & munic/est. ou part \\
\hline Tipo 2 - Média integridade & Público / Particular & munic/est ou part \\
\hline Tipo 3 - Integridade nula & Público / Particular & munic/est.ou part \\
\hline \multicolumn{3}{|l|}{4 - ESPAÇOS LIVRES PÚBLICOS URBANOS } \\
\hline Jardim Público & Público & subpref. I estad. \\
\hline Parque de Bolso & Público / Particular & subpref. ou part. \\
\hline \begin{tabular}{|l|} 
Mirante \\
\end{tabular} & Público & subpref. / estad. \\
\hline Praça & Público & subpref. / estad. \\
\hline \multicolumn{3}{|l|}{5 - ÁREAS VERDES DO SISTEMA VIÁRIO } \\
\hline Canteiro Central / Canteiro Lateral & Público & subprefeitura \\
\hline Calçada / Caminho Verde & Público & subprefeitura \\
\hline Canto de Quadra & Público & subprefeitura \\
\hline Escadaria / Beco & Público & subprefeitura \\
\hline Faixa de Domínio de Rodovia / Ferrovia & Público & mun./est./federal \\
\hline Illha / Rotatória & Público & subprefeitura \\
\hline Talude & Público & subprefeitura \\
\hline Terreno Remanescente & Público & subprefeitura \\
\hline Trevo & Público & mun.lest./federal \\
\hline \multicolumn{3}{|l|}{$\begin{array}{l}6 \text { - ÁREAS VERDES DA INFRAESTRUTURA } \\
\text { URBANA }\end{array}$} \\
\hline Bacia de Detenção / Retenção & Público & SIURB \\
\hline Estação de Tratamento de Agua / Esgoto & Público / Particular & SABESP \\
\hline $\begin{array}{l}\text { Faixa de Domínio de Dutos / Linhas de } \\
\text { Transmissão de Energia }\end{array}$ & Público / Particular & Concessionárias \\
\hline Reservatório de Água & Público / Particular & Concessionárias \\
\hline Terreno Remanescente & Público & subprefeitura \\
\hline Viela Sanitária & Público & subprefeitura \\
\hline \multicolumn{3}{|l|}{$\begin{array}{l}7 \text { - ÁREAS VERDES DE INSTITUIÇÖES E } \\
\text { SERVIÇOS PÚBLICOS }\end{array}$} \\
\hline Campus Universitário & Público / Particular & mun_/est./fed./part \\
\hline Cemitério & Público / Particular & mun./particular \\
\hline Centro Administrativo & Público / Particular & mun.lest \\
\hline Centro de Compras & Particular & particular \\
\hline Centro Desportivo / Recreativo & Público / Particular & mun_/est./part. \\
\hline Escola & Público / Particular & mun./est./part. \\
\hline Hospital / Posto de Saúde & Público / Particular & mun.lest./part. \\
\hline Museu / Centro Cultural & Público / Particular & mun_lest./fed./part \\
\hline \multicolumn{3}{|l|}{8 - ÁREAS VERDES PRODUTIVAS } \\
\hline \multicolumn{3}{|l|}{9 - AREAS VERDES PARTICULARES } \\
\hline Bairro Verde & Particular & Particular \\
\hline Bosque / Jardim & Particular & Particular \\
\hline Centro Campestre / Clube de Campo & Particular & Particular \\
\hline Chácara ou Sítio de Recreio & Particular & Particular \\
\hline Haras / Pesqueiro & Particular & Particular \\
\hline
\end{tabular}




\section{Anexo H - Critérios para o Índice de Qualidade de Aterros de Resíduos}

\begin{tabular}{|c|c|c|c|c|c|c|c|c|c|c|}
\hline \multicolumn{3}{|c|}{ Aterros } & 总盛 & 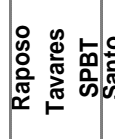 & 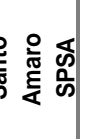 & 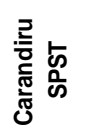 & 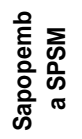 & 㖣 & 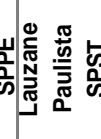 & 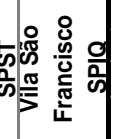 \\
\hline Ítem & Avaliação & Peso & \multicolumn{8}{|c|}{ Pontos } \\
\hline \multirow{3}{*}{ Volume de resíduos } & acima de 5.000 .000 ton & 2 & \multirow{3}{*}{1} & \multirow{3}{*}{1} & \multirow{3}{*}{2} & \multirow{3}{*}{0} & \multirow{3}{*}{1} & \multirow{3}{*}{1} & \multirow{3}{*}{0} & \multirow{3}{*}{0} \\
\hline & até 5.000 .000 ton & 1 & & & & & & & & \\
\hline & até 5.000 ton & 0 & & & & & & & & \\
\hline & sedimento & 2 & & & & & & & & \\
\hline Geologia & gnaisse / micaxisto & 1 & 2 & 1 & 2 & 2 & 1 & 2 & 0 & 2 \\
\hline & granito & 0 & & & & & & & & \\
\hline & acima da superfície & 0 & & & & & & & & \\
\hline Disposiçäo de residuos & abaixo da superfície & 1 & 1 & 0 & 1 & 1 & 0 & 1 & 1 & 1 \\
\hline & até 2 anos & 0 & & & & & & & & \\
\hline Tempo de funcionamento * & até 5 anos & 1 & 2 & 1 & 2 & 0 & 1 & 1 & 0 & 0 \\
\hline & mais de 5 anos & 2 & & & & & & & & \\
\hline & até 10 anos & 4 & & & & & & & & \\
\hline & até 15 anos & 3 & & & & & & & & \\
\hline Tempo de encerramento & até 20 anos & 2 & 3 & 1 & 4 & 0 & 2 & 1 & 0 & 0 \\
\hline & até 25 anos & 1 & & & & & & & & \\
\hline & até 30 anos & 0 & & & & & & & & \\
\hline & Livre & 0 & & & & & & & & \\
\hline & Comercial & 1 & & & & & & & & \\
\hline Uso atual & Recreativos & 2 & 0 & 2 & 0 & 1 & 0 & 2 & 1 & 3 \\
\hline & Residencial & 3 & & & & & & & & \\
\hline & Pública Municipal & 2 & & & & & & & & \\
\hline Titularidade da área & Pública Estadual & 1 & 2 & 2 & 2 & 1 & 2 & 1 & 0 & 0 \\
\hline & Particular & 0 & & & & & & & & \\
\hline Entorno ocupado por & Sim & 1 & 1 & 1 & 1 & 1 & 1 & 0 & 1 & 1 \\
\hline moradias * & Não & 0 & 1 & 1 & 1 & 1 & 1 & 0 & 1 & 1 \\
\hline Presenca de catadores & Sim & 1 & 0 & 0 & 0 & 0 & 0 & 0 & 0 & 1 \\
\hline rresença de calaaores & Não & 0 & 0 & 0 & 0 & 0 & U & 0 & 0 & 1 \\
\hline Próximo a áreas verdes & Sim & 1 & 0 & 0 & 0 & 0 & 0 & 1 & 0 & 0 \\
\hline Proxımo a areas veraes & Não & 0 & 0 & 0 & U & U & 0 & 1 & 0 & 0 \\
\hline Corpos d’água próximo a & Sim & 1 & 1 & 0 & 1 & 1 & 0 & 1 & 1 & 1 \\
\hline área & Não & 0 & 1 & U & 1 & 1 & & & & \\
\hline Área cercada & Sim & 0 & 0 & 0 & 0 & 1 & 0 & 1 & 0 & 1 \\
\hline Area cercada & Não & 1 & 0 & 0 & 0 & 1 & & & & \\
\hline Área possui viqilância & Sim & 0 & 0 & 0 & 0 & 1 & 0 & 0 & 1 & 1 \\
\hline Area possuı vigilancia & Não & 1 & 0 & 0 & 0 & 1 & 0 & 0 & 1 & 1 \\
\hline Área sob manutencão & Sim & 0 & 1 & 1 & 0 & 1 & 1 & 0 & 1 & 1 \\
\hline Area sob manutenção & Não & 1 & 1 & 1 & 0 & 1 & & & & \\
\hline Estruturas de drenagem de & Sim & 0 & 0 & 1 & 0 & 1 & 0 & 1 & 1 & 1 \\
\hline águas superficiais & Não & 1 & 0 & 1 & 0 & 1 & 0 & 1 & 1 & 1 \\
\hline Estruturas de drenagem de & Sim & 0 & 1 & 1 & 1 & 1 & 1 & 1 & 1 & 1 \\
\hline águas subterrâneas & Não & 1 & 1 & 1 & 1 & 1 & 1 & 1 & 1 & 1 \\
\hline Estruturas de drenagem de & Sim & 0 & 0 & 0 & 0 & 0 & 0 & 0 & 0 & 1 \\
\hline biogás & Não & 1 & 0 & 0 & 0 & 0 & 0 & 0 & & \\
\hline Estruturas de drenagem de & Sim & 0 & 0 & 0 & 0 & 1 & 0 & 1 & 1 & 1 \\
\hline líquidos percolados & Não & 1 & 0 & 0 & 0 & 1 & 0 & 1 & 1 & 1 \\
\hline Tratamento de líquidos & Sim & 0 & 1 & 1 & 0 & 1 & 0 & 0 & 1 & 1 \\
\hline percolados * & Não & 1 & 1 & 1 & 0 & 1 & 0 & 0 & 1 & 1 \\
\hline Cobertura superficial & Sim & 0 & 0 & 0 & 0 & 0 & 0 & 0 & 0 & 1 \\
\hline Cobertura supertıcıal & Não & 1 & 0 & 0 & 0 & & & & & \\
\hline Cobertura vegetal & Sim & 0 & 0 & 0 & 0 & 0 & 0 & 0 & 1 & 0 \\
\hline Cobertura vegetal & Não & 1 & 0 & 0 & 0 & 0 & 0 & 0 & 1 & 0 \\
\hline Imnermeabilizacão da hase & Sim & 0 & 1 & 1 & 1 & 1 & 1 & 1 & 1 & 1 \\
\hline & Não & 1 & & & & & & & & \\
\hline Suraência de chorume * & Sim & 1 & & & & 0 & & & & 0 \\
\hline surgencla de chorume & Não & 0 & 0 & 1 & 0 & 0 & 0 & 0 & 0 & 0 \\
\hline Afloramento de resíduos * & Sim & 1 & 0 & 1 & 1 & 0 & 0 & 0 & 1 & 1 \\
\hline Afioramento de resiauos & Não & 0 & 0 & 1 & 1 & 0 & 0 & 0 & 1 & 1 \\
\hline Miaracão de biogás & Sim & 1 & 1 & 1 & 1 & 1 & 1 & 1 & 1 & 1 \\
\hline & Não & 0 & & & & & & & & \\
\hline & Domiciliar & 1 & & & & & & & & \\
\hline Resíduo depositado & Industrial / Hospitalar & 2 & 1 & 2 & 1 & 1 & 2 & 1 & 1 & 1 \\
\hline & Entulho & 0 & & & & & & & & \\
\hline Total & Máx. & 36 & $19(4)$ & $19(5)$ & 20 & 17 & 14 & 18 & 15 & 22 \\
\hline
\end{tabular}

Fonte: SVMA (2005, p.54); Ramires et al. (2005, adaptado IPT/CEMPRE, 2000) 
Anexo I - Critérios para priorizar intervenções nos aterros municipais

\begin{tabular}{|c|c|c|c|c|c|c|c|c|}
\hline \multicolumn{3}{|c|}{ Aterros } & 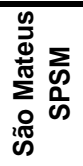 & 总品 & 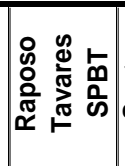 & 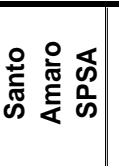 & 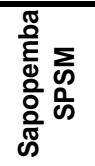 & 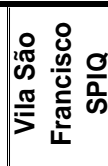 \\
\hline Critérios & Avaliação & Peso & & & Pon & tos & & \\
\hline \multirow{4}{*}{ Edificações } & Sobre o aterro & 3 & \multirow{4}{*}{0} & \multirow{4}{*}{0} & \multirow{4}{*}{3} & \multirow{4}{*}{0} & \multirow{4}{*}{0} & \multirow{4}{*}{3} \\
\hline & Pé do aterro & 2 & & & & & & \\
\hline & Próximas ao aterro & 1 & & & & & & \\
\hline & Sem edificações & 0 & & & & & & \\
\hline \multirow{4}{*}{$\begin{array}{l}\text { Existência de moradia } \\
\text { residencial }\end{array}$} & Sobre o aterro & 3 & \multirow{4}{*}{0} & \multirow{4}{*}{1} & \multirow{4}{*}{2} & \multirow{4}{*}{0} & \multirow{4}{*}{1} & \multirow{4}{*}{3} \\
\hline & Pé do aterro & 2 & & & & & & \\
\hline & Próximas ao aterro & 1 & & & & & & \\
\hline & Sem edificações & 0 & & & & & & \\
\hline \multirow{2}{*}{ Uso atual da população } & Sim & 1 & \multirow{2}{*}{0} & \multirow{2}{*}{1} & \multirow{2}{*}{1} & \multirow{2}{*}{0} & \multirow{2}{*}{1} & \multirow{2}{*}{1} \\
\hline & Não & 0 & & & & & & \\
\hline \multirow{2}{*}{ Migração de gás } & Sim & 1 & \multirow{2}{*}{0} & \multirow{2}{*}{1} & \multirow{2}{*}{0} & \multirow{2}{*}{1} & \multirow{2}{*}{1} & \multirow{2}{*}{0} \\
\hline & Não & 0 & & & & & & \\
\hline \multirow{3}{*}{ Tempo de maturação } & Até 30 anos & 2 & \multirow{3}{*}{1} & & & & & \\
\hline & Até 20 anos & 1 & & 1 & 1 & 0 & 1 & 2 \\
\hline & Até 10 anos & 0 & & & & & & \\
\hline Surgência de chorume & Sim & 1 & 0 & 0 & 1 & 1 & 0 & 0 \\
\hline & Não & 0 & 0 & & 1 & & & \\
\hline & Mata & 2 & & & & & & \\
\hline $\begin{array}{l}\text { Significativa } \\
\text { Siluo }\end{array}$ & Capoeira & 1 & 2 & 0 & 0 & 0 & 0 & 0 \\
\hline & Ausente & 0 & & & & & & \\
\hline Parque Municipal & $\begin{array}{l}\text { Existente / aprovado } \\
\text { por lei }\end{array}$ & 1 & 0 & 1 & 1 & 0 & 0 & 0 \\
\hline & Não & 0 & & & & & & \\
\hline Cobertura vegetal & Não & 1 & 0 & 0 & 0 & 0 & 0 & 1 \\
\hline & Sim & 0 & & & & & & \\
\hline Total & Máx. & 15 & 3 & 5 & 9 & 2 & 4 & 10 \\
\hline
\end{tabular}

Fonte: SVMA (2005, p.55); Ramires et al. (2005) 
Requalificação dos Aterros Desativados (Brownfields) no Município de São Paulo: Parques (Greenfields) X Raposo Tavares e Jardim Primavera

Luzia Helena dos Santos Barros

ANEXO J - Inventário de Fauna 2010

Liata Preliminar da Fauna do Parque Raposo Tavares,

Rua Telmo Coelho Filho 200, Distrito Butantä, Muricípio de São Paulo

Coondenadas geográfcas: UTM Córnego Alegre - 23 S X-320.728 Y-7.390.071

\begin{tabular}{|c|c|c|c|c|}
\hline & Táxon & Nome Popular & Status & $\begin{array}{l}\text { Datal } \\
\text { Observador }\end{array}$ \\
\hline & \multicolumn{4}{|l|}{ Reino Animalia } \\
\hline & \multicolumn{4}{|l|}{ Fillo Arthropoda } \\
\hline & \multicolumn{4}{|l|}{ Subfilo Chelicerata } \\
\hline & \multicolumn{4}{|l|}{ Classe Arachnida } \\
\hline & \multicolumn{4}{|l|}{ Ordem Araneae } \\
\hline & \multicolumn{4}{|l|}{ Familia Ctenidae } \\
\hline \multirow[t]{6}{*}{1} & Phoneutria nigniventer (Keysering, 1891) & aranho-armodeina & & $09 / 1994=$ \\
\hline & \multicolumn{4}{|l|}{ Filo Chordata } \\
\hline & \multicolumn{4}{|l|}{ Subfilo Vertebrata } \\
\hline & \multicolumn{4}{|l|}{ Classe Reptilia } \\
\hline & \multicolumn{4}{|l|}{ Ordem Squamata } \\
\hline & \multicolumn{4}{|l|}{ Familia Anguidae } \\
\hline \multirow[t]{2}{*}{1} & Ophiodes fragilis (Raddi, 1820) & colbra-de-vidro & & $091994 \#$ \\
\hline & \multicolumn{4}{|l|}{ Familia Anomalepididae } \\
\hline \multirow[t]{2}{*}{2} & Liotyphiops beui (Amaral, 1924) & colbra-cega & & $01 / 2008 \#$ \\
\hline & \multicolumn{4}{|l|}{ Familia Colubridae } \\
\hline \multirow[t]{4}{*}{3} & Sibynomonphus mikanï (Schlegel, 1837) & dormidein & & $02 / 1996 \#$ \\
\hline & \multicolumn{4}{|l|}{ Classe Aves } \\
\hline & \multicolumn{4}{|l|}{ Ordem Gathartiformes } \\
\hline & \multicolumn{4}{|l|}{ Familia Cathartidae } \\
\hline \multirow[t]{3}{*}{1} & Coragyps atratus (Bechstein, 1793) & $\begin{array}{l}\text { urubu-de-cabeģa- } \\
\text { preta }\end{array}$ & & $06 / 1998_{(m)}$ \\
\hline & \multicolumn{4}{|l|}{ Ordem Falconiformes } \\
\hline & Família Accipitridae & & & \\
\hline 2 & Banus levcunus (Vieillot, 1818) & peneira & CITES-II & 03/1999 (nax) \\
\hline 3 & Rupomis magnirostris (Gmelin, 1788) & gaviäo-carīo & CITES-II & $06 / 1998_{(m)}$ \\
\hline & Familia Falconidae & & & \\
\hline 4 & Caracara plancus (Miler, JF, 1777) & caracarà & CITES-II & $03 / 1999_{(\operatorname{man})}$ \\
\hline & Ordem Charadriiformes & & & \\
\hline & Familia Charadriidae & & & \\
\hline 5 & Vanellus chilensis (Molina, 1782) & quero-quero & & $11 / 4995 \#$ \\
\hline & Ordem Columbiformes & & & \\
\hline & Familia Columbidae & & & \\
\hline 6 & Columbina talpacoti (Temmind, 1810) & rolinha-roxa & & $03 / 4999_{\text {(nax) }}$ \\
\hline 7 & Columba livia Gmelin, 1789 & pombo-doméstico & $\begin{array}{l}\text { exótica } \\
\text { introduzida }\end{array}$ & $0641998_{\text {(m) }}$ \\
\hline & Ordem Paittaciformes & & & \\
\hline & Familia Paittacidae & & & \\
\hline 8 & Brotogeris tirica (Gmelin, 1788) & periquito-rico & $\begin{array}{l}\text { endênical } \\
\text { CITES-II }\end{array}$ & $06 / 1998_{(m)}$ \\
\hline & Ordem Cuculiformes & & & \\
\hline & Família Cuculidae & & & \\
\hline 9 & Guira guira (Gmein, 1788) & anu-branco & & $03 / 1999_{(\max )}$ \\
\hline & Familia Strigidae & & & \\
\hline 10 & Megascops choliba (Vieilot, 1817) & corujinha-do-mato & CITES-II & $03 / 1999_{\text {(nax) }}$ \\
\hline 11 & Athene cunicularia (Molina, 1782) & conja-kuraqueira & CITES-II & $03 / 1999$ (nam) \\
\hline & Ordem Apodiformes & & & \\
\hline & Familia Apodidae & & & \\
\hline 12 & Chaetura meridionalis Hellmayr, 1907 & $\begin{array}{l}\text { andorinhäo-do- } \\
\text { temporal }\end{array}$ & & $03 / 1999_{\text {(nax) }}$ \\
\hline & Familia Trochilidae & & & \\
\hline 13 & Eupetomena macroura (Gmelin, 1788) & beja-flor-tesoura & CITES-II & $06 / 1998_{\text {(m) }}$ \\
\hline
\end{tabular}


Requalificação dos Aterros Desativados (Brownfields) no Município de São Paulo: Parques (Greenfields) XI Raposo Tavares e Jardim Primavera

Luzia Helena dos Santos Barros

\begin{tabular}{|c|c|c|c|c|}
\hline 14 & Fumarus nufus (Gmein, 1788) & jo5̃o-de-kamo & & $06 / 1998$ (be) \\
\hline & Família Tyrannidae & & & \\
\hline 15 & Machetomis rixasa (Vieillot, 1819) & surivi-cavaleiro & & $03 / 1999$ (rma) \\
\hline 16 & Pitangus suphuratus (Linnaeus, 1766) & bentevi & & $06 / 1998_{(\text {inj }}$ \\
\hline \multirow[t]{2}{*}{17} & Tyrannus melancholicus Vieilot, 1819 & suiriti & & $03 / 1999_{(\text {max })}$ \\
\hline & Família Hirundinida $\theta$ & & & \\
\hline \multirow[t]{2}{*}{18} & Pygochelidon cyanoleuca (Nieilot, 1817) & $\begin{array}{l}\text { andorimha-pequena- } \\
\text { de-casa }\end{array}$ & & $06 / 1998$ (m) \\
\hline & Família Troglodytidae & & & \\
\hline \multirow[t]{2}{*}{19} & Troglodytes musculus Neumarn, 1823 & comina & & $06 / 1998$ (na] \\
\hline & Familia Turdidae & & & \\
\hline \multirow[t]{2}{*}{20} & Turdus rufiventris (Vieiliot, 1818) & sabiälaranjeira & & $03 / 1999_{(\max )}$ \\
\hline & Familia Mimidae & & & \\
\hline \multirow[t]{2}{*}{21} & Mimus satuminus (Lichtenstein, 1823) & sabiá-do-campo & & $06 / 1998_{(m]}$ \\
\hline & Família Coerebidae & & & \\
\hline \multirow[t]{2}{*}{22} & Coereba fiaveola (Linnaeus, 1758) & cambacica & & $06 / 1998$ (min] \\
\hline & Família Thraupidae & & & \\
\hline \multirow[t]{2}{*}{23} & Thraupis sayaca (Linnzeus, 1766) & sanhacy-cinzento & & $06 / 1998(m)$ \\
\hline & Família Emberizidae & & & \\
\hline 24 & Zonotrichia capensis (Statius Muller, 1776) & $600-6100$ & & $06 / 1998$ (m) \\
\hline \multirow[t]{2}{*}{25} & Paroaria dominicana (Linnoeus, 1758) & cardeal-do-nordeste & $\begin{array}{l}\text { nativa } \\
\text { introduzida }\end{array}$ & $03 / 1999$ (nnac) \\
\hline & Família Icteridae & & & \\
\hline \multirow[t]{2}{*}{26} & Molothus bonariensis (Gmelin, 1789) & chopim & & 03/1999 (max) \\
\hline & Família Estrildidae & & & \\
\hline \multirow[t]{2}{*}{27} & Estrilda astild (Limnoeus, 1758) & bico-delacre & $\begin{array}{l}\text { exótica } \\
\text { introduzida }\end{array}$ & $06 / 1998$ (m) \\
\hline & Família Passeridae & & & \\
\hline 28 & Passer domesticus (Linnaeus, 1758) & pardal & $\begin{array}{l}\text { exótica } \\
\text { introducrida }\end{array}$ & $06 / 1998$ (n) \\
\hline
\end{tabular}

Parque Raposo Tavares

Número total de especies: 32

Número de espécies da Classe Arachrida: 01

Número de especies da Classe Reptlia: 03

Número de espécies da Classe Aves: 28

Número de especies endèmicas: 01

Número de exóticas introducidas: 03

Número de natvas introducidas: 01

Nümero de espécies que constam na CTTES (| e ll): 07

Observadores: masc: Maria Amélia Santos de Carvaho, an: Sumiko Namka

Número de horas de observaçăo da avifauna: 3,7

\#Registros dos animais recekidos na Divisbio de Fauna (fonte: SISFAUNA)

Fonte: Diário Oficial do Município de São Paulo, São Paulo, Ano 55, № 94, p.59-60, de 21 de maio de 2010. Suplemento $114 \mathrm{p}$. 


\section{ANEXO K1 - LISTAGEM DE FLORA - PARQUE RAPOSO TAVARES}

\section{Roteiro Botânico - Parque Raposo Tavares - 1988}

\begin{tabular}{|l|l|l|l|}
\hline & Família & Nome Científico & Nome Popular \\
\hline 01 & Leguminosae & Peltophorum vogelianum & Faveira \\
\hline 02 & Agavaceae & Yucca aloifolia & luca; Vela-da-pureza \\
\hline 03 & Leguminosae & Bauhinia variegata & Bauínia; Unha-de-vaca \\
\hline 04 & Fabaceae & Tipuana tipu & Tipuana \\
\hline 05 & Euphorbiaceae & Euphorbia cotinifolia & Eufórbia-caracasana \\
\hline 06 & Arecaceae/Palmae & Syagrus romanzoffiana & Jerivá; Baba-de-boi \\
\hline 07 & Proteaceae & Grevillea robusta & Grevilha-gigante \\
\hline 08 & Melastomataceae & Tibouchina granulosa & Quaresmeira \\
\hline 09 & Bombacaceae & Chorisia speciosa & Paineira \\
\hline 10 & Leguminosae & Erythrina speciosa & Suinã \\
\hline 11 & Leguminosae & Sesbania marginata & Cambaí \\
\hline 12 & Apocynaceae & Nerium oleander & Espirradeira \\
\hline 13 & Oleaceae & Ligustrum lucidum & Alfeneiro \\
\hline 14 & Araceae & Philodendron bipinnatifidum & Guaimbé \\
\hline 15 & Moraceae & Ficus benjamina & Figueira-benjamim \\
\hline 16 & Malvaceae & Hibiscus rosa-sinensis & Hibisco \\
\hline 17 & Myrtaceae & Psidium guajava & Goiabeira \\
\hline 18 & Sapindaceae & Dodonaea viscosa & Erva-de-veado \\
\hline 19 & Moraceae & Ficus luschnathiana & Figueira \\
\hline 20 & Lythraceae & Lafoensia pacari & Dedaleira \\
\hline 21 & Liliaceae & Phormium tenax & Linho-da-Nova Zelândia \\
\hline 22 & Rosaceae & Pyracantha koidzumii & Piracanta \\
\hline 23 & Leguminosae & Caliandra selloi & Cabelo-de-anjo \\
\hline 24 & Cycadaceae & Cycas circinalis & Sagu-das-Molucas \\
\hline 25 & Dilleniaceae & Dillenia indica & Flor-de-abril \\
\hline 26 & Salicaceae & Salix babylonica & Chorão; Salgueiro \\
\hline 27 & Leguminosae & Deloix regia & Flamboyant \\
\hline 28 & Moraceae & Morus nigra & Amoreira \\
\hline 29 & Lythraceae & Lagerstroemia indica & Extremosa; Resedá \\
\hline 30 & Melastomataceae & Tibouchina mutabilis & Manacá-da-serra \\
\hline 31 & Arecaceae & Livistona chinesis & Palmeira-de-leque-da-China \\
\hline & & & \\
\hline
\end{tabular}

\section{TCA - AGROTEXAS - 13/07/2007}

\begin{tabular}{|l|l|l|l|}
\hline & Família & Nome Científico & Nome Popular \\
\hline 32 & Arecaceae & Syagrus romanzoffiana & Jerivá \\
\hline 33 & Fabaceae & $\begin{array}{l}\text { Caesalpina pluviosa var. } \\
\text { peltophoroides }\end{array}$ & Sibipiruna \\
\hline 34 & Bignoniaceae & Jacaranda $s p$ & Jacarandá \\
\hline 35 & Bignoniaceae & Tabebuia $s p$ & Ipê roxo \\
\hline 36 & Bignoniaceae & Tabebuia $s p$ & Ipê rosa \\
\hline 37 & Melastomataceae & Tibouchina mutabilis & Manacá \\
\hline 38 & Fabaceae & Acacia $s p$ & Acácia \\
\hline
\end{tabular}




\section{Espécimes Selecionados para Identificação (Plaqueamento) 28/09/2007}

\begin{tabular}{|l|l|l|l|}
\hline & Família & Nome Científico & Nome Popular \\
\hline 39 & Arecaceae & Archontophoenix cunninghamii & Seafórtia \\
\hline 40 & Arecaceae & Livistona chinesis & Palmeira-de-leque-da-China \\
\hline 41 & Arecaceae & Syagrus romanzoffiana & Jerivá \\
\hline 42 & Bixaceae & Bixa orellana & Urucum \\
\hline 43 & Cycadaceae & Cycas circinalis & Sagu-das-Molucas \\
\hline 44 & Euphorbiaceae & Euphorbia cotinifolia & Caracasana \\
\hline 45 & Fabaceae & Acacia mearnsii & Acácia Negra \\
\hline 46 & Fabaceae & Caesalpinia ferrea var. leiotachya & Pau-ferro \\
\hline 47 & Fabaceae & $\begin{array}{l}\text { Caesalpina pluviosa var. } \\
\text { peltophoroides }\end{array}$ & Sibipiruna \\
\hline 48 & Fabaceae & Enterolobium contortisiliquum & Tamboril \\
\hline 49 & Lytharaceae & Lagerstroemia indica & Resedá \\
\hline 50 & Moraceae & Ficus benjamina & Figueira-benjamim \\
\hline 51 & Oleaceae & Ligustrum lucidum & Alfeneiro \\
\hline 52 & Proteaceae & Grevillea robusta & Grevilha-gigante \\
\hline 53 & Dapindaceae & Koelreuteria elegans & Pinange \\
\hline 54 & Anacardiaceae & Schinus terebinthifolius & Aroeira-mansa \\
\hline 55 & Bignoniaceae & Jacaranda mimosifolia & Jacarandá-mimoso \\
\hline 56 & Fabaceae & Erythrina speciosa & Suinã \\
\hline 57 & Fabaceae & Peltophorum dubium & Faveira \\
\hline 58 & Fabaceae & Senna multijuga & Aleluia \\
\hline 59 & Fabaceae & Tipuana tipu & Tipuana \\
\hline 60 & Malvaceae & Ceiba speciosa & Paineira \\
\hline 61 & Melastomataceae & Tibouchina granulosa & Quaresmeira \\
\hline${ }^{*}$ Placa não enviada & & \\
& & & \\
\hline
\end{tabular}

TCA - PAISAGRO - 2008

\begin{tabular}{|l|l|l|l|}
\hline & Família & Nome Científico & Nome Popular \\
\hline 62 & & Alchornea sidaefolia & Tapiá \\
\hline 63 & Fabaceae & Bauhinia forficata & Pata de vaca nativa \\
\hline 64 & Fabaceae & Caesalpinia ferrea & Pau ferro \\
\hline 65 & Fabaceae & Cassia leptophylla & Canafistula \\
\hline 66 & & Cordia trichotoma & Cordia \\
\hline 67 & & Didymopanax morototoni & Mandioqueiro \\
\hline 68 & Fabaceae & Enterolobium maximum Ducke & Tamboril \\
\hline 69 & & Eugenia uniflora & Pitanga \\
\hline 70 & & Euterpe edulis & Palmeira Jussara \\
\hline 71 & & Inga marginata & Ingá \\
\hline 72 & & Lafoensia glyptocarpa & Mirindiba rosa \\
\hline 73 & & Myroxylon toluiferum & Cabreuva \\
\hline 74 & & Peltophorum dubim & Farinha seca \\
\hline 75 & & Piptadenia nitida & Angico \\
\hline 76 & & Psidium sp & Araçá \\
\hline 77 & & Schinus molle & Aroeira salsa \\
\hline 78 & & Schinus terebinthifolius Raddi & Aroeira mansa \\
\hline 79 & & Senna multijuga & Pau cigarra \\
\hline 80 & Bignoniaceae & Tabebuia crysotricha & Ipê amarelo \\
\hline 81 & Bignoniaceae & Tabebuia heptaphylla & Ipê roxo \\
\hline 82 & Bignoniaceae & Tabebuia odontodiscus & Ipê branco \\
\hline & & & \\
\hline
\end{tabular}




\begin{tabular}{|l|l|l|l|}
\hline 83 & Tibouchina granulosa & Quaresmeira \\
\hline
\end{tabular}

\section{TCA - João Palmeira - 2008}

\begin{tabular}{|l|l|l|l|}
\hline & Família & Nome Científico & Nome Popular \\
\hline 84 & Myrtaceae & Psidium guajava & Goiaba \\
\hline 85 & Melastomataceae & Tibouchina mutabilis & Manacá \\
\hline 86 & Bignoniaceae & Jacaranda micrantha & Caroba \\
\hline 87 & Mirsinaceae & Rapanea Guianensis & Caporroca \\
\hline 88 & Clusiaceae & Calophyllum bras & Guanandi \\
\hline 89 & Melastomaceae & Leandra sp & Pixirica \\
\hline 90 & & & Algodão \\
\hline 91 & & & Canela \\
\hline 92 & & & Crindiúva \\
\hline 93 & & Suinã \\
\hline
\end{tabular}

TCA - PAISAGRO/REPOSIÇÃO - 2008

\begin{tabular}{|l|l|l|l|}
\hline & Família & Nome Científico & Nome Popular \\
\hline 94 & & Euterpe edulis & Palmeira-jussara \\
\hline 95 & & Cecropia pachistachia & Embaúba \\
\hline 96 & & Schinus molle & Aroeira-salsa \\
\hline 97 & Anacardiaceae & Schinus terebinthifolia & Aroeira mansa \\
\hline 98 & & Citharexylum myrianthum & Pau viola \\
\hline 99 & & Inga vera & Ingá \\
\hline
\end{tabular}

\section{ANEXO K2 - levantamento do perfil dos visitantes Pq Raposo Tavares \\ $(26 / 12 / 07-30 / 10 / 08)$}

Total de Questionários aplicados:

1. Idade/Sexo

\begin{tabular}{|l|r|r|l|r|r|}
\hline Masculino & 29 & 56,86 & Feminino & 22 & 43,14 \\
\hline & & & & & \\
\hline Até 15 anos & 2 & 6,90 & Até 15 anos & 3 & 13,64 \\
\hline $16-25$ anos & 9 & 31,03 & $16-25$ anos & 8 & 36,36 \\
\hline $26-35$ anos & 8 & 27,59 & $26-35$ anos & 7 & 31,82 \\
\hline $36-45$ anos & 7 & 24,14 & $36-45$ anos & 3 & 13,64 \\
\hline $46-55$ anos & 1 & 3,45 & $46-55$ anos & 1 & 4,55 \\
\hline$>55$ anos & 2 & 6,90 & $>55$ anos & 0 & 0,00 \\
\hline
\end{tabular}

\section{Escolaridade}

\begin{tabular}{|c|r|r|}
\hline a. Sem Instrução / P. Incompleto & 10 & 19,61 \\
\hline b. Primário Completo & 22 & 43,14 \\
\hline c. Secundário Completo & 4 & 7,84 \\
\hline d. Superior Incompleto & 10 & 19,61 \\
\hline e. Superior Completo & 5 & 9,80 \\
\hline f. Pós-Graduação & 0 & 0,00 \\
\hline
\end{tabular}


3. Renda mensal do chefe da família:

\begin{tabular}{|c|r|r|}
\hline a. Até 1 salário mínimo $(\mathrm{R} \$ 380,00)$ & 4 & 7,84 \\
\hline b. Entre 1 a 2 salários mínimos & 14 & 27,45 \\
\hline c. Entre 2 a 5 salários mínimos & 26 & 50,98 \\
\hline d. Entre 5 a 10 salários mínimos & 1 & 1,96 \\
\hline e. Entre 10 a 20 salários mínimos & 2 & 3,92 \\
\hline f. Mais de 20 salários mínimos & 0 & 0,00 \\
\hline Não sabe/não informou & 4 & 7,84 \\
\hline
\end{tabular}

4. Freqüência de visita ao parque:

\begin{tabular}{|c|r|r|}
\hline a. Primeira vez & 4 & 7,84 \\
\hline b. Menos de uma vez ao ano & 0 & 0,00 \\
\hline c. Menos de uma vez ao mês & 6 & 11,76 \\
\hline d. 1 a 5 vez ao mês & 13 & 25,49 \\
\hline e. 6 a 15 vezes ao mês & 9 & 17,65 \\
\hline f. Mais de 15 vezes ao mês & 19 & 37,25 \\
\hline
\end{tabular}

5. Dias de visita ao parque:

\begin{tabular}{|c|r|r|}
\hline a. Finais de semana & 12 & 23,53 \\
\hline b. Qualquer dia & 30 & 58,82 \\
\hline c. Dias de semana & 9 & 17,65 \\
\hline
\end{tabular}

6. Atividades praticas no parque nesta visita (múltipla escolha):

\begin{tabular}{|c|r|r|}
\hline a. Caminhada & 12 & 10,53 \\
\hline b. Corrida & 10 & 8,77 \\
\hline c. Outras atividades esportivas & 12 & 10,53 \\
\hline d. Descanso & 18 & 15,79 \\
\hline e. Leitura & 4 & 3,51 \\
\hline f. Atividade e visitas culturais & 0 & 0,00 \\
\hline g. Recreação com a família / amigos & 32 & 28,07 \\
\hline h. Contemplação da natureza & 12 & 10,53 \\
\hline i. Eventos & 0 & 0,00 \\
\hline j. Passeio com o cachorro & 9 & 7,89 \\
\hline k. Alimentação & 0 & 0,00 \\
\hline I. Outros? Quais? PASSAGEM & 5 & 4,39 \\
\hline
\end{tabular}

7. Tipo de grupo desta visita:

\begin{tabular}{|c|r|r|}
\hline a. Sozinho & 19 & 37,25 \\
\hline b. Família & 18 & 35,29 \\
\hline c. Casal & 2 & 3,92 \\
\hline d. Amigos & 10 & 19,61 \\
\hline e. Grupo de estudo / trabalho & 2 & 3,92 \\
\hline f. Outro? Qual? & 0 & 0,00 \\
\hline
\end{tabular}

8. Local de residência:

\begin{tabular}{|c|r|r|}
\hline a. Bairro vizinho ao parque & 23 & 45,10 \\
\hline b. Bairro distante do parque & 0 & 0,00 \\
\hline c. Mesmo bairro do parque & 27 & 52,94 \\
\hline d. Outra cidade da Grande São Paulo & 1 & 1,96 \\
\hline $\begin{array}{c}\text { e. Cidade de fora da Grande São } \\
\text { Paulo }\end{array}$ & 0 & 0,00 \\
\hline f. Outro? Qual? & 0 & 0,00 \\
\hline
\end{tabular}


Requalificação dos Aterros Desativados (Brownfields) no Município de São Paulo: Parques (GreenfieldsXVI Raposo Tavares e Jardim Primavera

Luzia Helena dos Santos Barros

9. Principal meio de transporte utilizado para chegar ao parque:

\begin{tabular}{|c|r|r|}
\hline a. A pé & 38 & 74,51 \\
\hline b. Bicicleta & 4 & 7,84 \\
\hline c. Carro & 6 & 11,76 \\
\hline d. Ônibus & 3 & 5,88 \\
\hline e. Outro? Qual? & 0 & 0,00 \\
\hline
\end{tabular}

Fonte: Proposta de Plano de Gestão elaborado pelo ex-administrador do parque Raposo Tavares, Fábio Pellaes, em 2009-2010. 


\section{ANEXO - LEGISLAÇÃO}

BRASIL. CONSELHO NACIONAL DO MEIO AMBIENTE (CONAMA). Resolução no 5, de agosto de 1993. Dispõe sobre o gerenciamento de resíduos sólidos gerados nos portos, aeroportos, terminais ferroviários e rodoviários.

Resolução no 273, de 29 de novembro de 2000. Estabelece diretrizes para o licenciamento ambiental de postos de combustíveis e serviços e dispõe sobre a prevenção e controle da poluição. Alterada pelas Resoluções CONAMA 276/2001 e 319/2002.

Resolução no 420, de 28 de dezembro de 2009. Dispõe sobre critérios e valores orientadores de qualidade do solo quanto à presença de substâncias químicas e estabelece diretrizes para o gerenciamento ambiental de áreas contaminadas por essas substâncias em decorrência de atividades antrópicas.

CONSTITUIÇÃO DA REPÚBLICA FEDERATIVA DO BRASIL: promulgada em 5 de outubro de 1988. Organização do texto por Juarez de Oliveira. 4 ed. São Paulo: Saraiva, 1990. 168 p. (Série Legislação Brasileira).

GOVERNO FEDERAL. Decreto 73.030, de 30 de outubro de 1973. Cria, no âmbito do Ministério do Interior a Secretaria Especial do Meio Ambiente (SEMA), e da outras providências.

Decreto-lei 1.413, de 14 de agosto de 1975. Dispõe sobre o controle da poluuição do meio ambiente provocada por atividades industriais.

Lei 6.766 de 19 de dezembro de 1979. Dispõe sobre o parcelamento do solo urbano e da outras providÊncias.

Lei 7.347, de 24 de julho de 1985. Disciplina a ação civil publica de responsabilidade por danos causados ao meio-ambiente, ao consumidor, a bens e direitos de valor artístico, estético, histórico, turístico e paisagístico (vetado) e dá outras providências.

Lei 6.938, de 31 de agosto de 1981. Dispõe sobre a Política Nacional do Meio Ambiente, seus fins e mecanismos de formulação e aplicação, e dá outras povidências.

Lei 9.605, de 12 de fevereiro de 1998. (Crimes Ambientais). Dispõe sobre as sanções penais e administrativas derivadas de condutas e atividades lesivas ao meio ambiente, e da outras providências.

Lei 9.985, de 18 de julho de 2000. Regulamenta o art. 225, 1으, incisos I, II, II e VII da Constituição Federal, Institui o Sistema de Unidades de Conservação da Natureza (SNUC).

Lei 10.257. de 10 de julho de 2001. Regulamenta os artigos 182 e 183 da constituição federal, estabelece diretrizes gerais da política urbana e da outras providências

Lei no 12.305, de 02 de agosto de 2010. Institui a Política Nacional dos Resíduos Sólidos e altera a Lei 9.605, de 12 de fevereiro de 1998. Disponível em: http://www.planalto.gov.br/ccivil_03/Ato2007-2010/2010/Lei/L12305.htm. Acesso em 16/08/10.

SÃO PAULO (ESTADO). Decreto 47.400, de 04 de dezembro de 2002. Regulamenta dispositivos da Lei Estadual $n^{\circ}$ 9.509, de 20 de março de 1997, referentes ao licenciamento 
ambiental, estabelece prazos de validade para cada modalidade de licenciamento ambiental e condições para sua renovação, estabelece prazo de análise dos requerimentos e licenciamento ambiental, institui procedimento obrigatório de notificação de suspensão ou encerramento de atividade, e o recolhimento de valor referente ao preço de análise

Decreto 8.468, de 8 de setembro de 1976. Aprova o Regulamento da Lei n. 997, de 31 de maio de 1976, que dispõe sobre a Prevenção e o Controle da Poluição do Meio Ambiente. Ambiente.

Lei no 997, de 31 de maio de 1976. Dispõe sobre o Controle da Poluição do Meio

Lei no 1.817, de 27 de outubro de 1978. Estabelece os objetivos e as diretrizes para o desenvolvimento industrial metropolitano e disciplina o zoneamento industrial, a localização, a classificação e o licenciamento de estabelecimentos industriais na Região Metropolitana da Grande São Paulo, e dá providências correlatas.

Lei no 9.509, de 20 de março de 1997. Dispõe sobre a Política Estadual do Meio Ambiente, seus fins e mecanismos de formulação e aplicação.

Lei no 9.999, de 9 de junho de 1998. Altera a Lei $n^{0} \underline{9.472}$, de 30 de dezembro de 1996, que disciplina o uso de áreas industriais.

Lei no 12.300, de 16 de março de 2006. Institui a Política Estadual dos Resíduos Sólidos e define princípios e diretrizes. Diário Oficial do Estado de São Paulo, São Paulo, 17 de março de 2006. V. 116. N. 51, p. 1-4.

Lei no 13.577, de 8 de julho de 2009. Dispõe sobre diretrizes e procedimentos para a proteção da qualidade do solo e gerenciamento de áreas contaminadas, e dá outras providências correlatas.

Secretaria do Meio Ambiente (SMA). RESOLUÇÃo SMA N. 5, de 28 de março de 2001. Dispõe sobre a aplicação e o licenciamento ambiental das fontes de poluição a que se refere a Resolução n. 273, de 29 de novembro de 2000, do Conselho Nacional do Meio Ambiente - CONAMA.

SÃO PAULO (MUNICÍPIO). Decreto no 42.319, de 21 de agosto de 2002. Dispõe sobre diretrizes e procedimentos relativos ao gerenciamento de áreas contaminadas no Município de São Paulo. Diário Oficial do Município de São Paulo, São Paulo, Ano 47, no 158, p.01, de 22 de agosto de 2002.

Decreto no 41.713, de 25 de fevereiro de 2002. Regulamenta a lei n. 13155, de 29 de junho de 2001, que cria, na Secretaria Municipal do Meio Ambiente, o Fundo Especial do Meio Ambiente e Desenvolvimento Sustentável - FEMA, e da outras providências.

Decreto no 43.231, de 22 de maio de 2003, Regulamenta $\circ$ Fundo de Desenvolvimento Urbano, criado pela Lei n. 13430, de13 de setembro de 2002, que aprovou o Plano Diretor Estratégico.

Decreto no 50.899, de 2 de outubro de 2009. Dispõe sobre a extinção da escola municipal de ensino fundamental Clovis Graciano, vinculada a diretoria regional de educação de Freguesia/Brasilandia.

Decreto no 51.436, de 26 de abril de 2010. Regulamenta a Lei n. 15098, de 5 de janeiro de 2010, que obriga o poder executivo a publicar na imprensa oficial ou disponibilizar no site oficial da prefeitura relatório das áreas contaminadas do município de São Paulo.

Lei no 11.426, de 18 de outubro de 1993. Cria a Secretaria Municipal do Verde e do Meio Ambiente - SVMA; cria o Conselho Municipal do Meio Ambiente e Desenvolvimento Sustentável - CADES. 
Lei no 13.155, de 29 de junho de 2001. Cria, na Secretaria Municipal do Verde e do Meio Ambiente - SVMA, o Fundo Especial do Meio Ambiente e Desenvolvimento Sustentável FEMA, e da outras providências.

Lei no 13.430, de 13 de setembro de 2002. Institui o ao Plano Diretor Estratégico e o Sistema de Planejamento e Gestão do Desenvolvimento Urbano do Município de São Paulo. Diário Oficial do Município de São Paulo, São Paulo, Ano 47, no 175, p.01, de 14 de setembro de 2002.

Lei no 13.478, de 30 de dezembro de 2002. Dispõe sobre a organização do Sistema de Limpeza Urbana do Município de São Paulo; cria e estrutura seu órgão regulador.

Lei no 13.539, de 20 de março de 2003. Dispõe sobre a criação dos Conselhos Gestores dos Parques Municipais.

Lei no 13.564, de 24 de abril de 2003. Dispõe sobre a aprovação de parcelamento de solo, edificação ou instalação de equipamentos em terrenos contaminados ou suspeitos de contaminação por materiais nocivos ao meio ambiente e à saúde pública. Diário Oficial do Município de São Paulo, São Paulo, Ano 48, no 77, p.01, 25 de abril de 2003.

Paulo.

Lei no 13.725, de 9 de janeiro de 2004. Institui o Código Sanitário do Município de São

Lei no 13.885, de 25 de agosto de 2004. Estabelece normas complementares ao Plano Diretor Estratégico, institui os Planos Regionais Estratégicos das Subprefeituras, dispõe sobre parcelamento, disciplina e ordena o Uso e Ocupação do Solo do Município de São Paulo. . Diário Oficial do Município de São Paulo, São Paulo, Ano 49, no 189, suplemento, 687 p., 06 de outubro de 2004.

Lei no 14.186, de 4 de julho de 2006. Institui o Programa Municipal de Arborização Urbana e da outras providências.

Lei no 14.887, de 15 de janeiro de 2009. Reorganiza a SVMA e dispõe seu quadro de cargos de provimento em comissão; confere nova disciplina "CADES", "CONFEMA", "FEMA", Conselho Consultivo da Universidade Aberta Meio Ambiente Cultura de Paz e Conselho Regional Meio Ambiente Cultura de Paz.

Lei no 15.098, de 5 de janeiro de 2010. Obriga o poder executivo municipal a publicar na imprensa oficial ou disponibilizar no site oficial da prefeitura relatório das áreas contaminadas do município de São Paulo. 


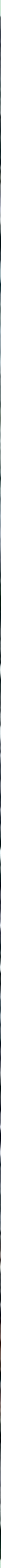

Imagem aérea (14/12/2010) do Parque Raposo Tavares, São Paulo.

Fonte: Google Earth (Ago.2011)

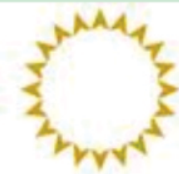


BARROS, L.H.S. Requalificação dos aterros desativados (brownfields) no município de São Paulo: Parques (greenfields) Raposo Tavares e Jardim. 2011. 403 p. : il. + CD ROM. Tese (Doutorado em Paisagem e Ambiente) - São Paulo, FAUUSP.

\section{Lista de Siglas}

ABNT - Associação Brasileira de Normas Técnicas

ABRELPE - Associação Brasileira de Limpeza Pública e Resíduos Especiais

AIA - Avaliação de Impacto Ambiental

AIDIS - Asociación Interamericana de Ingenieria Sanitaria y Ambiental

ASTDR - Agency for Toxic Substances and Disease Registry

CADES - Conselho de Meio Ambiente e Desenvolvimento Sustentável

CEF - Caixa Econômica Federal

CEM - Centro de Estudos da Metrópole

CEMPRE - Compromisso Empresarial para Reciclagem

CERCLA - Comprehensive Environment Response, Compensation, and Liability Act

CETESB - Companhia de Tecnologia de Saneamento Ambiental/Companhia Ambiental do Estado de São Paulo

CMSP - Câmara Municipal de São Paulo

CONAMA - Conselho Nacional do Meio Ambiente

CONFEMA - Conselho Especial do Meio Ambiente e Desenvolvimento Sustentável

CPI - Comissão Parlamentar de Inquérito

DECONT - Departamento de Controle da Qualidade Ambiental

DEPAVE - Departamento de Parques e Áreas Verdes

EIA - Estudos de Impacto Ambiental

EMPLASA - Empresa Paulista Metropolitana

EPA - Environment Protection Agency

ESALQ - Escola Superior de Agricultura Luiz de Queiroz

FAU - Faculdade de Arquitetura e Urbanismo

FEMA - Fundo Especial do Meio Ambiente e Desenvolvimento Sustentável

FEPRAC - Fundo Estadual para Prevenção e Remediação de Áreas Contaminadas

FFLCH - Faculdade de Filosofia, Letras e Ciências Humanas

FNS - Fundação Nacional da Saúde

FUNDURB - Fundo de Desenvolvimento Urbano

FUPAM - Fundação de Pesquisa em Meio Ambiente

HI-TOADS - High-impact Temporaly Obsolete, Abandoned or Derelict Sites

GAC - Grupo Gestor de Áreas Críticas

GIAC - Grupo Interinstitucional de Áreas Contaminadas

GTAC - Grupo Técnico Permanente de Áreas Contaminadas with

GTZ - Deutsche, Gesellschaft für Technische Zumamm eit PUF $^{\circ}$ 
IBAM - Instituto Brasileiro de Administração Municipal

IBAMA - Instituto Brasileiro do Meio Ambiente e Recursos Naturais Renováveis

IBGE - Instituto Brasileiro de Geografia e Estatística

IDRC - Centro Internacional de Investigaciones para el Desarrollo

IPT - Instituto de Pesquisas Tecnológicas do Estado de São Paulo

LEPaC - Laboratório de Ecologia da Paisagem e Conservação

LIMPURB - Departamento de Limpeza Pública

LULUs - Locally Unwanted Land Uses

MC - Ministério das Cidades

MCE - Multi Criteria Evaluation

MMA - Ministério de Meio Ambiente

MS - Ministério da Saúde

NBR - Normas Brasileiras

NCS - Sistema Nacional de Classificação

NPL - National Priorities List

NYC - NEW YORK CITY

PDE - Plano Diretor Estratégico

PRODAM - Empresa deTecnologia de Informação e Comunicação do Município de São Paulo

ProGAU - Projeto de Gestão Ambiental Urbana

PMSP - Prefeitura do Município de São Paulo

PNRS - Política Nacional de Resíduos Sólidos

PNSB - Pesquisa Nacional de Saneamento Básico

PRE - Planos Regionais Estratégicos

ReLASC - Rede Latina Americana de Prevenção e Gestão de Sítios Contaminados

RMSP - Região Metropolitana de São Paulo

RSU - Resíduos Sólidos Urbanos

SEADE - Sistema Estadual de Análise de Dados

SEAQUA - Sistema Estadual de Administração da Qualidade Ambiental

SECOVI - Sindicato das Empresas de Compra, Venda, Locação e Administração de Imóveis

Residenciais e Comerciais de São Paulo

SES - Secretaria de Serviços

SEHAB - Secretaria Municipal da Habitação

SELAV - Sistema de Espaços Livres e Áreas Verdes

SEMPLA - Secretaria Municipal do Planejamento

SMA - Secretaria do Estado Meio Ambiente

SMDU - Secretaria de Desenvolvimento Urbano

SMS - Secretaria Municipal da Saúde

SMSP - Secretaria de Coordenação das Subprefeituras

SNIS - Sistema Nacional de Informações sobre Saneamento

SNSA - Secretaria Nacional de Saneamento Ambiental ${ }^{\text {Created with }}$ 
SNJ - Secretaria de Negócios Jurídicos

SSE - Secretaria do Estado de Saneamento e Energia

SVMA - Secretaria Municipal do Verde e Meio Ambiente

TAC - Termo de Ajustamento de Conduta

TCA - Termo de Compromisso Ambiental

TOADS - Temporaly Obsolete, Abandoned or Derelict Sites

USP - Universidade de São Paulo

USEPA - United States Environmental Protection Agency

UNESP - Universidade Estadual Julio de Mesquita de São Paulo

ZUPI - Zonas de Uso Predominantemente Industrial 
BARROS, L.H.S. Requalificação dos aterros desativados (brownfields) no município de São Paulo: Parques (greenfields) Raposo Tavares e Jardim. 2011. 403 p. : il. + CD ROM. Tese (Doutorado em Paisagem e Ambiente) - São Paulo, FAUUSP.

\section{ERRATA}

\begin{tabular}{|c|c|c|}
\hline Folha & Linha & Onde se lê \\
\hline 14 & 1 e 11 & explosividade \\
\hline 14 & 9 & resgatafr \\
\hline 15 & 4 & toneladas de resíduos sólidos diárias \\
\hline 15 & 16 e 17 & país, nordeste e sudeste, bem como, \\
\hline 20 & 23 & urbana e o risco ... São Paulo \\
\hline 20 & 24 & (Valentim, 2005), \\
\hline 21 & 11 & (SVMA, 2004) \\
\hline 21 & 12 & (SVMA, 2004) \\
\hline 22 & 4 e 5 & e do \\
\hline 34 & 22 e 24 & inflamabilidde \\
\hline 36 & 6 & municípios se altera \\
\hline 36 & 11 & grave. \\
\hline 39 & 24 & se caracterizam \\
\hline 42 & 33 & jardisn \\
\hline 43 & 22 & por (Ogata,1978), \\
\hline 49 & 10 & Figura 1.19 \\
\hline 59 & 23 & ocorre \\
\hline 61 & 8 & Estadual de São Paulo \\
\hline 61 & 10 & Rio Claro \\
\hline 62 & 1 & $1.200 .000 \mathrm{~m}^{2}$ \\
\hline 68 & 8 & 45.650 acres \\
\hline 69 & 11 & 2.3.1 No Brasil \\
\hline 70 & 1 & 2.3.2 No Estado de São Paulo \\
\hline 70 & 33 & onde predominam \\
\hline 71 & 12 & 2.3.3 No Município de São Paulo \\
\hline 71 & rodapé & Hidrocarbonetos aromáticos \\
\hline 72 & 7 & $195 \mathrm{mil} \mathrm{m}^{2}$ \\
\hline 73 & 14 & $56 \%$ \\
\hline 79 & 22 & década de 1980 do século passado, \\
\hline
\end{tabular}

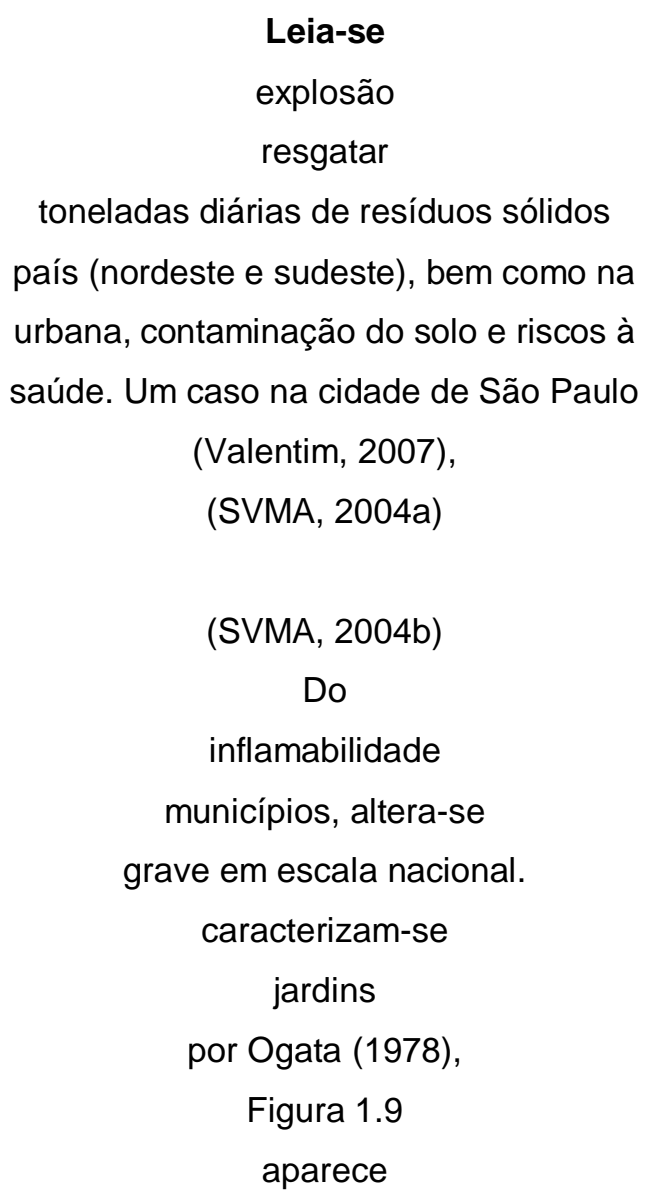

Estadual Julio de Mesquita de São Paulo Rio Claro/SP 120 ha 18.475 ha

2.3.1 No Estado de São Paulo

Excluir o ítem predominando 2.3.2 No Município de São Paulo Hidrocarbonetos aromáticos policíclicos 19,5 ha $67 \%$ década de 1980, 


$\begin{array}{cc}92 & 23 \\ 100 & 29 \\ 112 & 2 \\ 113 & 29 \\ 116 & 27 \\ 120 & 11 \\ 122 & 21 \\ 122 & 23 \\ 124 & 16 \\ 130 & 20 \\ 133 & 21 \\ 134 & 6 \\ 134 & 9 \\ 140 & 18 \\ 141 & 24 \\ 145 & 15 \\ 152 & 8 \\ 152 & 16 \\ 160 & 20 \\ 163 & 5 \\ 165 & 5 \\ 166 & 4 \\ 168 & 11 \\ 169 & 3 \\ 170 & 6 \\ 170 & 27 \\ 170 & 28 \\ 176 & 2 \\ & 5 \\ 130\end{array}$

3

9

$$
\begin{aligned}
& \text { se originam, } \\
& \text { eram a de Planejamento, }
\end{aligned}
$$$$
29
$$$$
27
$$
11 21 23 16 20

1

6

9

8

24

5

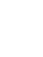

6

E, ainda segundo os autores, esse

(Bitencourt, 2009).

de vegetação está

Ver item 5.2.1

quatorze (14) antigos lixões

$224.000 \mathrm{~m}^{2}$

solo do

item 5.2.1,

treze

a $80 \%$

parques estaduais

$176 \quad 24$

$179 \quad 21$

$185 \quad 5$

$191 \quad 11$

$194 \quad 4$ e 5

$196 \quad 7$

$197 \quad 33$

$198 \quad 26$

$199 \quad 10$

$199 \quad 18$

2053

Atualmente, setembro de 2010 ,

$$
\text { década de } 90
$$

$\$$ de 53 milhões

ressalta

por dez a sessenta anos.

caminhos potencias

onde

devido

municipal, a seguinte

se observa

2

4

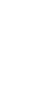

(Figuras 5.11 e 5.12) ... (Figura 5.12)

onde predominam

COHAB, onde foram

a sua montante,

energia

se destacam

item 5.3.1.

a confirmação de contaminação.

itens 5.3.1 e 5.3.2

re-estabelecimento
$\mathrm{TAC}^{20}$

originam-se,

eram: Planejamento,

na Sehab

Desde setembro de 2010, década de 1990

$\mathrm{R} \$ 53$ milhões

ocupados

ressaltam

caracterizam-se

por 10 a 60 anos.

caminhos potenciais

corresponde um

e

devido a

municipal, resultando na seguinte

observa-se

Esse

Bitencourt (2009).

de vegetação apresentada a seguir está

Ver item 5.1.1

14 antigos lixões

$$
214.000 \mathrm{~m}^{2}
$$

solo (imagem ALOS/2007) do

item 5.1.1,

13

a $80 \%$ da área total e no raio de $2 \mathrm{~km}$, parques urbanos sob administração

$$
\text { estadual }
$$

Figura 5.11

(Figuras 5.12 e 5.13) ... (Figura 5.13)

no qual predomina

COHAB. No aterro foram

a montante,

Energia

destacam-se

item 5.2.1.

a contaminação.

itens 5.2 .1 e 5.2 .2

restabelecimento 


\begin{tabular}{|c|c|c|}
\hline 208 & 2 & a sua percepção \\
\hline 209 & 25 & compactação e porosidade do solo \\
\hline 210 & 10 & $\mathrm{~Pb}, \mathrm{Hg} \mathrm{Th}$ \\
\hline 216 & 27 & quanto pela irrigação \\
\hline 221 & 2 & contribui paa \\
\hline 221 & 21 & O autor considera \\
\hline 235 & 26 & de habitat. \\
\hline 236 & 25 & se caracteriza, \\
\hline 239 & 21 & habitats \\
\hline 242 & 9 & evidencias \\
\hline 246 & 11 & publicas \\
\hline 247 & 24 & no item 7.2.2. \\
\hline 251 & 18 & drenagem de lixiados \\
\hline 260 & 6 & atividade glacila, \\
\hline 268 & 5 & de trinta anos, \\
\hline 277 & 3 & para noroeste \\
\hline 280 & 4 & acompanhando \\
\hline 280 & 18 & antigo dreno de drenagem de \\
\hline 281 & 9 & amostragem foi detectado \\
\hline 282 & 15 & (taut-galinha), ... (cachrro-do- \\
\hline 282 & 26 & e nem tão pouco captação \\
\hline 290 & 26 & com \\
\hline 291 & 11 & Quanto a renda \\
\hline 291 & 16 & item 5.2 \\
\hline 292 & 15 & item 5.2 \\
\hline 297 & 3 & na sub-bacia do Rio Jaguaré \\
\hline 299 & 23 & restante \\
\hline 306 & 26 & item 8.2 \\
\hline 308 & 9 & década de 50, \\
\hline 311 & 3 & se propagava \\
\hline 311 & 18 & onde desponta \\
\hline 314 & 12 & na água subterrânea. \\
\hline 316 & 19 & ítem 7.2.3, \\
\hline 318 & 14 & 5.2.1.1 \\
\hline 318 & 24 & (Figura 8.21). \\
\hline 319 & & capítulo 5, item 5.2.1.1 ... Figura 8 \\
\hline 323 & 2 & (Figuras 8.22) ... (Figuras 8.23). \\
\hline 324 & & Figura 8. \\
\hline 325 & & Figura 8. \\
\hline & 32 & se modificou \\
\hline
\end{tabular}
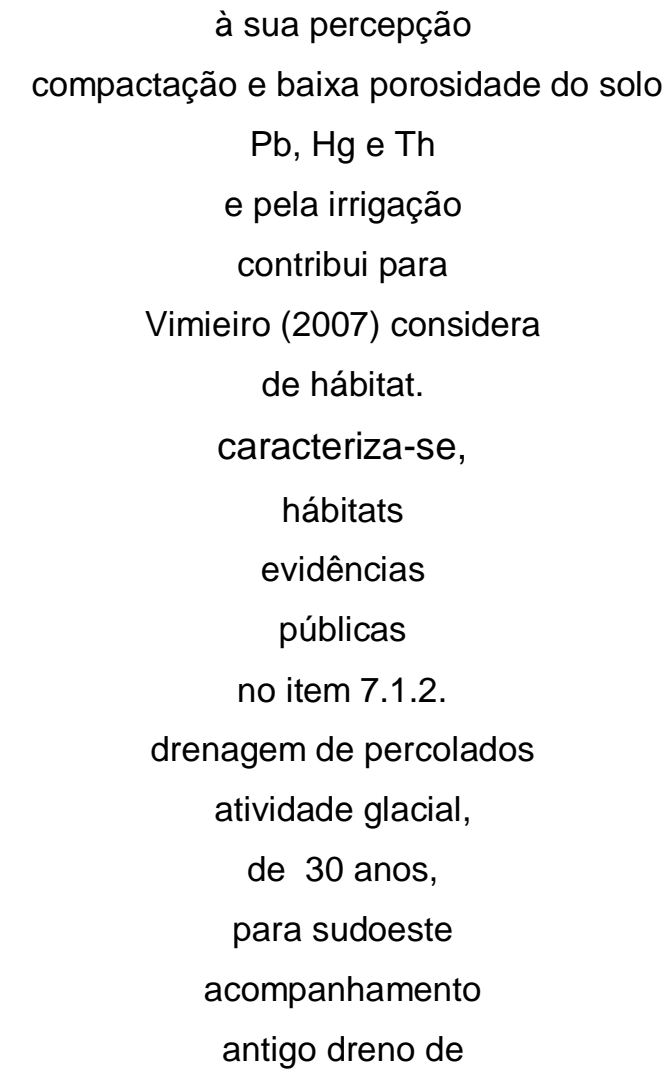

amostragem foram detectados

(tatu-galinha), (cachorro-do-

e nem captação

tem

Quanto à renda

item 5.1

item 5.1

na bacia do rio Jaguaré

restando

item 5.2.1

década de 1950,

propagava-se

onde despontam

na zona saturada

ítem 7.1.3,

5.2.1

(Figura 8.20).

capítulo 5, item 5.2.1.1 ... Figura 8.20

(Figuras 8.23) ... (Figuras 8.24).

Figura 8.23

Figura 8.24

modificou-se 


$\begin{array}{ccc}347 & 5 & \text { em subsuperfície } \\ 357 & 18 \text { e } 19 & \text { terreno, com relevo mais suave, no } \\ 369 & 32 & \text { desencadeou } \\ 333 & 13 & \text { habitat } \\ 334 & 12 & \text { revetação } \\ 334 & 16 & \text { Tipuana tipo } \\ 339 & 24 & \text { em direção a parte } \\ 368 & 11 & \text { habitats } \\ 371 & 4 & \text { se mostra } \\ 378 & 22 & \text { obra como } \\ 400 & 33 & \text { São Paulo. p. } 493-503 .\end{array}$

\author{
em superfície \\ terreno no \\ desencadearam-se \\ hábitat \\ revegetação \\ Tipuana tipu \\ em direção à parte \\ hábitats \\ mostra-se \\ obra bem como
}

São Paulo. 2009. p. 493-503. 